\title{
LIBERDADE ESTÁTICA, RAZÃO ESTÉTICA: PERMEABILIDADES ENTRE ARQUITETURA E ENGENHARIA NA OBRA DE OSCAR NIEMEYER
}


UNIVERSIDADE DE SÃO PAULO

FACULDADE DE ARQUITETURA E URBANISMO

ALEXANDRE AUGUSTO MARTINS

LIBERDADE ESTÁTICA, RAZÃO ESTÉTICA:

PERMEABILIDADES ENTRE ARQUITETURA E ENGENHARIA NA OBRA DE OSCAR NIEMEYER

SÃO PAULO

(2015) 


\title{
ALEXANDRE AUGUSTO MARTINS
}

\section{LIBERDADE ESTÁTICA, RAZÃO ESTÉTICA:}

\section{PERMEABILIDADES ENTRE ARQUITETURA E ENGENHARIA NA OBRA DE OSCAR NIEMEYER}

\author{
Dissertação apresentada à Faculdade de Arquitetura e \\ Urbanismo da Universidade de São Paulo para a obtenção \\ do título de Mestre em Arquitetura e Urbanismo. \\ Área de Concentração: Projeto, Espaço e Cultura \\ Orientador: Prof. Dr. Ricardo Marques de Azevedo
}

\section{SÃO PAULO}

(2015) 
AUTORIZO A DIVULGAÇÃo E A REPRODUÇÃo TOTAL OU PARCIAL DESTE TRABALHO, POR QUALQUER MEIO CONVENCIONAL OU ELETRÔNICO, PARA FINS DE ESTUDO E PESQUISA, DESDE QUE CITADA A FONTE.

E-MAIL DO AUTOR: martins-aa@uol.com.br

Martins, Alexandre Augusto

M379L Liberdade estática, razão estética: permeabilidades entre arquitetura e engenharia na obra de Oscar Niemeyer / Alexandre Augusto Martins. --São Paulo, 2015.

257 p.: il.

Dissertação (Mestrado - Área de Concentração: Projeto, Espaço e Cultura) - FAUUSP.

Orientador: Ricardo Marques de Azevedo

1.Arquitetura moderna 2.Arquitetura (Técnicas) 3.Estética 4.Arquitetura 5.Engenharia 6.Concreto armado 7.Niemeyer, Oscar, 1907-2012 l. Título

CDU 72.036 

AGRADEÇO ... ... AOS MEUS AMIGOS EM GERAL; ... AO MEU ORIENTADOR, PROFESSOR RICARDO MARQUES DE AZEVEDO; ... AOS PROFESSORES MÔNICA JUNQUEIRA DE CAMARGO E PAULO JULIO VALENTINO BRUNA; ... À DIREÇÃO, AOS DEMAIS PROFESSORES E AOS FUNCIONÁRIOS DA FAUUSP. 
POR OSCAR NIEMEYER ...

“DE UM TRAÇO NASCE A ARQUITETURA. E QUANDO ELEÉ BONITO E CRIA SURPRESA, 


\section{LIBERDADE ESTÁTICA, RAZÃO ESTÉTICA:}

\section{PERMEABILIDADES ENTRE ARQUITETURA E ENGENHARIA NA OBRA DE OSCAR NIEMEYER}

Este estudo coloca em pauta o diálogo entre duas diferentes áreas do conhecimento que caminham paralelamente sobre campos limítrofes, permeáveis e por vezes entrelaçados: arquitetura e engenharia. Reflete sobre a relação entre estética e técnica ao longo do tempo e apresenta a contribuição mútua entre ambas as disciplinas para um fazer construtivo mais interessante e eficiente. Elege Oscar Niemeyer como representante de um fazer projetual fundamentalmente propositivo e que, por isso, quebra fronteiras e busca inovações que tensionem o binômio plástica e partido - sempre por meio do concreto como seu material de construção predileto. Traça um breve panorama inclusive historiográfico - sobre a carreira desse arquiteto carioca entre as décadas de 1930 e 1960. Investiga também as influências que recebe e que reverberam na concepção de suas arquiteturas, alçando os mestres Lucio Costa (no Brasil) e Le Corbusier (na Europa) ao patamar de suas primeiras referências arquitetônicas de peso. Destaca os reflexos daí surgidos e presentes em sua obra, especialmente a partir do projeto do Ministério da Educação e Saúde (MES), no Rio de Janeiro, até a construção da nova Capital Federal - obedecendo, portanto, o recorte temporal escolhido para este estudo. Discute o desdobramento do ato projetual de Niemeyer pautado por momentos de profundas reflexões críticas pessoais e profissionais, a partir das quais novos posicionamentos arquitetônicos são definidos e paulatinamente exercitados no Brasil e no exterior. Analisa uma parte de seu repertório formal, na qual os projetos selecionados demandam a utilização de técnicas racionais e de tecnologias avançadas (ou não usuais) para que possam ser erigidos. Traz à tona episódios em que a engenharia é afastada de suas usuais zonas de conforto, o que faz dela uma área do conhecimento que não cansa de se reinventar, ao adaptar e readaptar conceitos e normas até então entendidos por ela mesma como estáveis e/ou imutáveis, fomentando um processo teórico-científico em contínua construção e que visa, em última instância, exaltar o fator plástico como imperativo mais importante. Questiona a existência de autonomia da forma diante da técnica e, consequentemente, dos arquitetos em relação aos engenheiros. Ressalta, por fim, a importância de um envolvimento profundo entre a estética da arquitetura e a estática da engenharia para que ambas caminhem em harmonia no mesmo compasso evolutivo.

\section{Palavras-chave:}

Arquitetura Moderna; Oscar Niemeyer; Técnica; Estética; Engenharia; Concreto Armado. 
STATICS FREEDOM, AESTHETICS REASON:

PERMEABILITY BETWEEN ARCHITECTURE AND ENGINEERING IN THE WORK OF OSCAR NIEMEYER

\begin{abstract}
This study brings forward the dialogue between two different areas of knowledge that walk in parallel on limitrophe, permeable and sometimes entangled fields: architecture and engineering. It reflects on the relationship between aesthetics and technique over time and presents the mutual contribution between both disciplines for a more interesting and efficient constructive act. It elects Oscar Niemeyer as an agent of a fundamentally propositional design who, therefore, breaks boundaries and seeks innovations that enforce the binomial plastic and design approach always using concrete as his favorite building material. It presents a brief overview - including historiographic issues - about this Brazilian architect's career from the 1930 s to 1960s. It investigates also the influences that he receives and that reverberate in the design of his architectures, taking the masters Lucio Costa (in Brazil) and Le Corbusier (in Europe) to the level of his early relevant architectural references. It highlights the arising consequences that appear in his works, especially from the Ministry of Education and Health project, in Rio de Janeiro, to the construction of the new Federal Capital - obeying, therefore, the study's time frame. It discusses the consecution of Niemeyer's design act, marked by moments of deep personal and professional critical reflections, from which new architectural attitudes are defined and gradually exercised in Brazil and abroad. It analyses part of his formal repertoire, in which selected projects require the use of rational techniques and advanced (or unusual) technologies so that they can be constructed. It brings out episodes in which engineering is far outside its usual comfort zones, making it an area of knowledge that does not become tired of reinventing itself, while adapting and readapting concepts, stated hitherto as stable and/or immutable, fostering a theoretical and scientific process in continuous construction and searching to exalt plastic factor as the most important imperative. It questions the existence of autonomy of shape in relation to technique and, consequently, of architects in relation to engineers. It demonstrates, finally, the importance of deep engagement between architectural aesthetics and engineering statics for both to walk in harmony and on the same evolutive compass.
\end{abstract}

\title{
Keywords:
}

Modern Architecture; Oscar Niemeyer; Technique, Aesthetics, Engineering, Reinforced Concrete. 
1. Introdução

Pontuações Iniciais, Justificativa e Delimitação do Tema

Obras Investigadas e Critérios de Escolha

Bibliografia Selecionada

Organização do Trabalho

2. Estética e Técnica: Prelúdios sobre uma Arquitetura Tecida entre Fronteiras

Explicações Necessárias

Arte e Estética: Filosofias e Reflexões

Estética e Arquitetura: Teorias e Meditações

Identidade e Pertencimento: Arquitetura Feita para o Homem

3. Aço e Cimento: Agentes de um novo Significado para Arquitetura e Engenharia

Pelo Mundo: Novas Técnicas Aliadas à Busca pelo Moderno

No Brasil: O Ferro, o Aço e a Indústria Siderúrgica Nacional 
4. Oscar Niemeyer: Razão e Liberdade na Arquitetura Moderna Brasileira

Explicações Necessárias

Primeiros Passos: O Estado Novo e o Ministério da Educação e Saúde (MES)

O Brasil Fora do Brasil: A Política da Boa Vizinhança e o Pavilhão Brasileiro na Feira Internacional de 1939

O Amadurecimento: Conjunto Arquitetônico da Lagoa da Pampulha

Entreatos: Meditações e Reflexões Niemeyerianas

A Nova Capital Federal: Um Olhar para o Interior do Brasil

Crepúsculo para uma nova Arquitetura: O Palácio da Alvorada

Dois Iguais Diferentes: O Palácio do Itamaraty e o Palazzo Mondadori

5. Considerações Finais

6. Referências

Em Meios Impressos

Em Meios Virtuais e/ou Digitais

Figuras (Créditos / Fontes)
110

111

113

130

144

176

188

199

213

230

236

237

246

249 
INTRODUÇÃo 


\section{Pontuações Iniciais, Justificativa e Delimitação do Tema}

A arquitetura é tecida entre dois valores e fazeres normalmente vistos como antagônicos: a estética e a técnica. Isso confere a ela um interesse bastante peculiar e uma oportunidade de buscar em fundamentos externos aos seus próprios conceitos, inspirações para responder a alguns dos seus constantes questionamentos - como o que se percebe nos diálogos que promove com outras áreas do conhecimento, como com a filosofia, a sociologia ou a engenharia. Trata-se, logo, de uma situação um tanto quanto ambígua na qual transita a arquitetura, pois é como se houvesse um embate decorrente da combinação de dois fatores: um teórico e relativo ao projeto e, outro, voltado à prática e à execução, cuja relação está no cerne da ambivalência em que o pensamento estético, desde a Antiguidade, tem conduzido esta disciplina à discussão no campo do sistema das artes'.

Como expressão artística, a arquitetura sente constantemente os ecos das modificações sociais e inerentes ao pensamento humano - e isso já por séculos: era assim na época de Platão e de Aristóteles, o é ainda hoje, e o será nos tempos futuros. Estimuladas pelas competências e habilidades humanas ao longo do tempo, as transformações pelas quais passa essa disciplina contribuem para que lhe sejam impostas alterações de forma independentes de quaisquer mudanças na consciência artística de seus projetistas.

Assim, no momento em que o arquiteto toma contato com alguma descoberta que pode influenciar o seu ato criador - e por conseguinte a sua obra quando construída - ele por vezes não hesita e bravamente incorpora tal inovação ao seu fazer projetual, mesmo que essa atitude comprometa, em algum momento, a evolução natural dos estilos (abalando-a, transformando-a ou mesmo interrompendo-a), motivado que está por um fator que por vezes não traz ascendência e/ou intenção estética. Pela permeabilidade das fronteiras nas quais caminha a arquitetura, esse fator motivador, se não estético, pode ter natureza técnica e/ou tecnológica suficientemente relevante para estimular o projetista a abandonar suas certezas e seguir adiante.

\footnotetext{
${ }^{1} \mathrm{O}$ sistema das artes abrange "o problema da classificação das artes, das relações que as unem, e das diferenças que as distinguem assume um significado muito diferente se a época em que se apresenta for anterior ao conceito moderno de arte ou se, pelo contrário, for colocado quando este conceito já está estabelecido e largamente partilhado". (CARCHIA e D’ANGELO, 2009: 324)
} 
É o caso por exemplo da descoberta do concreto armado, cujas implicações para o desenvolvimento e a evolução da arquitetura foram diversas: novas soluções construtivas, vãos mais ousados, aberturas mais generosas, velocidade de construção mais acelerada, volumetrias mais leves, formas mais livres, espacialidades mais amplas, acabamentos mais verdadeiros, enfim, um sedutor leque de possibilidades colocado diante dos olhos dos arquitetos e dos engenheiros que, a partir de determinado momento histórico, cedem à tentação e passam a optar por esta técnica como sua principal referência de projetação e de construção.

Assume-se portanto que os avanços técnicos e tecnológicos estiveram sempre intimamente conectados às novas tendências arquitetônicas. De meados do século 19 em diante esse entrelaçamento tem sido cada vez mais evidenciado por meio da evolução paulatina dos materiais de construção, resultando em arquiteturas muitas vezes distintas para cada lugar e para cada momento da história. Basta pensar em alguns exemplos: a valorização estrutural em ferro fundido da Bibliothèque Sainte-Genèvieve, projetada por Henri Labrouste e construída em Paris entre 1843 e 1850; a modulação cartesiana da estrutura pré-fabricada temporária feita também de ferro fundido para o Crystal Palace, de Joseph Paxton e destinado a abrigar a Grande Exposição de Londres de 1851; o uso de pilares e vigas metálicos como solução estrutural do primeiro arranha-céu do mundo, o Home Insurance Company Building, de William Le Baron Jenney, concluído em 1885 em Chicago; o concreto armado aparente adotado como expressão arquitetônica por Auguste Perret, em 1903, no edifício residencial parisiense da Rue Franklin; a construção de obras de arte feitas com o mesmo material, como a francesa Pont de la Libération, de 1912, projetada e calculada por Eugène Freyssinet; os grandes vãos conquistados na Polônia pelo uso também do concreto armado no projeto de Max Berg de 1913 para o Jahrhunderthalle; e a casca paraboloide de seção variável concebida para o efêmero pavilhão da Companhia de Cimento Portland na Exposição Nacional de Zurique de 1939, de Robert Maillart. Nota-se assim que a cena internacional ganha musculatura dos anos 1850 em diante e traz para o âmbito arquitetônico mundial uma nova realidade, sobretudo na França, na Inglaterra, nos Estados Unidos e na Alemanha. O uso de materiais como o ferro e o aço são agora incorporados ao fazer arquitetônico cotidiano, e a chegada do concreto armado à construção civil dá ainda mais fôlego a essas já tão intensas transformações.

E esse fluxo contínuo de modificações é também encorajado pela arquitetura moderna, mesmo que ela tenha tomado caminhos distintos entre Europa e Estados Unidos antes de se alastrar pelo mundo (inclusive pelo Brasil), encampada pelo uso redentor do concreto armado, do aço e do vidro. Na Alemanha em um primeiro momento e em outras partes 
do continente europeu logo depois, a arquitetura moderna, movida inicialmente pela filosofia da Bauhaus e desejosa para expressar seus ideais de liberdade, de democracia e de civismo tenta traduzir, da indústria para a arquitetura, os princípios de produção em série então existentes e que lhe ajudariam a criar novos jeitos de viver e de morar nas grandes cidades: edificações seriadas, moduladas, cartesianas e essencialmente racionalistas. Essa é a fórmula a partir da qual foram erguidos - sobretudo no mercado internacional pós-Segunda Grande Guerra - hospitais, escolas, moradias e universidades, todos, pré-fabricados (no entanto, ainda que técnica e tecnologicamente eficientes mostraram-se, com o passar do tempo, um tanto quanto falhos do ponto de vista prático e social).

Já no Brasil, o segmento da construção civil começa a amadurecer somente a partir do segundo quartel dos anos 1900. Entre as décadas de 1930 e 1960, as indústrias de base nacionais estão finalmente estabelecidas e contribuem para o franco processo de desenvolvimento vivenciado pelo país naquele momento. A participação do Estado por meio de investimentos em obras de grande porte aliada à abertura de cursos de graduação em engenharia civil e em arquitetura em várias partes do país, ajudam ativamente na expansão do setor construtivo nacional e na qualificação da mão-de-obra interna. Acrescente-se a esse quadro o papel fundamental das grandes construtoras que aqui se estabeleceram e contribuíram para a propagação das técnicas construtivas em território nacional, para a capacitação de uma massa trabalhadora local e para a execução de projetos de grande envergadura, como a construção da nova Capital Federal.

É nesse mesmo período, portanto, que o panorama técnico-tecnológico nacional encontrava-se em ebulição, fermentado que estava pela assimilação de novos ideais e de novos posicionamentos arquitetônicos opostos às linhas tradicionalistas até então dominantes. Defendidas por Lucio Costa - o mais respeitado arquiteto brasileiro daquele momento -, as tendências modernizantes ganharam força e foram plenamente abraçadas por todos de seu círculo, inclusive por seu discípulo, Oscar Niemeyer. Fundamentando-se nos princípios do movimento moderno pregados por seus dois mestres (no Brasil, o próprio Lucio Costa e na Europa, Le Corbusier), ao longo dos anos Niemeyer evoluiu da condição de um acanhado desenhista no escritório de Lucio Costa e Gregori Warchavchik à de um profissional empreendedor e propositivo, que optou por desbravar novos horizontes arquitetônicos ao adotar o concreto como sua técnica básica de projetação e de construção.

Descortinou-se a partir daí a oportunidade de alargar e de enriquecer o vocabulário da arquitetura moderna. Com o passar do tempo, Niemeyer complementou a obra corbusiana e revelou total apreensão de suas aspirações 
sistêmicas, colocadas em prática em cada nova obra projetada. Ao desenhar edifícios que fugiam aos preceitos modernos, mas que neles se alicerçavam, o arquiteto carioca não apenas concebeu novos volumes, espaços e formas mas, também, abriu caminhos para novas possibilidades arquitetônicas e para soluções técnicas e estruturais inovadoras, as quais motivaram, igualmente, novas apreensões e vivências estéticas. O reconhecimento do trabalho de Niemeyer deve também ser atribuído ao fato de ele não ter se limitado a contemplar passivamente as grandes conquistas técnicas e tecnológicas dos engenheiros de tempos passados e daqueles com os quais atuou diretamente. Em função de seus conteúdos programáticos, novas e crescentes exigências aos tecnologistas contemporâneos foram por ele sempre demandadas, contribuindo sobremaneira para a evolução da própria técnica em si.

Os resultados, inquestionáveis, frutificaram: a arquitetura de Niemeyer está presente em diversos continentes e conforma mais de oito décadas de produção ativa, nas quais teve construídos mais de trezentos edifícios derivados de mais de dois mil projetos desenhados - número superior aos atingidos por nomes de peso mundial, como Le Corbusier e Frank Lloyd Wright. Portanto, qualquer tentativa de abordar sua vasta obra a um só passo e em sua totalidade torna-se, assim, uma oportunidade de incorrer em simplificações ou em superficialidades que tendem a não resultar em uma reflexão satisfatoriamente consistente.

Em prol de um enfoque mais direcionado e quem sabe até mais modesto, é interesse deste estudo que nele seja delineada uma discussão por meio da seleção de um tema em específico, qual seja, a relação expressivamente imbricada entre técnica e forma ${ }^{2}$ na arquitetura moderna niemeyeriana. O recorte aqui indicado favorece a compreensão perspectivada de uma pequena parte da trajetória desse arquiteto (da sede para o Ministério da Educação e Saúde aos Palácios de Brasília, ou seja, dos anos 1930 aos 1960), colocando em questão a intersecção entre arquitetura e engenharia que, assume-se, caminham paralelamente em um campo limítrofe (e por vezes poroso) entre estética e técnica.

Tanto a historiografia quanto as leituras das obras de Oscar Niemeyer ora reforçam a independência do traço - e consequentemente a autonomia da forma, da estética e do desenho - ora (e de maneira muito lateral) destacam o

\footnotetext{
¿ É conveniente que o termo "forma"(e seus respectivos derivados formais), ao longo deste estudo, sejam compreendidos a partir da definição proposta em 2005 por Edson Mahfuz em "Ordem, Estrutura e Perfeição no Trópico", no qual manifesta que "sempre que utilizar a noção de forma neste texto, não estarei me referindo à aparência de um objeto, ao seu aspecto ou conformação externa, mas a uma estrutura relacional ou sistema de relações internas e externas que configuram um artefato ou episódio arquitetônico e determinam a sua identidade".
} 
vínculo de dependência destes para com a técnica - e, por conseguinte, da arquitetura em relação à engenharia. É intuito deste trabalho, assim sendo, colocar em pauta episódios (se é que existem) em que tanto a subordinação da forma à técnica quanto a sujeição da técnica à forma tornam-se inevitáveis e apresentam-se de maneira mais cristalina, nacional ou internacionalmente.

\section{Metodologia}

Este estudo tem como fio condutor o método inferencial de Michael Baxandall (2006), a seguir sucintamente apresentado. A partir dele traça-se uma apreciação crítica de um breve extrato da trajetória profissional de Oscar Niemeyer tomando como pano de fundo um conjunto formado por três variáveis densamente relacionadas entre si: “circunstâncias”, “autor” " “objeto”. Com a adoção deste método é possível desenvolver aqui uma única investigação baseada em duas perspectivas distintas, porém complementares entre si: o foco no individualismo por um lado e uma visão panorâmica, por outro. A partir de Baxandall, assim sendo, uma análise específica porém abrangente, passa a ser factível.

Na obra intitulada "Padrões de Intenção - A Explicação Histórica dos Quadros" de 2006, o historiador e professor de arte galês Michael Baxandall (1933 - 2008) examina, dentre outras questões, alguns fatos da linguagem quando direcionados à crítica de arte (e à apreciação dos quadros, em particular). Em última instância, pondera também sobre o modo de esses mesmos fatos influenciarem a compreensão de como a arte e os quadros podem ser explanados. $O$ autor deixa claro que, no momento em que se deseja explicar um quadro e que se tem o intuito de tornar visíveis suas causas históricas, o que efetivamente acontece é tanto mais a necessidade de apresentar uma representação que dele se tem e baseada em descrições relativamente interpretativas, que explicá-lo efetivamente.

Baxandall (2006) sugere ainda que a explicação dos quadros pode ser conduzida por um método idiográfico (ou teleológico) a partir do qual determinado acontecimento é relacionado diretamente às suas causas finais. Dito de outra maneira, o argumento do autor calca-se na ideia de que o mundo e a existência são constituídos de sistemas de relações entre meios e fins, porém, não de maneira geral ou abrangente, mas, sim, com propósitos baseados em fatos individuais que identificam e compreendem a singularidade de determinados objetos em particular. 
Como afirmação - e talvez até como defesa da adoção do método idiográfico em seus estudos - Baxandall (2006) comenta que tanto o pintor quanto o produtor de um artefato histórico defrontam-se inicialmente com certo problema cuja solução finda e resolvida nada mais é que o objeto propriamente dito e oferecido às pessoas para contemplação, uso ou para qualquer outro fim. Aqui é possível dilatar esse raciocínio e sugerir que nele sejam apreciados também os arquitetos e suas obras que perduram ao longo do tempo e que, uma vez edificadas e concluídas, passam a fazer parte da vida das pessoas, no entanto, não apenas daquelas que usufruem diretamente dessas obras, mas também das que entram em contato com as construções pontual e temporariamente em algum momento de suas vidas - isto é, as arquiteturas são parte integrante da dinâmica das cidades e de seus habitantes e/ou visitantes.

O escritor também propõe que seu método seja constituído por uma análise predominantemente relacional, considerando: a.) as relações de um problema e sua respectiva solução; b.) as relações entre o problema, a solução e a contextualização da qual fazem parte; c.) as relações entre a interpretação individual e a descrição de um objeto em especial; e d.) as relações entre uma descrição e o objeto que a motivou. Assim sendo, o método idiográfico de Baxandall ressalta a necessidade de promover investigações continuadas, entrelaçadas, combinadas e sustentadas por três principais variáveis: “circunstâncias”, “autor” e “objeto”, que ininterruptamente causam e sofrem influências mútuas.

Em linhas gerais, "circunstâncias" abarcam os fatos externos que direta ou indiretamente afetam tanto o trabalho de um indivíduo quanto o resultado final de sua atividade, este, consolidado pelo objeto quando concluído. Assim, são avaliados aqui, por exemplo, materiais, técnicas, tecnologias, legislações, matérias-primas, mão-de-obra especializada, fornecedores de insumos, localização, condições de trabalho e do sítio, enfim, fatores que, como se nota, posicionam-se externamente tanto ao trabalho do autor quanto ao objeto por ele desenvolvido, mas que reverberam no resultado e na qualidade de ambos. Já "autor" envolve questões pertinentes ao talento, à expertise e ao repertório cultural e profissional detidos por um profissional e que são colocados em exercício quando da execução de uma determinada tarefa. Por fim, entenda-se por "objeto" como sendo o produto final da conjugação entre “circunstâncias" e "autor" e que permite uma resposta única e bastante particular se consideradas tais variáveis em especial. Assim sendo, caso fossem outras “circunstâncias” e/ou outro “autor”, certamente um outro “objeto”, diferente, seria derivado dessa nova relação. 
Isto posto, para este estudo em particular, considerar-se-á:

- "Autor": o arquiteto carioca Oscar Niemeyer;

- “Circunstâncias": abarca diferentes cenários autônomos entre si, porém, fortemente relacionados: em um panorama mais geral e inicial, considera-se o surgimento e o desenvolvimento da técnica construtiva mais adotada no Brasil (e também por Niemeyer), ou seja, o concreto armado. Em um cenário mais específico, para cada obra niemeyeriana em particular aqui discutida, uma contextualização circunstancial é trazida à baila como forma de embasar cada uma das situações/arquiteturas analisadas;

- “Objeto": um conjunto de obras notáveis e paradigmáticas projetadas e/ou construídas entre as décadas de 1930 e 1960, naquilo que é por muitos entendido como o período áureo do modernismo no Brasil. A relação das obras e a justificativa a partir da qual a seleção foi feita, estão descritas no item "Obras Investigadas e Critérios de Análise".

Para sua elaboração, esta dissertação envolveu dois tipos de pesquisa:

- “Exploratória": levantamento bibliográfico alinhado ao eixo temático deste estudo e efetuado por meio de livros, revistas, artigos, dissertações, teses e sítios de Internet servindo como fontes de informação, todos, relacionados nas "Referências", ao final do trabalho. Os títulos mais relevantes ou que contribuíram mais decisivamente para a composição deste material, por sua vez, são mais bem apresentados no item "Seleção Bibliográfica";

- “Descritiva": levantamento de campo, a partir de visita às obras arquitetônicas projetadas por Oscar Niemeyer que são foco deste estudo, nas cidades do Rio de Janeiro, de Belo Horizonte e de Brasília.

Busca-se, desse modo, mais bem qualificar e caracterizar o tema aqui proposto, além de estabelecer um campo temático que possibilite trazer à berlinda aspectos técnicos e plásticos das obras e do repertório profissional niemeyeriano, de modo a refletir, consequentemente, sobre a simbiótica e permeável relação entre engenharia e arquitetura. 
Chega-se, agora, a um impasse para este trabalho: se nele é impraticável a análise da totalidade das obras niemeyerianas - tarefa hercúlea e de resultado duvidoso - uma pequena amostra de seus trabalhos deve, logo, ser identificada. E essa escolha há que considerar, para ser mais certeira, que a carreira do arquiteto não se desenrola em um único contínuo ascendente ao longo do tempo, pois se assim o fosse, as relações entre suas produções poderiam ser, quem sabe, mais evidentes e fáceis de se distinguir.

Isso significa dizer que a trajetória de Oscar Niemeyer pode ser organizada em quatro fases sequenciais, cada uma das quais interposta por uma profunda revisão crítica pessoal e profissional motivada e estabelecida pelo próprio arquiteto. A cada novo momento de introspecção, um novo posicionamento arquitetônico é adotado e paulatinamente aperfeiçoado até o próximo período de inflexão, e assim sucessivamente.

A primeira fase coincide com os projetos iniciais elaborados pelo arquiteto, a partir dos quais conquista reconhecimento gradativo seja no Brasil ou fora dele. É um período representado inicialmente pelas experimentações das teorias de Le Corbusier fundamentadas no "Sistema Domino". Com o passar do tempo e depois de completa assimilação das obras corbusianas, Niemeyer mostra-se capaz de alargar o repertório do mestre franco-suíço e ir além, fazendo proposições tais que resultariam futuramente em uma arquitetura moderna de feições nacionais transgredindo, portanto, os postulados da tradicional arquitetura moderna internacional.

Em meados da década de 1950, Oscar Niemeyer atravessa o seu primeiro período meditativo, que resulta em um novo ponto de vista sobre a arquitetura no geral, e sobre sua própria produção, em particular. Deste momento em diante, o arquiteto carioca passa a entender como coisa única forma e estrutura, resolvendo-as ambas concomitantemente (e não sequencialmente) à medida que um novo projeto é pensado. Potencializa, assim, o uso plástico do concreto e foca arquiteturas mais arrojadas, contudo, materializadas em volumetrias sintéticas, puras, limpas e plenas de leveza estética.

Esse novo olhar lançado sobre sua própria arquitetura é mais bem trabalhado a partir do próximo momento de ponderação crítica. Percebe-se, pois, nova alteração em seu fazer projetual - desta vez sutilmente mais discreta anos depois, quando chega próximo o final da década de 1960. Os projetos concebidos a partir de então são 
tecnologicamente mais desafiadores ao apostarem em soluções estruturais portantes de grandes proporções. Mas não é só isso. As estruturas assumem dali em diante o papel proeminente de determinar não apenas o partido arquitetônico, mas também o de se responsabilizar pela definição da forma dos próprios edifícios.

A partir de meados da década de 1980 e após sua última revisão profissional, a arquitetura niemeyeriana torna-se tanto mais individualista quanto menos se relaciona ao entorno, sendo marcada por volumes lacônicos abstratos, escultóricos e representativos. É uma fase em que o arquiteto, em prol de simplificações volumétricas, passa a não mais valorizar como outrora os problemas de cunho programático-funcionais. Interessa-Ihe mais que nunca antes aquilo que desperta surpresa e admiração - mesmo que para isso tenha que desafiar as leis do equilíbrio e da gravidade. Há, porém, nesta nova fase, instantes em que Niemeyer encontra-se novamente com o seu fazer arquitetônico que lhe foi tão característico ao longo da carreira, ao voltar sua atenção, uma vez mais, às questões de funcionalidade programática. Resultam daí arquiteturas pontuais, mas que muito remetem aos seus tempos passados - não necessariamente em termos formais, mas conceituais.

Baseando-se então na produção arquitetônica de Oscar Niemeyer - conduzida pelos seus vários momentos de introspecção crítica - e visando aqui a uma discussão que incentive reflexões calcadas na imbricada e permeável relação entre técnica e forma na arquitetura moderna por ele praticada, sugere-se a adoção de um conjunto de critérios de seleção a partir dos quais as obras devem ser:

- Integrantes do recorte temporal imposto a esta dissertação, ou seja, projetadas/construídas entre as décadas de 1930 e 1960;

- Pertencentes, individual ou coletivamente, a distintas fases pelas quais passou a carreira de Niemeyer, confirmando assim as diferenças projetuais e formais de suas arquiteturas a cada nova inflexão;

- Contextualizadas em momentos históricos que incentivassem as soluções nelas adotadas, isto é, que permitissem pensar sobre os reflexos dos acontecimentos externos nos projetos propriamente ditos;

- Representantes de avanços consistentes nas áreas técnicas/tecnológicas, tomando, portanto, a arquitetura também como um instrumento de materialização de novas possibilidades construtivas;

- Caracterizadoras de esforços simultâneos de cooperação entre diferentes áreas do conhecimento, ou seja, entre arquitetura e engenharia; $\mathrm{e}$ 
- Reconhecidas pela crítica como obras notáveis e/ou paradigmáticas, cujo simbolismo exerceria influência em outras arquiteturas delas decorrentes - sejam elas de Oscar Niemeyer ou não.

Resultam dos critérios de escolha, as arquiteturas 3 :

- No Rio de Janeiro, o Ministério da Educação e Saúde - MES (1945):

Projetado e construído entre 1936 e 1945 durante a primeira fase da carreira de Oscar Niemeyer. Trata-se de um momento de grandes transformações no segmento da construção civil brasileiro, no qual as indústrias de base de aço e cimento finalmente se estabeleceram e amadureceram. A sinergia entre as equipes de arquitetos e de engenheiros que trabalharam no projeto do MES resultou em uma obra alinhada aos preceitos modernos então vigentes. O resultado positivo só pôde ser alcançado mediante o empenho de ambas as equipes que, juntas, superaram obstáculos e impuseram avanços técnicos/tecnológicos por conta própria: basta pensar no sistema de contraventamento, nos extensos panos de vidro das fachadas e nas lajescogumelo moldadas em concreto armado e pela primeira vez especificadas no Brasil. O resultado é tão positivo que antes mesmo de estar concluída, esta obra já era reconhecida por sua qualidade e por conferir certo ar de brasilidade à arquitetura moderna mundial.

- Em Nova York, o Pavilhão do Brasil na Feira Internacional (1939):

Ao longo da demorada construção da nova sede para o Ministério da Educação e Saúde, o Brasil foi representado pelo pavilhão temporário de Lucio Costa e Oscar Niemeyer em uma importante feira internacional ocorrida em Nova York. Sob o tema "Construindo o Mundo de Amanhã”, o evento buscou ajudar na alavancagem das negociações econômicas entre os Estados Unidos e as demais nações, além de contribuir na recuperação do país frente a crise de 1929 e de servir como pretexto para a comemoração dos 150 anos da posse do primeiro presidente americano. O projeto brasileiro destacou-se pelo contraste frente os demais pavilhões: trouxe volumes curvos, rampas, elementos vazados, grandes aberturas, planta livre. O conjunto dessas soluções, assim, incentivou o fluxo de pessoas e a interação com sítio onde esteve implantado. Erigido

\footnotetext{
3 Não é pretensão deste estudo considerar que as edificações selecionadas sejam as únicas que se enquadram nos critérios sugeridos. Certamente em um repertório tão rico quanto o de Oscar Niemeyer, outros exemplos poderiam ser trazidos à pauta. Porém, acredita-se que estas obras sejam suficientemente desafiadoras, interessantes e apropriadas à discussão fomentada por este trabalho.
} 
em concreto armado e em estrutura metálica, representou o início de uma nova linguagem arquitetônica, elogiada em diversas publicações estrangeiras.

- Em Minas Gerais, o Conjunto Arquitetônico da Lagoa da Pampulha (1940 - 1943):

Ainda durante a primeira fase da trajetória de Oscar Niemeyer, esta empreitada representou o primeiro projeto de porte por ele elaborado em carreira solo. Do conjunto de edifícios presentes na proposta original para o novo bairro mineiro, foram construídos o Cassino, a Casa do Baile, o late Clube e a Capela de São Francisco de Assis - todos às margens da Lagoa da Pampulha, e cada um dos quais com suas inovações formais e conceituais que, gradualmente, ajudaram o arquiteto a amadurecer o seu próprio vocabulário projetual. Foi no desenho da Capela que Niemeyer mereceu destaque, ao subverter os postulados corbusianos. Adotou, neste caso, uma solução arquitetônico-estrutural até então só aplicada em construções de grande porte: para a cobertura da nave principal, uma casca paraboloide de seção variável que rompeu para com os limites préestabelecidos entre paredes e teto. Calculada pelo engenheiro civil Joaquim Cardozo, foi moldada em concreto armado e materializou a plasticidade de uma técnica que já tanta admiração despertava no arquiteto carioca.

- Em Brasília, os Palácios da Alvorada (1956) e do Itamaraty (1962):

A construção da Capital Federal a partir de uma tabula rasa representou, em meados dos anos 1900, uma ocasião única para expressar todo o potencial técnico e tecnológico que as estruturas de concreto poderiam proporcionar ao segmento da construção civil - e as edificações lá erguidas foram prova disso. Peças-chave, portanto, de um período pleno de experimentações e de novas descobertas para esse setor, no qual o país provava cada vez mais destaque frente à produção internacional.

Edifício pioneiro em Brasília, o Palácio da Alvorada foi inaugurado em 1958, logo após a primeira fase de revisão crítica vivenciada por Oscar Niemeyer. Nota-se, nesta obra pura e sintética, que o arquiteto já adotou um vocabulário predominantemente plástico, tirando proveito das questões estruturais como expressão arquitetônica: a arcada parabólica invertida que faz as vezes de apoio externo ao entablamento e ao teto plano é suportada por arcos que partem da parte inferior e que mal tocam o solo. Niemeyer e Cardozo valeram-se de uma solução arquitetônica que escamoteia a presença estrutural de malha regular como modo 
de conferir um caráter de leveza ao conjunto edificado: os pilares frontais curvilíneos, de ritmo contínuo e de claro destaque formal, são responsáveis por tolerar o peso da delgada laje por sobre eles, ao passo que o restante da edificação apoia-se em colunas de sustentação distribuídas no interior do edifício - e não necessariamente visíveis.

Já o Palácio do Itamaraty (ou Palácio dos Arcos) foi erguido para conformar a nova sede do Ministério das Relações Exteriores e compõe, juntamente com o Palácio da Justiça, um segundo conjunto de edifícios oficiais concebidos por Oscar Niemeyer em 1962 e inaugurados, ambos, em 1970 e em 1972, respectivamente. O Palácio do Itamaraty trouxe uma solução geral bastante sóbria e austera, porém leve e graciosa: é composta por um prisma recuado de vidro volteado por um peristilo de concreto aparente formado por arcadas simétricas de rigor cartesiano, cuja configuração edificada permite que seja estabelecida plena integração ao sítio urbano no qual se insere (a Esplanada dos Ministérios). O conjunto de pilares externos, aqui também, não são os únicos a amparar a laje da cobertura quadrangular, uma vez que pilares dispostos modularmente por todo o interior do edifício compartilham o peso das cargas descendentes.

- Em Milão, o Palazzo Mondadori (1968):

O segundo ponto de mudança de pensamento de Niemeyer ocorreu às vésperas da década de 1970, oportunidade na qual seus projetos assumiram um viés fortemente estruturalista e tecnológico. Nesta obra, a resposta às questões construtivas e técnico-funcionais satisfez igualmente às condições conceituais e normativas mais avançadas e exigentes à época. Ambos os fatores foram dados por resolvidos por Oscar Niemeyer no momento em que tanto a síntese da articulação quanto a da distribuição do programa tornaramse, enfim, estabelecidos.

O Palazzo Mondadori carregou consigo, no que concerne ao repertório niemeyeriano, a "novidade" de vincular à colunata externa uma função não conformada apenas pela estética, mas de pertinência estrutural portante. Além disso, à estrutura também foi atribuído o encargo pela adequação arquitetônica e de arranjo espacial, visando alcançar os limites máximos tecnológicos e construtivos disponíveis naquele momento. 
“Oscar Niemeyer”; “Modernismo”; “Arquitetura Moderna”; “Técnica”; “Tecnologia”; “Concreto”; “Forma”; "Estética". Todos temas de interesse deste estudo. Todos temas recorrentes em literaturas das mais variadas, o que tornou a seleção de títulos para esta dissertação, uma árdua empreitada. Houve, porém, algumas obras fundamentais que contribuíram para uma visão perspectivada da era moderna e da arquitetura ao longo dos anos. Guardadas as devidas particularidades entre cada caso, destacaram-se os compêndios: Los Ideales de la Arquitectura Moderna; Su Evolución - 1750 - 1950 (de Peter Collins; 1970); Teoria e Projeto na Primeira Era da Máquina (de Peter Reyner Banham; 1979); Arquitetura Contemporânea no Brasil (de Yves Bruand; 1997); Origens da Arquitetura Moderna e do Design (de Nikolaus Pevsner; 2001); Espaço, Tempo e Arquitetura - O Desenvolvimento de uma Nova Tradição (de Sigfried Giedion; 2004); História Crítica da Arquitetura Moderna (de Kenneth Frampton; 2008); Guia llustrado Zahar de Arquitetura (de Jonathan Glancey; 2012); e O Futuro da Arquitetura Desde 1889 (Jean-Louis Cohen; 2013). E sobre a abordagem da arquitetura moderna brasileira comentada por títulos estrangeiros, foram consultados: Brazil Builds: Architecture New and Old 1652 - 1942 (de Philip Goodwin: 1943) e Modern Architecture in Brazil (de Henrique Mindlin: 1956 - este, ainda que nacional, foi inicialmente publicado apenas em inglês).

Já no Brasil, das publicações mais recentes que abarcam um histórico consistente da arquitetura nacional, foram adotadas para este trabalho: Brasil: Arquiteturas Após 1950 (de Maria Alice Junqueira Bastos e Ruth Verde Zein; 2010) e Arquiteturas no Brasil 1900 - 1990 (de Hugo Massaki Segawa; 2010). Além destes e também considerando aspectos inerentes à história da arquitetura brasileira, os escritos em forma de artigos, ensaios, capítulos de livros e coletâneas ou afins, de: Carlos Eduardo Dias Comas; Edson da Cunha Mahfuz; Guilherme Wisnik, Jonathan Glancey; Júlio Roberto Katinsky; Lauro Cavalcanti; Luis Espallargas Gimenez; Roberto Segre; e Ruth Verde Zein serviram tanto para lançar luz sobre o panorama nacional ao longo do tempo quanto para motivar pesquisas sobre assuntos mais direcionados ao tema deste estudo, como: Le Corbusier; arquitetura brasileira; identidade arquitetônica nacional; a complexidade do movimento moderno; vida e obra de Oscar Niemeyer; e outros. 
Alguns títulos específicos também tiveram consulta obrigatória. Organizados por assunto e por data de publicação, citam-se os que mais subsídios trouxeram a este trabalho:

Arte e Estética: Padrões de Intenção: A Explicação Histórica dos Quadros (de Michael Baxandall; 2006): trata-se de uma obra (já comentada anteriormente, no item "Metodologia”) em que o autor propõe um novo procedimento para observar obras de arte; Dicionário de Estética (de Gianni Carchia \& Paolo D’Angelo; 2009): abrange assuntos diversos, mas sempre na óptica da sua relação para com a estética. Em geral, traz definições específicas que ajudam a compreender o vasto e complexo vocabulário relacionado às artes em geral; e Estética da Arquitectura (de Roger Scruton; 2010): direcionado ao estudo da estética e da história da arte, no qual o autor desenvolve uma discussão sobre as qualidades artísticas e formais da arquitetura, aos olhos de seu lugar na vida prática das pessoas.

\section{Arquitetura Moderna no Brasil e no Exterior: Manierismo y Arquitectura Moderna y Otros Ensayos (de Colin Rowe;} 1978): o autor conduz uma análise transversal da história da arquitetura por meio de uma coletânea de artigos publicados pela primeira vez na década de 1940 nas revistas "Architectural Review", "Oppositions", "Granta" e "Perspecta"; Registro de uma Vivência (de Lucio Costa; 1995): coloca-se como uma obra autobiográfica que traz a trajetória profissional e o pensamento de um dos maiores arquitetos e urbanistas do país. A partir dela, pode-se constituir uma visão panorâmica da cultura brasileira ao longo dos anos 1900; Depoimento de uma Geração: Arquitetura Moderna Brasileira (de Alberto Xavier - Org.; 2003): nesta reedição revista e ampliada, estão oitenta ensaios relacionados à arquitetura moderna brasileira, datados da primeira metade do século 20 e que contribuem cada um à sua maneira - na busca por uma identidade nacional em sentido amplo; e Moderno e Brasileiro: A História de uma Nova Linguagem na Arquitetura: 1930 - 1960 (de Lauro Cavalcanti; 2006): este livro discute como se formou e como amadureceu, entre 1930 e 1960, o grupo dos arquitetos modernos brasileiros (entre eles Lucio Costa e Oscar Niemeyer) e como estes se sobressaíram perante seus contemporâneos neocoloniais e acadêmicos. Como consequência, o autor mostra que a predominância moderna ajudou a forjar a imagem de um novo Brasil perante os públicos nacional e internacional.

\section{No Brasil: Engenharia Civil / Materiais de Construção / Técnica e Tecnologia: História da Técnica e da Tecnologia no} Brasil (de Milton Vargas; 1994): no qual o autor faz uma apresentação de fatos pouco conhecidos que ajudam a compreender os motivos pelos quais o Brasil é, até os dias de hoje, uma nação tecnologicamente defasada em relação a outros países do mundo. Aborda, também, os obstáculos e as possibilidades tecnológicas pertinentes à inserção do 
Brasil na era da modernidade; O Concreto no Brasil: Recordes, Realizações, História - Volume 1 (de Augusto Carlos de Vasconcelos; 1985): neste título, o autor mostra a evolução do concreto armado no Brasil não apenas considerando seus aspectos técnicos e/ou tecnológicos mas, também, valorizando os profissionais da engenharia (e suas respectivas obras) que contribuíram para fazer do concreto armado a técnica de construção mais utilizada no país; e Aspectos da História da Engenharia Civil em São Paulo: 1860 - 1960 (de Nestor Goulart Reis Filho; 1989): este livro representa uma importante contribuição à história da construção civil brasileira. Ainda que não se aproxime dos aspectos teóricos e nem dos programas de ensino ou de pesquisa, o autor volta seu olhar às realizações práticas da construção civil propriamente dita, abordando, inclusive, o valor estético dos vários exemplos colocados em pauta.

Por Oscar Niemeyer: Depoimento (In: Revista Módulo; 1958): texto basilar para compreender o momento de revisão crítica vivenciado pelo arquiteto carioca em meados dos anos 1900 e como isso se reflete em suas arquiteturas vindouras; e Minha Arquitetura (2008): trata-se de uma obra na qual Oscar Niemeyer faz uma avaliação de sua trajetória, considerando o período entre Pampulha e o Museu de Arte Contemporânea de Niterói, passando pelos palácios de Brasília, pelo Palazzo Mondadori em Milão, pela sede do Partido Comunista em Paris e por outros projetos no Brasil ou fora dele. A narrativa busca mostrar como a obra do arquiteto veio se compondo ao longo do tempo, como e o que a diferencia e quais relações podem ser estabelecidas entre seu trabalho e o dos grandes mestres.

Sobre Oscar Niemeyer e Suas Obras: The Work of Oscar Niemeyer (de Stamo Papadaki; 1950): aproxima-se do formato de um catálogo, no qual está relacionado - e ilustrado - um conjunto de obras de Oscar Niemeyer condizente ao seu período de produção até meados dos anos de 1900 - seja no Brasil ou no exterior; A Arquitetura de Oscar Niemeyer (de Lionello Puppi; 1988): Trata-se de um guia articulado iniciado por um ensaio crítico introdutório. Na sequência, dezesseis obras são discutidas e apresentadas com o suporte de imagens das obras do arquiteto; Ministério da Educação e Saúde: Ícone Urbano da Modernidade Carioca, 1935 - 1945 (de Roberto Segre; 2013): é uma das obras mais completas sobre o Ministério da Educação e Saúde no Rio de Janeiro. Vastamente ilustrado por imagens de época e atuais, além de desenhos e projetos, o livro efetua uma investigação dos fatores arquitetônicos, culturais e políticos que resultaram na síntese definida pela linguagem do prédio, a partir da qual, pode-se dizer, a arquitetura moderna ganhou uma feição brasileira; e Oscar Niemeyer e o Modernismo de Formas Livres no Brasil (de David Underwood; 2003): o autor parte do princípio que o ambiente carioca composto por cultura, sociedade e natureza tornou-se a principal inspiração para o fazer arquitetônico niemeyeriano. Coloca-se, portanto, em um ponto de vista oposto ao da 
crítica generalizada que prega que o sucesso de Niemeyer deve-se majoritariamente à preocupação formal de suas obras.

A bibliografia não publicada pelo mercado editorial, ou seja, aquela derivada de pesquisas acadêmicas como artigos científicos, dissertações e teses elaboradas principalmente nos cursos de arquitetura e urbanismo em várias instituições do Brasil, mostrou-se um terreno fértil para o desenrolar deste trabalho. Assume-se até que o maior grau de contribuição a este estudo tenha sido, justamente, o deste tipo de referência. Dentre as fontes consultadas, relacionam-se abaixo algumas delas (porém não em ordem de importância, mas cronológica):

Por uma Arquitetura, Brasileira (de Luiz Recamán; 1996 - Mestrado em Filosofia - Faculdade de Filosofia, Letras e Ciências Humanas da Universidade de São Paulo): ao propor a compreensão dos elementos que constituíram a obra de Oscar Niemeyer, o autor questiona os fatores que levaram à delimitação de um período de formação da nova fase da arquitetura brasileira. Avalia, para isso, o estabelecimento de temas que redistribuíram períodos, projetos, influências e conjunturas incidentes. Nos projetos analisados, o autor persegue aquilo que chama de "modelo" (ou de "arquitetura hegemônica” niemeyeriana), tentando explicá-lo não só por meio dos próprios projetos, mas também do ideário e da cultura. O trabalho de Recamán engloba um período que em muito se assemelha ao deste trabalho e foca, também, uma discussão sobre três obras aqui muito caras: o Ministério da Educação e Saúde (MES), o Pavilhão do Brasil na Feira Internacional de Nova York de 1939 e o Conjunto Arquitetônico de Pampulha.

Desenvolvimento da Forma e Procedimentos de Projeto na Arquitetura de Oscar Niemeyer, 1935 - 1998 (de Marco Antônio Alves do Valle; 2000 - Tese de Doutoramento - Faculdade de Arquitetura e Urbanismo, Universidade de São Paulo): a tese resulta em um estudo aprofundado do desenvolvimento formal e dos procedimentos de projeto que qualificam a obra do arquiteto Oscar Niemeyer. Mostra a reconfiguração das proposições projetuais de Le Corbusier e discute a formação de uma linguagem própria a Niemeyer dotada de significado e de identidade que lhes são muito peculiares, ou seja, que resultam em projetos autorais e facilmente reconhecíveis. Além disso, traça um histórico bastante preciso sobre a produção do arquiteto carioca. Este é um conteúdo fundamental para compreender a longa produção arquitetônica de Oscar Niemeyer e para perceber a maneira pela qual ele pensava e idealizava as formas de suas arquiteturas - daí a contribuição para esta dissertação. 
A Matéria da Invenção: Criação e Construção das Obras de Oscar Niemeyer em Minas Gerais, 1938 - 1954 (de Danilo Matoso Macedo: 2002 - Dissertação de Mestrado - Faculdade de Arquitetura e Urbanismo, Universidade Federal de Minas Gerais): trata-se de um trabalho bastante completo e bem-cuidado, que abrange uma parte significativa da primeira fase de produção arquitetônica de Oscar Niemeyer, na qual ele assimila e extrapola as proposições arquitetônicas corbusianas. Com recorte delimitado à sua produção mineira, serviu aqui como material de consulta, sobretudo para o Conjunto Arquitetônico da Pampulha, considerando suas influências, inspirações e consequências.

Exoesqueletos no Modernismo Brasileiro nas Décadas de 40 e 50 do Século XX (de Júlio Ramos Collares; 2003 Dissertação de Mestrado - Programa de Pesquisa e Pós-graduação em Arquitetura, Universidade Federal do Rio Grande do Sul): como o próprio título sugere, o trabalho busca discutir a estrutura exposta em um conjunto de obras de filiação modernista projetadas - mas não construídas - por Oscar Niemeyer. Dentre outras contribuições para este estudo, a mais significativa está reservada ao capítulo inicial, chamado "Antecedentes", no qual o autor traça uma ligeira evolução histórica do papel da estrutura na arquitetura. Foi a partir deste conteúdo que, em uma pesquisa revisada e ampliada, o panorama histórico sobre aço e cimento foi aqui desenvolvido.

Arquitetura Paulistana da Década de 1960: Técnica e Forma (de Luis Espallargas Gimenez; 2004 - Tese de Doutoramento - Faculdade de Arquitetura e Urbanismo, Universidade de São Paulo): mesmo apresentando tema alinhado ao deste trabalho segue uma linha diferente, pois Espallargas objetiva discutir o composto formado por forma e partido sob o viés do Brutalismo. Ainda assim, ao elaborar suas reflexões - por vezes dotadas de uma postura crítica bastante aguda - o autor lança luz a algumas obras-chave do movimento moderno brasileiro, dentre as quais, o Ministério da Educação e Saúde. A investigação do autor sobre este edifício ajuda a mais bem entendê-lo como objeto arquitetônico e como elemento que se insere em um contexto urbano pré-existente.

Oscar Niemeyer e Le Corbusier: Encontros (de Rodrigo Cristiano Queiroz; 2007 - Tese de Doutoramento - Faculdade de Arquitetura e Urbanismo, Universidade de São Paulo): este estudo promove uma leitura comparativa entre as obras de Niemeyer e de Le Corbusier, sugerindo que um diálogo pode ser estabelecido entre ambas. De acordo com Queiroz, não é apenas um caminho em uma única direção, ou seja, não é somente o arquiteto carioca que é influenciado por seu mestre, pois o inverso também ocorre, e isso é comprovado pelo autor. Se se procura uma obra que delineie um levantamento e um texto precisos sobre o entrelaçamento entre ambos os arquitetos, esta é de 
consulta obrigatória. Além disso, ajuda a compreender o amadurecimento de Oscar Niemeyer e as inspirações nas quais se baseou para muitas de suas arquiteturas.

Técnica e Estética no Concreto Armado: Um Estudo sobre os Edifícios do MASP e da FAUUSP (de Ana Clara Giannechini; 2009 - Dissertação de Mestrado - Faculdade de Arquitetura e Urbanismo, Universidade de São Paulo): ao sugerir uma análise no campo da história da técnica da arquitetura moderna no Brasil, o trabalho busca refletir sobre o uso do concreto em duas obras notáveis: o edifício da FAUUSP (de Vilanova Artigas) e o do MASP (de Lina Bo Bardi). Ainda que sejam arquiteturas e arquitetos distintos dos do foco desta dissertação, ambos os conteúdos tocam-se ao investigar os campos referentes à técnica (ou à construção) em relação à estética (ou à expressão).

Modernidade Concreta: As Grandes Construtoras e o Concreto Armado no Brasil, 1920 a 1940 (de Maria Luiza Macedo Xavier de Freitas; 2011 - Tese de Doutoramento - Faculdade de Arquitetura e Urbanismo, Universidade de São Paulo): a autora faz um apanhado histórico bastante interessante sobre a atuação das grandes empresas construtoras no Brasil, creditando a elas um papel fundamental para a modernização da arquitetura no período compreendido entre 1920 e 1940. Além de outros pontos, examina programas construtivos diversos por meio da premissa da técnica e de suas consequências na realização arquitetônica. Busca compreender a constituição do conhecimento sobre o concreto armado nos campos da engenharia e da arquitetura, e assim promove o intercâmbio entre ambas as disciplinas. Trata-se, portanto, de um conteúdo de grande valia para esta dissertação, sobretudo no que diz respeito ao histórico das indústrias de cimento no Brasil e o papel importante das grandes construtoras para o desenvolvimento do setor da construção civil no país e, consequentemente, para o aprimoramento das profissões de arquiteto e de engenheiro em território nacional.

Os Palácios Originais de Brasília (de Elcio Gomes da Silva; 2012 - Tese de Doutoramento - Faculdade de Arquitetura e Urbanismo, Universidade de Brasília): o trabalho baseia-se em uma análise minuciosa sobre quatro palácios da Capital Federal: o da Alvorada, o do Congresso Nacional, o do Supremo Tribunal Federal e o do Planalto, afirmando que essas obras representam os importantes marcos da arquitetura e da engenharia de estruturas no Brasil. O autor afirma que o domínio das soluções estruturais e o prazo exíguo para construção podem ser entendidos como determinantes das decisões projetuais arquitetônicas, constantemente revistas. Além disso, complementa a tese de doutoramento de Freitas (2011), ao expor quais construtoras se responsabilizaram pelas construções de quais palácios e aponta, ainda, as dificuldades que vivenciaram nessa empreitada. É uma pesquisa rica, completa e calcada em documentações 
originárias de arquivos brasilienses, portanto, fundamental para qualquer estudo que trate do tema, direta ou indiretamente.

Como aporte historiográfico que envolve, articula e permeia boa parte da discussão deste material, elegeu-se, a título de referência teórica, o artigo da Profa. Dra. Mônica Junqueira de Camargo, intitulado A Presença Brasileira na Historiografia da Arquitetura do Século XX, inicialmente publicado no "DOCOMOMO Journal” de 2006 e reeditado na “Desígnio Revista de História da Arquitetura e do Urbanismo” de 2011. Em seu estudo, Camargo procurou compreender a participação da produção nacional na trajetória da arquitetura do século 20 aos olhos de estudiosos e teóricos estrangeiros. Para tanto, valeu-se inicialmente do acervo da biblioteca da Faculdade de Arquitetura e Urbanismo da Universidade de São Paulo e identificou, nele, um total de vinte e dois compêndios publicados entre 1936 e 2002 , os quais traçam vastos panoramas sobre a arquitetura moderna no período aqui considerado 4 .

Os quase setenta anos de produção compreendidos nesse intervalo indicam que as obras arquitetônicas nacionais mais referenciadas nos títulos analisados encontram-se entre o Ministério da Educação e Saúde e Brasília - fato esse que reforça o motivo pelo qual o grupo de arquiteturas de Oscar Niemeyer aqui investigado, foi selecionado.

\section{Organização do Trabalho}

Como visto, é a partir da crítica inferencial de Baxandall (2006) que se objetiva efetuar aqui uma reflexão tanto sobre a subordinação da forma à técnica quanto em relação à sujeição da técnica à forma, tendo como objeto a arquitetura construída e representada por um pequeno grupo de obras de Oscar Niemeyer. A tríade de fatores "circunstâncias", "autor" e "objeto" é assim apontada como a responsável por dar andamento às questões propostas nesta dissertação. Busca-se, por fim, que o trabalho esteja equacionado de tal forma a que o leitor seja convidado a envolverse gradativa e crescentemente com o tema ora proposto.

\footnotetext{
4 Uma vez que esse levantamento é fundamentalmente direcionado à arquitetura moderna - fonte na qual bebeu Oscar Niemeyer - acreditase conveniente, aqui também, a utilização do mesmo conjunto bibliográfico utilizado por Camargo em sua pesquisa (devidamente destacado em itálico e com o título original mantido).
} 
Visando a moldar um painel teórico-conceitual inicial - e que ajuda a embasar as discussões vindouras, em “Estética e Técnica: Prelúdios sobre uma Arquitetura Tecida entre Fronteiras", pondera-se sobre o campo por vezes incerto em que habita a arquitetura, no qual há influências advindas de duas frentes distintas, porém complementares entre si: a arte e a técnica. Se seu perfil polissêmico motiva uma multiplicidade de apreensões a seu respeito, certo é que desperta interesse das mais variadas áreas do conhecimento. Ao ser compreendida como arte, é tema de investigações de vários pensadores já por séculos - e algumas de suas reflexões são aqui brevemente apresentadas. Sabe-se, contudo, que a arquitetura é também fruto de meditações dos próprios profissionais que com ela lidam, ou seja, dos arquitetos, os quais muitas vezes teorizam a seu respeito procurando situá-la, quem sabe, em um universo mais bem definido e que ajude-os a apaziguar as suas próprias inquietações projetuais e/ou construtivas. Por isso, as teorias que procuram relacionar o duo plasticidade e partido - são também trazidas à pauta, mesmo que sucintamente.

Como já mencionado, é fato que a arquitetura admite alterações de forma (e aí implícitas também mudanças de volumetrias, de técnicas construtivas, de materialidades e afins) mesmo que não relacionadas diretamente a qualquer variação na inspiração artística do seu projetista. Esta constatação pode ser mais bem exemplificada pela chegada do aço e do cimento Portland à construção civil de larga escala. Em “Aço e Cimento: Agentes de um novo Significado para Arquitetura e Engenharia" discute-se a industrialização de base como um dos marcos que caracterizaram o século 19, sobretudo no que se refere aos progressos alcançados, e nunca dantes vivenciados. Foi por meio dela que primeiro o ferro fundido e logo depois o aço passaram a fazer parte do cotidiano dos engenheiros e dos arquitetos, fundamentados que estavam na absorção de novas tecnologias e de técnicas construtivas. O panorama de desenvolvimento ascendente é complementado pela descoberta do cimento e do concreto dele derivado: novos materiais de construção que, juntos, ressignificaram o fazer construtivo mundial (inclusive no Brasil) e que, paulatinamente, colaboraram para a conformação daquilo que se tomaria por arquitetura moderna.

E é em um cenário industrializado cada vez mais relevante que toma vulto, em terras brasileiras, o nome do arquiteto carioca Oscar Niemeyer, o qual desde o início da carreira adota o concreto armado como a sua técnica basilar tanto projetual quanto construtiva. Os avanços vivenciados pela indústria daquela época - e as novas possiblidades provenientes do uso desse material - são logo exercitados pelo perfil empreendedor e propositivo desse arquiteto. Por isso, em “Oscar Niemeyer: Razão e Liberdade na Arquitetura Moderna Brasileira”, propõe-se uma visão histórica 
e perspectivada de uma diminuta parte da trajetória desse profissional, a partir da qual percebe-se sua gradativa evolução ao longo do tempo: uma trajetória que se conduz firme, porém, que se reinventa a cada novo ciclo vivenciado: a cada nova fase projetual, uma nova postura arquitetônica é por ele abraçada e que desemboca em obras que lhe são muito características.

Por fim, é também nesta etapa da dissertação que as obras previamente selecionadas são detidamente discutidas, cada uma a seu momento. Porém, não sem antes contextualizá-las todas em função das variáveis ambientais e circunstanciais que, se somadas às revisões críticas vividas por Niemeyer, resultam em objetos arquitetônicos cujos predicados não poderiam ser outros, se não aqueles alcançados. Esta investigação da prática niemeyeriana traz à tona, em paralelo, a relação de proximidade, de parceira e de companheirismo que o arquiteto carioca mantinha para com as suas equipes técnicas, mais bem representadas pelos engenheiros Emílio Baumgart e Joaquim Cardozo, os quais foram responsáveis por inúmeras inovações técnicas e tecnológicas que visavam a possibilitar que os projetos ora concebidos fossem também erigidos sem quaisquer variações e direcionados, portanto, à valorização das questões inerentes à plasticidade dos edifícios. 
2.

ESTÉTICA E TÉCNICA: PRELÚDIOS SOBRE UMA ARQUITETURA TECIDA ENTRE FRONTEIRAS 


\section{Explicações Necessárias}

A consciência da interdisciplinaridade da arquitetura faz recorrer constantemente ao auxílio de outros ramos do conhecimento como forma de delinear um entendimento mais abrangente, porém não menos profundo, desta área tão fascinante. Vista por alguns como uma ciência técnica ou exata, por outros como uma ciência social aplicada, por outros ainda como uma arte, ou mesmo como um conjunto dessas diferentes visões, a arquitetura dá margem a que várias interpretações sejam a ela imputadas, contribuindo, assim, para a manifestação de muitas teorias que, consequentemente, enriquecem a discussão a seu próprio respeito.

Ao admitir tantas denominações diferentes, a arquitetura demonstra e comprova o seu perfil polissêmico, voltado a uma multiplicidade de apreensões que, juntas ou isoladamente, ajudam-na a equacionar as variáveis universais às quais tem a intenção de atender. Dito de outra maneira, a arquitetura pode ser apreendida pelos seus cenários internos e externos, pela concatenação de ambientes, pela definição de materialidades, pelo caminhamento dos fluxos de pessoas, pelas soluções espaciais e tectônicas. Todas essas variáveis - e tantas outras mais - contribuem para a promoção da experiência estética arquitetônica e admitem um sem-número de entendimentos posteriores, sempre embasados nas vivências próprias de cada indivíduo que dela desfruta.

Mas a polivalência dessa disciplina não se limita à sua terminologia e nem mesmo ao seu caráter. Tanto é fato que, por um lado, as propostas derivadas das regras de composição predominantemente ortogonais, limpas, seriadas e funcionais praticadas pela arquitetura moderna de outrora buscam, em última instância, um modo de vida mais simples, de mais qualidade e relativamente mais eficiente ao ser humano. Por outro lado, as volumetrias mais ousadas da arquitetura contemporânea dissolvem cada vez mais uma dita fragmentação em uma "atmosfera genérica" que demanda arquiteturas que se identificam pelas formas e volumetrias das mais variadas, criativas e pouco convencionais, por vezes qualificadas pela fluidez, pela carência de limites, por mutações constantes e onde a "ação" parece ser efetivamente mais importante que qualquer outro predicado a ela associado.

Seja qual for a sua proposta, a arquitetura como expressão artística tem sido insistentemente debatida ao longo dos anos por diversos pensadores que tentam compreender o seu caráter tão particular, porém tão abrangente e diversificado. E é sobre isso que trata a discussão das próximas páginas. 
Ao admitir a arquitetura como uma expressão artística fundamental, este estudo propõe inicialmente que seja possível regredir no tempo e refletir sobre a própria arte, por exemplo, aos olhos da filosofia ${ }^{5}$. Com a ajuda de alguns pensadores que se preocupam em apreendê-la, sua teorização passa então a ser situada em duas ocasiões distintas: a primeira delas, contemporânea dos pensadores Platão (427 a.C. - 348 a.C.) e Aristóteles (384 a.C. - 322 a.C.), referese às artes sob o prisma da poética (termo derivado da "poiesis", isto é, "fabricação"). Já a segunda, conformada principalmente no transcorrer do século 18 em diante, trata as artes como expressão estética.

Ao contrário da física, que estuda o que é atinente à natureza, a poética foca as obras de arte fabricadas pelo homem, portanto, executadas com ações e gestos artificiais. Por isso, a arte observada sob este prisma lida com procedimentos e regras de construção e de constituição. Deriva daí o fato de que os tratados sobre artes poéticas desde a Antiguidade possuem um caráter predominantemente prescritivo, baseado em regras que devem ser seguidas e obedecidas tanto pelo artista ao conceber uma nova obra, quanto pelos seus receptores, para que estes possam avaliá-la da maneira considerada normativamente ideal.

Existe também uma preocupação bastante presente nos tempos de Platão e de Aristóteles em avaliar a arte condicionada à ética, à política e à metafísica, ou seja, estabelece-se uma relação de dependência com as ideias do bem (seja este mesmo bem individual ou coletivo) e da verdade. Além disso, o valor da obra de arte é subordinado às qualidades do objeto ou ao tema abordado. A segunda ocasião da teorização artística, por sua vez, pode ser mais bem explicada pelas palavras de Chaui:

Em seu uso inicial, a estética se referia ao estudo das obras de arte enquanto criações da sensibilidade (isto é, das experiências dos cinco sentidos e dos sentimentos causados por elas), tendo como finalidade o belo. Pouco a pouco, substituiu a noção de arte poética e passou a designar toda investigação filosófica que tinha por objeto as artes ou uma arte. Do lado do artista e da obra, a

\footnotetext{
${ }^{5} \mathrm{~A}$ ligeira discussão da arquitetura sob o viés estético-filosófico aqui trazida não tem a pretensão de ser aprofundada, tampouco de esgotar o assunto em questão. Se assim o fosse, certamente um novo trabalho deveria ser elaborado e direcionado inteiramente ao tema. Interessa a este estudo, portanto, mostrar que as variáveis teórico-conceituais pertinentes à arquitetura têm despertado o interesse de profissionais e de pensadores das mais diferentes áreas, dentre as quais está a filosofia, já ao longo de vários séculos. Além disso, é adequado a esta abordagem para que possa ser estabelecida uma relação - quem sabe de contraposição, quem sabe de complementação - à temática apresentada logo a seguir, a qual volta seu olhar à arquitetura calcada no ato de fazer, ou seja, na prática já de tão longe exercida, que inicialmente é compreendida como obra de engenharia e se revela, posterior e paulatinamente, como inegável tributo artístico-arquitetônico à humanidade.
} 
estética busca compreender como se dá a realização da beleza; do lado do espectador e receptor, busca interpretar a reação à obra de arte sob a forma do juízo de gosto ou do bom gosto. (CHAUl; 2010: 350)

Como se nota no trecho acima, a estética dedica sua atenção à expressão da sensibilidade e da fantasia do artista, além de ater-se ao sentimento que ela desperta no espectador (ou indivíduo contemplador). E levando em conta que o termo estética deriva do grego "aisthetiké", traduzido para "conhecimento sensorial", "experiência sensível" ou "sensibilidade", surge daí uma aproximação desta com os sentidos humanos.

Duarte (2012) defende que é somente a partir do século 18 que as questões referentes ao gosto e ao belo ganham interesse de filósofos que passam a teorizá-las juntamente às suas já correntes reflexões epistemológicas e/ou éticopolíticas. Dentre eles pode-se citar, por exemplo, o empirista David Hume (1711 - 1776) que foca as variáveis causais subjetivas do gosto e o intelectualista Alexander Baumgarten (1714 -1762), responsável pelo uso até então inédito da palavra "estética" para designar a nova disciplina filosófica que surge em plena modernidade (mesma época do racionalismo, da afirmação da autonomia do sujeito do conhecimento e, especialmente, da revolução científica).

Com o aparecimento da estética na era da modernidade passa a haver uma preocupação mais acentuada com a subjetividade decorrente da representação do belo em termos de gosto. Com isso, afirma Ferry (1951 - ), o belo fica entrelaçado a tal ponto com a subjetividade humana que pode ser definido, no limite, tanto pelo eventual prazer gerado quanto pelas sensações e pelos sentimentos despertados no homem. Assim, a partir do momento em que o gosto é levado em conta, aquilo que é praticado e discutido pela antiga filosofia da arte cede espaço a uma nova teoria calcada na sensibilidade.

O alemão Immanuel Kant (1724 - 1804) talvez seja considerado um dos fundadores da estética moderna ao publicar a obra "Crítica da Faculdade do Juízo" em 1790. Um dos grandes méritos que podem ser atribuídos a esse filósofo, no parecer de Rosenfield (2006), reside em sua capacidade de despregar-se de boa parte dos pressupostos históricos e culturais que influenciam os conceitos do belo e da arte.

Ao analisar o belo em suas duas frentes (a natural e a artificial), Kant, segundo a mesma autora, mantém o discurso na "experiência estética subjetiva e nas relações desta com a sensibilidade, o conhecimento e a razão prática" (ROSENFIELD; 2006: 27), procurando harmonizar - sempre que viável, a experiência estética e a artística como que dependentes e subordinadas às faculdades racionais e intelectuais do homem. A partir do momento em que Kant 
estipula uma diferenciação entre juízo lógico e juízo estético, deixa claro também que, no primeiro caso a atenção volta-se a um predicado do sujeito e, no segundo, a algo fundamentalmente subjetivo, formado a partir do sentimento de prazer particular e exclusivo do interior do indivíduo, ainda segundo explicação de Duarte (2012).

Entretanto, pode-se perguntar como é possível a Kant constituir uma crítica da faculdade de julgar uma vez que esta é tão subjetiva e tão particular a cada indivíduo para avaliar as obras de arte? Em outras palavras, como atribuir universalidade a tal juízo? Para contornar essa questão, o pensador alemão promove, sim e "apenas”, uma discussão do gosto visando um "afinamento das opiniões cuja finalidade é chegar a um acordo entre as partes" (CHAUÍ; 2010: 351). Da discussão resulta, pois, a reflexão sobre o juízo estético e, por fim, um posicionamento compartilhado por todos. Mas por que a reflexão é possível?

Porque a obra de arte é algo comunicável - aliás, só existe para comunicar-se, oferecendo-se à sensibilidade dos receptores. Se o artista parte, espontaneamente, da comunicabilidade da obra, é porque, em seu íntimo, reconhece que sentimentos, ideias e opiniões são, sim, compartilháveis. A experiência estética - tanto do lado do artista como do lado do público - é comunicável e partilhável. (CHAUI, 2010: 351)

E com isso Kant mostrará que, ainda que a experiência estética seja desinteressada, individual e subjetiva a cada um, a partir do momento em que é despertada no ser humano pela beleza, passa a relacionar-se com ideias universais da razão (simultâneas e iguais para todas as pessoas). Mesmo que seu conteúdo ou sua forma sofram determinadas variações de acordo com circunstâncias históricas ou de inspiração e sensibilidade do artista que as produz, esse pensador garante que o sentimento do belo - base do juízo do gosto por ele proposto - é universal porque, para ele, a beleza atua no campo da razão. No entender de Duarte (2012), Immanuel Kant imprime uma característica particular no juízo de gosto quando sugere que suas reflexões teóricas encontram respaldo mais nas belezas naturais que nas artificiais, deixando claro o seu posicionamento quanto à superioridade das coisas da Natureza sobre a artificialidade das belas artes.

Em oposição à estética de Kant coloca-se outro filósofo alemão, Georg Wilhelm Friedrich Hegel (1771 - 1831), responsável pelo desenvolvimento de uma vasta obra voltada à filosofia da arte e à estética e que pondera sobre uma desvalorização das belezas naturais em favor daquelas feitas pelo homem, cujo objeto estético é portanto artificial, mas com a intenção proposital de comunicar-se com a sensibilidade. 
Para Rosenfield (2006), a obra "Estética” de Hegel não se limita a uma aplicação prática ingênua da disciplina estética. Mais que isso, tal publicação altera o lugar do juízo de gosto e da experiência estética outrora atribuídos por Kant. Hegel busca enfatizar a beleza destacando os interesses ético e cognitivo que a arte torna reais, bem como o fato de procurar congregar a arte ao próprio movimento do conceito. Além disso - continua a autora - para Hegel, as formas artísticas das obras de arte (objetos particulares, contingentes e sensíveis) "sustentam o processo de autodeterminação do espírito até a conquista da consciência de si" (ROSENFIELD; 2006: 39).

Hegel acredita que a arte - superior às coisas naturais, à individualidade e à sociabilidade humanas - instala-se naquilo que ele chama de "Espírito Absoluto" e detém sobre ela a característica de uma sensibilidade de tal importância e poder que não é capaz de esgotar-se em si mesma. Ainda assim, coloca Santos (2007), é superada não apenas pela Religião, mas principalmente pela Filosofia. Depreende-se daí que Arte, Religião e Filosofia são, para Hegel, três reinos espirituais intimamente tecidos e constituídos como manifestações do Absoluto, isto é, apreensões e expressões da verdade propriamente dita.

A "arte" exterioriza o sensível do espírito, a "religião" internaliza a representação do Absoluto e a "filosofia", por si só, une ambos os fatores anteriores, superando-os e equivalendo-se ao próprio pensamento do Espírito Absoluto. É por isso que, continua Santos (2007), para Hegel, a arte é coisa do passado, portanto, coisa que serve apenas à manifestação de objeto do pensamento. Essa postura de Hegel começa a formar, nas palavras de Duarte (2012) um dito "enfoque lógico do fim da arte" (DUARTE; 2012: 33), que tem como consequência última não o seu desaparecimento, mas, quem sabe, a perda de sua "substancialidade dialética", deixando-a, assim e por fim, esvaziada de sentido.

Porém, ainda que essa afirmação possa motivar certa preocupação, para este filósofo alemão, ao contrário, justamente pelo fato de considerar esse acontecimento algo de viés otimista, mantém a esperança de que a arte assume uma conotação mais espiritual e etérea em um momento da história em que a racionalidade passa a habitar o "próprio cotidiano do homem moderno" (Ibidem: 34).

Ao longo dos anos muitos outros teóricos e pensadores têm dedicado trabalhos bastante interessantes tanto à discussão sobre as artes, quanto à importância das obras ou mesmo à sua extinção. Ponderam também sobre a arquitetura como forma de expressão estética e artística e seu poder de influenciar a vida do ser humano. Por exemplo, Martin Heidegger (1889 - 1976), que, no famoso conjunto de palestras agrupado sob o título “A Origem da 
Obra de Arte”, de 1935, põe em discussão o desvelamento da verdade do ser humano por meio da arte. Questionando a crise da cultura a partir do começo do século 20 está o filósofo Theodor Adorno (1903 - 1969), que teoriza sobre a necessidade de compreender o novo modelo de capitalismo e seus reflexos na cultura e na arte, sentidos mediante o maior controle sobre as pessoas e a banalização do cotidiano - além de traçar críticas severas à cultura de massa e à mercadoria cultural. 
Carchia e D’Angelo (2009) sugerem que, desde a Antiguidade de Platão e de Aristóteles, a imagem do arquiteto tem sido empregada como símbolo do saber orientado a um fim, ou seja, da teleologia própria e existente em todo ato de fazer e de conhecer. Complementam essa afirmação os estudos de Marcus Vitruvius Pollio (80-70 a.C. - 15 a.C), ao explicarem que o papel do arquiteto deve somar ao talento individual (ingenium) e à prática do ofício (opus), tanto os conhecimentos prévios acumulados teóricos, físicos e mecânicos (ratiocinatio) quanto uma metodologia para sua aplicação apropriada (disciplina). Vitruvius também "acrescenta a ideia de que, além dos requisitos da funcionalidade (utilitas) e da estabilidade (firmitas), os objetos arquitetônicos devem possuir uma qualidade estética especial (venustas) que os distinga do nível da mera execução técnica de um trabalho" (CARCHIA E D’ANGELO; 2009: 28). A partir daí Vitruvius alça a beleza a um novo patamar, fazendo com que ela seja apreendida não mais como uma qualidade secundária da arquitetura, mas, sim, como um caráter construtivo propriamente dito e redutível a três fatores: proporção, ordem e perfeição.

Os mesmos autores explicam que o arquiteto e teórico de arte Leon Battista Alberti (1404 - 1472), em seu tratado De re aedificatoria (publicado após seu falecimento), toma como base as investigações propositivas de Vitruvius e a elas acrescenta um pensamento de viés organicista e de cunho neoplatônico. A obra albertiana, como resultado, foca mais o horizonte teórico do projeto que a atividade prática (ou a ação de construir) propriamente dita. Assim sendo, podese deduzir que as questões estéticas, para Alberti, não são assim tão significativas quanto o são para Vitruvius. Não se pode negar, contudo, que os estudos tanto de Vitruvius quanto de Alberti tenham contribuído sobremaneira para a discussão da ambivalência arquitetônica referente ao projeto (ou à teoria) e à execução (ou à realização concreta) ao longo do tempo, servindo elas de base para novas teorias delineadas posteriormente, pois "divididas na avaliação das relações entre teoria e prática, entre momento do projeto e experiência do trabalho, as modernas teorias da arquitetura como reflexões estéticas rapidamente se distinguiram do campo das doutrinas técnicas e livrescas, mas também concordaram com a ênfase no contributo dado à definição de beleza arquitetônica pelos conceitos de finalidade, utilidade e função". (CARCHIA E D'ANGELO; 2009: 29) 
Já no século 18, o historiador e teórico de arquitetura italiano, Francesco Milizia (1725 - 1798) - cujo pensamento deriva dos estudos de Vitruvius - confere à arquitetura um caráter voltado à antropologia, o que se justifica porque ele acredita que é a partir de tal ciência que o homem ergue as suas próprias habitações. Para Milizia, o ser humano procura suprir a necessidade de aprimorar sua condição de vida por meio do uso adequado e bem regulado dos princípios da construção. Trata-se, pois, da adequação ao uso em arquitetura, fonte também de algumas das reflexões filosóficas kantianas. Nelas, Kant afirma ser este um traço característico e particular da beleza arquitetônica, pois, no seu entender, ela não tem a habilidade de agradar por si mesma, nem de conformar-se com o princípio do desinteresse estético (já que ela admite sua própria existência, uma vez que é concebida para um determinado fim), ou seja, tratase da união entre o belo e o bom, tão particular da "beleza aderente" kantiana.

Em uma tendência reflexiva oposta à de Kant estão dois pensadores, ambos alemães: Hegel - já citado anteriormente - afirma que a arquitetura deve pertencer ao lugar mais inferior na escala dos valores artísticos e espirituais. Para este filósofo, a arquitetura é a "primeira arte", inicialmente revelada na cabana e no templo como concretizações de manifestações de uma atividade humana motivada não apenas pelas necessidades imediatas, mas, também, por determinadas exigências estéticas. Hegel ainda coloca que a arquitetura somente alcança a sua mais legítima expressão como arte simbólica quando há uma prioridade da matéria sobre a ideia. Arthur Schopenhauer (1788 1860), por sua vez, acredita que a arte, representada pela arquitetura, seja a forma mais básica de objetivação da vontade uma vez que, pelo viés estético, sua finalidade é tornar mais evidentes à intuição as variáveis referentes a gravidade, peso, solidez e, portanto, as mais simples das amostras visíveis da vontade. Além disso, do ponto de vista deste pensador, pelo fato de a arquitetura produzir "coisas" e não "imagens das coisas" ela não pode almejar a universalidade estética, tampouco uma relação orgânica com a arte, já que os valores da beleza delegam aos seus resultados certas casualidade e subordinação.

Dentre os pensadores que atuam entre os séculos 18 e 19 chama a atenção o alemão Friedrich Wilhelm Joseph von Schelling (1775 - 1854), que vê a problemática da utilidade exclusivamente como uma condição de existência da arquitetura, e não uma razão de ser. Para ele, o trabalho arquitetônico alcança concomitantemente os níveis de arte livre e independente, o que se traduz em uma mesma criação a objetividade e a subjetividade do espírito. No momento em que Schelling tece suas investigações, 
a estética romântica exerce uma forte influência sobre as práticas e as teorias da arquitetura, de tal modo que transforma, em muitos aspectos radicalmente, os próprios termos da secular disputa entre estilo clássico e estilo gótico. Se até aquele momento as duas tendências eram de fato tidas como estando em radical oposição entre si, sendo a primeira associada a uma clara vocação historicista e institucional, e a segunda a uma exigência mais forte de conteúdos e de espiritualidade, no início dos Oitocentos surgem teorias de arquitetura mais complexas, orientadas para a busca de uma síntese que muitas vezes encontra expressão na própria investigação dos arquitetos, no desenvolvimento de seus projetos ao longo de percursos de trabalho que os veem rapidamente a experimentar as mais diversas soluções estilísticas. (CARCHIA E D'ANGELO; 2009: 30)

E é nesse cenário de transição de valores e de transformação de crenças que se encaixa o pintor, urbanista e arquiteto neoclassicista alemão Karl Friedrich Schinkel (1781 - 1841), interessado tanto na independência da função arquitetônica e quanto na sua assimilação automática como algo útil à vida do homem por meio da adoção de efeitos estéticos que, quando postos em evidência, contribuem para a dissimulação das funções de um edifício. Sob o ponto de vista de Schinkel, tanto o estilo gótico quanto o clássico podem, por exemplo, ser vistos como maneiras diferentes de se posicionar frente à questão que discute a mutação da função no parâmetro estético da beleza arquitetônica, por isso, nesse caso, o gótico assume a responsabilidade de representar estruturas, pesos e proporções "na ação do seu vir a ser", enquanto o clássico representa esses mesmos elementos, mas "no seu ser efetivamente existente". É como se, a partir desse momento, passasse a prevalecer uma estetização do conceito de função, que nada mais é que

o meio de permitir que numerosas teorias da arquitetura do século 19 se baseiem parcialmente no Positivismo e na sociologia, mantendo intacto um fundo de romantismo e de utopismo. Viollet-le-Duc é o primeiro a receber de forma sistemática as influências do Positivismo, desenvolvendo uma teoria da arquitetura muito próxima do pensamento de H. Taine [...]. Mas os problemas de correspondência funcional aos materiais, da inovação tecnológica, da relação com a engenharia civil e com a economia, como também do projetar o espaço na cidade em rapidíssima expansão, são considerados, no decorrer do século 19, no quadro de teorias que atribuem ao projeto arquitetônico, aos seus valores científicos e à sua sensibilidade cultural, um papel central no desenho da ordem social. (IBIDEM: 30)

Em meados dos anos 1800 verifica-se um novo direcionamento nas reflexões sobre a arquitetura, o qual considera, deste momento em diante, a representação de uma arquitetura não apenas concentrada em edifícios isolados ou distribuída espacialmente - isto é, compondo e formando a íntegra das cidades. Atribui-se a ela, pois, um novo e mais ativo papel, predominantemente propositivo no que tange à idealização de uma realidade moldada pelas qualidades de uma vida em harmonia (mas não alienada) e satisfatoriamente bem cadenciada para suprir as necessidades do indivíduo moderno, explicam os mesmos autores. Com isso, do utopismo de François Marie Charles Fourier (1772 1837), passando pela noção de arquitetura como personificação das estruturas históricas de Eugène Emannuel Violletle-Duc (1814 - 1879), pelo aperfeiçoamento tecnológico de Otto Wagner $(1841$ - 1918) ou pelo pragmatismo e o 
movimento "Arts \& Crafts" do artesão inglês William Morris (1834 - 1896), muitos são os que teorizam sobre a arquitetura e suas variáveis funcionais, técnicas, estruturais e plásticas.

O funcionalismo, que toma força na passagem do século 19 para o 20, é fruto, em grande parte, da combinação de elementos idealistas e racionalistas, "exemplarmente compendiada na reflexão de L. H. Sullivan, teórico em cujo pensamento entram de modo eclético a tradição romântica americana, o transcendentalismo, a teosofia e os símbolos do racionalismo francês" (CARCHIA e D’ANGELO, 2009: 31). Esta linha de pensamento resulta não apenas na controvertida negação de toda a estética alheia ao valor de uso do objeto arquitetônico, como também em uma tentativa de determinar matematicamente os modelos para uma nova, porém sempre idealizada, estandardização das dimensões arquitetônicas. O arquiteto e estudioso franco-suíço Charles-Edouard Jeanneret-Gris (1887 - 1965) - ou Le Corbusier - talvez seja visto até hoje como o grande representante do funcionalismo moderno. Sua influência atravessa fronteiras e espalha-se mundo afora desde o início dos anos 1900.

O diálogo Eupalino o dell'Architettura, publicado por P. Valéry em 1921, é um sintoma de como, referindo-se a disciplinas como a matemática e a antropometria, as teorias da arquitetura do princípio do século 20 relançam uma exigência de harmonia que remete para um classicismo vitruviano, mas é também a confirmação do papel demiúrgico que nesta época se atribui ao arquiteto como alguém que tem a competência de organizar a matéria inorgânica em formas coerentes com as expectativas do progresso social e tecnológico. (CARCHIA E D’ANGELO; 2009: 31)

Já os teóricos arquitetônicos do construtivismo russo e do futurismo italiano discutem o progresso social e tecnológico de forma um tanto quanto visionária e utópica, mas sempre postulando a separação das fronteiras sociais e materiais do projeto arquitetônico. Ernst Bloch (1885 - 1977), por sua vez, tem seus escritos sobre utopia sempre muito respeitados especialmente ao criticar o funcionalismo, por considerá-lo um veículo da automatização e da comercialização do mundo moderno. Defende, portanto, o retorno a uma estética voltada ao organicismo, representada no último quartel do século 19 pelos escritos do crítico de arte e de arquitetura inglês John Ruskin (1819 - 1900), na primeira metade do século 20 especialmente pelo arquiteto americano Frank Lloyd Wright (1867 - 1959) e, após 1945, tanto pelo manifesto japonês Metabolism quanto pelo engenheiro alemão Frei Otto (1925 - ) e suas obras de apelo sustentável e de rápida construção (contrárias, portanto, ao que é pregado pelo funcionalismo).

De acordo com Jencks (1991), ao longo dos anos 1960 e 1970, as várias reações contrárias ao funcionalismo - que em um primeiro momento trazem de volta o pensamento racionalista seguido logo depois por teorias de apelo formalista e anti-historicista culminam, por conseguinte, nas estéticas do pós-modernismo. Aqui, passa a ser adotada a 
combinação de diferentes estilos e de linguagens históricas diversas, compatibilizada por meio de técnicas calcadas em citações não contextualizadas e do posicionamento, por vezes irônico, dos arquitetos partidários desta tendência arquitetônica.

Koolhaas \& Mau (1995) explicam que, nos anos mais recentes, coloca-se o Desconstrutivismo como um movimento importante e que motiva discussões elaboradas sobre a arquitetura contemporânea e, como consequência, tanto sobre a sua possível redução a um jogo de formas e de volumes, quanto a uma concatenação despretensiosa de espaços cheios e vazios, ou mesmo a uma incidência desproporcionada de luzes e de sombras, ou seja, um dito novo papel assumido pela arquitetura atual. O movimento contemporâneo desconstrutivista procura refletir sobre a redução da arquitetura, seus atos, elementos, condições, materiais, motivações e estéticas. "A deformação das categorias clássicas, por exemplo, da regularidade, da proporção e da ideia corrente de função, é agora adotada para evidenciar o caráter artificial, logo não natural e não antropológico dos conhecimentos arquitetônicos" (CARCHIA e D’ANGELO; 2009: 32). São representantes desta discussão, dentre outros, o próprio Rem Koolhaas (1944 - ), Bernard Tschumi (1944 - ), Peter Eisenman (1932 - ), Daniel Liebeskind (1946 - ) e Frank Gehry (1929 - ). E esses mesmos dois autores traçam as seguintes considerações acerca da estética na arquitetura contemporânea:

D. Formaggio reviu as teorias contemporâneas da arquitetura, sugerindo de que modo estas - libertas de toda convicção dogmática e de toda a pretensão de normatividade estética - valorizam hoje toda a complexidade da arquitetura, prática construtiva politécnica que é ao mesmo tempo arte e não arte, disciplina científica e processo inventivo. [...] Partilhado por um amplo número de autores, o seu diagnóstico sobre o "renascimento" da arquitetura no mundo contemporâneo entra todavia em contraste com as teorias da arquitetura de raiz sociológica que diagnosticam a sua crise como sendo não só conceitual mas sobretudo de função social, face aos problemas postos pelas mutações históricas que não parecem conciliáveis com a dimensão sempre racionalizadora do "projeto". (CARCHIA E D'ANGELO, 2009: 32) 
Como se nota pelas ideias expostas pelos pensadores e pelos teóricos ao longo dos séculos, a arquitetura como expressão artística presente e pertencente à vida de qualquer indivíduo, instiga que a respeito dela discussões e investigações sejam sempre efetuadas. Independentemente da época, do lugar ou do estilo arquitetônico praticado, a arquitetura é também uma forma de expressão das próprias pessoas, se se pensar, por exemplo, naquilo que para elas representa a moradia (em uma dimensão mais reduzida e particular) ou a própria cidade (a partir de uma visão mais dilatada). Não é preciso ser teórico ou filósofo para refletir sobre arquitetura, logo, nem para expressar o que se pensa sobre ela e sobre qual influência traz para a vida do ser humano.

As obras de arquitetura, por assim dizer, praticamente impõem sua presença ao meio onde se inserem, e alteram, cada uma à sua maneira, as perspectivas visuais que os indivíduos têm da cidade. Ainda que por muitos possa ser vista como uma forma de expressão pessoal do arquiteto que a concebe, a arquitetura é pública não importando o desejo das pessoas. "Além disso, ocupa espaço: ou destrói pura e simplesmente o que existiu antes, ou então tenta combinar e harmonizar" (SCRUTON; 2010: 25). Como bem apontado por Ruskin (2008), essa disciplina pode ser tomada como a mais política das artes, uma vez que impele coercivamente uma visão do homem e de seus respectivos objetivos sem pedir autorização ou licença aos que convivem com ela. Por isso, não dá margem à escolha: uma vez edificada, força sua presença confrontando-se com as construções ao redor, com as pessoas presentes em seu ambiente e com a visão que elas têm do espaço construído. Um edifício, deste modo, pode afirmar-se tanto como um símbolo materializado de uma tradição, ou melhor, de uma continuidade histórica quanto como um prenúncio de novas exigências e de novas possibilidades.

As obras arquitetônicas constituem-se como fatos importantes no ambiente onde estão edificadas, da mesma forma que os locais de implantação exercem influência sobre essas mesmas obras. Decorre desse raciocínio o sentido de lugar, único e particular a cada arquitetura ou indivíduo, sempre envolvido e contextualizado em uma realidade maior que se torna mais importante e significativa à medida que estabelece uma comunhão de identidade entre as partes. Nesta abordagem, diz Scruton (2010), a arquitetura torna-se uma arte do conjunto, cujos componentes (edifícios, arredores e cidade) vivem uma combinação profunda mas permanentemente vulnerável a mudanças: qualquer 
alteração àquilo que é inicialmente proposto pode trazer consequências tais que a arquitetura e/ou o ambiente e/ou a cidade tornam-se elementos distintos dos originais, reconfigurando, assim, todo o conjunto (para melhor ou para pior).

A relação entre arquitetura, cidade e identidade é colocada em pauta nas investigações do arquiteto e teórico italiano Aldo Rossi (1931 - 1997). Segundo ele, a cidade é uma das mais puras representações do coletivo. Com uma nítida inspiração hegeliana, o autor estabelece um paralelo entre a cidade e a importância da arquitetura na vida do ser humano desde os primórdios da sociedade quando, além de buscar habitação, as pessoas tendem a criar ambientes artificiais propositadamente estabelecidos e com foco estético, justamente para favorecer sua relação com o lugar sendo essas, para Rossi (2001), as características estáveis da arquitetura (ambiente mais propício à vida e intencionalidade estética). Trata-se, pois, da presença da história e da experiência, que fazem da arquitetura um fatorchave para a condição da existência.

Dito de outra maneira, a arquitetura, sob o ponto de vista sugerido pelo escritor, nada mais é que a construção inseparável da vida civil e da sociedade como um todo (sendo portanto uma expressão coletiva). E ele afirma também que, praticamente desde as épocas mais remotas, o homem não constrói apenas para obter um local mais favorável à vida para lá habitar sem outras preocupações em mente. Ele pratica isso há tempos, sim, porém, embasado em uma intencionalidade plástica que faz com que brotem daí os primeiros desenhos urbanos, os quais são inseparáveis da formação da civilização e conformam, portanto, um fato permanente, universal e necessário. Além disso, é por meio dessa constatação que a sociedade obtém um formato concreto, estabelecido e que gera não só identidade, mas também um profundo significado para com o local físico onde se situa e para com a população que dele faz parte.

As considerações relacionais daí provenientes estão calcadas nesse diálogo de identidade que a cidade promove para com seus habitantes, reforçado e referenciado por meio dos aspectos históricos dos lugares ao longo do tempo, o que provoca uma experiência em um nível mais abrangente do que pode transmitir um único edifício. O próprio Rossi (2001) explica que, com o tempo, a cidade cresce sobre si mesma e adquire consciência de sua existência, entretanto, ao longo de sua construção, os motivos originais são mantidos intactos, enquanto que as razões de seu desenvolvimento tornam-se, por assim dizer, cada vez mais etéreas.

O autor entende que os elementos essenciais de um local são sempre preservados no decorrer da história. Ainda que uma cidade cresça e se transforme com o passar dos anos, que pessoas diferentes nela residam e por ela passem, os 
lugares são mais fortes que as pessoas e o cenário, por sua vez, mais forte que o acontecimento, justamente por serem esses mesmos lugares e esses mesmos cenários fatores estéticos mais permanentes que os indivíduos que com eles têm contato. A identidade e o significado são, dessa forma, reforçados e mantidos por gerações e a estética local tem papel de destaque nesse processo.

Rossi (2001) crê ainda que a cidade não pode ser apreendida apenas como um fato material, uma vez que simboliza o locus da memória coletiva. Isso significa dizer que ela retrata a relação existente entre determinada situação local e as construções que lá se encontram. Segundo o autor, do estudo de uma cidade decorre o reconhecimento da diferenciação entre o que nela é concreto, imagem ou memória e, para tanto, deve-se procurar reconhecer os aspectos que transcendem a própria materialidade em um processo causado pela relação entre o homem e a cultura na qual está inserido. Com isso, é desvelado, mais uma vez, o reconhecimento do valor real da cidade (por ele chamado de "artefato") e do que ela pode representar (algo nomeado pelo autor como "significado simbólico").

Portanto, a relação de proximidade que a arquitetura estabelece para com os indivíduos, participando ativa e permanentemente de suas vidas, é confirmada - como mostrado nos parágrafos acima - no momento em que nasce um sentimento de identidade entre ambos, sentimento esse potencializado pela crença de pertencimento à terra, à edificação, à cidade, ou seja, à arquitetura da vida cotidiana que dela faz parte. Assim sendo,

\begin{abstract}
a arquitetura é primordialmente uma arte vernácula: existe primeiro e principalmente como um processo de arranjo em que todo o homem normal pode participar, e participa na verdade, na medida em que constrói, decora ou arranja os sítios em que vive [...]. A arquitetura é simplesmente uma aplicação daquele sentido do que se "ajusta", que governa todos os aspectos da existência diária. Pode se dizer que, propondo-se uma estética da arquitetura, o mínimo que se deve propor é uma estética da vida de todos os dias. Afastamo-nos do reino da arte superior para o da sabedoria prática comum. (SCRUTON; 2010: 26-27)
\end{abstract}

Isso não significa dizer que a arquitetura, a partir do momento em que estabelece uma relação de identidade para com o ser humano, não possa mais ser alterada, ou que deva permanecer inerte eternamente. Pelo contrário. Ela é uma expressão artística modificável, pois ressignifica-se constantemente - mesmo que mantenha, em seu âmago as qualidades que lhe são originais e, por assim dizer, imutáveis - como referenciado por Rossi (2001). Já Scruton (2010) entende que as mudanças pelas quais passa a arquitetura ao longo dos anos são também estimuladas pelas competências e pelas habilidades humanas. 
Nesta disciplina, assim sendo, é comum serem consideradas alterações de forma totalmente independentes de quaisquer mudanças na consciência artística. Dito de outra maneira, no momento em que o arquiteto toma contato com alguma descoberta que pode influenciar o seu ato criador - e consequentemente o seu projeto quando concluído - ele não hesita e corajosamente incorpora tal inovação ao seu fazer projetual. Para Katinsky (2007), “inteligências inovadoras são perspicazes e extremamente rápidas em reconhecer a inovação onde quer que ela se dê e, além disso, são capazes de rapidamente submeter a inovação alheia às suas próprias leis", (KATINSKY; 2007: 60). Entretanto, é possível que essa atitude do arquiteto projetista chegue a comprometer, por consequência, a evolução natural dos estilos, interrompendo-a e transformando-a motivado que está por um fator, quem sabe, sem ascendência e/ou sem intenção estética.

É o caso, por exemplo, da descoberta do concreto armado e de suas consequências para o desenvolvimento e a evolução da arquitetura: novas soluções construtivas, vãos mais audaciosos, aberturas mais generosas, velocidade de construção mais acelerada, volumetrias mais leves, formas mais livres, enfim, um leque de possibilidades colocado diante dos arquitetos e dos engenheiros que, a partir de determinado momento histórico, passam a optar pelo concreto como sua principal técnica construtiva - e a tradição e a preocupação para com as variáveis históricas no período pré-concreto perdem parte da importância, ou melhor ainda, continuam fundamentais, mas são colocadas de lado frente aos tentadores horizontes projetuais e construtivos que se descortinam a olhos vistos.

E em um cenário favorável ao desenvolvimento e ao crescimento, é comum o entrelaçamento entre técnica e tecnologia que, ainda que distintas, são por vezes intercambiáveis entre si. Vargas (1994) sugere uma distinção entre ambos os termos:

A técnica é, assim, uma habilidade humana de fabricar, construir e utilizar instrumentos. É tão antiga quanto a humanidade, admitindo-se a ideia de certos antropólogos de que um fóssil só pode ser considerado humano se ao lado dele forem encontrados instrumentos [...].

As técnicas modernas, nas quais já estão incorporados os conhecimentos empíricos de origem científica, aparecem durante o Renascimento, quando homens, como Leonardo da Vinci, não a distinguem das Belas Artes e nem hesitam em aplicar, na solução de seus problemas, alguns conhecimentos científicos, obtidos da experiência direta.

A tecnologia, por fim, só pode ter vigência depois do estabelecimento da Ciência moderna, principalmente pelo fato dessa cultura ser um saber que, apesar de teórico, deve necessariamente ser verificado pela experiência científica. (VARGAS; 1994: 15-16) 
A permeabilidade entre ambos os termos fica nítida no instante em que um invade o campo do outro e ambos se confundem como forma de conhecimento. Porém, ao contrário do que pode dar a entender o trecho acima, a técnica não pode mais ser vista somente como fabricação de simples artefatos, distanciando-se, por assim dizer, tanto da antiga "poíesis" quanto da "theoría". Isso acontece porque ela não deve mais ser compreendida como um saber desinteressado do mundo e alheio à busca de fins imediatos. Nesse ponto, a arte - e aí incluída a arquitetura - assume uma posição de expressão criadora, ou seja, de transformação do mundo em obra artística e, com isso, a "verdade" figura como o grande valor dessa mesma expressão criadora. A arte procura também exprimir ou interpretar, por meios artísticos, a própria realidade, recorrendo, para tanto, às técnicas e aos instrumentos técnicos, de forma mais clara e evidente que no passado.

Chaui (2010) diz que a partir das décadas de 1920 - 1930, a fronteira entre os campos da arte e da técnica tornam-se gradativamente mais tênues. Isto é, cada vez mais há uma influência mútua entre as partes, que gera até certa dependência entre ambas. Como exemplos dessa relação delicada estão a necessidade de uma película perfeita para o cinema de arte, de uma tecnologia perfeita para a gravação de um disco de ópera, da técnica perfeita para a montagem de cenários de um musical no teatro, da fabricação de equipamentos acústicos perfeitos para a apresentação de uma banda musical ao vivo, da multiplicação da paleta de cores para a pintura perfeita de telas e painéis, do surgimento de matérias-primas sintéticas perfeitas para esculpir novas esculturas, enfim, de uma infinidade de itens técnico-tecnológicos que perfeitamente se enquadram na relação cada vez mais próxima e intensa com as atividades artísticas. E com a arquitetura não há como ser diferente: materiais, revestimentos, acabamentos, matérias-primas, estruturas, novas tecnologias, técnicas inovadoras e tantas outras variáveis necessariamente perfeitas para atingir resultados cada vez melhores e mais adequados à realidade na qual é inserida e contextualizada. Se realmente a arquitetura transita entre duas variáveis geralmente tomadas como contrárias, ou seja, a estética e a técnica, e se por vezes ela realmente busca ajuda em outras áreas do conhecimento para responder aos seus próprios questionamentos, é possível assumir que a engenharia exerça um papel fundamental sobre a arquitetura, pois é uma área do conhecimento que tanto complementa quanto instiga o seu desenvolvimento (e a recíproca é também verdadeira). Há, portanto, uma relação altamente imbricada entre técnica e forma a partir da qual verifica-se, já de longa data, uma permeabilidade mútua entre ambas as disciplinas. 
Scruton (2010) mostra - como já discutido - que a arquitetura admite alterações de forma (e aí implícitas também mudanças de volumetrias, de técnicas construtivas, de materialidades e afins) mesmo que não relacionadas diretamente a qualquer variação na consciência artística. Isto é, quando em contato com novas possibilidades projetuais e/ou construtivas - teóricas e/ou técnicas, portanto -, o arquiteto tende a assimilá-las e a incorporá-las ao seu próprio trabalho. O resultado decorrente de uma situação nova como essa estabelece um novo patamar arquitetônico (não necessariamente melhor que o anterior, mas, sim, diferente).

Um elemento-chave, por que não clássico, que abarca e exemplifica essa conceituação, está na migração do aço para a arquitetura cotidiana das cidades e na descoberta do cimento como material de construção. A conjugação de ambos - somada a outros ingredientes (como água, agregados e, quando o caso, aditivos) - resulta no concreto armado: técnica revolucionária que imprime resultados superlativos ao cenário arquitetônico mundial, a partir da passagem do século 19 para 020.

É pertinente a este estudo ${ }^{6}$, assim sendo, apresentar as razões pelas quais o aço torna-se uma solução estrutural que praticamente liquida com as alvenarias auto-portantes existentes até o terceiro quartel do século 19, favorecendo edificações mais altas, esbeltas e significativamente mais leves. E também é o intuito desta investigação trazer à baila a trajetória do cimento (e por assimilação, do concreto armado), desde a descoberta até o seu aproveitamento em estruturas completamente distintas das adotadas até o início do século 20. Trata-se, portanto, de técnica inovadora que influencia o fazer projetual arquitetônico, o modus operandi da engenharia e, por derivação, o binômio plasticidade-partido das construções.

\footnotetext{
${ }^{6}$ Vale ressaltar que os personagens e suas respectivas obras abarcados nas páginas seguintes, quando somados aos contextos nos quais se inserem, são entendidos como um fio condutor pertinente à narrativa deste estudo. Isso significa dizer que existem inúmeros outros profissionais, obras, pesquisas e investigações que poderiam ser citados aqui, porém, se todos eles o fossem, este trabalho tornar-se-ia inviável! Optou-se, portanto, por colocar na berlinda alguns acontecimentos, pontuais mas na maioria das vezes dependentes e concatenados entre si, de forma a que a narrativa aqui proposta seja válida e coerente - dotada de continuidade, por assim dizer. Por fim e uma vez mais, não se deve considerar que o assunto em questão seja encerrado nas próximas páginas, pois certamente novos e mais aprofundados estudos são sempre necessários.
} 
3.

AÇO E CIMENTO: AGENTES DE UM NOVO SIGNIFICADO PARA ARQUITETURA E ENGENHARIA 


\section{Explicações Necessárias}

A industrialização é um dos marcos que caracterizam o século 19, sobretudo no que se refere aos progressos alcançados, e nunca dantes vivenciados. Torna-se, pois, o leitmotiv de uma sociedade na qual processos históricos e sociais devem ser inteiramente revistos, uma vez que ela passa a dominar a economia existente. Assim sendo, o modo de operar tradicional perde o sentido e precisa ser, gradativamente, substituído por novos instrumentos, novos processos e novas demandas de produção - portanto, por uma nova e tentadora realidade. Com ela (e a partir dela), há a promessa de aumento de produtividade dos fatores aliado a uma maior geração de riqueza. Na sociedade ocidental, com forte apelo capitalista, estas são, assim, as motivações que impelem a um grande desenvolvimento generalizado.

A industrialização pode ser interpretada como parte de uma ação mais ampla de modernização, na qual três fatores são intensamente relacionados entre si e determinantes para esse processo de mudança: a inovação tecnológica, o desenvolvimento econômico e a transformação social. Trata-se, pois, de uma ruptura para com o passado que busca, por assim dizer, o progresso calcado no desenvolvimento industrial. No momento em que as tradições são abaladas por um processo de crescimento sem igual, faz-se a oportunidade de abandonar as velhas certezas e de ceder lugar a um mundo revigorado. Em um cenário como esse as economias, outrora baseadas na agricultura, no artesanato e no mercantilismo, passam a ter participações mais ativas tanto nas questões urbanas quanto nas industriais. É o momento de enfrentar transformações no modo de vida e nas relações sociais até então praticadas, nas atitudes dos indivíduos e na sociedade como um todo.

Assim, os sistemas de produção manufatureiros, artesanais, de pequeno porte e espacialmente pulverizados são substituídos por sistemas mais racionais, cujas produções são mecanizadas, seriadas, padronizadas e fisicamente concentradas. $O$ resultado previsto é não mais a existência de pequenas variações na produção, dados os processos manuais em andamento, mas, sim, uniformidade e homogeneidade. Merecem destaque, nesse momento crucial do desenvolvimento industrial mundial, os avanços alcançados nas áreas voltadas aos transportes e às comunicações: trens, automóveis, eletricidade, telégrafo e telefone, a partir de então, mudam completamente a sociedade, 
principalmente a ocidental. As viagens tornam-se mais ligeiras, as distâncias são encurtadas, as ideias e as pessoas circulam pelo mundo, assim sendo, com mais facilidade e com mais velocidade.

E esse panorama de progresso acelerado é reforçado por Collares (2003) ao explicar que, em função do alto grau de desenvolvimento encontrado em países como Inglaterra e França, já naquela época são efetuados aportes maciços de investimentos em novas técnicas e em tecnologias inovadoras voltadas, sobretudo, às obras de grande porte em infraestrutura viária. Como exemplos podem-se citar a abertura de novas estradas de ferro, a construção de suas respectivas gares, ou mesmo o incremento do sistema de transporte marítimo e fluvial, além de pontes de grande envergadura estrategicamente posicionadas. Tudo isso visando atender às necessidades latentes de infraestruturas capazes de absorver não só o escoamento das colheitas agrícolas, mas principalmente para incentivar as produções industriais locais cada vez mais potentes, rápidas e volumosas.

Como se percebe, até então os caminhos traçados para esses investimentos não estão diretamente relacionados à arquitetura. Porém, com o passar do tempo e levando em conta seu nível de abrangência, suas ramificações consequentes e os diversos campos de atuação daí decorrentes, forma-se aquilo que pode ser compreendido como a base gestacional do novo movimento moderno que influenciaria a arquitetura local e mundial por gerações.

Um dos agentes que motivam o início do movimento moderno na arquitetura, prossegue o mesmo autor, talvez seja o anseio por atingir uma expressão sólida e factível que represente os progressos técnicos e tecnológicos verificados em diversas áreas do conhecimento (progressos esses anteriormente anunciados como promessas de um futuro mais próspero às nações). Existe, assim, o desejo de levar para o campo arquitetônico as conquistas já adquiridas na indústria, como: fabricações em série, produções em massa, reduções de preços, padronizações de produtos.

Se são os engenheiros os responsáveis por alçar a industrialização a um nível de importância jamais pensado, no momento em que alguns dos novos materiais que contribuíram para essa revolução, finalmente, chegam à arquitetura, constata-se uma quebra de paradigmas estimulada, por exemplo, pelo uso do aço e do concreto armado. Passam a prevalecer, logo, novas maneiras de construir edifícios dependentes de novas formar de conceber os projetos: é um momento histórico que será absorvido pelos arquitetos com tal profundidade que representará uma ressignificação dos atos de pensar e de fazer a arquitetura mundial. E esse é o mote para a discussão apresentada nas páginas a seguir. 
A partir do momento em que nomes como o do arquiteto-engenheiro francês Henri Labrouste (1801 - 1875) ou mesmo o de seu aluno e futuro destaque no cenário arquitetônico mundial, o arquiteto francês Eugène-Emmanuel Viollet-leDuc (1814 - 1879) propõem novos conceitos teóricos focados na problemática tectônica das edificações, as bases para as primeiras reflexões que futuramente desembocariam no modernismo, passam a ser, efetivamente, desenhadas.

Henri Labrouste é considerado por muitos autores como um dos fundadores da arquitetura moderna, além de ser um ferrenho defensor, em território francês, da arquitetura racionalista. Santa Rosa (2013) explica que este engenheiroarquiteto é um dos precursores na adoção do aço não só como componente estrutural, mas também como elemento de ornamentação - pois em alguns casos prefere deixar a estrutura deliberadamente exposta, tornando-a, portanto, parte ativa dos espaços por ele elaborados. Dentre outras importantes obras concebidas por Labrouste, estão duas bibliotecas: a primeira delas, a Bibliothèque Sainte-Genèvieve [Figuras 3.1 - 3.2], é erguida em Paris entre 1843 e 1850 nas proximidades da Sorbonne e do Panthéon. Segundo Glancey (2012), além da fachada sóbria, feita em alvenaria e que remete aos palácios renascentistas, merece destaque a solução estrutural propositadamente deixada aparente: formada por colunas esbeltas, é totalmente modulada e forjada em ferro fundido, com colunas jônicas que dividem e organizam os espaços interiores em corredores e em alas individuais e de apoio. A sala de leitura distribui-se ao longo de uma ampla área bem iluminada e coberta por duas abóbadas de berço de grandes dimensões (executadas em gesso estruturado reforçado por malhas de aço diretamente conectadas ao sistema estrutural principal), sustentadas por arcos moldados em ferro fundido e apoiados nas mesmas esguias colunas feitas também de ferro fundido. Desde sua inauguração, este edifício tem sido reverenciado pelos adeptos do movimento moderno justamente pela introdução de soluções em alta tecnologia aplicadas, racional e conscientemente, a um edifício público monumental.

Já a Bibliothèque Nationale de France [Figuras 3.3 - 3.4], construída entre 1862 e 1868, localiza-se também na capital francesa e, pode-se dizer, resulta em um desdobramento ainda mais avançado das já inovadoras soluções aplicadas anteriormente, na Bibliothèque Sainte-Genèvieve. Neste novo edifício, Henri Labrouste também faz uso extensivo do ferro fundido sem disfarces no sistema estrutural e, uma vez mais, a sala de leitura - talvez por seu caráter de permanência e de estar - recebe atenção especial do engenheiro-arquiteto. Distribuídas modularmente estão delgadas colunas de ferro fundido encimadas por capitéis coríntios que ajudam a sustentar as nove amplas cúpulas 
abatidas que vencem os largos vãos internos. Cada uma das cúpulas traz, em seu ponto mais elevado e central, uma claraboia envidraçada, estruturada em metal e situada a quase dez metros acima do solo. A partir deste conjunto de aberturas zenitais, a luz natural invade difusa e uniformemente o interior da sala - conferindo-lhe unidade, coesão e conforto para a leitura. "As cúpulas são sustentadas por quatro filas de três colunas de ferro fundido, das quais se originam os arcos que sustentam as cúpulas. As bordas inferiores são cobertas de arabescos em ferro fundido. $O$ efeito é intencionalmente grandioso - um sistema utilitário de construção usado para criar o máximo de impacto visual" (GLANCEY; 2012: 388)

Ambas as obras de Henri Labrouste, projetadas e construídas com o intuito de destacar o uso do ferro e do vidro na arquitetura, trazem à tona novos conceitos relacionados ao projeto e ao desfrute de bibliotecas, estas, tomadas a partir de então como espaços de troca de conhecimento e de contemplação espacial. Em ambos os casos há um forte entrelaçamento do design clássico às tecnologias mais inovadoras então disponíveis, além da adoção de materiais de construção e de revestimentos dos mais recentes. Mas não é só isso. A partir de seus projetos, Labrouste ressignifica o conceito arquitetônico de espaços fechados, porém de uso público, utilizados até aquele momento: estruturas aparentes moduladas, vedações em alvenarias com detalhes ornamentais e novas soluções mecânicas para iluminação artificial e para aquecimento interno - a partir das quais ambas as bibliotecas passam a permanecer abertas, inclusive, durante a noite (coisa que até então não acontecia).

Para Kruft (1994), ao aluno e discípulo de Labrouste, Eugène-Emmanuel Viollet-le-Duc, pode-se creditar o mérito pela criação dos estilos nacionais na Europa, estilos esses calcados em fatores técnicos, formais e sócio-históricos tão apregoados por le-Duc ao longo de sua trajetória. O mesmo autor cita que é esse mesmo arquiteto francês quem investiga questões imbricadas entre a arquitetura e o caráter de seu povo, alçando o gótico francês ao estilo representante da cultura nacional francesa.

Viollet-le-Duc é também o responsável por uma série de restaurações em edificações históricas, dentre as quais destacam-se: a Catedral Notre Dame de Paris (Paris) [Figura 3.5], as basílicas de Sainte-Marie-Madeleine de Vézelay (a noroeste da capital francesa) [Figura 3.6], e de Saint Nazarius e St. Celsus (em Carcassonne, no sudoeste da França). É dele também o trabalho minucioso de restauro do Hôtel de Cluny (em Paris) e dos castelos de Roquetaillade (na região da Gironda) [Figura 3.7] e de Vincennes (a leste de Paris) [Figura 3.8]. Além de diversos trabalhos práticos de construção e/ou de restauração, elabora uma importante obra teórica calcada em estudos aprofundados sobre 
arquitetura. De suas investigações nasce, por exemplo, um dos mais importantes dicionários ilustrados de arquitetura (o Dictionnaire Raisonné de l'Architecture Française du Xle au XVI Siécle), o qual alcança repercussão bastante significativa dentro e fora da França.

Viollet-le-Duc interessa-se pelo papel do arquiteto aliado às suas condições de atuação, e redige estudos referentes, por exemplo, a técnicas medievais de esculpir pedras, de realizar rejuntamentos e de maneiras de levantar, verificar e analisar as patologias nas edificações (indicando os melhores caminhos, no seu entender, para restaurá-las). E vai além. Em seus escritos, como defende Santos (2005), ele evidencia seu

grande conhecimento sobre arquitetura e construção, especialmente da arquitetura medieval, e uma forte preocupação com a adequação de formas, materiais, funções e estruturas que, na concepção de um projeto de restauro, deveriam formar um "sistema lógico, perfeito, e fechado em si" de forma a estabelecer o "modelo ideal" e retornar o edifício a "um estado completo que pode não ter existido nunca em um dado momento". Para isso, fazia uma análise profunda de como teria sido feito o projeto original se detivesse todo o conhecimento e experiência da época da concepção, concebia o "modelo ideal" e impunha sobre a obra esse esquema já montado. Por isso em sua obra muitas vezes percebese a falta de respeito pela matéria e pelas modificações sofridas pelo edifício ao longo do tempo, pois "acertava os defeitos" buscando a pureza de estilo através da retomada do projeto original ou, como aconteceu em diversas obras, reconstituía edifícios inteiros a partir desse "modelo ideal" resultando em um edifício completamente diferente do original. (SANTOS; 2005: 1-2; passim)

De acordo com a mesma autora, o arquiteto francês coloca-se como um dos primeiros pesquisadores que, ao tratar o conceito moderno de restauração, não apenas estabelece os princípios ideais de intervenção em edificações históricas, como também cria uma metodologia específica para a execução da ação de restauro propriamente dita. Santos (2005) leva adiante suas considerações e diz que, mesmo o pensamento e a atuação de le-Duc sendo racionais, lógicos e coesos, sua postura dogmática e abusiva de agir sobre as construções existentes baseado em boa medida em suas próprias conclusões, lança-o praticamente ao esquecimento ao longo das décadas seguintes, "e somente muitos anos após sua morte é que suas teorias foram revistas e avaliadas dentro do contexto em que foram produzidas, evidenciando a contribuição do seu trabalho para o restauro contemporâneo" (ibidem; 2005: 1).

Outro ponto importante sobre as pesquisas deste arquiteto francês recai, no entender de Frampton (2008), na busca por estabelecer uma clara diferença entre programa e construção. Na sua obra intitulada "Entretiens sur l'Architecture" publicada inicialmente em dois volumes entre 1863 e 1872, le-Duc tece uma linha de raciocínio direcionada a vestir, com certo ar de independência, aquilo que arquitetonicamente vinha sendo praticado até então. Dito de outra maneira, ele sistematiza uma nova aproximação à arquitetura e ao ensino de arquitetura 
diametralmente oposta ao que prega a École de Beaux-Arts francesa (por ele renegada e desprezada, ainda em sua juventude). Nesta obra, Viollet-le-Duc ressalta a importância de ser fiel ao programa de uma edificação no momento em que são atendidas as condições impostas por ela como necessárias. Já no que diz respeito à construção - continua o autor - le-Duc prega que os materiais devem ser utilizados de acordo com suas qualidades e propriedades intrínsecas, ou seja, materiais como ferro e vidro e tantos outros precisam, para ele, ser utilizados também em função de suas propriedades resistentes, e não apenas como substitutos (ou alternativas) aos materiais mais tradicionais (como o que se verifica no Neoclassicismo).

No entender de Macedo (2002), esta é a oportunidade que o arquiteto tem de ser verdadeiro com o programa e com o processo construtivo - aqui incluída a verdade para com os materiais adotados. Para le-Duc, avança o mesmo autor, é como se a forma devesse seguir a construção em uma espécie de antecipação, por assim dizer, da famosa frase " $a$ forma segue a função", de Louis Sullivan, cunhada vários anos depois. "Trata-se de explicitar a técnica utilizada, e não de ocultá-Ia". (MACEDO; 2002: 97)

Como consequência, questões voltadas aos aspectos de simetria e de forma aparente passam a ser tratadas em um nível secundário, quando comparadas aos princípios dominantes abordados em sua publicação da segunda metade do século 19. Ainda para Santos (2005), é fundamental considerar a obra de Viollet-le-Duc sob o ponto de vista da

\begin{abstract}
atualidade de muitas das suas formulações e sua aplicabilidade nas intervenções de restauro atuais: a restauração tanto da função portante do edifício como de sua aparência, o estudo do projeto original como fonte de conhecimento para resolução de problemas estruturais, a importância dos levantamentos detalhados da condição existente, a reutilização do edifício para sua sobrevivência e, principalmente, a atuação baseada em circunstâncias e especificidades de cada projeto. (SANTOS; 2005:3)
\end{abstract}

Já segundo Collares (2003), o binário programa-construção proposto por le-Duc sugere certa autonomia em relação ao ecletismo historicista anterior e antecipa-se, de certa maneira, ao Art Nouveau muito adotado nos anos seguintes. Além disso, serve de berço para novas propostas nos campos da engenharia e da arquitetura, alicerçadas nos princípios do racionalismo estrutural.

Os efeitos da tomada de consciência de um futuro inovador são sentidos em diversas áreas do conhecimento. Novos horizontes estruturais são então desbravados principalmente pelos profissionais atuantes no campo da engenharia, seduzidos que estão pelo leque de possibilidades oferecidas pelo ferro e pelo aço, em um primeiro momento, e pelo 
vidro como complemento. Assim, contribuições significativas aos avanços técnicos e tecnológicos são registradas com cada vez mais frequência.

Desnecessário dizer que esses avanços não são conquistados automaticamente, de uma hora para outra. A contribuição de le-Duc, portanto, chega para estabelecer um novo ponto de vista para questões importantes que até aquele momento não haviam sido discutidas com propriedade ou clareza adequadas. Mas isso não significa dizer que, antes de le-Duc, o trabalho dos engenheiros e dos arquitetos não tenha alcançado êxito. Pelo contrário. Basta remeter ao final do século 18 e trazer à tona as pioneiras e inovadoras obras projetadas e construídas pelo engenheiroarquiteto escocês Thomas Telford (1757 - 1834), como estradas, pontes, canais, elementos de infraestrutura, portos e túneis, sendo ele visto por muitos como o precursor no uso do ferro fundido para grandes estruturas voltadas à construção civil.

Dentre seus trabalhos de maior reconhecimento - e na ativa até os dias de hoje - encontra-se o aqueduto navegável de Pontcysyllte [Figura 3.9], no Vale de Llangollen (localizado no distrito de Wrexham, a nordeste do País de Gales). Parte integrante do complexo destinado ao Canal de Ellesmere, o aqueduto é concluído no ano de 1805 e é, até o presente momento, a obra desse tipo mais alta e mais longa de toda a Grã-Bretanha. Trata-se de um canal suspenso, ao ar livre, com 307,0 metros de comprimento; 3,4 metros de largura; 1,60 metro de profundidade e com 38,0 metros de altura (a contar do ponto mais baixo do vale no qual se situa). São dezenove vãos de 16,0 metros de largura cada, vencidos por estruturas em forma de arco e que estão separados entre si por pilares de alvenaria vazados internamente. Fruto da inventividade de Telford, assume-se que esta seja a primeira oportunidade em que o ferro fundido tenha sido utilizado em uma obra de construção civil. Neste caso, tal elemento encontra-se em forma placas dobradas que formam calhas, fixadas nas alvenarias dos pilares e que ajudam na constituição e na montagem do aqueduto propriamente dito.

Já na metade do século 19 destaca-se a atuação de Joseph Paxton (1803-1865). Jardineiro e paisagista, este inglês de nascimento vê-se acostumado, ao longo de parte de sua trajetória profissional, a projetar estufas para os jardins de seus clientes. Ainda que projetos como estes possam dar a entender que sejam necessários conhecimentos técnicos moderados ou razoavelmente específicos, as obras de Paxton procuram tirar o máximo proveito da resistência mecânica das matérias-primas utilizadas, aliando os resultados a interessantes efeitos estéticos. 
Normalmente suas estufas adotam a madeira e o vidro como insumos principais, porém, em casos especiais, elementos portantes moldados em ferro fundido são também utilizados.

Paxton é até os dias de hoje lembrado por seu projeto mais ousado: o Palácio de Cristal [Figura 3.10], idealizado para a Grande Exposição de 1851 (no bairro de Hyde Park, em Londres) e que resulta em um notável avanço no desenvolvimento da arquitetura e da engenharia praticadas à época. De acordo com Kühl (1998), do ponto de vista construtivo, este edifício de aproximados 560,0 metros de comprimento corporifica uma síntese de elementos componentes previamente investigados separadamente e coordenados entre si, no momento de sua junção, por uma malha horizontal constante e basicamente constituída e comandada por uma modulação de 2,44 metros. Primeira construção auto-portante erguida em ferro fundido, nela são dispostas 3.300 esguias colunas metálicas unidas entre si por um total de 2.224 vigas produzidas no mesmo material. Esta solução estrutural, como afirmam Kühl (1998) e Glancey (2012), é vedada superior e lateralmente por cerca de 300 mil placas de vidro laminado importadas da França especialmente para atender a este projeto. Tudo isso para suprir os 71.793 metros quadrados de superfície coberta, nos moldes, por assim dizer, de uma gigantesca estufa destinada a abrigar os espaços expositores dos mais diversos países.

Tal a relevância do Palácio de Cristal para a arquitetura e para a engenharia mundiais que Pevsner (2001) afirma ser esta obra a primeira totalmente desenhada, pensada e construída modularmente em ferro e vidro - justamente para atender não apenas às necessidades de produção em nível industrial, como também às exigências dos organizadores do evento: edificação efêmera facilmente erguida, ampliada ou desconstruída, e que se valha de materiais de construção de baixo custo final. Além disso, pode-se assumir, seguindo ainda o raciocínio do mesmo autor, que esta obra seja também a responsável por confirmar o primeiro afastamento arquitetônico, em larga escala, dos estilos historicistas francamente praticados naquela época. Segundo Glancey (2012), tal a importância desta obra que “o Palácio de Cristal foi o primeiro edifício do mundo pré-fabricado em grandes dimensões, antecipando uma nova geração de fábricas. Em 1852, após o encerramento da Grande Exposição, a estrutura foi transferida para Sydenham, sudeste de Londres, e infelizmente destruída por um incêndio em 1936”. (GLANCEY; 2012: 385)

Ainda considerando os avanços técnicos e tecnológicos vivenciados pelo ferro e pelo vidro durante o século 19, e voltando os olhos novamente para o território francês, observa-se que duas obras chamam a atenção de teóricos e de estudiosos do assunto e demonstram, uma vez mais, a qualidade inovadora desses materiais quando aplicados 
conscientemente na construção, influenciando o modus operandi da arquitetura e da engenharia daquele tempo. Sob o comando da dupla formada pelo arquiteto francês Charles Louis Ferdinand Dutert (1845 - 1906) e pelo engenheiro estrutural, também nascido na França, Victor Contamin (1840 - 1893) nasce, para a Exposição Universal de Paris de 1889, a Galérie des Machines [Figura 3.11], localizada no distrito de Grenelle, junto ao Campo de Marte e muito próxima à Escola Militar parisiense.

Cramer e Breitling (2007) explicam que este projeto conforma a planta retangular de um amplo salão de vidro e metal delimitado em uma área de 115,0 metros por 420,0 metros atingindo, em seu ponto mais elevado, aproximadamente 50,0 metros de altura. A estrutura modulada dispensa apoios internos e é constituída por vinte pórticos autoportantes treliçados de grandes dimensões. No momento em que tocam o solo, o fazem por meio de um afunilamento gradativo no sopé dos pilares até encontrar os aparelhos de apoio articulados (rótulas) proporcionalmente bastante esbeltos e pontuais. São ao todo vinte treliças também articuladas, cuja tecnologia fora anteriormente desenvolvida para obras de maior porte, como pontes e viadutos e que agora chega à cidade, invadindo e influenciando a vida do cidadão comum - mostrando-lhe seu poderio e sua possiblidade de perfeito diálogo para com o entorno, especialmente no que tange a seu uso futuro e às promessas de participar de projetos urbanos e arquitetônicos em escalas mais modestas, porém, não menos interessantes.

Ainda segundo ambos os autores, as dimensões da Galerie des Machines são assustadoras para a época, sendo que até então nenhuma outra obra conseguira vencer um vão livre tão significativo. Entretanto, vale ressaltar que não é apenas o tamanho do edifício o seu ponto forte: deve-se pensar também na estética da estrutura de ferro que toma para si o papel de elemento de sustentação por um lado, e de ornamentação por outro. Junto a um projeto arquitetônico como este, coloca-se a habilidade de a engenharia impor-se como uma expressão da ciência, da civilização e do desejo de criar e representar uma sociedade tecnologicamente avançada.

Os mesmos pesquisadores dizem que é possível estabelecer aqui uma ligeira comparação entre a Galérie des Machines (de Dutert e Contamim) e a Bibliothèque Nationale (de Labrouste). De acordo com eles, mesmo que o conjunto arquitetônico e estrutural da Biblioteca apresente-se esteticamente agradável e envolvente, seu resultado está aquém da sofisticação tecnológica adotada no pavilhão de exposições francês. Essa constatação não é justificada pelos autores somente pelos vinte anos que separam um projeto do outro, mas também à conceituação projetual: o sistema estrutural da Galeria é completamente independente de qualquer artifício para manter-se erguido (ao passo 
que, na Biblioteca, estrutura e vedação estão intrinsecamente conectados, ambos, estruturais), o que atribui à Galeria ainda mais leveza e sofisticação. Este fato pode ser compreendido como um dos primeiros passos para arquiteturas que se valem da estrutura independente e da planta livre, algo amplamente adotado anos mais tarde em escalas por vezes mais acanhadas, por exemplo, como o que se vê nas obras de Mies van der Rohe no Pavilhão Alemão para a Feira Mundial de 1929, em Barcelona (Espanha), ou para o Crown Hall, de 1956, em Illinois (Chicago, Estados Unidos).

Assim sendo, já durante a segunda metade do século 19 as arquiteturas estruturadas em metal não mais carecem, em função dos avanços técnicos e tecnológicos propostos pela engenharia, de paredes estruturais que auxiliem no travamento das edificações das quais fazem parte. Isso significa dizer que a partir desse momento as construções maciças são paulatinamente abandonadas em favor da utilização de soluções que permitem (e incentivam) o ato projetual e construtivo mais livre e criativo, ou seja, em praticamente todas as dimensões e formatos, com novos limites horizontais ou verticais, desde que elementos e componentes adequados pré-fabricados sejam adotados - o que admite que as novas edificações sejam erguidas, também, em prazos cada vez mais enxutos (o Palácio de Cristal, por exemplo, foi montado em apenas dezessete semanas, graças ao processo de industrialização e pré-fabricação de seus componentes).

Monumentos da conhecida Era da Máquina, como o Palácio de Cristal e a Galérie des Machines representam, portanto, as várias potencialidades técnicas e tecnológicas da estruturação em metal. Todavia, a aceitação do público ou dos profissionais da área não é unânime, pois nem todos apostam nesse novo cenário. Ou seja,

a Revolução Industrial eclodiu na Inglaterra em meados do século 18. A aplicação confiável da força a vapor ao maquinário produtivo, a capacidade de transporte naval de mercadorias para o mundo inteiro, a exploração das colônias e a ascensão das classes médias emancipadas e trabalhadoras foram apenas algumas das razões que levaram à rápida industrialização da Grã-Bretanha. Os arquitetos conservadores se viram na contramão da história. (GLANCEY; 2012: 379)

E esse conservadorismo ao qual se refere o autor no extrato acima não se resume apenas à Grã-Bretanha, pois a França - também bastante avançada na época - sofre o mesmo tipo de preconceito. O gosto pela perpetuação da tradição construtiva pode ser representado pela não interpretação (e consequentemente pelo não aceite), como arquiteturas de fato, de fábricas, armazéns, pontes, naves para exposições ou gares ferroviárias ou fluviais - dentre tantos outros exemplos cabíveis. Ou seja, novas propostas construtivas que tragam consigo novas possibilidades à arquitetura e à engenharia (portanto, diferentes daquilo que então é praticado), são vistas meramente como 
estruturas utilitárias, mesmo sendo dotadas de qualidades evidentes, entretanto, sem uma veia arquitetônica alinhada ao que se entende por uma obra de qualidade.

Assim, esses novos materiais construtivos (o ferro e o aço) são compreendidos como elementos enganadores, pois muitos acreditam que, a partir desses elementos, proposições artísticas e ornamentais ao menos satisfatórias nunca podem ser obtidas. Deste modo, quando utilizados, os componentes estruturais devem ser mantidos completamente escondidos pelos revestimentos que lhes são apostos. Um exemplo que vai contra essa necessidade de disfarçar a estrutura pelo medo de que ela não apresente qualidades estéticas adequadas recai sobre um segundo exemplo que vem da França, a Torre Eiffel [Figura 3.12], fortemente criticada quando de sua construção. Concebida pelo mais famoso engenheiro francês do final do século 19, Alexandre Gustave Eiffel (1832 - 1923), a torre parisiense estruturada em ferro fundido deixado aparente é identificada como a mais importante obra desse profissional. Além dela, Eiffel também projeta diversas outras estruturas revolucionárias de metal em diferentes pontos do território europeu e no exterior. Na Europa, dentre outras, são de sua autoria: a Estação Ferroviária de Toulouse, de 1862 (no sudoeste da França); a Pont de Ferro, de 1876 (em Girona - Espanha); a Estação Ferroviária Ocidental, de 1877 (em Budapeste Hungria); a Ponte Maria Pia, de 1877 (no Porto - Portugal); o Observatório de Nice, de 1886 (em Nice - França); o Grand Hotel Traian, de 1882 (em laşi - Romênia). Até mesmo na América do Sul estão presentes alguns projetos de Gustave Eiffel, e dentre eles citam-se dois: a Igreja de San Marcos, de 1875 (em Arica - Chile) e a Catedral de San Pedro de Tacna, de 1875 (Tacna - Peru). É também deste engenheiro francês o projeto estrutural da Estátua da Liberdade, inaugurada em 1886, em Nova York - Estados Unidos.

Para Silver, McLean e Evans (2013), os louros pelo sucesso da torre francesa devem ser compartilhados principalmente com o arquiteto francês Charles Léon Stephen Sauvestre (1847 - 1919), que entra na equipe de Eiffel para transformar o projeto de uma torre básica e retilínea inicialmente pensada em uma estrutura predominantemente decorativa e funcional. Sauvestre propõe pedestais executados em pedra posicionados nas extremidades inferiores dos quatro pilares da torre, junto ao solo, visando auxiliar tanto a absorção de cargas verticais quanto a estética dos quatro pilares inclinados ao tocarem o chão; elabora os arcos monumentais que conectam a base da torre ao primeiro andar; nos pavimentos, prevê amplos ambientes de permanência fechados lateralmente em vidro para estimular a contemplação dos arredores; e a estrutura em formato de bulbo alocada no topo da construção também é fruto de sua sugestão. Levando em conta o que postula Glancey (2012), pode-se dizer que esta obra toma para si o papel de símbolo absoluto 
da liderança tecnológica da Europa ocidental no último quartel dos anos 1800: é erguida para ser o ponto de referência da Exposição Universal de Paris de 1889 e representa, além disso, um marco do primeiro centenário da Revolução Francesa.

O mesmo autor apresenta alguns dados técnicos da Torre Eiffel: atinge 324,0 metros de altura, é erguida sobre uma base que ocupa uma área de 15.625,0 metros quadrados (inserida em um quadrilátero fictício de 125,0 metros de lado) e pesa 7.300 toneladas. Silver, McLean e Evans (2013) complementam as informações de Glancey e explicam que todos os componentes da construção são processados na fábrica do próprio Gustave Eiffel, situada nas cercanias de Paris e, pelo princípio da pré-fabricação, são todos montados no próprio canteiro de obras. Como se isso não bastasse,

cada uma das 18.038 seções usadas para construir a torre foi projetada com uma precisão de décimos de milímetro. Foram então colocadas juntas, empregando-se parafusos provisórios para formar seções pré-fabricadas de aproximadamente cinco metros de comprimento. No local, os parafusos foram substituídos um a um por 2,5 milhões de rebites montados termicamente, que se contraíram durante o resfriamento para assegurar um ajuste muito prefeito.

Os pilares repousam em fundações de concreto instaladas poucos metros abaixo do nível do solo sobre uma camada de cascalho compactado. Cada borda repousa sobre seu próprio bloco de apoio, aplicando-lhe uma pressão de 3 a 4 quilogramas-força por centímetro quadrado, e cada bloco une-se aos demais por paredes subterrâneas. (SILVER, McLEAN e EVANS; 2013: 118)

Complementa o uso do ferro fundido na construção civil, a descoberta do cimento Portland, cuja patente é apresentada pelo empresário inglês Joseph Aspdin (1778 - 1855) em Leeds (Inglaterra) no ano de 1824. As bases para a fabricação em larga escala das descobertas feitas por Aspdin, entretanto, são colocadas em prática pelo desenhista, construtor e empresário britânico Isaac Charles Johnson (1811 - 1911). O sistema de processamento lançado por Johnson foca, de acordo com Freitas (2011), a adaptação de um método deveras rudimentar sobre o qual trabalha Aspdin para algo mais exato e profissional, baseado em pesquisas científicas, controle de qualidade, ensaios, dosagens racionais e procedimentos industriais que repercutem, tempos depois, na montagem das fábricas produtoras de cimento.

Collares (2003) sugere que, já próximo ao início do século 20, as investigações sobre novas materialidades e alternativas construtivas estimulam o aparecimento do concreto armado na Europa, inicialmente na França (neste caso, já com qualidades e propriedades bem próximas daquilo que se tem atualmente disponível no mercado). Entretanto, embora a técnica do concreto armado tenha sido desenvolvida pelos franceses, são os alemães os 
responsáveis por utilizá-la em um nível mais sistemático e mais adequado para a produção em larga escala na construção civil europeia, em um primeiro momento, e mundial, tempos mais tarde.

A descoberta do concreto armado (inicialmente chamado de ferrocimento) é creditada ao agricultor francês JosephLouis Lambot (1814 - 1887), que em 1849 efetua os primeiros experimentos práticos para testar e avaliar o efeito da introdução de ferragens em uma argamassa de concreto. Além de pequenos reservatórios de água e de bebedouros, Lambot adota esse material em uma situação mais inusitada, porém interessante, em sua fazenda: desenha, projeta e constrói um barco [Figura 3.13] com armadura de ferro e argamassa de concreto para ser utilizado nos lagos de sua propriedade. Tamanha é a sua satisfação com o resultado obtido que resolve não somente apresentá-lo na Feira Mundial de Paris de 1855, mas também solicita o registro de sua produção junto aos órgãos competentes.

O barco de ferrocimento, porém, não consegue a repercussão esperada, mas seu baixo custo de produção, sua relativa leveza final, e sobretudo o conceito estrutural que envolve a criação de Lambot, chamam a atenção de um jardineiro e fabricante de produtos para jardinagem, o francês Joseph Monier (1823 - 1906). A partir da ideia de Lambot, Monier vislumbra a oportunidade de substituir os vasos de plantas ornamentais que ele próprio fabrica artesanalmente em madeira ou cerâmica por este novo material. No momento em que familiariza-se com as propriedades do ferrocimento e compreende seu uso e suas limitações, Monier expande sua produção e, além de modelos de vasos mais diversificados, passa também a fabricar e a patentear estruturas para reservatórios de água [Figura 3.14], tanques, tubos para escoamento de água, manilhas de esgoto, painéis decorativos para fachadas de edifícios, passarelas, vigas e até mesmo pontes.

Collins (2004) lembra que é Monier quem estuda e diversifica o uso do concreto armado, e mesmo que suas investigações sejam mais empíricas e intuitivas que teóricas e racionais, é fato consumado que elas tenham chegado a uma importante variedade de experimentos nunca dantes estudados. É também Monier quem nota pela primeira vez a trabalhabilidade da argamassa de concreto, (ou seja, sua facilidade de manuseio enquanto ainda plástica e maleável), bem como suas infinitas possibilidades de moldagem, além da alta resistência à compressão e ao esmagamento, porém, muito sensível aos efeitos de tração e de cisalhamento. Monier chega à conclusão que o aço, quando adequadamente adicionado e posicionado na peça a ser moldada, ajuda a suprir a falta de resistência da argamassa de cimento aos esforços de alongamento. Trata-se, no seu entender, do casamento perfeito de diferentes materiais com funções distintas que, juntos, trabalham em sinergia e alcançam resultados mais interessantes. 
Paralelamente aos estudos de Monier na França, o industrial, político e empreendedor americano Thaddeus Hyatt (1816 - 1901) realiza ensaios científicos com o cimento armado, visando definir suas características e propriedades intrínsecas especialmente em relação ao comportamento híbrido de uma estrutura quando submetida a situações de risco, como no caso de incêndios. Carvalho (2008) explica que Hyatt está na Inglaterra em 1877 quando se interessa por questões relacionadas ao cimento e, nesse momento, realiza uma série de experimentos que resulta na descoberta de que ambos os materiais - cimento e aço - possuem coeficientes de dilatação equivalentes quando submetidos a altas temperaturas. Dilatam-se, pois, proporcionalmente e do mesmo modo - o que favorece seu uso conjunto. Assim sendo, a partir das investigações de Monier e de Hyatt, a preocupação desta nova técnica construtiva passa a ser direcionada às variáveis de aderência entre aço e cimento.

Collins (2004) aponta que, anos depois, em 1886, o engenheiro civil alemão Gustav Adolf Wayss (1851 - 1917) adquire o direito de uso das patentes registradas pelo jardineiro Monier e, de forma mais técnica e quem sabe mais científica e profissional conduz, por intermédio de sua empresa Wayss \& Freytag, inúmeras pesquisas para a aplicação do concreto armado como material de construção. Conduz assim ensaios tanto no concreto quanto em suas armações, testes esses majoritariamente focados em fatores entendidos como nocivos aos elementos estruturais, como corrosão, limites de resistência e estresse dos seus componentes. Os resultados das pesquisas são divulgados em publicações especializadas e contribuem para a conquista de novos mercados (incluindo o Brasil). Ainda de acordo com o mesmo autor, além de Wayss, também o engenheiro e empresário da construção civil, o britânico William Boutland Wilkinson (18019 - 1902) é tido como um dos pioneiros na migração do concreto armado para fins arquitetônicos, ao construir a primeira laje com esse material de que se tem notícia, em 1852, cuja patente é por ele requerida dois anos mais tarde.

Frampton e Futagawa (1983) citam que na Europa o primeiro edifício de vários andares que faz jus ao uso do ferro como elemento estrutural - e que retira das alvenarias esta responsabilidade - é concebido em 1871, na França, pelo arquiteto Jules Saulnier (1828 - 1900). Trata-se da fábrica de chocolates “Chocolat Menier” [Figura 3.15], construída sobre o Rio Marne, em Noisel-sur-Marne, na região de Île-de-France, e existente até os dias de hoje. Neste projeto, o posicionamento do prédio sobre a linha d'água justifica-se porque, em seu interior, um conjunto de moinhos tira proveito da correnteza agitada do rio para produzir energia hidráulica, por meio de três turbinas que, juntas, abastecem a linha de produção dos chocolates. 
Glancey (2012), explica que o delgado exoesqueleto exposto corre longitudinalmente e abraça esta edificação em toda a sua extensão e altura. O revestimento externo feito em tijolo e cerâmica - que não possui função estrutural, mas apenas de fechamento - confere estabilidade lateral e resistência aos ventos ao conjunto edificado. Internamente, duas linhas moduladas de pilares em ferro fundido seguem paralelamente à estrutura principal exposta e, ao formar um corredor interno que ajuda na distribuição dos ambientes e circulações de funcionários, contribui para o vencimento do vão entre as grandes treliças e trava o pequeno prédio como um todo. O mesmo autor diz ainda que "as janelas poderiam ter sido maiores, porém, janelas pequenas eram, e ainda são, uma forma de desenho aceita entre os arquitetos que continuam a acreditar que um edifício deve seguir formas funcionais e proporções clássicas". (GLANCEY; 2012: 411)

Simultaneamente aos acontecimentos europeus e ao empenho de seus engenheiros e arquitetos no desenvolvimento de projetos modulados, racionais e que aproveitem as melhores qualidades de suas matérias primas (como o ferro, o aço e agora o concreto), nos Estados Unidos outras pesquisas que seguem a mesma tendência estão sendo elaboradas. Assim, efetivamente e de acordo com Macedo (2003), é em território norte-americano que, de fato, o mais alto empreendimento totalmente estruturado em aço é pela primeira vez erigido: a matriz da Home Insurance Company [Figura 3.16], em Chicago. Projetado e construído entre 1883 e 1885 pelo engenheiro-arquiteto William Le Baron Jenney (1832 - 1907), o prédio é ampliado em 1891 e demolido quarenta anos depois, em 1931. Nesta obra, pilares e vigas são feitos em aço, resultando em uma edificação mais rápida e cerca de um terço mais leve caso tivesse sido levantada com alvenarias estruturais convencionais.

Jenney é um dos profissionais da construção civil com participação ativa na reconstrução de uma Chicago parcialmente devastada após um incêndio de grandes proporções ocorrido em 1871. Ao longo da segunda metade do século 19, a cidade torna-se um importante entreposto mundial de madeira - material este também usado como base (junto com o ferro) para boa parte das edificações localizadas no centro, a região mais atingida: casas, pequenos prédios e até ruas e passagens, todos, feitos com um material altamente combustivo (a madeira) - daí o rápido alastramento das chamas, que em dois dias impõe enormes prejuízos a todos: cerca de trezentos mortos, noventa mil desabrigados e duzentos milhões de dólares em danos ao patrimônio. Todavia, mesmo com o estrago generalizado, parte da infraestrutura permanece intocada: redes de água e de esgoto, além do sistema de transportes são então reaproveitados e readaptados na etapa futura de recomposição, especialmente, das áreas arrasadas. 
A reconstrução nos anos seguintes configura a oportunidade que têm arquitetos e engenheiros locais e provenientes de diversas partes dos Estados Unidos de contribuir para reerguer a cidade. Nomes como o do próprio William Le Baron Jenney, além de Daniel Hudson Burnham (1846 - 1912), John Wellborn Root (1850 - 1891), William Holabird (1854 - 1923), Martin Roche (1853 - 1927), George Herbert Wyman (1860 - 1939) e Louis Henry Sullivan (1856 - 1924) participam dessa força-tarefa. E dentre eles merece destaque o último, justamente por sua contribuição para aquilo que se sabe hoje como arquitetura moderna e para o entendimento das variáveis intrínsecas aos prédios de grandes alturas.

Consenso entre os envolvidos, as soluções arquitetônicas adotadas na recuperação da Chicago pós-incêndio focam a verticalização do centro, já que os terrenos, ali, sofrem altas de preço exorbitantes movidas pela exploração espacial ditada pelo mercado imobiliário ávido em fazer novos negócios e em compensar seus prejuízos. Tendo em vista os preços proibitivos praticados na comercialização do solo, bem como as restrições legislativas impostas para uso e ocupação dos espaços agora vagos, a solução recai nas edificações de diversos pavimentos - que têm como mote o melhor aproveitamento dos lotes nos quais se inserem. Serve como incentivo a invenção do elevador com dispositivos de segurança, em 1853, por Elisha Graves Otis (1811 - 1861), cuja existência passa a ser fundamental para permitir a circulação vertical dos usuários nos chamados arranha-céus que serão erguidos nos anos seguintes.

As estruturas em concreto armado - relativamente tradicionais até aquele momento - passam a ser utilizadas juntamente com as de aço e abrem um sem-número de possibilidades à indústria da construção civil americana. Como vantagens, tem-se que o emprego das estruturas de metal reduz a necessidade de paredes estruturais, e torna as fachadas dos edifícios menos compactas e mais abertas. Ajudam ainda no melhor aproveitamento dos espaços disponíveis, pois não há mais grandes maciços estruturais construídos no pavimento térreo para sustentar os pisos superiores - o que, segundo Frampton (2008), direciona a solução construtiva para as ossaturas metálicas préfabricadas: mais esbeltas, rápidas de serem tanto produzidas quanto montadas in loco e, em uma situação de calamidade como a de Chicago, na qual inúmeras obras são executadas simultaneamente, obtém-se custo final total relativamente mais baixo quando comparado às estruturas convencionais. $O$ temor por novos incêndios também pode ser apontado como um dos motivos de se ter optado pelo aço como solução estrutural, como afirma Giedion (2004). Material patenteado em 1856 pelo engenheiro metalúrgico britânico Henry Bessemer (1813-1898), as equipes de engenheiros e arquitetos de Chicago elegem esta como a matéria-prima mais importante para as novas estruturas 
pois, diferentemente da madeira que entra em colapso rapidamente quando em contato com o fogo, o aço aqui é revestido com uma camada de argamassa refratária, o que lhe confere resistência ao fogo mais acentuada, portanto, uma garantia de confiabilidade maior nas novas obras executadas.

O centro de Chicago é então reerguido utilizando-se basicamente duas tecnologias inovadoras: por um lado, o aço representando a ossatura autônoma dos novos arranha-céus e, por outro, o apuro da aplicação do concreto armado na construção civil - cuja evolução em termos teóricos e de aplicabilidade inicia-se na França e reflete-se especialmente pela Europa, chegando, com o passar do tempo, aos Estados Unidos (e especificamente, a Chicago). Collares (2003) esclarece que o aperfeiçoamento da tecnologia do concreto armado atinge o ápice com o trabalho do construtor francês François Benjamin Joseph Hennebique (1842 - 1921). É dele a técnica moderna de uso desse material como matéria-prima adaptável a diversos tipos de arquitetura e capaz de atender de forma eficiente a indústria da construção civil. O sistema estrutural hennebequiano [Figura 3.17] complementa e desdobra as investigações do americano Thaddeus Hyatt ao focar a atenção na aderência (processos, causas e consequências) entre aço e concreto. Suas pesquisas caracterizam-se pelo uso de estribos (isto é, de barras de aço de pequeno diâmetro, de seção retangular, cortadas e dobradas em formato de "U") inseridos nas vigas de maneira a conectar mais eficientemente as barras circulares de aço longitudinais sujeitas à tração às zonas comprimidas do concreto. Dessa maneira, as peças moldadas em concreto armado trabalham com mais unidade e resistência às solicitações de tração, de compressão, ou mesmo de cisalhamento vertical - aqui, graças à ação dos estribos.

Ao analisar de forma geral o sistema estrutural composto por pilares e vigas, o comportamento individual de ambos os elementos e as interinfluências provocadas e recebidas entre eles, Hennebique apura o modelo estrutural em concreto armado. Sua ideia baseia-se na conversão e na integração de componentes outrora compreendidos como autônomos (leia-se: pilares e vigas) em um único e monolítico elemento, ou seja, em uma única solução estrutural constituída por um arranjo interno de componentes bastante similar ao adotado atualmente e que tira melhor proveito das capacidades resistentes do conjunto edificado como um todo.

Os pontos de maior preocupação para o construtor francês recaem sobre a transição da estrutura de cobertura para as vigas de sustentação imediatamente inferiores (por ele denominadas como "vigas-mestras") e sobre a relação intrincada entre os demais pilares e as demais vigas. Suas investigações dão margem a novos processos construtivos que sugerem, como reforço resistente, a dobragem das armaduras de ferro das vigas e sua junção às dos pilares. 
Dessa forma, ao compreender que todos os materiais passam a trabalhar com mais eficiência e, portanto, com os seus níveis de resistência às solicitações externas mais adequados, Hennebique verifica que é possível reduzir significativamente a quantidade de matérias-primas utilizadas em obra, o que representa não apenas economia de custos, mas também a chance de construir edificações racionais mais leves, com fundações mais modestas e, quem sabe, com a possibilidade de se sobrepor um número cada vez maior de pavimentos sem quaisquer danos ao esquema estrutural inicialmente projetado (desde que, claro, dimensionado adequadamente).

Entretanto, fato é que à proposta do construtor francês não podem ser creditados méritos por inovação ou exclusividade propriamente ditos e assim tão significativos. Com sua veia inata mais voltada à prática que à teoria, e por isso mesmo com o uso de critérios quase que empíricos e calcados em avaliações científicas limitadas, Hennebique baseia suas descobertas em exercícios de “tentativa e erro”. Logo, ele conclui que seu sistema aceita configurações espaciais variadas e flexíveis, as quais garantem de forma cabal a resistência necessária para absorver diferentes sobrecargas simplesmente por adicionar um número maior de pilares a um vão de abertura constante. Percebe-se que, em verdade, o construtor francês deve ser agraciado por ser o primeiro a traduzir para a linguagem do concreto armado, algo já existente no uso de outros materiais de construção. É o que crê Macedo (2003), ao dizer que

o sistema estrutural de Hennebique funcionava por analogia ao sistema estrutural de madeira, ferro e aço - com laje, vigas e pilares - suas lajes venciam vãos pequenos e eram reforçadas por vigotas com espaçamento também reduzido, à semelhança de barrotes de madeira apoiados em esteios ou de esqueletos de ferro fundido - ou aço - montadas in loco. Em Hennebique, verificamos a união de duas tradições recentes distintas: a construção metálica modular - de natureza padronizada - e a construção em concreto, de plasticidade virtualmente ilimitada, (MACEDO; 2003: 70-71)

Tamanha é a aceitação do método construtivo hennebiqueano que sua empresa sediada na capital francesa possui em 1910 cerca de quarenta mil obras realizadas: de edifícios de diversos usos a pontes, reservatórios de água e a obras com inúmeras outras finalidades, distribuídas em vários países. Isso não significa dizer, no entanto, que a partir da sede parisiense a equipe comandada por Hennebique projeta e constrói para o mundo inteiro, ou que tenha sucursais distribuídas em cada parte do planeta. Pelo contrário. Na verdade, esse construtor francês (e nesse momento mais que empresário, um competente profissional de marketing) vende o direito de uso de suas estruturas patenteadas. Trabalhando dessa forma, os engenheiros calculistas centralizados na matriz da empresa passam projetar e a dimensionar as estruturas e, paralelamente, Hennebique delega a construção das edificações (em qualquer parte do mundo) a agentes e concessionários locais previamente credenciados pelo seu próprio escritório. 
Como consequência, a disseminação do racionalismo - agora não mais atrelado apenas ao uso do ferro e do aço, mas também à adoção do concreto armado - torna-se cada vez mais presente na Europa e fora dela (principalmente nos Estados Unidos. Collares (2003) mostra que, "na esteira do racionalismo estrutural de Viollet-le-Duc aparecem os nomes de Gaudí, Horta e Belarge, na virada do século 19 para o 20, cada um buscando uma arquitetura de feições nacionais, respectivamente na Espanha (Cataluña, mais especificamente), Bélgica e Holanda". (COLLARES; 2003: 24)

Surge nesse cenário promissor o nome do arquiteto francês Anatole de Baudot (1834 - 1915). Aluno da École des BeauxArts de Paris e discípulo da dupla Henri Labrouste e Eugène Viollet-le-Duc, é mais conhecido por seu projeto para a Igreja de Saint-Jean-de-Montmartre [Figura 3.18], inaugurada em 1904 na capital francesa. Aqui, Baudot "demonstra as qualidades expressivas da técnica do concreto armado num marco importante, revelando a estrutura e defendendo-a como única maneira válida de expressão arquitetônica" (COLLARES; 2003: 24). Trata-se do primeiro exemplo edificado de que se tem notícia de uma construção religiosa que usa concreto armado com fins estruturais (na cúpula e na ossatura modulada do corpo principal), aliado a vedações não estruturais compostas por tijolos reforçados com delgadas barras de aço. Este edifício, além de internamente fazer nítidas referências ao estilo gótico, representa a busca de Baudot por uma arquitetura de cunho racionalista, aos moldes do que aprendera com Viollet-le-Duc, reforçando a intenção de fazer do esqueleto do edifício uma forma de expressão da linguagem arquitetônica.

Anatole de Baudot interessa-se pela arquitetura em várias frentes: tanto na investigação de diferentes possibilidades de uso de materiais já correntes, como na adoção de novos elementos estruturais e/ou arquitetônicos. Acredita que ambas as ações somam oportunidades para explorar novas ideias e para encará-las sob diferentes perspectivas - daí seu apreço especial pelas potencialidades trazidas pelo concreto armado. Torna-se assim partidário do sistema concebido pelo engenheiro civil Paul Cottancin $(1865$ - 1920) da École Centrale des Arts et Manufactures, no qual colunas e arcos de concreto armado ajudam a vencer vãos mais largos, além de prover uma unidade mais interessante ao projeto estrutural.

As pesquisas de Baudot levam-no a pensar e a construir arquiteturas mais ousadas, especialmente no que se refere aos tamanhos dos vãos, cada vez maiores. E é neste caminho também que se coloca, tempos depois, o arquiteto alemão Max Berg (1870 - 1947). Ele projeta e constrói o Jahrhunderthalle [Figura 3.19] na cidade polonesa de Wroclaw entre 1911 e 1913 como parte de uma série de eventos comemorativos do centésimo aniversário da Batalha das Nações (contra Napoleão Bonaparte, derrotado pelas forças aliadas de Prússia, Áustria, Rússia e Suécia). Este edifício é 
considerado um dos marcos da arquitetura europeia feita em concreto armado e, em 2006, é considerado Patrimônio Mundial pela UNESCO. Glancey (2012) ressalta que esta obra, exemplo da arquitetura expressionista alemã, deve ter seu mérito dividido entre Berg e o engenheiro civil, também alemão, Willi Gehler (1876 - 1953) - professor titular da Universidade Técnica de Dresden, além de um atuante profissional da engenharia. 0 mesmo autor explica que o edifício Jahrhunderthalle tem

a forma de uma cúpula de 62 metros de diâmetro que se ergue sobre 32 nervuras de concreto e cobre um enorme auditório quadrado com capacidade para 10 mil pessoas. A cúpula apoia-se nos quatro cantos do quadrado e lembra as do arquiteto islâmico [Mimar Koca] Sinan (1489 - 1588). As paredes, com generosas janelas, formam laterais escalonadas e fazem com que o interior abobadado surpreenda os visitantes. (GLANCEY; 2012: 461)

Voltando aos Estados Unidos, se a contribuição da equipe de arquitetos e engenheiros já mencionada anteriormente é fundamental para a reconstrução da Chicago pós-incêndio, outro arquiteto americano - discípulo direto de Louis Henry Sullivan - elege a arquitetura moderna como a identidade de seus projetos e o concreto armado como um de seus principais materiais de trabalho. Trata-se de Frank Lloyd Wright (1867 - 1959), engenheiro não formado e nascido em Richland Center, no estado de Wisconsin. No ano de 1887, poucos meses antes de concluir o curso de engenharia civil, Wright abandona a faculdade e muda-se para Chicago em busca de emprego em alguma empresa ligada à arquitetura ou à engenharia. Determinado a encontrar uma oportunidade de trabalho em uma cidade que naquele momento passa por um processo profundo de reestruturação, é logo contratado como desenhista pelo arquiteto Joseph Lyman Silsbee (1848 - 1913). Já a partir do ano seguinte, e até 1893, Wright presta serviços ao escritório Adler \& Sullivan, um dos mais respeitados à época. E é aqui que Wright efetivamente aprende a projetar e a entender o significado da arquitetura, além de obter boas oportunidades de mostrar seu talento, sempre incentivado de perto pelo seu mentor, Louis Sullivan.

Os anos se passam e após deixar a Adler \& Sullivan, Wright resolve trabalhar por conta própria a partir do estúdio que ele mesmo projeta no andar superior de sua residência, no bairro de Oak Park, Chicago. Não necessariamente construídas três são as propostas pioneiras de Frank Lloyd Wright feitas nessa época para o emprego do concreto armado, como explica Collares (2003): o projeto do Village Bank, de 1901; a E-Z Polish Factory, terminada em 1905 ; e o Unity Temple, concluído em 1908 - e é sobre este último que algumas considerações sobre a aplicação do concreto armado e a relação com a arquitetura moderna podem ser esboçadas. 
Em um período no qual Wright encontra-se em amadurecimento profissional, e praticamente no início de suas atividades autônomas (ou seja, desenvolvendo projetos a partir de seu próprio estúdio em Oak Park), em 1905 surge a chance de conceber um edifício de maior envergadura: o Unity Temple [Figura 3.20]. Wright é indicado por alguns dos membros da Congregação Universalista Unitária para projetar a nova matriz da igreja, substituta da sede anterior, consumida pouco tempo antes por um grande incêndio. A importância desta obra é tal que pode-se assumi-la como sendo uma significativa contribuição para o movimento moderno logo no início dos anos 1900, bem como o alicerce a partir do qual a linguagem arquitetônica de Wright é construída e lapidada nas décadas seguintes.

O arquiteto americano encara a missão do novo projeto com responsabilidade e dedicação, não apenas porque ele próprio é também um membro da igreja, mas por entender que o edifício fruto de seu projeto materializa um espaço no qual o homem encontra seu próximo e cultua a Deus, logo, de grande significado para a comunidade. Com isso em mente, Wright opta por um projeto capaz de refletir essa importância e, do seu ponto de vista, nada mais justo que uma solução inovadora, que fuja ao típico estilo até então adotado em outros templos da Congregação. Escolhe, assim, o concreto armado como principal material para nortear o projeto e para erguer o templo, material esse raramente adotado naquele momento para edifícios de usos similares ou não nos Estados Unidos.

Vale ressaltar, entretanto, que Wright é conduzido também por forças das circunstâncias a trazer o concreto para seu projeto: se por um lado há o apelo inovador e a chance de elaborar um edifício com um material relativamente original, por outro, o pouco dinheiro angariado e consequentemente o orçamento apertado da Congregação, limitam as possibilidades arquitetônicas e o uso de tecnologias ainda mais avançadas. O entrelaçamento dessas variáveis faz do concreto a escolha mais acertada, pois além de viabilizar a ideia de Wright em função da flexibilidade no design, possibilita a construção de algo duradouro e que demanda manutenção relativamente reduzida e com baixo custo de construção e de preservação.

Externamente este prédio remete a um pequeno prisma de concreto, pesado, uniforme e sem aberturas, pois praticamente não há janelas, exceto aquelas situadas junto à cobertura e sutilmente desniveladas em relação aos demais elementos que compõem a fachada. Todavia, a austeridade externa não se repete no lado de dentro. O vão livre suportado pelo concreto armado e que conforma o espaço reservado para os cerimoniais situa-se no centro da construção e passa a sensação de amplidão. É banhado de uma luz difusa que emerge tanto dos vitrais das janelas no topo das paredes quanto de um conjunto de claraboias posicionadas no teto da sala de celebração. O ambiente é 
muito claro, confortável e convidativo ao encontro de pessoas. Já aqui os espaços são projetados por Wright para serem eficientes e visualmente dilatados - uma de suas qualidades projetuais estendidas e aperfeiçoadas em seus projetos vindouros.

Uma vez mais referenciando a Europa e, tomando a França como o berço principal na investigação da tecnologia do concreto armado, chega-se ao arquiteto borgonhês Auguste Perret (1874 - 1954). Trata-se de um dos alunos mais destacados de Julien Azaïs Gaudet $(1834$ - 1908) na École de Beaux-Arts de Paris. Inicialmente Perret opõe-se ao ecletismo ao adotar, em seu fazer projetual, dois princípios fundamentais: por um lado as influências classicistas, representadas pela clareza geométrica, pelo rigor na construção, pela simplificação formal e pela simetria espacial e, por outro, a coerência estrutural movida pela ênfase nas soluções construtivas. Este seu posicionamento deriva do aprendizado que recebe de François Hennebique, com quem trabalha durante algum tempo. Em seus projetos, Perret busca reinterpretar o estilo clássico a partir da utilização de tipologias históricas, mas desenvolvidas e construídas com base nas teorias modernas, seja com a aplicação de novos materiais, seja com a releitura de materiais anteriormente já adotados, como o concreto armado por exemplo.

Uma de suas arquiteturas que merece destaque refere-se ao edifício residencial situado à Rue Franklin, em Paris, de 1903 [Figuras 3.21 - 3.22]. De planta livre e estruturado em concreto, o volume em formato de " $U$ " condensa fachadas ordenadas em cinco compartimentos horizontais que se repetem verticalmente ao longo de seis pavimentos. Tratase de uma sacada central fechada e ladeada por duas varandas abertas ao lado das quais, em cada uma das extremidades, os volumes mais próximos ao alinhamento da calçada abrigam os cômodos de melhor vista para a rua. Internamente, Perret confere flexibilidade às plantas dos apartamentos e, do lado de fora, adota a ossatura estrutural exposta e evidenciada sem camuflagens, ressaltando as qualidades estéticas do concreto armado - coisa que até então nunca havia sido feita. Este projeto de Perret é entendido por muitos como o pioneiro "no emprego do concreto armado como meio de expressão arquitetônica, e muitas de suas características se mostraram sementes de futuros desenvolvimentos". (GIEDION; 2004: 357)

No entender de Collares (2003), a edificação destinada a abrigar um conjunto de garagens na Rue Ponthieu, na capital francesa, é outro exemplo da iminência do modernismo europeu. Este projeto de Perret concluído em 1905 é conhecido como Garage Marbouef e materializa de maneira bastante simples a expressão estrutural do concreto armado. Macedo (2003) complementa esse ponto de vista e explica que 
trata-se de uma garagem incrustrada em um lote em "L" com estrutura aparente, um grande vão linear central iluminado zenitalmente, por onde corriam plataformas móveis que "estacionavam" os veículos. A necessidade de área livre para estacionamento transforma a garagem numa espécie de galpão onde a única construção é a estrutura ordenada simetricamente em duas fileiras de pórticos com balanços laterais, de modo a afastar a fundação dos pilares da divisa, preservando a integridade das construções vizinhas. (MACEDO; 2002: 71)

De 1917, o grupo de depósitos situados no cais de Casablanca, em Marrocos é, para o mesmo autor, uma chance de Perret adotar cascas abobadadas de concreto armado sequenciadas e dispostas de tal forma que os esforços decorrentes do empuxo de cada uma delas é absorvido pelas cascas adjacentes, ou seja, pelas abóbadas imediatamente contíguas. Esta solução estrutural tem como resultado a adoção de pilares também de concreto significativamente mais esbeltos para suportar as coberturas encurvadas, uma vez que os momentos fletores nas regiões de apoio precisam ser desprezados, pois são inexistentes. Além destes edifícios, a igreja de Notre-Dame du Raincy, também em Paris (1922-1923) [Figuras 3.23 - 3.24], apresenta inspirações em Viollet-le-Duc e em Anatole de Baudot, ao propor o uso racional de elementos pré-fabricados, soluções moduladas, espaços simétricos, colunas delgadas, poucas ornamentações e, principalmente, uma releitura do teto formado por arcos sucessivos moldados em concreto armado e que conferem um movimento ondulante à cobertura desta igreja.

Já Robert Maillart, (1872 - 1940), engenheiro estrutural suíço e um dos responsáveis por potencializar o uso do concreto armado para vencer grandes distâncias, tem como uma de suas primeiras obras construídas uma ponte em Zuoz, na Suíça, de 1901, com 38 metros de vão livre [Figura 3.25]. Basicamente trata-se de uma estrutura formada por um grande conjunto monolítico fruto da combinação de tabuleiro e viga mestra, entendidos pelo engenheiro como peça única em formato de grande arco triarticulado e, por isso, de elementos moldados, concretados e curados simultaneamente - o que resulta em uma construção mais ligeira e financeiramente mais atraente. De acordo com Carrieri (2007), outro exemplo de ponte de Maillart é erguido em Tavanasa, também na Suíça, sobre o Rio Reno em 1905 [Figura 3.26] para um vão único de 48 metros: mais um arco triarticulado, porém, neste caso, de elementos estruturais de seção vazada e com aberturas laterais transversais e triangulares, pensadas tanto para aliviar o peso total da estrutura como para favorecer a expressão estética geral da obra, ou seja, uma preocupação de viés arquitetônico, normalmente não encontrada em projetos feitos por engenheiros. Infelizmente em 1927 esta ponte é destruída por uma avalanche e reconstruída tempos depois, todavia, com uma solução estrutural diferente e que acaba por descaracterizar, em parte, a proposta inicial maillariana. 
Baseando-se no concreto armado, Robert Maillart também explora processos de construção, materialidades, soluções estruturais e, em especial, pontos de contato. Entenda-se, neste caso, que "pontos de contato" são as junções, por exemplo, entre pilar e viga (como já pesquisado em outros momentos por Hennebique), ou mesmo entre pilar e laje. Neste caso em específico, os diagnósticos indicados por Maillart recomendam a necessidade de amortecer os efeitos da punção tão presentes na região de contato entre ambos os elementos pois, em função do tipo e das dimensões de ambas as peças estruturais, consequências nocivas ao conjunto arquitetônico podem surgir, como fissuras, desgastes, rompimentos e, em último caso, colapso da edificação como um todo.

Assim sendo, o engenheiro suíço desenvolve uma saída simples, porém, inteligente - e quem sabe até inspirada nas colunas gregas da Antiguidade: um capitel. Porém, um capitel não apenas com função estética, uma vez que também trabalha absorvendo os esforços prejudiciais do contato certeiro entre pilar e laje, distribuindo-os uniformemente ao longo de sua superfície. Este nada mais é que um componente hiperbólico de ligação que, por seu formato final, torna toda a solução conhecida por “laje cogumelo". Outra inovação deste sistema é que ele dispensa as vigas, já que a laje reforçada somada ao pilar e a seu respectivo capitel suportam por si sós os esforços de toda a edificação.

O primeiro edifício europeu que abraça essa solução em concreto armado é projetado pelo próprio Maillart. No número 62 da Rua Giesshübel, zona oeste da capital suíça, é construído em 1910 um armazém retangular de cinco pavimentos. Internamente, os pilares de seção octogonal são coroados por capitéis hiperbolicamente curvos [Figura 3.27]. Tanto o piso quanto os próprios pilares são moldados in loco e, como acontece no Brutalismo, ainda hoje se percebem nitidamente os veios dos madeiramentos utilizados durante a fase de moldagem das peças. Os pilares distribuídos pelo térreo possuem dimensões consideravelmente superiores àqueles dos andares superiores, o que é justificado pelo fato de suportarem cargas também maiores. Em todos os pavimentos - e sem exceção - a largura do topo dos capitéis dos pilares chega a alcançar quatro vezes o diâmetro da base - o que auxilia no vencimento dos vãos, na configuração dos espaços internos e na distribuição dos carregamentos verticais.

Há também o pavilhão de Maillart para a Companhia de Cimento Portland na Exposição Nacional de Zurique (Suíça), em 1939 [Figura 3.28] - demolido logo após o término do evento. O Cement Hall, como é conhecido, materializa “ $a$ arte e a elegância que a estrutura de concreto armado é capaz de exibir" (GIEDION; 2004: 501) em função de ser formada tanto por única abóbada paraboloide semicilíndrica, como por possuir seção variável ao longo do eixo longitudinal, tornando-a levemente cônica na parte posterior. Quatro apoios esbeltos elevam o pavilhão do chão e fazem as vezes 
não apenas dos momentos de toque do edifício com o solo, mas - por seu prolongamento ao redor da abóbada assumem também o papel de duas nervuras de reforço, "unidas à passarela de ligação que vence o vão entre elas e que representam tudo o que Maillart precisa para produzir uma estrutura sólida que paira sobre o solo como um balão de seda prestes a subir ao céu". (GIEDION; 2004: 502)

Assim como faz em suas pontes, o engenheiro suíço adota uma parte ativa na estrutura, neste caso, o corredor de passagem (ou a passarela) transversal, que liga as paredes opostas do pavilhão e que auxilia no controle dos empuxos derivados dos caminhamentos das cargas, cuja responsabilidade estrutural é dividida com o formato em catenária da edificação. Percebe-se assim sendo, que neste projeto maillariano o espaço arquitetônico é definido pelas exigências da forma estrutural.

Eugène Freyssinet (1879 - 1962), por sua vez, engenheiro e arquiteto francês, é um dos destaques dos avanços técnicos e tecnológicos conseguidos para o concreto no primeiro quarto do século 20. Dentre outras investigações, desenvolve métodos de análise da reologia dos concretos e de aplicação prática, em obra, dos sistemas de vibração e de compactação mecânicas das argamassas de cimento ainda em estado plástico. É o inventor do concreto protendido, no qual aço e cimento trabalham em seus estados limites de tração e de compressão (respectivamente), aumentando em demasia a resistência final da peça concretada quando endurecida. O resultado é a possibilidade de vencer maiores vãos nos quais até então apenas as estruturas metálicas são aplicadas.

Suas obras reforçam as formas dos elementos estruturais, compreendidos por ele como representantes arquitetônicos de grande valor para o conjunto edificado como um todo. A título de exemplo, tome-se o ano de 1912, quando Freyssinet tem seu projeto selecionado em um concurso público para a construção de uma ponte em Villeneuve-sur-Lot, na região de Aquitaine, na França. Trata-se da Pont de la Libération [Figura 3.29], cuja proposta está guiada por uma solução de concreto armado que adota um par de arcos estruturados em concreto (com 3,00 metros de largura cada), paralelos e separados entre si em 4,90 metros para vencer o vão único de 96,25 metros. O formato aproximadamente funicular concebido por Freyssinet permite que o peso-próprio da estrutura seja distribuído mais homogeneamente ao longo de toda sua extensão, aliviando, consequentemente, a sobreposição de cargas. À medida em que se direciona para as extremidades, a seção desses mesmos arcos é gradativa e propositadamente aumentada até chegar ao seu limite nas fundações, sob o solo, justamente para que haja uma resposta estrutural adequada aos esforços decorrentes dos empuxos longitudinais dos arcos de concreto. Quando concluída, em 1922, esta ponte 
recebe o mérito de quebrar todos os recordes mundiais de pontes em concreto, com características semelhantes, e erigidas até aquele momento.

Outro exemplo construído de Freyssinet e que também trabalha com a associação de arcos é a Pont de Plougastel (ou Pont Albert-Louppe) [Figura 3.30], sobre o Rio Elórn, nas proximidades de Bern, França. Sua construção estende-se por quatro anos, de 1926 a 1930. No entanto, quatorze anos mais tarde, em 1944, sofre vários e sérios danos devido aos incidentes arrasadores provocados pela Segunda Grande Guerra. Somente quando esta é dada por terminada, inicia-se um trabalho cuidadoso e completo de reparo estrutural, sendo a ponte reaberta ao público tempos depois.

A Pont de Plougastel possui arcos sequenciados de concreto ao longo de seu eixo longitudinal e atinge 888,0 metros de margem a margem. Cada um dos vãos vencidos tem dimensões aproximadas de 188,o metros e o tabuleiro superior alcança 9,0 metros de largura após sua recuperação (no projeto original, esta medida não passa de 3,0 metros). A construção também é pensada para acontecer por etapas, tanto é fato que o sistema de fôrmas e de escoramento após a primeira utilização - é totalmente reaproveitado nos arcos subsequentes (o que agiliza a velocidade da obra e contribui para a redução de custos).

E é com um projeto anterior, do início da década de 1920 - mais precisamente de 1921 (e demolido em 1944) que Freyssinet é lembrado. Segundo Gonçalves (2010), o engenheiro e arquiteto francês é reconhecido pelas estruturas parabólicas de um par de hangares para abrigar dirigíveis e pequenas aeronaves no antigo aeroporto de Orly, na França [Figuras 3.31 - 3.32]. A mesma autora prossegue dizendo que as soluções arquitetônico-estruturais aqui usadas extinguem por completo a relação histórica entre pilar e viga (ou entre parede e teto) ao fundir estes mesmos elementos em um só composto, que faz as vezes tanto de contorno estrutural de ambos os hangares quanto de solução arquitetônica, simultaneamente. A título de informação, estas construções de Freyssinet em Orly representam a primeira oportunidade de uso de fôrmas reaproveitáveis derivadas de um novo processo de escoramento e, por assim dizer, de um novo processo construtivo. Cada hangar possui 86,0 metros de largura total e vãos livres internos de 75,0 metros, 56,0 metros de altura e 144,0 metros de comprimento, dimensões possíveis apenas de serem atingidas em função da curvatura acentuada dos arcos abobadados estruturais, e do seu sistema construtivo.

A intersecção entre o final do século 18 e o início do 19 dá margem a alçá-la a um dos períodos mais férteis da arquitetura e da engenharia mundiais: as novas metodologias construtivas propostas pelos estudos de Hennebique e 
Berg, na Europa, aliadas às aplicações inovadoras do ferro e do aço motivadas pela reconstrução de Chicago, na América do Norte, fazem com que um dos materiais presentes em ambos os cenários, o concreto armado, revele suas possibilidades expressivas e conquiste um número cada vez maior de adeptos. Basta conferir os edifícios de Frank Lloyd Wright e de Auguste Perret, ou mesmo as obras de arte de Robert Maillart e de Eugène Freyssinet (como mostrado). E além destes profissionais, tantos outros que também se enveredaram por novos horizontes projetuais e construtivos, empírica ou cientificamente, motivados que estavam pelas novas técnicas e tecnologias construtivas.

E é nesse mesmo panorama fundamentalmente promissor e estimulante do uso do concreto armado e do aço, sobretudo nas arquiteturas europeia e americana - no qual há um desenvolvimento jamais visto da linha tectônica modernista - que surge o nome do jovem pintor e arquiteto franco-suíço Charles-Edouard Jeanneret-Gris (1887 1965), mais conhecido por seu pseudônimo: Le Corbusier.

Entre 1908 e 1910, durante parte de sua permanência em Paris, Le Corbusier trabalha no escritório de Auguste Perret. A inspiração que recebe do mestre desvela no jovem arquiteto o gosto pelas questões estruturais arquitetônicas, as quais fazem-no vislumbrar a disseminação pelo mundo de espacialidades mais flexíveis aliadas a vedações independentes, postas em prática nos seus projetos futuros. Somada aos ensinamentos que recebe diretamente de seu mestre, há a influência sugerida pelo contato que toma com a obra de Viollet-le-Duc, uma vez que Perret mostra ao seu jovem pupilo, de uma maneira clara e profunda, os ensinamentos deixados por le-Duc, do qual é grande admirador e também seguidor - especialmente no que diz respeito à postura verdadeira que deve assumir o arquiteto quanto ao programa, à construção e às materialidades de uma obra.

O contato direto com Auguste Perret, a pesquisa da obra de Viollet-le-Duc e o apelo dos resultados das investigações construtivas e de potencialidades de aplicação de materiais feitas por François Hennebique, instigam Le Corbusier a desenvolver análises no campo arquitetônico fundamentadas no uso do concreto armado, na ossatura autônoma e nas novas possibilidades de organização dos edifícios daí decorrentes. A consequência desta fase de estudos do arquiteto franco-suíço - em conjunto com o engenheiro Max Du Bois (é apresentada anos depois no seu conhecido "Sistema Domino", que "continha muito da carga corbusiana seguinte, dando suporte ao enunciado teórico posterior dos cinco pontos". (COLLARES; 2003: 26).

Palermo (2006) explica que a solução estrutural autônoma do tipo Domino [Figura 3.33] é concebida entre 1914 e 1917 por Le Corbusier e deve ser entendida como uma alternativa construtiva composta por lajes planas (sem vigas e com 
balanços em ambos os extremos), pilares e fundações em concreto armado, indicando um ordenamento racional entre elementos e construção. O resultado imaginado engloba a adoção de subsistemas de organização, cujo conjunto objetiva prover as edificações que os empregam de qualidades formais modernas, tanto nos aspectos tangíveis (pisos em balanço, plantas e fachadas livres, pilotis), quanto nos intangíveis (economia de meios, rapidez, rigor e precisão na construção, universalidade). Como efeito do "Sistema Domino", são à época atingidas flexibilidade e autonomia no projeto e na construção até então impensáveis. Molda-se, deste modo, o cenário ideal para lidar com programas atrelados à necessidade de ambientes mais amplos, desimpedidos, flexíveis e, por conseguinte, com vãos de proporções mais significativas. Vale a pena citar Katinsky (2007) que formula algumas considerações entre as proposições construtivas feitas pelo arquiteto alemão Walter Gropius (1883 - 1969) e o “Sistema Domino" corbusiano, no mesmo período:

Bem típica da mentalidade da época são as experiências com pré-fabricação do arquiteto Walter Gropius na década de 20 na Alemanha e depois em Boston, construindo sua casa exclusivamente com peças de catálogo industrial. Quase como um jogo de armar, onde a criatividade do arquiteto (ou designer) não se exercia diretamente sobre o produto industrial, visto como paradigma, mas exclusivamente na reunião das peças já prontas.

Contra essas proposições, Le Corbusier, desde o início de sua atividade, apresentou soluções que foram se aperfeiçoando ao longo do tempo, mas perseguindo sempre a mesma procura da diversidade na unidade. Essas posturas já se distinguem nas variações das casas dominó (1916) onde, com uma estrutura básica sempre igual, ele procurou configurar um sem-número de projetos de habitações.

Não se pode deixar de anotar que essa proposta de 1916, quando Le Corbusier estava protegido pelo refúgio da neutra Suíça, não tinha como fundamento uma meditação sobre a indústria, mas destinavase a resolver o problema das populações desalojadas de seu habitat tradicional pela violência da guerra moderna. A mesma atitude, aliás, ele irá adotar durante a Segunda Guerra com as habitações Murondin. Sua meditação em torno da arte contemporânea expressa no projeto dominó já encontrava uma via de resolução do aparente paradoxo: produção artística singular versus produção industrial anônima e de massa. (KATINSKY; 2007: 59)

Como exemplo de obras construídas, tome-se primeiramente a Villa Savoye [Figura 3.34], concebida e construída entre 1928 e 1929, em Poissy - região suburbana de Paris. O projeto é inicialmente pensado para atender o desejo de uma pequena família (casal mais um único filho) em ter uma casa de final de semana implantada em uma extensa área verde, sem vizinhos próximos. Porém, como resultado, o arquiteto franco-suíço consegue algo muito além que uma simples residência, pois ela "representa um momento de síntese na obra de Le Corbusier, quando pela primeira vez o arquiteto teve a possibilidade de concretizar integralmente suas proposições apresentadas nos cinco pontos para uma nova arquitetura". (MACIEL; 2002: 1) 
Dito de outro modo, esta é a primeira oportunidade na qual as investigações corbusianas acerca de uma nova arquitetura podem, de fato, ser materializadas. É nesta residência que ele idealiza e concretiza, sem interferências e sem camuflagens, as suas proposições para uma arquitetura inovadora, proposições essas que nascem de pesquisas anteriores, como no "Sistema Domino", e amadurecem com o passar do tempo. Na Villa Savoye, estão presentes: a.) os pilotis, que elevam o edifício do solo e liberam o lote para um espaço utilizável, seja pela presença de pessoas, seja pela circulação de automóveis; b.) terraço jardim, que convida o indivíduo a usufruir deste novo local de encontros outrora inexistente, pois as construções tradicionais servem-se de telhados inclinados como coberturas ideais; c.) planta livre, que só é possível graças à autonomia das estruturas e das vedações, trazendo como consequência a flexibilidade de espaços e a sua livre articulação, sem comprometimento da edificação propriamente dita; d.) fachada livre, que pode ser entendida como o contraponto entre as grandes aberturas das paredes externas, agora mais esbeltas e leves e os maciços de alvenaria das construções tradicionais, mais robustos e fechados, pois suportam todas as cargas da construção; e e.) janelas em fita, que resultam da combinação entre planta e fachada livres, uma vez que a estrutura autônoma presente em ambas permite aberturas mais generosas, logo, uma integração entre exterior e interior mais acentuada, com vistas panorâmicas de (e para) ambos os lados. E sobre o papel da Villa Savoye na arquitetura moderna mundial, é possível assumir que ela:

\begin{abstract}
torna manifesto um novo modo de ver e viver no mundo. Para isso, utiliza a tecnologia de ponta da época, tornando explícitos os operadores que permitiam a sua realização arquitetônica. É um manifesto de um novo modo de vida que se expressa em uma nova e diferenciada articulação dos usos que toma lugar nos espaços que o conceito da promenade architecturale possibilitava. $O$ edifício foi construído utilizando-se de uma tecnologia inovadora do concreto armado que se mostrava através de um repertório formal sintetizado pelos Cinco Pontos por uma Nova Arquitetura. Contudo, as premissas de projeto definidas pelos Cinco Pontos, embora tenham sido apresentadas pelo arquiteto como requisitos para uma nova arquitetura, dita moderna, constituem-se apenas em um dos diversos repertórios formais possíveis. (MACIEL; 2002: 3)
\end{abstract}

Durante a década de 1920 Le Corbusier realiza diversos projetos, muitos contendo como eixo temático a questão da habitação. Representam, em essência, exercícios projetuais (construídos ou não) nos quais o mestre franco-suíço busca aplicar os seus princípios teóricos - o que não desmerece os resultados alcançados. Assim, "a repetição do tema da habitação ou a repetição que o tema da habitação coletiva contém, foram basicamente os objetos de especulação para a ideia de esquema construtivo, de solução normativa, de repetição e construção seriada". (COLLARES; 2003: 32) 
Já entre os anos 1920 e 1930, Le Corbusier arrisca-se a pensar sobre questões mais amplas e a elaborar projetos com programas mais diversificados, motivado que está pela participação em concursos internacionais, como aqueles instituídos para a Sede da Sociedade das Nações (Genebra, 1927), o Centrosoyus (Moscou, 1928 - 1929), ou o Palácio dos Soviets (Moscou, 1931) [Figura 3.35]. Este último, por exemplo, merece aqui um pouco mais de atenção. Ainda que não tenha sido o vencedor do concurso - e tampouco tenha sido construído -, é reconhecido como um dos mais interessantes e mais bem resolvidos projetos apresentados à comissão julgadora. Trata-se da resposta de Le Corbusier à necessidade de atender um programa amplo e composto por espaços de grandes dimensões, cujo conjunto arquitetônico final deve considerar, de acordo com o edital publicado, as variáveis urbanísticas reais para que haja o correto entrosamento entre o prédio proposto e a situação urbana existente (esta, porém, passível de intervenções pontuais em função da solução ganhadora).

A análise minuciosa do projeto-candidato de Le Corbusier não cabe a este trabalho, tampouco uma descrição de todas as suas composições, conceituações, inspirações e resultados. Todavia, a apenas um elemento de destaque, estrutural, pode-se dedicar algumas palavras: um arco parabólico que sustenta a sala maior (feita para comportar quinze mil espectadores) possui 160,0 metros de distância entre apoios e 90,0 metros de atura, quando em relação ao seu ponto mais elevado. Do arco encurvado nascem tirantes metálicos que dão suporte às vigas de travamento da cobertura dessa mesma sala, seja de maneira direta (em planos inclinados em direção ao palco), seja de modo indireto (por meio de pilares com aproximadamente 65,0 metros de altura). Assim, a estrutura que apoia o edifício torna-se independente, portanto, gera flexibilidade para o assentamento dos ambientes internos do projeto, para a circulação de pessoas e para a realização de eventos dos mais diversos. É, por assim dizer, uma derivação dos cinco pontos da nova arquitetura definidos por Le Corbusier poucos anos antes - mas aplicados em um projeto de escala monumental. Anos mais tarde, o mestre franco-suíço retoma os projetos voltados à habitação e projeta a Unité d'Habitation [Figura 3.36], em Marselha (França). Fruto de um programa comandado pelo governo francês para reconstruir a cidade após a Segunda Grande Guerra, Le Corbusier projeta e constrói, entre 1947 e 1953, este grande edifício modular feito em concreto armado. Além deste, são erguidas outras unidades semelhantes em Nantes (França, 1955) e em Berlim (Alemanha, 1958), dentre outras. A Unité d'Habitation é um edifício residencial de baixo custo, desenhado em forma de lâmina, tendo aproximadamente 100,0 metros de comprimento e 30,0 metros de largura. Além disso, apresenta 12 pavimentos e 337 unidades, com 23 plantas diferentes. 
O bloco único, modulado, retilíneo e racional está disposto sobre um conjunto de pilotis distribuídos cartesianamente. Possui estrutura independente (por isso é comum muitos autores se referirem às unidades habitacionais - ou aos apartamentos - como células); há, na cobertura, um terraço-jardim que serve à creche, ao solário e às piscinas. Le Corbusier e sua equipe responsabilizam-se pela íntegra do projeto, ou seja, desenham desde o edifício propriamente dito e sua relação para com o entorno imediato, até as proteções contra a insolação excessiva, as soluções de estímulo à ventilação, os elementos construtivos, além de móveis, equipamentos de cozinha, esquadrias e afins. A título de curiosidade, trata-se da primeira oportunidade em que o mestre franco-suíço aplica o seu sistema universal de relações métricas, conhecido como Modulor.

De acordo com Comas (1989), o "Sistema Domino", somado aos "Cinco Pontos da Nova Arquitetura" (publicados por Le Corbusier na revista L'Esprit Nouveau em 1926) - e ambos calcados sobretudo nas pesquisas hennebequianas do uso do concreto armado - procuram uma maneira factível de padronização das construções, ou mesmo uma espécie de lógica compositiva que assegure a mesma maleabilidade semântica do classicismo. Seja como for, a crença na nova arquitetura e no modelo modernista derivada dos fatores discutidos nos parágrafos anteriores - e por fim personificados na figura de Le Corbusier - dá margem a estabelecer relações de causa e consequência em várias partes do planeta - inclusive no Brasil, durante os anos seguintes. A respeito das ramificações dos postulados corbusianos e seus reflexos no Brasil, pode-se assumir que

o alcance internacional de Le Corbusier no período entre guerras é total. Em todas as latitudes, as influências do seu discurso estético-social são absorvidas. A inteligentzia arquitetônica brasileira também está atenta a esse momento. São os planos para a Cidade Universitária do Rio de Janeiro e o projeto para o Ministério da Educação e Saúde que trazem Le Corbuiser ao Brasil.

Lucio Costa, o nome mais expressivo da arquitetura brasileira da época, coordena estes trabalhos com grande equipe, na sua maioria jovens arquitetos. O vínculo direto com o modernismo europeu e corbusiano se estabelece com este contato que frutifica no Brasil de maneira espetacular. (COLLARES; 2003: 26-27)

Os efeitos e os desdobramentos sugeridos pela passagem acima não acontecem exclusivamente pela inegável influência corbusiana no aparecimento de uma dita arquitetura moderna de feições nacionais. Antes mesmo do mestre suíço, o Brasil já mostra sinais de crescimento e de desenvolvimento que pedem a adoção de sistemas de construção mais adequados e de técnicas construtivas mais rápidas, baratas e que possam ser inseridas em um mercado deficitário, ou seja, no qual não há indústrias de base e de processamento tão adiantadas quanto no exterior. Neste quesito, como visto nas páginas anteriores, Estados Unidos, França, Inglaterra e Alemanha já encontram-se 
bastante avançados, investigando alternativas construtivas, valendo-se do aço como elemento estrutural, trazendo o vidro como um dos protagonistas arquitetônicos e, por fim, acreditando que o concreto armado pode ser um grande aliado da construção civil. O resultado da conjugação desses fatores - incorporados a outros mais - reflete-se nos trabalhos de engenheiros e de arquitetos que constroem edifícios cada vez mais altos, pontes com vãos cada vez mais significativos, armazéns e galerias cada vez mais ousados.

No Brasil, o ritmo é significativamente mais lento. Pode-se assumir que a indústria nacional de bens intermediários como o aço e o cimento - apareça com competência somente depois de começado o século 20 , e que tenha efetiva participação no desenvolvimento do país depois dos anos 1920, ou seja, no período entre guerras no qual o papel de Le Corbusier é fundamental. Sua influência vence fronteiras e chega por aqui por meio de profissionais atuantes na área, dentre os quais destaca-se Lucio Costa, como mostrado no extrato da obra de Collares (2003) parágrafos acima. Antes de dar prosseguimento a este estudo, no qual discute-se um pouco da relação entre engenharia e arquitetura, ou seja, entre técnica e plástica, é interessante que se expliquem os reflexos dos avanços técnicos e tecnológicos sentidos e praticados pelo Brasil, referentes à utilização da estrutura metálica e do concreto armado nas construções civis nacionais. 


\title{
FERRO FUNDIDO: COMPONENTE ESTRUTURAL E ELEMENTO DE ORNAMENTAÇÃO
}

\author{
Henri Labrouste:
}

Bibliothèque Sainte-Genèvieve [3.1 - 3.2] $\mathrm{e}$ Bibliothèque Nationale de France [3.3 - 3.4]

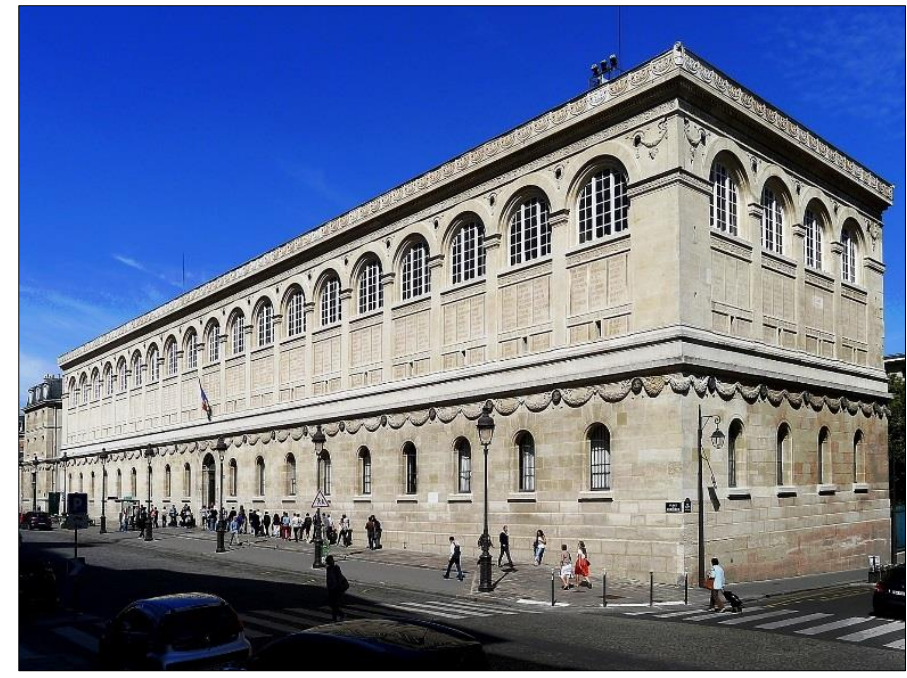

[3.1] Perspectiva externa da biblioteca: sobriedade e austeridade norteiam o desenho das fachadas construídas em alvenaria. Nesta parte do projeto, Henri Labrouste claramente inspira-se na arquitetura renascentista europeia.

[3.3] As nove amplas cúpulas são suportadas pelo conjunto estrutural modulado, aparente e todo feito em ferro fundido: vigas arqueadas decoradas com arabescos e finas colunas com capitéis coríntios conformam o principal espaço para leitura.

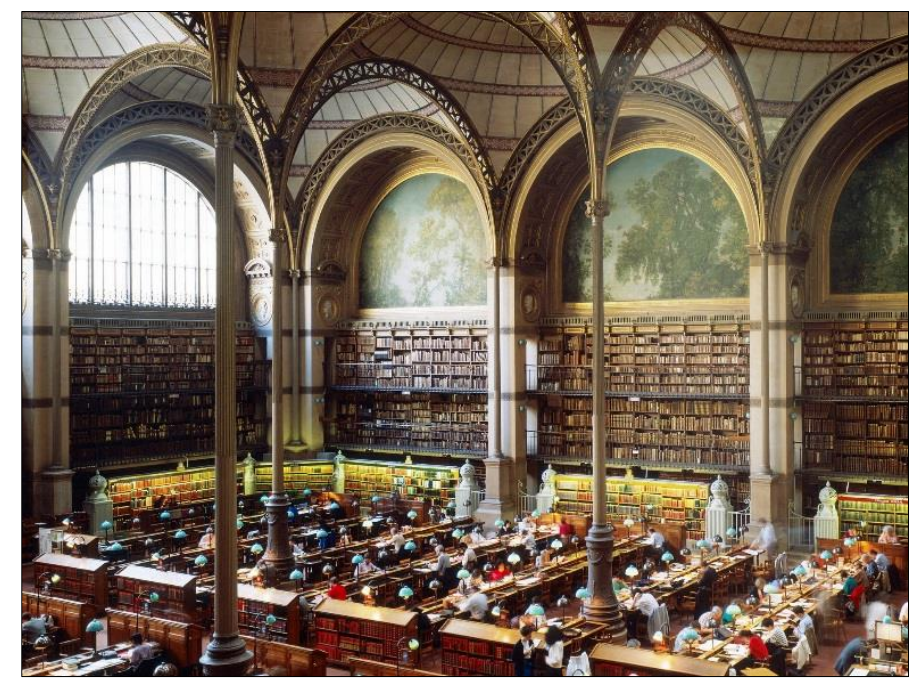

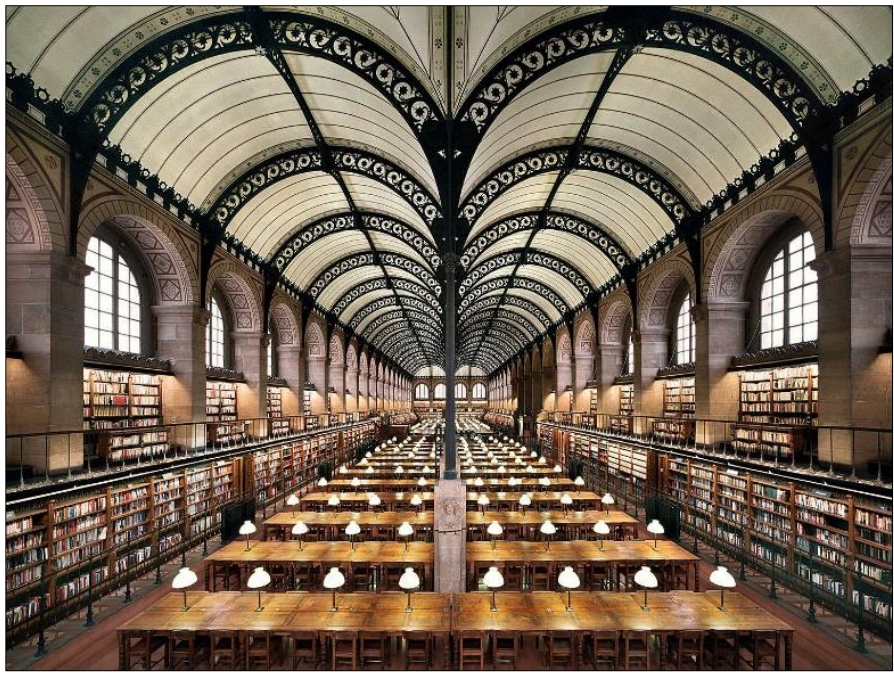

[3.2] Internamente, notam-se as abóbadas de berço sustentadas pelas vigas arqueadas e pelas delgadas colunas jônicas. A estrutura modular, propositadamente deixada aparente, é forjada em ferro fundido e ajuda a compor a ambientação da sala de leitura.

[3.4] As cúpulas abatidas da sala de leitura possuem, nos seus pontos mais elevados, claraboias armadas em metal e fechadas em vidro, as quais deixam passar uma luz natural difusa que invade o ambiente interno, mas sem prejudicar os usuários.

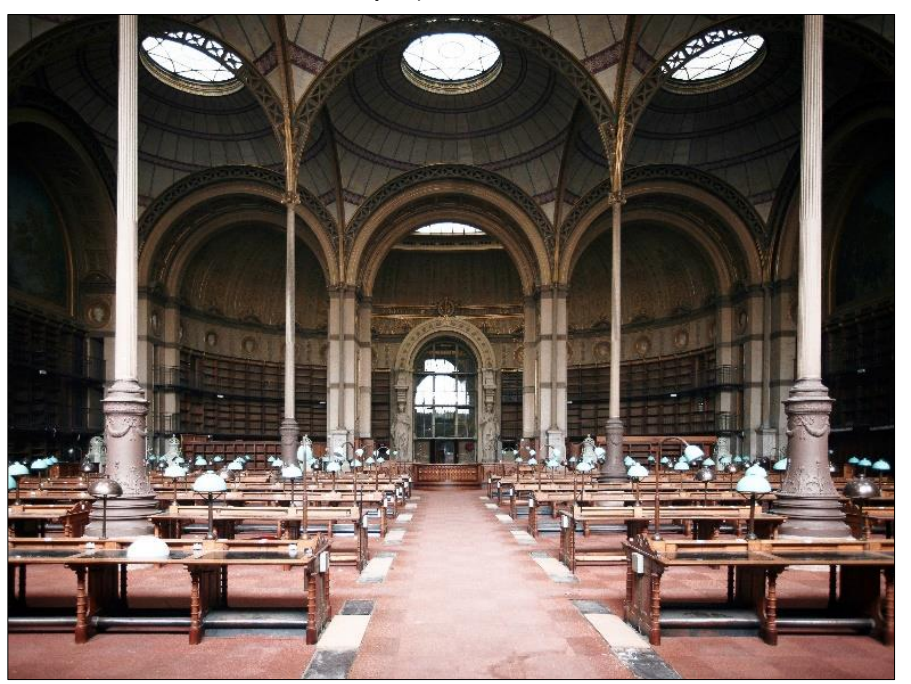




\section{RESTAURO: UM REENCONTRO COM O PASSADO}

Eugène-Emmanuel Viollet-le-Duc:

\section{Catedral de Notre Dame de Paris [3.5]; Basílica de Sainte-Marie-Madeleine de Vézelay [3.6];}

Castelos de Roquetaillade [3.7] e de Vincennes [3.8]

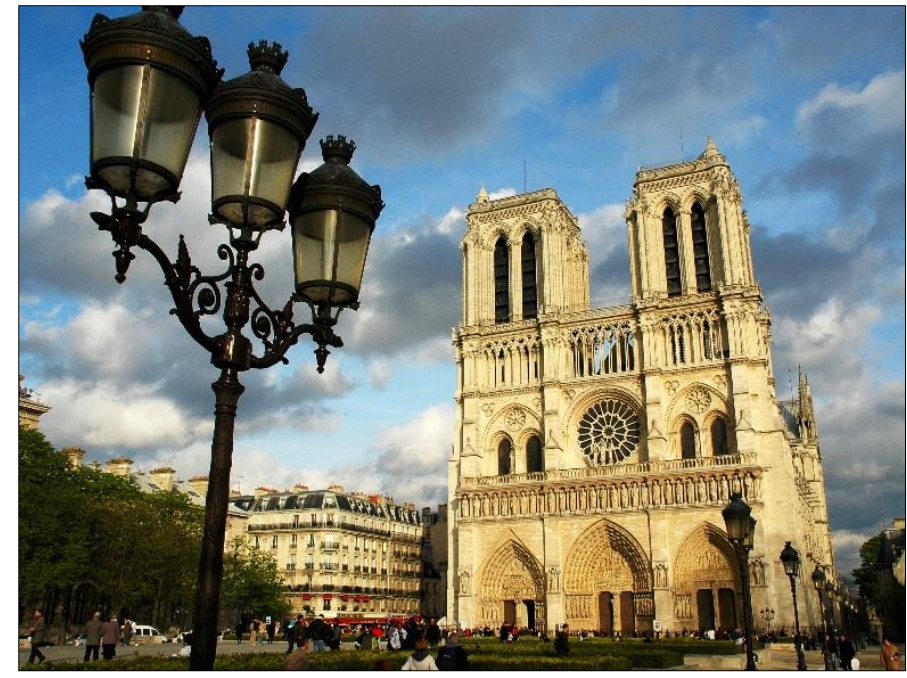

[3.5] Situa-se na Praça Parvis, na île de la Cité, em Paris, junto ao Rio Sena. Iniciada em 1163, é um dos mais antigos exemplos de catedrais francesas em estilo gótico. Os trabalhos de restauro acontecem a partir de 1844 e estendem-se por vinte e três anos.

[3.7] Localiza-se em Mazères, na Gironda. Formado pela simbiose de duas fortificações, uma do século 11 e outra do 14, é restaurado apenas no século 19. São de le-Duc, além da ação de recuperação do castelo, algumas intervenções na decoração e no mobiliário.

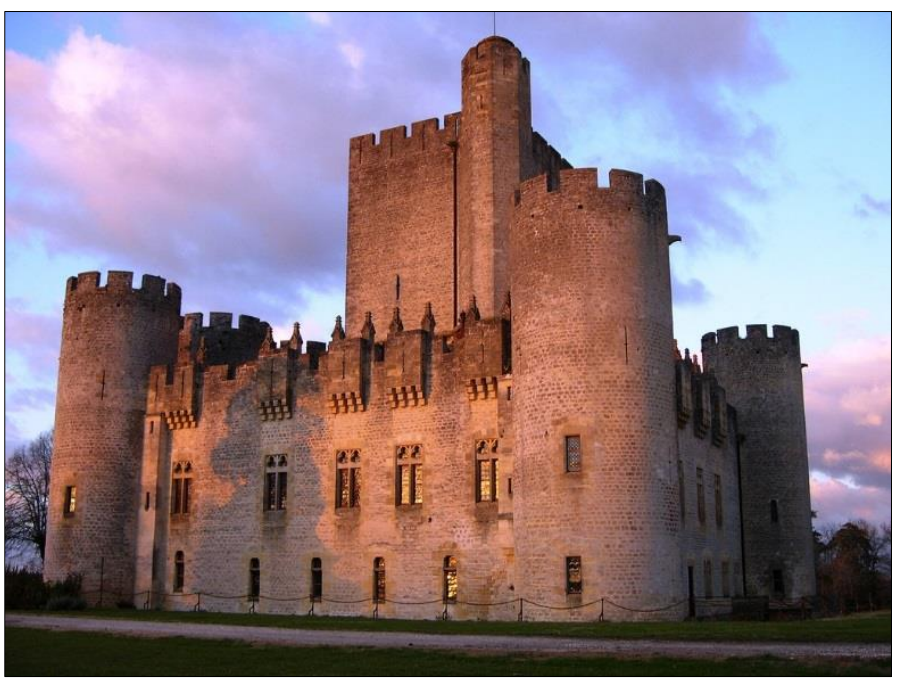

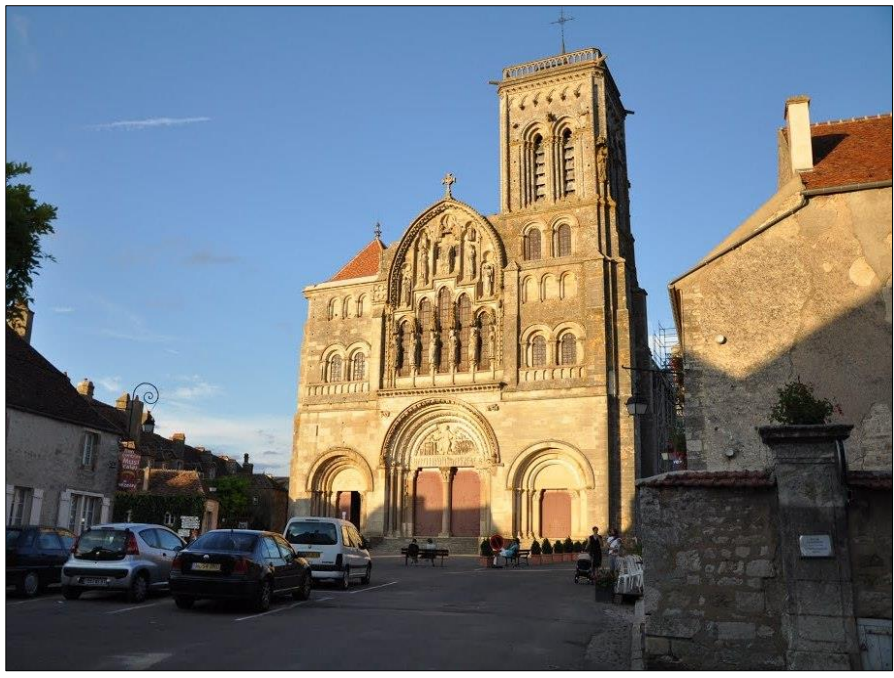

[3.6] Construída entre 1096 e 1150, é implantada na região de Bourgogne, a noroeste de Paris. Durante os anos de 1840 e 1861 , Viollet-le-Duc coordena a restauração desta basílica, cujo resultado faz com que ela recupere suas características originais.

[3.8] Erguido a leste de Paris, chega a atingir 52 metros de altura, o que o torna a mais alta fortaleza de planície da Europa. Viollet-le-Duc responsabiliza-se pela reestruturação do parque (inspirando-se nos jardins ingleses), da Capela e da Torre de Menagem.

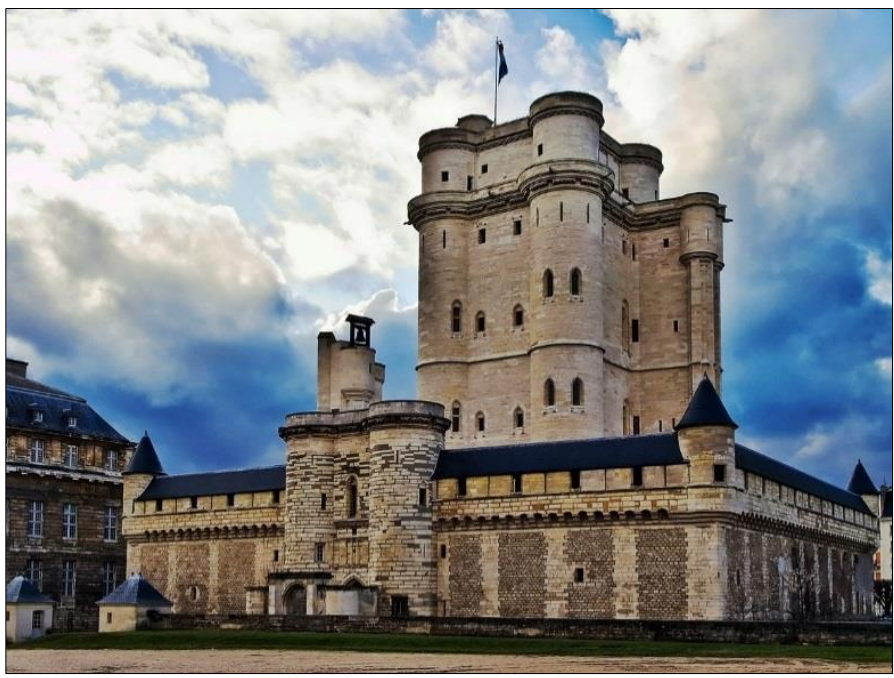




\section{FERRO FUNDIDO: A ESTRUTURA COMO ARQUITETURA}

Thomas Telford: Aqueduto de Pontcysyllte [3.9]; Joseph Paxton: Palácio de Cristal [3.10]; Charles Louis Ferdinand Dutert + Victor Contamin: Galérie des Machines [3.11];

Alexandre Gustave Eiffel: Torre Eiffel [3.12]

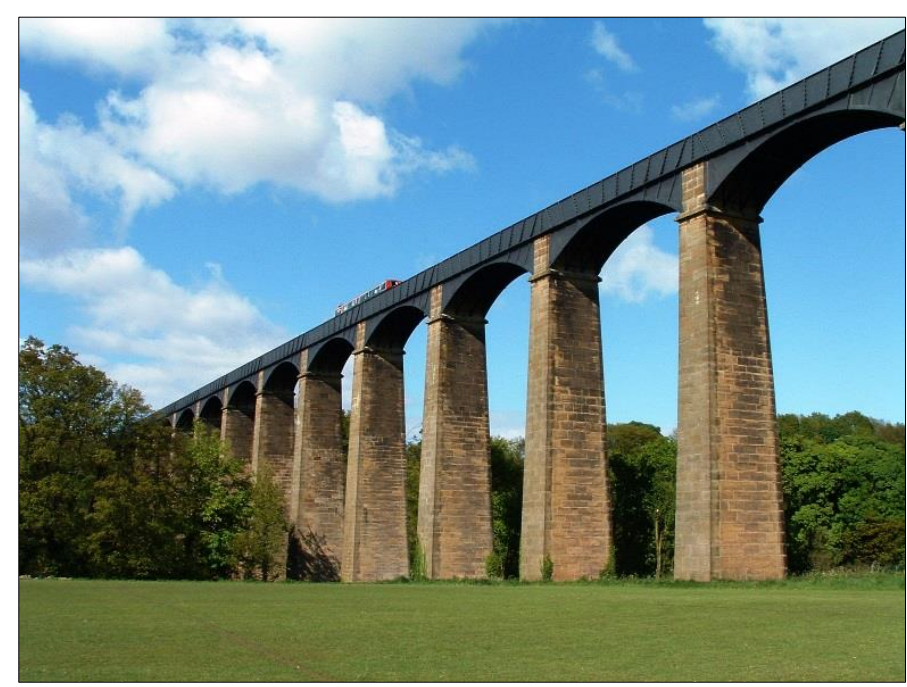

[3.9] Terminado em 1805 e funcionando até os dias de hoje, é o aqueduto mais alto e mais longo da Grã-Bretanha. Esta obra é a primeira, no mundo, a adotar o ferro fundido na construção civil (no caso, na montagem da estrutura superior, navegável).

[3.11] Destinada a abrigar a Exposição Universal de Paris de 1889, é composta por uma estrutura de vinte pórticos auto-portantes treliçados. A ossatura aparente moldada em ferro faz as vezes de componente de sustentação e de elemento estético do projeto.

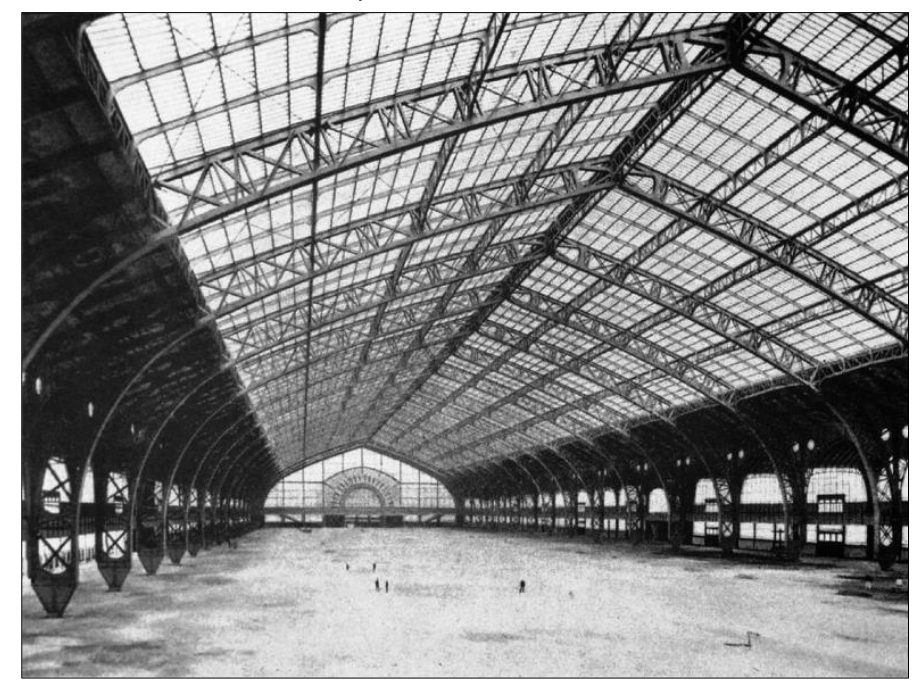

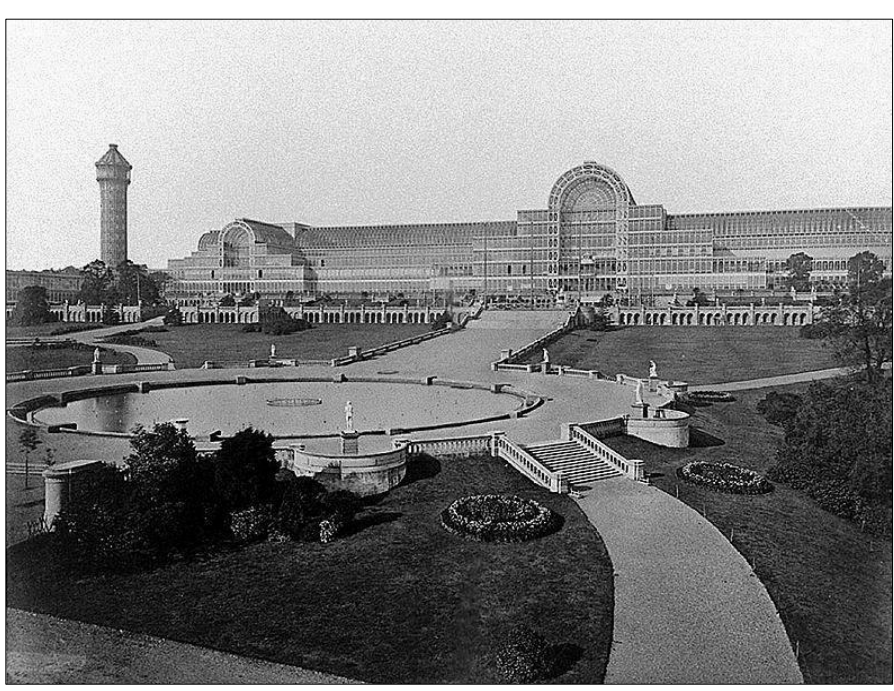

[3.10] Idealizado para a Grande Exposição de Londres de 1851, este edifício auto-portante pré-fabricado é desenhado, pensado e construído em ferro fundido. É um bom exemplo do afastamento arquitetônico, em larga escala, dos estilos historicistas da época.

[3.12] Concebida para ser o símbolo da Exposição Universal de Paris de 1889 , esta torre feita em ferro fundido deixado à vista possui 324,0 metros de altura, e foi toda pré-produzida na fábrica do seu próprio projetista, o engenheiro francês Gustave Eiffel.

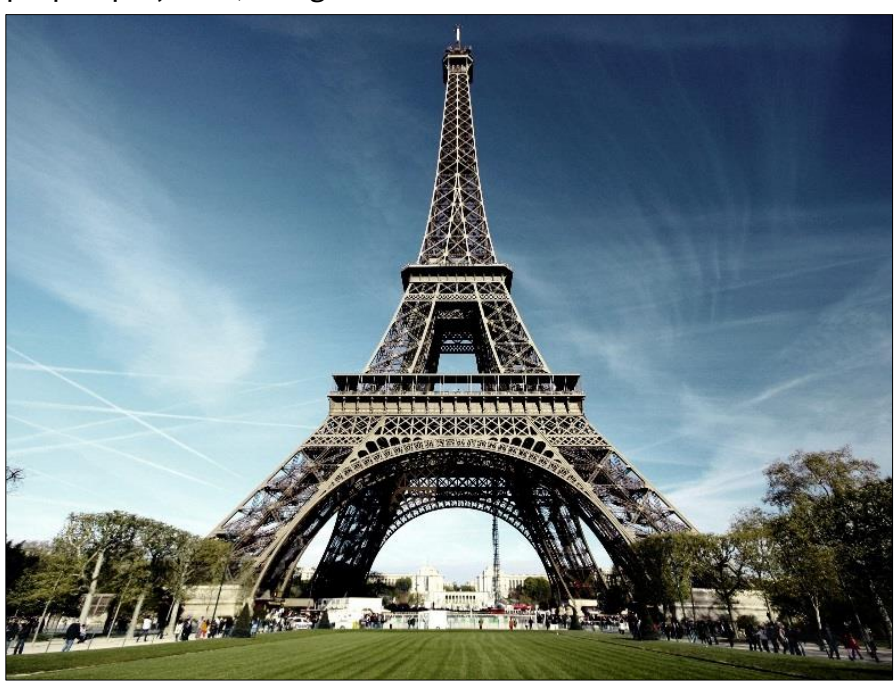




\section{FERROCIMENTO E ESTRUTURA METÁLICA: NOVAS POSSIBILIDADES CONSTRUTIVAS}

Joseph-Louis Lambot: Barco em Ferrocimento [3.13]; Joseph Monier: Reservatório de Água [3.14];

Jules Saulnier: Fábrica de Chocolates "Chocolat Menier" [3.15];

William Le Baron Jenney: Home Insurance Company Building [3.16]

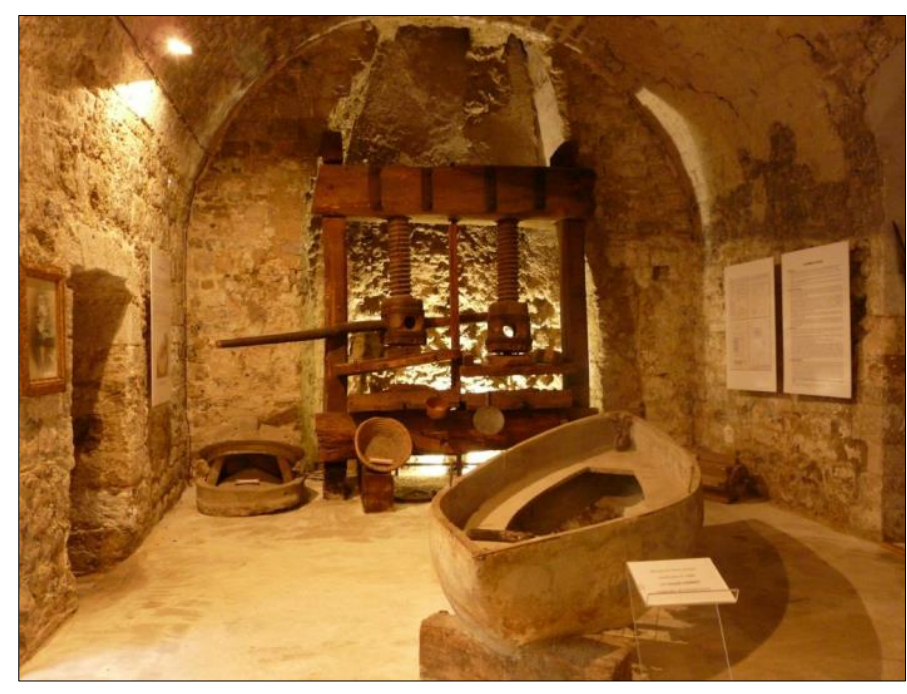

[3.13] No grupo de experimentos feitos por Lambot utilizando o ferrocimento está um barco moldado com esse material. Inicialmente testado em um lago de sua fazenda, é oficialmente apresentado na Feira Mundial de Paris de 1855.

[3.15] Um exoesqueleto metálico exposto envolve o edifício longitudinalmente, mantendo-o em pé. Internamente, duas linhas moduladas de pilares em ferro fundido seguem paralelamente à estrutura principal, travando o conjunto edificado como um todo.

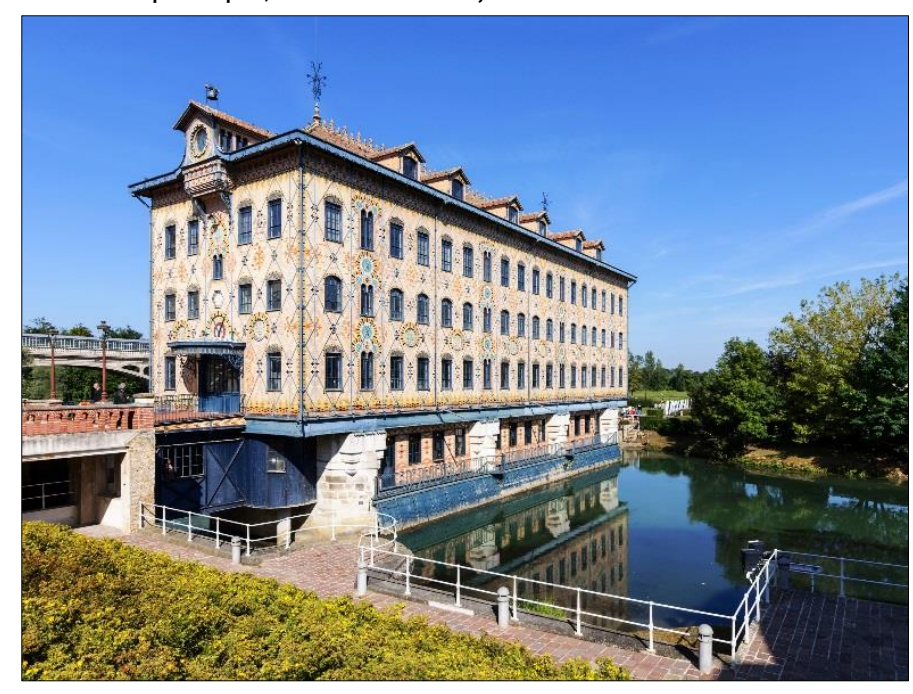

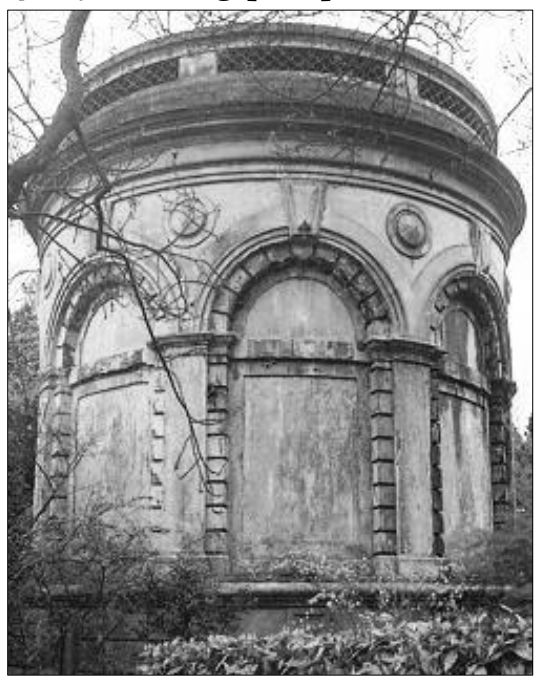

[3.14] A partir de ideia de Lambot (porém mais bem estudada e aperfeiçoada), Monier propõe uma série de elementos construídos em ferrocimento, dentre eles, um reservatório de água ainda existente na cidade de Clamart, na França - construído em 1890.

[3.16] Projetado e construído entre 1883 e 1885, este edifício é um dos primeiros exemplos de estrutura erguida com pilares e vigas metálicos. Como resultado, uma construção mais ligeira e significativamente mais leve que as demais à sua volta.

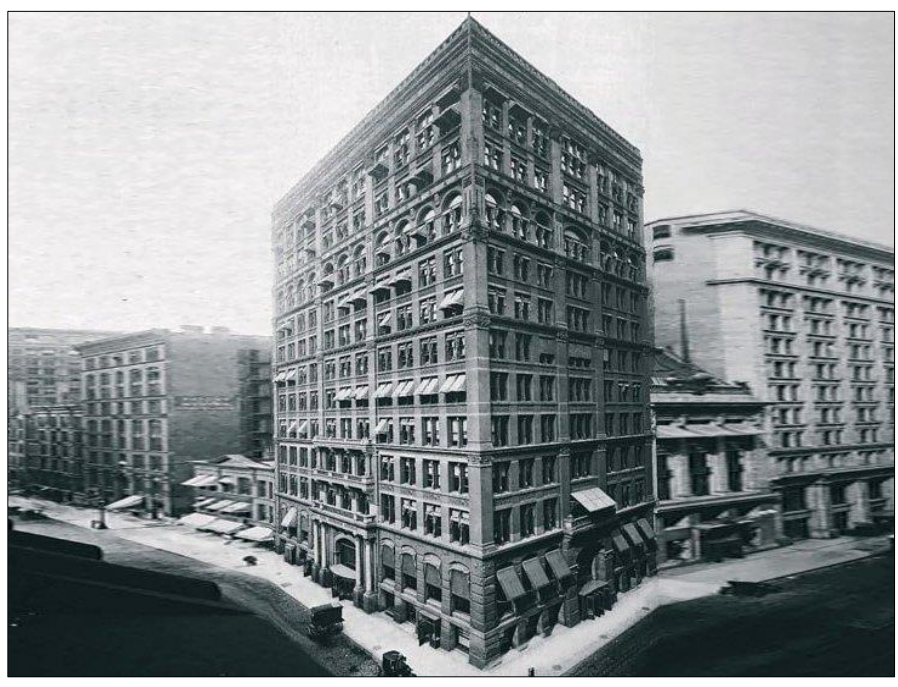




\section{CONCRETO ARMADO: DO AVANÇO DA TÉCNICA SURGE UMA NOVA ARQUITETURA}

François Benjamin Joseph Hennebique: Sistema Estrutural em Concreto Armado [3.17]; Anatole de Baudot: Igreja de Saint-Jean-de-Montmartre [3.18]; Max Berg: Jahrhunderthalle [3.19];

Frank Lloyd Wright: Unity Temple [3.20]

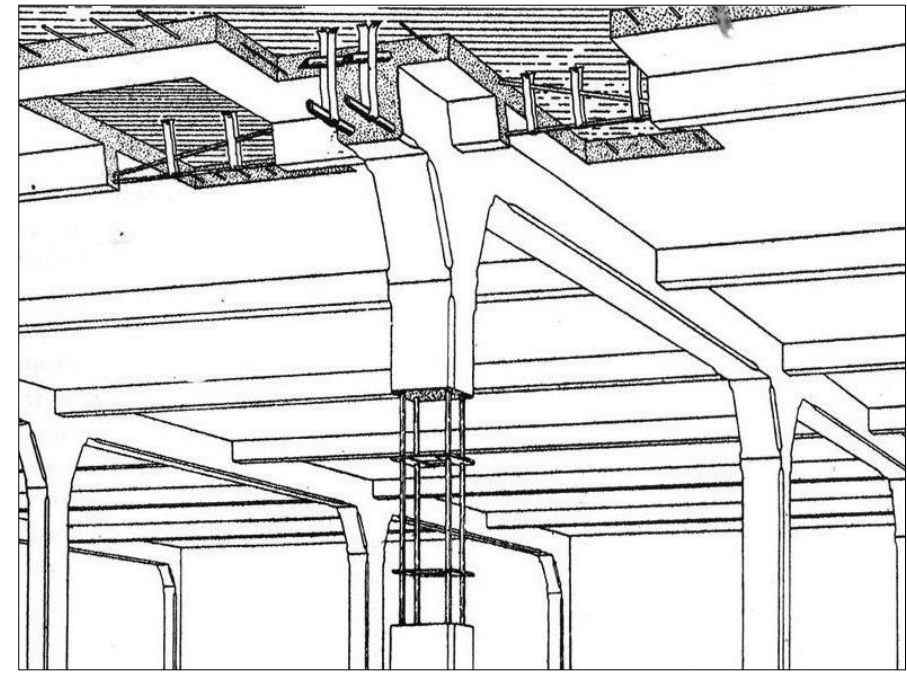

[3.17] Ao focar a aderência entre os elementos formadores do concreto armado, Hennebique passa a perceber a estrutura de um edifício como um único elemento monolítico, completamente integrado e que deve ser analisado em sua totalidade.

[3.19] Com o domínio da técnica do concreto crescendo ao longo dos anos, os projetos arquitetônicos buscam a ousadia. Aqui, a cúpula vence um vão livre de 62 metros e é suportada por 32 nervuras distribuídas radialmente, todas, em concreto armado.

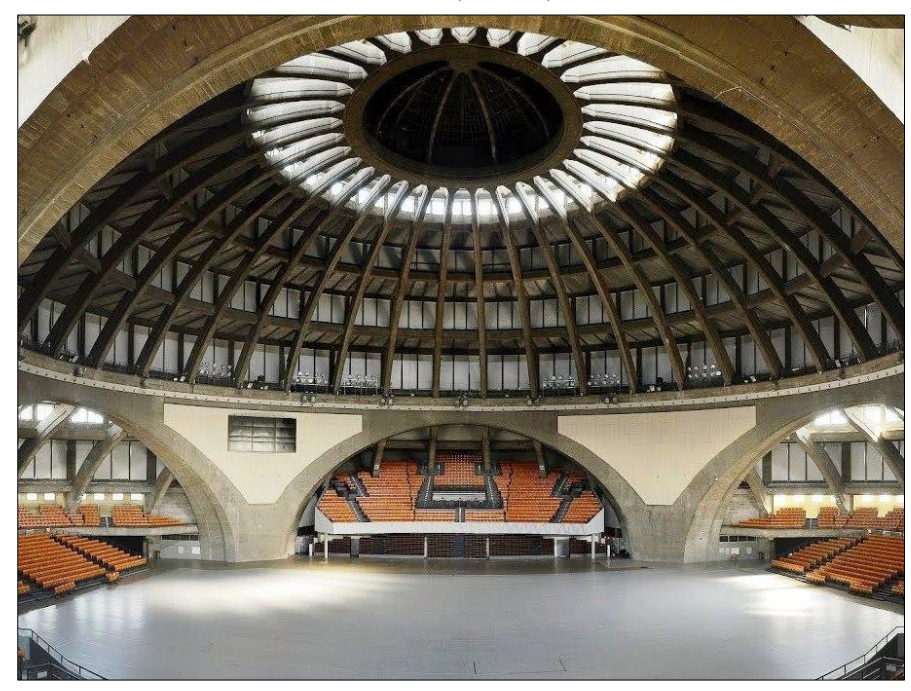

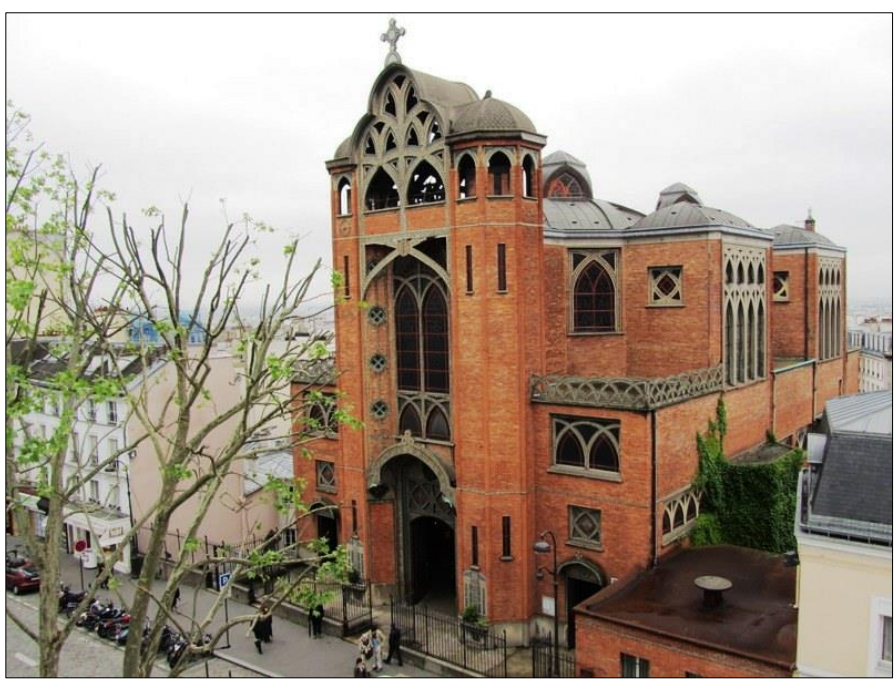

[3.18] Erguida na capital francesa, esta Igreja representa a primeira edificação religiosa com a estrutura de concreto mantida aparente. Nela, os fechamentos externos laterais são compostos por tijolos cerâmicos reforçados com finas barras de aço.

[3.20] Wright posiciona a área para os cerimoniais no coração do edifício, e faz dela um local visualmente maior do que realmente é. As claraboias no teto e as janelas nos topos das paredes deixam a luz natural entrar, porém, sem interferência do lado externo.

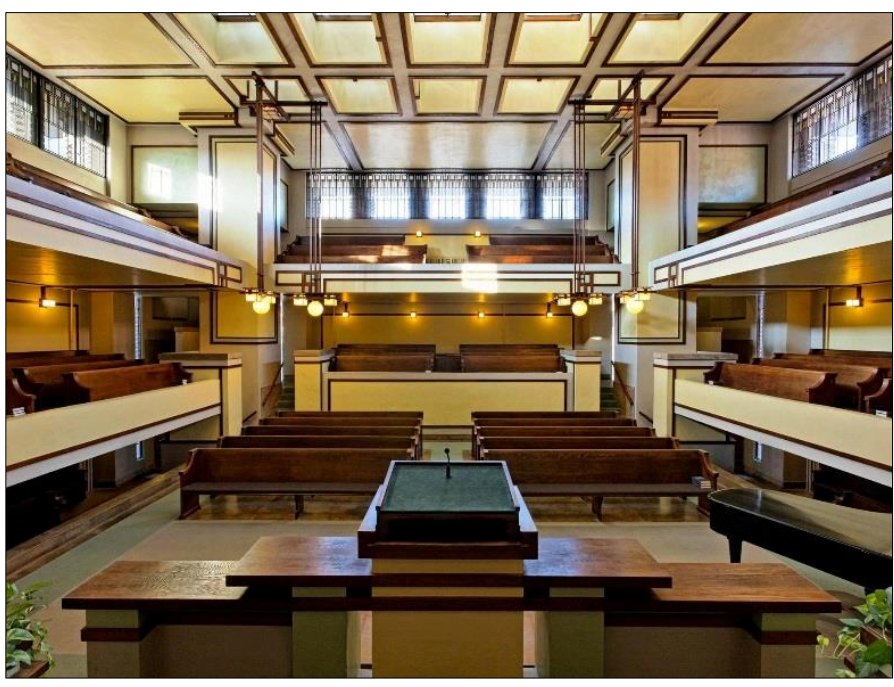




\section{CONCRETO ARMADO: EXPRESSÃO ARQUITETÔNICA NÃO CAMUFLADA}

Auguste Perret:

Edifício Residencial na Rue Franklin [3.21 - 3.22] e Igreja de Notre-Dame du Raincy [3.23 - 3.24]

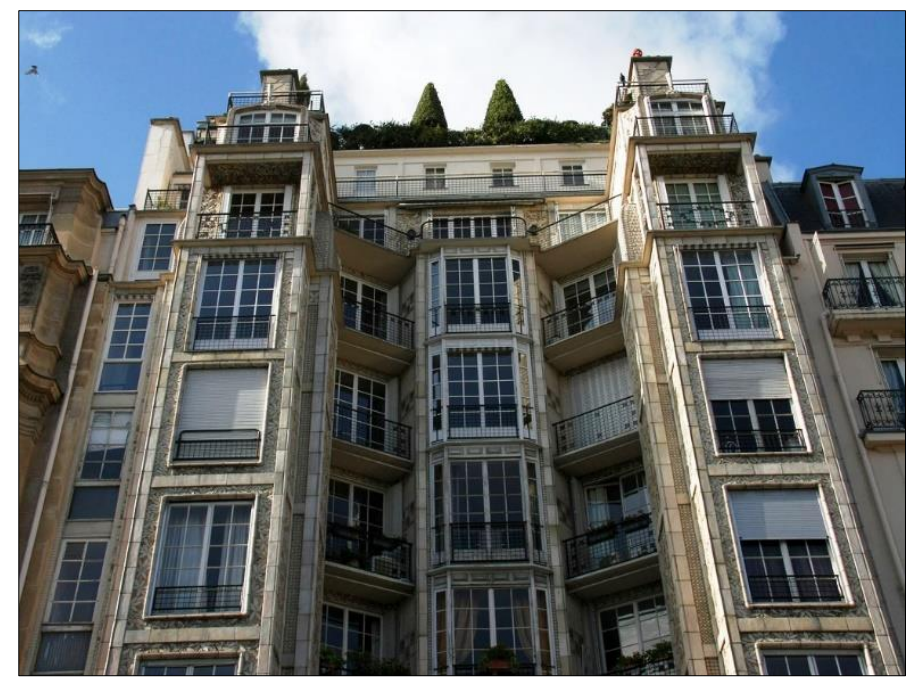

[3.21] Vista parcial da fachada do edifício residencial parisiense: plantas flexíveis e concreto aparente conferem a Auguste Perret o título de pioneiro no uso do concreto armado como expressão arquitetônica.

[3.23] A paginação da cobertura adota uma sucessão de abóbadas transversais ao maior eixo da edificação, o que the confere movimento e um ar de grata leveza sobre o conjunto de vitrais dispostos nas paredes de fechamento perimetral.

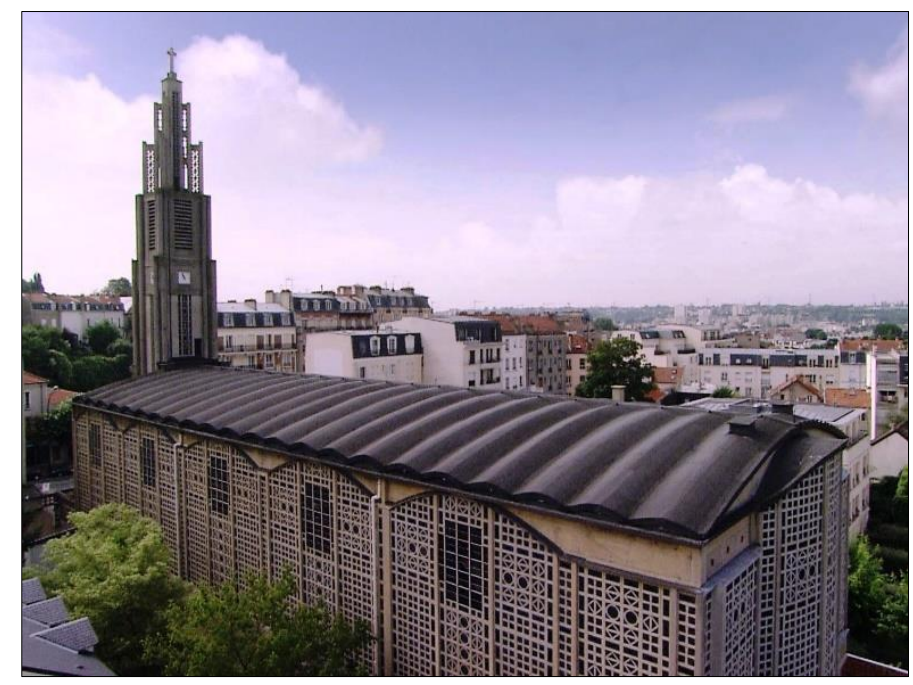

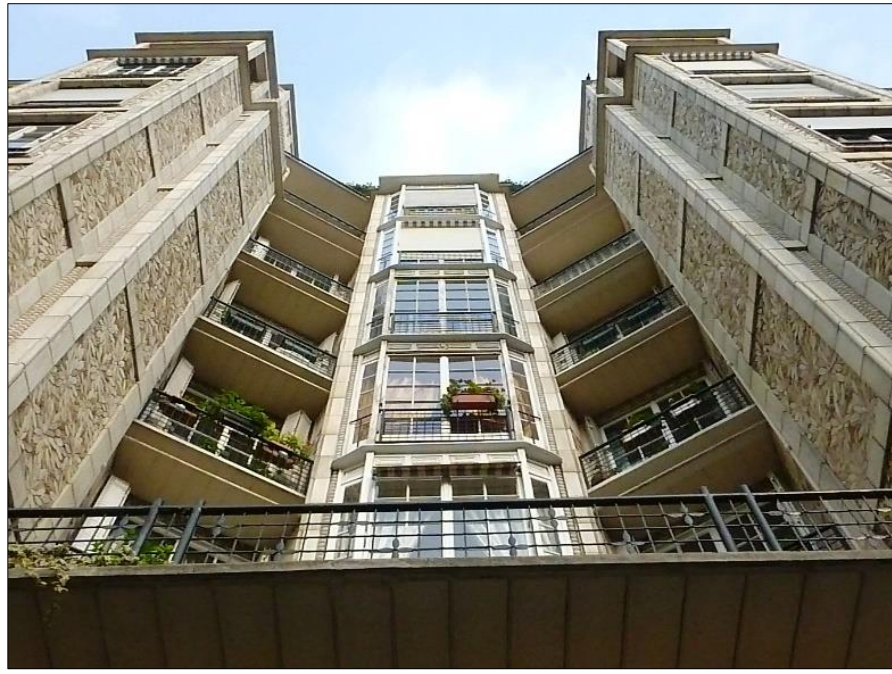

[3.22] O edifício adota a ossatura exposta, sem camuflagens - coisa que até esse momento nunca havia sido feita para este tipo de projeto. Além disso (e também por isso), ressalta a estética do concreto armado e sua contribuição para a arquitetura.

[3.24] Internamente, o teto ondulado e moldado em concreto armado é deixado aparente: prova da capacidade estrutural de um material ainda pouco explorado. A esbelteza dos pilares feitos do mesmo material não confronta a ampla espacialidade da igreja.

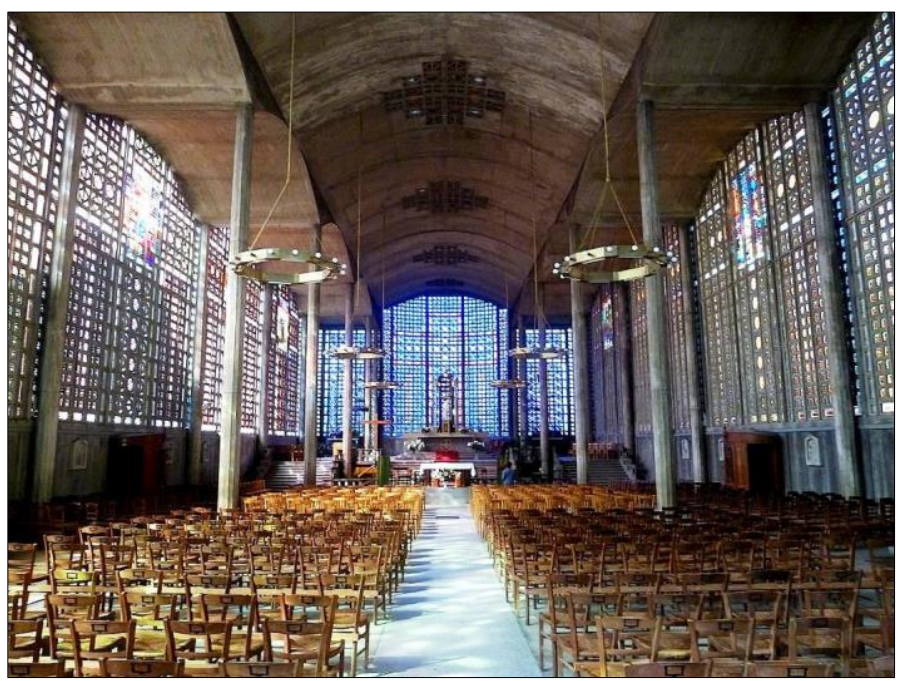




\section{CONCRETO ARMADO: NOVAS SOLUÇÕES, NOVAS FORMAS, NOVOS ESPAÇOS}

Robert Maillart:

Pontes sobre os rios Zuoz [3.25] e Reno [3.26]; Armazém na Rua Giesshübel [3.27] e Pavilhão da Companhia de Cimento Portland na Exposição Nacional de Zurique de 1939 [3.28]

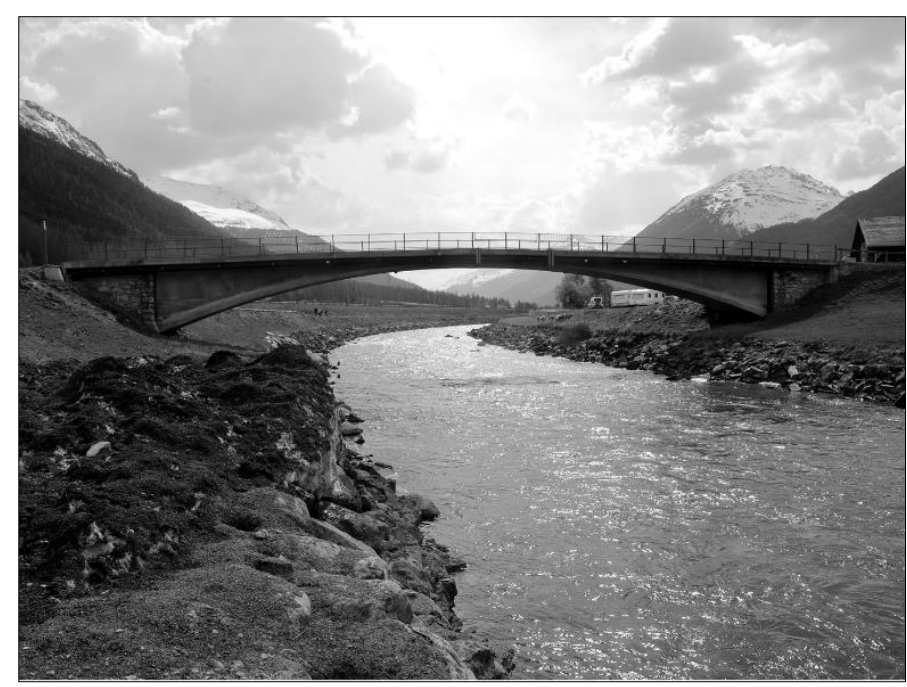

[3.25] Perspectiva da ponte suíça em arco triarticulado, com 38 metros de vão livre. Concreto armado é o material adotado para confeccionar tanto o tabuleiro quanto a viga-mestra, ambos, moldados, concretados e curados em conjunto.

[3.27] Todos os pilares distribuídos pelos cinco pavimentos do armazém possuem seção octogonal, encimados por capitéis hiperbolicamente curvos. Por questões estéticas e estruturais, a largura do topo dos capitéis é de quatro vezes o diâmetro de base.

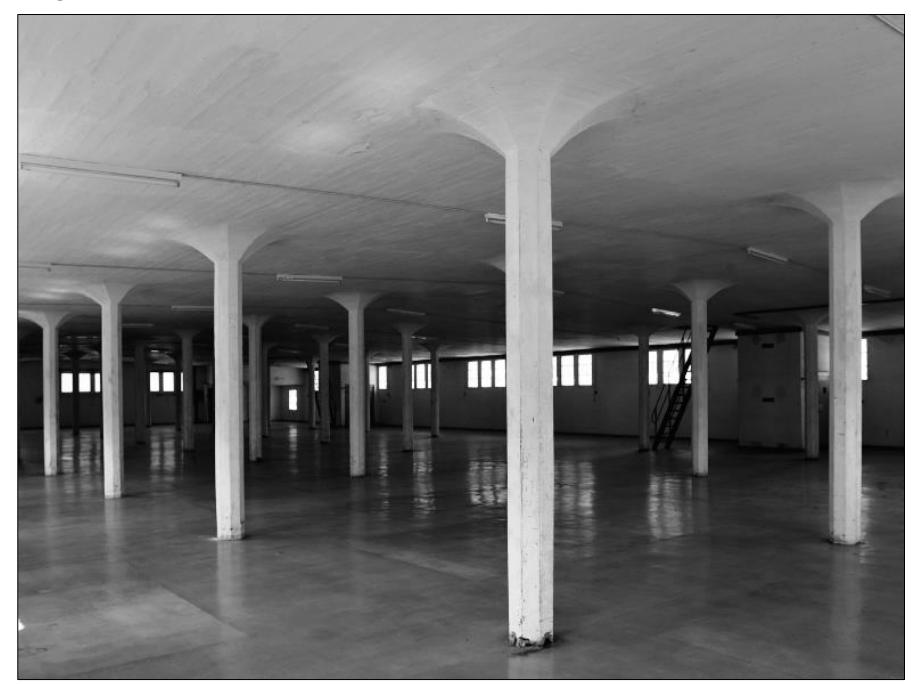

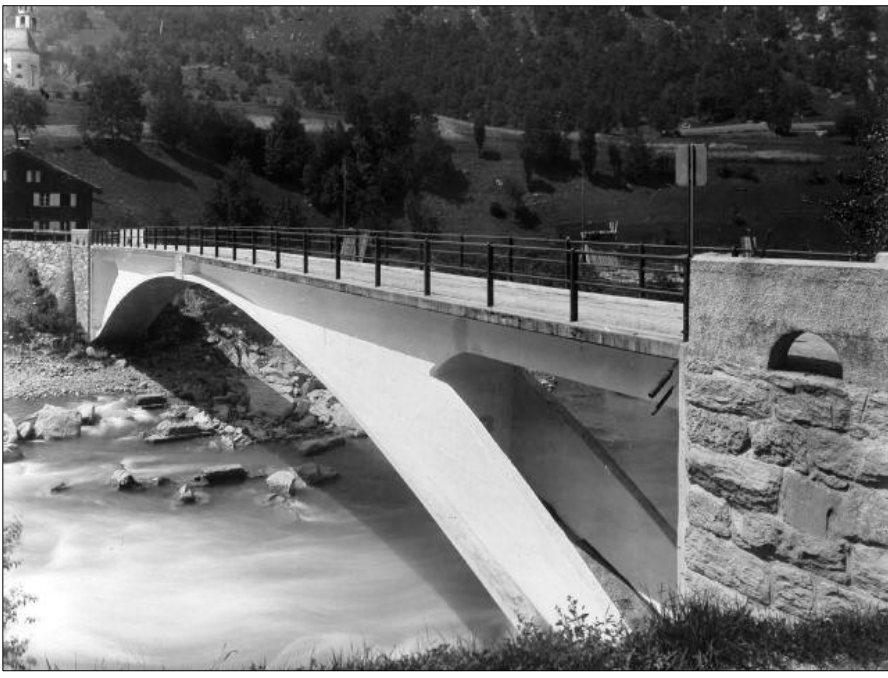

[3.26] Com formato de arco triarticulado, a ponte em concreto armado traz seção vazada e aberturas laterais transversais e triangulares. Esta solução ajuda a aliviar o peso final da construção e a incrementar a estética da obra de arte.

[3.28] Construído em concreto, o pavilhão de exposições possui: abóbada paraboloide semicilíndrica, quatro apoios que a elevam do chão, duas nervuras transversais de reforço estrutural e uma passarela de ligação entre ambos os lados da casca de concreto.

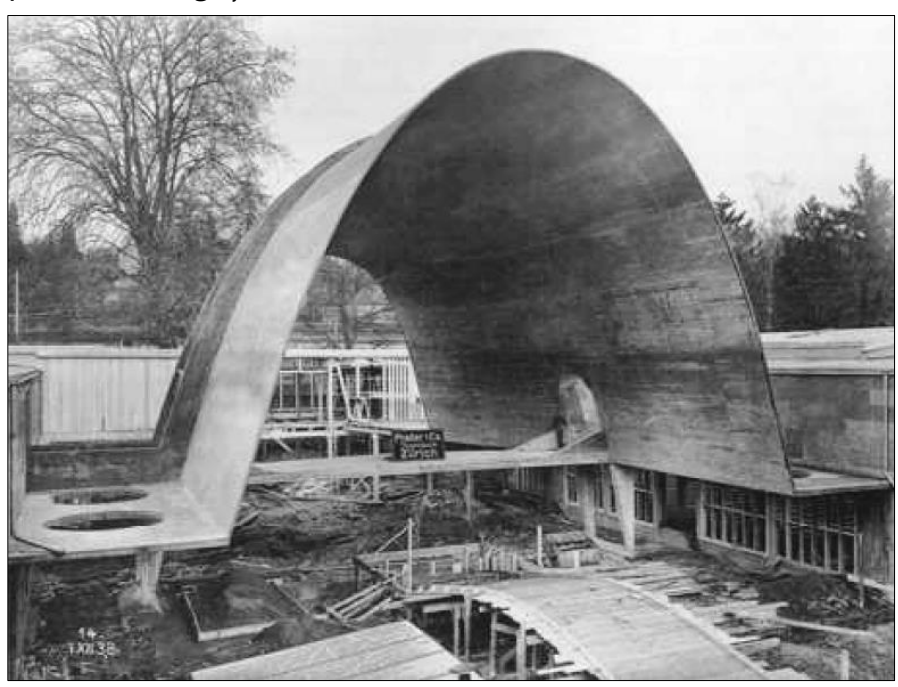




\section{CONCRETO ARMADO: ARCOS E PARÁBOLAS PARA GRANDES VÃOS}

Eugène Freyssinet:

Pont de la Libération [3.29]; Pont de Plougastel - ou Pont Albert-Louppe [3.30] e Hangares no Aeroporto de Orly [3.31 - 3.32]

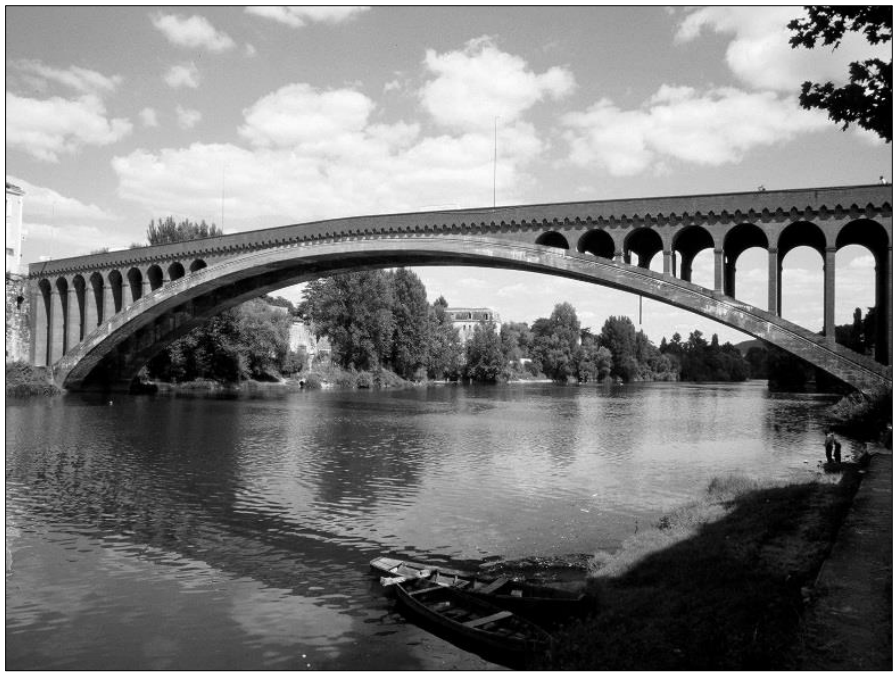

[3.29] Um par de arcos paralelos e aproximadamente funiculares, moldados e estruturados em concreto, vence o vão de 96,25 metros entre margens. Este formato permite que o peso-próprio da estrutura seja distribuído ao longo de toda sua extensão.

[3.31] Os arcos parabólicos fundem, em um só contexto, a solução estrutural e o apelo arquitetônico. Não há delimitação entre aquilo que é cobertura e o que é fechamento lateral, pois a solução de Freyssinet extrapola as definições até então existentes.

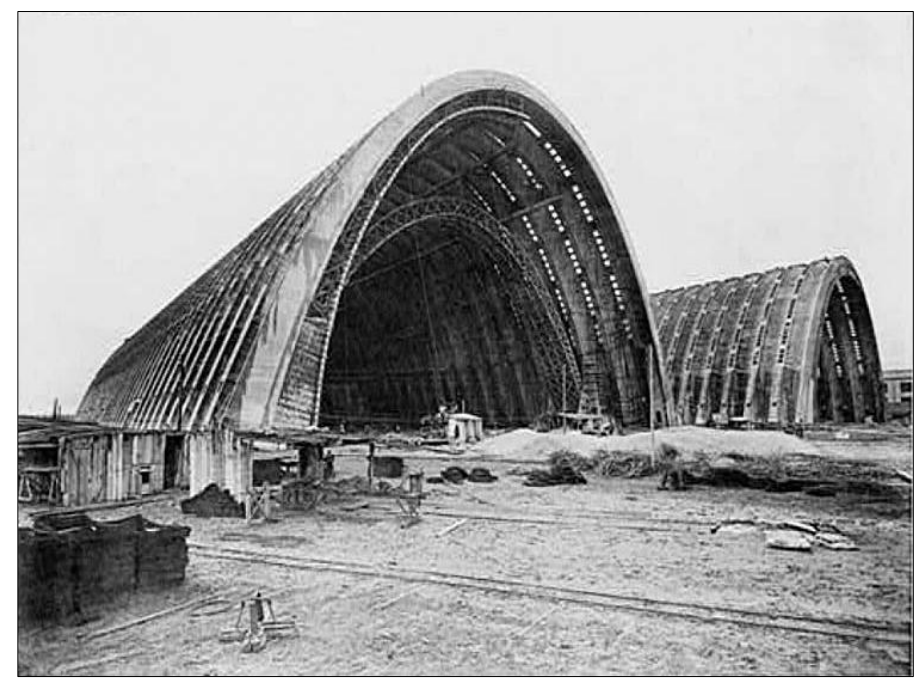

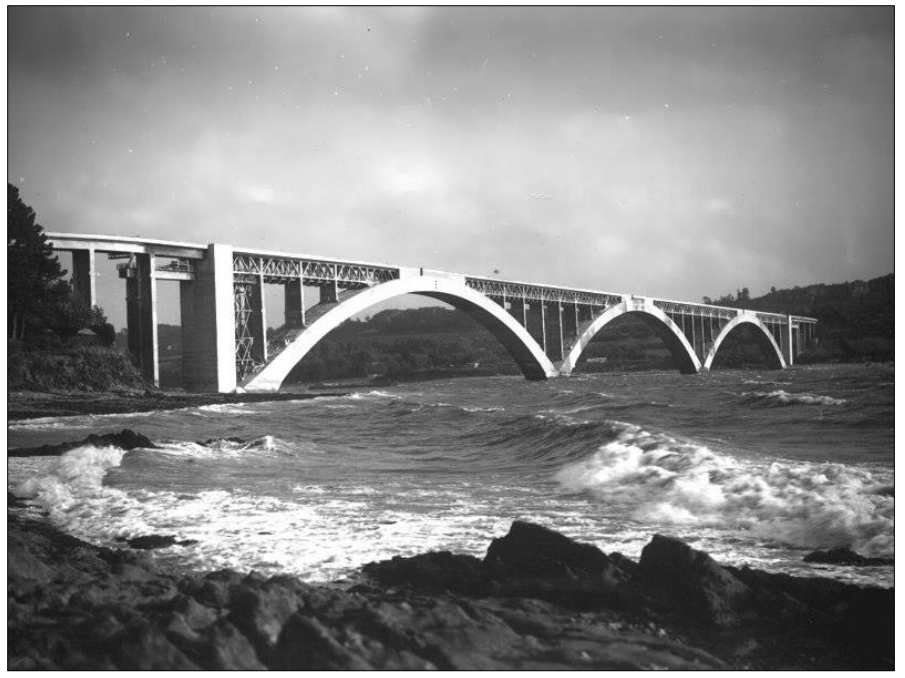

[3.30] Composta por três arcos sucessivos feitos em concreto armado (cada um vencendo um vão de 188,0 metros) a ponte atinge, quando acrescentados os balanços, uma extensão total de 888,0 metros entre as margens do Rio Elórn, na França.

[3.32] Internamente, a sucessão de arcos parabólicos realizados em concreto deixa nítida a ossatura independente e contribui para que o vão transversal de 75 metros de comprimento e de 56 metros de altura seja vencido, sem quaisquer obstruções.

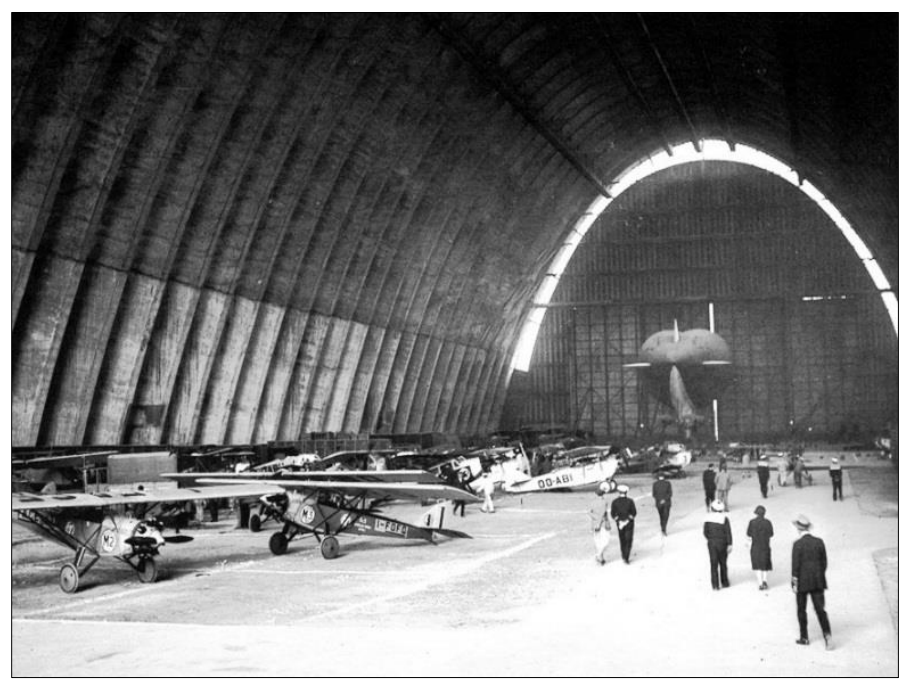




\title{
CONCRETO ARMADO: A OSSATURA INDEPENDENTE AMPLIA OS LIMITES DA ARQUITETURA
}

\author{
Le Corbusier:
}

"Sistema Domino" [3.33]; Villa Savoye [3.34];

Palácio dos Soviets [3.35] e Unité d'Habitation [3.36]

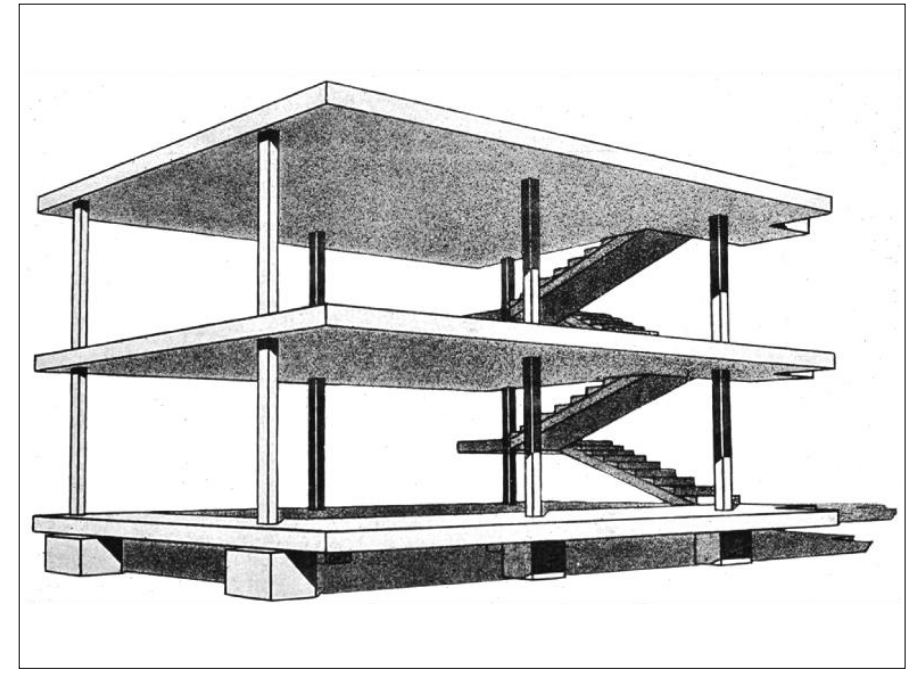

[3.33] "Sistema Domino": um método construtivo formado por lajes planas, pilares e fundações em concreto armado. Propõe uma ordem racional entre os seus elementos e a sua construção, por meio da aplicação de subsistemas de organização estrutural.

[3.35] Nunca construído, o projeto para o "Palácio dos Soviets" marca uma fase em que Le Corbusier busca desafios e programas mais complexos. Aqui, o arco parabólico em concreto de 160,0 metros de extensão sustenta a cobertura de um grande auditório.

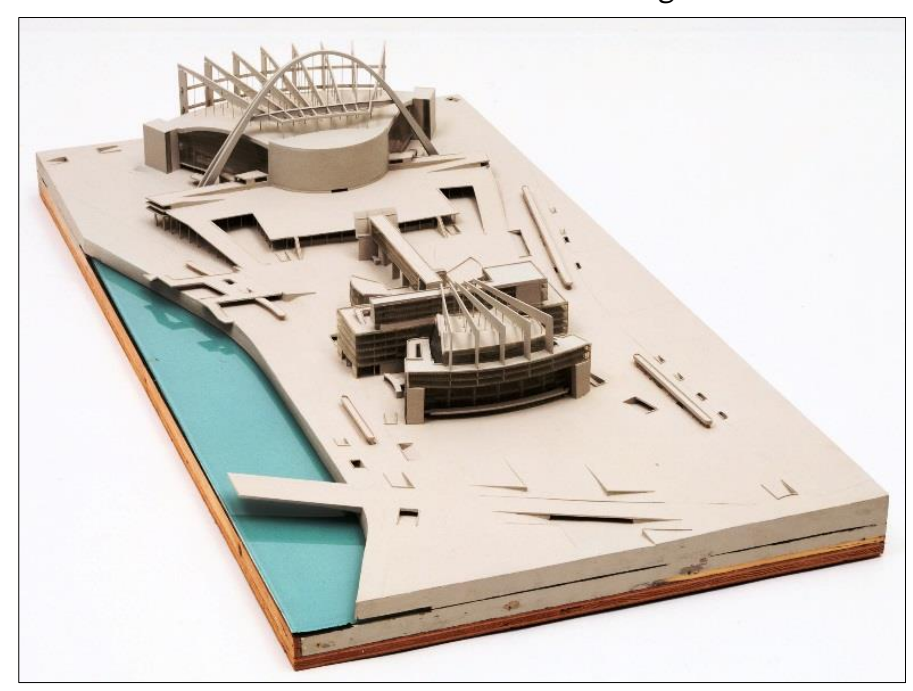

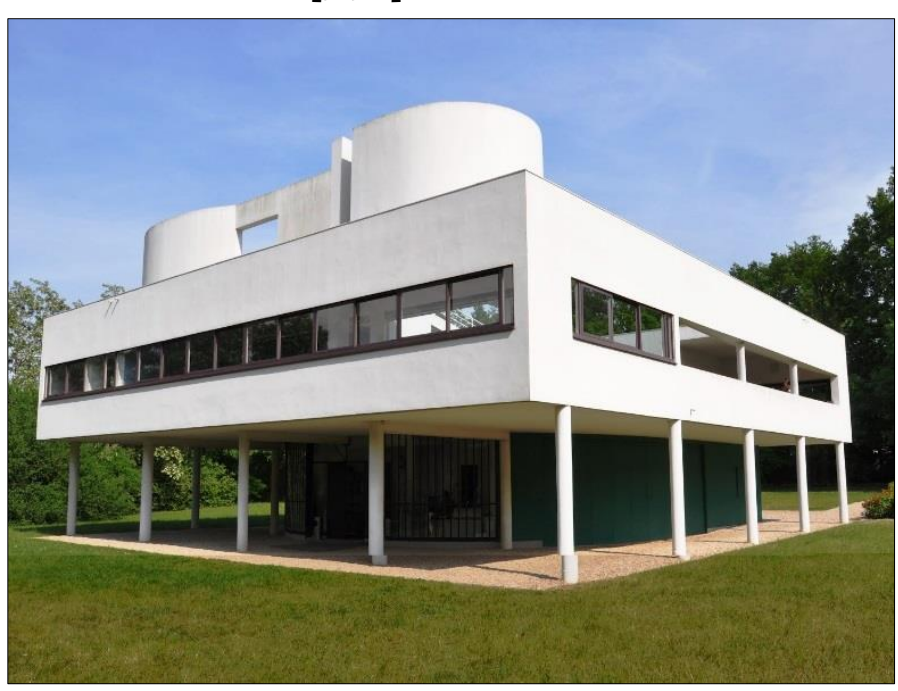

[3.34] Esta residência representa um momento de síntese na trajetória do mestre franco-suíço ao materializar, pela primeira vez em sua carreira, a integração entre o "Sistema Domino" e os "Cinco Pontos para uma Nova Arquitetura”

[3.36] Executado em concreto armado, este edifício de baixo custo também traz os "Cinco Pontos" corbusianos, porém, em uma escala maior e mais complexa. São eles: pilotis, terraço-jardim, planta livre, fachada livre e janelas em fita.

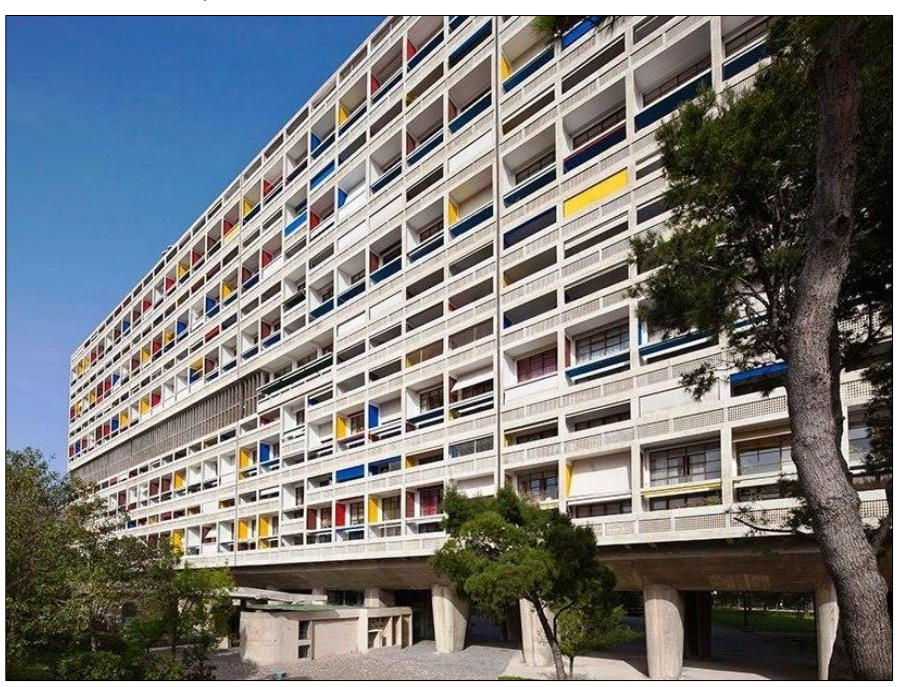




\section{No Brasil: O Ferro, o Aço e a Indústria Siderúrgica Nacional}

Por aqui, já a partir do terceiro quartel do século 19, verifica-se o uso das estruturas metálicas em uma escala considerável, todavia, em sua maior parte composta por materiais importados. Segundo Macedo (2002), seja na forma de elementos isolados (vigas, pilares ou tesouras), seja como sistemas completos (armazéns, galpões, estacionamentos e afins), parte dos elementos ou dos conjuntos arquitetônico-estruturais são originários de fábricas estrangeiras, como por exemplo, a do arquiteto e industrial americano James Bogardus (1800 - 1874) - pioneiro na produção e na adoção do ferro fundido estrutural na arquitetura e detentor dos direitos de sua patente desde 1850. Note-se que ele não inventa o ferro fundido, mas é o primeiro a perceber que este elemento oferece propriedades tais que fazem dele uma escolha competitiva quando empregado adequadamente na construção civil: estabilidade, resistência, leveza, boa resposta ao fogo (quando comparado à madeira), além de ter moldagem maleável em termos de tamanho e de formato, e de ser rapidamente montado em campo.

Bogardus visualiza um mercado latente e ávido por peças avulsas ou por projetos integrais, todos, pré-fabricados em ferro fundido. Aproveitando sua formação em arquitetura, ele mesmo projeta seus edifícios como um todo, desenha seus componentes, pensa nas ligações e nas uniões necessárias, modula suas soluções, define detalhes construtivos e vende suas propostas, em partes ou completas. A produção em larga escala barateia o produto final, e o sucesso de sua ideia é tamanho que chega até a exportar seus artigos para outros estados americanos e para fora do país incluindo o Brasil, mercado bastante atraente para a empresa de Bogardus principalmente por não haver aqui, à época, concorrente páreo para seus produtos, preços e qualidade.

Costa (1995) esclarece que as encomendas às indústrias estrangeiras se justificam em casos pouco convencionais nos quais são exigidos componentes mais complexos, por não serem fabricados adequadamente em território nacional dadas as limitações da produção local. Cúpulas, escadarias, coberturas, itens de ornamentação ou quaisquer outros elementos desejados, quando em terras brasileiras, demandam muitas vezes a adaptação dos edifícios existentes por meio, por exemplo, de alvenarias portantes reforçadas com elementos metálicos, diz o autor. Entram neste grupo, dentre outras obras, gares e terminais ferroviários, muitos dos quais pré-fabricados por completo - fato justificado por este um momento de bons investimentos e de um desenvolvimento palpável na área de infraestrutura no país. 
O atraso na indústria nacional de ferro remonta a tempos anteriores e resulta de uma sucessão de acontecimentos que, quando somados, ajudam a compreender os motivos que conduzem a indústria brasileira a se desenvolver, efetivamente, apenas a partir do século 207. De acordo com o Instituto Aço Brasil (2015), em linhas gerais, pode-se dizer que a primeira empresa que lida com a redução do minério de ferro é inaugurada pelo empreendedor português Afonso Sardinha (? - 1616) no final da segunda metade dos anos 1500, em uma área próxima às atuais cidades de Araçoiaba e de Sorocaba, no interior paulista. As forjas desta fábrica funcionam até pouco depois da morte de seu fundador e, daí em diante, a siderurgia brasileira enfrenta um dilatado período de paralisação que dura décadas, e assim prossegue até o século seguinte.

A descoberta de ouro, pedras e metais preciosos na região hoje ocupada pelo estado de Minas Gerais altera fortemente a dinâmica local, despertando novo interesse pela indústria siderúrgica nacional. Na primeira metade do século 18 novas fundições começam suas atividades, focadas que estão na fabricação de artefatos fornecidos às empresas mineradoras: ferramentais, trilhos, equipamentos de carga e afins são então produzidos. Todavia, ainda que desperte certa contrariedade, as mesmas atividades mercantilistas que estimulam a descoberta de metais preciosos em terras brasileiras, contribuem também para uma fase de repressão à consolidação de uma indústria de processamento siderúrgico nacional.

Isso significa dizer que, ainda que o Brasil-colônia deva ser explorado ao máximo, ao comércio português interessam apenas os artefatos preciosos (ouro, pedras e metais) acrescidos dos produtos agrícolas (derivados de outro tipo de monopólio). Portanto, toda e qualquer atividade diferente, ordena o reinado português então vigente, deve ser sumariamente desmantelada. Com isso, Portugal chega ao ponto de proibir a construção de novas fundições, além de ordenar o encerramento das atividades daquelas já existentes, sem levar em conta as consequências que essa ação pode acarretar ao futuro do Brasil.

\footnotetext{
7 A explicação completa que ajuda a elucidar os motivos pelos quais a indústria brasileira de siderurgia não acompanha o ritmo frenético de descobertas e/ou de pesquisas e/ou de aplicações práticas vivenciadas por outros países quanto ao uso na construção civil do ferro fundido em um primeiro momento, e do aço logo depois (considerando suas causas, consequências e ramificações), demanda uma abordagem cuidadosa, bastante extensa e que foge tanto aos limites impostos a este trabalho, quanto ao efetivo interesse de serem aqui apresentados.

Todavia, é importante que ainda que brevemente o percurso da siderurgia brasileira seja discutido, justamente para que se tenham em mãos ferramentas suficientes para compreender, no transcorrer da história brasileira, como essa indústria se consolida, quais os principais obstáculos enfrentados, como seu desenvolvimento repercute na economia do país e qual o momento em que a produção e o consumo nacionais se tornam praticamente independentes do mercado internacional.
} 
O cenário é alterado gradativamente depois que Dom João VI (1767 - 1826) assume o trono de Portugal. No final do século 18, por exemplo, as processadoras de minério (isto é, as fundições) voltam a ser autorizadas, e o número de novas indústrias nesse segmento cresce significativamente após a chegada da família real e de sua comitiva, em 1808, ao Brasil. Uma nova dinâmica manufatureira, industrial e de consumo passa a vigorar desde então - fato esse que tonifica o mercado nacional e que desperta, consequentemente, o interesse de novos empresários e de novos investidores (sejam eles brasileiros ou estrangeiros).

Com isso, várias indústrias de processamento de materiais férreos são constituídas durante os anos seguintes. Dentre outras, em 1815 a Usina do Morro do Pilar, em Minas Gerais, começa suas atividades. Três anos mais tarde, na área conhecida como Floresta Nacional de Ipanema (no interior de São Paulo e uma vez mais junto à cidade de Sorocaba), é inaugurada a Real Fábrica de Ferro de Ipanema (esta, alçada ao título de primeira siderúrgica nacional de fato). E também em Congonhas do Campo, em Caeté e em São Miguel de Piracicaba outras fábricas são abertas na mesma época, todas elas no território do estado de Minas Gerais. Baer (1970) esclarece que antes das citadas mudanças geradas com a chegada da família de Dom João VI ao Brasil e a nova produção nacional de ferro fundido daí derivada, o material feito em ferro e consumido em território brasileiro é encomendado da Europa, principalmente de fornecedores suecos, alemães e espanhóis.

Nos anos seguintes, De Paula (2012) explica ter havido um declínio substancial na produção de ferro nacional (ainda que as previsões feitas no início do século 19 apontem para um cenário mais próspero). Sugere-se que, já naquela época, os produtos importados tenham prejudicado a indústria nacional: um reflexo tardio, quem sabe, do Tratado de Methuen (também conhecido por Tratado dos Panos e Vinhos), assinado em dezembro de 1703 por Inglaterra e Portugal. Neste documento, ambos os países comprometem-se a consumir a produção alheia de um produto em específico, ou seja, a necessidade portuguesa por têxteis deve ser atendida pela importação de produtos britânicos, exclusivamente. E o mesmo vale quanto ao vinho, porém, em situação oposta: os ingleses devem importar de Portugal o vinho que abastece seu mercado interno.

Essa centralização de atividades afeta negativamente Portugal e ecoa no Brasil, pois além de sua economia estar sensivelmente abalada à época (por motivos diversos que não vêm ao caso neste estudo), o foco passa a ser o vinho (cuja produção praticamente já tem venda garantida por conta do Tratado de Methuen - porém, não em quantidade suficiente para fazer diferença na recuperação da economia lusitana). Assim, os investimentos que podem ser feitos 
em outras áreas, não o são, tornando-as ainda mais instáveis e debilitadas. Como se isso não bastasse, no Brasil há escassez de mão-de-obra, já que esta é praticamente toda absorvida por três segmentos produtivos: sobretudo a exploração aurífera (mas já faceando o declínio), além da lavoura do açúcar e, com o transcorrer dos anos, o plantio do café.

Paulatinamente a situação indica sinais de melhoria. Tanto é fato que na década de 1880 verifica-se o primeiro surto industrial brasileiro, oportunidade na qual a quantidade de empresas beneficiadoras passa de 200 (em 1881), para 600 (em 1889), acarretando o interesse na substituição de produtos importados, por nacionais. Já no século 20, segundo Carvalho (2012), o panorama torna-se mais promissor: são registrados avanços na siderurgia nacional, estimulados especialmente pelo segundo surto industrial ocorrido entre as décadas de 1917 e 1930, logo após a Primeira Grande Guerra. Sobre as conquistas e as transformações nesse mercado, é interessante notar que

\begin{abstract}
as primeiras décadas do século XX foram de avanços para a siderurgia brasileira, impulsionados pelo surto industrial verificado entre 1917 e 1930. O mais importante foi a criação, na cidade de Sabará (MG), da Companhia Siderúrgica Mineira. Em 1921, a CSBM-Cia. Siderúrgica Belgo-Mineira foi criada como resultado da associação da Companhia Siderúrgica Mineira com o consórcio industrial belgoluxemburguês ARBEd-Aciéres Réunies de Bubach-Eich-dudelange que, em 1922, associou-se a capitais belgas e se transformou na Companhia Siderúrgica Belgo-Mineira. (INSTITUTO AÇO BRASIL; 2015)
\end{abstract}

O motor cafeeiro, que conduz a economia nacional até os anos 1930, toma para si praticamente toda a atenção daqueles que governam nesse período - mas isso não afeta as empresas de siderurgia. Pelo contrário: favorecidas que estão por benefícios fiscais, aumentam expressivamente suas produções. Em 1937, coloca Baer (1970), a mesma companhia Belgo-Mineira inaugura seu maior investimento até então realizado: a Usina de Monlevade, em território mineiro, com capacidade para produzir anualmente 50 mil toneladas de lingotes de aço. Três anos depois, quando dá início às atividades de laminação, essa empresa torna-se a maior siderúrgica integrada da América Latina. Além dela, entre o final da década de 1930 e o começo da de 1940, são abertas a Companhia Siderúrgica de Barra Mansa (na cidade de Barra Mansa, ao sul do Rio de Janeiro) e a Companhia Metalúrgica de Barbará (em Caeté, Minas Gerais).

A despeito de todos esses investimentos, o Brasil segue dependente de aços importados até a ascensão de Getúlio Vargas ao governo brasileiro. Tendo em vista que a política do novo presidente é calcada na valorização nacional - aí incluídas indústria, cultura, educação e economia - Vargas tem como meta incentivar a indústria de base nacional, tornando-a maior, mais forte e, acima de tudo, nacionalizada. Para tanto, é inaugurada, em 1946, em Volta Redonda (Rio de Janeiro), a Companhia Siderúrgica Nacional (CSN), inicialmente produzindo coque metalúrgico. E, "no mesmo 
ano, foram ativados os altos-fornos e a aciaria. As laminações entraram em atividade em 1948 e marcaram o início da autonomia brasileira na produção de ferro e aço". (INSTITUTO AÇO BRASIL, 2015) 
Não há que se falar em concreto armado sem que seja considerado o seu principal componente: o cimento Portland. Como já mencionado, a patente desse aglomerante é registrada por Joseph Aspdin em 1824, e as bases para sua produção em escala industrial são desenvolvidas por Isaac Charles Johnson na mesma época. Freitas (2011) cita que a primeira fábrica de cimento Portland é de origem, portanto, britânica. Em 1850, continua a autora, são quatro indústrias pelo mundo: três na Inglaterra e uma na Alemanha. Nos anos seguintes o cenário se dilata e surgem novos concorrentes de peso: Estados Unidos, Noruega, Bélgica, Dinamarca, França, Suécia, Suíça, Polônia e Espanha. "No Brasil, os primeiros cimentos empregados, principalmente em São Paulo, eram, sobretudo de origem belga, transportados por rota marítima dentro de barricadas de madeira tendo, portanto, prazo de validade". (FREITAS; 2011: 79)

De acordo com o SNIC - Sindicato Nacional da Indústria do Cimento (2014), os índices de crescimento e de desenvolvimento apresentados pelo Brasil no final do século 19 impelem o estabelecimento de uma indústria nacional de cimento. Várias são as obras pontuais ou de grande porte feitas pelo Brasil, da construção de edifícios a intervenções no território urbano. Essas obras refletem um movimento ascendente conduzido, por exemplo, pela remodelação urbanística e arquitetônica ocorrida entre 1875 e 1906 na capital carioca - a qual, explica Pires (2010), é inspirada no urbanismo sanitarista, nos planos de melhorias e de embelezamentos das cidades e em um forte apelo às influências do urbanismo haussmanniano.

Futuramente essas ações são reforçadas por um novo impulso gerado pelo término da Primeira Grande Guerra, em 1917, fato que carrega de fôlego os mercados da construção civil mundial e brasileiro e que ressoa no segmento cimenteiro - demandando, então, novos e pesados investimentos públicos e/ou privados no setor. Há também, nesse cenário de transformação (ou de transição), o fator financeiro: no final da década de 1880 o Brasil compra cerca de 40,0 mil toneladas de cimento de outros países a taxas de importação médias equivalentes a 30,0\%. Na medida em que a procura interna por esse produto cresce, os custos de manter abastecido o mercado brasileiro tornam-se, aos poucos, proibitivos. 
A proclamação da República de 1889 dispara uma nova consciência para com o país. Nela, buscam-se ações que ajudem a promover a estabilidade política e a conformação de um mercado interno voltado à construção civil, até então marcada

pela importação de produtos industrializados, já que não existia uma indústria de base local, nem tampouco um mercado da construção consolidado, com mão-de-obra treinada [...]. Assim, a importação de elementos industrializados de cimento aconteceu nas duas últimas décadas do século 19. Neste momento, a fabricação de elementos decorativos, de componentes construtivos e acessórios industrializados (como vasos, esculturas e fontes) era das características da construção civil. (BONDUKI, KOURY, BOTAS, NASCIMENTO e FREITAS; 2010)

Configura-se assim o momento ideal para implantar fábricas de cimento Portland em território nacional, e três são as iniciativas que acontecem quase que simultaneamente para sanar essa necessidade. Em 1888 o empresário paulistano Antônio Proost Rodovalho (1838 - 1913) empenha-se para instalar uma fábrica de cimento em uma de suas propriedades (a Fazenda Santo Antônio), situada nas adjacências de Sorocaba, interior paulista. Trata-se de uma região com reservas calcárias e grandes pedreiras, e já bastante procurada por outros empresários focados na abertura de indústrias de diversos fins, como a siderúrgica Real Fábrica de Ferro de Ipanema, de 1818. A companhia cimenteira de Rodovalho - que produz o cimento da marca "Santo Antônio" - começa a funcionar em 1897 e opera apenas até 1904. Retoma a produção três anos depois (detendo agora as marcas “Laje”, “Torquês” e “Meia Lua”), porém, em função da baixa qualidade dos seus produtos finais, é extinta em 1918.

Dois anos mais tarde, em 1890, outro empreendedor aventura-se na tentativa de vingar uma produtora de cimento. Nesse ano, o engenheiro gaúcho Louis Felipe Alves da Nóbrega dá início à construção da sua própria fábrica na Ilha do Tiriri (defronte a João Pessoa, capital da Paraíba), junto a uma extensa reserva de calcário. No entanto, a proximidade da fábrica à reserva não garante o sucesso da empreitada, pois três meses após inauguração, no ano de 1892, o empreendimento é fechado. Duas são as justificativas atribuídas ao fracasso da empresa paraibana: a grande distância dos seus principais centros consumidores (o que encarece o custo do frete e, logo, o do produto final) e a produção em uma escala muito pequena, que não suporta a concorrência dos cimentos importados.

A terceira tentativa para a implantação de uma fábrica brasileira de cimento se dá no Espírito Santo, já no século 20 (mais precisamente em 1912). Esta iniciativa é fruto de um infeliz programa estatal de industrialização promovido pelo governo desse estado, resultando, logo, em mais um episódio frustrado: “a fábrica - Cimento Monte Líbano - em sua fase primitiva, nunca chegou a funcionar regularmente tendo sido paralisada em 1924, quando foi arrendada $e$ 
remodelada, operando com grandes paralisações temporárias até encerrar definitivamente suas atividades em 1958". (SNIC; 2014: 2).

Mesmo enfrentando dificuldades, com companhias cimenteiras que abrem e fecham suas portas em pouco tempo ou se sobrevivem por períodos maiores o fazem com alto grau de dificuldade - fato é que há cada vez mais a consciência de que um país com dimensões continentais e com reservas naturais abundantes como o Brasil não pode depender eternamente de fornecedores estrangeiros. Se em 1880 o país gasta muito ao importar cerca de 40,0 mil toneladas de cimento Portland ao ano, quatro décadas depois ele contabiliza ainda mais inquietações. Dados do SNIC (2014) indicam que no início da década de 1920 as importações brasileiras de cimento Potland batem 400,0 mil toneladas/ano e representam um total de $97,0 \%$ de todo cimento consumido no mercado interno. A produção local de 13,0 mil toneladas é, deste modo, praticamente toda sobrepujada pelos principais fornecedores internacionais: Estados Unidos, Inglaterra, França, Alemanha, Dinamarca, Bélgica e Argentina. Além disso, esses mesmos países investem maciçamente em campanhas de marketing que visam destacar as qualidades dos produtos por eles oferecidos, ao passo que denigrem o cimento fabricado no Brasil - e isso gera alto índice de desconfiança dos consumidores locais para com a produção brasileira.

Esse cenário preocupante apresenta melhorias somente a partir dos anos 1920, momento no qual por toda a América Latina novas fábricas de cimento Portland são implantadas. Um ano marcante para o mercado local é 1926, quando a Companhia Brasileira de Cimento Portland, de capital canadense, inicia suas atividades

em Perus, a 23 quilômetros da cidade de São Paulo. A instalação da nova fábrica representou o início do processo de crescimento da produção brasileira de cimento, que saltou imediatamente de 13.000 toneladas em 1926, para 54.000 em 1927, 88.000 em 1928 e 96.000 em 1929. O cimento Perus havia conquistado o mercado e superado todas as desconfianças dos consumidores.

A partir daí, a indústria brasileira do cimento iniciou um consistente processo de consolidação e crescimento. Depois de sete anos de hegemonia da Companhia Perus, a Companhia Nacional de Cimento Portland, subsidiária da norte-americana Lone Star, entrou no mercado cimenteiro. Adquiriu uma jazida calcária recém descoberta em Itaboraí, no Estado do Rio de Janeiro, e em seguida inaugurou sua fábrica no município de São Gonçalo, lançando o hoje tradicional cimento Mauá. O resultado é que, já em 1933, a produção nacional começava a ultrapassar as importações. (SNIC; 2014: 3)

E Freitas (2011) complementa essas informações do Sindicato Nacional da Indústria do Cimento ao argumentar que

a expansão da produção do cimento não parou por aí. Em 1935 foi aberta uma usina na Paraíba, produtora da marca Dolaport, seguida, em 1936, por uma em Monte Líbano, no estado do Espírito 
Santo, da marca Barbará, e de outra em Santa Helena (próxima a Sorocaba, no interior de São Paulo), a Votoran. Em 1939, a Itaú abriu uma empresa no estado de Minas Gerais. Entre 1926 e 1939, houve concomitantemente tanto um aumento no consumo como na produção de cimento Portland nacional, que quase alcançou o status de autossuficiência. (FREITAS; 2011: 82)

Como visto, ao longo da primeira metade do século 20 as indústrias de base brasileiras são progressivamente constituídas e amadurecidas em dois flancos distintos, independentes entre si, mas intimamente relacionados: por um lado, as necessidades de produção e de beneficiamento de metais são abastecidas por empresas de grande porte, dentre as quais destacam-se a Companhia Siderúrgica Belgo-Mineira, de 1922, e a Companhia Siderúrgica Nacional (CSN), vinte e quatro anos mais nova. Por outro lado, a produção de cimento Portland brasileiro encontra sua redenção em 1926, a partir do início da produção cimenteira da Companhia Brasileira de Cimento Portland e, depois de sete anos, a mesma Companhia Siderúrgica Nacional (CSN) inaugura, na atual São Gonçalo (e antiga Guaxindiba), a fábrica de cimentos Mauá.

Gitahy (2002) explica que tais indústrias de base são fundamentalmente importantes para a produção de dois dos elementos constitutivos que caracterizam o concreto armado, ou seja, o aço redondo e o cimento Portland. Sem ambos os materiais não há o concreto propriamente dito (além deles, adotam-se também a pedra britada, a areia, a água e, quando for o caso, algum aditivo químico mais pertinente ao uso que o concreto terá). Há que se considerar que o desenvolvimento e o crescimento das indústrias de bens intermediários aqui abordados - aço e cimento podem ser rastreados, por exemplo - e dentre tantas outras possibilidades - com base nos registros de abertura e/ou de encerramento de suas atividades. É, assim, uma tarefa de pesquisa que, ainda que trabalhosa, rende frutos consistentes na forma de mapeamentos claros do mercado produtor ao longo dos anos - principalmente no que tange a quantos e a quais participantes estão atuando ativamente em determinado momento da história. Além disso, mesmo que indiretamente, ajudam a compreender como transcorrem as atividades ligadas à arquitetura e à engenharia civil - ambas, absolutamente dependentes dos materiais de construção aço e cimento.

É um setor que demanda valores de investimento dos mais elevados, não apenas para a construção, a montagem e a manutenção das indústrias propriamente ditas, mas também em relação à prospecção de jazidas (de minérios e de calcário para a confecção do aço e do cimento, respectivamente), à extração e ao beneficiamento da matéria-prima, aos custos de transporte até os revendedores intermediários ou, quando for o caso, até o consumidor final. Além disso, devem ser levados em conta os custos inerentes ao controle de qualidade tanto dos insumos quanto da linha de produção e também dos produtos acabados, além do acesso ao sistema viário para transporte da produção e, 
atualmente muito importantes, as questões de sustentabilidade e referentes à preservação do meio ambiente - algo essencial quando se considera que estas grandes companhias são extratoras de produtos naturais como base para suas atividades de produção.

Desnecessário dizer, assim sendo, que as documentações referentes a todos os fatores elencados no parágrafo acima devem, sempre, existir e estar atualizadas. Quando em ordem asseguram ao fabricante que ele atua de acordo com a legislação vigente e, ao consumidor, que está adquirindo produtos de qualidade devidamente certificados e garantidos pelos produtores. A grosso modo - e em linhas gerais - não há novidade nisso, ou seja, documentações e registros são imperativos para qualquer tipo de negócio, na vida privada, jurídica ou mesmo na pública. Contudo, nem sempre foi assim, especialmente no Brasil. Se se deixar de lado momentaneamente as indústrias siderúrgica e cimenteira abordadas nos parágrafos acima e se a atenção for voltada a um dos produtos decorrentes da combinação em proporções adequadas de aço e cimento - ou seja, o concreto armado (sem contar os demais ingredientes de sua composição) - notar-se-á que a história catalogada e construída com o valioso auxílio de documentos e registros, deixa muito a desejar.

É o que diz Vasconcelos (1985), por exemplo. Segundo ele, pouco se sabe sobre o efetivo início do uso do concreto armado no país, tampouco há documentação consistente e embasada o bastante sobre as primeiras realizações nacionais. No entanto, Macedo (2002), diverge dessa informação ao afirmar que é em 1892, pelas mãos do engenheiro civil carioca Carlos Poma, que se institui o começo da construção civil em concreto armado no Brasil. O mesmo autor explica que Poma é o primeiro brasileiro a conseguir a patente de uma das variantes do sistema construtivo do francês Joseph Monier. Por meio da Empresa de Construções Civis, em 1904 o engenheiro Poma constrói, no bairro de Copacabana (Rio de Janeiro), um conjunto de seis casas de diferentes configurações (dois sobrados, duas residências térreas e dois assobradados), utilizando-se da nova técnica por ele patenteada para uso no Brasil. Com o êxito conseguido nesse empreendimento, Poma dá prosseguimento à sua trajetória e, em Petrópolis, ergue quatro edifícios com dois pisos cada, além do reservatório d’água da cidade. Ambas as empreitadas, em concreto armado.

De acordo com Vasconcelos (1985), até os anos 1920 as construções brasileiras em concreto armado são bastante tímidas: pequenas pontes, reservatórios de água e residências unifamiliares. Freitas (2011) vai além ao citar que, mesmo assim, nesse mesmo período tanto os profissionais da construção civil quanto as empresas construtoras atuam como agentes de divulgação dessa técnica, visando o incremento de sua participação de mercado. É a partir 
de ambas as frentes - e presenciando as modificações propostas/impostas pelo uso paulatino do concreto armado que não apenas a cidade passa a se estabelecer e a adquirir feições modernas (mesmo que pontuais e tempos depois), mas começa a acontecer um novo posicionamento em relação ao leque de possibilidades gerado pelo uso dessa nova técnica construtiva.

Ainda segundo a mesma autora, um cenário propício à troca de informações serve também de estímulo aos diálogos que ocorrem entre diferentes partes do planeta, especialmente entre a Europa e as Américas do Norte e do Sul. Esses diálogos se dão ora pelas viagens de turismo ou de negócios de brasileiros ao exterior e vice-versa, ora pela consulta à já vasta bibliografia internacional disponível sobre as obras em concreto armado publicadas fora do país. Além disso, a mídia impressa divulga os arranha-céus de Nova York ou os de Chicago em veículos de apelo geral, e também os periódicos especializados e focados em públicos interessados no assunto noticiam o que de mais novo acontece nesse setor, no Brasil ou no exterior. É o que se tem, por exemplo, no anúncio de empresas estrangeiras trabalhando em território nacional: "as revistas especializadas da época demonstram que Hennebique vendia seus serviços de projetos e de cálculo estrutural no Brasil”. (MACEDO; 2003: 83). Vale ressaltar que a empresa de Hennebique não está alocada no Brasil, mas aqui oferece plantas e orçamentos para obras em concreto armado, normalmente confeccionados pelo seu escritório parisiense. Independentemente do tipo de veículo adotado, fato é que essa técnica passa a ser difundida mais largamente no país, refreando, anos mais tarde, toda e qualquer outra alternativa construtiva.

De acordo com Vasconcelos (1985), mesmo fazendo publicidade de seu trabalho em alguns dos periódicos nacionais - como no carioca Almanak Laemmert (isto é, no “Almanaque Administrativo, Mercantil e Industrial do Rio de Janeiro”) - a investida de Hennebique no Brasil é de curta duração, já que, "com a chegada da firma alemã Wayss \& Freytag, Hennebique perdeu seu mercado de trabalho, o que se evidencia pela extinção dos anúncios". (VASCONCELOS; 1985: 17) Outros processos construtivos desenvolvidos no exterior são também divulgados e adotados no Brasil. É, por exemplo, por intermédio da companhia citada acima, a alemã Wayss \& Freytag, que o método de Monier chega por aqui, já evoluído, cientificamente mais bem elaborado e relativamente diferente da patente cedida ao engenheiro Carlos Poma, mencionada anteriormente. O começo de suas atividades, essa empresa abarca apenas a fabricação de cimento, momento no qual é estabelecida com o nome de Freytag \& Heidschuch HG, Cementröhren-Fabrik, em 1875, em Frankfurt (Alemanha) pelo construtor alemão Conrad Freytag (1846 - 1921). Em 1890, a partir da associação com 
o engenheiro civil também alemão Gustav Adolf Wayss, a companhia expande seus negócios e funda a construtora Wayss \& Freytag - especializada em obras feitas em concreto armado.

Funcionando no Brasil até meados da década de 1970 e com filiais em São Paulo, Juiz de Fora, Recife e Salvador, ao chegar ao Brasil em 1924, a Wayss \& Freytag instala-se no Rio de Janeiro e passa então a adotar o nome de Companhia Constructora em Cimento Armado. Logo depois assume a denominação de Companhia Construtora Nacional S.A., sob o comando do construtor alemão Lambert Riedlinger. Para Macedo (2002), "o papel de Riedlinger é fundamental porque, através do seu contato com a Wayss \& Freytag foi viabilizada a vinda de mestres de obra ao Brasil, bem como o acesso à literatura interna da construtora alemã, incorporando ao cálculo, as fundamentais pesquisas de Emil Mörsch" (MACEDO; 2002: 83). Futuramente, a Companhia Construtora Nacional S.A. participará da mega-operação montada para erguer Brasília e será responsável, dentre outras obras da nova Capital Federal, pela construção do Palácio do Congresso Nacional.

A vinda de mão-de-obra técnica internacional ao Brasil, como mencionado no trecho acima, ajuda a preencher a lacuna formada pela falta de profissionais adequadamente capacitados em território nacional, uma vez que o uso do concreto armado no país é algo relativamente novo, que requer tempo de adaptação e de assimilação de toda as suas características e funcionalidades pelos trabalhadores da área. Assim, a transmissão de conhecimentos práticos já bastante arraigados fora do Brasil conforma-se como uma oportunidade que os profissionais locais têm de absorver esses conhecimentos e de transformá-los em trabalhos futuros, autônomos, portanto, sem a dependência de seus mentores internacionais. E esse fato se aplica tanto às atividades de campo quanto àquelas feitas dentro das empresas, como os cálculos estruturais ou os dimensionamentos de peças em concreto armado. Para esta situação, o contato e o aprendizado com base nos registros do diretor da própria Wayss \& Freytag, Emil Mörsch, é essencial (sem contar os seus livros teóricos e de cálculos voltados à engenharia civil e publicados em língua portuguesa).

Vasconcelos (1985) explica que mesmo que de grande valor, não é duradoura a participação de técnicos estrangeiros na formação de mão-de-obra mais bem capacitada na elaboração de projetos feitos no Brasil, para o Brasil e por cérebros brasileiros. Segundo o autor,

a formação de especialistas nacionais, propiciada pela firma alemã, logo liquidaria com a participação de técnicos estrangeiros no setor de projetos. Essa formação constituiu uma das grandes razões do rápido progresso no Brasil no campo do concreto armado, mais do que nos Estados Unidos [...]. Naturalmente houve algumas exceções que possibilitaram, mesmo após a vinda da Wayss \& Freytag, 
a participação de técnicos estrangeiros em projetos, podendo citar-se o projeto do cálculo estrutural (1929) da estátua do Cristo Redentor no Corcovado, feito em Paris pelo Bureau d'Études L. Pelnard, Considère \& Caquot [...]. Desde 1924, entretanto, quase todos os cálculos de concreto são feitos no Brasil, destacando o nome de Emílio Henrique Baumgart como o primeiro brasileiro de destaque internacional nessa atividade. (VASCONCELOS; 1985: 18)

Vale ressaltar que o setor de projetos citado na passagem acima refere-se àquele existente na própria Wayss \& Freytag, portanto, sua participação no treinamento de especialistas brasileiros, ainda que relevante, é concentrada e fruto de um interesse próprio, uma vez que ela precisa qualificar sua própria mão-de-obra para lidar com os projetos que surgem com cada vez mais frequência. Ao pensar em um cenário mais abrangente, há que se considerar, portanto, a propagação dos cursos de engenharia civil e de arquitetura no Brasil.

Voltando no tempo, Florençano e Abud (2002) apontam que a Academia Real Militar do Rio de Janeiro (de 1810) posteriormente denominada de Escola de Engenharia da Universidade do Rio de Janeiro - é a primeira destinada a oferecer um curso direcionado às construções, formando especialistas militares em fortificações. Já o final do século 19 traz a abertura de outras instituições de ensino superior com graduação em diferentes engenharias, tais como: “ $a$ Escola de Minas e Metalurgia de Ouro Preto (1875), a Escola Politécnica de São Paulo (1894) e o Mackenzie College (1897), hoje Escola de Engenharia da Universidade Mackenzie" (FLORENÇANO e ABUD; 2002: 3). Já no que se refere ao ensino de arquitetura no Brasil, Segawa (2010) mostra que

\begin{abstract}
data de 1816 a vinda de um grupo de artistas franceses para a corte do Rio de Janeiro, ainda sob a regência do príncipe D. João (1767 - 1826 - futuro D. João VI, rei de Portugal), para introduzir no país um conhecimento artístico de gosto neoclássico. Mas é somente em 1827 que começa a funcionar regularmente a Academia de Belas Artes, incluindo em seu currículo a arquitetura, curso organizado por Auguste Henri Victor Grandjean de Montigny (1776 - 1890), arquiteto francês de algum prestígio em seu país de origem, autor de um álbum de levantamentos arquitetônicos, Architecture toscane, ou palais, maisons, et outres édifices de la Toscane, publicado entre 1806 e 1813. (SEGAWA; 2010: 30)
\end{abstract}

Derivam dessa primeira iniciativa, tanto as Escolas de Belas Artes presentes no Rio de Janeiro, na Bahia e em Pernambuco, quanto as instituições que formam engenheiros-arquitetos, a partir de 1899, como a Escola Politécnica de São Paulo. A graduação em arquitetura propriamente dita acontece no Brasil somente a partir dos anos 1940, dentre as quais são abertas:

a Escola de Arquitetura da Universidade de Minas Gerais (1944), a Faculdade Nacional de Arquitetura do Rio de Janeiro, separada em 1946 da Escola Nacional de Belas Artes e, em São Paulo, sucessivamente, a Faculdade de Arquitetura Mackenzie (1947) e a Faculdade de Arquitetura e Urbanismo da Universidade de São Paulo (1948), desmembradas, respectivamente, da Escola de Engenharia Mackenzie e da Escola Politécnica. (FLORENÇANO e ABUD; 2002: 3) 
Antes da década de 1940, assim sendo, é a engenharia civil o grande destaque nas obras públicas ou privadas pelo país, obras essas das mais variadas: de pontes a edifícios residenciais, de cinemas a prédios comerciais. Nesse panorama em constante efervescência, merece destaque o engenheiro civil Emílio Baumgart (1890 - 1943), citado por Vasconcelos (1985) parágrafos acima e peça-chave no cenário nacional da construção civil durante a primeira metade dos anos 1900. Desde meados da década de 1910, quando ainda é estudante de engenharia civil na Escola Politécnica da Universidade de São Paulo, o catarinense Baumgart trabalha em empresas de construção civil. Começa sua carreira em um estágio na construtora de Lambert Riedlinger, engenheiro alemão sediado no Rio de Janeiro desde 1911 (e futuramente contratado como diretor técnico da Wayss \& Freytag e como presidente da Companhia Constructora em Cimento Armado, como já citado). Depois de formado, Baumgart é levado pelo mesmo Riedlinger para a Wayss \& Freytag, empresa na qual tem a chance de aprimorar os seus conhecimentos de cálculo estrutural em concreto armado e de profissionalizar o seu talento inato para a área de exatas até o ano de 1923, quando resolve abrir seu próprio escritório de cálculo estrutural.

A trajetória deste engenheiro catarinense é pautada por projetos que contribuem para a formação de uma engenharia civil de qualidade no Brasil, admirada, respeitada e referenciada por especialistas de vários países, inclusive dos Estados Unidos e da Alemanha, berço da técnica do concreto armado que se conhece hoje. Além disso, Baumgart é por muitos considerado como o pioneiro do concreto no país, pois tanto participa ativamente da aplicação da tecnologia alemã por aqui, quanto é responsável por desdobrá-la (e por vezes superá-la) em várias obras importantes em território nacional.

Jermann (1944) destaca alguns dos projetos que têm a participação direta ou indireta do engenheiro catarinense, tais como: em Recife: a Ponte Maurício de Nassau (de 1917) [Figura 3.37] e os Armazéns do Açúcar (de 1938); em Santa Catarina: as pontes Dos Arcos (de 1926) [Figura 3.38], do Herval (de 1930); e sobre o Rio Pelotas (de 1935); no Triângulo Mineiro, a ponte sobre o Rio Paraíba (de 1938); em Belo Horizonte: o Edifício Santa Teresa (de 1929) e o Cinema Teatro Brasil (de 1932); em Porto Alegre: o Edifício Salic (de 1940); em Belém do Pará: o Hangar da PANAM (de 1930); em São Paulo: o Edifício Banco do Brasil - na Rua São Bento (de 1942) [Figura 3.39]; no Rio de Janeiro: o Estádio do Fluminense (de 1922), os edifícios Armando Guinle (de 1923) e “A Noite” (de 1930); os hotéis Glória (de 1922) e Copacabana Palace (de 1923) [Figura 3.40], os cinemas Capitólio (de 1925) e Roxy (de 1936), o Hangar no Campo dos Afonsos (de 1928); 
as pontes Victor Konder (de 1927) e Das Garças (de 1929); o Viaduto Cascadura (de 1930); os teatros São Pedro (de 1930) e João Caetano (de 1930).

O engenheiro civil Emílio Baumgart coordena também os cálculos estruturais baseados em soluções que ele mesmo cria e incorpora à nova sede para o Ministério da Educação e Saúde - MES (concluído em 1945), no Rio de Janeiro. Este edifício, fruto do projeto arquitetônico desenvolvido pela equipe chefiada por Lucio Costa (na qual está presente o então novato Oscar Niemeyer), e sob a consultoria do mestre franco-suíço Le Corbusier, torna-se rapidamente um símbolo da arquitetura moderna brasileira e mundial. Por isso, e por tantos outros fatores, esta obra merece que se dediquem a ela, dentro em pouco, algumas páginas deste estudo.

Já a partir da década de 1950, o Brasil vivencia um período promissor no desenvolvimento de sua indústria. O setor da construção civil consolida-se e passa a produzir com maior eficiência itens como: cimentos e argamassas, aços e derivados de siderurgia, alumínios e similares, vidros e plásticos, equipamentos de instalações, elevadores, dentre outros. Nesse mesmo momento estabelecem-se normas das mais variadas e controles de qualidade mais profissionalizados: a Associação Brasileira de Normas Técnicas (ABNT), reconhecida nacionalmente desde 1940, passa então a atuar na avaliação da conformidade e a dispor de programas voltados à certificação de produtos, de sistemas, de pessoas e de rotulagem ambiental. A partir dos anos 1960, portanto, as bases da indústria nacional da construção estão, de uma vez por todas, lançadas e em franco processo de desenvolvimento.

Não é possível esquecer da participação ativa do Estado na consolidação das bases da indústria nacional da construção civil. Conforme Silva (2012), é no Estado que se deposita a responsabilidade pela gestão dos elementos tecnológicos e pela capacitação técnica da mão-de-obra que, juntas, atuam no enfrentamento dos desafios gerados por um país em crescimento. Insere-se assim, nesse contexto, o tratamento especial dado ao trio de fatores: indústria de materiais de construção, companhias construtoras e mão-de-obra de construção.

Grandi (1985) aponta que é logo após a Segunda Grande Guerra que as transformações vivenciadas com o governo de Getúlio Vargas efetivamente surtem efeito no trio de variáveis mencionado no parágrafo anterior: se em um primeiro momento (no período de 1930 a 1945) há a formação das bases que alicerçam o desenvolvimento, logo a seguir (entre 1945 e 1955) essas mesmas bases são postas à prova por meio de obras de grande porte para as quais o Estado atua como o principal órgão fomentador (ora pela criação de programas de incentivo à construção, ora com a efetuação de aportes financeiros de qualidade). 
O Estado, logo, tem papel preponderante na solidificação do segmento da construção civil brasileira. Sobre esse fato, vale a pena citar Silva (2012), que também explica quais elementos estão envolvidos tanto no que nomeia de "primeiro período" (ou seja, o da formação das bases), quanto no denominado “segundo período" (isto é, na fase de consolidação):

No primeiro período, o uso do sistema do concreto armado teve sua hegemonia consolidada a partir da conjunção de eventos conhecidos. $O$ crescimento das construções em função do aumento da ocupação urbana, com a execução de edifícios altos de concreto armado, pavimentação de estradas e execução de pontes rodoviárias. O aprimoramento do conhecimento sobre a técnica construtiva, que teve a relevante atuação de empresas estrangeiras, o aporte de firmas de projeto e os avanços no ensino da engenharia. O suporte para evolução tecnológica, com apoio e participação do Estado, a partir do desenvolvimento sistemático de ensaios de materiais nos órgãos de pesquisa e da criação da normalização técnica. Por fim, o incremento da produção nacional dos materiais básicos, de cimento e aço, com destaque para o favorecimento do Estado à implantação de fábricas de cimento a partir de 1924, quando o país passou de importador a fabricante do material.

No segundo período, as obras demandadas pelo Estado tiveram repercussão direta na acumulação de capital, no aparelhamento de construtoras nacionais e no domínio tecnológico por parte destes agentes. Por meio dos trabalhos demandados - em particular na construção pesada, com destaque para construção de estradas, hidroelétricas, indústrias siderúrgicas -, o Estado agiu como propulsor da acumulação de capital das empresas privadas, que se beneficiaram economicamente e se equiparam no período. Outro aspecto da ação estatal foi o de promover a transmissão de conhecimento tecnológico, principalmente nos contratos que congregaram empresas estrangeiras com empresas nacionais, em virtude dos consórcios exigidos nas concorrências, não só por questões tecnológicas, mas também por questões políticas. Este conjunto de fatores permitiu o crescimento das empreiteiras - em especial de São Paulo, Minas Gerais, Rio de Janeiro e Rio Grande do Sul - e a existência cada vez maior de um mercado de empresas construtoras nacionais. De uma atuação preponderante dominada por empresas estrangeiras no período anterior, a transição define o novo contexto de convivência com o crescimento e com a parceria de empresas nacionais. (SILVA; 2012: 110111)

Por fim, a partir do momento em que o segmento da construção civil atravessa uma fase de profundas transformações, nas quais os avanços materiais, técnicos e tecnológicos são evidentes, paralelamente, porém, a mãode-obra de produção sente os reflexos negativos desse novo cenário. Isso significa dizer que, de acordo com Grandi (1985), se anteriormente há a presença maciça de mão-de-obra qualificada atuando no mercado brasileiro (proveniente, em grande parte, dos fluxos imigratórios que chegam ao Brasil entre o final do século 19 e as primeiras décadas do século 20), com o passar do tempo, esses mesmos trabalhadores são gradativamente absorvidos pelo crescimento das indústrias. Suas atividades que até então são personalizadas e calcadas nos conhecimentos adquiridos nas escolas técnicas de seus países de origem, passam a ser pulverizadas em um emaranhado de 
trabalhadores das empresas onde estão alocados, ou seja, passa a prevalecer a despersonalização das funções, gerando, como consequência direta "uma mão-de-obra proveniente da falta de opção do trabalho, cuja instrução caracteriza-se, sobretudo, pelo ensino da técnica repassado no próprio canteiro". (GRANDI; 1985: 211) 


\section{CONCRETO ARMADO: EXEMPLOS DO AVANÇO DA CONSTRUÇÃO CIVIL BRASILEIRA}

Emílio Henrique Baumgart:

Ponte Maurício de Nassau [3.37]; Ponte dos Arcos em Indaial [3.38];

Edifício Banco do Brasil [3.39] e Copacabana Palace [3.40]

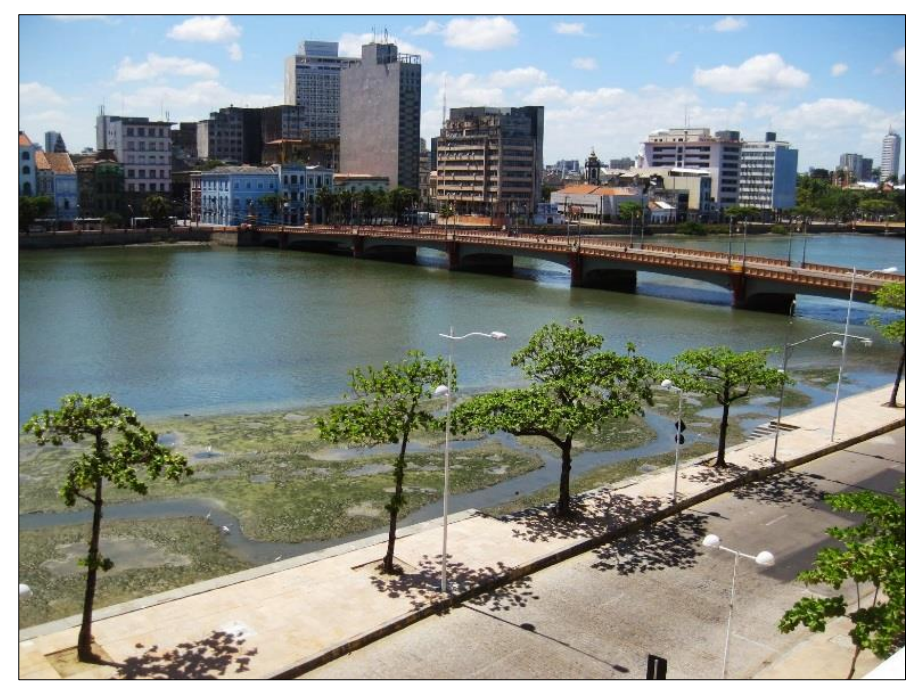

[3.37] A ponte, em concreto armado, apresenta 160,0 metros de extensão e 16,0 metros de largura. Sobre cada um dos sete vãos encontram-se cinco arcos de 30,0 metros de comprimento cada e dois de 3,0 metros (estes, nas extremidades junto às margens).

[3.39] A partir da Ponte Santa Ifigênia, no centro da capital paulista, avista-se o edifício do Banco do Brasil (o mais alto), ao lado do Prédio Martinelli (à direita) e do Edifício Altino Arantes (à esquerda). Este é o último edifício projetado por Emílio Baumgart.

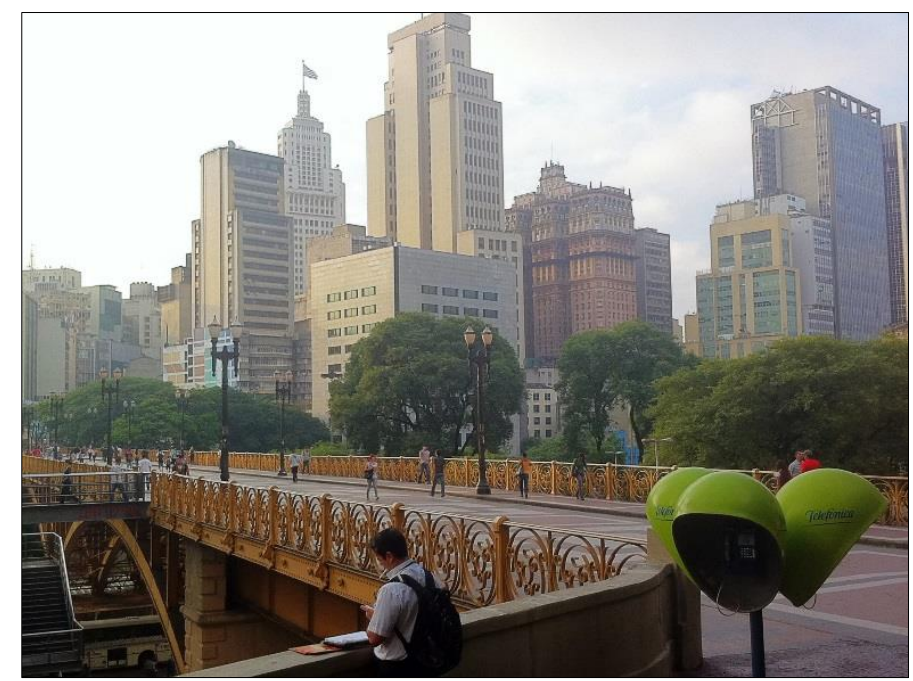

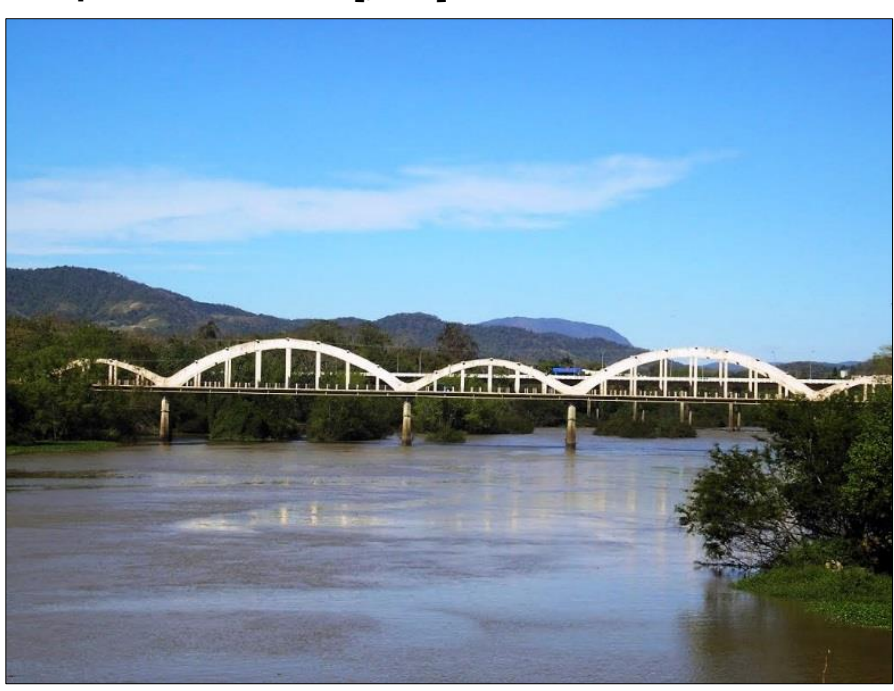

[3.38] Primeira ponte em concreto armado erguida sobre o rio ItajaíAçú, em Indaial (SC). Possui 175,0 metros de extensão e 6,0 metros de largura, sendo formada por uma sucessão de arcos abatidos nos quais brotam elementos de sustentação do tabuleiro.

[3.40] O arquiteto Joseph Gire elabora este projeto (calculado por Emílio Baumgart) a partir de referências internacionais. Servem de inspiração para ele, o Hotel Negresco (em Nice) e o Hotel Carlton (em Cannes), ambos situados na Riviera Francesa.

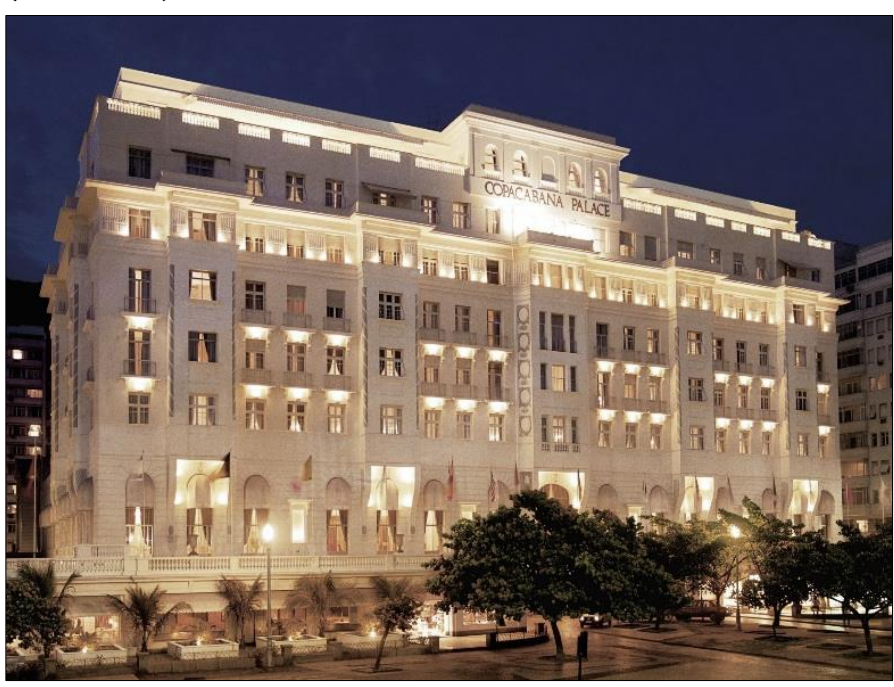


OSCAR NIEMEYER: RAZÃO E LIBERDADE NA ARQUITETURA MODERNA BRASILEIRA 


\section{Explicações Necessárias}

Oscar Niemeyer é tido como um dos mais importantes arquitetos de todos os tempos. É reconhecido como um dos precursores da modernidade arquitetônica nacional, ao lado de outros nomes de peso como Lucio Costa, Jorge Moreira, Affonso Eduardo Reidy e os irmãos Marcelo, Milton e Maurício Roberto, por exemplo. O conjunto das obras desses profissionais é o responsável, aponta Zein (2005), pelo surgimento de uma dita "escola moderna brasileira" (sobretudo ao longo das décadas de 1930 a 1950) que conquista espaço no Brasil e fora dele em função, por um lado, do alto padrão dos projetos propostos e, por outro, da ampla capacidade de apresentar respostas genuinamente brasileiras a questões universais relativas aos ideais modernos.

Entre as décadas de 1930 e 1940 colaboram para atiçar o interesse nacional pela arquitetura moderna de Oscar Niemeyer três obras em especial: o Ministério da Educação e Saúde (MES), o Pavilhão do Brasil na Feira Internacional de Nova York de 1939 e o Conjunto Arquitetônico da Lagoa da Pampulha. Percebe-se, ao longo do desenvolvimento e da construção desses três empreendimentos, que Oscar Niemeyer passa da condição de pálido discípulo de Costa à de um profissional empreendedor e propositivo, que assume para si responsabilidades importantes e que tem participação ativa nas inúmeras soluções arquitetônicas adotadas.

Se no Ministério da Educação e Saúde ele é um membro inicialmente sem expressão de uma equipe chefiada por Lucio Costa, o contato e o aprendizado com o mestre franco-suíço Le Corbusier desperta nele novo interesse pela arquitetura. Tanto é fato que o resultado reconhecidamente positivo para o projeto seguinte, o Pavilhão brasileiro na feira de 1939 se deve, em parte, às decisões projetuais tomadas pelo próprio Niemeyer. Já em Pampulha o arquiteto carioca coloca em prática, por conta própria, uma releitura das investigações arquitetônicas corbusianas, desdobrando-as e reconfigurando-as, até atingir resultados repletos de superlativos.

Talento e inventividade são características inatas de Oscar Niemeyer, porém, não suficientes para justificar a amplitude de suas realizações. A troca de informações com diversas áreas do conhecimento, dentre elas as técnicas e as exatas, é fundamental para o alcance dos resultados por ele esperados. A engenharia civil, parte integrante desse grupo de parceiros - ou melhor, de cúmplices - faz sua contribuição à arquitetura niemeyeriana ao possibilitar a materialização da imaginação do arquiteto. $O$ esqueleto estrutural, tal como pensado por Niemeyer, ao favorecer a 
construção de espaços amplos, simboliza e idealiza liberdade e democracia. O concreto armado, por sua vez, tornase um recurso artístico e estético, que permite ao arquiteto expressar-se em toda sua liberdade projetual: plasticidade e maleabilidade fazem desta a técnica preferida de Niemeyer.

No entender de Segre (2009), porém, não é por acaso que Oscar Niemeyer escolhe o concreto armado como material básico de seu fazer arquitetônico. Vários são os fatores que contribuem para tal escolha e dentre eles podem-se mencionar a grande disponibilidade aliada ao custo reduzido do cimento no país, além de uma tradição cultivada pelos engenheiros brasileiros de constantemente questionar as austeras normas estruturais, adotadas no Brasil mas advindas da Europa e dos Estados Unidos. As inovações admitidas e estimuladas por tais engenheiros brasileiros dentre os quais Emílio Baumgart em um primeiro momento, e Joaquim Cardozo logo a seguir - produzem resultados técnicos jamais pensados.

Ao longo da formação do repertório niemeyeriano identifica-se um aproveitamento constante das possibilidades geradas pelo uso do concreto armado, resultando em obras fundamentalmente autorais cujas formas são cada vez mais livres, os vãos são cada vez mais ousados e as propostas, consequentemente, cada vez mais inovadoras. O dom criativo de Niemeyer - que a partir de volumetrias e espacialidades básicas consegue conceber arquiteturas notáveis e dotadas de universalidade - deve-se igualmente e em grande parte, à sua capacidade de não separar - ou melhor, de entender como coisa única - forma e estrutura, resolvendo-as ambas concomitantemente (e não sequencialmente) à medida que um novo projeto é pensado. Isso significa dizer, no entender de Mahfuz (2007), que em suas obras não é fácil distinguir "a estrutura resistente da sua estrutura formal”. Quem sabe esta seja uma justificativa para o fato de que não exista uma diferença expressiva nos elementos principais das edificações contempladas nos croquis iniciais e aqueles presentes nas arquiteturas quando finalizadas, enfatiza o mesmo autor. Como oportunidade de analisar alguns projetos do percurso desse arquiteto caioca, propõe-se a partir de agora que o olhar seja direcionado à relação dotada de permeabilidade entre engenharia e arquitetura, técnica e forma, a fim de refletir sobre os graus de contribuição e de dependência - se é que existem - entre duas disciplinas tão distintas, porém, tão complementares entre si. 
No período compreendido entre 1937 e 1945, o então presidente da República, Getúlio Vargas, comanda o regime político batizado de "Estado Novo". Caracterizado por uma premissa de centralização do poder, nacionalismo e anticomunismo, além de ser marcado por um perfil autoritário e austero, o alvo inicial do governo é o de promover e em seguida aprofundar a reestruturação do Estado firmada na profissionalização do serviço público, na adoção de medidas ampliadas de burocratização estatal, na valorização e proteção do indivíduo e do trabalhador, na regeneração e modernização da sociedade, no desenvolvimento do interior do Brasil por meio de territórios federais nas fronteiras, na promoção de manifestações cívicas e nacionalistas, além de ações guiadas por fortes apelos patrióticos na impressa e nos livros didáticos adotados nas escolas, dentre outras iniciativas governamentais que, em conjunto, visam promover a construção de um "novo homem brasileiro".

Pela primeira vez na história brasileira delineia-se uma preocupação efetiva e autêntica na busca por uma identidade nacional que seja representada clara e adequadamente perante seu povo, sua indústria e seu patrimônio - sobretudo dentro do país, mas também internacionalmente. Por meio do importante papel assumido pelo recém criado Instituto do Patrimônio Histórico e Artístico Nacional (SPHAN) - especialmente nas pessoas de Mário de Andrade (responsável pela elaboração de um parecer sobre a criação de um instituto de proteção ao patrimônio a partir do qual nasceria o próprio SPHAN) e do diretor da instituição quando já em funcionamento, Rodrigo Mello Franco de Andrade - tem-se a oportunidade de alargar o pensamento relativo à "antropofagia cultural”, cunhado na Semana de Arte Moderna de 1922, em São Paulo, na qual é admitida como verdadeira a cultura de um povo quando nascida e enraizada à sua própria terra. Trata-se de uma resposta à dominação cultural, política e econômica do Brasil pelos estrangeiros, especialmente promovida pelas tradições francesa, alemã e americana, admitidas naquele momento como as grandes referências culturais suficientemente dignas de serem assimiladas dentro do Brasil.

Por conta dessa necessidade de afirmação de uma identidade nacional vista e reconhecida por sua população e que nela deve incitar o desejo de pertencimento ao território brasileiro, o governo Vargas aproveita o período de pujança econômica do país vivenciado principalmente ao longo da década de 1930 e investe maciçamente em ações que possam "imprimir sua marca nas formas da capital federal, e elege como uma de suas prioridades a construção de palácios para abrigar ministérios e órgãos públicos da nova administração". (CAVALCANTI; 2006: 12) 
A partir daí e de forma bastante incisiva, reflexos concretos das mudanças são sentidos na cidade do Rio de Janeiro (então Capital Federal), por vezes materializados em intervenções de grande envergadura realizadas em diferentes pontos da cidade. Busca-se nas adequações espaciais e urbanísticas, possibilidades de simbolização dos esforços renovadores direcionados à conquista de um futuro mais promissor ao país e a seu povo.

Dentre as obras de porte que recebem o aval para construção estão as novas sedes dos ministérios da Fazenda, do Trabalho e da Educação e Saúde. Quando concluídos, somente o último é proclamado como o primeiro exemplo canônico da arquitetura moderna brasileira, ao passo que ambos os outros prédios ministeriais, até hoje, permanecem palidamente estudados ou compreendidos como concretizações arquitetônicas significativas, provavelmente ofuscados pelo sucesso obtido pelo próprio MES. Desvenda-se, durante o Estado Novo, a oportunidade de a arquitetura brasileira participar ativamente de um episódio fundamental da história do Brasil, ao contribuir com projetos de edificações que materializem o desejo pelo novo e pelo moderno. Entre a opção por arquiteturas neocoloniais, acadêmicas ou modernas como representantes desse mesmo momento crucial da história nacional, Cavalcanti (2006) acredita que

os arquitetos modernos brasileiros conquistam a posição de dominantes graças a vários movimentos que comprovam a sua superioridade em face dos competidores acadêmicos e neocoloniais nas duas extremidades do campo: a popular e a erudita. A eliminação de ornatos, a estrutura aparente, a planta "livre", a ideia de protótipo e a possibilidade de reprodução industrial muito mais que opções formais, eram apresentadas como justificativas éticas do movimento moderno. Não só as casas do rico e do pobre seriam igualmente despojadas, como haveria a possibilidade de, com esse despojamento, produzir casas operárias em larga escala. Gostar ou não das formas modernas deixa de ser um direcionamento estilístico para se tornar uma necessidade política e social, como frisava "corbusianamente" Lucio Costa. (CAVALCANTI; 2006: 13)

A gestão do Ministério da Educação e Saúde é assumida por Gustavo Capanema em 1934, que logo a seguir adquire também a responsabilidade por erguer tanto a própria sede (na Esplanada do Castelo, no Centro), quanto a Cidade Universitária do Brasil (em Quinta da Boa Vista), ambas a serem executadas no Rio de Janeiro. Entre uma obra e outra, a Cidade Universitária é tomada pelo ministro - ao menos inicialmente - como a mais importante, uma vez que, de acordo com Segawa (2010), trata-se da primeira obra no gênero no país e que, quando pronta, espera-se, sirva como ponto de referência para a arquitetura brasileira ${ }^{8}$.

\footnotetext{
${ }^{8}$ A Cidade Universitária do Brasil (CUB), jamais construída, demandou grandes esforços para que saísse do papel. O arquiteto italiano Marcello Piacentini, convidado pelo ministro Capanema para desenvolver o projeto nos moldes da Cidade Universitária de Roma, não consegue autorização para trabalhar no Brasil em função dos trâmites legais para estrangeiros prestarem serviços no país. Também foi descartado o
} 
Recamán (1996) cita que surge já nessa ocasião certo desconforto no campo arquitetônico, que precisa ser revigorado em prol de simbolizar a renovação política e a ampla modernização em andamento no país, necessidades agenciadas pelo estadonovismo. "Com as dificuldades crescentes em definir um programa viável para a Universidade do Brasil, muito mais complexo e disputado que o novo edifício, cada vez mais sua nova sede concentrava a criação de uma imagemsímbolo da administração Capanema". (RECAMÁN; 1996: 71)

Em abril de 1935 é aberto um concurso para o novo quartel-general do MES, cujo resultado é divulgado em outubro do mesmo ano. Os vencedores, Archimedes Memória e Francisque Cuchet, apresentam, de acordo com Segawa (2010), um projeto que se sobressai pela ornamentação marajoara. Porém, no entender de Capanema, ainda que eleita pelo júri, esta proposta não responde satisfatoriamente às questões modernizantes tão amplamente difundidas pelo Estado Novo. O ministro resolve então assumir para si o desafio de premiar o projeto ganhador, mas nunca construílo. Vale-se, explica ainda Segawa (2010), do arbítrio pessoal e despreza o resultado oficial do concurso, convocando Lucio Costa para desenhar o novo MES.

E assim acontece. Para compor sua equipe, Costa convida os arquitetos participantes desse mesmo concurso mas que, por motivos diversos, não saem dele vencedores. Sua ideia é ter junto a si os autores dos anteprojetos concebidos com base nos preceitos modernos, dadas a familiaridade e a identificação com o assunto e conhecimento prévio das questões relativas às especificidades do edifício (como anteriormente descritas no Edital), o que facilita em demasia os esforços de entrosamento com o tema em questão e seus desdobramentos futuros. Além disso, esta é uma atitude de Lucio Costa que tenta não só valorizar os esforços individuais dos concorrentes, mas também potencializá-los quando atuando em conjunto sob a égide da arquitetura moderna.

Carlos Leão, Affonso Eduardo Reidy, Jorge Machado Moreira, Ernani Vasconcelos (atuando como auxiliar de Moreira) e Oscar Niemeyer (como assistente de Costa) integram a equipe que desenvolve o projeto final do MES. Além deles, Le Corbusier (em sua segunda passagem pelo Brasil) assume o papel de consultor da equipe e atua sobre ela indiretamente. No entender do mestre franco-suíço, é fundamental para o "êxito da empreitada de Capanema" (QUERIOZ; 2007: 51) que a construção seja transferida para um novo endereço que ressalte as perspectivas

projeto de Le Corbusier, possivelmente por identificar-se diretamente com os princípios modernos - o que ia contra as crenças arquitetônicas da comissão julgadora. Por fim, "com o ingresso do Brasil na guerra contra o Eixo, nada resultou desses esforços desenvolvidos durante o Estado Novo, com a queda de Vargas em 1945". (SEGAWA; 2010: 90) 
desimpedidas e a valorização do edifício, como consequência. Chega a propor uma nova localização à beira do mar, a qual torna-se impraticável por fatores burocráticos. Ao final de sua curta permanência no país de pouco mais de um mês, sugere uma versão projetual de sua própria autoria, calcada em seus princípios arquitetônicos estudados à época e destinada ao terreno original, já devidamente cedido e legalizado pela prefeitura carioca. Sobre esta última versão corbusiana para o MES, Costa e equipe debruçam-se para desenvolver o projeto definitivo, aceitando-a como principal fonte de inspiração a partir da qual a versão final é, efetivamente, erguida.

Idealizada e construída entre 1935 e 1945, a obra inaugural da arquitetura moderna no Brasil [Figuras 4.1. - 4.14] resulta em uma "solução com personalidade própria, embora com evidentes citações dos esboços e das ideias de Le Corbusier" (SEGAWA; 2010: 91). Essa "personalidade própria" mencionada por Segawa refere-se a um resultado edificado que traz diversas inspirações nos estudos de Le Corbusier, porém, as traduz e as adapta a uma nova situação e a uma nova realidade local e contextual, daí derivando uma obra simbólica e emblemática sem precedentes no Brasil ou fora dele.

Recamán (1996) explica que a sintaxe tropical atribuída à nova sede do MES não pode ser apreendida unicamente como uma aplicação direta dos ensinamentos corbusianos, pois a mutação para uma linguagem predominantemente nacional somente é aqui alcançada após a participação e a opinião ativas da experiente equipe chefiada por Lucio Costa, e em decorrência da consultoria e das teorias de Le Corbusier - ou seja, uma há uma confluência de fatores.

De acordo com o mesmo autor, é na etapa de finalização e de detalhamento do projeto, iniciada após a partida do mestre franco-suíço, que o "abrasileiramento" das ideias e dos conceitos absorvidos pela equipe de arquitetos é colocada em campo. Assim sendo, a "arquitetura corbusiana deixa de ser o resultado lógico do desenvolvimento de uma simplicidade e racionalidade próprios de uma tradição construtiva - como a definia Lucio Costa - e passa a exigir um amaneiramento que necessita de muito mais elaborações formais que as discretas alterações no projeto básico do MES" (RECAMÁN; 1996: 127)

Há, no edifício erigido, claras referências aos "Cinco Pontos da Nova Arquitetura" - já aqui citados anteriormente - e a presença de espaços públicos no interior da quadra, o que estimula a circulação de pedestres de maneira mais livre e desimpedida. Para Espallargas Gimenez (2004), é como se os espaços urbanos representados pelas ruas e pelas calçadas das redondezas fossem convidados a adentrar o lote, demolindo as fronteiras normalmente tão presentes entre ambos - fronteiras essas potencializadas pelas então vigentes diretrizes construtivas do plano de remodelação urbana da cidade do Rio de Janeiro, popularmente conhecido como “Plano Agache”, que exigem a construção de 
edificações sempre alinhadas aos perímetros externos dos lotes. O resultado, como se intui, sufoca as ruas por meio de extensos corredores de altos edifícios quase que alinhados às calçadas.

Intencionalmente isolado no terreno [Figura 4.1], o edifício principal do MES não impõe obstrução aos pedestres, uma vez que a colunata monumental ampara-o no ar, aproximadamente a dez metros de altura. Com isso, descortina-se por entre as árvores uma nova paisagem tanto no local de implantação quanto na cidade. Segawa (2010) assume que o posicionamento do MES praticamente no centro do quarteirão subverte o Plano Agache ao opor-se às demais quadras fechadas no entorno. Esse fato atribui ao conjunto edificado do Ministério certo ar de monumentalidade "resultante do contraste da imponência da escala da obra e dos vazios criados no distanciamento entre o volume prismático do MES com os edifícios adjacentes, muros contínuos compulsoriamente estabelecidos pelo Plano Agache". (SEGAWA; 2010: 91)

Os pilares [Figura 4.2], por sua vez, não mais apresentam atributos exclusivamente estruturais de sustentação, pois passam a ser vistos de outra maneira, compondo paisagens e unificando espaços. Reflexo disso está na possibilidade de cruzar da praça frontal à posterior livremente, sem bloqueios [Figuras 4.3 - 4.4]. "Uma encarnação memorável dos croquis corbusianos referidos à cidade moderna. O que num quadro correspondia à dissolução do fundo e da figura em relações formais, na cidade poderia corresponder à máxima integridade formal dos vazios e à equiparação entre frente $e$ fundo do terreno". (ESPALLARGAS GIMENEZ; 2004: 34)

Do ponto de vista estrutural, esta obra propõe uma releitura dos preceitos teóricos de uniformização dos espaços definidos sobretudo pelos princípios construtivos de Le Corbusier, elaborados no primeiro quartel dos anos 1900 - o conhecido "Sistema Domino" [Figura 3.33] - e pelo Estilo Internacional, os quais corroboram para a ênfase nas estruturas independentes. No texto de 1978 "Manierismo y Arquitectura Moderna y Otros Ensayos", Colin Rowe pondera sobre a relação entre forma e arquitetura moderna, em particular sobre o espaço interno presente no Estilo Internacional. Segundo ele,

[...] em geral, o espaço do Estilo Internacional era um sistema que tendia a proibir que se vissem as vigas, e o mais relevante não era que o telhado fosse plano, mas sim que o fosse o teto interior, e que tetos e pisos apresentassem planos ininterruptos. Esta restrição parece ser deduzida do conceito de liberdade da coluna, já que a coluna livre dificilmente poderia assumir uma relação explícita com as vigas que sobre ela pudessem descansar sem acarretar uma compartimentação do espaço e, por conseguinte, certa violação da liberdade do plano. Assim, a presença visível das vigas teria que acabar prescrevendo posições fixas para as divisões e, dado que estas mesmas posições fixas deveriam 
alinhar-se com as colunas, resultava essencial que, se se queria afirmar com certa eloquência a independência de colunas e divisões, a parte interior do telhado, o teto, seria expressa como uma superfície horizontal ininterrupta. (ROWE; 1978: 140 - tradução nossa)

É importante frisar que a flexibilidade conseguida por meio da solução estrutural do tipo Domino, contudo e como aponta Recamán, "permitirá, apesar da estrutura ortogonal rigorosa, a exploração plástica dos volumes -, e sua expansibilidade, horizontal, num primeiro momento, e vertical, a partir de um plano para a cidade de três milhões de habitantes, de 1922 [proposto por Le Corbusier]". (RECAMÁN; 1996: 91). Isso significa dizer que - continua o autor em verdade, ainda que certamente muitos os benefícios construtivos gerados a partir do "Sistema Domino", inicialmente ele é pensado, como visto anteriormente, para resolver questões urbanas voltadas à reconstrução das cidades europeias prejudicadas pela Grande Guerra. Vale-se, portanto, da união da expertise no uso do concreto armado (já adotado naquela época, porém de forma pontual e escamoteado pelos revestimentos ornamentados do final dos anos 1900), e a concepção de espacialidades mais amplas, como uma quadra ou um bairro completo.

Os princípios do "Sistema Domino" e do "Estilo Internacional" são materializados e adaptados no MES mediante o papel fundamental do engenheiro calculista da obra, Emílio Henrique Baumgart. Vasconcelos (1985) explica que o engenheiro catarinense vê-se motivado a inovar na aplicação das técnicas do concreto armado para que as novas ideias modernas enfatizadas no projeto da equipe dos seis arquitetos brasileiros possam ser não só mantidas, mas ressaltadas quando da obra finalizada. Uma vez que as raras normas de construção vigentes na década de 1930 não atendem às solicitações estruturais necessárias a esta obra, Baumgart vê-se obrigado a driblá-las e a tomar para si a livre concepção e o livre desenvolvimento dos cálculos e das soluções estruturais, sempre baseado em sua própria experiência profissional e em sua capacidade empreendedora. Torna-se, assim, o único responsável técnico gabaritado para um desfecho construtivo do MES alinhado à proposta moderna arquitetônica.

As principais variáveis estruturais que exigem uma dedicação mais incisiva de Baumgart relacionam-se, por exemplo, à espessura reduzida das lajes (que demandam condições ideais de resistência à punção) e que buscam, como resultado, os mesmos tetos uniformes citados por Rowe em 1978. A solução encontrada é a de pilzdecken, ou seja, lajes-cogumelo invertidas [Figuras 4.5 - 4.6] (derivadas dos estudos anteriores de Robert Maillart e pela primeira vez especificadas em território nacional, por um engenheiro brasileiro). Essas lajes são, neste caso, projetadas de uma forma não usual, na qual os capiteis são substituídos por pastilhas de engrossamento voltadas para cima e instaladas no encontro com as colunas. Para aliviar possíveis problemas decorrentes dos efeitos das punções, Segre (2013) 
explica que o engenheiro calculista prevê um reforço na malha de aço nos pontos de apoio das lajes sobre os pilares, constituindo aí um elemento quadrangular de 4,8 metros de lado e de 10,0 centímetros de altura completamente camuflado na espessura total da laje, conformando, assim, o "cogumelo invertido de apoio superior" (SEGRE; 2013: 360).

De acordo com a localização no edifício e com os carregamentos recebidos, Baumgart determina uma espessura-base das lajes entre 10,0 e 20,0 centímetros. Nos casos pontuais e mais exigidos estruturalmente, elas chegam a atingir de 30,0 a 50,0 centímetros, sendo preenchidas por uma mistura leve composta de cimento e escória de alto-forno - o que preserva a espessura uniforme média em toda a extensão e libera a passagem das tubulações de serviços (instalações elétricas e de telefone), porém, sem acréscimo significativo no peso das lajes como um todo. Cria-se, assim, "o teto plano contínuo, sem interrupções, assumido como um 'sexto plano', que facilita a transparência e a flexibilidade interna e a autonomia das fachadas". (SEGRE; 2013: 359)

O sistema estrutural do edifício é desenhado como autônomo, retirando das vedações, portanto, a responsabilidade tanto pelo suporte da edificação quanto pelo caminhamento das cargas descendentes - o que traz leveza e amplidão ao Ministério da Educação e Saúde. Citando Lucio Costa e seu ponto de vista favorável à técnica do concreto armado e à ossatura independente:

A nova técnica reclama a revisão dos valores plásticos tradicionais. O que caracteriza e, de certo modo, comanda a transformação radical de todos os antigos processos de construção - é a ossatura independente.

Em todas as arquiteturas passadas, as paredes de cima para baixo do edifício eram cada vez mais espessas até se esparramarem solidamente ancoradas no solo - desempenharam função capital: formavam a própria estrutura, o verdadeiro suporte de toda a fábrica. Um milagre veio, porém, libertálas dessa carga secular. A revolução, imposta pela nova técnica conferiu outra hierarquia aos elementos da construção, destituindo as paredes do pesado encargo que lhes fora sempre atribuído e do qual - seja dito a bem da verdade - souberam desempenhar-se a contento e com inexcedível dedicação. Embora essa destituição possa representar - sob o ponto de vista estritamente "moral" um rebaixamento, necessário se torna, no entanto, convir que, em idade tão avançada e na contingência de precisar resistir a esforços sempre maiores - mantê-las no cargo seria expor-se a surpresas desagradáveis de consequências imprevisíveis. A nova função que lhes foi confiada - de simples vedação - oferece, sem os mesmos riscos e preocupações - outas comodidades.

Toda a responsabilidade foi transferida, no novo sistema, a uma ossatura independente, podendo tanto ser de concreto armado quanto metálica. (COSTA; 1995: 112) 
Desde os primeiros esboços do projeto do MES, Lucio Costa adota a questão estrutural como premissa arquitetônica, na qual o esqueleto destacado do edifício deve ser sutilmente exibido e percebido nas fachadas por meio das extensas transparências externas. Ao observador mais cuidadoso é possível notar a partir daí que a modulação dos pilares não é única, pois acomoda-se aos diferentes volumes construídos em função das dimensões e das cargas suportadas. Segre (2013) menciona que esse fato ajuda a ressaltar a monumentalidade do prédio, além de reforçar o seu caráter institucional perante a sociedade.

Os panos de vidro das fachadas solicitam que as demandas referentes ao conforto térmico sejam também previstas pela equipe de arquitetos cariocas Tanto é fato que o projeto elaborado prevê a fachada norte do MES totalmente resguardada por brise-soleils horizontais [Figura 4.7] - o que melhora em demasia as condições internas da edificação, especialmente nos dias de verão. Já a fachada sul, que não é banhada pelo sol direto em nenhum momento do ano, traz uma cortina de vidro explícita em toda sua composição. Esta é "a primeira aplicação de uma fachada de vidro em escala monumental (anterior às aplicações das torres de vidro norte-americanas, do início dos anos 1950)". (SEGAWA; 2010: 92)

Este mesmo autor mostra também que a distribuição modulada dos pilares colabora para um entrosamento cuidadoso entre ambos os volumes edificados do MES. Se no mais alto o espaçamento de pilares é cadenciado a cada 6,0 metros, no mais baixo esse intervalo é estendido para 7,0 metros. Na área estabelecida pela intersecção de ambos [Figura 4.8], a modulação assume a dimensão de 8,0 metros, o que não é notado no salão de exposições, uma vez que a paginação dos pilares coincide com o fechamento externo do núcleo rígido. As demais colunas, por sua vez, repousam escondidas ao longo das vedações perimetrais das instalações do auditório. Sobre ambas as malhas estruturais de diferentes modulações presentes nos volumes que compõem o MES, Queiroz cita que

\footnotetext{
com o rompimento da trama regular de pilares, estão transgredidas tanto a lógica corbusiana que rege as relações entre as massas puras no espaço como a própria regra do esquema Domino. A trama se sujeita à forma arquitetônica no momento em que a sequência de pilares se abre apara receber o volume trapezoidal do auditório. Nesse instante, inverte-se um pressuposto corbusiano da forma que se condiciona à retícula regular de pilares. No caso do projeto brasileiro, a retícula é esgarçada para adaptar-se à forma. (QUEIROZ; 2007: 75)
}

Além da resolução da problemática relativa às espessuras das lajes que remetem a planos contínuos uniformes por todo interior da edificação, o sistema de contraventamento também coloca-se como mais uma variável estrutural que pressupõe uma proposta inovadora para que o projeto arquitetônico original mantenha-se o mais fidedigno possível. 
Nas palavras de Vasconcelos, Baumgart leva em conta, para a concepção estrutural resistente aos esforços dos ventos, que

a utilização dos pilotis impedia que se aproveitassem paredes do térreo para embutir nas mesmas, os elementos estruturais resistentes ao vento. As paredes externas que continuavam no térreo, estavam recuadas, quebrando a continuidade necessária ao bom funcionamento como elemento enrijecedor. O raciocínio de Baumgart, hoje generalizadamente difundido, constituía na época uma novidade: as lajes eram consideradas como gigantescas vigas dispostas horizontalmente. Essas vigas se apoiam nas paredes cegas das extremidades do edifício, e também no conjunto enrijecedor de escadas e de elevadores. Os esforços eram todos transferidos para os elementos enrijecedores do andar térreo, através da laje do teto do térreo, apropriadamente engrossada para essa finalidade. (VASCONCELOS; 1985: 29)

Segre (2013) não apenas concorda com a passagem acima como vai além, ao explicar que, em função das grandes dimensões do edifício do MES, a resistência às solicitações tangenciais provocadas pelo caminhamento dos ventos é também avaliada no projeto do engenheiro Baumgart. O corpo suspenso do edifício principal certamente contribui para a estética arquitetônica moderna, além de estimular a circulação permanente de pessoas, como mencionado anteriormente. Todavia, essa opção projetual acarreta certos cuidados especialmente no que se refere à não possibilidade de aproveitamento das paredes do pavimento térreo para nelas embutir o sistema de contraventamento, justamente pelo fato de elas não tocarem o chão, pois são interrompidas junto ao topo dos pilotis. Além disso, essa opção construtiva ajuda a explicar que a responsabilidade de resistir aos ventos não pode ficar concentrada somente nas caixas de circulação vertical - praticamente os únicos elementos construídos que cruzam verticalmente o edifício do térreo ao terraço-jardim, na cobertura.

Para garantir a resposta adequada aos esforços gerados pela ação dos ventos, o engenheiro Baumgart opta por um sistema casado de elementos resistentes: por um lado, junto às grandes empenas-cegas laterais, as colunas de canto que vencem toda a altura do prédio são duplicadas, permanecendo separadas entre si por um pequeno vão de 130,0 centímetros [Figura 4.9]. Por outro lado, o núcleo rígido que comporta elevadores e escadas é estruturado em concreto armado maciço e potencializa o sistema de travamento do edifício como um todo. Contribui para a coesão estrutural, o sistema de engastes entre a laje suspensa do solo e a colunata perimetral, ambas junto ao salão de exposições. Neste ponto, o contato entre diferentes elementos é feito por intermédio de peças resistentes aos esforços cortantes, tecnicamente conhecidas como mísulas (ou cachorros) [Figura 4.10]. 
A partir da contribuição do engenheiro calculista para o edifício carioca, Niemeyer sente-se motivado a investigar com mais afinco os princípios da engenharia de estruturas. Por meio do contato com Emílio Baumgart, Oscar Niemeyer tem a oportunidade de se familiarizar com a leveza das lajes sem vigas de suporte. Percebe, como explica Segre (2009), que a partir de soluções estruturais criativas praticamente não há limites para o uso do concreto armado e que as fronteiras de sua imaginação já bastante fértil à época podem, portanto, ser estendidas exponencialmente. Compreende que é possível trabalhar com formas livres sem as restrições impostas pelos componentes modulares fixos provenientes das soluções que empregam madeira ou aço. Entende, por fim, que tanto o concreto armado não estabelece a adoção de elementos com formatações regulares, quanto não requer a contratação de mão-de-obra qualificada, resultando, por isso, em uma disciplina de canteiro de obras acentuadamente diferente da praticada nos países desenvolvidos desde o século 19, a partir das construções com estruturas metálicas e de madeira.

Tomando em conta os princípios de integração entre arte e arquitetura proclamados pelo Movimento Moderno, o Ministério da Educação e Saúde é arrematado por um conjunto de obras de arte especialmente pensado para enriquecer a experiência espacial no novo edifício carioca. Dentre outros notáveis artistas que contribuem com os seus trabalhos, estão: Adriana Janacópulos (1897 - 1978), que possui uma de suas esculturas, “Mulher”, locada no espaço reservado ao terraço-jardim do ministro, na cobertura do volume mais baixo do MES. No mesmo espaço, Roberto Burle Marx (1909 - 1994) providencia o tratamento paisagístico para esta nova área de convivência, mais particular, porém não menos interessante [Figura 4.11]; Celso Antônio de Menezes (1896 - 1984), responsável pela confecção de algumas das esculturas em granito, como aquela por ele batizada de "Mulher Reclinada" inicialmente situada no jardim ao ar livre e posteriormente transferida para o grande salão de exposições, mais especificamente no topo do acesso feito pela escada helicoidal [Figura 4.12]; Cândido Portinari (1903-1952) e seus murais no gabinete do Ministro e as obras em azulejaria que revestem os fechamentos externos de várias áreas do prédio [Figura 4.13]; e Jacques Lipchitz (1891 - 1973), cuja pequenina escultura em bronze escuro, “Prometeu e Abutre” está exposta na grande parede externa do salão de conferências [Figura 4.14].

Ao considerar o contexto historiográfico que envolve a obra do Ministério da Educação e Saúde, chama a atenção o enfoque constante e bastante insistente dado ao legado deixado por Le Corbusier em sua passagem pelo Brasil. Ainda que ligeira, a participação do mestre franco-suíço nesta obra é crucial para impulsionar a visibilidade internacional da arquitetura brasileira, antes mesmo da Exposição Universal de 1939 e da mostra Brazil Builds - Architecture New and 
Old 1652 - 1942, organizada em 1943. Le Corbusier não só toma o MES como uma de suas primeiras produções públicas executadas, como a contempla em sua Ouevre Complete 1934 - 1938, que também compreende outros trabalhos seus de grande importância, como a Vila Savoye e o Palácio dos Soviets, exemplos canônicos do movimento moderno mundial. Recamán concorda com a ascendência corbusiana no projeto do MES, e indica algumas de suas inspirações e consequências ao dizer que

a conclusão geral, pelo menos da historiografia específica, é que, reconhecida a filiação a Le Corbusier, as modificações introduzidas [no projeto, pela equipe brasileira] foram pertinentes - dentro do repertório original - e significativas, fato comprovado pelo sucesso do edifício e de seus autores nas décadas que se seguiram. Esse algo que se sobrepõe ou modifica a arquitetura moderna - criatividade, leveza, liberdade formal, plástica, síntese com a tradição construtiva brasileira, etc. - será o bordão que, a partir da década de 40, identificará a nossa produção arquitetônica. (RECAMÁN; 1996: 69)

Elogios ao edifício do Ministério são manifestados por Sigfried Giedion, no texto “The Need for a New Monumentality”, publicado no livro “New Architecture and City Planning” editado por Paul Zucker em 1944. A associação deste prédio brasileiro ao "mestre do modernismo mundial” faz com que parte das publicações panorâmicas sobre arquitetura em especial as de arquitetura moderna - enfatizem a influência corbusiana em território nacional. Segundo Camargo (2011), em 1958 Henry Russel-Hitchcock publica Architecture: Nineteenth and Twentieth Century, no qual discorre sobre a arquitetura brasileira de meados do século XX, mencionando Oswaldo Bratke (e o projeto de sua segunda residência, de 1950), Affonso Eduardo Reidy (com o Conjunto Pedregulho, de 1947) e Jorge Moreira (representado pela Cidade Universitária do Rio de Janeiro, de 1952). Além destes, merece destaque nesta publicação, também, as obras projetadas por Lucio Costa e Oscar Niemeyer, dentre as quais figura uma vez mais o Ministério da Educação e Saúde, culpado, no entender de Hitchcock, pelo surgimento de uma chamada “Escola Carioca” de arquitetura.

Ainda segundo Camargo (2011), em 1959 é lançada A History of Modern Architecture, na qual Jürgen Joedicke investiga a origem do movimento moderno que, do seu ponto de vista, está atrelada às modificações sociais e tecnológicas estabelecidas ao longo do século 19. Ao voltar seus olhos para projetos arquitetônicos das décadas de 1940 e 1950 , o autor destaca as produções americanas e brasileiras (dentre as quais está o MES), além de outras obras do próprio Niemeyer, de Reidy, de Moreira e de Levy, ressaltando sempre que possível a inspiração baseada em Le Corbuiser, que, segundo ele, pode ser apreendida nos trabalhos de tais arquitetos.

Já Leonardo Benevolo, em Storia dell'architetura Moderna, inicialmente publicada em 1960, dedica algumas linhas ao edifício carioca, porém, de uma maneira diferente da elaborada por outros autores. Aqui, Benevolo relaciona esta 
edificação a outras arquiteturas e procura enfatizar que ela não representa somente um caso isolado, mas, sim, uma tendência, ou melhor, um "movimento consistente”, nas palavras de Camargo (2011). Arthur J. Boase, por sua vez, publica entre 1944 e 1945 três artigos na revista Engineering News Record, nos quais discute questões relativas ao cálculo em concreto armado no Brasil, destacando o importante papel de Emílio Baumgart no Ministério da Educação e Saúde.

Não é raro encontrar comentários que tomam a arquitetura moderna como um contraponto à clássica, conferindoIhe um apelo negativo em função de suas soluções entendidas como simplistas ou livres de inventividade nos quesitos estruturais. Segre (2013) vai no caminho oposto ao defender que a equipe chefiada por Lucio Costa para a concepção do novo edifício do Ministério da Educação e Saúde no Rio de Janeiro - primeiro exemplo amplamente reconhecido de arquitetura moderna em terras brasileiras - produz uma obra que

\begin{abstract}
constitui um exemplo palpável de elaboração complexa e intensa dos elementos formais, espaciais e estruturais, que fazem desse edifício uma obra-prima da arquitetura moderna brasileira e latinoamericana. O projeto da estrutura possui o caráter orgânico do esqueleto, não tendo como única função o apoio do edifício. Metaforicamente, podemos assumir o pórtico monumental como os troncos de uma árvore, e as colunas internas como os seus galhos. As variações em dimensão e módulos, adaptados a cada caso específico de distribuição espacial, são a clara evidência de sua existência, não como um simples sistema abstrato e geométrico, mas relacionado aos usuários, suas funções e percepções. (SEGRE; 2013: 361)
\end{abstract}

Entre críticas positivas e negativas proferidas por teóricos e estudiosos do assunto, é difícil acreditar que o prédio do Ministério da Educação e Saúde não represente um marco para a arquitetura mundial. A capacidade da equipe de arquitetos brasileiros de aproveitar os conceitos propostos por Le Corbusier para esta obra, desdobrá-los e incrementá-los, faz com que o projeto final se diferencie do do mestre franco-suíço justamente pelas suas semelhanças, ou seja, pela leveza, pelos pilotis de pé-direito duplo, pelo posicionamento no terreno ou mesmo pela acentuada verticalização. Sobre o posicionamento nacional frente ao que é produzido na arquitetura internacional, Valle assegura que "essa consciência desperta passou a ser incorporada como procedimento constituidor da arquitetura brasileira, cristalizado depois do projeto do pavilhão do Brasil na Feira de Nova York (1939) e recorrente nas décadas seguintes, identificado com a própria arquitetura brasileira, especialmente na obra de Oscar Niemeyer". (VALLE; 2000: 105)

Até os dias de hoje, a representatividade da obra do Ministério perante a crítica especializada é seguramente bastante acentuada. Tanto é fato que Segawa (2010) a considera como a primeira representante de uma arquitetura moderna 
qualificada por predicados brasileiros. Underwood (2003), por sua vez, mesmo atribuindo ao MES um grau de significativa importância, aponta não este, mas o edifício temporário do pavilhão do Brasil na Feira Internacional de 1939 em Nova York, como a primeira oportunidade de tradução do Estilo Internacional para uma linguagem predominantemente brasileira. E é sobre este edifício, suas circunstâncias de construção e seus reflexos historiográficos pelo mundo de que trata o próximo tópico de discussão. 


\section{ARQUITETURA MODERNA BRASILEIRA: PRIMEIROS PASSOS, GRANDES AVANÇOS}

Lúcio Costa e equipe, com consultoria de Le Corbusier:

Ministério da Educação e Saúde Pública - MESP

(Rio de Janeiro, 1945)

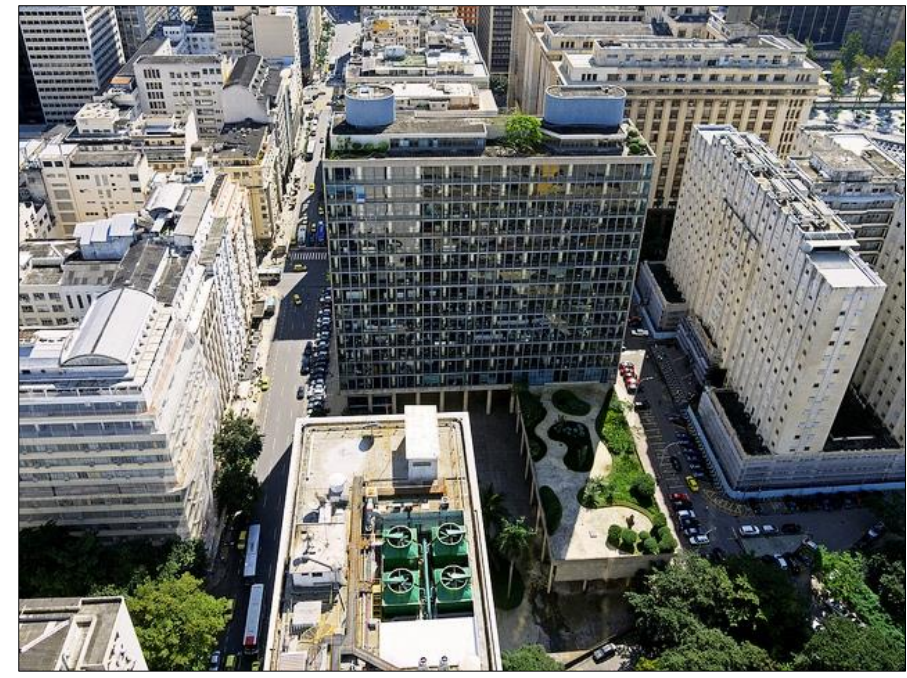

[4.1] Inserção urbana do Ministério da Educação e Saúde, no centro do Rio de Janeiro. O posicionamento no centro do lote confere ao edifício um destaque diferente do das demais edificações, além de passar certa noção de monumentalidade.

[4.3] A presença de pilotis faz com que seja possível o cruzamento da praça frontal à posterior, livremente. Mesmo não havendo bloqueios para os pedestres na grande área de circulação, os acessos ao edifício permanecem reservados e limitados.

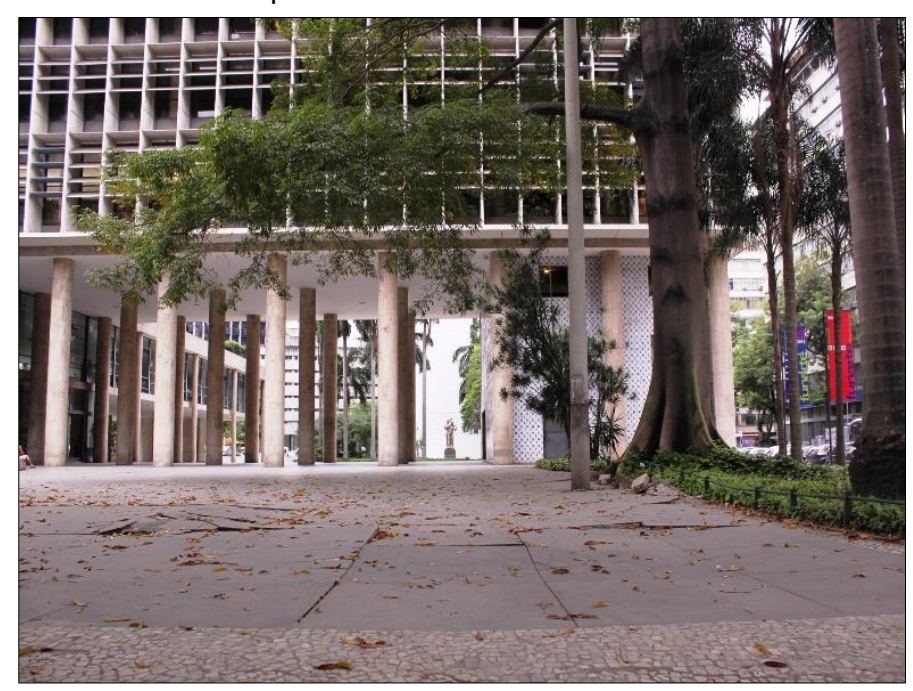

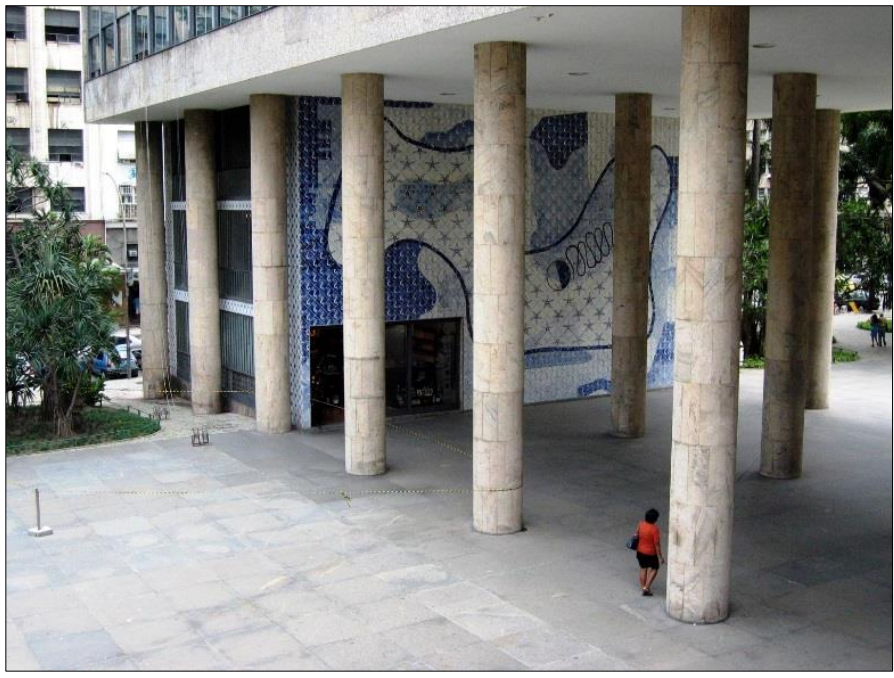

[4.2] Ao "sustentar o edifício no ar", o conjunto de pilotis - com aproximadamente 10,0 metros de altura - possibilita a integração de espaços, a interação com o entorno e o estímulo à livre circulação de pessoas pelas áreas externas.

[4.4] O tratamento paisagístico de Roberto Burle Marx dado à área de implantação do MES ajuda a perceber a colunata de concreto não apenas como ponto de sustentação do edifício, mas como personagem compositiva de espaços.

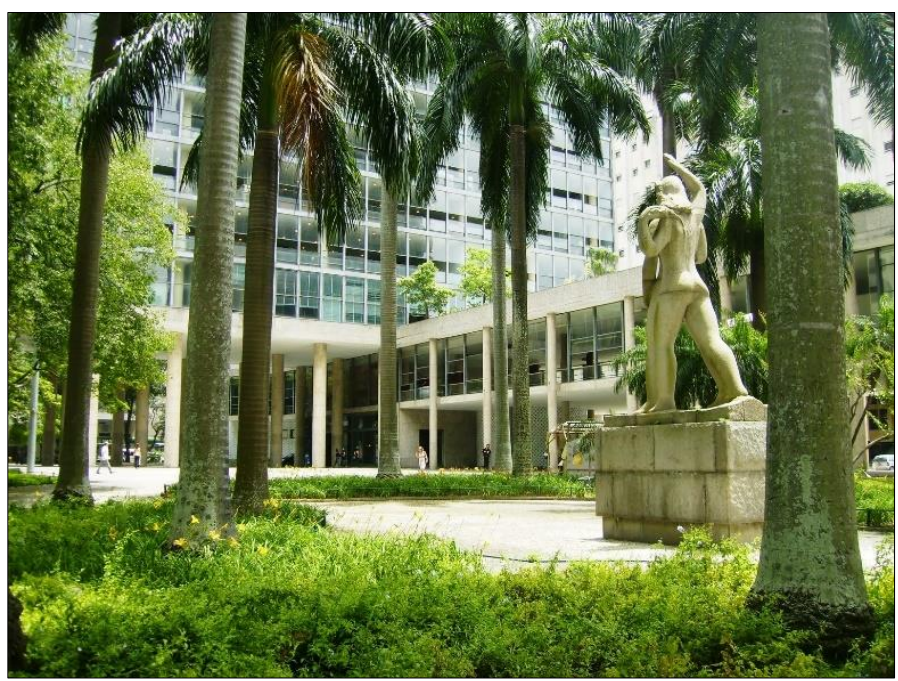




\section{ARQUITETURA MODERNA BRASILEIRA: PRIMEIROS PASSOS, GRANDES AVANÇOS}

Lúcio Costa e equipe, com consultoria de Le Corbusier:

Ministério da Educação e Saúde Pública - MESP

(Rio de Janeiro, 1945)
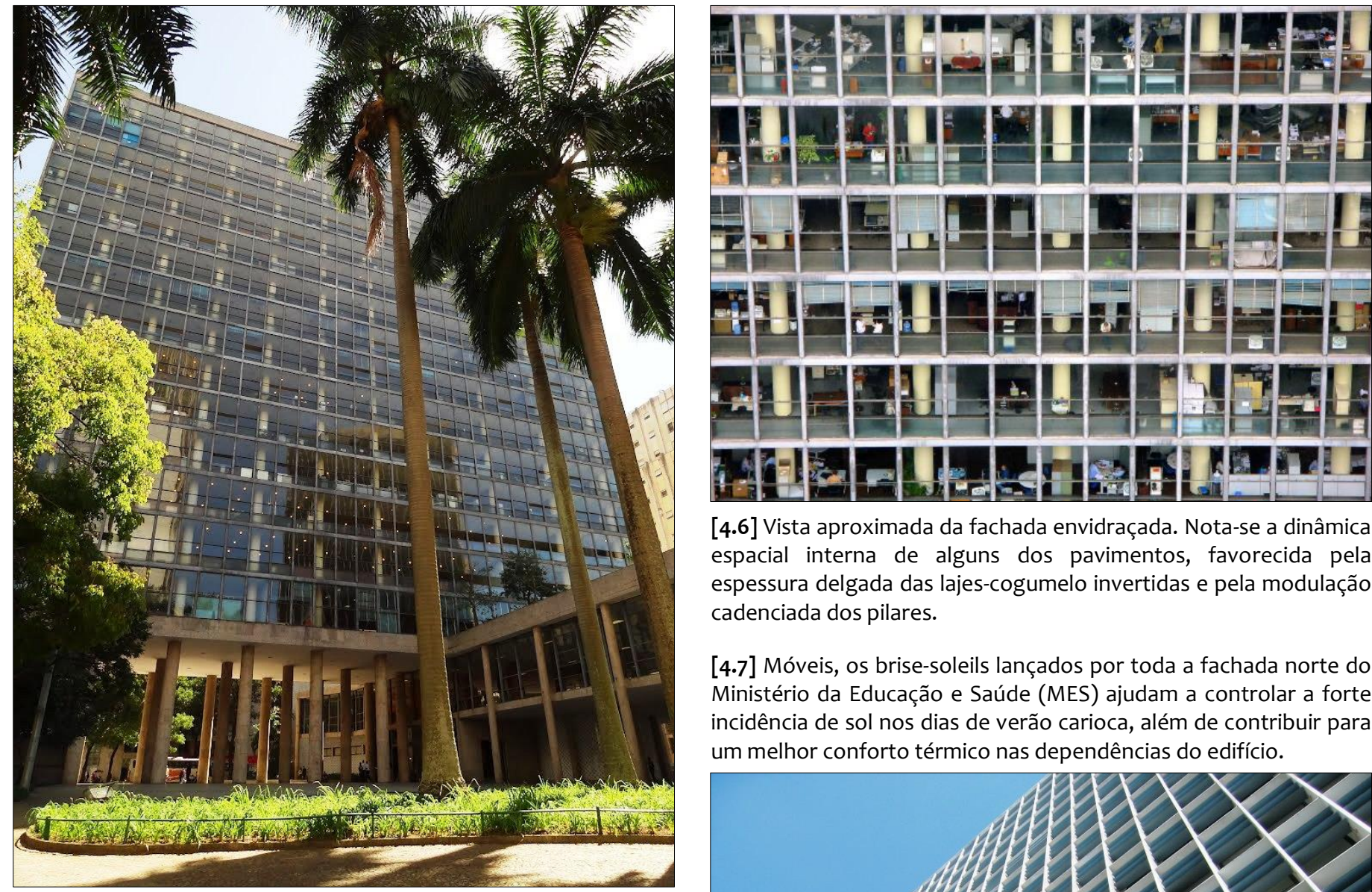

[4.6] Vista aproximada da fachada envidraçada. Nota-se a dinâmica espacial interna de alguns dos pavimentos, favorecida pela espessura delgada das lajes-cogumelo invertidas e pela modulação cadenciada dos pilares.

[4.7] Móveis, os brise-soleils lançados por toda a fachada norte do Ministério da Educação e Saúde (MES) ajudam a controlar a forte incidência de sol nos dias de verão carioca, além de contribuir para um melhor conforto térmico nas dependências do edifício.

[4.5] A desobstrução espacial ao nível da quadra favorece a unidade arquitetônica entre áreas cobertas e livres.

$\mathrm{Na}$ fachada sul e sobre a colunata monumental, descortinam-se amplos panos de vidro através dos quais visualiza-se, discretamente, o esqueleto estrutural independente composto por pilares localizados nos mesmos alinhamentos verticais dos pilotis do piso térreo e por delgadas lajes de concreto armado.

Este projeto de Lucio Costa e equipe representa o primeiro exemplo construído com uma pele de vidro usada em grande escala (a qual ocupa toda a extensão da fachada sul). Esta solução arquitetônica antecede ao seu uso maciço, a partir dos anos 1950, especialmente nas torres europeias e norte-americanas.

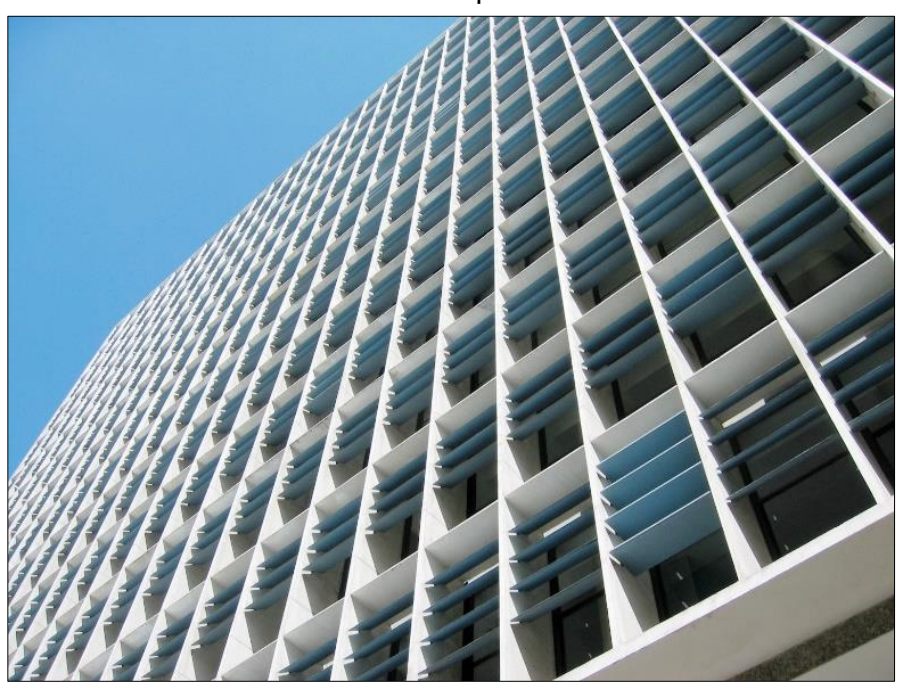




\section{ARQUITETURA MODERNA BRASILEIRA: PRIMEIROS PASSOS, GRANDES AVANÇOS}

Lúcio Costa e equipe, com consultoria de Le Corbusier:

Ministério da Educação e Saúde Pública - MESP

(Rio de Janeiro, 1945)

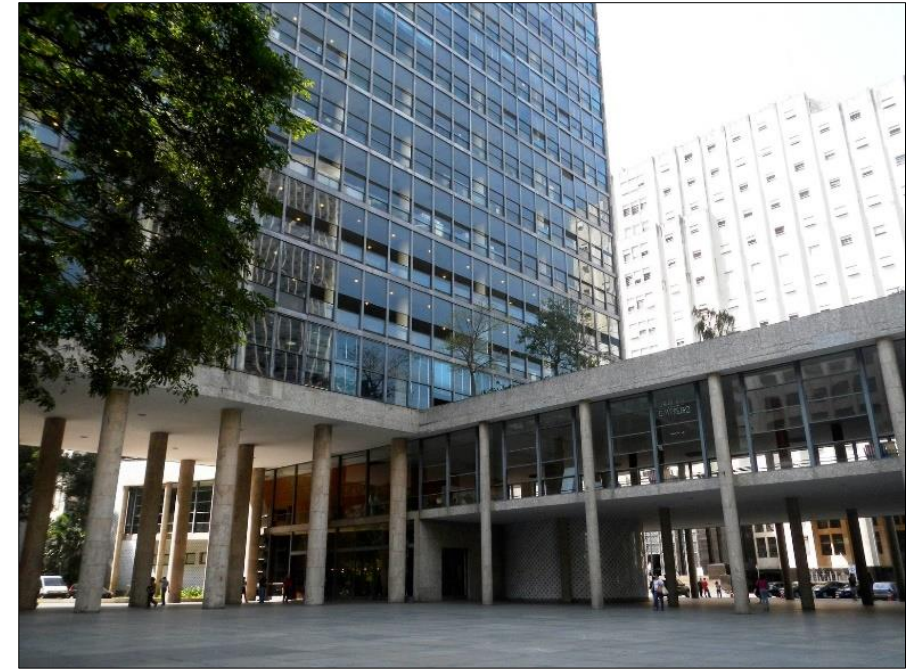

[4.8] Este é o ponto de contato entre os diferentes volumes construídos. No mais alto, a laje que cobre o vão e toca os topos dos pilotis responde por parte do sistema de contraventamento, daí sua espessura avantajada.

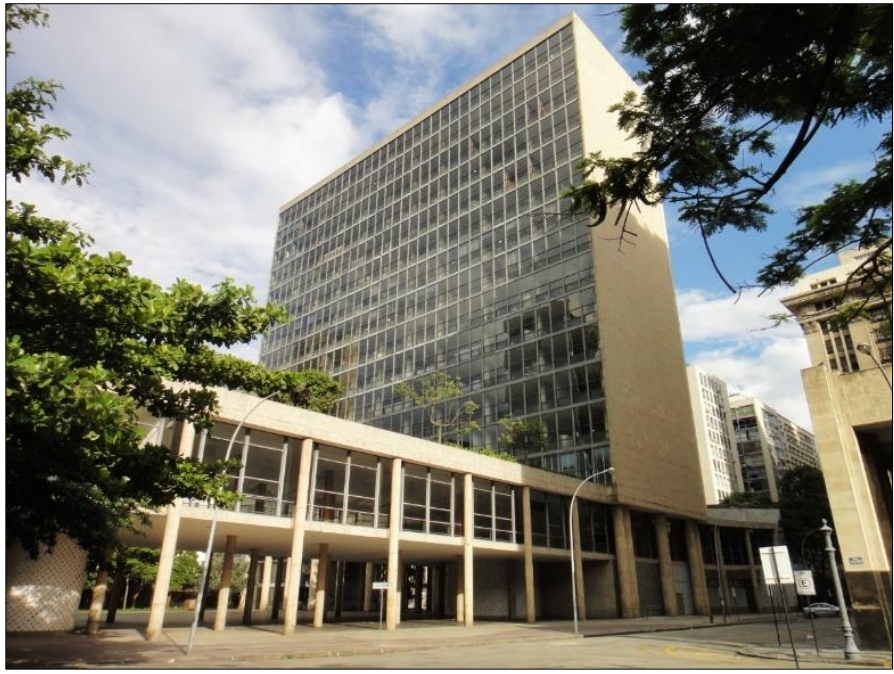

[4.9] Mais uma vista da permeabilidade de circulação por entre os volumes do MES gerada pela adoção dos pilotis. Abaixo dos cantos da empena-cega, as colunas duplicadas horizontalmente ajudam a suportar as cargas provocadas dos ventos.

[4.10] Vista externa parcial do salão de exposições. O engaste entre a laje elevada do solo e a colunata perimetral faz-se por intermédio de peças resistentes aos esforços cortantes, tecnicamente conhecidas como mísulas (ou cachorros).

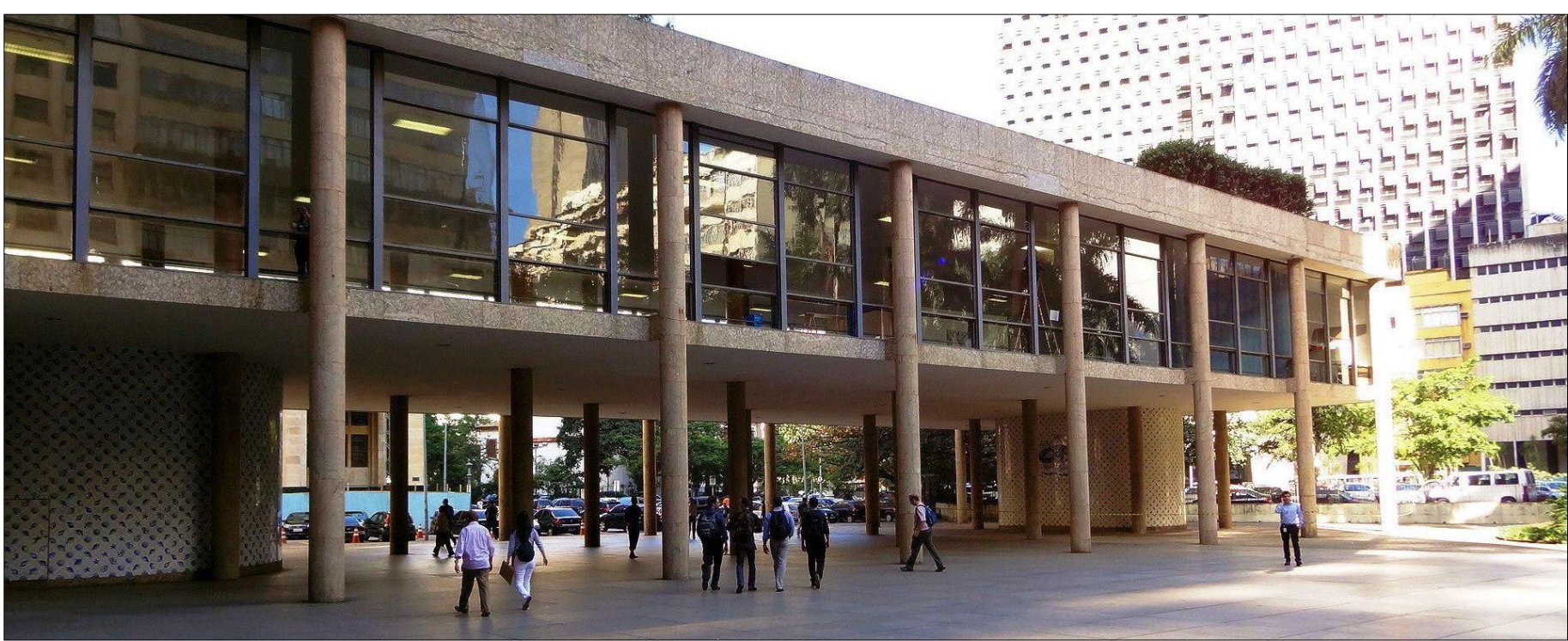




\section{ARQUITETURA MODERNA BRASILEIRA: PRIMEIROS PASSOS, GRANDES AVANÇOS}

Lúcio Costa e equipe, com consultoria de Le Corbusier:

Ministério da Educação e Saúde Pública - MESP

(Rio de Janeiro, 1945)

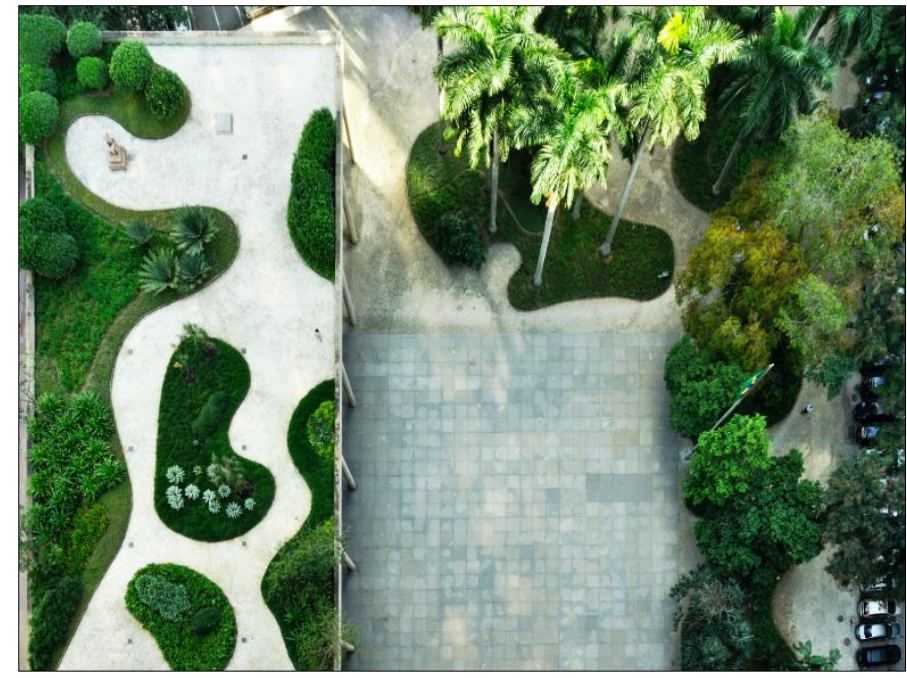

[4.11] O paisagismo de Roberto Burle Marx em dois momentos: à esquerda, o terraço-jardim do Ministro traz como acréscimo a estátua "Mulher", de Adriana Janacópulos. À direita, área de circulação livre, no mesmo patamar da quadra aberta.

[4.13] Painel de azulejos acoplado à parede do bloco de funcionários, sob o pórtico sustentado pelos pilotis: obra do artista plástico paulista Cândido Portinari, que também produz outras obras adotadas no MES.

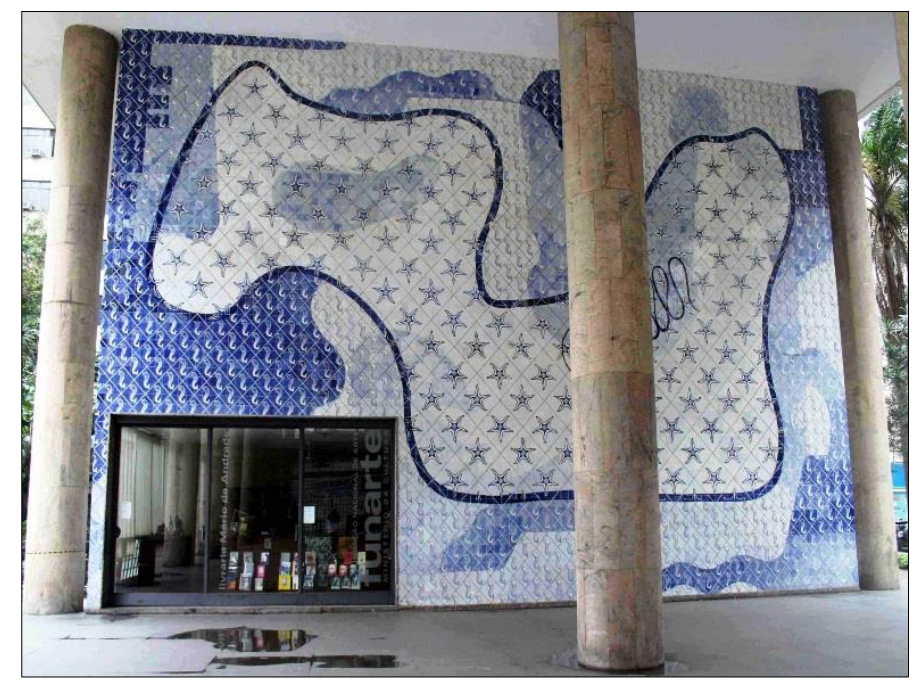

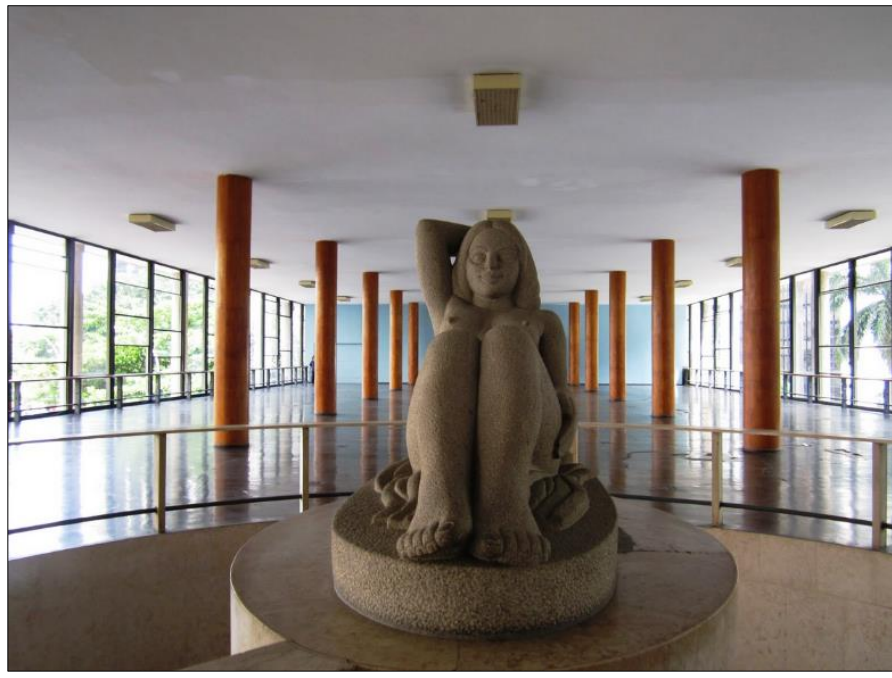

[4.12] Em primeiro plano, a escultura "Mulher Reclinada" (de Celso Antônio) situa-se junto à escada helicoidal do salão de exposições. Ao fundo, dois preceitos da arquitetura moderna: modulação das colunas internas e laje superior plana contínua, sem obstruções.

[4.14] De Jacques Lipchitz, a escultura "Prometeu e o Abutre" é cunhada em bronze. Suas dimensões reduzidas conferem-lhe um tamanho ainda menor quando comparada à extensa parede externa do salão de conferências, onde está instalada desde 1946.

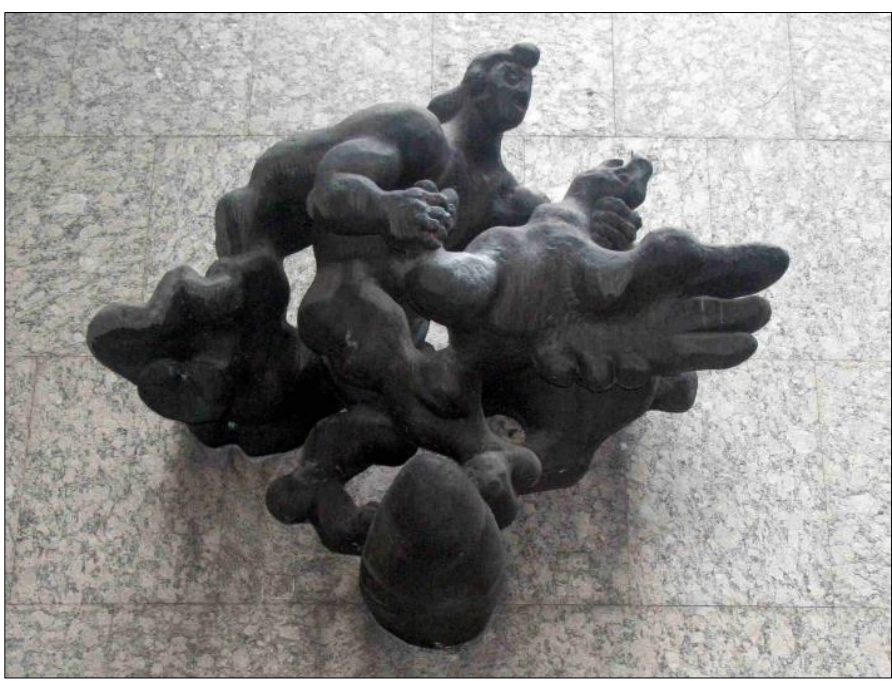




\section{O Brasil Fora do Brasil: A Política da Boa Vizinhança e o Pavilhão Brasileiro na Feira Internacional de 1939}

A Política da Boa Vizinhança [Figuras 4.15 - 4.18] - uma estratégia de relacionamento dos Estados Unidos para com a América Latina - é assinada e oficializada pelo presidente dos Estados Unidos, Franklin D. Roosevelt, em dezembro de 1933 durante a Conferência Panamericana de Montevideo. Perdura até 1945, assim que a Segunda Guerra Mundial é finalizada e o novo presidente americano, Harry Truman, assume o poder.

Em linhas gerais, sua característica mais marcante refere-se à substituição das ações intervencionistas exercidas até aquele momento pelo conjunto dos estados americanos junto aos países latinos, em prol de políticas mais amenas de negociação, agora conduzidas por diálogos diplomáticos mais abertos e transparentes e em relacionamentos cooperativos mais abrangentes, com o intuito de incentivar e colaborar para com o desenvolvimento local nas áreas militar, cultural e econômica. Todavia, essa predisposição americana não pode ser apreendida como uma preocupação legítima e despretensiosa por si só. Trata-se, em verdade, de um interesse próprio calcado em manobras planejadas para "impedir a influência europeia na região, manter a estabilidade política no continente e assegurar a liderança norte-americana no hemisfério ocidental" (CPDOC | FGV; 2014), liderança essa ameaçada pela chegada da Segunda Guerra Mundial em setembro de 1939, a qual repercute com grande influência nos interesses americanos ao redor do mundo.

Entre o final dos anos 1930 e início dos 1940, o Brasil mantém relações diplomáticas bastante próximas com os países do Eixo, especialmente com a Alemanha. Para alguns setores do governo Vargas, "incluindo boa parte dos militares, o modelo de desenvolvimento através de um Estado forte e a extraordinária recuperação germânica, após o Tratado de Versalhes, pareciam ser um excelente modelo a seguir". (CAVALCANTI; 2006: 149) - o que muito desagrada aos Estados Unidos. Tanto é fato que em agosto de 1940, o presidente Roosevelt nomeia Nelson Rockefeller para comandar a recém-criada agência de coordenação dos negócios interamericanos, ou Office of the Coordinator of Inter-American Affairs (OCIAA) - diretamente vinculada ao Conselho de Defesa Nacional dos Estados Unidos - a fim de estreitar as relações entre as Américas do Norte e do Sul com atenção redobrada à Argentina e ao Brasil.

Dentre as várias ações tomadas, descreve Cavalcanti (2006), no campo militar está o empenho americano em estabelecer, em território latino, uma base aérea para auxiliar as aeronaves a cruzar o Oceano Atlântico em direção à 
guerra que se desenrola em território europeu. Além disso, a OCIAA investe pesadamente em estratégias para melhorar a imagem dos Estados Unidos junto à América do Sul, já bastante desgastada devido às fortes medidas intervencionistas em voga desde 1901, quando lançadas pelo presidente Theodore Roosevelt. Arte e cultura passam a ser os canais utilizados pelos Estados Unidos para colocar em prática o seu plano de conquista extrafronteiras que visa, gradativamente, ganhar adeptos ao american way of life [Figura 4.15], em contraponto ao modelo europeu já bastante disseminado entre os sul-americanos. Cria-se, como consequência e sob os auspícios da OCIAA, o departamento cultural americano, comandado por Wallace Harrison - arquiteto-chefe da Feira Internacional de Nova York de 1939.

De acordo com Cavalcanti (2006), dentre as medidas adotadas por Harrison, destacam-se: a.) o financiamento de viagens de longa duração de intelectuais e formadores de opinião da América do Sul em direção aos Estados Unidos; b.) o envio do escultor Jo Davison para moldar os bustos dos presidentes ditadores sul-americanos - dentre eles o do presidente Getúlio Vargas; c.) o patrocínio da música erudita, representada tanto pelo convite a diversas companhias de balé e à Orquestra Sinfônica de Nova York (então sob a regência de Leopold Stokowski) para apresentações em território brasileiro, quanto pelos concertos em palcos americanos de compositores nacionais, como Heitor VillaLobos, Francisco Mignone e Camargo Guarnieri; d.) publicação de revistas estadunidenses nas línguas portuguesa e espanhola, como a "Em Guarda" e a "Seleções do Reader's Digest”; e e.) a retransmissão, em português, de diversos programas de rádio americanos, tais como os das emissoras Columbia Broadcast System (CBS), National Broadcast Company (NBC) e a General Sound Corporation (GSC).

O mesmo autor ainda explica que o estreitamento das relações no campo cultural é favorecido pelo fato de, no início da década de 1940, o Brasil ser apontado como um dos mercados mais prósperos para a exibição cinematográfica do continente. Hollywood aproveita esse mote para assinar acordos de cooperação mútua para a produção de filmes para o cinema, geralmente realizados com elencos de grande destaque e admiração pública. Fred Astaire (em "Voando para o Rio", de 1933) ou Bette Davis (em “Now, Voyager”, de 1942) são apenas dois dos astros famosos que filmam no Brasil. Além deles, três são os representantes cinematográficos que alcançam repercussão além das expectativas: a.) Carmem Miranda [Figura 4.16], considerada por muitos como a musa, nas grandes telas, da Política de Boa Vizinhança; b.) o projeto It's All True, documentário dirigido por Orson Welles [Figura 4.17] que busca revelar um Brasil repleto de interesses e de qualidades positivas, mas que até aquele momento permanece relativamente 
desconhecido dos americanos. Porém, o projeto é suspenso antes mesmo de estar concluído, pois Welles estoura o orçamento e o prazo de produção, bem como confere um ar autoral à película, distanciando-se, portanto, daquilo que é inicialmente acordado. O comportamento visto como boêmio e abusivo de Welles em terras tropicais é usado também como argumento para não dar continuidade à empreitada; e c.) o personagem de desenho animado Zé Carioca [Figura 4.18], criado depois da estadia de Walt Disney (convocado diretamente por Nelson Rockfeller), no Rio de Janeiro, no início da década de 1940.

Já na frente econômica - prossegue Cavalcanti (2006) - aos Estados Unidos interessa dilatar a atuação de suas empresas a ponto de dominar os negócios no continente sul-americano, tanto para opor-se à participação alemã cada vez mais significativa nesse mesmo mercado quanto para aproveitar a oportunidade de se recuperar dos efeitos ainda sentidos da grande depressão de 1929 sobre sua economia. A respeito da política de conquista e cultivo de novos mercados consumidores externos, o Centro de Pesquisa e Documentação de História Contemporânea do Brasil, da Fundação Getúlio Vargas, afirma que

a retórica da solidariedade e os métodos cooperativos no relacionamento com os países latinoamericanos facilitavam a formação de mercados externos para os produtos e investimentos norteamericanos, além de garantir o suprimento de matérias-primas para suas indústrias. A implantação dessa nova estratégia de relacionamento com a América Latina representou a vitória da corrente política do governo norte-americano que advogava o livre-cambismo como solução para a recuperação econômica dos Estados Unidos no plano internacional. (CPDOC | FGV; 2014)

De acordo com Comas (2010), a Feira Internacional de Nova York de 1939 [Figuras 4.19 - 4.25] tem papel importante para ajudar na alavancagem das negociações econômicas entre os Estados Unidos e as demais nações mundiais, para contribuir na recuperação do país frente a crise de 1929 e para servir como pretexto para a comemoração dos 150 anos da posse do primeiro presidente americano. Sob o tema "Construindo o Mundo de Amanhã" o evento representa o "paradigma da democracia e do livre mercado, em contraste com o autoritarismo estatal na Europa à beira de graves conflitos". (CAVALCANTI; 2006: 173)

Locada em Flushing Meadows, no bairro do Queens, a cerca de sete quilômetros do centro de Nova York (Estados Unidos) [Figuras 4.19 - 4.20], a Feira é concebida em 1935, durante o período crítico da depressão econômica americana. Quatro anos depois, porém, quando de sua inauguração oficial, os Estados Unidos já vivenciam sutis efeitos positivos da retomada econômica provocada pela política do New Deal. Mesmo assim buscam, sempre que possível, exibir seu domínio tecnológico ao mundo, representado não apenas na transmissão ao vivo pela televisão 
da cerimônia de abertura do evento, mas também pela veia tecnológica que conduz os diversos produtos americanos apresentados às demais nações participantes: a fotografia em cores, os aparelhos de ar-condicionado, as lâmpadas fluorescentes e o nylon.

O núcleo referencial do evento é definido por um par elementos arquitetônicos marcantes [Figuras 4.21 - 4.22]: o "Trylon", um obelisco estruturado em metal, com 183,0 metros de altura e projetado por Wallace Harrisson e André Fouilloux. Além dele, também o "Perisfério" criado por Henry Dreyfuss, uma esfera metálica de 54,0 metros de diâmetro no interior da qual ocorre a mostra Democracity, um "gigantesco diorama que buscava mostrar o mundo em 2039" (CAVALCANTI; 2006: 174). A importância da Feira é tamanha que a empresa americana General Motors decide reproduzir, em escala reduzida, uma cidade completa (com edifícios, sistemas viários e até linhas férreas): trata-se da exposição Highways and Horizons, ou simplesmente Futurama, uma das mais importantes e até hoje lembradas proposições da Feira de 1939 não somente por sua ousadia projetual, mas também pelos elevados custos de construção e de manutenção.

Sistemas viários formados por pequenos viadutos, passarelas, ruas e avenidas são abertas no interior da área de implantação da feira com o objetivo de facilitar o fluxo contínuo de pedestres visitantes, bem como o de automóveis (estes, vistos pela comissão organizadora como representantes simbólicos responsáveis pelo desenvolvimento técnico e tecnológico de grandes empresas no futuro) [Figuras 4.23 - 4.25]. Tendo em vista serem, já naquela época, os Estados Unidos um dos mais importantes núcleos produtores e consumidores do segmento automotivo mundial, todos os esforços são considerados válidos para ressaltar sua importância no contexto do desenvolvimento mundial - daí os elevados investimentos nas questões referentes à infraestrututra da Feira de Nova York.

A partir de ambos os elementos arquitetônico-simbólicos centrais, estruturam-se os sistemas viários, as áreas expositivas descortinam-se e o espaço da Feira organiza-se em três divisões principais: a primeira delas, centralizada, destina-se a abrigar os pavilhões expositivos das grandes empresas e corporações americanas. Logo a seguir há uma envoltória que recebe os espaços de exposição também de empresas americanas, mas de portes e segmentos diversos. Por fim, a última divisão comporta os estados da confederação norte-americana, dentre os quais está o Brasil, materializado pelo pavilhão projetado pela dupla de arquitetos Lucio Costa e Oscar Niemeyer [Figura 4.22].

A intenção da participação brasileira na feira americana é revelada no ano anterior, em 1938, oportunidade na qual o Ministério da Agricultura do Brasil promove um concurso para escolher o melhor anteprojeto moderno para seu 
pavilhão temporário. Lucio Costa é consagrado vencedor, ficando Oscar Niemeyer com a segunda posição. Todavia, em um ato de livre e espontânea vontade, Costa renuncia à sua vitória, mas não ao interesse pela elaboração do projeto. Ao reconhecer as qualidades inerentes à proposta de Niemeyer, convida-o para, juntos, trabalharem em uma terceira solução que entrelaça algumas das características de cada uma das propostas anteriores.

O projeto final construído [Figuras 4.26 - 4.33], ao contrário do que se pode pensar, não é um elemento híbrido sem identidade. Trata-se em verdade de um edifício bastante singular, que costura com competência e destreza dois conceitos relativamente diferentes: do de Lucio Costa, toma para si "os pilotis, a rampa de acesso e os elementos vazados de fachada, a título de brise-soleil" [Figura 4.26]. (SEGAWA; 2010: 93). Já de Oscar Niemeyer, aproveita-se tanto do volume curvo lateral quanto da área destinada ao jardim tropical, na parte posterior do lote.

De acordo com Underwood (2003), juntos, Costa e Niemeyer baseiam-se no passeio público originário de Le Corbusier e, como consequência, imputam ao pavilhão erguido em Nova York qualidades como fluidez de percursos e integração de espaços. Note-se que essa preocupação já havia sido exercitada anteriormente, no projeto da sede do Ministério da Educação e Saúde, o qual também busca preservar a unificação dos espaços e a livre circulação de pedestres, estabelecendo, a partir daí, um estreito diálogo entre obra, entorno imediato e pessoas.

Na Feira de 1939, o pavilhão do Brasil localiza-se em um terreno de esquina de formato curvilíneo (com dimensões aproximadas de 50,0m x 100,om), ao lado do lote reservado ao projeto desenvolvido pelos escritórios de Roger Expert e Pierre Patout para o pavilhão da França. Este, um prédio de volumetria austera, gabarito alto e massa densa. 0 adiantado das obras do edifício francês dá margem aos arquitetos brasileiros de repensarem sua proposta, fazendo dela a chance de a arquitetura do Brasil impor-se por contraponto, ou seja, de propor uma solução que se destaque por qualidades como simplicidade, horizontalidade, leveza, fluidez e porosidade.

A resposta de Costa e Niemeyer resulta em um edifício recuado em relação à rua, pousado sobre pilotis e que apresenta partido no formato de "L", em cujo centro há um grande espelho d'água e um jardim tropical [Figura 4.27]. Trata-se, pois, de um espaço praticamente aberto e que favorece a circulação de pessoas até as margens do Rio Flushing, aos fundos da implantação [Figura 4.28]. A permeabilidade da planta aliada às fachadas parcialmente compostas ora por vidros, ora por elementos vazados (aqui, em uma referência à arquitetura tradicional brasileira), possibilita forte sinergia entre as áreas interna e externa do edifício. 
A adoção de elementos curvos gerada pelo leve arqueamento do terreno colabora para a adequação do Estilo Internacional ao feitio brasileiro, o que ecoa em vários pontos da arquitetura do pavilhão: na rampa diagonal de acesso, na marquise, nas paredes de fechamento, na sinuosidade do lago artificial, ou mesmo no auditório, nas ondulações do mezanino interno e na laje da cobertura [Figuras 4.29 - 4.31]. É de se pensar, contudo, se o rebatimento do formato do lote no corpo do edifício temporário brasileiro é decorrente, apenas, da vontade de preservar uma concordância com a curvatura pré-estabelecida do sítio de implantação ou se o uso das formas livres possui outras fontes de inspiração, experimentadas por Niemeyer em projetos passados.

Sobre esse fato, Valle (2000) lembra que a intenção plástica representada por volumes de formas livres já é anteriormente esboçada em três oportunidades tímidas e pontuais no Ministério da Educação e Saúde, no qual a equipe de arquitetos chefiada por Lucio Costa desenha um par de volumes enfáticos no topo do prédio. Um desses elementos possui formato mais tradicional, talvez elipsoidal, e abriga a caixa d'água superior, ao passo que o outro, que remete a uma figura ameboide, funciona como caixa de máquinas para os elevadores. Já o terceiro elemento ainda de acordo com Valle (2000) - é construído para servir de ampliação ao salão de exposições e tem como solução volumétrica uma réplica do ameboide presente da laje de cobertura.

Queiroz (2007) explica que, se no projeto do Ministério da Educação e Saúde o distanciamento aos princípios do "Sistema Domino" é ainda discretamente sugerido, no Pavilhão do Brasil para a Feira Internacional de Nova York " $a$ dissolução da retícula regular confere a gestualidade em "S" do próprio bloco de exposições" (QUEIROZ; 2007: 83) tornando-se, portanto, mais manifesta e destacada. Há, aqui, uma valorização aos preceitos ditados pelo mestre franco-suíço, porém, acrescida de certo desejo pela liberdade exibida na contraposição da modulação dos pilares à sutil curvatura dos elementos arquitetônicos da obra.

Ainda no caso do pavilhão para a Feira de 1939 desdobra-se a ideia de plasticidade por meio do uso de formas livres mais amplas, porém mais suaves e distribuídas em diversos pontos da arquitetura, "compondo uma verdadeira diversificação e distribuição de formas pelo espaço" (VALLE; 2000: 104). O contraste que geram em relação às formas ortogonais da estrutura cartesiana até então largamente propagadas pelos seguidores da arquitetura moderna faz com que Bruand (1997) - em consonância com o pensamento de Underwood (2003) anteriormente mencionado acredite que esta pode ser a primeira oportunidade que o Brasil tem para romper com os preceitos rigorosos e 
ortogonais do Estilo Internacional, servindo também de prenúncio à brasilidade do vocabulário tão próprio e tão característico da arquitetura moderna nacional.

Comas (2010) menciona que para o projeto da exposição propriamente dita (a qual acontece no interior do pavilhão) é designado o arquiteto norte-americano Paul Lester Wiener [Figura 4.32]. Tanto o detalhamento dos elementos arquitetônicos quanto a execução da obra ficam a cargo da empresa americana contratada, Hegemann-Harris. O projeto estrutural é de responsabilidade do engenheiro calculista e já conhecido da dupla Costa e Niemeyer, Emílio Baumgart. Quanto à solução estrutural, explicam Fraga (2006) e Comas (2010), o pavilhão do Brasil para a Feira Internacional de 1939 traz estrutura metálica com pilares de aço revestidos por chapas de metal. Todavia, Macedo (2012) sugere que apenas o bloco mais longo e curvilíneo - como também a rampa de acesso ao piso superior - são efetivamente estruturados em aço. Além disso, tanto o volume frontal quanto o auditório, indica o mesmo autor, são realizados em concreto armado moldado in loco.

Ao basearem-se no esquema corbusiano da planta livre, Lucio Costa e Oscar Niemeyer apostam na diversidade de possiblidades para a organização e a concatenação de ambientes. A flexibilidade da malha estrutural adapta-se tanto à curvatura do terreno quanto aos fechamentos internos, aos locais de pé-direito duplo ou mesmo aos balanços das lajes do segundo pavimento. Assegura-se assim não apenas a integração visual mas, também, a coesão e a unidade arquitetônica do projeto. Há, distribuído pelos ambientes internos do pavilhão, um conjunto de obras de artistas brasileiros. No amplo salão nobre, por exemplo, encontram-se grandes pinturas de Cândido Portinari [Figura 4.33].

A Feira perdura de maio de 1939 a maio de 1941. Nesse período, a repercussão do pavilhão brasileiro junto à crítica especializada é bastante positiva. A revista americana Architecural Forum (de junho de 1939) e a londrina Architectural Review (que em agosto de 1939 dedica uma edição completa à cobertura do evento) são duas das publicações que tecem comentários (em sua maioria positivos) à obra de Niemeyer e Costa. Segre (2009) menciona que tanto a competência projetual quanto o resultado final construído elevam o pavilhão brasileiro a igual patamar das propostas para o mesmo evento feitas por Sven Markelius (Suécia) e Alvar Aalto (Finlândia) - que também são largamente enaltecidos nos periódicos de arquitetura da época.

No entanto, mesmo tendo despertado o interesse internacional de diversas publicações especializadas, este projeto brasileiro é desconsiderado pela análise efetuada posteriormente, por exemplo, por Bruno Zevi em sua Storia Dell'architettura Moderna, originalmente publicada em 1950. Camargo (2011) coloca que o autor discute em um dos 
capítulos de sua obra a difusão do trunfo do movimento racionalista pelo mundo e entende como significativas, apenas, as participações na Feira de 1939 das produções arquitetônicas sueca e finlandesa.

Difícil negar, contudo, que a reconhecida participação brasileira neste evento não tenha sido efeito de uma “atualização moderna de ascendência corbusiana" (MACEDO; 2012: 114), evidenciada especialmente na importante atuação e capacidade projetual de Oscar Niemeyer. Trata-se da oportunidade não apenas de amadurecer, mas também de superar o "racionalismo mais ortodoxo, com a consciência de uma nova dimensão estética da arquitetura moderna acima da aridez do mero rebatimento da função sobre a forma - lição aprendida com Le Corbusier em 1936" (SEGAWA; 2010: 95).

O resultado acima das expectativas de público e de crítica alcançado pelo Brasil na Feira Internacional de 1939 impulsiona o "Museum of Modern Art (MoMA) de Nova York a realizar um reconhecimento mais abrangente da arquitetura brasileira" (IBIDEM: 100). A presidência do museu, comandada por Nelson Rockfeller, ajuda no interesse da instituição pela produção artística latino-americana, e o MoMA torna-se um dos mais importantes veículos de aplicação da Política de Boa Vizinhança. Em 1942 a dupla formada pelos futuros curadores da exposição, o arquiteto e vice-presidente executivo do museu Philip L. Goodwin e o também arquiteto e fotógrafo G.E. Kidder-Smith, passa seis meses no Brasil com a finalidade de investigar arquiteturas novas e antigas erguidas ao longo do território nacional "visitando prédios, fotografando e entrevistando a nova geração de arquitetos. Fascinados pelo modernismo brasileiro, foram os primeiros a apontar o singular elo entre formas revolucionárias e a descoberta e preservação de prédios históricos". (CAVALCANTI; 2006: 167)

Como resultado, em janeiro de 1943 é inaugurada a mostra "Brazil Builds - Architecture New and Old 1652 - 1942 " que, aliada ao livro/catálogo dela derivado, representam a maior divulgação da arquitetura moderna brasileira até aquele momento. Este evento busca estabelecer relações entre aquilo que se propõe como arquitetonicamente moderno no Brasil e a relação surgida a partir daí com "história e geografia, memória e lugar, operação e comunicação, necessidade e desejo" (COMAS, 2010: 92). Disposta em duas partes a mostra expõe, por um lado, a arquitetura “antiga” praticada ao longo do período colonial e do Império e, por outro, a arquitetura “nova”, representada por "39 obras organizadas por tipologias, equiparadas às obras mais paradigmáticas do movimento moderno" (CAMARGO; 2011: 76).

Comas (2010) comenta que a parte "antiga" inicia-se por um edifício neoclássico de 1854 que naquela época abriga a sede do Ministério das Relações Exteriores no Rio de Janeiro e encerra-se com uma vila neoclássica de 1789 adaptada 
para abrigar uma escola. Já a parte "nova” é aberta pelo edifício do Ministério da Educação e Saúde (MES) - ainda em fase de construção. Esta parte da mostra é encerrada com pavilhão do Brasil na Feira Internacional de 1939. Percebese assim que, além do edifício temporário para a Feira nova-iorquina, o prédio carioca assume, também, o papel de um dos exemplos mais relevantes da arquitetura moderna brasileira - inclusive aos olhos estrangeiros. Para Philip $\mathrm{L}$. Goodwin, a inspiração nos preceitos do mestre franco-suíço nesta obra é bastante clara:

Nele a sua influência reflete-se acentuadamente, o mais importante porém é que aí se manifestam livres a imaginação do desenho e a condenação da velha trilha oficial. Enquanto o clássico dos edifícios federais de Washington, o arqueológico da Academia Real de Londres e o clássico nazista de Munich dominam triunfantes, o Brasil teve a coragem de quebrar a rotina e tomar um rumo novo tendo como resultado poder o Rio orgulhar-se de possuir os mais belos edifícios públicos do continente americano. (GOODWIN; 1943: 91)

Após o período nova-iorquino, a mostra organiza-se em versões reduzidas e itinerantes que percorrem diversos museus e galerias mundo afora, como Canadá, México e Brasil. Aqui, é exibida no próprio Ministério da Educação e Saúde, com projeto museográfico a cargo de Oscar Niemeyer. Segundo Segawa (2010) e Camargo (2011), a partir da Brasil Builds várias revistas internacionais focadas em arquitetura começam a tomar interesse pelo que acontece no cenário arquitetônico brasileiro, como é o caso, por exemplo, das publicações monográficas em Architectural Review (1944 e 1954); Architectural Forum (1947); Progressive Architecture (1947) L'Architecture d'aujourd'hui (1947, 1952, 1960, 1964); Casabella (1954); Arquitectura México (1958), Nuestra Arquitectura (1960); e Zodiac (1960).

Em 1956, depois da publicação “Brazil Builds”, o arquiteto paulistano Henrique Mindlin lança no Rio de Janeiro, em Amsterdã e em Nova York o livro bilíngue “Modern Architecture in Brazil”, no qual a produção arquitetônica brasileira é retomada e vastamente difundida. A partir desta obra, amplia-se e atualiza-se, em terras estrangerias, os referenciais até então conhecidos sobre a produção nacional. Colabora para a ampla aceitação deste livro - além de sua notória qualidade e dos 115 projetos nela apresentados (a maioria dos quais não contemplada na exposição americana anterior) - o fato de o prefácio ser escrito por Sigfried Gideon. Neste texto, Gideon ressalta que é apenas no Brasil em que há realmente a possibilidade de aproveitar de maneira mais ampla as ideias propagadas por Le Corbusier, ainda que este tenha visitado muitos outros países antes de ter estado aqui, todavia, sem despertar nele a mesma empatia e sem provocar as mesmas consequências. 


\section{RELAÇÕES INTERNACIONAIS: A CONQUISTA DE NOVAS FRONTEIRAS}

Brasil e Estados Unidos:

\section{Estado Novo e Política de Boa Vizinhança}

(Décadas de 1930 e 1940)

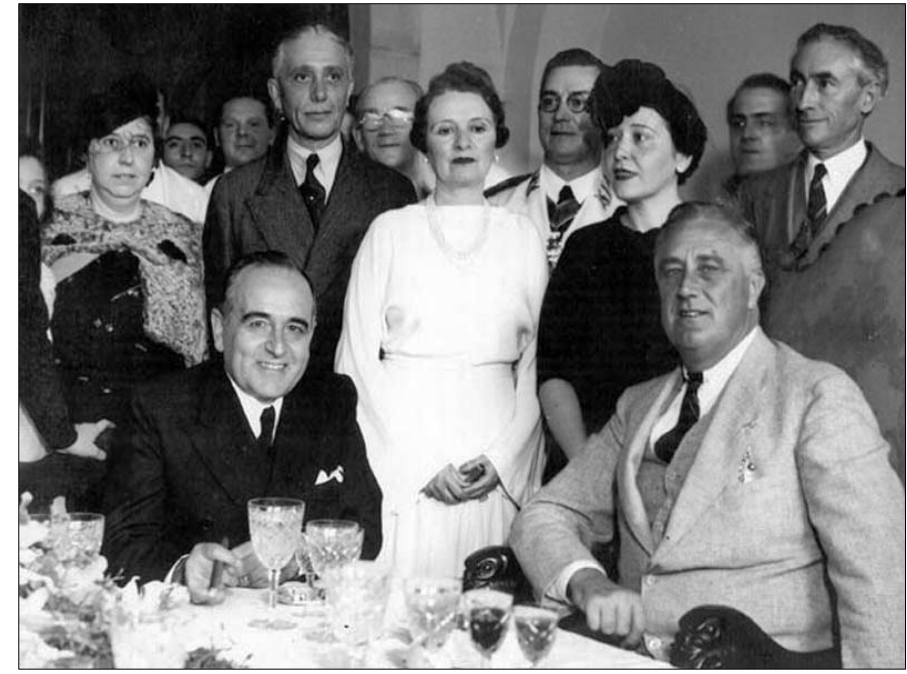

[4.15] A relação próxima entre os presidentes dos Estados Unidos, Franklin Roosevelt (à direita), e do Brasil, Getúlio Vargas (à esquerda), motiva a "Política da Boa Vizinhança" e a ampla divulgação, aqui, do american way of life.

[4.17] Orson Welles (à frente, de terno), diretor americano do projeto cinematográfico nunca concluído It's All True. Filmado no Brasil, o documentário busca revelar um Brasil repleto de qualidades, porém, ainda desconhecido nos EUA.

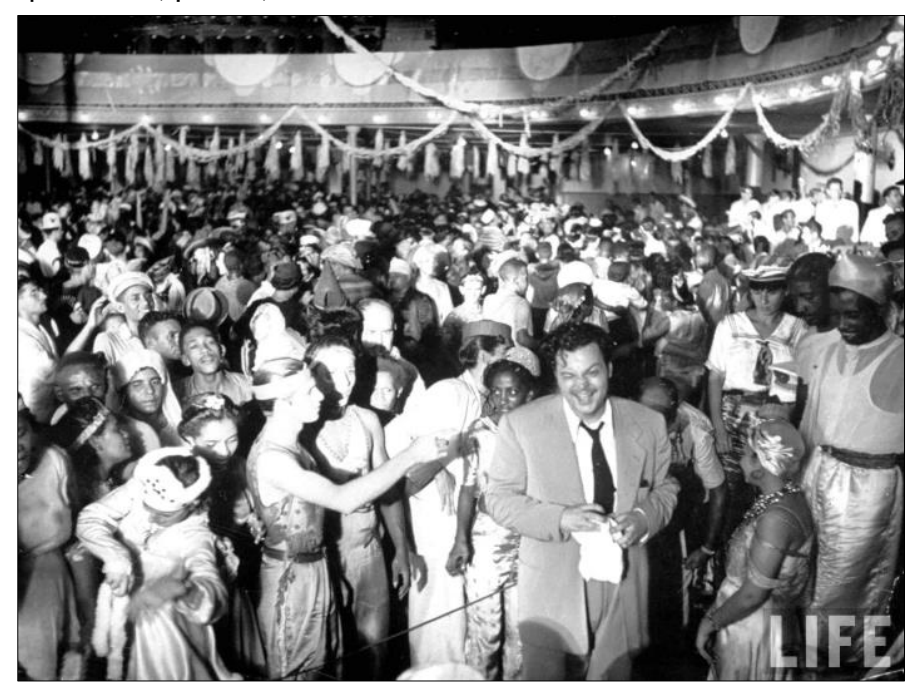

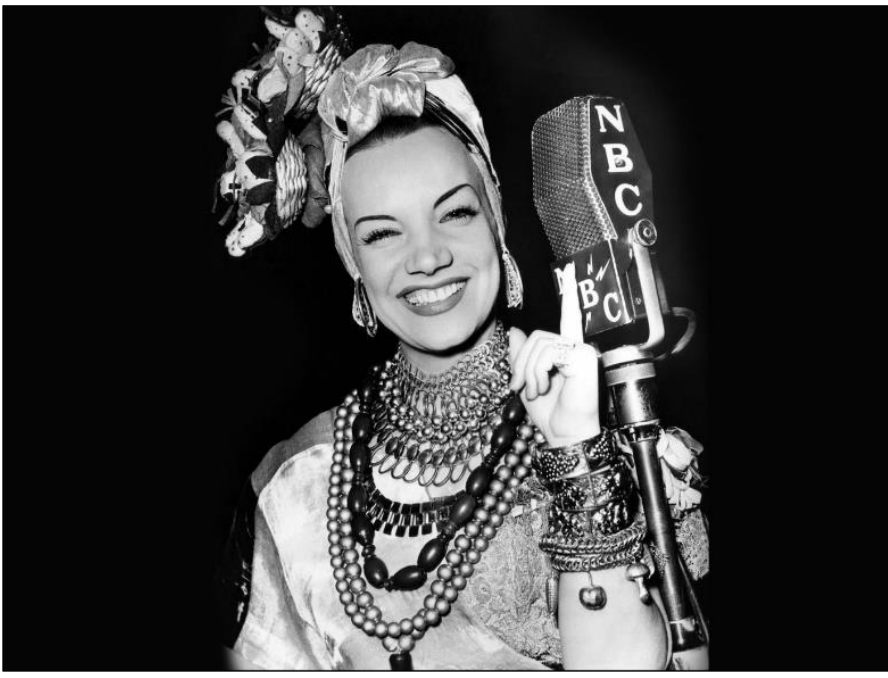

[4.16] Carmem Miranda ainda hoje é lembrada por muitos como a grande musa, nas telas de cinema, da "Política de Boa Vizinhança". É com a ajuda de sua presença marcante que uma melhor imagem do Brasil é trabalhada e divulgada mundo afora.

[4.18] No início dos anos 1940, Walt Disney realiza uma turnê pela América Latina, à pedido de Nelson Rockfeller. Como resultado de sua passagem pelo Brasil em 1941, é criado o novo personagem de desenhos animados, o papagaio Zé Carioca.

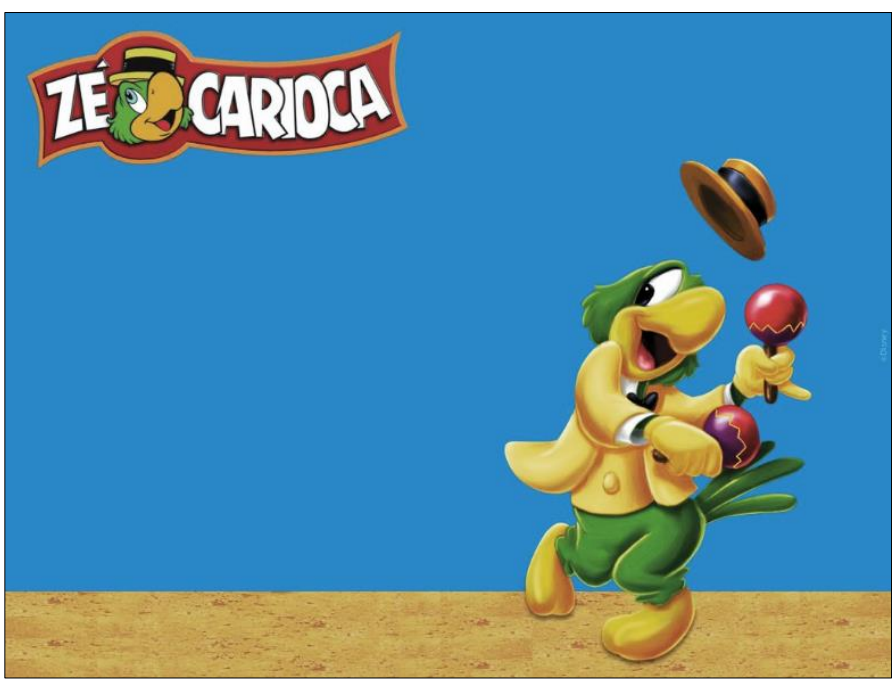




\title{
ARQUITETURA MODERNA BRASILEIRA: DESENHO NACIONAL, ALCANCE MUNDIAL
}

\author{
Estados Unidos:
}

Feira Internacional de Nova York

(Queens, Nova York , 1939)

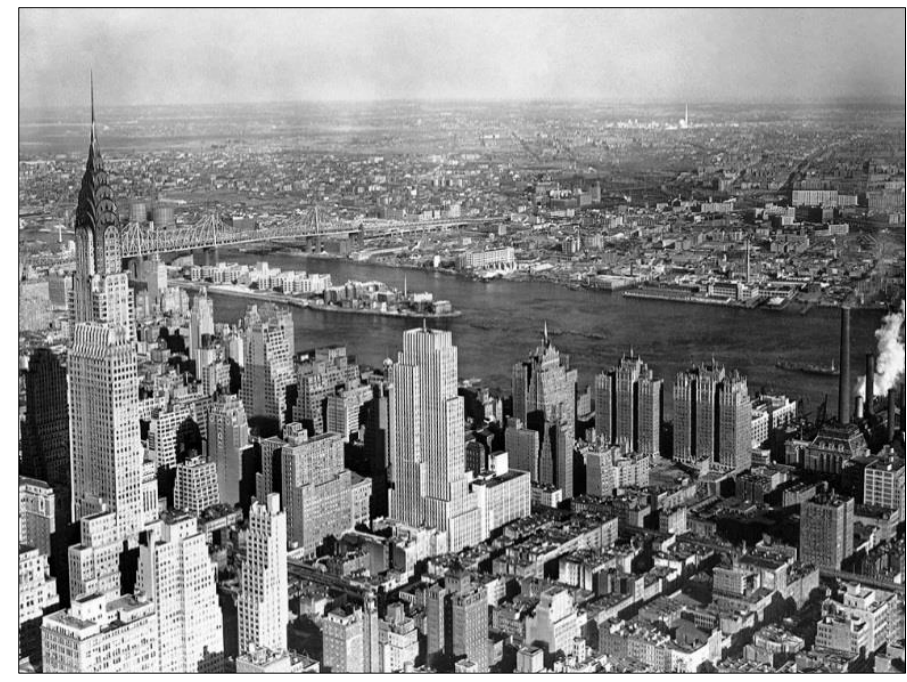

[4.19] A Feira de 1939 localiza-se no bairro do Queens (no canto superior direito, ao fundo), em Nova York, a cerca de sete quilômetros de distância do centro da cidade. É já facilmente avistada do topo do Empire State Building, em fevereiro de 1939.

[4.21] Dois símbolos da Feira de 1939: "Perisfério", ao centro: esfera estruturada em metal, com 54,0 metros de diâmetro, construída para abrigar a mostra Democracity. À direita, o "Trylon": obelisco simbólico, também metálico, com 183,0 metros de altura.

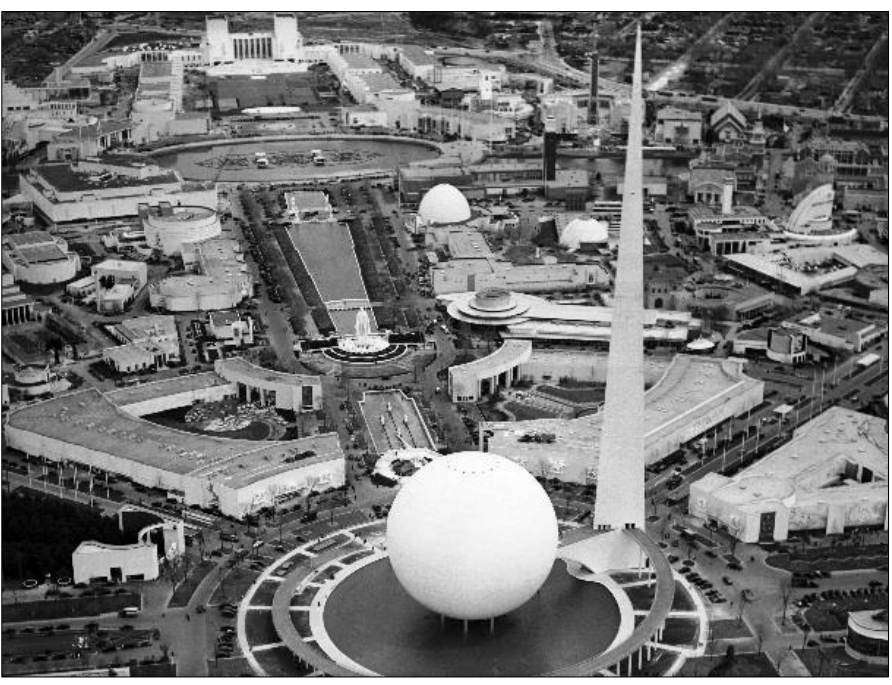

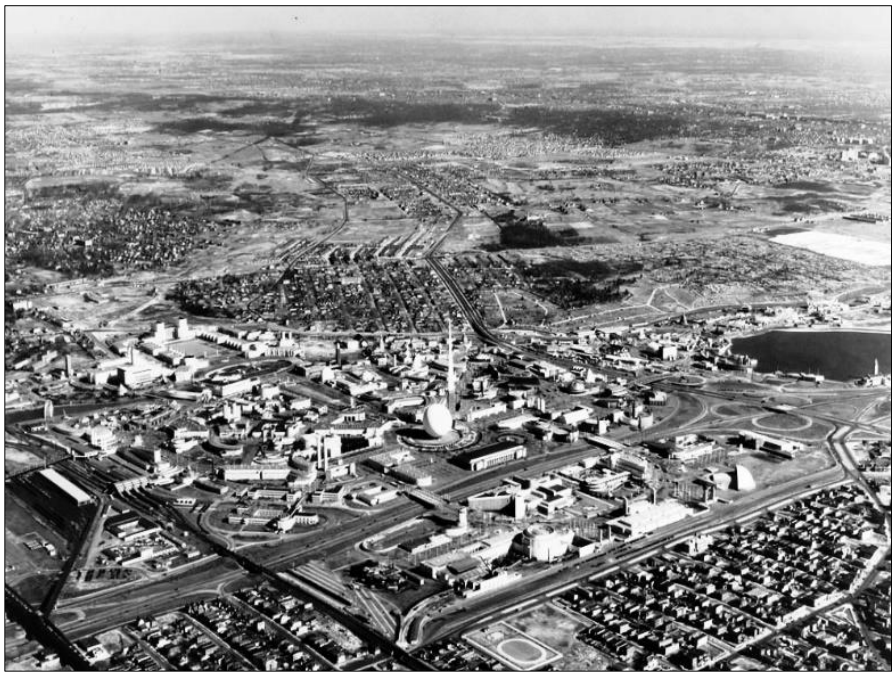

[4.20] Perspectiva aérea da Feira de 1939. Nota-se a relação do local do evento para com o entorno imediato, naquela época ainda pouco ocupado. Percebe-se também a grande escala espacial da Feira e a quantidade de edifícios erguidos para atendê-la.

[4.22] Panorâmica geral da área de implantação destinada a abrigar o importante evento americano (mas de escala mundial). No destaque, em amarelo, a localização do pavilhão brasileiro, projetado pela equipe encabeçada por Costa e Niemeyer.

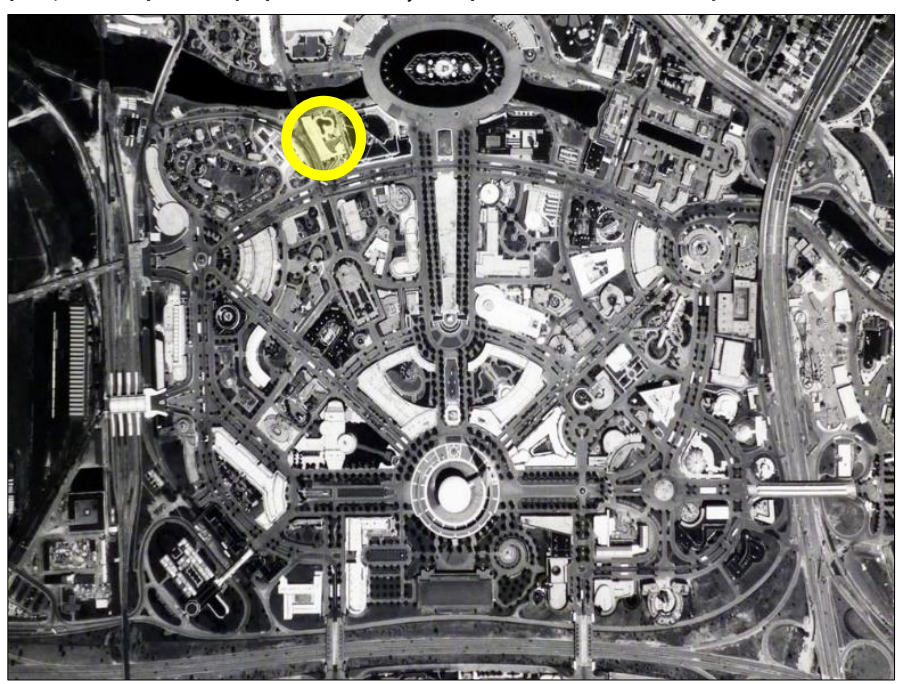




\title{
ARQUITETURA MODERNA BRASILEIRA: DESENHO NACIONAL, ALCANCE MUNDIAL
}

\author{
Estados Unidos:
}

Feira Internacional de Nova York

(Queens, Nova York , 1939)

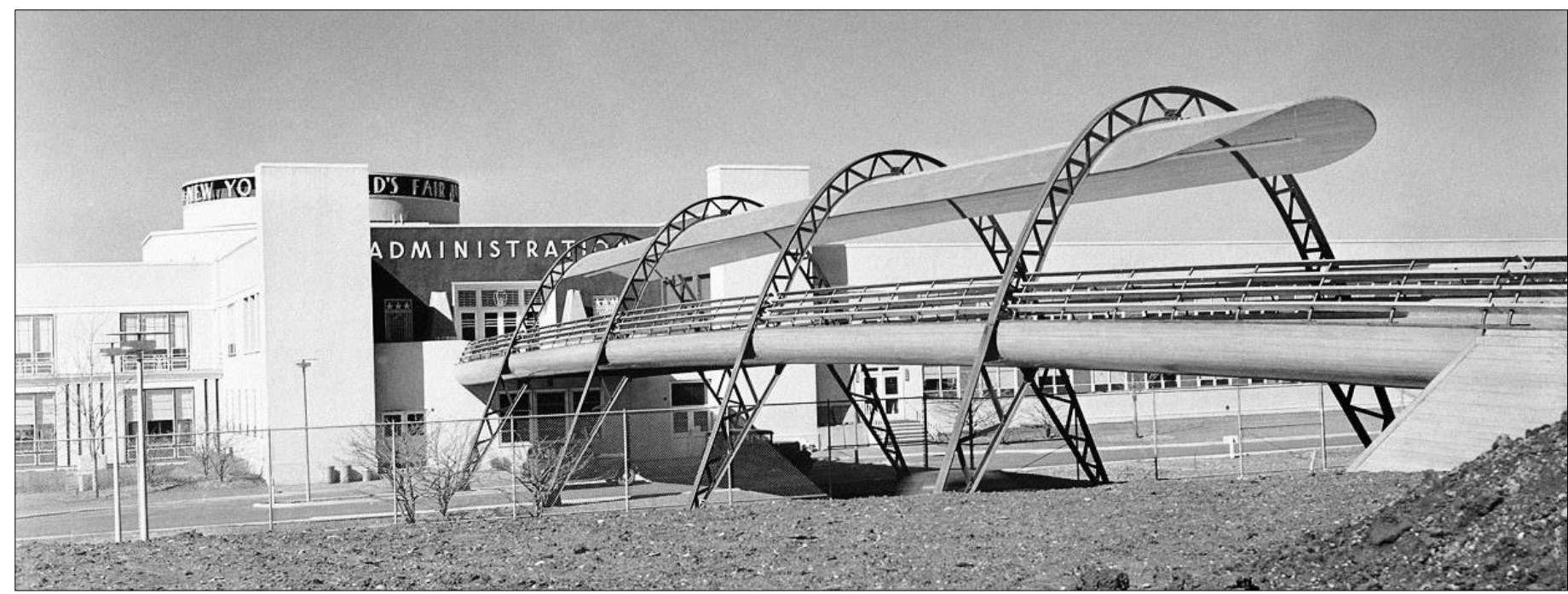

[4.23] Uma das grandes preocupações dos organizadores da Feira Internacional de 1939 recai sobre a qualidade da infraestrutura e sobre os sistemas viários, de transporte e de acessos aos pavilhões expositivos. Na imagem, ainda sob construção, uma passarela em estrutura metálica conecta o espaço externo a um dos edifícios administrativos e de atendimento aos visitantes e aos expositores.

[4.24] Grandes empresas americanas, como a General Motors, investem maciçamente em seus pavilhões, não apenas considerando os aspectos arquitetônicos das edificações em si mas, também, nos acessos e nas circulações externas.

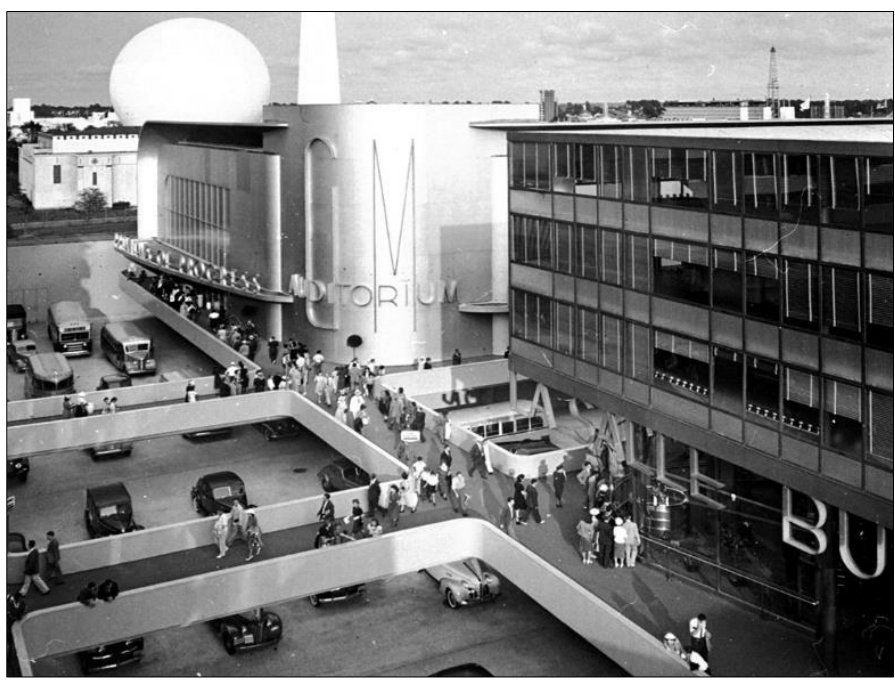

[4.25] "A Estrada do Amanhã": uma das vias elevadas de circulação de automóveis é especialmente construída para a Feira. Trata-se de um dos exemplos de grandes investimentos para o sucesso deste evento, mesmo que temporário.

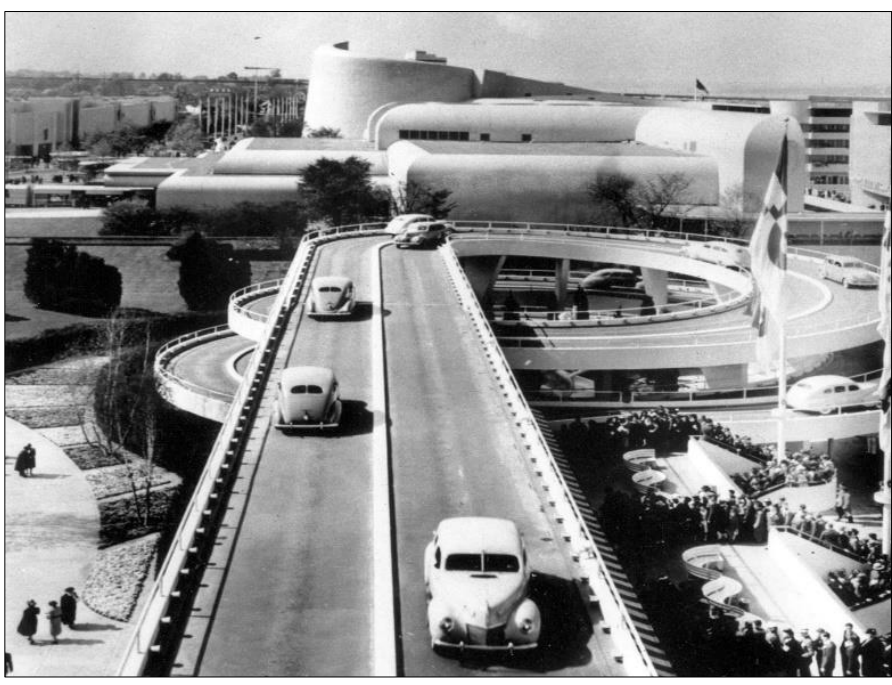




\section{ARQUITETURA MODERNA BRASILEIRA: DESENHO NACIONAL, ALCANCE MUNDIAL}

Estados Unidos:

Feira Internacional de Nova York

(Queens, Nova York , 1939)

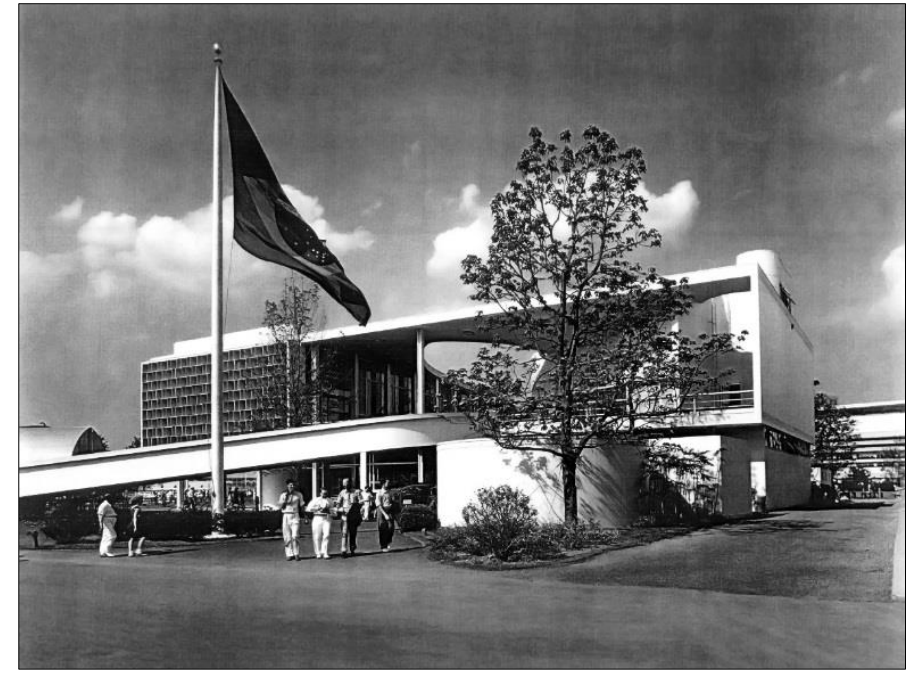

[4.26] Vista frontal do pavilhão brasileiro, a partir da qual destacamse: a rampa de acesso, os elementos vazados, a laje de cobertura com abertura sinuosa, os pilotis metálicos e as amplas áreas permeáveis para circulação de visitantes.

[4.28] Se a construção brasileira relaciona-se por contraposição ao edifício vizinho, o pavilhão francês, o mesmo não se pode dizer com o que acontece aos fundos: há plena integração entre o projeto erguido e o entorno, no caso, o Rio Flushing.

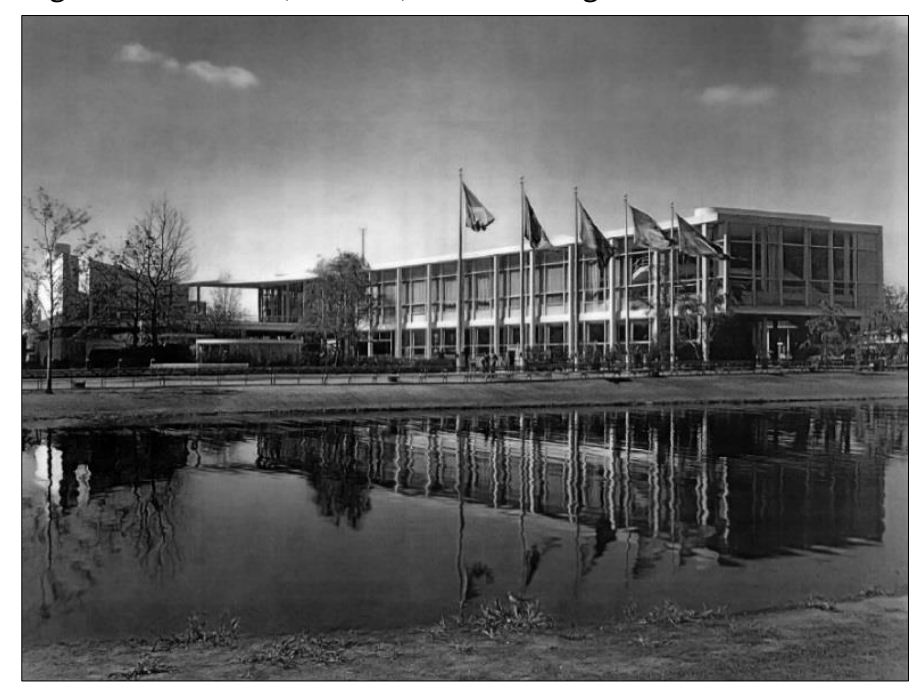

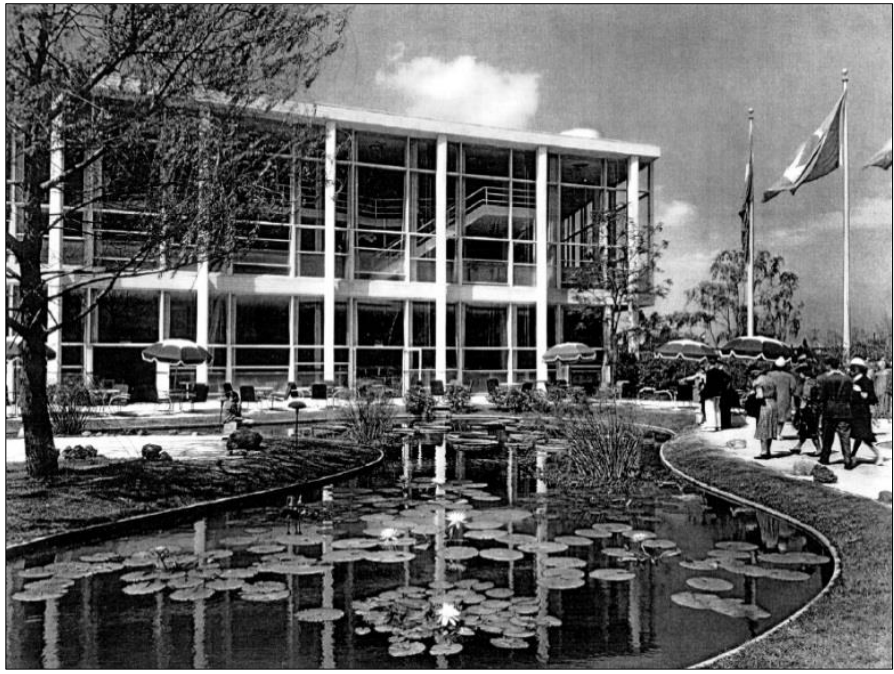

[4.27] A parte posterior do edifício recebe o jardim tropical com um generoso lago artificial. Nota-se a extensa pele de vidro que ajuda tanto no entrelaçamento das áreas externas e internas quanto nas amplas perspectivas visuais dos visitantes.

[4.29] A ondulação lateral do edifício replica o desenho da rua adjacente. Sob o volume destinado às exposições, os pilotis metálicos garantem integração espacial e leveza a todo o conjunto arquitetônico proposto por Costa e Niemeyer.

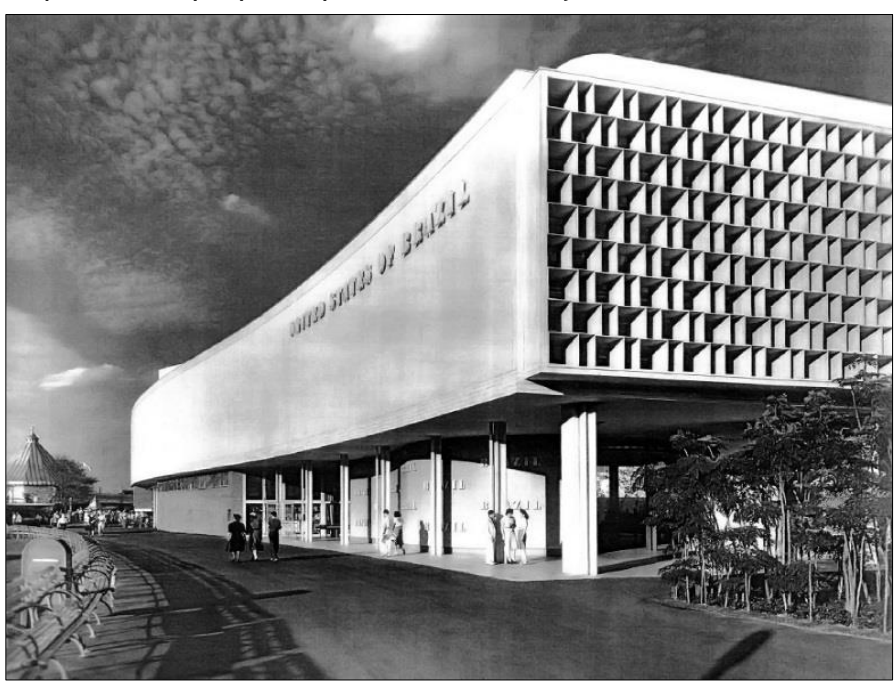




\section{ARQUITETURA MODERNA BRASILEIRA: DESENHO NACIONAL, ALCANCE MUNDIAL}

Estados Unidos:

Feira Internacional de Nova York

(Queens, Nova York , 1939)

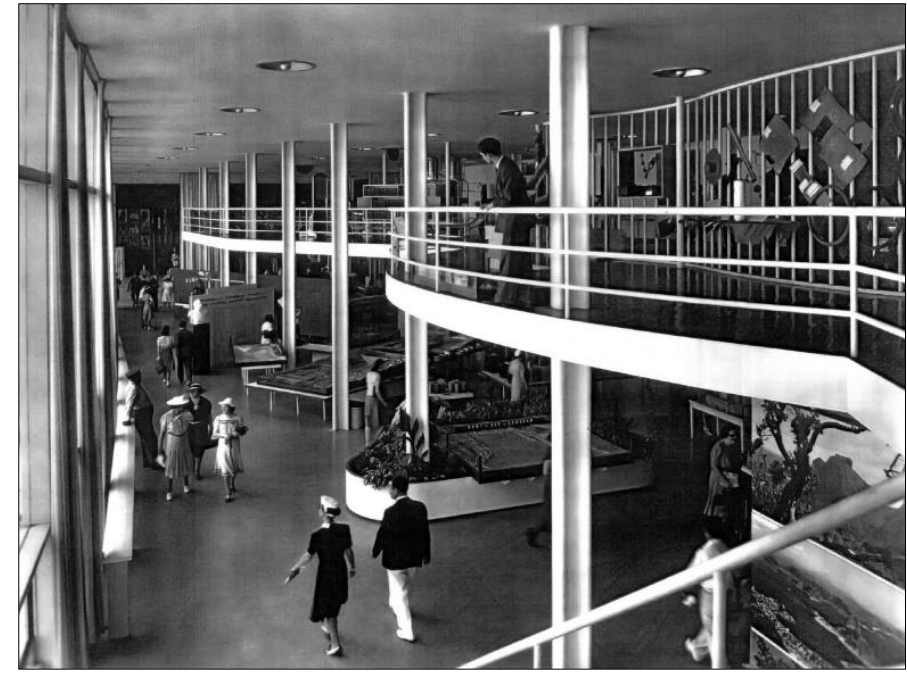

[4.30] A curvatura lateral do volume construído ecoa em diversos pontos do pavilhão brasileiro, como no sinuoso mezanino interno sustentado por pilares metálicos. A relação entre os espaços resulta coesa e a arquitetura mostra unidade plástica e formal.

[4.32] A disposição interna da mostra, desalinhada e distribuída de forma pouco convencional, é planejada pelo arquiteto Paul Lester Wiener, que em sua solução expositiva busca priorizar a circulação espacial e as amplas perspectivas visuais dos visitantes.

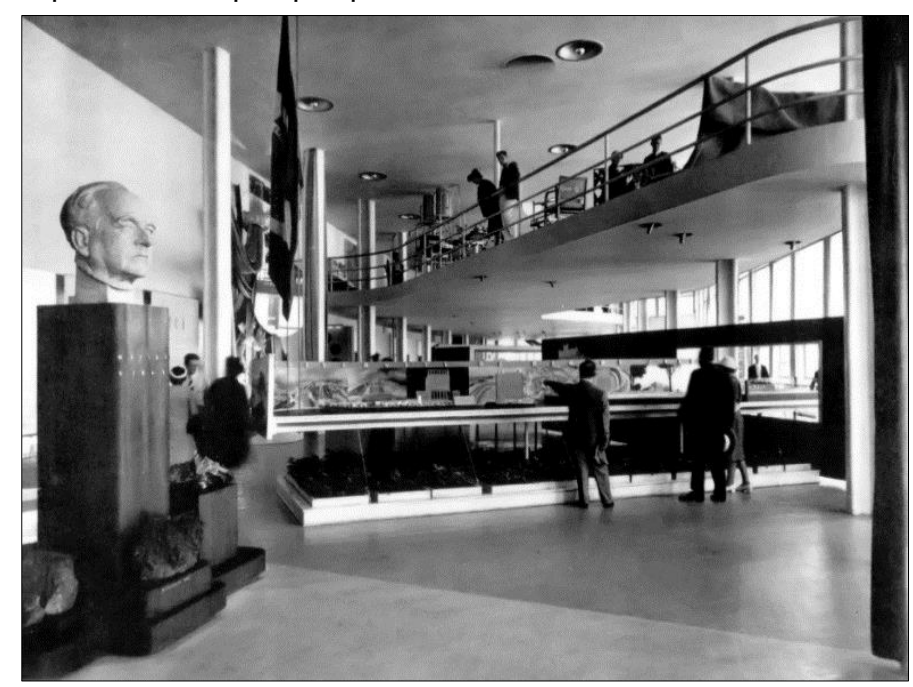

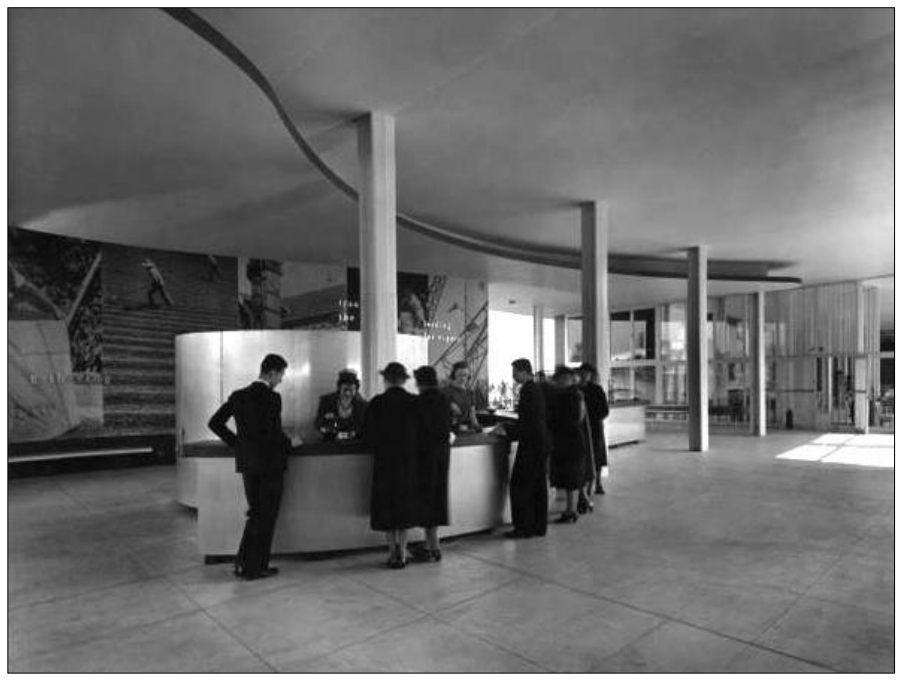

[4.31] Junto ao café, nota-se o alinhamento pouco convencional dos pilares metálicos, não retilíneo, e que propositadamente materializa a inspiração da rua externa. Nota-se que a paginação do teto rebaixado também faz referência às curvas niemeyerianas.

[4.33] Visando a integração entre arte e arquitetura, por todo o pavilhão brasileiro estão distribuídos trabalhos de artistas nacionais. No amplo salão nobre, por exemplo, encontram-se as pinturas concebidas por Cândido Portinari.

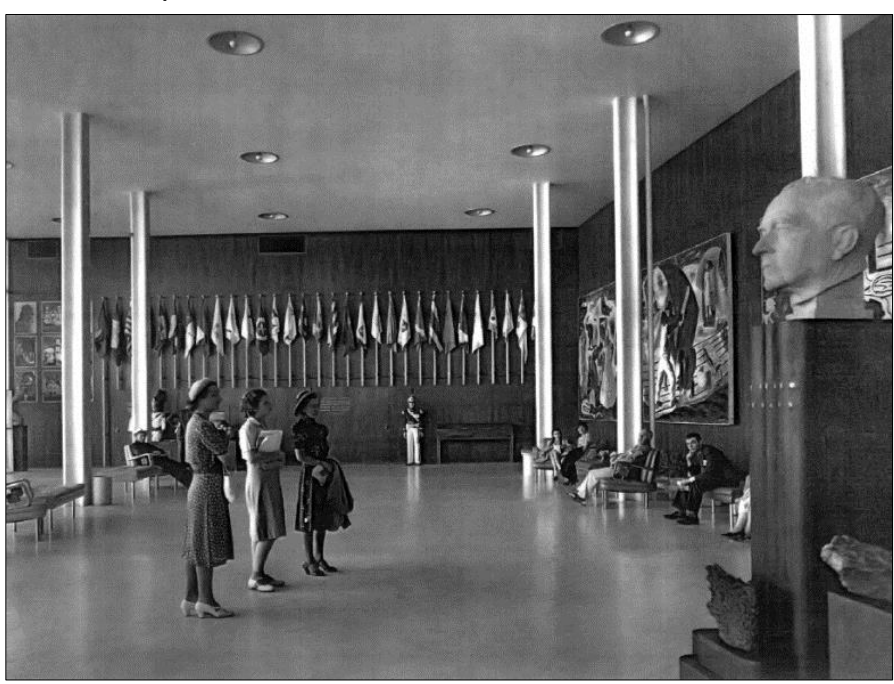


Com o passar do tempo, a trajetória arquitetônica de Oscar Niemeyer toma fôlego, transformando-o de um talentoso membro de equipes em escritórios de prestígio - como o da dupla Lucio Costa e Gregori Warchavchik - a um profissional com predicados próprios, que consegue interpretar as influências recebidas por seus maiores mestres (novamente Lucio Costa e Le Corbusier) a ponto de assumir, já como dono de sua própria empresa de arquitetura, projetos de maior vulto, responsabilidade e dificuldade e a eles imputar uma identidade muito particular e difícil de ser negada.

Tome-se como exemplo o ano de 1939, no qual ele recebe a incumbência de desenhar dois importantes projetos no cenário arquitetônico nacional. Primeiramente, do Serviço do Patrimônio Histórico e Artístico Nacional (SPHAN) então dirigido por Rodrigo Mello Franco de Andrade, parte o aceite de seu nome (anteriormente indicado por Lucio Costa) para a elaboração do Grande Hotel de Ouro Preto [Figuras 4.34 - 4.36], um desafio embasado na contextualização de um edifício moderno, novo e "de grande porte, a ser inserido no setecentista tecido urbano preservado da capital do ciclo de exploração de ouro na então província de Minas Gerais". (SEGAWA; 2010: 96)

Cavalcanti (2006) explica que, antes do aceite da solução final, o projeto de Niemeyer é submetido a uma bateria de revisões a fim de incorporar as orientações vindas de Lucio Costa e da diretoria do SPHAN quanto à pertinência de sua ideia inicial, especialmente no que se refere à substituição da laje plana ajardinada pela cobertura com telhas de barro, mais indicadas, segundo eles, para mimetizarem-se às tradicionais construções da malha urbana da cidade histórica de Ouro Preto.

Em linhas gerais, a obra apresenta volumetria horizontalizada com quatro pavimentos, utilização de pilotis para acompanhar as curvas de nível em um lote com declive acentuado, telhamento colonial inclinado de barro, treliças em madeira para fechamento dos terraços, pilares externos de concreto com seção quadrada e balcões na fachada dispostos em sequência ao longo do extenso comprimento longitudinal do hotel. Entretanto, o edifício construído prova-se interessante, mas resulta em um efeito morno e sutilmente desarmônico em relação à paisagem do entorno. A partir daí, no entender de Segawa (2010), pode-se apreender que o Grande Hotel de Ouro Preto comporta-se como 
o ponto inicial de uma atitude em que a conveniência do "novo" dentro do "velho" se realiza com a ética de evidenciar a inserção nova na trama antiga atribuindo-lhe identidade própria - isto é, o novo não copia o antigo buscando confundir o presente com o passado, de modo que a arquitetura antiga seja reconhecida e valorizada por ser a genuína, distinguindo-se das imitações". (SEGAWA, 2010: 98)

O segundo projeto relevante conferido ao arquiteto carioca no ano de 1939 é o Conjunto Arquitetônico da Lagoa da Pampulha, em Belo Horizonte [Figuras 4.37 - 4.61]. Esta também é uma das obras niemeyerianas destacadas pela mostra "Brazil Builds", contudo, de forma incompleta, já que de todos os edifícios que a compõem, a Capela de São Francisco de Assis ainda está sendo erguida quando da visita de Goodwin e Kidder-Smith ao Brasil, em 1942. Assim sendo, da exposição fazem parte, somente, os demais três edifícios: o Cassino, a Casa do Baile e o late-clube. No livro/catálogo derivado da mostra, aos três são oferecidas doze páginas compostas por descrições, desenhos e fotografias. Vale ressaltar que, além destas quatro obras construídas entre 1940 e 1943, o planejamento original prevê também um Clube de Golfe (construído, porém, praticamente sem repercussão junto à crítica especializada e atualmente abrigando outra função: a da Sede Administrativa do Zoológico de Belo Horizonte) e um Hotel Resort (que, por motivos diversos, nunca foi concretizado).

O desejo de ter Oscar Niemeyer como projetista dos edifícios mineiros surge no final da década de 1930, quando o então prefeito de Belo Horizonte, Juscelino Kubitschek acata a recomendação do diretor do SPHAN, Rodrigo Mello Franco de Andrade e oferece este projeto ao arquiteto carioca com o intuito de criar um bairro inspirado nas cidadesjardim norte-americanas e voltado predominantemente às classes mais abastadas da capital mineira. Como bem lembra Recamán (1996), não se pode deixar de lado que, em verdade, Pampulha mostra-se contraditória a um momento politicamente delicado para o país, tendo em vista que o Brasil enfrenta, entre as décadas de 1930 e 1940 , um dos períodos mais severos da ditadura do Estado Novo promovida, como visto anteriormente, pelo presidente Getúlio Vargas. Assim sendo, investir em um empreendimento desse porte e direcionado à burguesia soa, no mínimo, incoerente.

Afastado cerca de dez quilômetros do centro de Belo Horizonte, o novo bairro inicialmente apresenta acesso restrito a boa parte da população da cidade devido à falta de infraestrutura adequada e aos sistemas viário e de transporte insuficientes. É também posicionado ao longo das margens de uma lagoa artificial, nas quais pretende-se distribuir novos equipamentos de lazer e de turismo para incentivar a vida social de seus moradores/frequentadores - tudo isso permeado por áreas verdes cuidadosamente planejadas e articuladas por Roberto Burle Marx e que remetem, em larga escala e guardadas as devidas proporções, às cidades-jardim norte-americanas. 
Uma das principais preocupações de Niemeyer na elaboração do projeto recai na necessidade de tirar o maior proveito possível das qualidades paisagísticas do entorno, do sítio de implantação de cada uma das construções e da unidade do conjunto arquitetônico como um todo. Underwood (2003) menciona que as obras do Conjunto da Pampulha não são inicialmente idealizadas como um grupo de peças inter-relacionadas, mas como elementos independentes que valorizam a individualidade de quem delas desfruta. "As construções têm em comum o compromisso com o prazer da liberdade e um interesse por inovações formais e estruturais. Na verdade, tudo foi pensado com relação ao encanto em meio ao cenário natural não corrompido" (UNDERWOOD; 2003: 54). A coesão arquitetônica entre os elementos autônomos de Pampulha é evidenciada por Recamán (1996), ao mencionar que a visibilidade atua como fator de amarração do conjunto, ou seja, a exposição clara e desobstruída dos edifícios a partir do interior de cada um deles atua concomitantemente à sua revelação e percepção imediata aos usuários.

Tal a importância das obras de Pampulha que é possível assumir, no entender de Segre (2007), que elas representam o ponto de partida para uma nova linguagem arquitetônica praticada por Niemeyer a partir da qual ele "abandona a ortodoxia racionalista cartesiana e começa a utilizar as formas curvas que caracterizam as cascas da lgreja e a laje sinuosa da Casa do Baile" (SEGRE; 2007: 34). Trata-se, assim, da concepção de um trabalho que gradualmente se distancia da sintaxe corbusiana ao passo que se aproxima de uma "expressão mais pessoal, decerto amadurecida com a sua experiência nova-iorquina" (SEGAWA; 2010: 98). Gera-se como consequência e a partir deste projeto, a oportunidade em que "Oscar Niemeyer estrutura sua linguagem de arquiteto, organiza seu repertório formal próprio e estabelece uma relação de maneira simples e clara entre essas formas, colocando diante de seus mestres inspiradores, Lucio Costa e Le Corbusier, novas perspectivas para ambos". (VALLE, 2000: 176)

Recamán (1996) tem posição partidária às considerações dos autores acima e vai além ao discutir que, no pavilhão do Brasil para a Feira Internacional de Nova York de 1939, a posição assumida pela dupla de arquitetos brasileiros é a de buscar uma repaginação dos princípios da arquitetura moderna visando comprovar os momentos nos quais o Brasil pode se destacar em função de suas especificidades e particularidades (como na unidade interna do edifício e no seu diferencial externo, quando comparado às demais construções do evento nova-iorquino). 0 mesmo autor assume que é em Pampulha que,

sobre tal fundamento será definitivamente mapeado o vocabulário formal dessa arquitetura - pois aí se já se tratava apenas disso. Completa, essa encomenda "principesca", a base necessária para o termo do processo de formação da arquitetura brasileira. Oscar Niemeyer vai aí definir algumas 
estruturas-forma - não são tipologias - que serão a partir daí utilizadas em diferentes funções, escalas, contextos, terrenos, etc. (RECAMÁN; 1996: 167)

Fato é que essa transformação projetual niemeyeriana não acontece de uma hora para outra. Diz Comas (2009) que a influência de Le Corbusier é sem dúvida fundamental para Niemeyer desenvolver suas habilidades inatas e, com o tempo, tornar-se o responsável tanto pelo alargamento quanto pelo enriquecimento da linguagem arquitetônica moderna, quem sabe alinhando seus feitos às realizações do próprio mestre franco-suíço. O autor prossegue e enfatiza que, mesmo no passado (especialmente entre 1930 e 1935), Niemeyer já dá sinais de complementar a obra corbusiana. É a época em que ele tem contato direto com Le Corbusier (quando este vem ao Brasil pela segunda vez e atua como consultor no projeto do Ministério da Educação e Saúde), e esta experiência desvela em Niemeyer a capacidade de completa apreensão das aspirações sistêmicas propostas pelo mestre europeu e o faz conquistar, por fim e anos depois, resultados bastante singulares que passam a lhe ser muito característicos em seus trabalhos vindouros.

Entre a década de 1930 e a construção de Brasília, por exemplo, Niemeyer profissionaliza cada vez mais o seu talento. Os trabalhos que desenvolve atingem novos patamares e fazem dele um arquiteto que se destaca pela constante releitura das influências semeadas por Le Corbusier e por Lucio Costa. Niemeyer não apenas abraça a estratégia projetual do "Sistema Domino" como também potencializa seu campo de aplicação ao incorporá-la, definitivamente, ao seu fazer arquitetural. O projeto dos edifícios às margens da Lagoa da Pampulha representa, por assim dizer, o exemplo de um grupo de obras notáveis que materializa as novas possibilidades arquitetônicas e estruturais conquistadas pelo arquiteto carioca e a equipe com a qual trabalha.

Cavalcanti e Lago (2005) assumem que, se o Ministério da Educação e Saúde materializa uma resposta nacional à altura do que de mais interessante se produz nas décadas de 1930 e 1940 fora do país, o conjunto arquitetônico da Pampulha comprova que ao menos um arquiteto brasileiro tem capacidade para ir além e exercer influência sobre a própria arquitetura moderna. Além disso - continuam os autores - a conformação de uma chamada "Escola Brasileira" ajuda na sustentação da performance positiva, em terras estrangeiras, que o Brasil desempenha à época. Essa percepção fica evidenciada e reforçada, por exemplo, pela projeção internacional recebida pelas obras paisagísticas de Roberto Burle Marx. 
O conjunto arquitetônico da Lagoa da Pampulha é tão importante em sua carreira que o próprio arquiteto afirma que sua obra inicia-se mesmo naquele instante, a partir do qual a liberdade plástica passa a responder, no seu entender, a todas as exigências do concreto armado. Para Niemeyer (2000), o projeto mineiro deve ser encarado como uma chance de questionar não apenas a uniformidade monótona praticada pela arquitetura daquela época, mas também um dito funcionalismo que sequer é plenamente compreendido e que cerceia, por meio de suas definições limitadoras e de seus princípios ortodoxos, as possibilidades estéticas que o concreto armado desencadeia.

Vale lembrar que, como já comentado, antes mesmo de Pampulha, a plasticidade das formas livres já é adotada na arquitetura niemeyeriana, porém, mais timidamente ou com um caráter, quem sabe, mais experimental e discreto. Tanto é fato que os volumes das caixas d'água da cobertura do Ministério da Educação e Saúde (MES) são curvos, como também o são o auditório e a longilínea empena cega que comporta as áreas expositivas e que acompanha o arqueamento do terreno do pavilhão do Brasil na Feira Internacional de 1939, em Nova York.

Em Belo Horizonte, o amadurecimento arquitetônico de Niemeyer concretiza-se pela utilização mais enfática de elementos de formas curvas. Esses elementos curvos estão no Cassino (representados pelo volume destacado que abriga o restaurante e a pista de dança), tanto no corpo principal quanto na marquise sinuosa da Casa do Baile e, principalmente, na cobertura do edifício mais emblemático deste conjunto de obras: a Capela de São Francisco de Assis. Assim, o arquiteto tira partido das curvas para opor-se à ortogonalidade exacerbada da arquitetura moderna praticada até então, assumindo, por fim, uma liberdade de projeto fundamentada na plasticidade do concreto armado e na ressignificação dos ensinamentos herdados de Le Corbusier e de Lucio Costa.

Cumpre admitir que o resultado arquitetônico positivo alcançado pelo conjunto da Lagoa da Pampulha somente é conquistado mediante o trabalho integrado de diferentes profissionais que, a partir de suas experiências anteriores, unem-se em favor do sucesso de um único empreendimento. Para a construção, foi chamada a Construtora Rabello S.A., vinda de Diamantina e fundada em 1945. A parceria com esta empresa rende frutos positivos, tanto é fato que ela é uma das contratadas para participar da construção de Brasília no final de década de 1950, especificamente erigindo os Palácios da Alvorada e do Supremo Tribunal Federal. No que tange ao cálculo estrutural, a equipe capitaneada por Niemeyer convida o engenheiro civil recifense Joaquim Maria Moreira Cardozo $^{9}(1897$ - 1979), antigo

\footnotetext{
9 De todos os edifícios da Pampulha, apenas a Casa do Baile não é projetada por Joaquim Cardozo. Neste caso, cálculo estrutural fica a cargo do engenheiro civil Albino Froufe.
} 
conhecido dos tempos do SPHAN do Rio de Janeiro. É este o início de uma parceria pessoal e profissional mais ativa e próxima que estende-se por anos e que rende inúmeros edifícios canônicos à arquitetura brasileira.

Além de ser um profissional que domina diversos campos do conhecimento (literatura, poesia, teatro, artes plásticas, topografia, engenharia, teoria e história da arquitetura) e de lecionar e atuar como engenheiro calculista de estruturas arquitetônicas, Rebello e Leite (2007) sugerem que Cardozo possivelmente detenha uma maneira muito própria e característica de trabalho, especialmente no que diz respeito à concepção de tipos estruturais. Isso é demonstrado nas oportunidades em que o engenheiro não adere às normas técnicas de edificação vigentes à sua época em prol de alcançar soluções estruturais inéditas que mais bem se adaptem, no seu entender, aos projetos arquitetônicos inovadores dos quais participa.

E Pampulha mostra-se como a chance que Cardozo tem de traduzir a poética niemeyeriana em realidade solidificada, como ele mesmo acredita. Os mesmos autores colocam ainda que isso não significa dizer que o engenheiro desconsidere ou despreze os cálculos estruturais normatizados, mas, sim, que especule novos campos de atuação e que proponha, sempre que possível, inovações matemáticas e construtivas jamais usadas anteriormente. Desnecessário dizer, contudo, que as investigações mais profundas e detalhadas de Joaquim Cardozo ocorrem somente nos casos excepcionais, nos quais aquilo que já é normatizado e válido não pode ser diretamente utilizado. Em casos mais particulares e inovadores de fato, passa a valer a sua propensão pela pesquisa e pelo desenvolvimento de novas técnicas e tecnologias.

Se Oscar Niemeyer dedica um tempo importante de sua carreira para compreender os princípios pregados pela arquitetura corbusiana, absorvendo-os e expressando-os, por fim, em seu próprio vocabulário, permitindo que sua obra seja lida a partir de uma linguagem que toma forma gradativa e constantemente, o mesmo processo de amadurecimento e de evolução pode ser verificado em um só local: no Conjunto Arquitetônico da Lagoa da Pampulha. Da primeira à última obra construída (isto é, do Cassino à Capela de São Francisco de Assis), o arquiteto carioca transforma-se e supera-se, saindo de uma dita zona de conforto na qual aplica as influências recebidas da arquitetura moderna de Le Corbusier e sutilmente imputa-Ihes uma feição própria. Essa característica de projeto de Niemeyer é trabalhada sucessivamente até culminar em uma nova e arriscada proposta conceitual que guarda referências ao "Sistema Domino", porém, de maneira subvertida e relida por meio da criação de uma nova possibilidade arquitetônica que tira proveito direto da engenharia de estruturas para apreendê-la como a própria arquitetura em si 
(e, para este caso, a participação próxima das equipes técnicas é, por certo, fundamental). Uma das qualidades projetuais que distancia Oscar Niemeyer de seus colegas arquitetos - dentre eles o mestre Lucio Costa - pode ser atribuída por sua postura proativa em relação à técnica e à tecnologia, como mostra Katinsky:

A lição de Oscar Niemeyer dirige-se no sentido contrário ao dos grandes arquitetos acadêmicos franceses, herdeiros da ideologia das luzes. Por efeito talvez da lição de Boullée e Durand, a tendência dos arquitetos do século 19 foi apropriar-se dos avanços técnicos já consagrados, às vezes com 30 anos de experiência técnica comprovada, e incorporá-los na nova ordem espacial por eles proposta, sem nada exigir dessa mesma técnica, ajustando-se com maior ou menor felicidade ao status quo técnico do momento. Modelos dessa postura foram Grandjean de Montigny, no Brasil e Henry e Theodore Labrouste e Charles Garnier, na França, cuja ópera tem sido reproduzida continuamente, desde sua inauguração (1875), mesmo por seus detratores.

Coube, entretanto, a alguns arquitetos da escola de Chicago, nos Estados Unidos, e artistas Art Nouveau na Europa inverter essa situação: admiradores dos grandes êxitos dos engenheiros de seu tempo, mas não contentes com a anterior atitude de passividade perante a técnica, configuraram em função de seus conteúdos programáticos, exigências crescentes aos tecnologistas contemporâneos e, por isso mesmo, contribuíram poderosamente para a evolução da própria técnica de seu tempo.

Niemeyer expõe com meridiana clareza essa segunda postura, diferenciando-se de Lucio Costa, este muito mais aderente aos preceitos e orientações da grande Escola Francesa.

Sua obra nos propicia uma releitura da arquitetura do século passado, permitindo-nos uma conceituação clara do que permanece das lições do passado para a construção do futuro. Conhecidos inventores estruturais de nosso tempo, como Felix Candela, Frei Otto, Santiago Calatrava ou mesmo Renzo Piano mostram em suas obras, leitura e afinidades com a obra de Oscar Niemeyer. (KATINSKY; 2007: 61)

Todavia, antes de tecer uma investigação mais detida e completa sobre essa última edificação emblemática de Pampulha, é interessante que se trace aqui uma visão geral e global sobre as demais construções - visão essa intencionalmente sem o devido aprofundamento que lhes possam fazer jus - a fim de compreendê-las como importantes produções arquitetônicas por si mesmas, suas inter-relações e as preocupações projetuais que Niemeyer teve ao concebê-las.

De 1940, o Cassino [Figuras 4.37 - 4.43] - obra inaugural do Conjunto, desativado logo após sua abertura e convertido em 1957 no Museu de Arte da Pampulha - destaca-se pela sobriedade volumétrica pontuada por momentos de expressão livre e mais pessoal de seu arquiteto projetista. Para Queiroz (2007), isso significa dizer que este projeto assume, como nenhum outro projeto de Oscar Niemeyer, "o exato limiar entre o respeito e a libertação" (QUEIROZ; 2007: 151) para com Le Corbusier. De acordo com Valle (2000) e Recamán (1996), o Cassino não apenas expressa citações ao repertório corbusiano, mas também incorpora elementos originados no MES. Rampas posicionadas 
praticamente no centro da edificação e planta em formato quadrangular pousada sobre pilotis aludem à Villa Savoye, de 1929, projetada por Le Corbusier. Do salão de exposições do Ministério da Educação e Saúde, de 1936, projetado por Lucio Costa e equipe, Niemeyer toma emprestada a relação entre pilotis que se sobrepõem aos extensos panos de vidro de alturas variadas encimados por grandes lajes planas horizontalizadas. Nos quesitos estruturais, Valle comenta que, no Cassino de Pampulha,

\begin{abstract}
Joaquim Cardozo utiliza os mesmos procedimentos técnicos empregados por Emílio Baumgart no que se refere aos sistemas invertidos de pilotis, liberando os pilotis e engastando a marquise nas colunas, na verdade, uma variação estrutural dos procedimentos utilizados no salão de exposições do MES. Porém, tratou sua planta estrutural de forma ortogonal e quase quadrada no que se refere ao salão de jogos do Cassino. Contrariamente a Le Corbusier na Villa Savoye (1929), onde as quatro fachadas foram tratadas como uma "única", igualadas pelas janelas longitudinais, Niemeyer tratou as três superfícies das fachadas expostas na forma prismática do Cassino da Pampulha de maneiras diferentes. (VALLE; 2010: 139)
\end{abstract}

O Cassino é inicialmente pensado para ser o centro de atenção de todo o projeto a partir do qual as demais edificações organizam-se e distribuem-se (daí ser ele o primeiro prédio construído no novo bairro belo-horizontino). Estrategicamente posicionado no promontório de uma península, sua localização permite uma vista panorâmica para a lagoa e favorece com que ele seja também contemplado de qualquer ponto externo [Figura 4.37]. A solução de Niemeyer tira proveito do relevo do terreno e da alternância de volumes planos e curvos, de cheios e vazios e de luzes e sombras para compor uma arquitetura que dialoga abertamente com seu sítio de implantação e com os demais elementos do conjunto [Figura 4.38]. Segawa descreve-o como "uma contrastante combinação de um volume prismático regular, de rigorosa modulação estrutural - explorando a liberdade de ordenação dos espaços internos proporcionados pelos pilotis - associado ao curvilíneo e translúcido corpo que abriga a pista de dança". (SEGAWA; 2010: 99)

Há, aqui, uma contraposição entre o volume posterior ovoide (ou, segundo Comas (2007), em formato de tambor) em relação à ortogonalidade das construções principais: uma, maior e frontal, remete a uma caixa prismática em cujo interior está instalado o amplo salão de jogos. Uma galeria envidraçada costura esta caixa maior ao bloco menor que, por sua vez, é retilíneo e encontra-se posicionado lateralmente ao maior volume, abrigando cozinha e demais áreas de serviços e de apoio. O confronto entre elementos retos e curvos ressoa também tanto na parede arqueada do térreo quanto na marquise de formato irregular [Figura 4.39], sustentada por delgados pilaretes metálicos cilíndricos ou no volume ameboide que encerra a caixa d’água na cobertura. Mais uma oposição pode ser anunciada no 
posicionamento verticalizado dos caixilhos externos, quando relacionados à predominância horizontal da construção, ou mesmo na leveza das cortinas de vidro que domam boa parte dos fechamentos externos e a robustez não só dos pilares cartesianamente modulados, mas também das paredes cegas exteriores. De acordo com Comas (2007), é possível identificar uma nova contraposição ao ser examinada a seriedade de acabamentos externos versus a riqueza das materialidades internas [Figuras $4.40-4.41$ ]:

O contraste é reiterado nos materiais escolhidos, tanto por razões pragmáticas quanto representativas: o revestimento em travertino das colunas, bordos de laje, platibandas e paredes reforça a aura de elegância imponente associada à simetria e à ordem colossal, enquanto azulejos industriais em padrão Império cobrem parapeitos, misturando a serialidade com conotações domésticas locais. [...] Niemeyer monta um cenário rigorosamente faiscante para os rituais de dissipação mundana. As colunas são prateadas e brilhantes. O piso é mármore e amarelo, as rampas ostentam seu ônix esverdeado. Espelhos de bronze vestem a parede da galeria que une caixa, bloco e tambor. (COMAS; 2007: 8)

De acordo com Cavalcanti (2006), é a partir do primeiro andar que se tem acesso ao volume circular, situado sobre o restaurante, o bar e a pista de dança. A transição do elemento curvilíneo para a caixa principal é regida por uma escada envidraçada em forma de "S", colocada propositadamente na parte de fora do edifício [Figuras 4.42 - 4.43]. Para Valle (2000), esta é uma das mais significativas soluções adotadas no projeto, tendo em vista que, por meio ela, estabelece-se uma percepção espacial equilibrada e unificada entre o volume ovoide que fica para traz quando se desce a escada e aquele que se descortina logo à frente, destinado ao salão de jogos. Há, aqui, uma compensação volumétrica em ambas as formas, definida por uma delicada e sutil interpenetração de espaços.

No momento em que são analisadas as áreas destinadas ao salão de jogos e de serviço, percebe-se, como confirma Gonçalves (2010), que há forte inspiração na arquitetura racionalista, seja pelo formato ortogonal dos ambientes propriamente ditos, seja pela frequência compassada dos pilares. Já no volume cilíndrico, posterior, Niemeyer experimenta novos horizontes, mais flexíveis e com a possiblidade de adaptações às mais variadas configurações solicitadas pelos eventos ali promovidos. "Aqui, Niemeyer encontra-se em um importante momento de transição entre os preceitos de Le Corbusier e a ocasião propícia para experimentar seu próprio modo de conceber arquitetura, reintroduzindo a curva, banida do movimento moderno". (GONÇALVES; 2010: 52)

No entender de Valle (2000), esta obra de Oscar Niemeyer é norteada por um processo de adições frequentes e sequenciais, a partir das quais o arquiteto carioca elabora a coordenação dos espaços internos tornando-os, todos, um único elemento que exala unidade e coesão projetual. Em consonância com o que dizem Segawa (2010) e Comas 
(2007), Katinsky (2007) interpreta o Cassino como um jogo bem articulado de contraposições, contrastes e adições, no qual a regra, para ele, é ditada pela relação entre as normas projetuais da arquitetura purista corbusiana e seu embate com o programa antecipadamente estabelecido. O mesmo autor mostra que, neste projeto, há uma diferença conceitual entre Le Corbusier e Niemeyer e que é possível analisar a planta do Cassino

com as áreas definidas em sua configuração individual e agregadas como volumes justapostos: o restaurante e pista de dança, o prisma dos serviços e o grande salão com seus mezaninos destinados a modalidades de jogos específicos, nota-se que cada uma das áreas obedece a uma norma própria, com um espaçamento de colunas estabelecido em função do uso do espaço. Ou, em outras palavras, enquanto o mestre francês aceita uma norma prévia (fornecida impositivamente pela indústria contemporânea) e sobre esta constrói sua impressionante e criativa inventividade, para o arquiteto brasileiro sucede exatamente o contrário: ele submete sempre a norma ao programa previamente proposto e cuja forma também foi estabelecida por razões expressivas.

Ou seja, à ditadura da norma, nos arquitetos europeus, o nosso arquiteto propõe uma liberdade no agenciamento dos espaços que só atende às necessidades sentidas e pressentidas dos homens que vão sofrê-las. (KATINSKY; 2007: 60)

O segundo edifício que merece destaque no Conjunto Arquitetônico de Pampulha é a Casa do Baile (inaugurada em 1942) [Figuras 4.44 - 4.49], na qual Oscar Niemeyer praticamente não adota linhas retas. Pensado para abrigar eventos populares, trata-se, como explica Segawa (2010), de um edifício estabelecido sobre uma pequena ilha artificial de 60,0 metros de extensão, conectada à orla por uma pequena ponte arqueada moldada em concreto armado [Figura 4.44]. A obra é basicamente composta pela integração espacial curvilínea de um restaurante, uma pista de dança e um pequeno palco para apresentações, cujos fechamentos perimetrais são predominantemente transparentes [Figura 4.45]. A planta de formato circular gera um volume cilíndrico, e é desenvolvida com base em duas circunferências que se tangenciam internamente e, a partir delas, desprende-se uma marquise sinuosa [Figuras 4.46 - 4.47] que acompanha o contorno da lagoa até um "vestiário de contorno oblongo revestido de cerâmica pintada, aos moldes do vestiário presente no pavimento térreo do Ministério da Educação". (QUEIROZ; 2007: 185)

A marquise serpenteante acaba por despertar um valor simbólico na obra, representante quase que inicial das formas livres que definem parte das arquiteturas projetadas por Oscar Niemeyer nos anos seguintes. A fluidez dela derivada deve uma porção da sua tônica à solução estrutural definida pelo engenheiro Albino Froufe, com "altura constante de seu topo em $30 \mathrm{~cm}$, ocultando uma grelha no vão interno e lajes maciças com vigas invertidas transversais na marquise externa" (MACEDO; 2008: 25). Como resultado, esse elemento arquitetônico-estrutural torna-se a peça-chave da Casa do Baile que, para Queiroz (2007), demonstra um exemplo notório da relação existente entre planos delgados e 
volumes com contornos e superfícies diversos, resultando em uma configuração diferente da adotada, por exemplo, tanto no Pavilhão do Brasil na Feira Internacional de Nova York de 1939 (no qual há sinuosidade na empena cega lateral e na cobertura), como no Cassino (e seu volume posterior de formato ovoide que se debruça sobre a lagoa).

Para Bruand (1997), as curvas em duas das outras arquiteturas niemeyerianas para Pampulha (Cassino e late Clube) são empregadas como estratégias de contraposição, em maior ou menor escala, mais ou menos visíveis. Todavia, neste projeto da Casa do Baile, não há outra forma que predomine senão a curva. Desconsiderando os pilares de concreto armado que amparam a laje superior e a marquise de desenho livre, além dos montantes presentes na caixilharia da pele de vidro, a linha reta é, definitivamente, desconsiderada. No que diz respeito à curva, "baseia-se ela na marquise sinuosa que liga as duas pequenas edificações: forma livre inspirada no contorno da pequena ilha que acompanha de modo mais ou menos exato, é na verdade a essência da obra, e quem lhe assegura o caráter tão particular de leveza caprichosa e de transparência absoluta". (BRUAND; 1997: 112)

Já do ponto de vista de Recamán (1996), é com base na marquise que se vislumbra a possibilidade de separar a forma moderna da lógica estrutural. Dito de outra maneira, esse elemento arquitetônico-estrutural materializa duas importantes considerações: ao deixar lado o alinhamento preciso dos pilares, a própria laje dançante coloca-se como contraponto à ortogonalidade tão cara à arquitetura moderna [Figuras 4.48 - 4.49]. Ou seja, a não disposição em forma de renque das colunas de sustentação torna-as imprevisíveis, quem sabe casuais ao não serem direcionadas pelo eixo central da marquise (eixo esse difícil até de ser estabelecido, dada sua forma nada convencional). Como consequência, a laje apresenta-se como uma solução sem forma definida ortogonalmente, porém, sustentada por pilares que também não seguem uma lógica pré-estabelecida. É um conjunto, portanto, que se afasta por completo das bases modernas e que vai, desse instante em diante, tornar-se parte do fazer projetual de Oscar Niemeyer. Sobre isso, Recamán esclarece que

Assim se constitui um dos elementos mais marcantes da mitologia da arquitetura moderna brasileira, emblema de sua volatização ideológica e social. E esse é o espaço possível para o exercício de sua autoproclamada criatividade e "liberdade": uma ilha dentro de uma "ilha" (que por causa de sua introversão narcísica faz a terra gravitar a água do lago/espelho da Pampulha). Tal isolamento permitiu a depuração de um repertório que pôde então, por repetição e discretas alterações, repetir-se como uma "tipologia" sem "tipo" - por que não diretamente atrelada a uma função -, mas propositora de "extratos" homogêneos de concretos distintos (tradição cultural, base formal e conceitual da arquitetura moderna e modernismo sob o impacto da ação do Estado empreendedor). (RECAMÁN; 1996: 176) 
É o gosto pela técnica, aliado ao interesse pela tecnologia e pelas variáveis estruturais que motivam Oscar Niemeyer, já na década de 1940, a testar os limites do concreto armado nesta sua primeira incursão no campo arquitetônico feita de forma realmente independente. De acordo com Valle (2000), ainda que o arquiteto carioca tenha como uma de suas premissas a investigação dos potenciais construtivos desse material, o que the permite chegar ao resultado desejado, fazendo uma abstração do contorno da ilha e transportando-o quase que totalmente ao formato da marquise são, em verdade, "os antecedentes nas experiências do MES em 1936, posteriormente reforçadas pelo desenho do paisagismo de Burle Marx, ambos influenciados pelo princípio “biomórfico" de Hans Arp (1888-1966)". (VALLE; 2000: 148).

Se, continua o autor, em um primeiro momento o intuito de Niemeyer é provocar e contestar o funcionalismo por meio das obras de Pampulha, particularmente as ondulações da marquise acabam por conferir uma identidade muito própria aos seus projetos e permitem, como consequência, que diferentes leituras sejam feitas simultaneamente. A valorização das possibilidades do concreto armado, acompanhada de um posicionamento que se coloca contra o funcionalismo mexem profundamente com o fazer projetual de Niemeyer. Em suas próprias palavras, "Durante os primeiros tempos, procurei aceitar tudo isso como uma limitação provisória e necessária, mas, depois, com a arquitetura contemporânea vitoriosa, voltei-me inteiramente contra o funcionalismo, desejoso de vê-la integrada à técnica que surgira e juntas caminhando pelo campo da beleza e da poesia" (NIEMEYER; 2005: 22)

Do Conjunto Arquitetônico da Pampulha faz parte, também, o edifício destinado à sede late Clube [Figuras 4.50 4.55], cuja inspiração mais próxima pode ser creditada à Casa Errazuris de 1930, concebida por Le Corbusier e Pierre Janneret. Em um segundo momento, o late Clube cita a casa em Maltes, de 1935, a casa de fim de semana de Jaoul, de 1937 e a casa GMMAS, de 1938, todas elas também derivadas do trabalho do mestre franco-suíço. Com estas obras, as semelhanças incidem especialmente no que se refere aos dois prismas trapezoidais opostos, encimados por planos inclinados direcionados a um só foco, quase que central à cobertura, no qual está instalada a calha de coleta de águas pluviais. A circulação externa, avarandada, pode ter sido guiada por uma obra de Le Corbusier de 1920, a Casa Citrohan.

Segundo Valle (2000) a solução arquitetônica do late Clube indica o momento em que o novo repertório de Oscar Niemeyer se cristaliza a partir da forma do telhado invertido (do tipo borboleta), da distribuição ao longo de uma extensa plataforma, da flutuação sobre pilotis e da predominância horizontalizada de toda a edificação, ladeada por 
uma rampa de acesso à entrada principal [Figuras 4.50 - 4.52], todavia, de presença mais modesta se comparada à rampa curvada do Pavilhão do Brasil na Feira Internacional de Nova York de 1939.

Note-se que não há menção à curva como um importante elemento constituinte do late Clube. Ela é encontrada acanhada e pontualmente em alguns volumes arqueados que formam os pilotis e em alguns trechos do salão principal. Sobre esse fato Queiroz (2007) diz que, ao contrário dos demais edifícios do Conjunto Arquitetônico da Pampulha, neste, a curva não pode ser explicada como um condicionante plástico que define a concepção formal. Todavia, em concordância com aquilo que ocorre com os outros edifícios da Pampulha, a fluidez não está presente apenas na forma, mas também nas soluções adotadas para as superfícies. Prova disso está, ainda segundo o autor, no volume vazado suspenso, nas fachadas completamente envidraçadas, nos fechamentos verticais provocados por ambas as lajes de diferentes inclinações. "É quase uma dobradura, um invólucro regular composto praticamente de vidro e brise em suas faces maiores. Não há interrupção, a esbelteza da laje transfere-se para as paredes". (QUEIROZ; 2007: 227). Esta é, por assim dizer, mais uma oportunidade em que Niemeyer desfaz a rigidez purista corbusiana ditada pelos fortes contrastes entre as áreas externas e internas das edificações, sobretudo daquelas projetadas na década de 1920, integrando-as como um único espaço quase que contínuo e desobstruído. E essa relação interior x exterior só é quebrada - ou melhor, suavizada - pelo conjunto de brises verticais estrategicamente posicionados nas fachadas mais castigadas pelo sol [Figuras 4.53 - 4.54]: esta, na verdade, é solução recuperada futuramente no projeto da Capela de São Francisco de Assis, também junto à lagoa da Pampulha. Mesmo com os fechamentos que atenuam os efeitos do sol, ainda assim, permanece uma forte integração entre a dinâmica interna do edifício e a vida recreativa ao ar livre.

Ao comparar plantas e elevações da Casa do Baile e do late Clube, Recamán (1996) chega à conclusão que, no primeiro caso, as elevações não deixam transparecer o dinamismo organizacional e espacial da planta. Porém, no segundo caso, a diversidade das alturas dos pilares provocada pelo telhado borboleta gera alterações não na planta, mas, sim, nas elevações. E as lajes internas sustentadas pelos pilares de diferentes alturas resultam em elementos também inclinados [Figura 4.55], que trilham o caminho oposto ao que é pregado pela arquitetura moderna no que diz respeito tanto à preferência pela continuidade dos planos horizontais (aqui, interrompidos quando da inversão da inclinação da laje superior) quanto ao desejo por tetos completamente planos, como defende Rowe (1978). Assim sendo, configura-se nesta obra e ainda de acordo com Recamán (1996), mais uma ruptura com os preceitos modernos 
referentes tanto à dimensão vertical dos elementos arquitetônicos quanto ao posicionamento dos planos horizontais constantes do "Sistema Dominó".

A Capela de São Francisco de Assis [Figuras 4.56 - 4.61] é a última das obras do Conjunto Arquitetônico de Pampulha aqui estudada. É deixada propositadamente para o fim não apenas por ter sido a derradeira edificação construída (e concluída em 1943) mas também por representar o membro mais emblemático desse grupo de obras notáveis. Assim sendo, a ela deve-se dedicar uma investigação mais cuidadosa a fim de motivar discussões calcadas na relação entre arquitetura e engenharia e as suas interinfluências à arquitetura moderna praticada à época e suas consequências futuras.

De todas as curvas do conjunto de Pampulha, destacam-se as das coberturas em formato de abóbada parabólica da Capela de São Francisco de Assis, implantada com destaque junto a uma das margens da lagoa [Figuras 4.56 - 4.57]. Nela, não há mais - ao menos não claramente - as releituras do purismo corbusiano, representadas pela tradicional tríade viga - pilar - laje, como nos projetos do Cassino, da Casa do Baile e do late Clube. Trata-se, sim, de uma solução estrutural de casca paraboloide de seção variada para o corpo principal, onde está a nave [Figura 4.58]. De acordo com Pereira (2012), esta parábola principal possui 19,90 metros de comprimento sendo que, em seu ponto mais elevado, frontal, apresenta 9,11 metros de altura contra os 6,57 metros da parte posterior. A Capela traz também uma combinação de abóbadas autoportantes de diferentes dimensões para acomodar a sacristia, a secretaria, a sala do padre, a pequena loja e os demais ambientes reservados. Uma dessas abóbadas sobrepõe-se transversalmente à casca principal - o que causa um pequeno desnível de elementos arquitetônico-estruturais e permite a entrada de luz natural, difusa, diretamente sobre a nave central e sobre o amplo painel de Cândido Portinari intitulado "São Francisco se Despojando das Vestes", situado logo atrás do altar. As curvas abobadadas são tão importantes para o desenvolvimento conceitual deste projeto que "Niemeyer faz do desenho da abóbada o desenho do próprio edifício". (QUEIROZ; 2007: 285)

A Capela está implantada de tal forma que chega-se a ela pela parte posterior, que faceia a rua de acesso [Figura 4.59]. Neste momento, os visitantes são recebidos por mais um extenso painel de Cândido Portinari, executado em azulejaria, e que representa uma retrospectiva da vida de São Francisco de Assis. A partir daí, o percurso trilhado leva à descoberta gradativa dos volumes encurvados e incentiva a formação de diferentes perspectivas à medida em que se atinge a entrada principal, amplamente aberta à Lagoa da Pampulha. 
Internamente, a abóbada de maior dimensão é revestida por um forro de madeira e acolhe um programa considerado tradicional às antigas igrejas brasileiras: ao pé da porta principal encontra-se o batistério. A seu lado uma escada helicoidal conduz à tribuna do coro posicionada em um mezanino retilíneo com vãos livres em ambos os lados maiores. Uma cortina de vidro transparente cobre toda a fachada frontal, porém, a parte superior é protegida por quebra-sóis verticais (nos moldes daqueles adotados anteriormente, no late Clube, junto à piscina) situados da linha de piso do mezanino até o contorno inferior da grande laje arqueada [Figura 4.60]. No final da nave, um par de púlpitos colocam-se nas extremidades do retábulo, como que a emoldurá-lo. Não há corredores laterais que percorram longitudinalmente a Capela, pois Niemeyer decide abraçar em um só vão, contínuo, todo o espaço interior.

Uma marquise de aproximadamente 17,0 metros de extensão, com desenho retilíneo em planta e inclinado em elevação, protege o acesso principal. Sua extremidade mais baixa toca o corpo frontal da Capela e é sustentada por dois pilares metálicos em forma de "V", que rememoram os suportes da marquise do Cassino. Do outro lado, na extremidade de cota mais alta, a delgada cobertura inclinada fatia parcialmente o campanário, isolado, que traz formato de tronco de pirâmide invertido com 14,0 metros de altura, moldado em concreto armado e com uma treliça de madeira de trama irregular em toda sua extensão vertical - confiando-lhe mais leveza. [Figura 4.61]

Em função do empuxo estrutural, as abóbadas descem em extensões de reta até o chão, conferindo à Capela um feitio diferente e diametralmente afastado de "qualquer formulação do racionalismo do pós-guerra" (SEGAWA; 2010: 100). Queiroz (2007) vai além e entende que o prolongamento em linha reta tangencial à curvatura das abóbadas dá à Capela niemeyeriana a precisão de um gesto no papel transposta para o espaço, representada e comprovada por meio das perspectivas contínuas e lineares. Além disso, "as relações dessas formas com a paisagem e com o solo serão caracterizadas pelo comportamento contundente de um objeto que se configura como uma continuidade do solo, ou como um bólido que - em tensão extrema - apenas tangencia, esbarra no chão". (QUEIROZ; 2007: 287)

Uma vez que aqui as paredes já não fazem mais as vezes de suporte, é possível assumir uma expressão de criação mais acentuada e livre e que indica, por si só, um desdobramento inesperado e de associação derivada das premissas do "Sistema Domino" como um caminho tentador e possível a ser trilhado pela arquitetura brasileira, representada e capitaneada pela figura de Oscar Niemeyer. Neste momento, o arquiteto percorre uma trajetória de plena ascensão profissional, na qual amadurece seu traço, assume uma posição de vanguarda e investe em seu próprio vocabulário projetual. É uma fase de constante crescimento por um lado, mas também de contínuo aprendizado por outro. Cerca- 
se, portanto, de profissionais dos mais competentes para, juntos, trilharem novos horizontes criativos e factíveis de serem construídos.

Um dos pivôs da ousadia projetual de Niemeyer é seu amigo e parceiro, o engenheiro civil calculista Joaquim Cardozo, que se envolve com a equipe de Pampulha desde o início. Em diversas ocasiões, Cardozo incentiva o atrevimento estrutural das formas inventivas de Niemeyer e, para efetivá-las, concebe detalhes construtivos específicos, bem diferentes tanto daquilo que se pratica em outros projetos quanto de suas experiências profissionais anteriores. A Capela de São Francisco de Assis representa o ensejo de erguer uma cobertura que resiste pela forma, ou seja, cujo traçado é completamente fiel à sua estrutura de suporte e ao caminhamento das cargas descendentes. Uma arquitetura verdadeira, como aponta o próprio Joaquim Cardozo em 1955, na qual a relação entre carga e suporte é clara e não preocupada em escamotear-se sob a arquitetura. E ele mesmo complementa, ampliando seu pensamento às demais edificações do novo bairro mineiro:

Nesse conjunto da Pampulha, o arquiteto Oscar Niemeyer começa a manifestar a sua ilimitada força
de invenção, toda ela dirigida para o problema da estrutura: estrutura no seu aspecto formal e nos
seus princípios de equilíbrio. Procura purificar a forma, retirando das entranhas posições de equilíbrio,
um conteúdo emocional que é, segundo o critério de muitos, o principal atributo da 'beleza nova'.

O uso frequente das linhas curvas, no Cassino, na Igreja e na Casa do Baile, uso este que tem a sua origem no Art Nouveau e se manifesta definitivamente na 'forma aerodinâmica', não aparece nas composições do arquiteto Niemeyer como uma textura decorativa, que era o ponto de vista de Gottfried Semper, e sim numa intenção de leveza, de desligamento do solo e das condições materiais, e mais ainda, numa sugestão de efeito dinâmico.

Compreendendo, já nessa época, que as imposições orgânicas a que está sujeita a boa arquitetura já não definem categoricamente a sua forma, antes, deixam-na ainda indeterminada, ele alcança, partindo daquelas premissas indispensáveis, uma expressão mais pura, mais fácil de ver, provocando também um movimento de admiração e surpresa.

É assim desde o início um artista de grande ação especulativa no propósito de liberar a forma arquitetônica - sem prejuízo, evidentemente, das suas funções ligadas à vida humana - das contingências por assim dizer 'vulgares', e que lhe dão certa impureza do ponto de vista estético.

Cumpre assinalar entretanto que nesses projetos da Pampulha a ideia de forma purificada não repousa mais naquele espírito geométrico tradicional, e sim nesse outro mais moderno de desafio e oposição às teorias estabelecidas, onde se investigam as possibilidades de novas funções matemáticas que não se subordinam a essas teorias, introduzindo no pensamento dedutivo um sentido de aventura e talvez mesmo sugerindo uma ordem para a fantasia. (CARDOZO, 1956; In MACEDO e SOBREIRA; 2009: 128)

De acordo com Vasconcelos (1985), a dedicação extrema de Joaquim Cardozo ao seu trabalho espelha um profundo respeito não apenas ao colega Niemeyer, mas também à arquitetura moderna tida como expressão técnica e cultural 
brasileira. Talvez isso explique, ao menos em parte, a investigação ininterrupta por novas soluções estruturais que evidenciem os aspectos arquitetônicos e mantenham intactas as novas propostas de cada projeto em particular. Diz Niemeyer (2000) que Cardozo nunca demonstra reservas, preocupações ou sugestões sobre a necessidade de alterações de caráter econômico ou de cautela em relação às estruturas de seus projetos. Pelo contrário. Consideraos um desafio para acrescentar novas oportunidades de destacar suas características arquitetônicas por meio de técnicas e de tecnologias construtivas eficientes e competentes.

Segundo Recamán (1996), para a Capela especificamente, todo o programa é atendido por apenas um volume, mesmo que seccionado. Diferentemente do que ocorre nos demais edifícios da Pampulha, não existe, neste, qualquer luta por manter harmônicos elementos conflitantes, diz o autor. Trata-se de uma arquitetura que é resultante de um único "elemento estrutural de concreto cuja forma define o volume”. (RECAMÁN; 1996: 179) E esse elemento estrutural tem o formato de uma parábola, como qualquer outra parábola já utilizada como solução estrutural em obras de arte (em pontes ou em viadutos) ou mesmo como sistema de cobertura para vencer grandes vãos (em galpões, armazéns ou em hangares). O mesmo autor enfatiza ainda que Niemeyer deve ser reconhecido como o responsável por traduzir (ou adaptar?) uma solução já largamente aplicada em grandes estruturas para uma escala consideravelmente diminuída, quem sabe mais introvertida ou simples (porém, jamais simplista). Dito de outra maneira,

Foi a solução "arquitetônica", desvinculada de sua aplicação em grandes estruturas, que marcou a criação desses arcos. Mais ainda: se o desenvolvimento da engenharia brasileira possibilitou o cálculo e a construção dessa forma, através da tradição da abóbadas e arcos, isso não significa que a solução desse edifício tenha partido de preocupação ou necessidade estrutural. A sequência das parábolas na parte posterior, própria do movimento do traço sobre o papel, não é "lógica" do ponto de vista estrutural (ainda que facilmente resolvida pelo cálculo, inclusive por suas pequenas dimensões). Um arco sugere um sistema estrutural - de absorção de compressão - que não pode ser interrompido e reiniciado a partir de um ponto arbitrário (como a necessidade de pé-direito na sacristia). Essa forma gráfica não se explica através de uma coerência estrutural, ainda que inspirada em arcos de concreto (requintada solução técnica). Tampouco expressa naturalmente a concordância das forças da natureza e as regras da beleza, argumento em que se baseia a "espontaneidade" das soluções de Oscar Niemeyer. Formas estruturais "puras" (arcos, parábolas, cascas, etc.) serão utilizadas enquanto elementos arquitetônicos em diversos projetos, e que não traduzem a "pureza" ou "franqueza" da solução estrutural, como nesse caso, de soluções estruturais mistas (RECAMÁN; 1996: 179-180)

Bruand (1997) reforça a posição de Recamán (1996) acima pois, aqui, acredita que Niemeyer não seja influenciado pela tradição histórica da arquitetura brasileira ou estrangeira pois, em sendo isso verdade, o resultado para a Capela apontaria para uma outra direção. Logo, ao propor pela primeira vez um edifício que mescla forma e estrutura e que 
rompe, portanto, com a tridimensionalidade da caixa modernista, é possível assumir que haja uma legítima preocupação do arquiteto carioca para com o importante papel assumido pela engenharia de estruturas no desenvolvimento de novas tecnologias calcadas em possibilidades construtivas inovadoras e motivadas, sobretudo, pelos horizontes abertos a partir do acentuado desenvolvimento do concreto armado verificado naquele mesmo período (e como já abordado anteriormente neste estudo). O conjunto de tais variáveis faz com que Niemeyer exercite essas mesmas possibilidades ao adotar a casca paraboloide como solução final de seu projeto para o edifício religioso de Belo Horizonte.

Katinsky (2007) acredita que a Capela de São Francisco de Assis reserva em si uma qualidade muito particular a Oscar Niemeyer, qualidade essa despertada pela correta conjugação, no entender do autor, daquilo que é a ela interno e externo:

[...] mas a capela, devido ao pintor Portinari, nos revela uma outra característica do arquiteto: sua vertente dramática, tantas vezes expressa em seus textos. Houve uma conjunção extremamente feliz em que o conteúdo se confunde com o continente: o drama não se instala ao nível das relações do homem com a natureza. Ao contrário, as cargas se encaminham suavemente para o solo, o peso da estrutura descansa levemente sem esforço aparente no terreno. Mas justamente essa suavidade contrasta com a pintura do mestre de Brodosqui, desde o grande painel externo de azulejos, representando o santo de Assis, criando-se assim uma relação explosiva entre a parede suporte e a casca envoltória. Não só a parede é anulada visualmente, acentuando a invenção estrutural (puro arbítrio), como o próprio conteúdo histórico acentua o conflito: o santo e sua ordem, desde o início, foram presença incômoda para a Igreja, desde a tendência dos espirituais na Idade Média até a teologia (franciscana) da libertação. Essa ordem mendicante sempre repropôs a presença dos deserdados das sociedades diante dos nossos olhos.

O drama, no caso do arquiteto, se revela pelo conflito nas relações dos homens consigo mesmos e se expressa agudamente pela ausência eloquente de qualquer tortura, pela modenatura serena, comum aos neoclássicos contemporâneos da Revolução (1789) e transmitida à arquitetura brasileira por Grandjean de Montigny. (KATINSKY; 2007: 61)

Vale ressaltar que as trajetórias de três profissionais podem ser apontadas como agentes influenciadores de Oscar Niemeyer para esta obra da Pampulha e para várias de suas produções posteriores, não apenas considerando os aspectos formais ou estéticos da Capela, mas também em relação aos avanços tecnológicos gerados por seus estudos empreendedores e especuladores. A pesquisa contínua desses profissionais por novas formas para as construções e pela superação dos limites entre engenharia e arquitetura permite que, quando pensadas em relação ao movimento moderno, acomodem uma linguagem que se pretende mais ajustada às necessidades sociais e à industrialização em 
grande escala mediante, certamente, algumas necessárias adaptações projetuais, de proporções, de usos e de aplicações.

Assim sendo, os três importantes nomes para a arquitetura e para a engenharia mundiais - anteriormente apresentados com mais cuidado neste estudo - e que servem de inspiração para o trabalho de Oscar Niemeyer, são: o arquiteto borgonhês Auguste Perret, criador de obras notáveis e precursor no uso do concreto armado na arquitetura de uma forma jamais usada. Dentre suas obras, destacam-se o edifício residencial situado à Rue Franklin, em Paris, de 1903 [Figuras 3.21 - 3.22] o grupo de depósitos localizados no cais de Casablanca, em Marrocos, de 1917 e a Igreja de Notre-Dame du Raincy, também em Paris, de 1922-1923. [Figuras 3.23 - 3.24]

Além de Perret, merece destaque o engenheiro estrutural suíço Robert Maillart, que se vale do concreto armado para vencer vãos de grandes dimensões, especialmente em obras de porte, como pontes e viadutos. Dentre seus projetos, podem-se mencionar duas pontes na Suíça: em Zuos, de 1901 [Figura 3.25] e em Tavanassa, sobre o Rio Reno, de 1905 [Figura 3.26]. Para Macedo (2012), é possível indicar como uma das principais referências niemeyerianas para a Capela de São Francisco de Assis, o pavilhão de Maillart para a Companhia de Cimento Portland na Exposição Nacional de Zurique (Suíça), de 1939 [Figura 3.28], projeto esse que guarda claras semelhanças plásticas, volumétricas e conceituais para com a Capela niemeyeriana.

Eugène Freyssinet, engenheiro e arquiteto francês, é mais uma inspiração para o projeto mineiro, basta pensar nos arcos em concreto da Pont de la Libération em Villeneuve-sur-Lot, na França, de 1912 [Figura 3.29]. Além dela, outro exemplo construído de Freyssinet e que também remete ao projeto de Pampulha é a Pont Plougastel (ou Ponte AlbertLouppe) [Figura 3.30], sobre o Rio Elórn, nas proximidades de Bern, França, de 1926. Todavia, pode-se dizer que seja em um projeto anterior, de 1921 (e demolido em 1944), que uma inspiração de Niemeyer para o desenho da Capela de São Francisco de Assis pode ser mais bem identificada. Segundo Gonçalves (2010), o arquiteto carioca pode ter sido influenciado pelas estruturas parabólicas de ambos os hangares projetados para abrigar dirigíveis e pequenas aeronaves no antigo aeroporto de Orly, na França. [Figuras 3.31 - 3.32]

Voltando ao Brasil e à Capela de São Francisco de Assis propriamente dita, Niemeyer e Cardozo partem para uma averiguação mais particularizada e precisa sobre os novos horizontes que podem ser trilhados a partir das técnicas do concreto armado desenvolvidas tanto fora quanto dentro do Brasil mesmo que, para atingir os seus objetivos, as teorias matemáticas e as normas de cálculo estrutural vigentes em território nacional àquela época precisem ser 
extrapoladas. Guardadas as devidas particularidades, retoma-se aqui o mesmo posicionamento profissional adotado anteriormente, no projeto do Ministério da Educação e Saúde, quando o responsável estrutural, o engenheiro civil Emílio Baumgart, aborta os códigos normatizados em favor de possibilitar a construção do MES fundamentada em cálculos e em soluções estruturais nunca dantes utilizados, justamente para que o edifício possa ser erguido exatamente como concebido no projeto arquitetônico da equipe carioca chefiada por Lucio Costa.

A capela abobadada niemeyeriana materializa a primeira edificação nesse formato construída no país. Assim sendo, é de se esperar que a inovação gerada a partir dela cause estranheza por um lado e, por outro, certas dificuldades aos profissionais técnicos envolvidos, pois as referências existentes são muito distantes da realidade brasileira. Além disso, em função do projeto muito particularizado desenvolvido por Niemeyer, o edifício construído traz em si algumas diferenças estruturais em relação às delgadas cascas em concreto armado construídas em outras partes do mundo, sobretudo na Europa.

Como explica Macedo (2002), por exemplo, já que há necessidade de o mezanino reservado ao coro apoiar-se nas paredes laterais da capela, aos carregamentos uniformemente distribuídos característicos deste tipo de estrutura parabólica são adicionados outros, pontuais, representados pelos momentos fletores das áreas de toque da tribuna do coro com as paredes encurvadas. Para efetivar a sustentação adicional desta carga extraordinária, Joaquim Cardozo prevê um reforço na armação de aço naquela região específica de modo a absorver estes carregamentos concentrados e somá-los aos os esforços tangenciais normalmente presentes em estruturas de forma parabólica. Além disso, o engenheiro propõe juntas de dilatação pertinentemente alocadas de maneira a absorver as diferentes movimentações tanto do piso do coro quanto do corpo da Capela em si.

Como se isso não bastasse - continua o mesmo autor - com o intuito de atenuar a transmissão de momentos e de empuxos horizontais às fundações, tanto a abóbada maior de seção variável como aquela que cobre o altar aproveitam a laje do piso como sistema de travamento (este, funcionando permanentemente em tração). Assim, todo o complexo estrutural trabalha de maneira mais coesa e coerente ao conjunto de esforços deste tipo de estrutura. $O$ resultado, como já mencionado, não é uma casca paraboloide aos moldes das europeias (finas e que vencem grandes vãos), e sim uma arquitetura modesta mas proporcionalmente mais robusta, porém, esteticamente sem comprometimento e estruturalmente bastante eficiente - graças à engenhosidade de Joaquim Cardozo que não poupa esforços para valorizar o binômio plasticidade-partido. 
Para Valle (2000), é no Conjunto Arquitetônico da Lagoa da Pampulha que as concepções arquitetônicas e a variação formal mais significativas na trajetória de Oscar Niemeyer têm o seu ponto inicial demarcado. "Essas formas têm suas utilizações dadas pela simplificação máxima entre as possíveis associações formais de seu repertório, já que ele está sendo criado". (VALLE; 2000: 174). Para o caso específico da Capela, o mesmo autor explica que a abóbada hiperbólica coloca-se como um avanço qualitativo e formal concebido pelo arquiteto carioca em relação ao repertório corbusiano. Valle prossegue ainda dizendo que é neste projeto de cunho religioso que Niemeyer formula e exercita, em conjunto com o engenheiro Joaquim Cardozo, a sua vontade de tensionar a técnica, ou seja, a intenção de investir em soluções arquitetônico-estruturais que busquem fugir das soluções tradicionais ao mesmo tempo em que proponham fomentar o uso do concreto armado em toda sua plenitude - colocando-se, portanto, em um caminho diferente daquele trilhado por Le Corbusier. Ainda de acordo com Valle,

\begin{abstract}
a diferenciação entre Niemeyer e seu mestre será, portanto, evidenciada na observação dos campos de tangência, que Joaquim Cardozo qualifica, juntamente com as características da "modenatura" da obra de Niemeyer, como a propriedade de fazer o cálculo participar da obra no seu processo criativo, questão distanciada de Le Corbusier, preocupado com os processos de industrialização da construção, como nas Casas Monol (1919), ou com o vernacular no croquis de um ateliê (1929). No entanto, o encadeamento particularizado do "conjunto de arcos abobadados", que estabelece um entrosamento com o corpo da igreja, realizado por uma única "abóbada hiperbólica", corresponde a um "zero grau" dessas formas encadeadas, que misturam "arcos abobadados" com "arcos abobadados hiperbólicos" e chegam, com sua modenatura, pousando suavemente sobre o solo. (VALLE; 2000: 174 e 176).
\end{abstract}

O autor ainda complementa seu raciocínio ao mostrar que acredita que a diferença mais significativa entre as produções arquitetônicas de Le Corbusier e de Oscar Niemeyer recaia no uso distinto do repertório de cada um deles, ou seja,

industrializado no repertório corbusiano e particularizado no repertório de Niemeyer, o que determina uma absoluta diferença interna entre os repertórios formais de ambos: Corbusier estabelece a individualidade formal possível interna humanizada de uma técnica no vislumbre de sua humanização, e Niemeyer particulariza essa individualidade formal tensionando a técnica, possibilitando estabelecer o limite de suas possibilidades formais sem industrializá-la. Niemeyer seguirá o procedimento de caracterização e diversidade formal, acrescentando à sua pesquisa plástica a estrutural, o que o levará, dos anos 40 aos 50, a uma experimentação da versatilidade na utilização de seu repertório, muitas vezes caindo no exagero. (IBIDEM: 176).

As inovações formal e tecnológica desta obra chamam a atenção dos historiadores fora do Brasil. Com o passar do tempo, além de serem publicados novos títulos que delineiam um painel da arquitetura moderna mundial, antigas publicações são revisadas e ampliadas. Em todos eles, a participação do Brasil se vê cada vez mais presente. Como 
exemplo pode-se citar a sexta reedição (de 1957) do vasto livro An Outline of European Architecture, originalmente publicada em 1942, de Nikolau Pevsner. Trata-se de uma das raras ocasiões em que o autor de uma publicação tão extensa faz alguma alusão a materialidades e possibilidades plásticas e tecnológicas, especialmente referindo-se ao Brasil. Pevsner "destacou a produção brasileira no sentido de ilustrar a influência de Le Corbusier e os perigos das acrobacias estruturais" (CAMARGO; 2011; 81). Dentre as obras que se encaixam nas considerações de Pevsner, está a Capela de São Francisco de Assis e o conjunto residencial de Pedregulho, de Reidy, no Rio de Janeiro.

Ainda de acordo com a mesma autora, William Curtis - em sua obra Modern Architecture Since 1900 (de 1982 ) desenvolve uma análise baseada em variáveis arquitetônicas formais, tipológicas e estruturais de uma amostra de obras que ele julga ser fundamental para o entendimento do pensamento arquitetônico moderno. Dentre as arquiteturas de Niemeyer incluídas neste livro - e por ele estudadas mais detalhadamente - estão o Ministério da Educação e Saúde, o Pavilhão de 1939, a Pampulha, o Parque do Ibirapuera, a Casa de Canoas e Brasília. Já em Modern Architecture 1920 - 45, Kenneth Frampton também destaca a Igreja da Pampulha, ao aventar a possibilidade de tê-la como um dos símbolos de identidade nacional, mas sem tocar nas questões estruturais desta obra.

Assim como acontece nos trabalhos anteriores de Niemeyer e ainda que o complexo de Pampulha suscite admiração e elogios por boa parte da crítica arquitetônica da época (e por que não dizer, até os dias de hoje), ele não é unanimidade. Diversos são os profissionais forasteiros que se manifestam contra aquilo que está sendo produzido no Brasil nas décadas de 1930 e 1940, e Pampulha é uma das obras que serve de mote para esses teóricos expressarem os seus pontos de vista negativistas e mordazes. Castellotti (2006) aponta que talvez a manifestação do designer, artista plástico e reitor da Hochschule für Gestaltung (Ulm, Alemanha), Max Bill, tenha sido a mais ácida ao colocar em xeque a função social, o sentimento de coletividade e a necessidade de um individualismo descomedido dos arquitetos brasileiros, principalmente de Oscar Niemeyer e seu projeto de Pampulha. Nas palavras de Max Bill,

... não se levou em conta a função social. O sentimento da coletividade humana é aí substituído pelo individualismo exagerado. Niemeyer, apesar de seu evidente talento, projetou por instinto, por simples amor da forma pela forma, elaborou-o em torno de curvas caprichosas e gratuitas, cujo sentido arquitetural apenas para si mesmo é evidente. O resultado (...) é um barroquismo excessivo que não pertence à arquitetura nem à escultura. (...) Afirmo, mais uma vez, que, em arquitetura, tudo deve ter sua lógica, sua função imediata. (BILL; 1953, appud CASTELLOTTI; 2006: 62). 
Castellotti (2006) também diz que Lúcio Costa, certamente o mais preparado intelectualmente dentre os arquitetos brasileiros, acha por bem responder à altura as críticas de Max Bill, reforçando o papel importante que tanto Niemeyer quanto o conjunto da Pampulha assumem para a arquitetura brasileira. Diz Costa:

Ora, sem a Pampulha, a arquitetura brasileira na sua feição atual - o Pedregulho inclusive - não existiria. Foi ali que as suas características diferenciadoras se definiram. Aliás, os argumentos que traz à baila no caso são dignos da Beócia. Trata-se de um conjunto de edificações programadas para a burguesia capitalista. (...) Como era de se prever, [a Igreja de São Francisco] foi qualificada de barroca com a habitual intenção pejorativa. Ora graças, pois se trata no caso de um barroquismo de legítima e pura filiação nativa que bem mostra não descendermos de relojoeiros, mas de fabricantes de igrejas barrocas. Aliás, foi precisamente lá, nas Minas Gerais, que elas se fizeram com maior graça e invenção. (COSTA; 1953, appud CASTELLOTTI; 2006: 62).

Segawa (2010) mostra que o revide do Brasil às inúmeras críticas que recebe acontece em diversos veículos impressos, mas possivelmente a mais enfática seja atribuída à revista Módulo, do grupo de Oscar Niemeyer. Aos comentários negativistas à arquitetura moderna brasileira articulados por Max Bill e Ernesto Rogers (este, editor da revista italiana Casabella-Continuità), por exemplo, a Módulo publica artigo sobre um conjunto habitacional bastante acanhado projetado por Rogers em Milão como forma de atacar a capacidade opinativa de um arquiteto que desenha obras menores, portanto, que não tem competência argumentativa para criticar os projetos brasileiros. Dito de outra maneira: do ponto de vista dos editores da revista Módulo, a intenção é a de desqualificar o autor da crítica, e não a crítica propriamente dita. Segawa ainda coloca que,

infelizmente, o esnobismo e as reações intempestivas tornaram-se as normas de resposta às críticas formuladas contra a arquitetura brasileira. Contrariamente à elegância contundente de Lucio Costa, os arquitetos brasileiros, de maneira geral, preferiram o caminho mais fácil e menos inteligente de não assimilar e raciocinar sobre as opiniões contrárias, virtualmente criando uma barreira contra críticas de qualquer natureza - formuladas no exterior ou aqui, mesmo sendo pertinentes. Esse comportamento inibiu algumas gerações de arquitetos brasileiros e sufocou uma discussão construtiva - em parte, responsável pela atitude refratária a qualquer forma de crítica à arquitetura brasileira desde então até hoje. (SEGAWA; 2010: 110) 


\section{ARQUITETURA MODERNA BRASILEIRA: UM DIÁLOGO COM AS TRADIÇÕES LOCAIS}

Oscar Niemeyer:

Grande Hotel de Ouro Preto

(Ouro Preto, Minas Gerais, 1939)

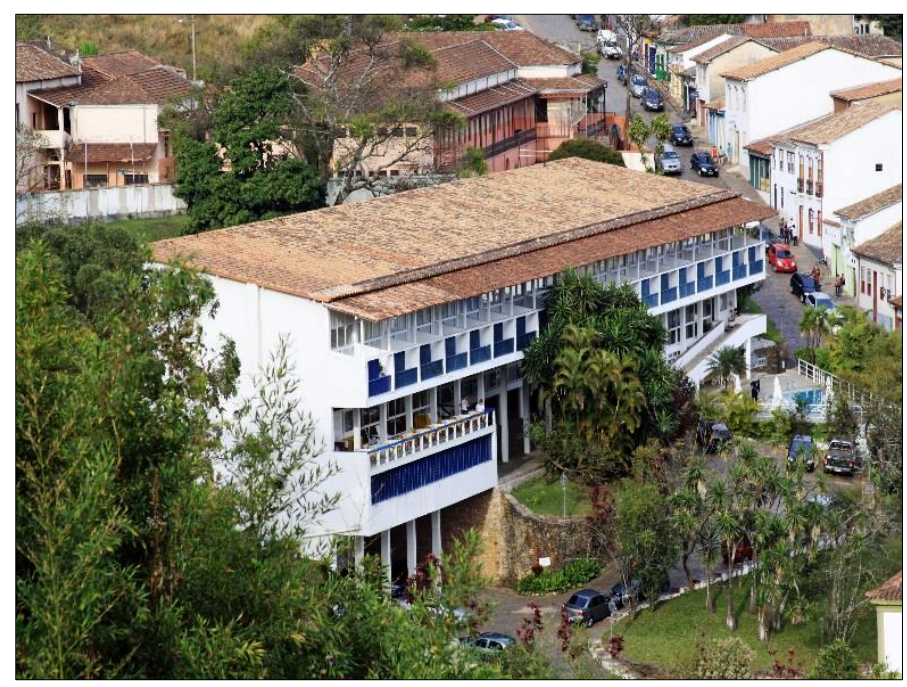

[4.34] A partir da imagem nota-se o conjunto de elementos que caracteriza este projeto niemeyeriano: a cobertura em telhas de barro, as treliças nas sacadas, o volume suspenso sobre pilotis de seção quadrada e o formato horizontalizado do edifício.

[4.35] Perspectiva parcial de um dos ambientes internos, com destaque para: laje contínua sem obstruções, alinhamento dos pilares modulados e seu afastamento da fachada e, do lado de fora, ilotis de seção quadrangular.

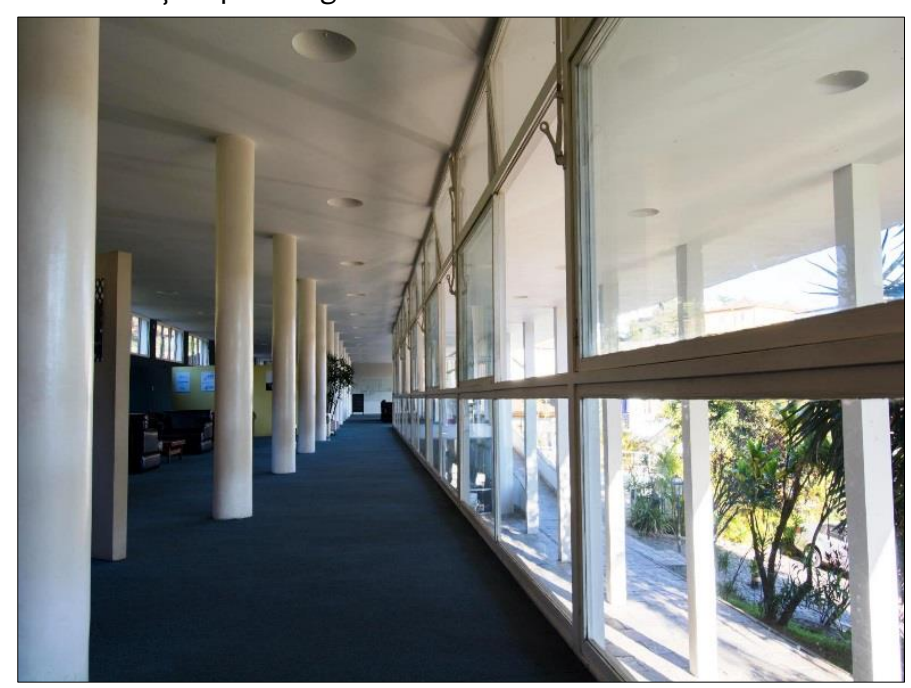

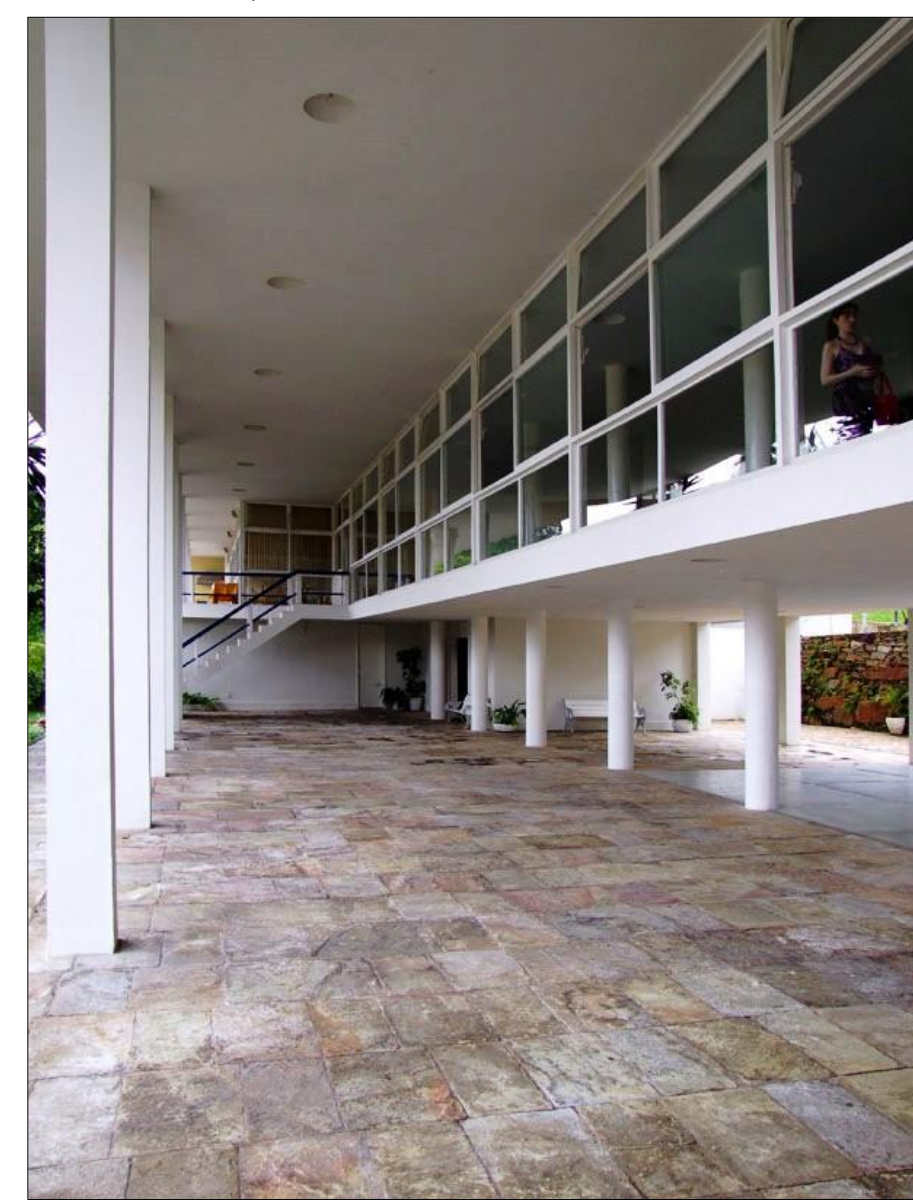

[4.36] O Grande Hotel de Ouro Preto - um dos primeiros projetos idealizados por Oscar Niemeyer em carreira solo - caracteriza-se como uma solução limpa, ortogonal e de clara influência moderna.

Por meio da imagem é possível assumir que há, nesta obra mineira, certa inspiração - quem sabe consciente ou não - no projeto do Ministério da Educação e Saúde (MES). Nota-se a integração espacial, o alinhamento e a modulação cadenciada dos pilotis externos, o posicionamento do volume horizontal acima do solo (conferindo-lhe um ar de leveza), a permeabilidade de circulações e de fluxos, a transparência discreta do extenso pano de vidro no andar superior (o qual não esconde por completo o caminhamento dos pilares internos) e as lajes lisas e desobstruídas. 


\section{CURVAS E RETAS EM UM JOGO DE FORMAS CONCRETAS}

Oscar Niemeyer:

Conjunto Arquitetônico da Pampulha: "Cassino"

(Belo Horizonte, Minas Gerais, 1940)

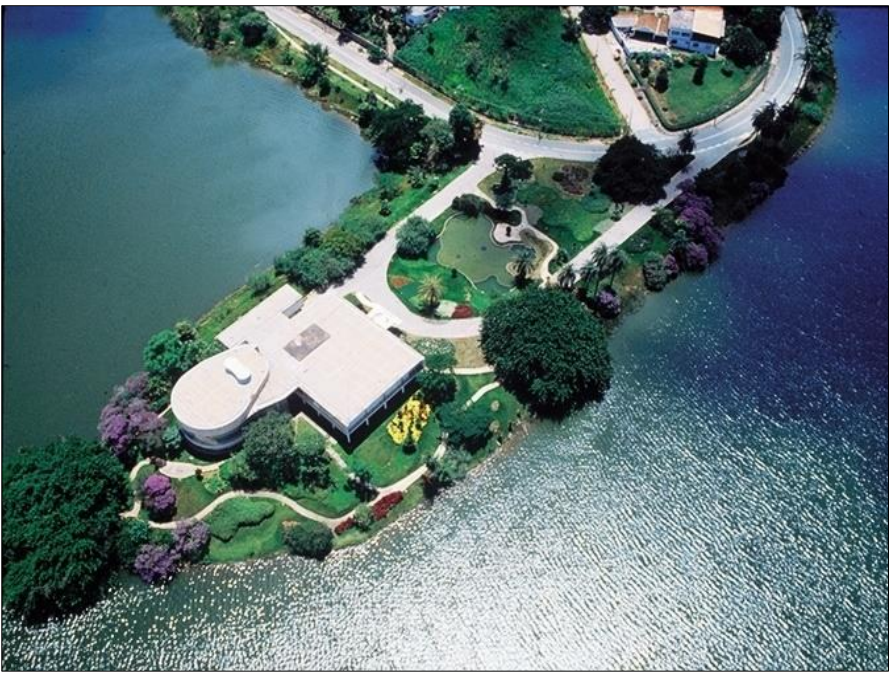

[4.37] Perspectiva geral da península de implantação do Cassino. $O$ projeto, sóbrio, é composto pela intersecção de três volumes: o salão principal, quadrangular, o volume circular reservado à pista de dança e um menor, retangular, para serviços e apoio.

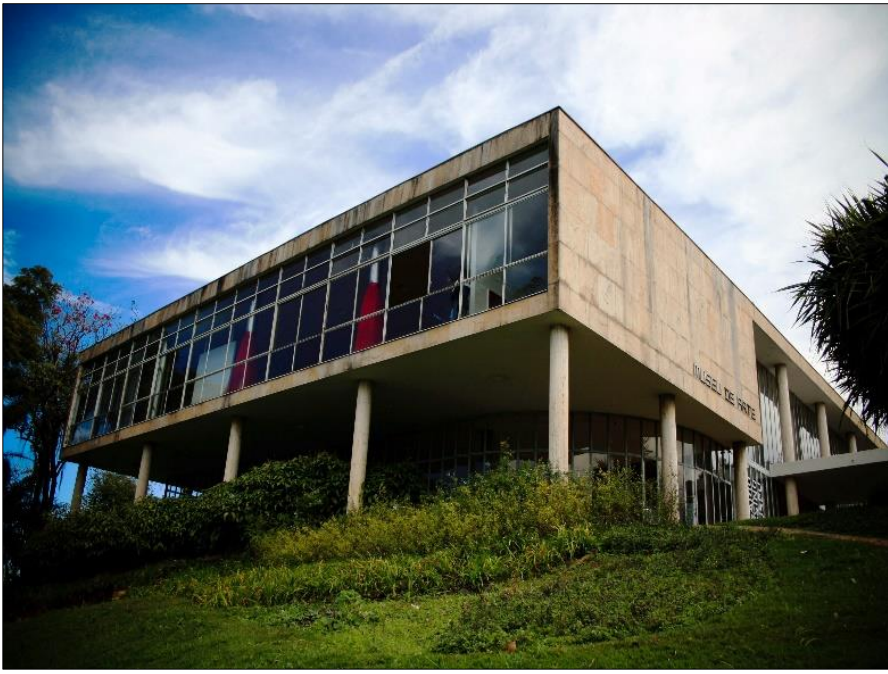

[4.38] O edifício do Cassino é estruturado em concreto armado. Tira proveito do promontório onde se localiza ao adotar pilotis que valorizam o terreno de implantação. Há variações de volumes opacos e translúcidos, de cheios e vazios e de luzes e sombras.

[4.39] Vista geral do acesso frontal do antigo Cassino. Chama a atenção o diálogo entre a marquise de formato pouco convencional (moldada em concreto armado e pousada sobre delgados pilares de aço) e a ortogonalidade prismática do corpo do edifício: o que poderia resultar em um contraponto negativo acaba por gerar uma interessante complementação de volumes.

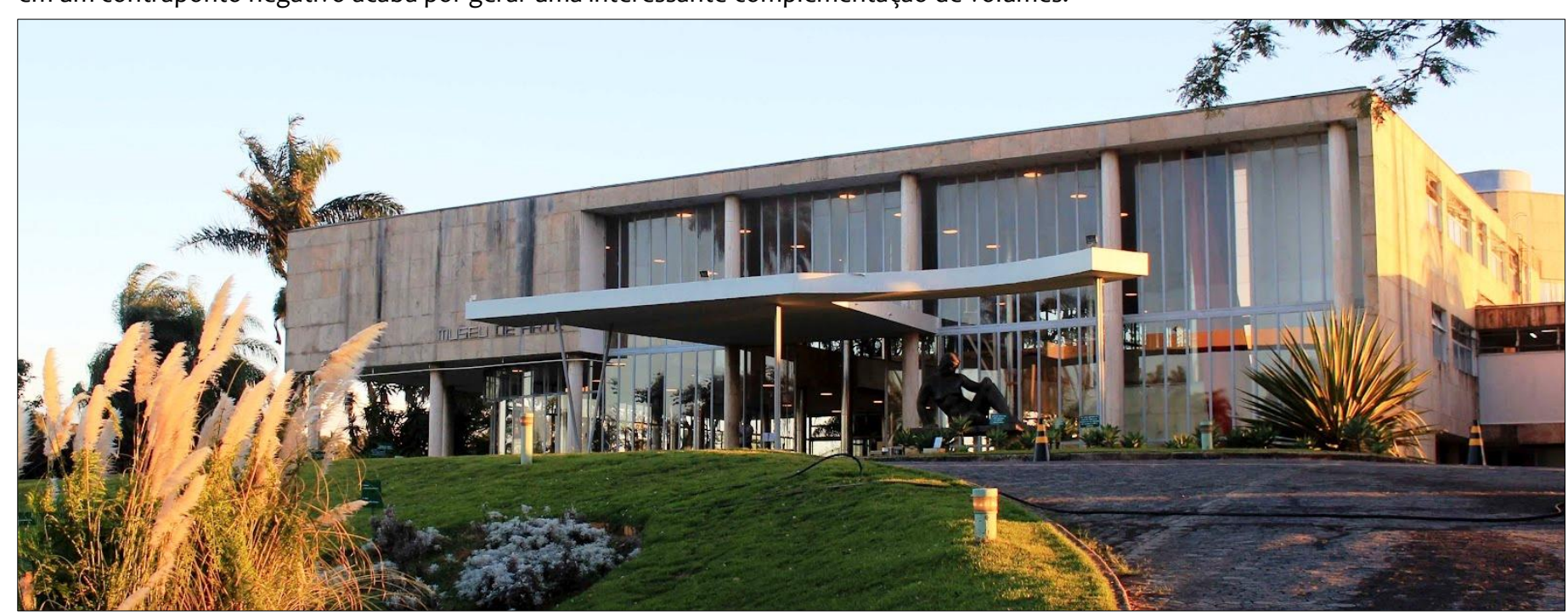




\section{CURVAS E RETAS EM UM JOGO DE FORMAS CONCRETAS}

Oscar Niemeyer:

Conjunto Arquitetônico da Pampulha: "Cassino"

(Belo Horizonte, Minas Gerais, 1940)

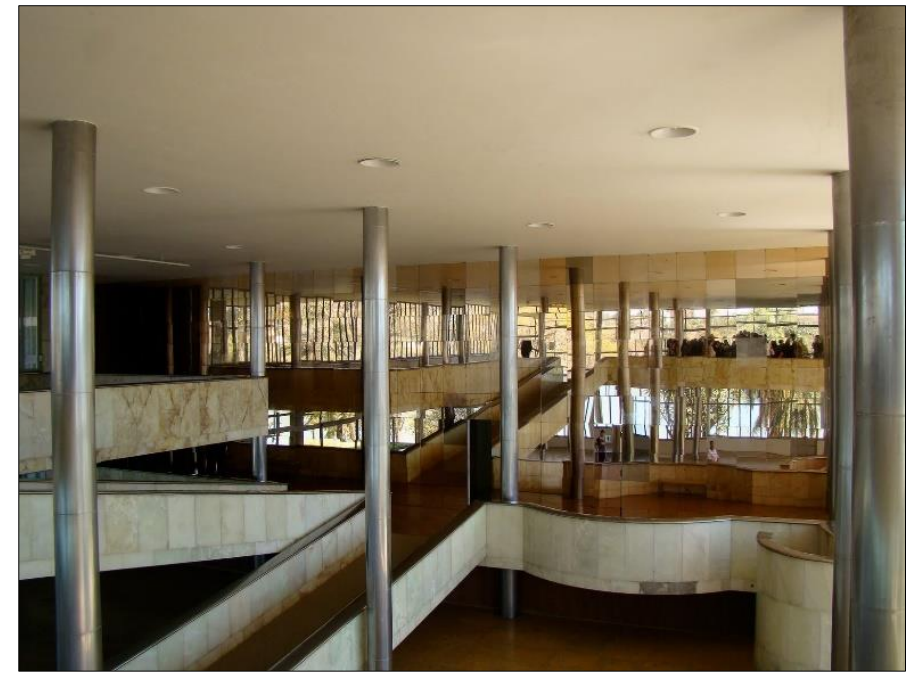

[4.40] A sobriedade externa da obra é quebrada no momento em que se adentra o edifício: revestimentos de mármore e bronze aliados a cores vivas ajudam a conferir uma identidade bastante particular ao espaço e às rampas centrais.

[4.42] Desativado logo após sua inauguração, o antigo Cassino é convertido, em 1957, no Museu de Arte da Pampulha. O edifício traz clara inspiração corbusiana no volume ortogonal, nos pilotis e na independência da estrutura (que confere leveza ao edifício).

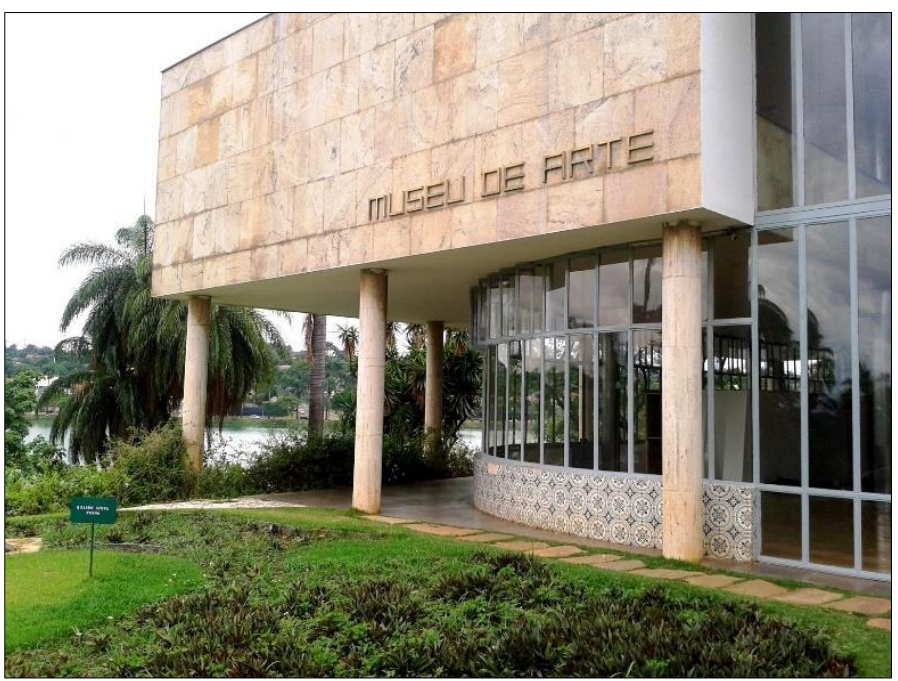

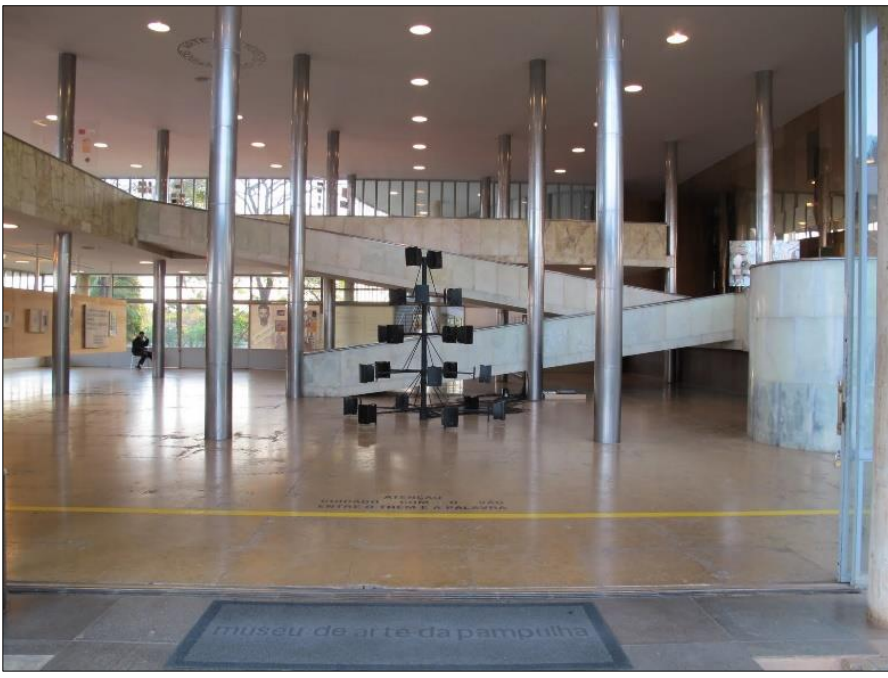

[4.41] O salão principal, que inicialmente é direcionado às áreas para jogos de azar do Cassino, hoje é utilizado como espaço de exposições. A distribuição cartesiana dos pilares ajuda na montagem de diferentes mostras artísticas, sem nelas interferir.

[4.43] A transição entre diferentes volumes de formas distintas é feita, por exemplo, por meio da escada envidraçada em forma de "S", que conduz o visitante do volume ovoide da pista de dança, posterior, para a caixa prismática, frontal, do salão de jogos.

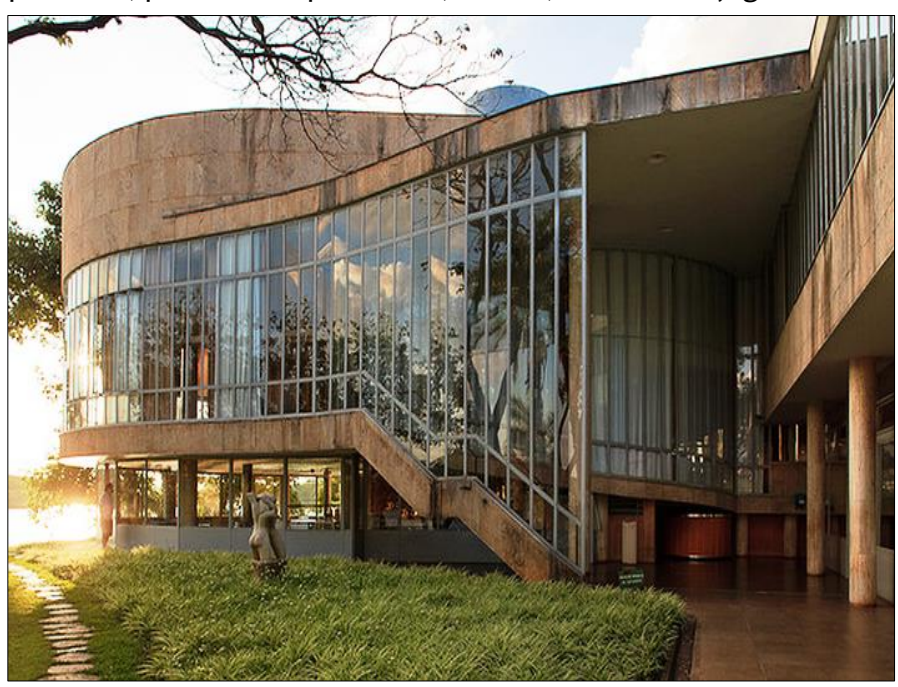




\section{UM EXERCÍCIO SOBRE A PLÁSTICA DO CONCRETO ARMADO}

Oscar Niemeyer:

\section{Conjunto Arquitetônico da Pampulha: "Casa do Baile"}

(Belo Horizonte, Minas Gerais, 1942)

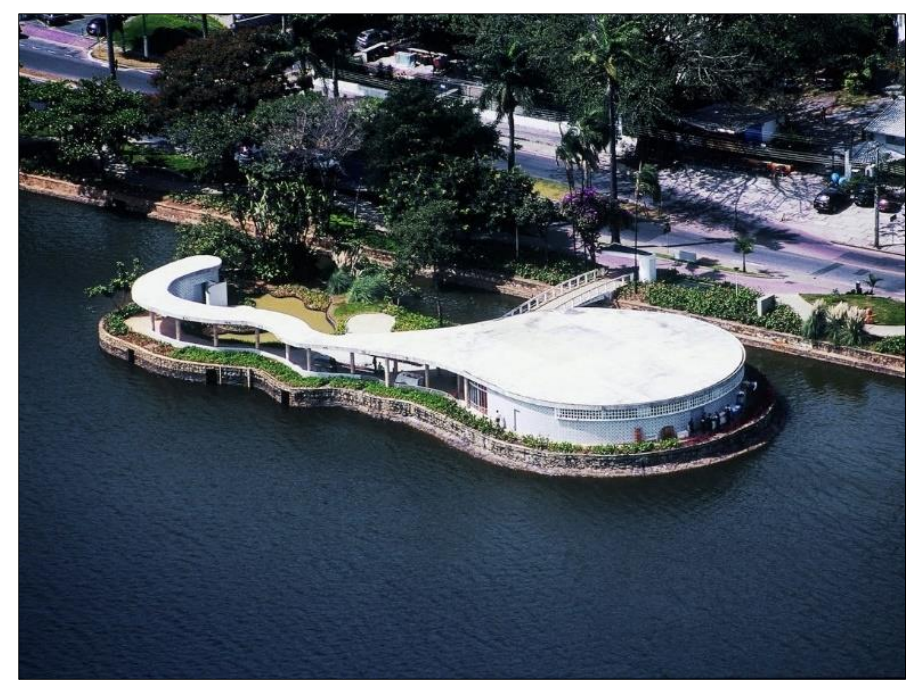

[4.44] Tomada panorâmica da Casa do Baile. O volume maior e principal possui volumetria cilíndrica. No lado oposto encontra-se a pequena construção oblonga que abriga o vestiário. Entre ambos, a marquise sinuosa é suportada por pilares de concreto armado.

[4.45] Projetada para receber eventos populares, a Casa do Baile traz, em seu edifício maior e circular, um restaurante, uma pista de dança e um pequeno palco para apresentações. O fechamento externo que faceia a marquise é feito por uma cortina de vidro.

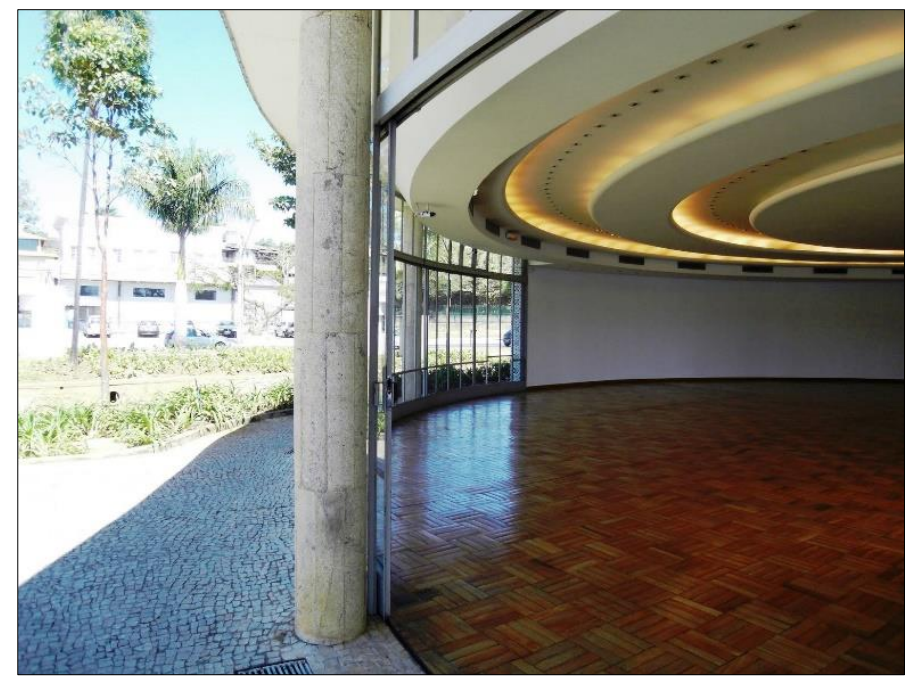

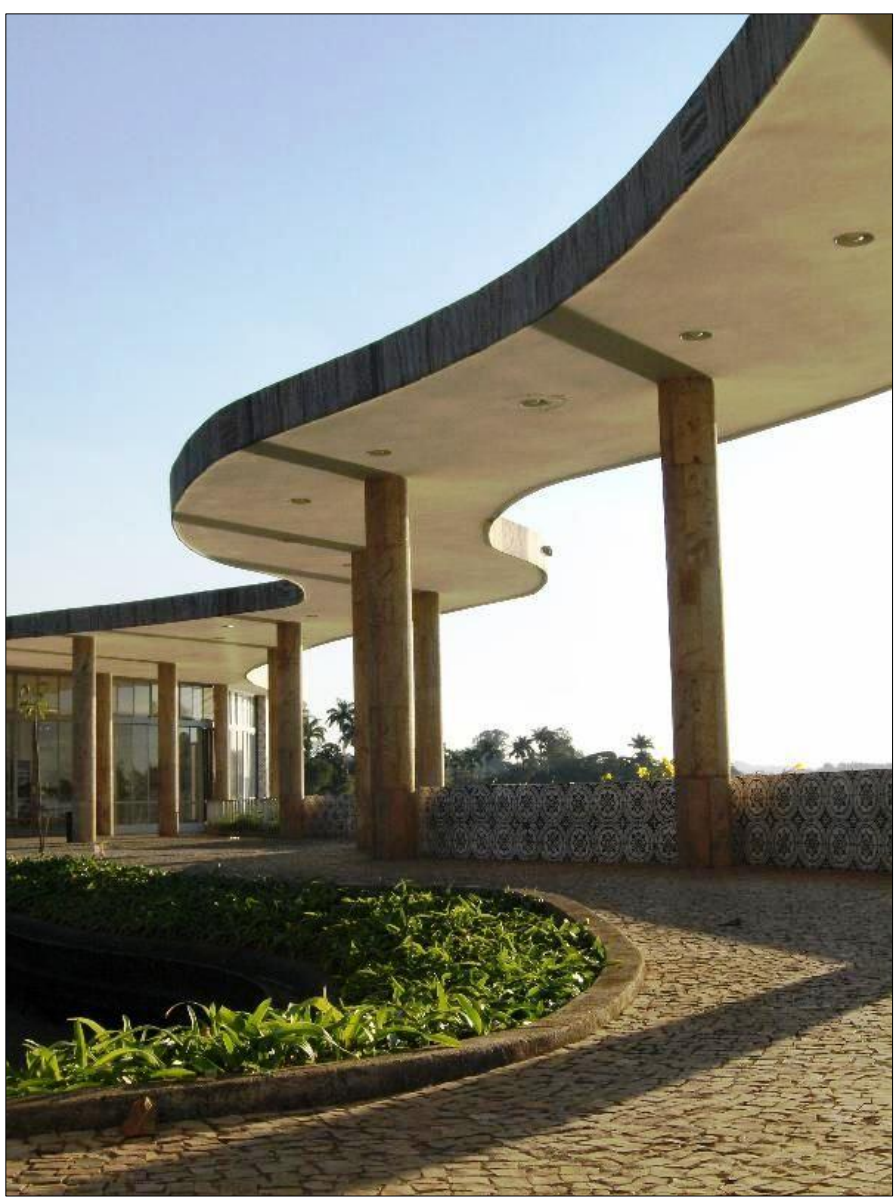

[4.46] A marquise de formas livres desprende-se da construção cilíndrica e caminha até o vestiário, no outro lado da ilha artificial.

Sua fluidez estrutural pode ser justificada pela altura constante, de apenas 30 centímetros, resultante não apenas de uma grelha disposta no vão interno superior, mas também de pequenas lajes maciças de concreto armado e de vigas invertidas transversais ao seu comprimento, localizadas sobre os topos dos pilares.

Pode-se dizer que este elemento sinuoso materialize tanto um dos primeiros desejos de Niemeyer de contrapor-se à ortogonalidade cartesiana do movimento moderno, quanto a oportunidade de exercitar a capacidade arquitetônica e estrutural do concreto armado, a matéria-prima mais utilizada em suas obras vindouras. 


\section{UM EXERCÍCIO SOBRE A PLÁSTICA DO CONCRETO ARMADO}

Oscar Niemeyer:

\section{Conjunto Arquitetônico da Pampulha: "Casa do Baile"}

(Belo Horizonte, Minas Gerais, 1942)

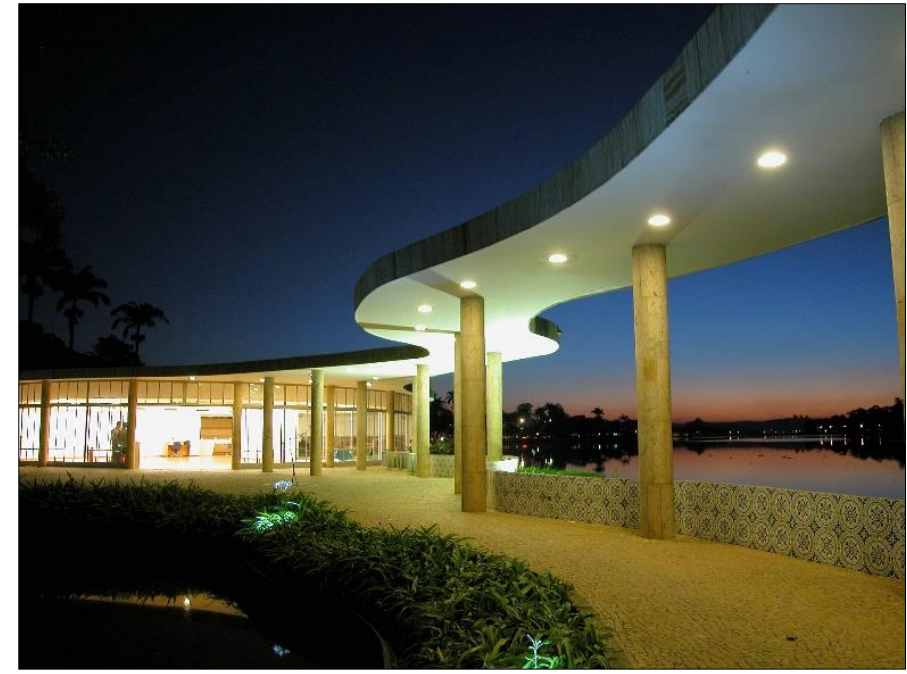

[4.47] A marquise serpenteante projetada por Oscar Niemeyer segue, em parte, a curvatura da pequena ilha artificial na qual a Casa do Baile está implantada. $O$ formato circular do edifício principal ajuda na harmonia arquitetônica do conjunto edificado.

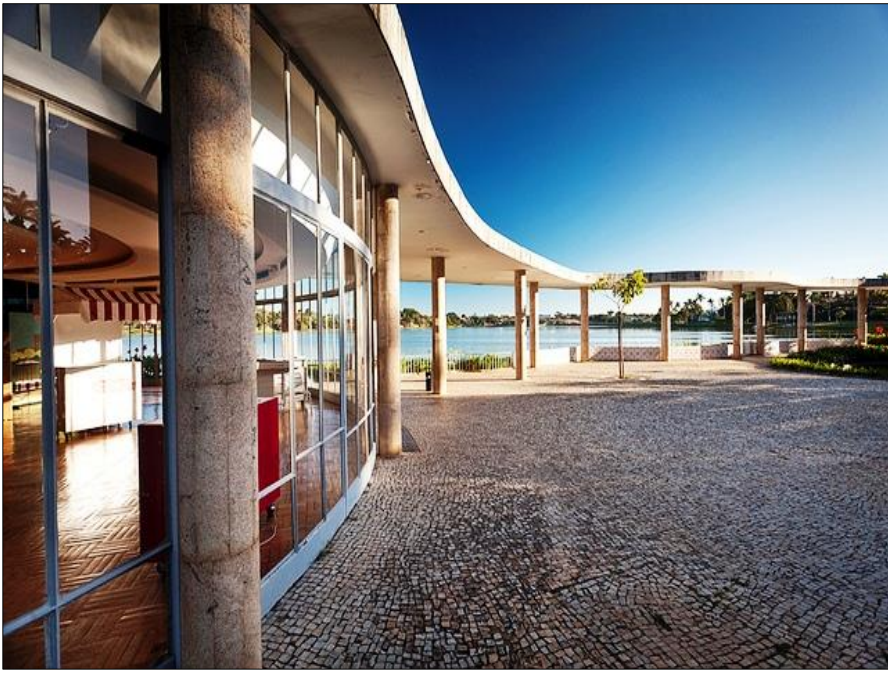

[4.48] Os pilares, que em princípio também acompanham a curvatura do salão cilíndrico principal, a partir do início da marquise adquirem distribuição variável que não segue nem o eixo da cobertura, nem suas ondulações laterais.

[4.49] A ampla área vencida pela marquise, da edificação principal ao vestiário, é permeada por uma praça seca na qual está inserido um espelho d'água que abraça um pequeno palco para apresentações de eventos diversos. A esbelteza da cobertura curvilínea em concreto armado, em conjunto com o grupo de pilares do mesmo material, não compromete a contemplação da Lagoa da Pampulha.

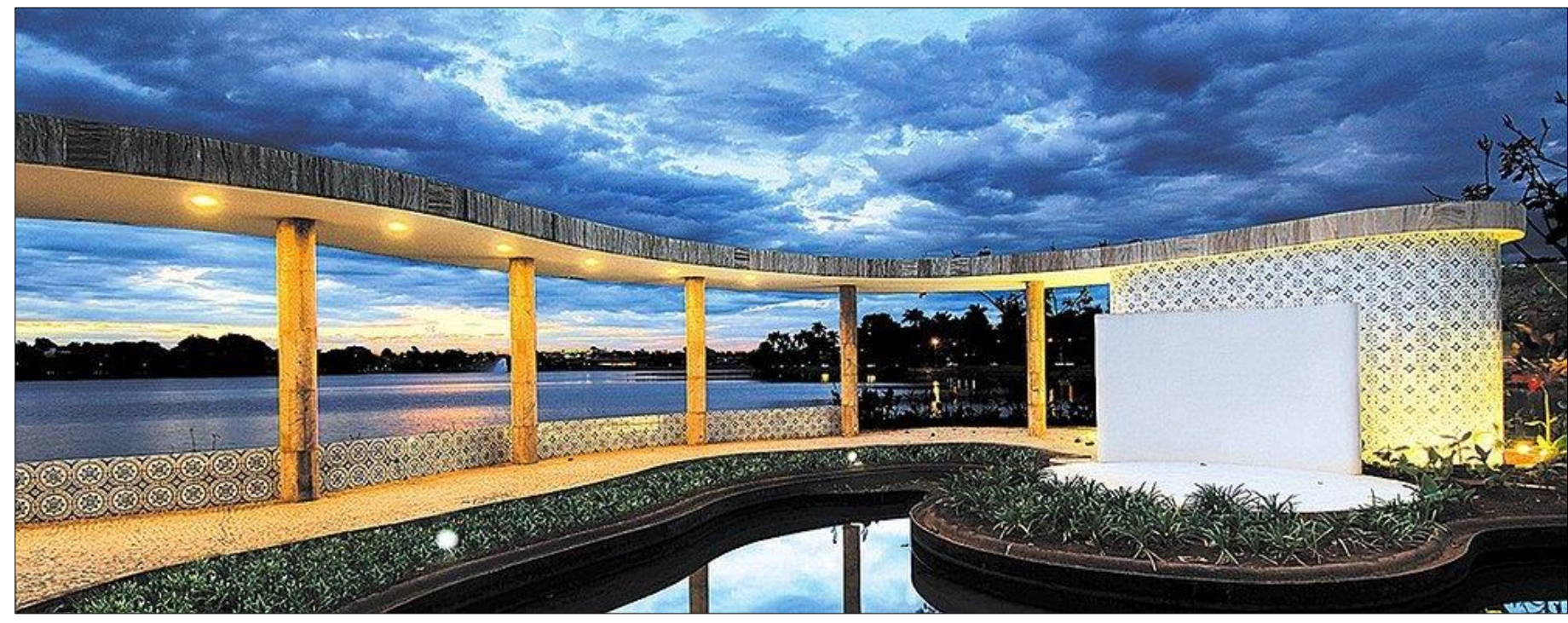




\section{O CONCRETO QUE FLUTUA SOBRE AS ÁGUAS}

Oscar Niemeyer:

Conjunto Arquitetônico da Pampulha: "late Clube"

(Belo Horizonte, Minas Gerais, 1942)

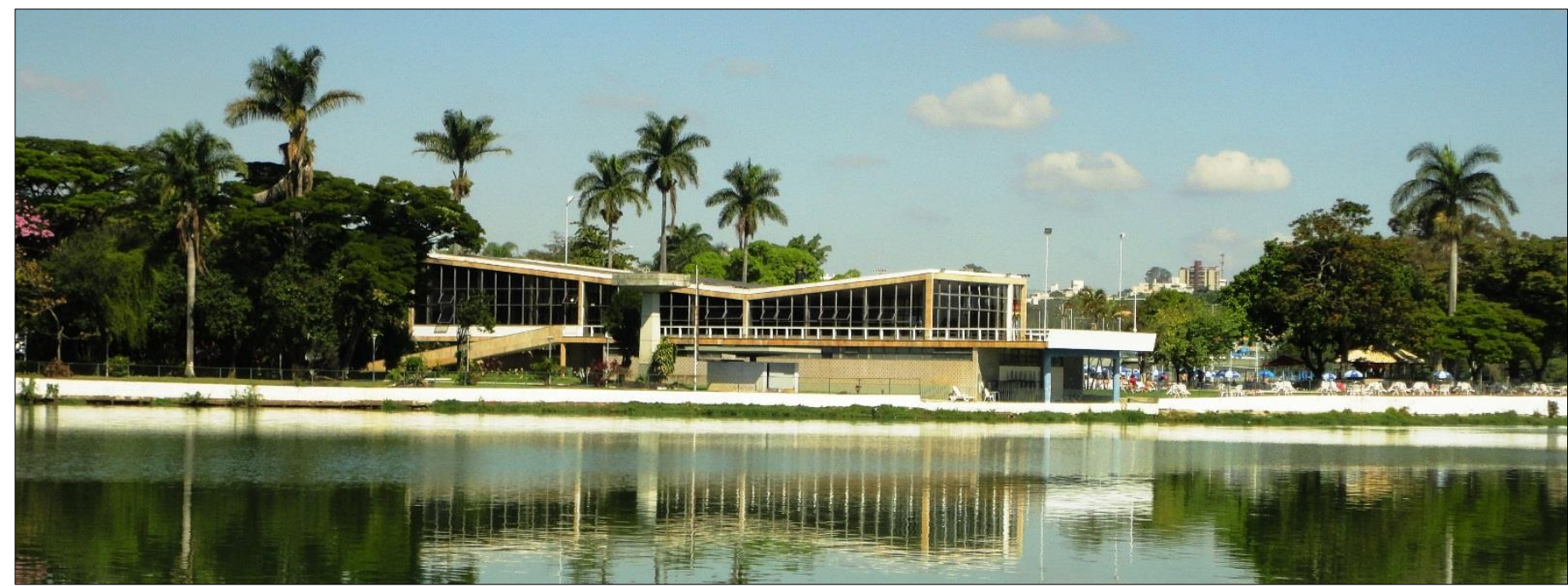

[4.50] Perspectiva geral do late Clube em relação à Lagoa da Pampulha. Percebem-se o telhado borboleta, a horizontalidade volumétrica que remete a uma embarcação, os fartos panos de vidro que contornam a construção, a predominância ortogonal das fachadas, o volume principal, situado acima do solo e cujo acesso pode ser feito por meio de uma rampa lateral.

[4.51] A partir dos jardins do Museu de Arte da Pampulha (antigo Cassino) avista-se, ao fundo o late Clube. Em primeiro plano, a escultura "O Abraço", moldada em mármore pelo artista brasileiro Alfredo Ceschiatti em 1943.

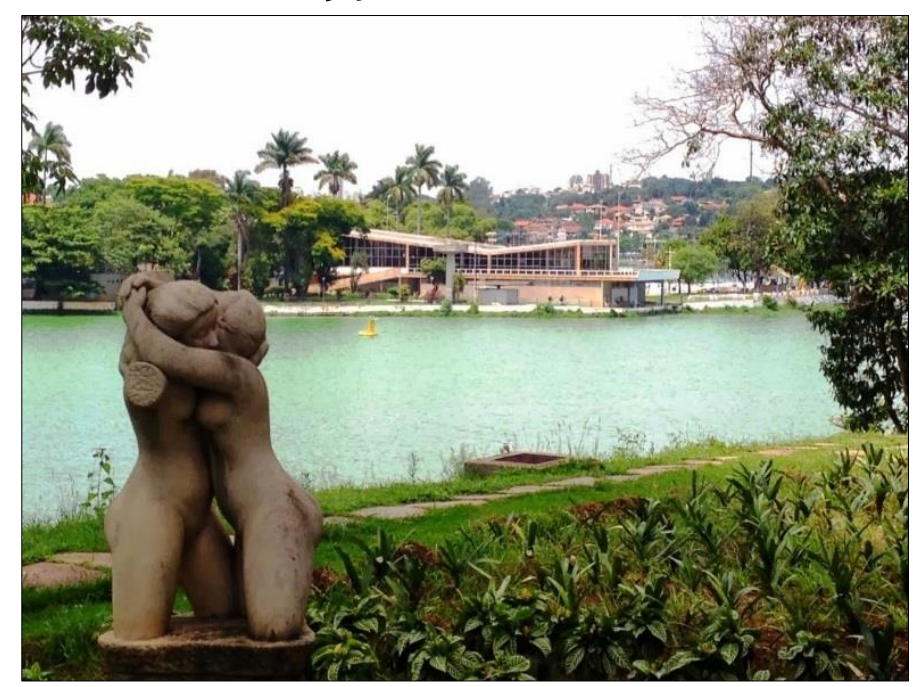

[4.52] Estruturada em concreto armado, a rampa lateral conduz o visitante à entrada principal do edifício. Comparativamente, trata-se de uma solução arquitetônica mais modesta e mais discreta que aquela adotada no Pavilhão do Brasil em Nova York, em 1939.

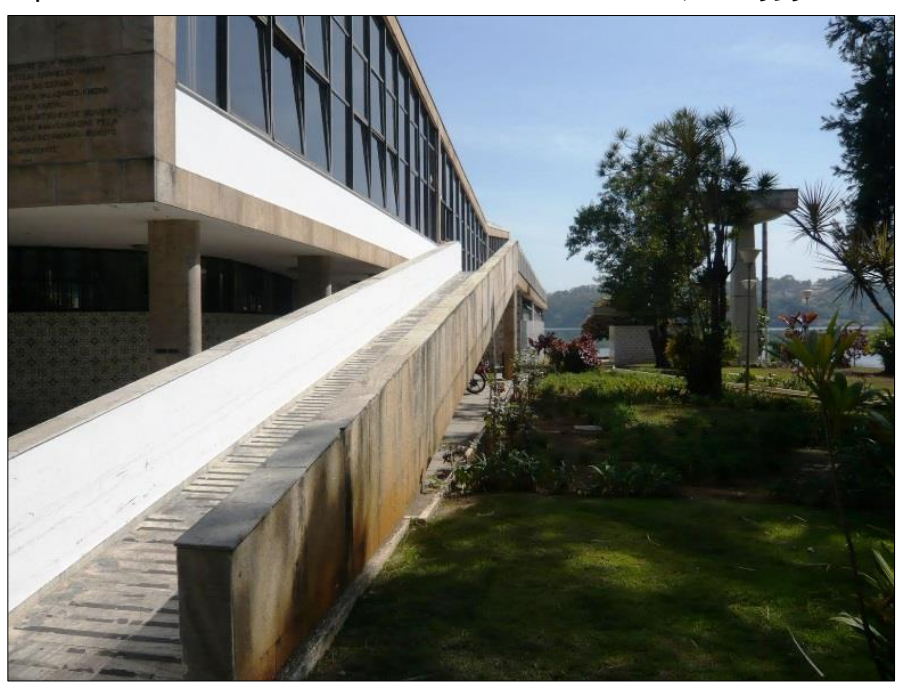


O CONCRETO QUE FLUTUA SOBRE AS ÁGUAS

Oscar Niemeyer:

Conjunto Arquitetônico da Pampulha: "late Clube"

(Belo Horizonte, Minas Gerais, 1942)
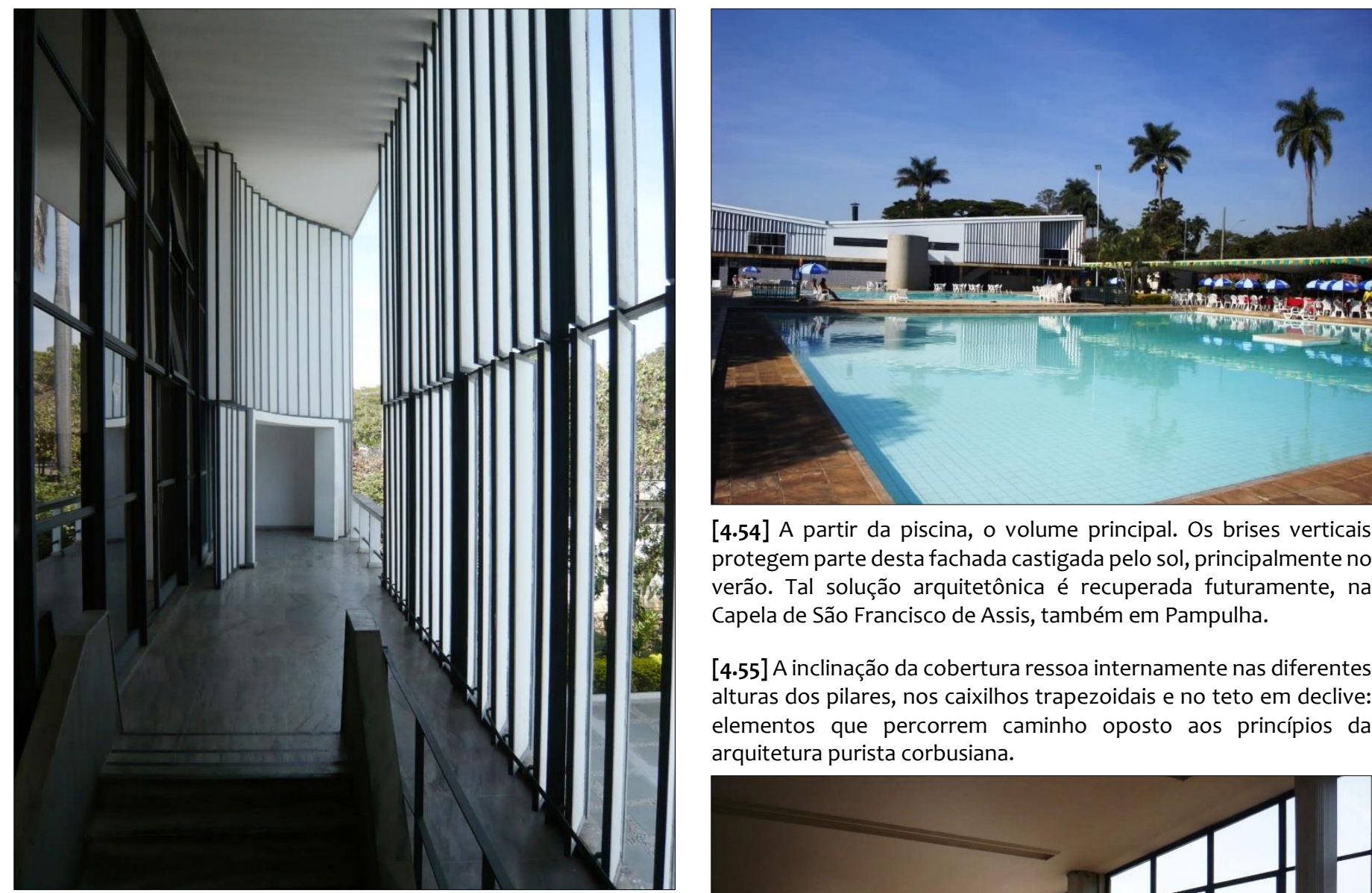

[4.54] A partir da piscina, o volume principal. Os brises verticais protegem parte desta fachada castigada pelo sol, principalmente no verão. Tal solução arquitetônica é recuperada futuramente, na

[4.53] As fachadas completamente envidraçadas promovem transparência e integração interna e externa ao late Clube. Na imagem acima, nota-se um dos acessos aos terraços de contemplação, debruçado sobre as ampla áreas de lazer.

Contudo, esta proposta de Niemeyer não pode ser colocada em prática, plenamente, sem que alguns artifícios sejam adotados com o intuito de melhorar a qualidade de vida interna, especialmente no que diz respeito às condições térmicas e lumínicas.

Opta-se, então, pela disposição de brises verticais, articuláveis, ao longo de toda a fachada que recebe mais incidência solar. A partir daí é possível controlar a intensidade da luz natural nos ambientes internos e manter a temperatura nessas áreas mais agradável.

[4.55] A inclinação da cobertura ressoa internamente nas diferentes alturas dos pilares, nos caixilhos trapezoidais e no teto em declive: elementos que percorrem caminho oposto aos princípios da arquitetura purista corbusiana.

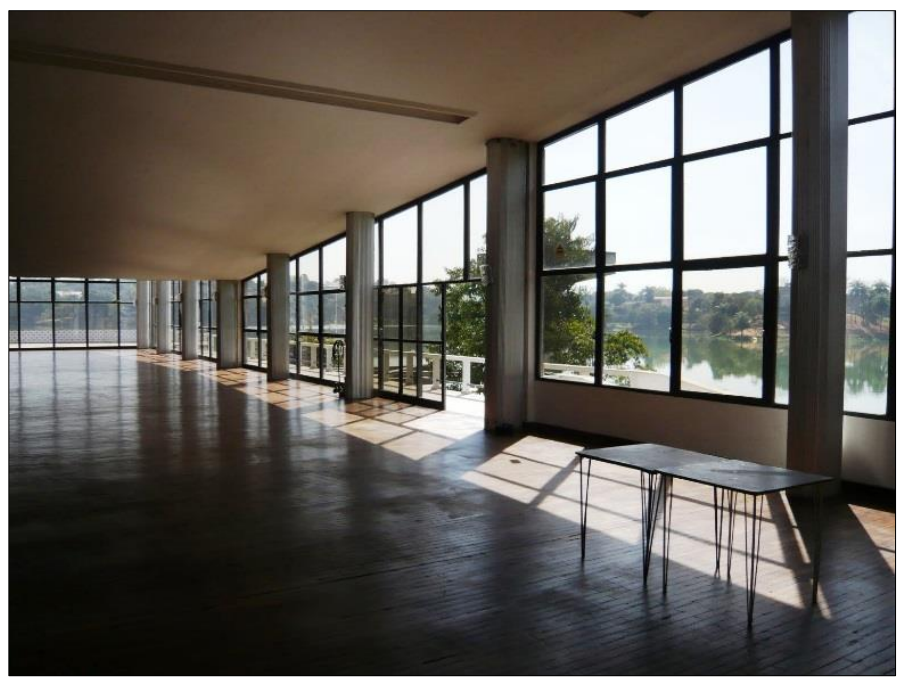




\section{A ESTRUTURA COMO EXPRESSÃO DA ARQUITETURA}

Oscar Niemeyer:

\section{Conjunto Arquitetônico da Pampulha: "Capela de São Francisco de Assis"}

(Belo Horizonte, Minas Gerais, 1943)

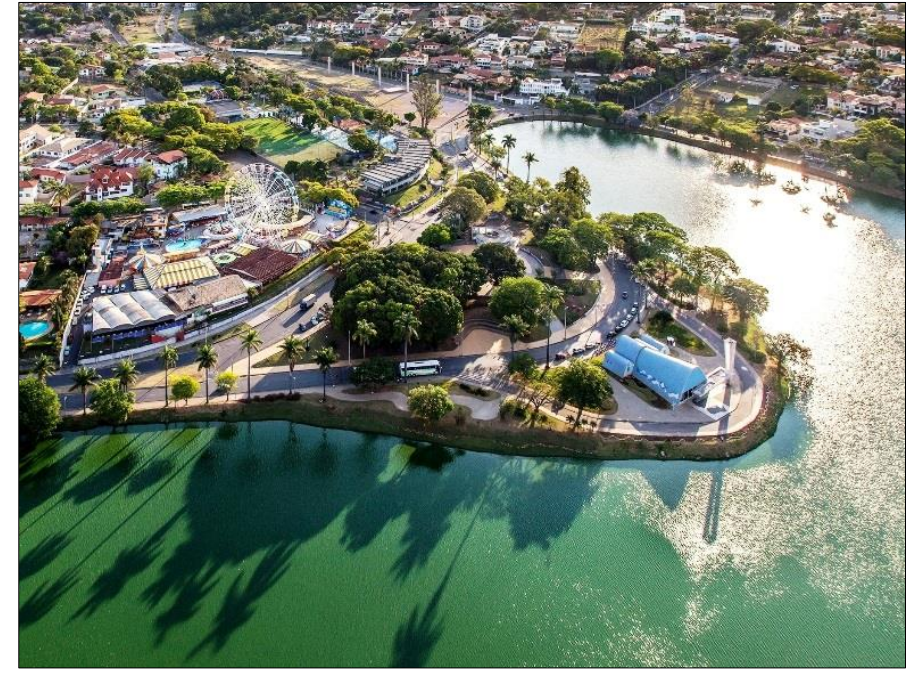

[4.56] Em uma vista aérea pode-se notar o sítio de destaque dedicado à implantação da Capela de São Francisco de Assis, em Pampulha (bairro nobre criado em 1939 e distante dez quilômetros do centro de Belo Horizonte, junto a uma extensa lagoa artificial).

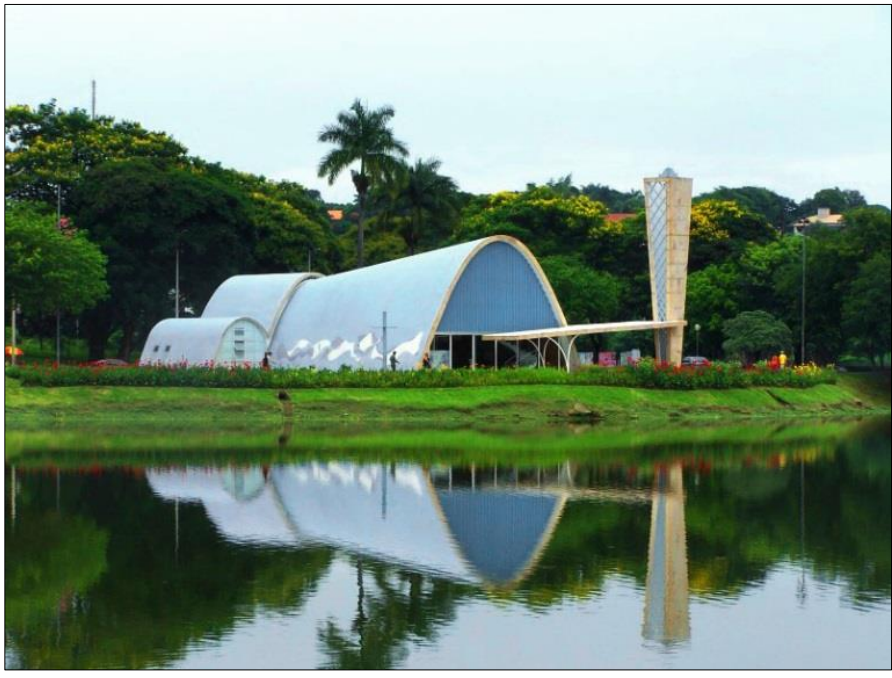

[4.57] A ampla fachada frontal e principal da Capela abre-se para a Lagoa da Pampulha e estabelece, a partir daí, uma relação próxima com o entorno. Nota-se que o volume ondulado do edifício não agride a paisagem, pelo contrário, integra-se a ela plenamente.

[4.58] Neste projeto, Niemeyer não faz mais uma releitura do purismo corbusiano (e o seu tradicional sistema viga - pilar - laje). Ele opta, sim, por uma nova solução arquitetônico-estrutural conformada por uma casca paraboloide de seção variada para o corpo frontal (que cobre a nave) e, ao fundo, um conjunto de abóbodas autoportantes de dimensões variadas para abrigar as demais funções. Uma dessas abóbodas sobrepõe-se transversalmente à casca principal e admite a entrada de luz sobre o altar, a partir do desnível gerado nesse ponto.

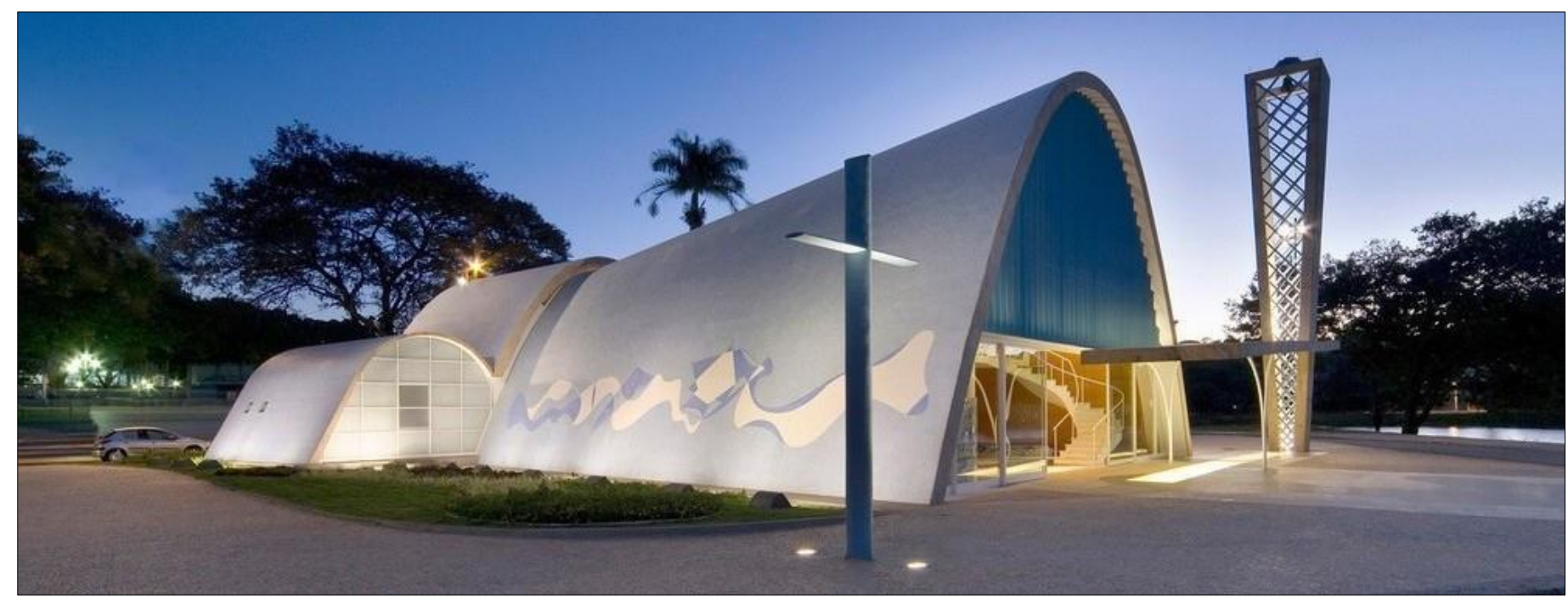




\section{A ESTRUTURA COMO EXPRESSÃO DA ARQUITETURA}

Oscar Niemeyer:

\section{Conjunto Arquitetônico da Pampulha: "Capela de São Francisco de Assis"}

(Belo Horizonte, Minas Gerais, 1943)

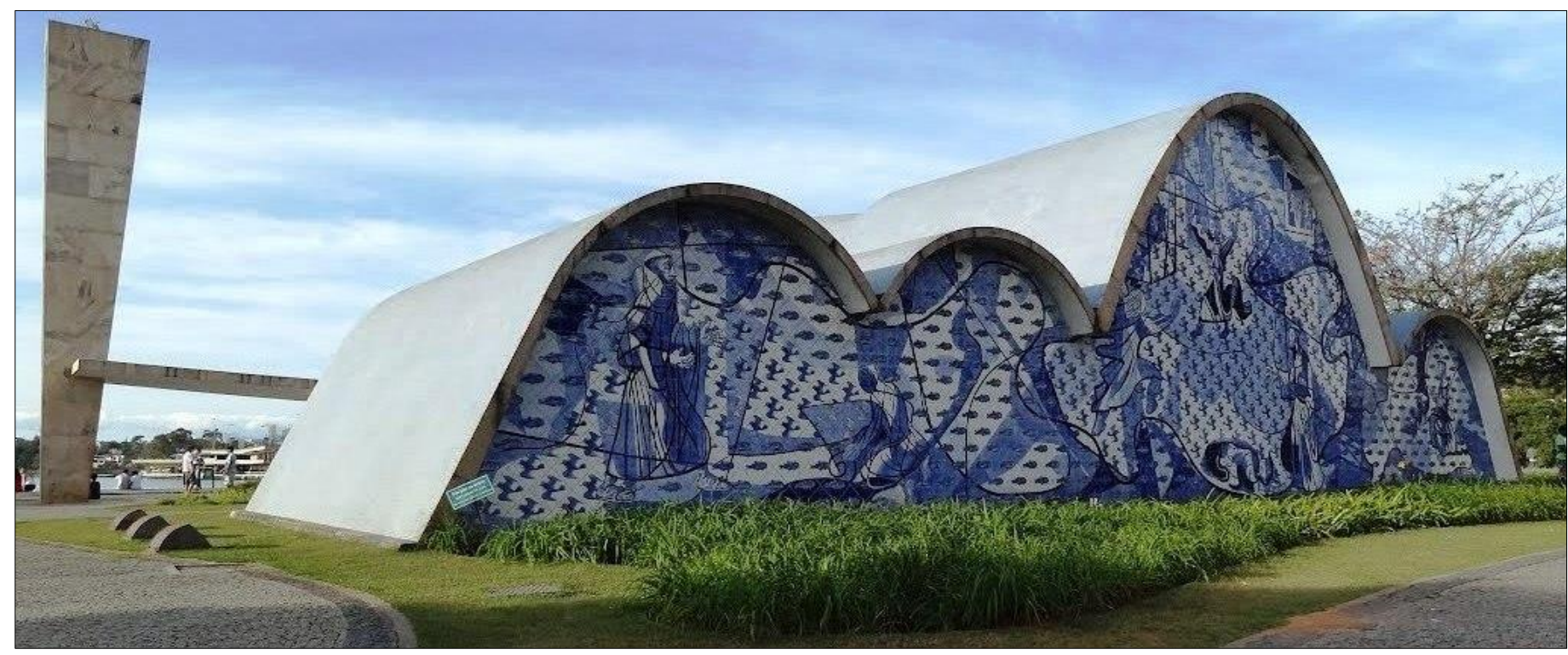

[4.59] O posicionamento da Capela faz com que o visitante seja recebido, a partir da rua de acesso, pela fachada posterior do edifício. Nela encontra-se uma obra em azulejaria de Cândido Portinari, a qual traça uma retrospectiva da vida de São Francisco de Assis.

[4.60] Internamente a nave é revestida por forro de madeira. O coro situa-se em uma plataforma suspensa, transversal à casca de concreto e acessada por uma escada helicoidal. Brises verticais, como os do late Clube, debelam a forte luminosidade externa.

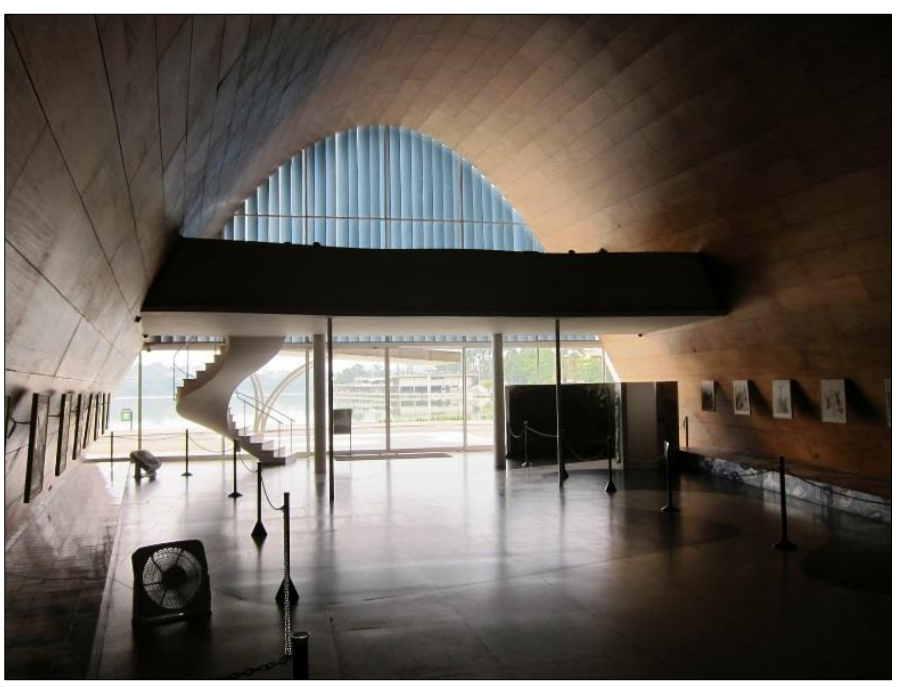

[4.61] Junto ao acesso principal está uma marquise inclinada que, em um dos lados, pousa sobre delgados pilares metálicos encurvados. Na extremidade oposta ela fatia parte do campanário vertical. Ambos os elementos são moldados em concreto armado.

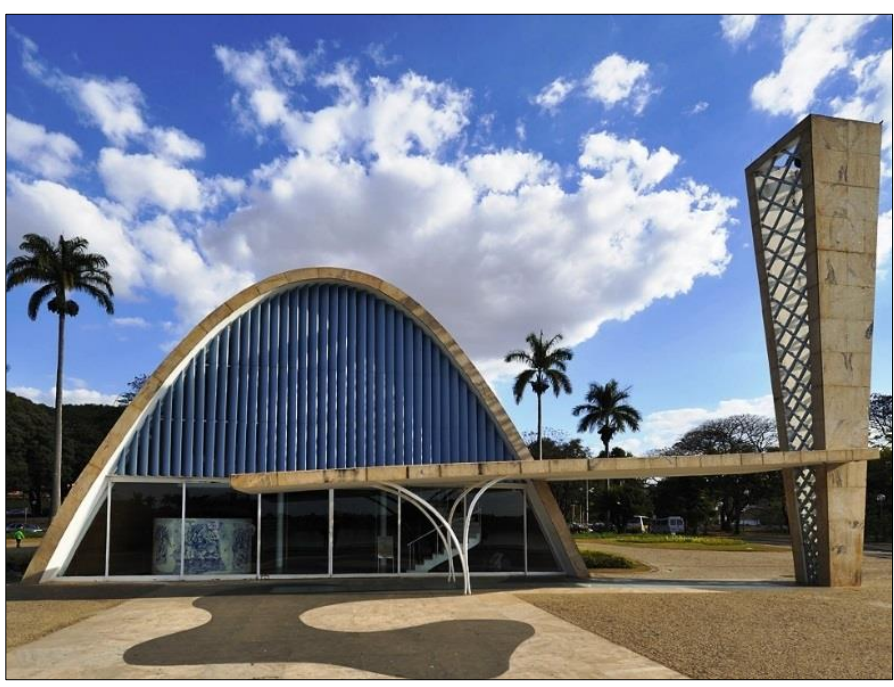




\section{Entreatos: Meditações e Reflexões Niemeyerianas}

Apreende-se, até este ponto da discussão aqui lançada, que o papel de Oscar Niemeyer na arquitetura moderna brasileira é fundamental desde o início - dadas a qualidade das obras e a projeção nacional e internacional obtidas logo nos primeiros projetos construídos. Ao entrelaçar técnica e estética em suas produções - sobretudo com a aplicação do concreto como material básico de construção - o arquiteto carioca mantém a essência moderna, porém, conduz suas dimensões construtiva, espacial e projetual a patamares jamais imaginados. Isso não significa dizer, entretanto, que Niemeyer seja necessariamente melhor que outros arquitetos modernos a ele contemporâneos, mas, sim, que deles se distancie sobretudo pelo contraponto, pelo talento inato e pela coragem em inovar.

O Conjunto Arquitetônico da Lagoa da Pampulha, cuja obra de maior representatividade é a Capela de São Francisco de Assis é a chance, segundo o próprio Niemeyer (2000), de satisfazer a todas as exigências plásticas que o concreto armado demanda no início dos anos 1940. Queiroz (2007) concorda com essa afirmação e vai além, ao explicar que Pampulha permanece decalcada no ato projetual niemeyeriano desde então - isto é, seus projetos posteriores, em quaisquer amplitudes, trazem implícitas referências à Pampulha e aos desdobramentos das soluções ali aplicadas. Corporificam, por assim dizer, variações dos temas formais inaugurados em Belo Horizonte. Vale a pena citar o próprio autor, cuja explicação para esse fato é bastante clara e abrangente:

Os projetos de Oscar Niemeyer que sucedem sua experiência em Pampulha, em sua imensa maioria, versam sobre um conjunto de soluções que possuem como matriz formal os recursos utilizados em cada um dos edifícios da Pampulha: planta circular e marquise sinuosa na Casa de Baile; marquise sinuosa e pilar em "V" e planta circular irregular no Cassino; telhado invertido e plataforma no late Clube; abóbada e telhado invertido no Clube de Golfe; bloco em curva, fachada inclinada e laje sinuosa/plataforma no Hotel Resort; abóbadas sucessivas e pilar em "V" na Igreja de São Francisco de Assis.

Os projetos de Niemeyer realizados no período posterior a Pampulha podem ser considerados como variações, em diferentes intensidades, das soluções formais do projeto mineiro. Entretanto, devemos atentar para o fato de que as soluções presentes no conjunto da Pampulha não são consequência da mera "invenção", e sim variações sobre temas já abordados por Le Corbusier em projetos realizados entre 1919 e 1930, tais como: o pilar em "V", a marquise inclinada e o cilindro do Exército da Salvação (1929); as abóbadas sucessivas da Casa Monol (1919) e de seu estúdio particular (1919); o cilindro transparente e o paralelepípedo suspenso por um reticulado de pilares presente na Casa Savoye (1929); a marquise arqueada da Liga das Nações em Genebra (1927) e do Centrosoyus (1929); o telhado invertido da Casa Errazuris (1930), entre outros. 
Nos projetos realizados entre 1942 e 1954, cada uma das soluções formais elencadas acima sofrerá transformações de escala, proporção e desenho. A organização de diversos componentes desse conjunto de formas é consequência de estratégias compositivas onde, em alguns casos, um único projeto pode conter todas as soluções presentes em Pampulha.

Projetos como o Fluminense late Clube (1945), o Hotel Regente na Gávea (1949), o Restaurante e Garagem de Barcos da Lagoa Rodrigo de Freitas (1944), o Hotel em Nova Friburgo (1945) e a Residência Burton-Tremaine na Califórnia (1947) são exemplares que se constituem a partir da manipulação de todos os componentes formais presentes no conjunto da Pampulha.

Esses componentes se relacionam conforme uma estratégia que estabelece padrões de hierarquia entre as formas expressivas - consideradas como apêndices ornamentais - e as formas simplificadas derivadas de volumetrias prismáticas.

É evidente que a produção de Niemeyer posterior à experiência de Pampulha não se resume apenas às variações originais sobre os temas formais lançados no projeto de Belo Horizonte. $E$, certamente, o raciocínio de Niemeyer não deve ser compreendido como uma mera equação combinatória. $O$ repertório formal de Pampulha representa a gênese criativa de uma obra calcada, antes de tudo, na sensibilidade.

Entre os projetos dos edifícios da Pampulha (1940 - 1943) e os projetos que ilustram sua revisão crítica, realizados a partir de 1954, Niemeyer executa algumas obras-chave para o desenvolvimento de sua pesquisa pessoal, tais como os projetos em Diamantina para a Escola Julia Kubitschek e para o Hotel Tijuco (1951), o Conjunto do Parque do Ibirapuera (1951 - 1953) e sua residência particular na estrada de Canoas no Rio de Janeiro (1953).

Os projetos de Niemeyer que sucedem a experiência em Pampulha não serão reconhecidos pelo ineditismo de suas formas, mas serão compreendidos como uma variação sobre um original, ou seja, a própria matriz que contém a gênese criadora de Niemeyer: Pampulha. (QUEIROZ; 2007: 383-384)

Pode-se admitir então, frente o trecho acima transcrito, que a base conceitual dos projetos de Niemeyer - iniciada com as obras de Belo Horizonte - frutifica em arquiteturas que paulatinamente incorporam novos fazeres projetuais, novas soluções arquitetônicas e novas proposições estruturais, porém, sem abrir mão de sua essência. Ainda tomando o concreto como principal técnica construtiva, os projetos elaborados pós-Pampulha guardam entre si certas similaridades, ou melhor, alimentam a concepção de arquiteturas que trazem implícitos certos predicados que deixam clara a identidade do arquiteto. São, pois, qualidades autorais, reconhecíveis, que ajudam a entender o percurso evolutivo de Niemeyer - como já discutido anteriormente neste estudo. Entretanto, esta fase que mantém subentendida uma raiz em Pampulha, não é duradoura.

Ao contrário do que possa parecer, a carreira de Oscar Niemeyer não se desenrola uniformemente, em um contínuo e ininterrupto processo ascendente [Figura 4.62]: passados mais de vinte anos de formado, com aproximadamente dois mil projetos desenhados (mas não necessariamente edificados), após fazer uma extensa viagem para fora do 
país, às vésperas da construção de Brasília e gozando de claro reconhecimento em terras nacionais e estrangeiras, o arquiteto carioca enfrenta uma primeira fase de várias e densas reflexões críticas focadas, especialmente, em sua própria arquitetura. Este período delicado da carreira de Niemeyer abrange os anos de 1954 a 1958, como esclarecido por Queiroz (2007).

Ao compor o texto "Considerações sobre a Arquitetura Brasileira", veiculado inicialmente em 1958 na revista "Módulo" e republicado pouco depois sob o título "Depoimento" na "Acrópole”, Niemeyer registra que a arquitetura - e aí incluídos os seus próprios trabalhos - deve buscar a unidade formal por meio de soluções plásticas mais simples e com equilíbrio ideal no que se refere às respostas aos problemas funcionais e construtivos. Dito de outra maneira, passam a interessar-lhe, deste momento em diante, as criações compactas simplificadas e predominantemente geométricas, além das questões hierárquicas e de caráter arquitetônico de unidade e de harmonia, potencialmente expressas, sempre que possível, por suas próprias soluções estruturais (tomadas como partes integrantes dos conceitos plásticos originais, entretanto não compreendidas, ainda, como elementos arquitetônicos fundamentais).

A meditação crítica feita por Niemeyer nessa época é causada não apenas pelas variáveis de cunho pessoal em relação à sua própria arquitetura ou a transformações formais, técnicas e tecnológicas que passam a lhe interessar cada vez mais. Ela acontece também em função das ácidas críticas desferidas contra ele e tanto provocadas pelas publicações nacionais (mais bem representadas, aqui, pela revista "Habitat", fundada pelo casal Bardi em 1950) quanto pelas manifestações internacionais proferidas, por exemplo, pelo arquiteto e teórico italiano Ernesto Nathan Rogers ou pelo então diretor da Escola de Ulm (Alemanha), o suíço Max Bill - cujos duros comentários envolvem, dentre outras obras, o Conjunto Arquitetônico da Lagoa da Pampulha (como já mostrado anteriormente).

A inflexão na carreira desse arquiteto iniciada em 1954, a partir da qual propõe um redirecionamento plástico nos novos projetos, faz com que ele busque atender mais fortemente os problemas fundamentais da arquitetura. Passa então a entender como coisa única forma e estrutura, resolvendo-as ambas concomitantemente (e não sequencialmente) à medida que um novo projeto é pensado. Potencializa, assim, o uso estético do concreto e foca arquiteturas mais arrojadas, porém, materializadas em volumetrias sintéticas, puras, limpas e plenas de leveza volumétrica.

Há que se considerar que essas novas investigações trabalhadas por Oscar Niemeyer não são derivadas de um ponto de inflexão momentâneo em sua carreira e a partir do qual ele simplesmente opta por uma nova estratégia projetual 
aliada a um novo fazer arquitetônico. Trata-se, logo, de uma lenta e gradativa evolução maturada ao logo dos quatro anos apontados na página anterior por Queiroz (2007). Sobre a relação entre as produções anteriores e as mudanças plásticas ocorridas na arquitetura niemeyeriana, Bruand explica que

No plano estético, ele foi atingido pela clareza e lógica de estilos que até então tinha desprezado por não ter aprendido seu verdadeiro espírito. Não hesitou mais em cultivar as verdadeiras qualidades essenciais desses estilos, e até em procurar neles ocasionalmente uma fonte de inspiração, mas sem renunciar aos princípios fundamentais que até então tinham orientado a sua própria arquitetura: emprego de materiais modernos, exploração da flexibilidade do concreto armado, linguagem formal incessantemente renovada por uma vigorosa imaginação plástica. A mudança de estilo ocorreu levando a uma procura sistemática de simplificação e de equilíbrio. Não operou, portanto, uma completa reviravolta de tendências: ela foi fruto não de circunstâncias acidentais, mas, sim, de uma evolução ponderada, cujas premissas podem ser vistas no período anterior. Mas não há dúvidas de que essa mudança foi subitamente acelerada pelo choque que se seguiu ao descobrimento da Europa e de seu passado, descoberta essa que agiu como um catalisador. Contudo, não houve ruptura, mas a decantação de um talento que amadureceu e se libertou das últimas amarrações que até então ele mesmo se tinha imposto. (BRUAND; 1997: 181)

Essa primeira meditação é experimentada inicialmente em projetos de menor porte, como na Residência Edmundo Cavanelas [Figura 4.63] (Rio de Janeiro; 1954). Logo a seguir, é também exercitada mais formalmente nos edifícios brasilienses, seguindo até meados dos anos 1960 - período no qual o arquiteto carioca realiza importantes obras fora do Brasil, como a Universidade de Haifa [Figura 4.64] (Haifa - Israel; 1962) e a Sede do Partido Comunista Francês [Figura 4.65] (Paris - França; 1965). Neste novo momento arquitetônico de Niemeyer, "o jogo entre marquises sinuosas, abóbadas e pilotis escultóricos [nos moldes do de Pampulha] dá lugar a soluções nitidamente simplificadas $e$ concisas, onde o programa não mais se organiza a partir da justaposição de formas livres, mas abriga-se sob um traço rigoroso e elementar". (QUEIROZ; 2007: 389)

Entretanto, é com o não construído Museu de Arte de Caracas [Figura 4.66] - concebido em 1954 - que Niemeyer, efetivamente, inaugura seu novo enfrentamento profissional. As soluções adotadas neste projeto venezuelano são tão importantes para o arquiteto carioca que repercutem em seus trabalhos posteriores de uma maneira bastante contundente, tanto é fato que ecos deste mesmo projeto serão futuramente sentidos nas arquiteturas adotadas em Brasília (e de maneira especial, nos projetos definitivos dos Palácios), assinala Queiroz (2007).

Implantado junto às encostas montanhosas da capital venezuelana, o prédio repousa sobre um promontório a partir do qual tem-se uma relação privilegiada para com capital venezuelana. No entender de Fraga (2006), Niemeyer adota uma volumetria pura, que remete a um tronco de pirâmide invertido. Nela, as vedações externas são praticamente 
cegas, portanto, a valorização das paisagens ao redor cede lugar, em um primeiro momento, à contemplação do edifício propriamente dito. Isso não significa dizer que o entorno seja ignorado: se ele não pode ser devidamente usufruído estando-se no interior da construção, "a vista da cidade de Caracas é franqueada pelo espaço livre que se estende à volta de todo o museu projetado sobre apoio único”. (GONÇALVES; 2010: 103)

A iluminação natural penetra na edificação de forma direcionada, quase que exclusivamente por meio da cobertura. Neste pavimento, Niemeyer prevê uma espécie de laje feita em concreto e em forma de grelha que, favorecida pelo seu formato, ajuda no controle lumínico interno sem interferir na limpeza da volumetria. São seis pisos no total, dos quais três dedicados às áreas de exposição. Para o sistema estrutural moldado também em concreto armado, há uma preocupação especial do arquiteto, dada a dificuldade e a inovação volumétrica pela primeira vez adotada:

as paredes externas inclinadas, formadas por dois painéis de concreto ligados por nervura com 90 centímetros de profundidade a cada metro, além de vedação, desempenham papel estrutural que só funciona em conjunto com as lajes, numa relação em que parede inclinada tensiona laje que, por sua vez, segura parede. Este tensionamento também proporciona um aumento do vão vencido pela laje e a consequente diminuição de pilares internos. Apenas quatro pilares sobem para a sustentação dos pisos de foyer e salão de exposições acima, com espaçamento de aproximadamente 15 metros. 0 mezanino, diferentemente, é suspenso pela cobertura através de quatro colunas (chamadas por Niemeyer de colunas-pêndulo) e quatro tensores diagonais (que novamente servem para segurar tanto a laje do mezanino quanto as paredes externas). Esta estratégia libera o salão de exposições imediatamente inferior da interferência de pilares

A forma das lajes admite ainda alguma liberdade de contorno, ligando-se às paredes em pontos específicos (como no $3^{\circ}$ pavimento e no mezanino).

A cobertura é um plano virtual, composto em sua maior parte (aproximadamente $3.600 \mathrm{~m}^{2}$ ) por painéis de concreto que refletem e controlam a luz natural para o interior dos salões de exposição. Em uma faixa mais restrita funciona como terraço para exposições de escultura ao ar livre, apoiado em uma das duas vigas tubulares de seção quadrada (medindo 1,5 metro de altura) que seguram os tensores verticais de sustentação do mezanino. (FRAGA; 2006: 118)

Queiroz (2007) arremata a representatividade desta fase de reflexões nas produções futuras do arquiteto carioca ao explicar que,

para Niemeyer, a tensão intelectual dessa revisão crítica não reside na mera dimensão plástica da arquitetura, mas no novo foco presente em seus procedimentos de projeto.

A partir de 1954, Niemeyer não apenas considera o conteúdo das críticas sofridas desde 1952, como formula um novo raciocínio a partir de uma severa revisão sobre suas formulações especuladas desde Pampulha. 
A partir do projeto do Museu de Arte de Caracas (1955) e de seu Depoimento (1958), Niemeyer não apenas revê a dimensão plástica de sua obra, como antevê uma nova perspectiva para sua arquitetura: a condição de monumento. (QUEIROZ; 2007: 396)

E esse novo olhar lançado sobre a arquitetura de Oscar Niemeyer é mais bem trabalhado a partir de seu próximo momento de ponderação crítica. Percebe-se, pois, nova alteração em seu fazer projetual - desta vez sutilmente mais discreta - anos depois, quando chega próximo o final da década de 1960. Os projetos concebidos a partir de então são tecnologicamente mais desafiadores ao apostarem em soluções estruturais portantes de grandes proporções. Mas não é só isso. As estruturas assumem dali em diante o papel proeminente de determinar não apenas o partido arquitetônico, como também o de se responsabilizar pela definição da forma dos edifícios. É a oportunidade a partir da qual Oscar Niemeyer trabalha em um compasso ainda mais cadenciado ao das equipes técnicas que o cercam estas, formadas em sua maioria por competentes profissionais da engenharia - dadas as soluções construtivas mais ousadas requisitadas por seus projetos. Nesta nova transição profissional, chamam a atenção os trabalhos para a primeira etapa da Universidade de Constantine [Figura 4.67] (Constantine - Argélia; 1969) e o Quartel-General das Forças Armadas [Figura 4.68] (Brasília; 1968), mas, principalmente, as propostas cariocas nunca edificadas para o Centro Musical da Barra (1968) [Figura 4.69] e para o Museu Exposição Barra'72 - Pavilhão do Saber (1969). [Figura 4.70]

Mesmo situado em um período já fora do recorte escolhido para este estudo, pode ser apontado ainda outro período de reflexão vivenciado por Oscar Niemeyer, anos depois, dizem Bastos e Zein (2010). A partir de meados da década de 1980, sua arquitetura torna-se tanto mais individualista quanto menos se relaciona ao entorno, sendo marcada por volumes lacônicos abstratos, escultóricos e representativos. É uma fase em que o arquiteto, em prol de simplificações volumétricas, passa a não mais valorizar adequadamente os problemas de cunho programático-funcionais. InteressaIhe mais que nunca antes aquilo que desperta surpresa e admiração - mesmo que para isso tenha que desafiar as leis do equilíbrio e da gravidade.

Como exemplos desta fase projetual tem-se o Museu de Arte Contemporânea de Niterói [Figura 4.71] (Rio de Janeiro; 1996), que sublima uma metamorfose volumétrica e formal da pirâmide invertida, fazendo com que seja possível apreendê-lo como uma releitura do Museu de Arte de Caracas de 1954. Além dele, pode-se apontar o Museu Oscar Niemeyer [Figura 4.72] (Curitiba; 2002), que por sua forma livre, fluida e curva simula, por assim dizer, um instante em 
que Niemeyer encontra-se novamente com o seu fazer arquitetônico tão característico ao longo da carreira, ao voltar sua atenção, uma vez mais, às questões de funcionalidade programática, como bem ressaltam as mesmas autoras.

Há que se citar, por fim, dois projetos mais recentes, mas que sugerem a mesma linha de raciocínio derivada do último momento de revisão crítica identificado por Bastos e Zein (2010). O Centro Cultural Principado de Astúrias / Oscar Niemeyer [Figura 4.73] (Avilés - Espanha; 2006) é o seu primeiro projeto em território espanhol. Trata-se de um grupo de edifícios que claramente exprime a identidade projetual niemeyeriana, ou seja, é este um projeto autoral de Niemeyer composto por uma ampla praça seca aberta ao público na qual distribui-se um conjunto de quatro peças arquitetônicas espacialmente isoladas, mas complementares entre si: um museu com áreas diversas para exposições; uma grande cúpula que conforma um auditório; um restaurante suspenso que também faz as vezes de mirante; e um edifício polivalente, no qual estão alocados cinemas e salas de ensaio, além de uma ala em separado dedicada à administração do complexo cultural e dotada de espaços para reuniões e conferências, além dos escritórios administrativos propriamente ditos.

Já a Cidade Administrativa Presidente Tancredo Neves (Belo Horizonte; 2010) é a nova e atual matriz do Poder Executivo mineiro. Com caráter monumental, é formada por cinco megaedifícios: os prédios Minas e Gerais (destinados às secretarias de estado), o Auditório Juscelino Kubitschek e um prédio que compreende as instalações de apoio ao governo do estado. Além destas, das edificações que fazem parte do conjunto erigido, a mais instigante é o Palácio Tiradentes [Figura 4.74] (sede da governadoria mineira), cujas imponentes dimensões (talvez exageradas?) creditam a esta obra feita em concreto protendido, o título de maior edifício totalmente suspenso do mundo.

Percebe-se portanto, que as reflexões críticas feitas por Oscar Niemeyer acompanham-no em boa parte de sua produção arquitetônica, servindo como impulso à criação de um fazer projetual que constantemente se reinventa e se reafirma, porém, sem que sua essência seja perdida e sem que sua identidade seja comprometida. Se a cada nova transição novas preocupações passam a tomar a mente do arquiteto a ponto de lhe influenciar o ato criativo, certamente não o fazem comprometendo-o ao ponto de exauri-lo. Isso significa dizer que Oscar Niemeyer tira proveito desses momentos de "incerteza” para recolocar-se perante seu trabalho, sempre, com fôlego revigorado. Com o passar do tempo, torna-se - conscientemente ou não - hábil artesão das formas no sentido de, a partir de uma determinada base pré-estabelecida, conseguir resultados diversificados, porém, que bebem igualmente de uma única fonte original: o próprio arquiteto. 
Para Wisnik (2007), Niemeyer carrega consigo uma vocação predominantemente autoral, concebendo projetos com identidade própria e alicerçados em um forte viés plástico, além de possuir significativa liberdade ao lidar com a relação entre volumetria e estrutura. Mahfuz (2007) compartilha desse pensamento e acrescenta que principalmente depois de Brasília o referencial básico é direcionado para a sua própria obra. Além disso, o mesmo autor explica que nos trabalhos de Niemeyer há uma intensa identidade ritual, fruto tanto da existência de nítidas estruturas formais responsáveis pela organização dos projetos, do uso de volumetrias básicas no tratamento dos fatores compositivos, quanto de um número de componentes arquitetônicos bastante limitado em seus projetos. Sobre essas três características, o mesmo autor aponta que elas "definem uma obra altamente sintética, fácil de entender e de memorizar - por isso de alto poder simbólico". (MAHFUZ, 2007: 76)

Se com Brasília o referencial projetual de Niemeyer passa a ser ainda mais marcadamente a sua própria obra, é lá também que ele consegue colocar em prática todo seu talento criativo, influenciado que está pelas aspirações e pelas intenções político-ideológicas das equipes envolvidas em um projeto de tamanha dimensão e de tal importância. A nova Capital Federal configura-se como a primeira oportunidade real na qual ele, efetivamente, degusta o resultado de suas profundas meditações iniciadas com o projeto do Museu de Arte de Caracas (1954). Projeto esse que reverbera nas soluções arquitetônico-estruturais de diversos edifícios brasilienses, dentre os quais, os Palácios da nova capital brasileira. 


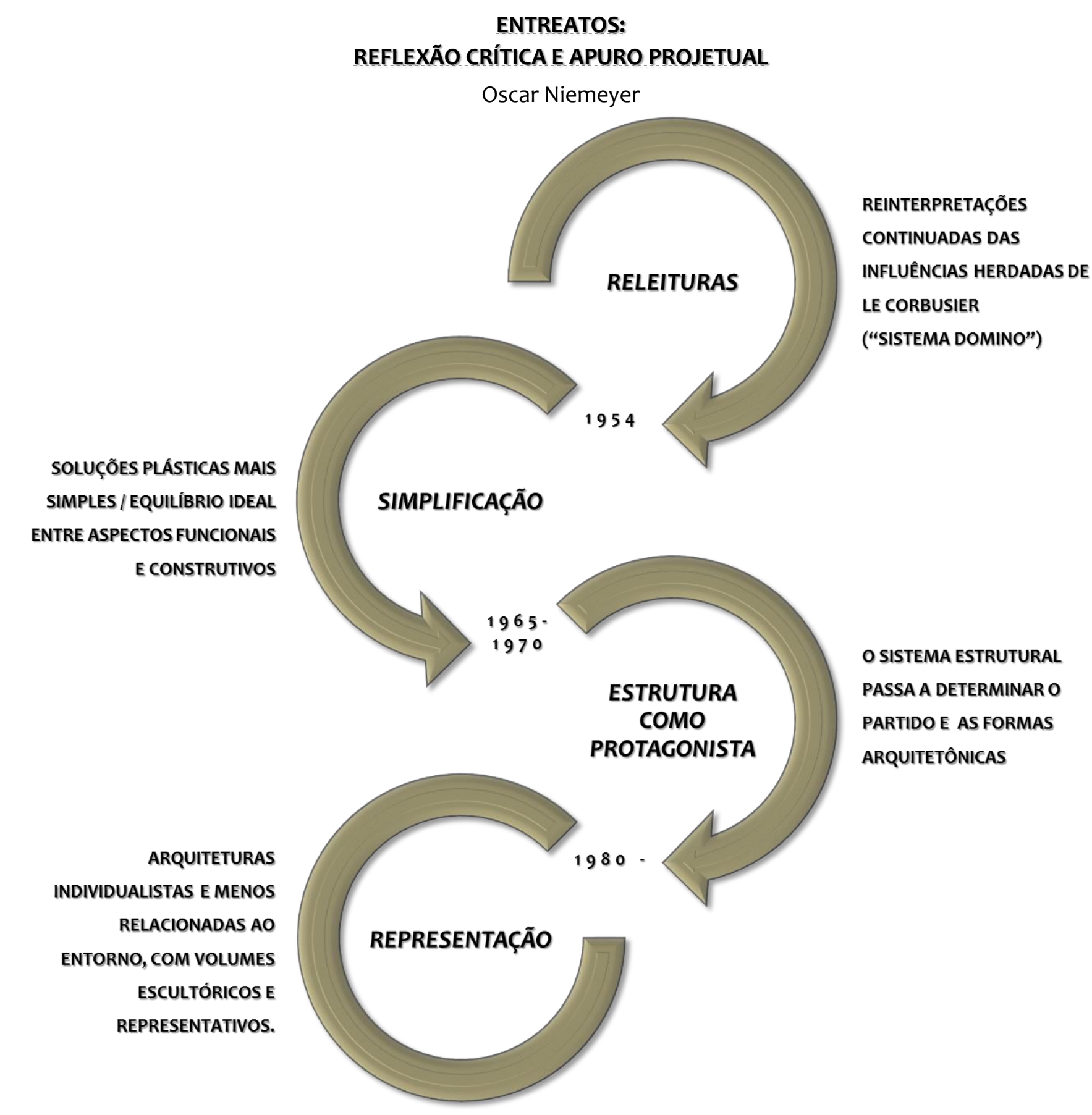

[4.62] Na trajetória de Oscar Niemeyer identificam-se fases projetuais distintas influenciadas e pontuadas por momentos de profundas revisões críticas exercidas pelo próprio arquiteto. A cada um desses pontos de inflexão podem ser identificados novos posicionamentos arquitetônicos que reverberam, por sua vez, nos projetos seguintes por ele concebidos. 


\section{ENTREATOS: REPOSICIONAMENTO CRÍTICO 1}

Oscar Niemeyer:

Residência Edmundo Cavanelas (1954) [4.63]; Universidade de Haifa (1962) [4.64]; Sede do Partido Comunista Francês (1965) [4.65]; e Museu de Arte de Caracas (1954) [4.66]

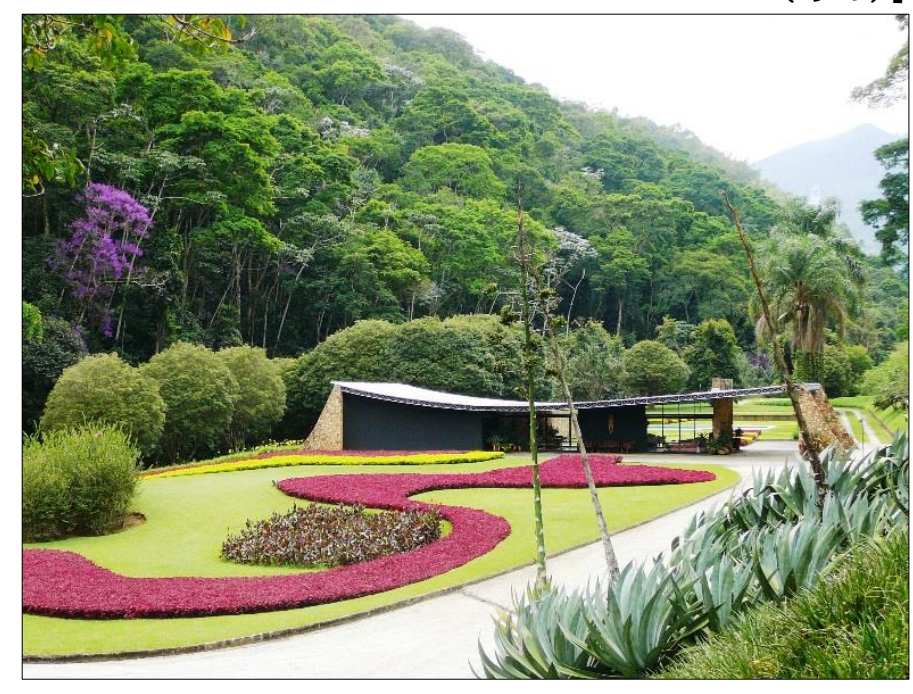

[4.63] Leveza visual da estrutura, desenho limpo, planta simples e integração ao sítio são algumas das qualidades desta casa carioca. A cobertura metálica, encurvada, pousa sobre quatro colunas trapezoidais e duas paredes de concreto, internas.

[4.65] Construído em concreto armado, possui o hall de acesso principal semienterrado, favorecendo a amplitude do lote livre. Há salas de espera, exposições, livraria e um generoso auditório. Todos, acompanham as curvas externas do edifício, em unidade.

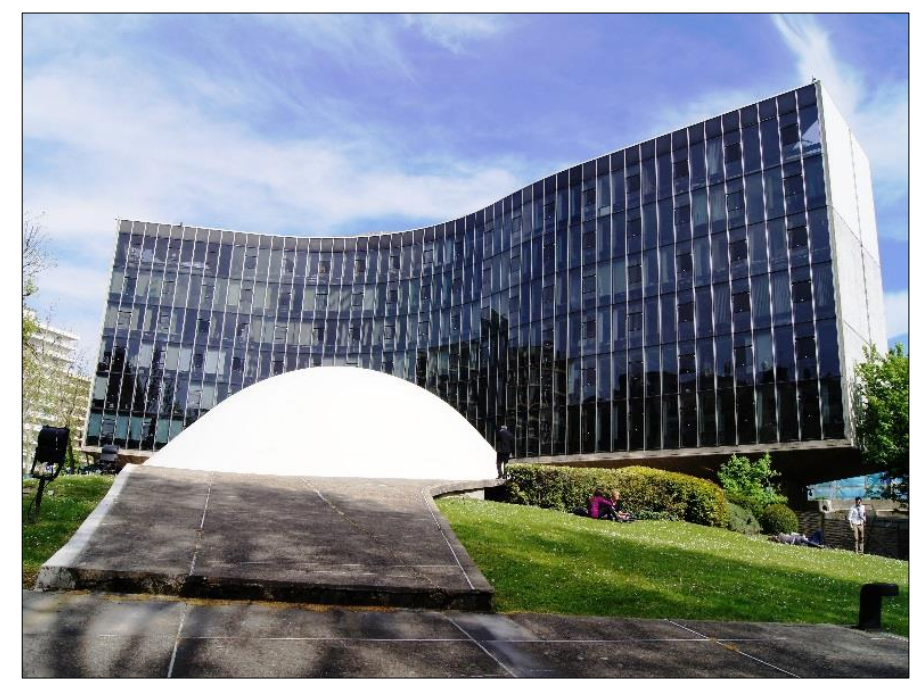

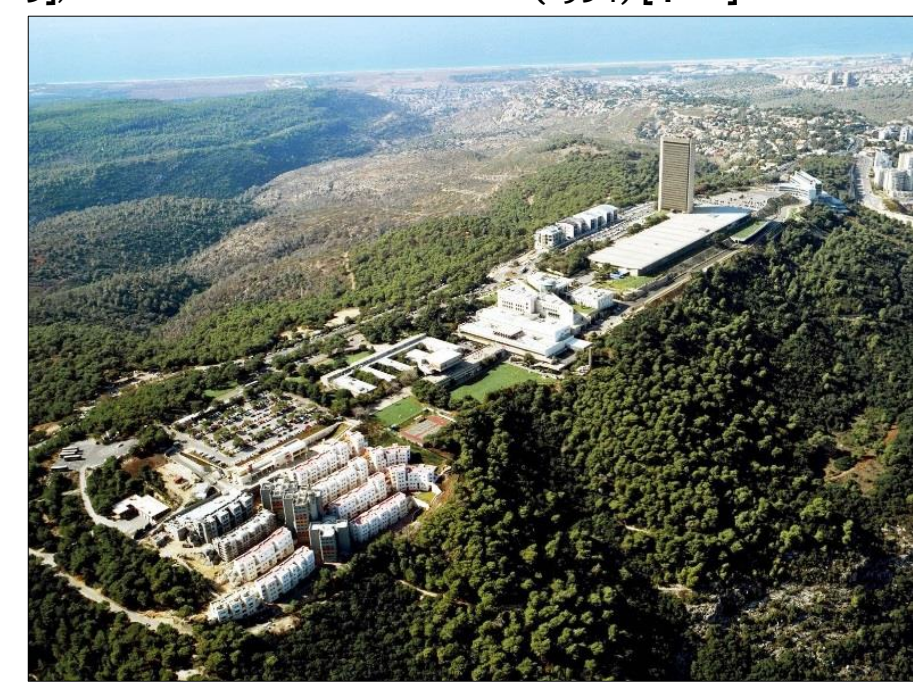

[4.64] Configura-se como uma ampla plataforma horizontal situada no topo do Monte Carmel, a partir da qual ergue-se uma única torre (à direita, na imagem) - além dos volumes destinados aos ambientes de ensino e de administração.

[4.66] Oscar Niemeyer aponta o "Museu de Arte de Caracas" como o pivô de seu primeiro redirecionamento crítico. Feito em concreto armado, possui volumetria pura que remete ao tronco invertido de uma pirâmide. Esta ideia ecoa nos projetos vindouros do arquiteto.

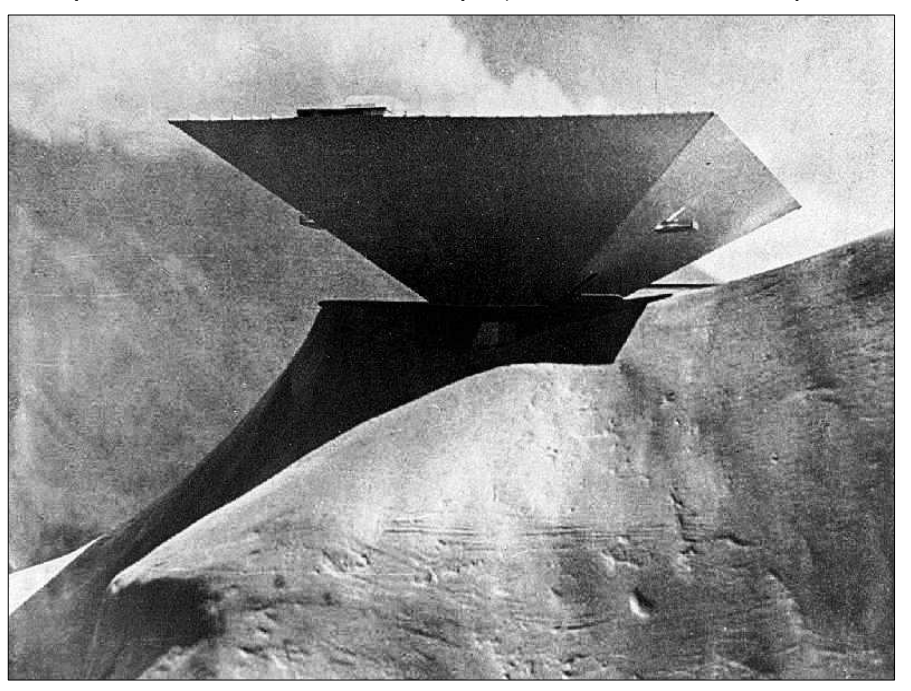




\section{ENTREATOS: REPOSICIONAMENTO CRÍTICO 2}

Oscar Niemeyer:

Universidade de Constantine (1969) [4.67]; Quartel-General das Forças Armadas (1968) [4.68]; Centro Musical da Barra (1968) [4.69]; e Museu Exposição Barra'72 - Pavilhão do Saber (1969) [4.70]

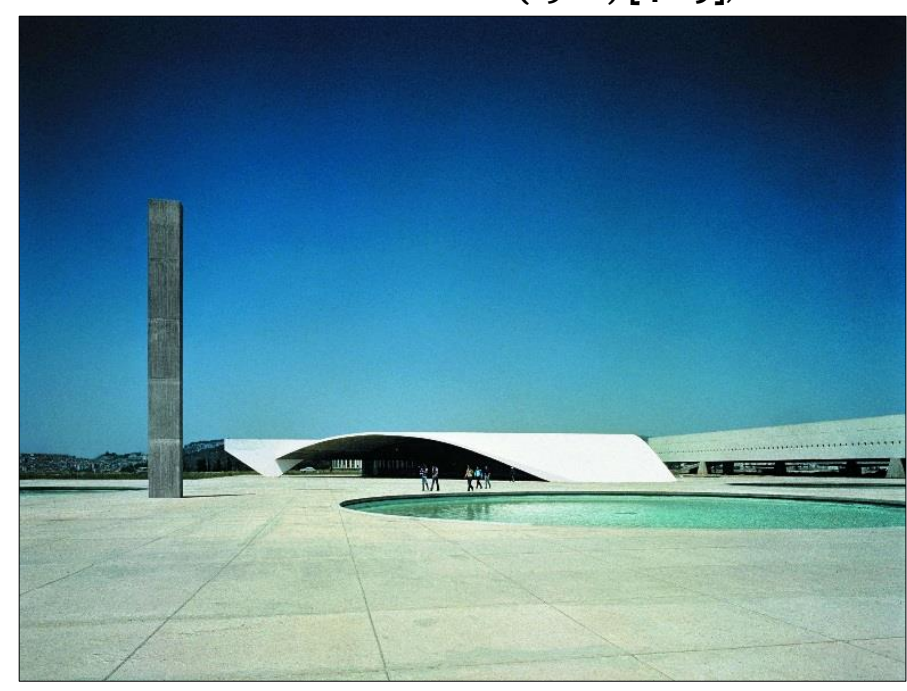

[4.67] Dentre os edifícios, destacam-se: o "Bloco de Classes" (à direita): em concreto protendido, com vãos de 50,0 metros. E o "Auditório" (ao centro): duas cascas de concreto conectam-se ao pórtico bi-rotulado com 60,0 metros comprimento longitudinal.

[4.69] Nunca construído, o projeto do centro cultural abrange um único volume pousado sobre um apoio central. Há vigamentos em concreto na cobertura, além de tirantes metálicos que possibilitam o vencimento de balanços de até 50,0 metros.

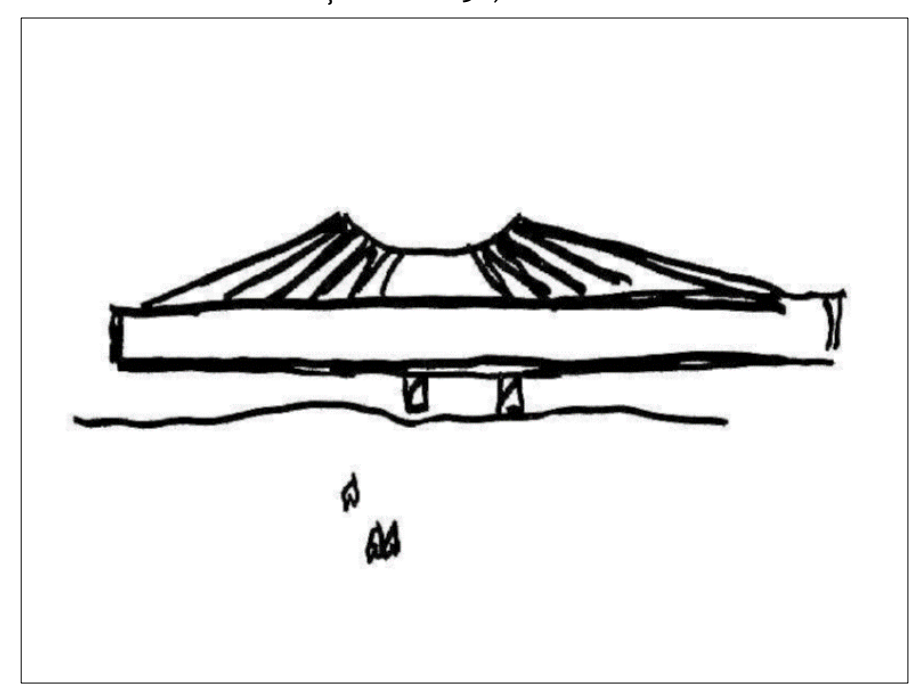

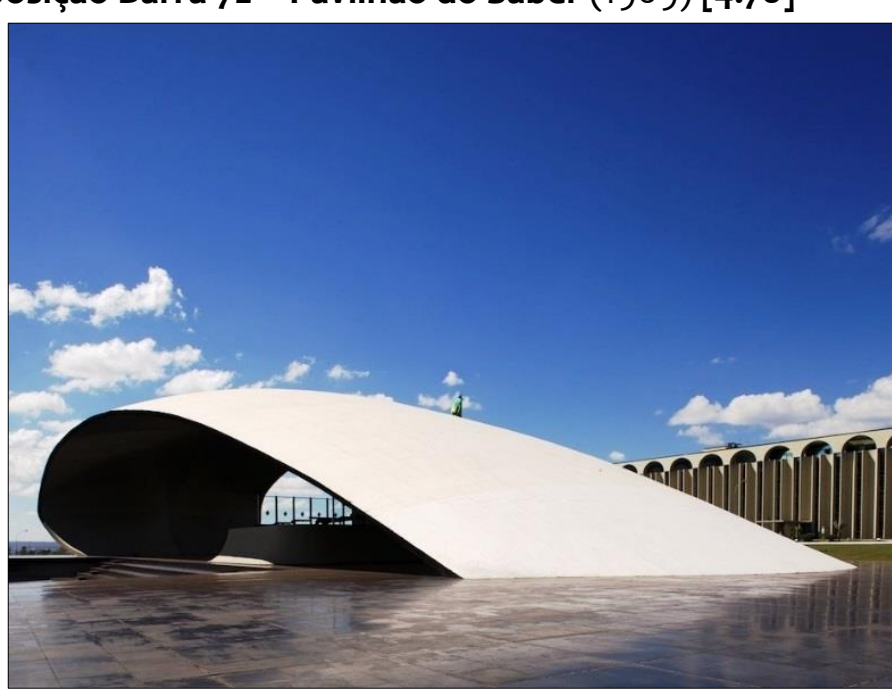

[4.68] Os volumes sóbrios do projeto contrastam com o "Monumento a Caxias", formado por uma escultura e uma grande placa moldada em concreto armado que remete a uma casca flexível, equilibrada em apenas três pontos de apoio.

[4.70] Museu nunca erigido, é solucionado por meio de um formato inusitado: composto por dois apoios centrais de 2,5 X 15,0 metros tem, na cobertura, o vigamento principal a partir do qual nasce um conjunto de tirantes metálicos que sustentam os pisos.

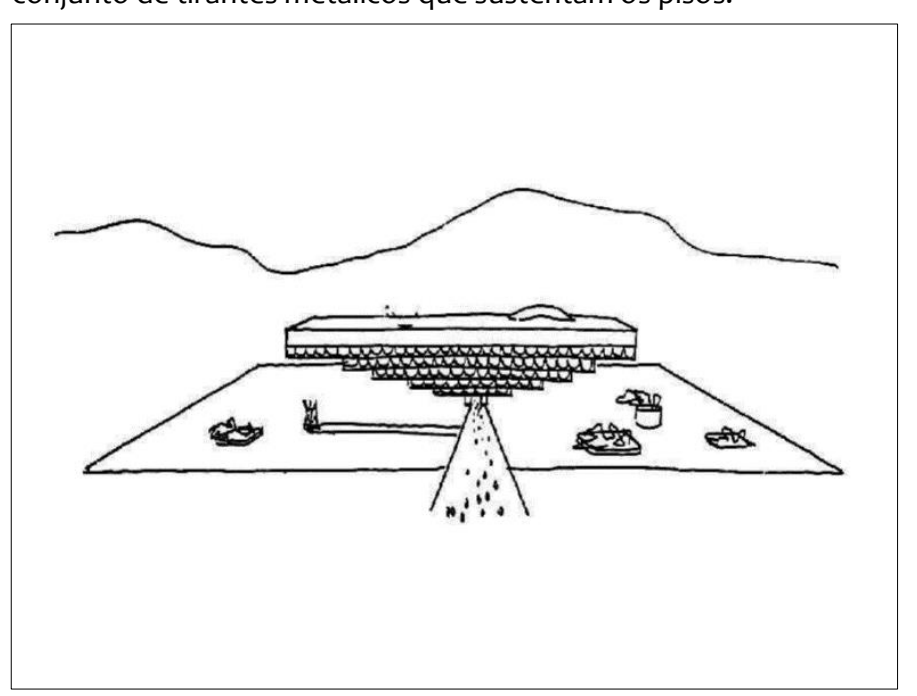




\section{ENTREATOS: REPOSICIONAMENTO CRÍTICO 3}

Oscar Niemeyer:

Museus de Arte Contemporânea de Niterói (1996) [4.71]; e Oscar Niemeyer (2002) [4.72]; Centro Cultural Principado de Astúrias / Oscar Niemeyer (2006) [4.73]; e Palácio Tiradentes (2010) [4.74]

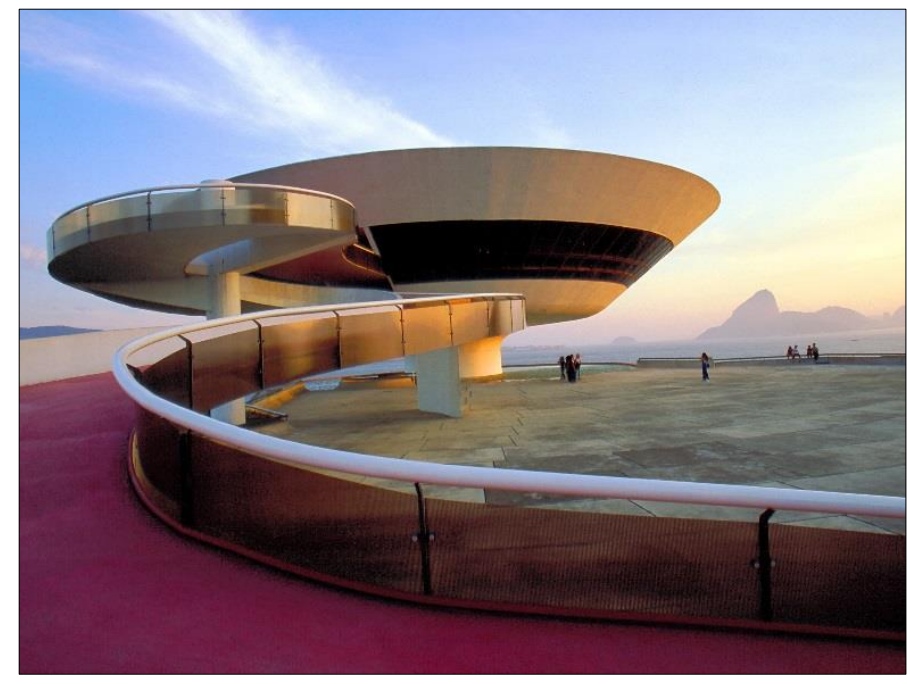

[4.71] Faz grande referência ao "Museu de Arte de Caracas", ao aproveitar a situação de implantação, o material de construção (concreto) e o posicionamento sobre um único apoio a partir do qual o museu se abre à medida em que ganha altura.

[4.73] Uma praça seca e quatro peças arquitetônicas autônomas, mas complementares entre si: um auditório, um restaurantemirante suspenso por um único apoio (ambos, na imagem), além de um museu e um prédio polivalente (com usos diversos).

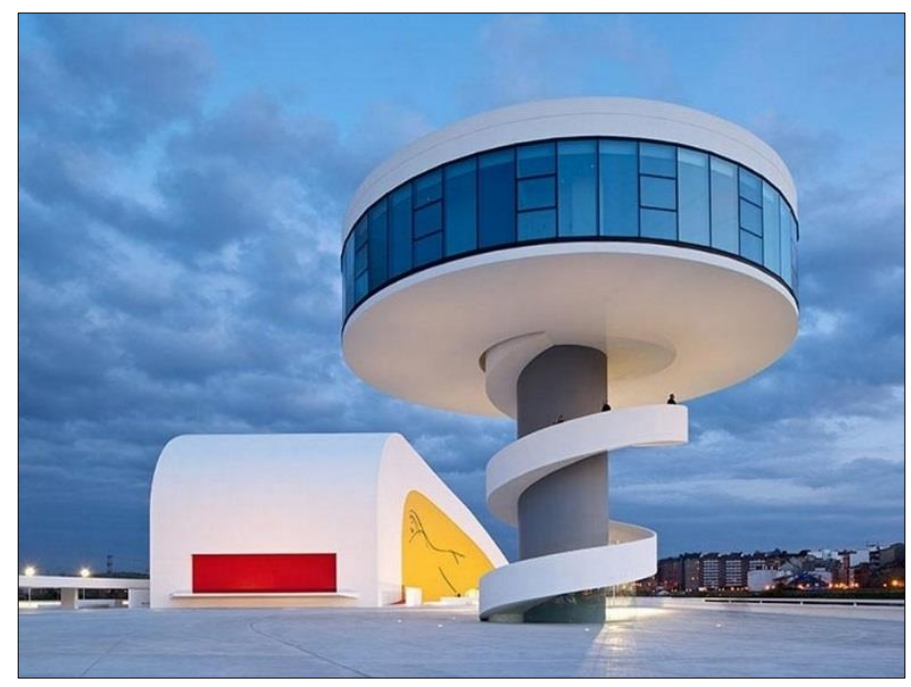

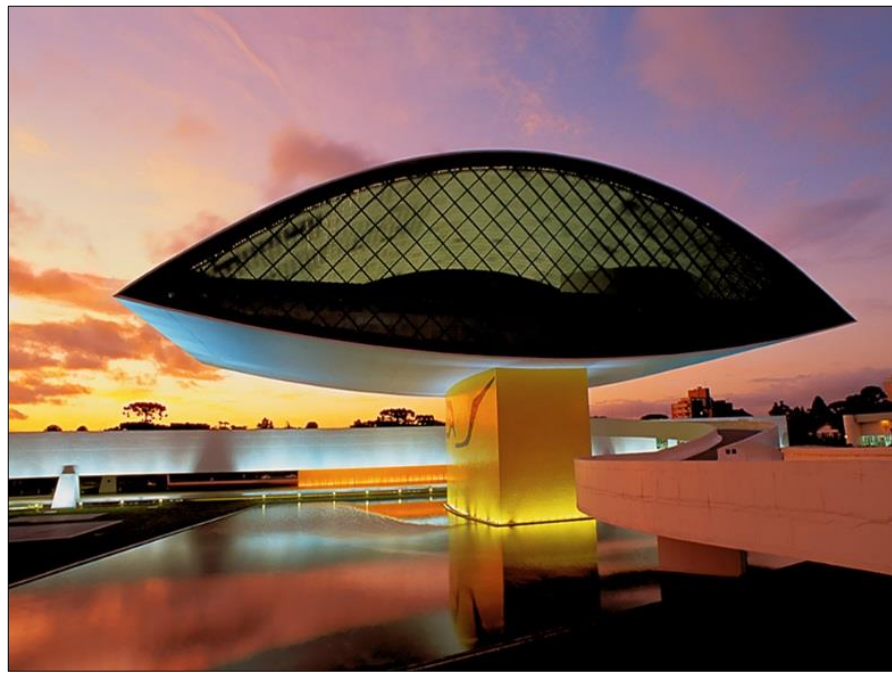

[4.72] Uma nova roupagem aplicada também à inspiração no museu venezuelano de 1954: construído em concreto, o volume simbólico é isolado e frontal. O monobloco posterior, horizontal e discreto, atua como contraponto e complemento ao programa.

[4.74] Edifício emblemático na Cidade Administrativa Presidente Tancredo Neves. Trata-se de um desdobramento da solução usada no Palazzo Mondadori (1968): pórticos de concreto protendido sustentam prisma de vidro e formam o maior vão livre do mundo.

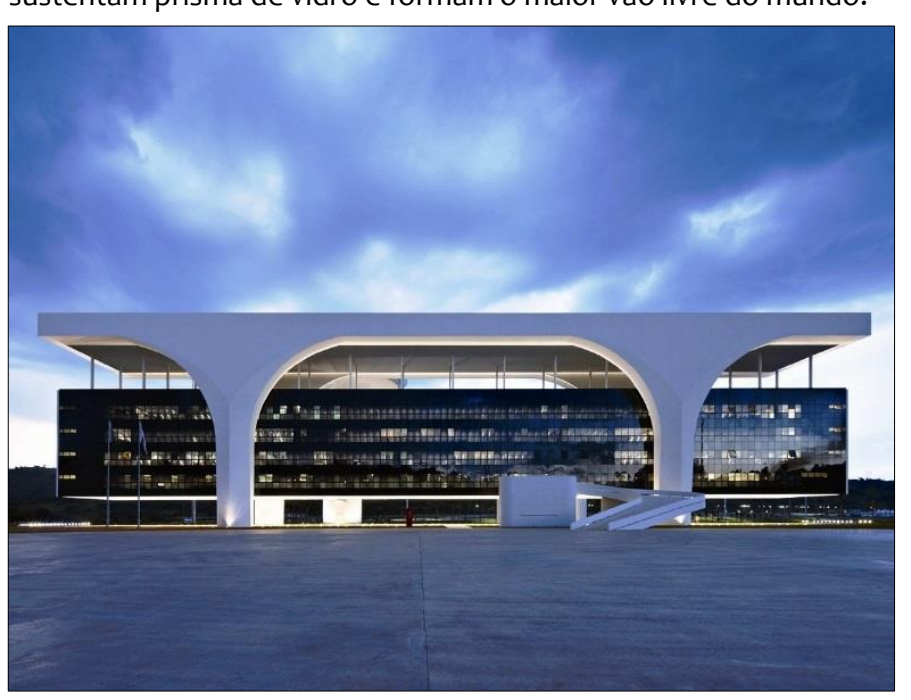




\section{A Nova Capital Federal: Um Olhar para o Interior do Brasil}

Do gesto primário de quem demarca um lugar por meio de dois eixos que se cruzam, nasce a nova Capital Federal do Brasil, inaugurada em 21 de abril de 1960. No coração da nação, em uma ampla extensão de terras áridas até então inóspitas e castigadas pelo sol inclemente do cerrado, surge, no Planalto Central, a promessa de uma nova era desenvolvimentista para o país e de uma vida mais digna para seus habitantes. Empreitada capitaneada pelo então Presidente da República, o visionário Juscelino Kubitschek, Brasília pode ser apreendida como um gigantesco impulso para a sua gestão governamental: “50 anos em 5”, diz o slogan presidencial [Figuras 4.75 - 4.78].

Antes estabelecida no Rio de Janeiro, a transferência da capital para o interior do país não é uma ideia concebida por Kubitschek, pois na verdade essa solicitação data de tempos anteriores. Junqueira (2014) explica que tal mudança de endereço remonta ao século 18, a partir das formulações iniciais feitas pelo diplomata e estadista português Sebastião José de Carvalho e Melo, mais conhecido como Marquês de Pombal (1699 - 1782). Tempos depois o assunto vem novamente à tona no conjunto de aspirações proclamadas pelos inconfidentes mineiros em 1789. No século seguinte, com o advento da Independência do Brasil em 1822, retoma-se, uma vez mais, a possibilidade de mudança da capital do país para o interior, sendo esta solicitação abordada na Constituição de 1823. No último quartel dos anos $1800-$ mais especificamente em 1891 - está também prevista na primeira constituição republicana nacional a transferência da Capital Federal para o interior do país.

A partir daí - e até meados dos anos 1900 -, vários estudos são feitos buscando a viabilização de uma tarefa tão árdua quanto essa. Finalmente, em agosto de 1956 "o Congresso Nacional aprovava a mensagem de lei prevendo a transferência da capital para nova localidade, situada no Planalto Central - região árida, a cerca de 1.10om de altura do mar e com pouca densidade humana -, em área junto a um lago artificial, delimitada a partir de estudos de uma consultoria norte-americana". (SEGAWA; 2010: 123)

Logo depois, em setembro de 1956, é instituído um concurso público nacional cujo edital concentra-se no planejamento urbanístico da nova capital. As demandas arquitetônicas, isto é, as edificações propriamente ditas, são anteriormente delegadas a Oscar Niemeyer por uma determinação oficial do próprio presidente, confortável que está pela confiança que deposita no arquiteto carioca em função do sucesso dos trabalhos anteriores que já 
desenvolveram juntos (como os edifícios que conformam Conjunto Arquitetônico da Lagoa da Pampulha, em Minas Gerais).

Segawa (2010) ainda aponta que, como exigências e/ou delimitações impostas pelo referido edital, estão: a.) a concepção de uma cidade para não mais que quinhentos mil habitantes; b.) um esquema gráfico básico de cidade no qual se reconhecem os componentes da estruturação urbana; c.) a apresentação dos elementos responsáveis pela interligação entre diferentes setores, centros, centralidades, instalações e serviços; d.) a disposição territorial das áreas livres; e.) a delimitação das vias de comunicação; e f.) a redação de um memorial justificativo da proposta em questão.

O júri, composto por uma equipe multilíngue, tem como representantes: o arquiteto inglês William Graham Holford (1907 - 1975); o arquiteto franco-húngaro André Sive (1889 - 1958); o teórico e historiador grego Stamo Papadaki (1906 - 1992); o arquiteto e urbanista carioca Paulo Antunes Ribeiro (1905 - 1973); o arquiteto Luiz Horta Barbosa (1900 - ?); o engenheiro e político mineiro Israel Pinheiro (1896 - 1973) e o também arquiteto e urbanista carioca, o próprio Oscar Niemeyer (1907 - 2012).

O resultado do concurso, anunciado em março de 1957, declara a proposta de Lucio Costa como vencedora. Ao contrário dos demais concorrentes, que apresentam projetos mais complexos e mais completos - incluindo até pesquisas socioeconômicas e de desenvolvimento arquitetônico - Costa trilha caminho oposto e opta pela concisão: uma resposta enxuta aos termos do edital, calcada em um "plano-piloto" desenhado em uma única planta na qual os conceitos mais importantes são ilustrados por um conjunto de croquis. Junto a esse material, diga-se, esquemático, surge um relatório justificativo esboçando, somente, aquilo que para Costa é essencial ao entendimento de sua ideia. Mesmo que breve, o projeto elaborado por Lucio Costa é o mais preciso ao atender aquilo que o comitê de avaliação busca encontrar de acordo com as diretrizes anteriormente estabelecidas pelo edital do concurso.

Ao comparar a proposta vencedora e aquelas apresentadas pelos demais concorrentes, notam-se diferenças conceituais significativas. Em um primeiro momento, todas as equipes inspiram-se nos estudos urbanísticos feitos por Le Corbusier, cujas pesquisas são muito respeitadas à época. Porém, nos projetos não ganhadores, as interpretações das investigações do mestre franco-suíço podem ter sido problemáticas, uma vez que ele mesmo imprime um direcionamento diferente daquele solicitado pelos organizadores do concurso: 
a questão de como deve funcionar uma cidade qualquer e não de como deveria ser a capital de um país é o que respondem todos os participantes - com a exceção do projeto ganhador. Nem poderia ser de outra forma, para bons discípulos da modernidade: o que se busca é uma resposta prototípica e genérica [...]. As soluções propostas muito devem aos estudos urbanísticos de Le Corbusier, realizados nos anos de 1920-1940, momento em que o mestre não estava interessado em definir o que poderia ser um centro simbólico nacional - ao contrário, sua Paris do Plano Voisin é a antítese da Paris centro do mundo, é apenas um exercício demonstrativo de como poderiam ser as cidades em geral. $\mathrm{O}$ problema da centralidade e da representatividade - e seu corolário, a monumentalidade - é o ponto de conflito no movimento moderno, mesmo ainda nos anos de 1950; e apesar de já haverem textos preocupados em debatê-lo, segue sendo uma característica considerada como negativa, ademais pela aproximação com o então recente exemplo dos excessos fascistas. (BASTOS e ZEIN; 2010: 65)

A passagem acima encontra um complemento em Segawa, ao assumir que

Brasília nasceu sob o signo da hierarquia pensada como capital de um país. Lucio Costa atribuiu ao seu projeto o coerente caráter de civitas - atributo nem sempre evidenciado nos demais participantes do concurso, mas devidamente formulado pelo vencedor e destacado na ata do júri. Hierarquia que permeia o desenho da cidade: uma clara definição da dimensão pública (eixo monumental), da dimensão privada (eixo residencial) e, no aspecto interurbano, a setorização das atividades em áreas especializadas (setor hoteleiro, setor bancário, setor industrial, setor de diversões, etc.). (SEGAWA; 2010: 125)

No entender do mesmo autor, Lucio Costa confere à cidade uma organização sistemática e fundamentada nos princípios urbanísticos do movimento moderno. Da ideia inicial, simbolizada pelo cruzamento de dois traços solitários, derivam os dois grandes troncos de circulação rodoviária da nova Capital Federal: O “eixo monumental” [Figura 4.79], menor, posiciona-se no sentido leste-oeste e acolhe tanto as atividades públicas (centro cívico e centro administrativo) quanto os setores destinados a comércio, serviços e cultura. O "eixo rodoviário-residencial” [Figura 4.80], maior e arqueado, aloca-se transversalmente ao anterior, logo, no sentido norte-sul. Cortado pelas vias locais, é representado pelas autopistas de acesso às regiões adjacentes.

Distribui-se ao longo do "eixo rodoviário-residencial" um extenso conjunto de blocos para moradias projetados nos moldes das "unidades de vizinhança", concebidas em Radburn, Estados Unidos, no ano de 1929 pela dupla de arquitetos e urbanistas Clarence Stein (1882 - 1975) e Henry Wright (1878 - 1936). Na “escala residencial”, como é denominada em Brasília a área destinada às habitações, os prédios são organizados em "superquadras", isto é, em grupos formados por quatro quadras com aproximadamente 300,0 metros de lado cada e abraçadas por um tratamento paisagístico intenso. Nelas, com variedade formal de posicionamento, estão apenas edifícios de baixo gabarito (com no máximo, seis pisos) pousados sobre pilotis. Como forma de favorecer os moradores reduzindo as 
distâncias percorridas pela cidade, a comunidade local das superquadras é atendida por uma infraestrutura destinada a satisfazer as necessidades de comércios e de serviços de pequeno porte.

A "escala bucólica" [Figura 4.80], por sua vez, permeia e integra todas as regiões edificadas valendo-se de espaços verdes distribuídos por toda a cidade: faixas gramadas, canteiros ornamentais, parques, áreas arborizadas e de lazer. Já a "escala gregária" é simbolizada pelo ponto de cruzamento de ambos os troncos de circulação, ou seja, pela ampla "Plataforma Rodoviária" [Figura 4.81], responsável tanto pelo equacionamento do sistema viário quanto por servir de referência ao seu entorno imediato: centros comerciais e de serviços de grande porte, além de núcleos de recreação para as populações local e flutuante.

Se a construção da nova Capital Federal representa a mais importante alavanca da gestão presidencial de Juscelino Kubitschek, deve-se reconhecer o papel fundamental que ela assume ao promover o crescimento e o desenvolvimento de uma região até então tida como periférica e sem atrativos significativos. A escolha do Planalto Central para receber Brasília é facilmente justificada, pois

o pressuposto ancestral da transferência da capital para o interior fundamentava-se na necessidade estratégica de ocupação territorial de vasta área inarticulada econômica e demograficamente com o resto do país. Nesse sentido, uma nova cidade plantada na aridez do Planalto Central estabelecia um elo de ligação entre o Sudeste industrializado e densamente ocupado e o Norte e o Centro-Oeste, fronteiras agrícolas virtualmente virgens na busca de reconhecimento e ocupação política do território brasileiro. (Segawa; 2010: 126)

Este, é um momento de efervescência que traz nova dinâmica ao coração do território brasileiro. A transferência da Capital Federal para o Planalto Central demanda, como consequência, um novo posicionamento do Brasil, acostumado até então a valorizar unicamente as suas bordas litorâneas. Deve a partir de agora ampliar seu olhar e buscar novas perspectivas em áreas praticamente inexploradas de seu próprio território. Embutida nesse processo está a formalização de um amplo desenvolvimento econômico e social, não só motivado pela conquista de novas fronteiras internas, mas, também, "pelos recursos que seriam transpostos para a construção da cidade em novo horizonte geográfico" (JUNQUEIRA; 2014: 181). Por tudo isso, a construção da nova Capital Federal praticamente no centro do Planalto Central, mesmo sofrendo vigorosas críticas, consegue

[...] entusiasmar a maioria dos brasileiros, sobretudo aqueles das camadas populares. Houve recrutamento de operários por todo o país, principalmente no Nordeste, que havia sofrido uma grande seca. O governo lançou uma campanha associando a ida para o Centro-Oeste à epopeia do far-west norte-americano do século anterior. A nova capital era associada a uma oportunidade para os mais 
pobres e a um marco do futuro brasileiro mais rico e mais justo. A correlação de uma "assinatura" arquitetônico-urbanística ao projeto político provou-se eficaz: apoiar a construção de Brasília era considerado um gesto progressista - abraçado por fração significativa dos intelectuais e da classe estudantil - e os oponentes da empreitada ganhavam a pecha dos conservadores. Da perspectiva atual, não deixa de ser surpreendente que, mesmo com os mais sensatos argumentos, a oposição não tenha conseguido colocar a opinião pública, sequer no Rio de Janeiro, contra a transferência da capital. (CAVALCANTI; 2006: 217)

Logo após a aprovação da construção, o presidente Juscelino Kubitschek estipula que a Companhia Urbanizadora da Nova Capital seja a responsável pela promoção, pela organização e pela operacionalização de Brasília. Também conhecida como NOVACAP, a empresa é então presidida pelo engenheiro Israel Pinheiro (que fora jurado do concurso vencido pelo "plano-piloto" de Lucio Costa). Oscar Niemeyer, por sua vez, é convidado para o cargo de diretor do Departamento de Arquitetura.

Além da NOVACAP, uma quantidade significativa de construtoras desembarca em Brasília, ávidas que estão tanto para ampliar seus leques de atuação em território nacional, quanto para participar de um projeto de tamanha magnitude para o Brasil e para o mundo. Move-as, além disso, claro, a ambição por elevar seus ganhos frente aos montantes investidos pelo governo federal. Tomando como exemplo apenas as empresas ligadas à construção dos palácios brasilienses (alguns destes, foco da análise posterior aqui desenvolvida), Silva (2012) explica que todas elas apresentam vínculos políticos que as conduzem a Brasília, seja por meio de ligações e/ou contatos com agentes públicos, seja por meio da determinação estatal direta. Não seria equivocado se essa afirmação fosse estendida, portanto, às demais obras/empreiteiras da Capital Federal, pois todas elas, naquele momento, compartilham situações semelhantes.

Ao contrário do que possa parecer, essas companhias enfrentam uma série de problemas ao longo de sus atividades no Planalto Central. A localização de Brasília em um sítio praticamente desocupado e a grandes distâncias dos centros urbanos (onde estão estabelecidos os fornecedores de matérias-primas e de materiais de construção) traz como contrapartida o aumento do custo final dos fretes, uma maior dificuldade no cumprimento dos prazos estipulados nos cronogramas das obras e a não capacidade de contratar facilmente mão-de-obra qualificada e em número suficiente para abastecer as diversas obras que acontecem simultaneamente. 
Vale a pena aproveitar, ainda de Silva(2012), as investigações feitas sobre alguns dos agentes construtores que atuam em Brasília, levando em conta suas características e suas trajetórias. Ressalte-se que algumas das informações fornecidas pelo autor já foram anteriormente abordadas por este estudo:

A Construtora Rabello S.A., proveniente de Diamantina e fundada no ano de 1945, tendo como representante o engenheiro Marco Paulo Rabello, foi uma das primeiras relacionadas para as tarefas em Brasília, ficando responsável pelos Palácios da Alvorada e do Supremo Tribunal Federal. Além de ter sido responsável por obras em Minas Gerais, tais como as da Pampulha e diversas outras de edificações urbanas, a construtora também atuou em serviços de maior porte, relacionados à infraestrutura urbana e provenientes de contratos públicos. As experiências precedentes com a atuação da empresa em trabalhos projetados por Niemeyer e a associação indicada nas obras públicas de Minas Gerais, especialmente nos grandes investimentos do governo, apontam os principais motivos da escolha feita por Juscelino Kubitschek.

A Companhia Construtora Nacional S.A., com sede no Rio de Janeiro, embora não apresentasse vinculação direta com Kubitschek, estava sob o controle militar desde a década de 40, por ocasião de intervenção realizada em decorrência da Segunda Guerra Mundial. A importância desta disponibilidade pode ser entendida a partir do histórico da empresa, que tem origem como uma das primeiras especializadas em concreto armado no Brasil: a Companhia Constructora de Cimento Armado, do alemão Lambert Riedlinger, que desde 1911 dedicava-se a projetos e a construções de obras com o sistema. Pioneiro no ramo, embora não fosse engenheiro, Riedlinger conseguiu trazer técnicos e mestres de obras da Alemanha que tinham domínio no cálculo e na execução do sistema construtivo. Em 1913 a empresa de Riedlinger torna-se subsidiária da alemã Wayss \& Freytag, uma das mais importantes firmas de concreto armado no mundo, responsável pelo desenvolvimento tecnológico e os avanços ocorridos na Alemanha e que já havia se instalado em Buenos Aires no ano de 1909. Em 1924 a firma passou a ser denominada Companhia Construtora Nacional S.A. que, além da sede no Rio de Janeiro contou com filiais em São Paulo, Recife, Salvador e Juiz de Fora. Durante a atuação no Brasil, a construtora fora responsável por parcela significativa das realizações relevantes no país - inclusive para o Estado - e na difusão da tecnologia por meio do treinamento e formação de especialistas em concreto armado.

Embora administrada pelo pessoal do Exército e sob o comando do Estado, a construtora ainda mantinha as características de uma empresa particular e contava com técnicos qualificados e mestres de obras, na maior parte, portugueses. Kubitschek tinha à sua disposição uma das mais importantes empresas com domínio histórico na técnica do concreto armado, sistema que era base da indústria da construção e também da arquitetura elaborada por Niemeyer. Possibilidade para os desafios previstos e com a qual o Presidente poderia contar, como o fez para erigir o Palácio do Congresso Nacional.

A Construtora Pacheco Fernandes Dantas Ltda., de São Paulo era - segundo nos relata o engenheiro Fausto Favale - um escritório de engenharia de pequeno porte que se transformou em construtora e cuja participação nas obras de Brasília deu-se pela ocorrência e combinação de fatores políticos. Os partidos da oposição haviam requerido oportunidade para indicação de firmas que pudessem participar dos certames para trabalhos na capital. No entanto, não conseguiram lograr êxito na indicação de firmas para fazer face às concorrências. Eduardo Pacheco Fernandes, o proprietário da empresa foi sondado por Íris Meinberg - um dos diretores da NOVACAP nomeado pela oposição acerca do interesse de participar como firma indicada. Tendo assentido ao convite, a empreiteira foi 
relacionada entre as participantes. Na sequência, intercedeu a favor da firma, junto a Juscelino Kubitschek, o então Deputado Federal, pelo estado de São Paulo, Brasílio Machado de Oliveira Neto, dando origem à participação da empreiteira nas tarefas para o Hotel de Turismo Brasília - Brasília Palace Hotel. A desenvoltura apresentada na condução da obra, por certo, foi aspecto relevante para que a empresa, posteriormente, fosse escolhida como responsável pela construção do Palácio Presidencial, o Palácio do Planalto. (SILVA; 2012: 112-114 - com grifos nossos)

Ainda que enfrentando algumas situações delicadas, deve-se admitir que Brasília significa uma oportunidade única para essas grandes empresas construtoras - e para a engenharia civil brasileira como um todo, se se pensar em um campo mais amplo. A nova Capital Federal configura-se também uma chance sem precedentes para a arquitetura moderna e para seus adeptos. Tanto é fato que qualquer arquiteto moderno, como é o caso de Costa e Niemeyer, almeja poder um dia projetar uma cidade integralmente, livre de sujeições culturais ou de edificações e estruturas préexistentes, concebendo-a e realizando-a ex-nihilo. Brasília, que a partir do último quartel da década de 1950 oferece essa oportunidade, representa não só o sonho de materializar o imaginário de toda uma nação, mas também a consolidação dos ideais outrora previstos na "Carta de Atenas"

a crença nas vantagens utópicas do urbanismo moderno até então pouco havia sido aplicada de maneira plena, pois colidia com as condições geográficas e históricas concretas de cada cidade, que ofereciam variados graus de resistência às intervenções baseadas nessas ideias. Assim, para se compreender a importância da progressiva e inexorável implantação do urbanismo modernista desde meados do século 20 , há de se levar em conta, como complicador da análise, as peculiaridades dos casos particulares que se apresentam. No Brasil, entretanto, é possível estudá-la de maneira quase laboratorial, em um caso exemplar, que nos permite uma melhor compreensão dos traços comuns que caracterizam o pensamento urbanístico dos anos 1950: uma situação "ideal”, em que aparentemente todas as condições estão dadas para que os arquitetos realizem, sem estorvos, as aspirações utópicas do urbanismo moderno: obviamente o concurso de Brasília (1957). Sem restrições de verba, num terreno quase plano, sem a presença e o peso da história, era a possibilidade de liberdade criativa plena dos desejos dos arquitetos daquele momento. (BASTOS e ZEIN; 2010: 63-64)

\footnotetext{
10 Em 1933, o IV Congresso Internacional de Arquitetura Moderna (CIAM) ocorre na cidade grega de Atenas e tem como tema a "cidade funcional". O manifesto urbanístico daí resultante, influenciado e redigido por Le Corbusier, recebe o nome de "Carta de Atenas". Esse documento não apenas define o conceito de urbanismo contemporâneo, mas também aponta diretrizes cabíveis de serem aplicadas a qualquer cidade do mundo. Defende, dentre outros pontos que: a.) as cidades devem ser compreendidas como organismos que permitam a sua concepção de modo funcional; b.) as necessidades dos homens devem ser claramente expostas, discutidas e resolvidas; c.) as áreas urbanas devem ser organizadas e separadas em áreas distintas, isto é, em espaços destinados à habitação, ao trabalho e ao lazer; e d.) em detrimento do que ocorre nas cidades tradicionais, deve-se fomentar a baixa densidade por meio de edificações desenvolvidas em altura e cercadas de amplas áreas verdes.
}

Percebe-se assim que a "Carta de Atenas" inspira diretamente não apenas a reconstrução das cidades europeias prejudicadas pela Segunda Grande Guerra, mas reverbera também no Brasil, ao se considerar os fatores que conduzem Lucio Costa a propor o seu "plano-piloto" para Brasília. 
Para a construção da nova Capital Federal, são então equacionadas três principais frentes de trabalho: a concepção das demandas urbanísticas fica a cargo de um grupo do qual Lucio Costa faz parte, uma vez que é de sua autoria o projeto vencedor do concurso. Na segunda frente está Oscar Niemeyer, designado diretamente pelo presidente Juscelino Kubitschek para tratar das questões arquitetônicas, recebendo dele também "carta branca" para o desenho das novas edificações brasilienses. Uma terceira equipe, composta por artistas de várias especialidades, é focada na implantação de esculturas públicas distribuídas pela cidade. A reunião dessas três áreas de conhecimento compõe uma tríade de pensadores e de profissionais que persegue a fusão perfeita entre urbanismo, arquitetura e artes plásticas. Molda-se, com isso, a concretização de mais um dos ideários do Movimento Moderno.

Considerando apenas as questões arquitetônicas, como efeito obtêm-se com os projetos niemeyerianos edificações plasticamente inovadoras, por vezes leves e puras, que resultam não de um marco na tecnologia nacional, mas, sim, do uso original na construção civil, da técnica e da tecnologia então disponíveis. Obras sintéticas porém simbólicas, frutos do trabalho conjunto entre arquitetura e engenharia. Edifícios notáveis e representantes de uma era repleta de novas aspirações e de novas proposições arquitetônicas.

A construção da Capital Federal a partir de uma tabula rasa, em meados dos anos 1900, é uma ocasião única para expressar todo o potencial técnico e tecnológico que as estruturas de concreto podem proporcionar ao segmento da construção civil - e as edificações lá erguidas são prova disso. Peças-chave, portanto, de um período pleno de experimentações e de novas descobertas para esse setor, no qual o país prova cada vez mais destaque frente à produção internacional. Trata-se, além disso, "de uma bem-sucedida ação de marketing internacional: o Brasil - uma terra subdesenvolvida - projetava-se no mundo como um país de grandes iniciativas, capaz de realizações que uma potência do Primeiro Mundo não tinha ousado empreender [...]". (SEGAWA; 2010: 126)

No entanto, nem sempre esse destaque internacional é favorável ao país. Ao assumir que a novidade de Brasília não está apenas nos seus elementos considerados um a um, mas essencialmente na conjugação simultânea desses mesmos elementos pelos seus criadores, uma grande quantidade de historiadores e de críticos de arquitetura estrangeiros manifesta-se a respeito da nova Capital Federal, analisando-a como um todo. Levam em conta, para tecer seus comentários geralmente negativistas, tanto a inspiração política de Juscelino Kubitschek quanto a concepção urbana/arquitetônica da dupla Lúcio Costa e Oscar Niemeyer. 
Alguns desses forasteiros vêm ao país e conhecem, in loco, a proposta brasileira para a concretização da nova Capital Federal. Outros, entretanto, acham por bem produzir suas críticas calcadas naquilo que já está publicado a respeito, ou seja, ficam suscetíveis a influências outras que acabam por direcionar seus próprios argumentos.

Bruno Zevi, por exemplo, na quinta edição de Storia Dell'architettura Moderna (de 1973) - a mesma em que vê Niemeyer como uma alternativa à crise do racionalismo (como já mencionado) - contrapõe esta crítica "positiva" ao arquiteto brasileiro e desenvolve comentários um tanto quanto amargos à Brasília, considerando-a uma metrópole kafkiana e surreal, de edifícios incômodos e sem conteúdo.

Diz Camargo (2011) que também Manfredo Tafuri e Fracesco dal Co, no manual Architettura Contemporanea (de 1976), classificam a arquitetura brasileira como neo-expressionista e, especificamente sobre as construções de Brasília, colocam-nas como supérfluas aspirações. Kenneth Frampton, por sua vez, no livro Modern Architecture: a Critical History (de 1980) imputa a Brasília parte da responsabilidade pela crise da arquitetura moderna mundial. Para ele, "Brasília [...] levou o desenvolvimento progressivo da arquitetura brasileira a um ponto crítico. Essa crise, que terminaria por provocar uma reação mundial contra os preceitos do Movimento Moderno, impregnou todo o projeto, não apenas no nível da construção individual, como também na escala do plano em si". (FRAMPTON, 1980: 312)

Por fim e como único exemplo de comentários favoráveis à empreitada brasileira, pode ser mencionado aquele feito no livro Masters of Modern Architecture, de John Peter, baseado em entrevistas e depoimentos orais. Camargo (2011) diz que na edição de 1994, Peter enfatiza que o sonho de criar novas cidades foi apenas realizado em Brasília - mesmo com a tentativa anterior de Chandigarh, de Le Corbusier. Aponta, também que, apesar das críticas que a nova cidade recebe, não se pode negar que ela seja definitivamente distinta de tudo o que já se vira antes. 


\section{A NOVA CAPITAL FEDERAL DESCOBRE O BRASIL}

Lucio Costa e Oscar Niemeyer:

Brasília Nasce do Cruzamento de Dois Eixos [4.75]; Entusiasmo Nacional com a Nova Capital Federal [4.76] "Eixo Monumental” em Fase de Construção [4.77]; Palácio da Alvorada e Lago Paranoá [4.78]

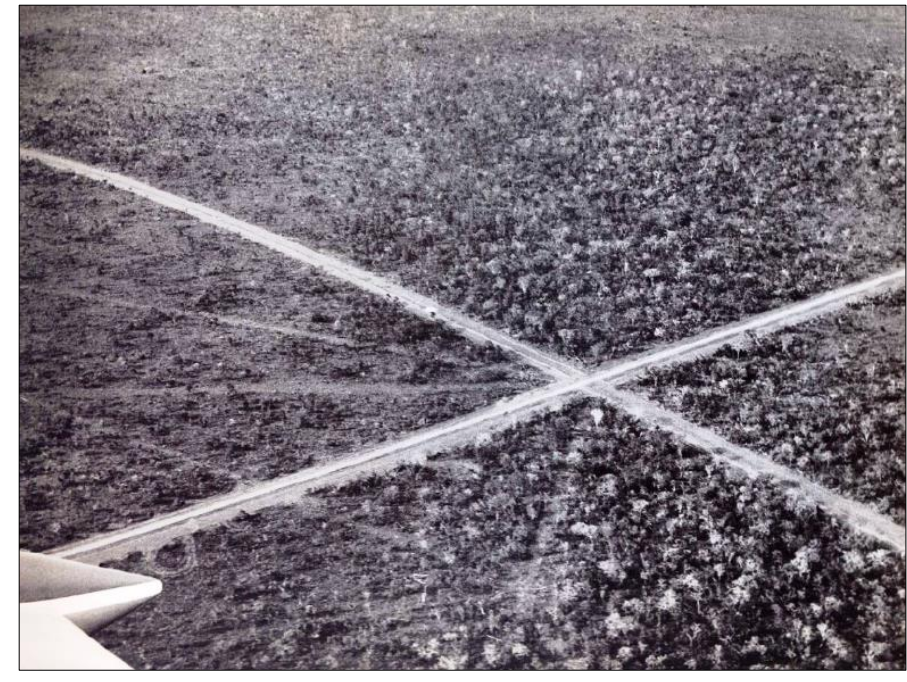

[4.75] O "plano-piloto" de Lucio Costa prevê que a futura Capital Federal seja construída ao longo de dois eixos que se cruzam: o menor "Eixo Monumental" (no sentido Leste-Oeste) e o maior, "Eixo Rodoviário-residencial” (no sentido Norte-Sul)

[4.77] Até então, a região do Planalto Central escolhida para receber Brasília era terra praticamente desocupada. Construir uma cidade ex-nihilo significa investir em toda as frentes: na imagem, parte do movimento de terra (para o futuro "eixo-monumental").

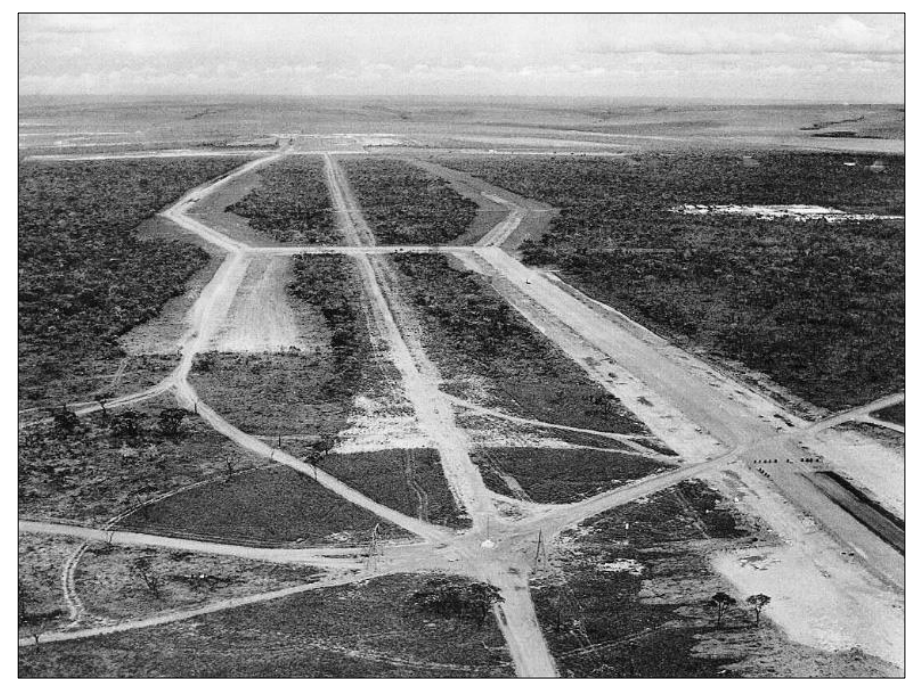

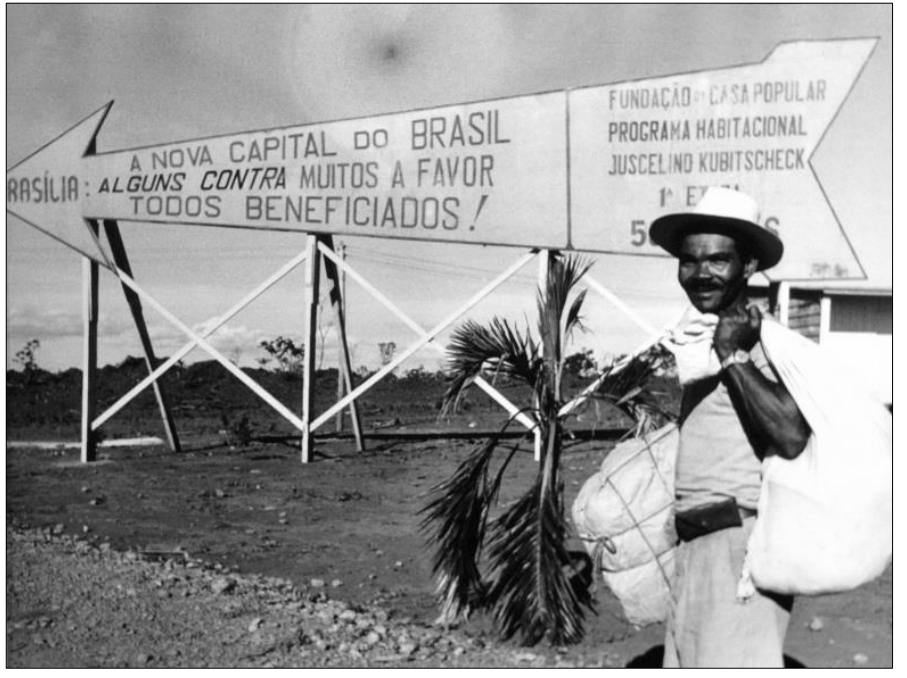

[4.76] O Governo Federal lança programas por todo o Brasil para angariar interessados em atuar na construção de Brasília. Aqueles que aceitam o desafio o fazem tanto pelas novas oportunidades de trabalho, quanto pela promessa de melhorarem de vida.

[4.78] Primeiro edifício erguido na nova Capital Federal, o Palácio da Alvorada seguiu às margens do "plano-piloto", sendo concluído antes de o resultado do concurso ser divulgado. $\mathrm{Na}$ imagem, ao fundo, a Esplanada dos Ministérios e o Congresso Nacional.

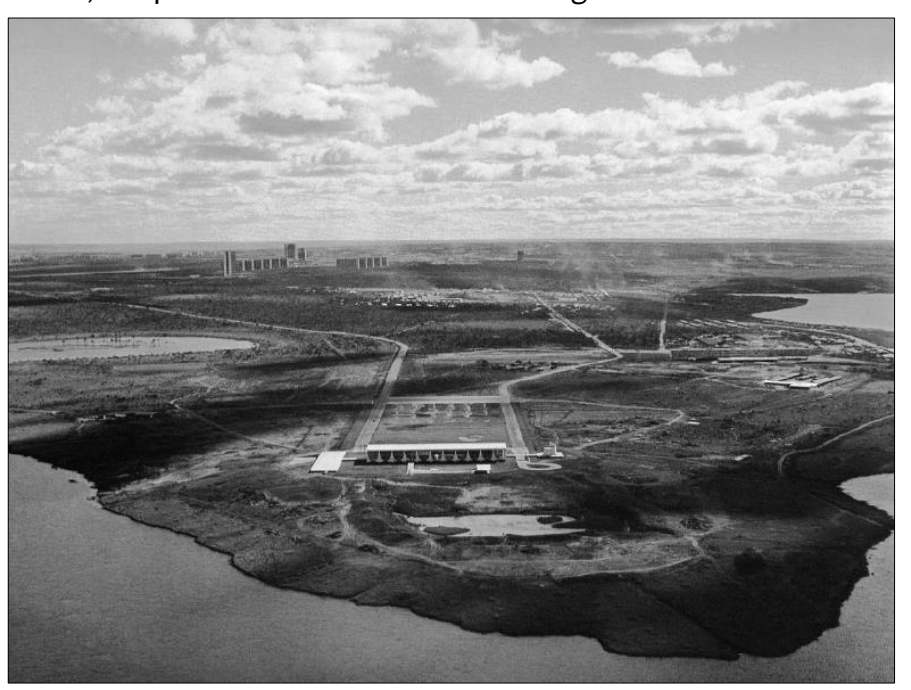




\section{A NOVA CAPITAL FEDERAL DESCOBRE O BRASIL}

Lucio Costa e Oscar Niemeyer:

“Eixo Monumental” [4.79]; "Eixo Rodoviário-residencial” + "Escala Bucólica” [4.80]; "Plataforma Rodoviária" [4.81]

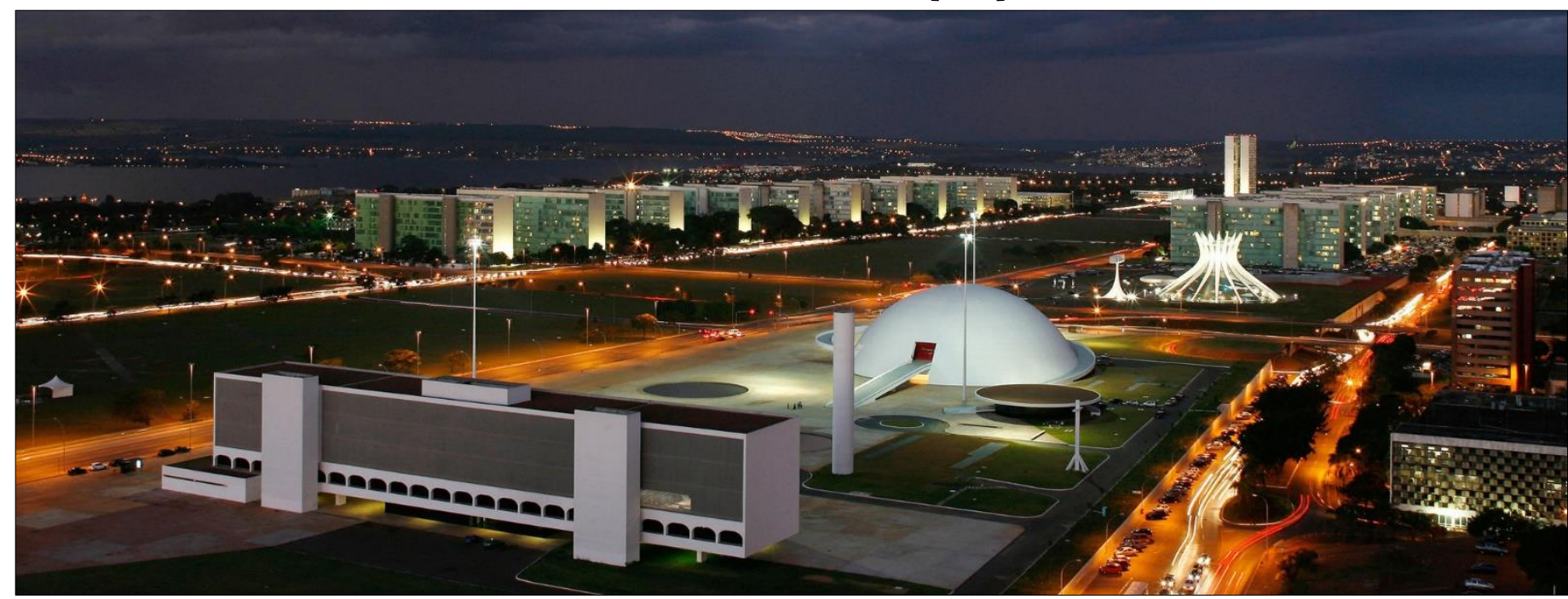

[4.79] O "Eixo Monumental" conforma as atividades de cunho cívico e administrativo do país. Ao longo de sua extensão, estão distribuídos alguns dos edifícios mais simbólicos e representativos implantados na nova Capital Federal, dentre os quais, destacam-se: Biblioteca Nacional de Brasília; Museu Honestino Guimarães; Catedral de Brasília e Ministérios de diversas alçadas.

[4.80] O "Eixo Rodoviário-residencial" serve de referência às superquadras, criadas a partir do princípio das "unidades de vizinhança” americanas. A "Escala Bucólica”, por sua vez, integra a cidade com o uso de inúmeros espaços verdes e permeáveis.

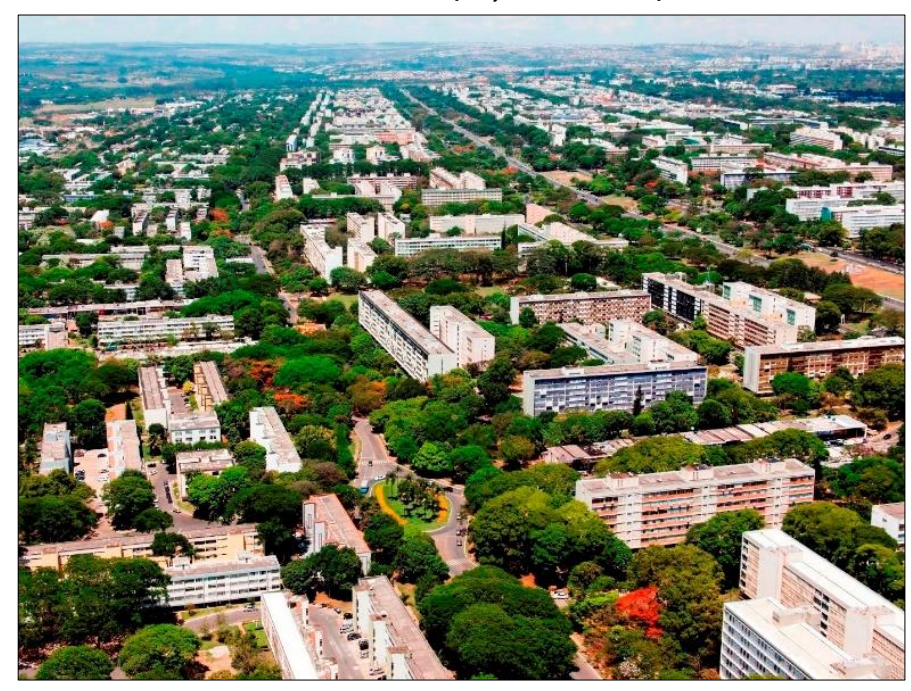

[4.81] O ponto de cruzamento dos dois eixos originais do "planopiloto" de Lucio Costa é materializado em uma "Plataforma Rodoviária" de grandes dimensões. Por meio dela equaciona-se o sistema viário local e estrutura-se o entorno imediato.

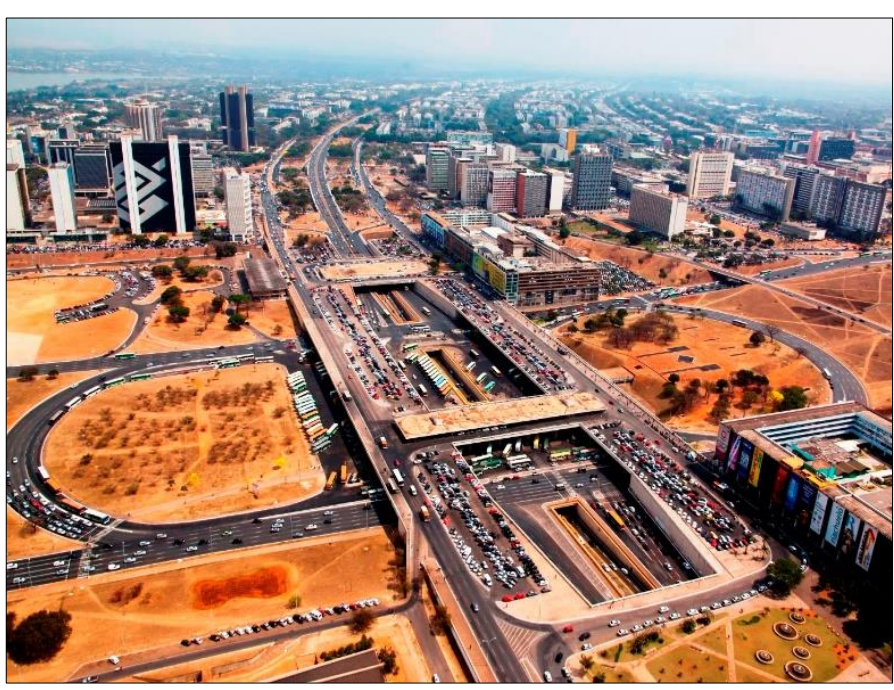




\section{Crepúsculo para uma nova Arquitetura: O Palácio da Alvorada}

O Palácio da Alvorada, residência oficial do Presidente da República, é projetado, construído e inaugurado entre 1956 e 1958, portanto, em período simultâneo à primeira revisão crítica de Oscar Niemeyer. Como já visto, é a partir desta reflexão que passa a valer uma nova orientação metodológica do arquiteto carioca: há, agora, além da depuração e da simplificação formal, o interesse em perseguir a expressão arquitetônica atrelada à técnica estrutural - isto é, uma atenção mais atida ao binômio plástica e partido passa a prevalecer. "Nesta nova fase, Niemeyer acirra a ideia do desafio estrutural, ou seja, ao entendimento do concreto como material plástico se soma a ideia do arrojo estrutural" (BASTOS e ZEIN; 2010: 68).

O Palácio da Alvorada é o primeiro edifício construído em Brasília, não constando do "plano-piloto" de Costa, que sequer estava concluído quando da idealização deste projeto. Ao receber carta branca para o desenho dos palácios de Brasília, o arquiteto prova de uma liberdade projetual que pode comprovar toda a sua inventividade criativa. Árdua tarefa, ainda mais se se pensar que este também pode ser encarado como um momento de experimentação para Niemeyer, ao colocar em prática - pela primeira vez em um projeto de tamanha magnitude - suas novas premissas arquitetônicas ainda em fase de amadurecimento. Além disso,

essa situação de poucos limites repetia-se na geografia do Planalto Central - terra virgem que carecia de acidentes naturais expressivos. Sem as curvas da natureza para dialogar, nem a cidade existente para confrontar, restava ao arquiteto apenas a linha do horizonte, assumida pelo projeto urbanístico de Lucio Costa, que determinara a ocupação da cidade com edifícios soltos entre si, sem definir recintos urbanos [...]. (PONTES; 2004: 65)

O sítio de implantação escolhido, um lote peninsular junto ao Lago Paranoá [Figura 4.82], apresenta algumas particularidades que ajudam a desenhar as características finais do projeto: além de aproveitar as curvas de nível preexistentes para acomodar a nova edificação, sugerem que o acesso principal seja direcionado ao lado oeste e que junto a ele também a maior parte das funções públicas sejam alocadas. Essa distribuição prévia dá margem a que as demais fachadas privativas e de lazer sejam voltadas à contemplação do lago, e que os espaços internos secundários estejam, a partir de ambas as condicionantes anteriores, automaticamente lançados e concatenados entre si.

Uma vez decidida a orientação principal do Palácio, Niemeyer opta por um programa tripartite, ou seja, três edificações em princípio autônomas, mas sutilmente entrelaçadas: uma edificação principal de qualidade simbólica e 
monumental, ao centro. A norte deste edifício, a diminuta capela dedicada à Nossa Senhora da Conceição e destinada a celebrar pequenos rituais litúrgicos traz um formato que remete a uma casca em concreto armado em revolução

[Figura 4.83]. Ao sul, um extenso bloco retangular para abrigar os serviços de apoio. Este, por ser semienterrado, favorece o destaque da monumentalidade do corpo principal do Palácio e não interfere, portanto, nas perspectivas visuais do conjunto edificado.

O volume principal do Palácio da Alvorada é dividido em três níveis. O piso térreo, de modo geral, destina-se aos ambientes de convívio social, isto é, aos de uso público (como eventos diversos e recepções a autoridades, quando o caso). Há aqui uma ligação direta à área externa onde estão a piscina, o abrigo coberto com bar conectado, além de um lago artificial (mais afastado e incorporado aos jardins tratados por Roberto Burle Marx). Já no pavimento superior do prédio central, alocadas mais reservadamente, estão as dependências privativas residenciais propriamente ditas (incluindo áreas de estar íntimo e de dormitórios), cujo acesso é permitido exclusivamente às pessoas autorizadas. No piso inferior, semienterrado, estão os serviços de apoio imediato para atendimento ao Palácio, como também dormitórios e refeitórios para os funcionários, almoxarifado, salão de jogos, despensa, cozinha, lavanderia, garagem, auditório com trinta assentos e uma área reservada à administração do palácio propriamente dita. É neste espaço que se configura um eixo de circulação comum que atende simultaneamente a capela, o hall do pavimento térreo do edifício central e o bloco de serviços administrativos.

Por ser obra pioneira em território brasiliense, o Palácio da Alvorada estreia uma nova linguagem arquitetônica, adotada posteriormente inclusive nos demais palácios: caixa de vidro prismática, horizontalizada, que encerra o corpo principal do prédio e protegida, em ambos os lados maiores, por peristilos compostos por colunas de formas sinuosas

[Figura 4.84]. Sobre a solução arquitetônica deste Palácio em específico e a atenção devotada à colunata externa, Niemeyer comenta que

Na solução do Palácio Residencial de Brasília, procuramos adotar os princípios da simplicidade e pureza que, no passado, caracterizaram grandes obras da Arquitetura. Para isso, evitamos soluções recortadas, ricas de forma e elementos construtivos (marquises, balcões, elementos de proteção, cores, materiais, etc.) adotando um partido compacto e simples, onde a beleza decorresse apenas de suas proporções e da própria estrutura.

Dedicamos às colunas, em virtude disso, a maior atenção, estudando-as cuidadosamente nos seus espaçamentos, forma e proporção, dentro das conveniências da técnica e dos efeitos plásticos que desejávamos obter. Estes nos levaram a uma solução de ritmo contínuo e ondulado, que confere à 
construção leveza e elegância, situando-a como que simplesmente pousada no solo. (OSCAR NIEMEYER. In REVISTA MÓDULO; 1957: 21)

Percebe-se pelo extrato acima uma preocupação de Oscar Niemeyer para com três variáveis em particular: espaçamento, forma e proporção que, mesmo que indiretamente, remetem à composição clássica em arquitetura. Inspirando-se nas investigações sobre esse tema elaboradas pelo historiador inglês John Newenham Summerson (1904 - 1992), Silva (2012) esboça uma leitura interessante sobre o assunto:

Summerson nos lembra que a composição clássica, na antiguidade, exigia disciplina: a ordem escolhida determinava as dimensões e a regra do jogo, a partir da qual toda alteração tinha repercussões no resultado final. Em essência, a manutenção da relação entre as partes e a medida definida pela ordem garantiam harmonia e proporção ao objeto. Para o Palácio da Alvorada, não se tratava do uso das ordens clássicas, nem mesmo de determinado módulo da coluna elaborada controlando todas as medidas do edifício, mas sim, de dimensões escolhidas para e por uma nova forma de coluna regendo a composição geral e a harmonia do conjunto. Nesta releitura, embora o fundamento modular não seja o mesmo, a disciplina da regra clássica é subjacente: a alteração em uma dimensão ou variável exige a revisão das demais em busca da harmonia pretendida. A partir deste raciocínio, verificamos que o próprio Niemeyer nos fornece a indicação das variáveis que delimitam a regra do jogo em pauta e que se resumiam em: espaçamento, forma e proporção. Variáveis para a criação de novas formas para colunas que, regidas por critérios elegidos de simplicidade e pureza, fossem também expressão da função estrutural.

Nesta leitura, destituída a coluna da exigência rigorosa de fornecer um módulo absoluto ao edifício, cabe ao intercolúnio, ou espaçamento entre as colunas, a função de definir a principal dimensão que regula as partes do palácio. Tal qual na composição clássica, o intercolúnio continua nos informando o ritmo da colunata, no entanto, em apropriação moderna o espaçamento passa a ser determinado pela busca do melhor resultado entre forma e proporção do novo elemento e, simultaneamente, pela intenção de expressar o potencial da técnica construtiva em uso. (SILVA; 2012: 181-182 - grifo nosso)

Nota-se assim que nesta obra já é adotado um vocabulário predominantemente plástico que tira proveito das questões estruturais como expressão arquitetônica pura e sintética. O intercolúnio de dez metros é usado como marco inicial tanto para guiar a composição das esquadrias dos extensos panos de vidro que revestem a caixa prismática retangular recuada, quanto para determinar as demais características das próprias colunas: a arcada parabólica invertida que faz as vezes de apoio externo ao entablamento e ao teto plano é suportada por arcos que nascem na parte inferior e que mal tocam o solo. Niemeyer vale-se de uma solução arquitetônica que escamoteia a presença estrutural de malha regular interna como forma de conferir mais leveza ao conjunto edificado: pilares frontais curvilíneos, de ritmo contínuo e de claro destaque formal, responsáveis por tolerar somente o peso da delgada laje por sobre eles, ao passo que o restante da edificação apoia-se em mais duas linhas de colunas cilíndricas 
de sustentação distribuídas pelo interior do prisma de vidro [Figura 4.85] - e não necessariamente visíveis aos mais desavisados.

Além disso, a forma e o ritmo da colunata exterior ajudam a manter mais discreta a divisão vertical do volume principal do palácio presidencial, ou seja, a solução em três níveis sobrepostos é disfarçada pelo destaque dado aos pilares curvilíneos, cuja interrupção assimétrica marca a entrada solene ao edifício. Nas duas principais fachadas, entre a colunata e o corpo envidraçado do prédio principal, localiza-se uma extensa varanda (ou loggia) [Figura 4.86], a qual ajuda a compor a solução arquitetônica, a domar a forte iluminação natural do cerrado do Planalto Central, e a configurar um ambiente intermediário de acesso ao edifício, com nítido apelo colonial ou mesmo como um reforço referencial aos antigos templos gregos e romanos. Quem sabe até - mas em uma outra dimensão - Niemeyer tenha bebido da fonte das obras pavilhonares miesianas para a composição desta edificação residencial.

A especulação acima, referente ao trio de alusões possivelmente adotadas por Oscar Niemeyer em seus palácios brasilienses - dentre os quais está o da Alvorada - merece uma reflexão mais detida. Se é Lucio Costa quem inicialmente atribui uma afinidade genérica às casas de fazenda coloniais, nas quais a varanda intermedeia a colunata e o corpo residencial - servindo, pois, de espaço intersticial de permanência - é com Santos (1981) que essa referência à tradição se materializa e se especifica, ao vincular o Palácio da Alvorada à Fazenda Colubandê [Figura 4.87], em São Gonçalo, Rio de Janeiro. Como justificativa, ao autor chamam-lhe a atenção qualidades como grandeza, nobreza despretensiosa, certo ar de brasilidade e, acima de tudo, um profundo respeito à tradição e ao espírito mais que a atenção à forma final edificada.

Recuperando as citações clássicas, além das variáveis espaçamento, forma e proporção mencionadas por Silva (2012) parágrafos acima, é possível identificar algumas características do Palácio da Alvorada que também remetem à arquitetura da Antiguidade: "a contenção volumétrica dos palácios e a clareza de seus elementos constituintes já seriam suficientes para aproximar a arquitetura de Niemeyer de grandes obras do passado, mas é a opção pela configuração de volume único com galerias de colunas nas principais fachadas que precisa sua principal referência: o templo grego" (PONTES; 2004: 61) [Figura 4.88]. Referenciais calcados em um chamado sistema clássico de “ordens" e em uma tipologia do templo grego são mais bem explicados nas palavras da mesma autora:

O sistema de "ordens" que atua na caracterização dos palácios de Brasília insere-se na linguagem moderna porque a impressão estética resultante não depende de quaisquer elementos figurativos 
tradicionais, mas da manipulação abstrata de formas. Trata-se de um recurso de caracterização bastante distinto daquele do Ministério da Educação e Saúde, que, empregando elementos diretamente associados à cultura nacional - como os azulejos e os granitos típicos das construções coloniais e o brise-soleil próprio para o clima tropical - valorizava uma modernidade adaptada às especificidades locais. Ao combinar a tipologia do templo grego com a linguagem abstrata nos palácios da nova capital brasileira, Niemeyer não parece especialmente preocupado em expressar nem o "espírito de época", nem o "espírito do lugar". O que procurou evidenciar foi o caráter particular a cada instituição, entendida em suas propriedades universais, essenciais e abstratas. A tipologia do templo grego pôde servir de suporte para essa caracterização porque também está associada a valores concebidos em seu tempo como universais - como os que estruturam o ideal de beleza clássica. (PONTES; 2004: 70-71)

No entender de Valle (2000), a intenção de trabalhar o “caráter” dos edifícios já é anteriormente considerada por Niemeyer nos edifícios do Conjunto Arquitetônico da Lagoa da Pampulha, isto é, “esse aspecto clássico estava presente em sua arquitetura, mas era expresso pelas diferenciações da forma arquitetônica ou pelas características explícitas de sua modenatura, como a "abóbada hiperbólica" da Igreja de São Francisco de Assis". (VALLE; 2000: 458 e 462 )

Somadas às teorizações que buscam encontrar vínculos (por vezes efetivamente identificados) entre os projetos dos edifícios cívicos de Brasília e as tradições coloniais e clássicas, estão aquelas que se destinam a traçar citações mais recentes, isto é, calcadas nas arquiteturas contemporâneas à própria execução de Brasília. Bastos e Zein (2010) creem que Niemeyer pode ter encontrado uma fértil fonte de inspiração para os projetos dos palácios originais na fase americana do arquiteto alemão Mies van der Rohe no que diz respeito, sobretudo, à idealização de modelos-tipo universais e à sua independência da forma plástica.

Se se pensar no partido pavilhonar miesiano, merece destaque o Crown Hall (1950 - 1956) [Figura 4.89], do Illinois Institute of Technology: uma solução em monobloco, norteada pela horizontalidade, cujas fronteiras verticais são delimitadas, à cima, pelo fechamento de cobertura e, abaixo, pela laje de piso propositadamente destacada do solo solução que atribui um ar de grata leveza flutuante ao edifício. Os limites horizontais, por sua vez, são comandados pela vasta pele de vidro que abraça e envolve toda a edificação.

Ao refletir sobre um modelo de caráter universal, o arquiteto alemão dota seu pavilhão de um espaço interno que pode ser entendido - ao menos em teoria - como uma espécie de curinga, ou seja, passível de receber as mais diversas configurações para as mais variadas finalidades. Para tanto, ainda no entender das autoras, Mies van der Rohe concebe um volume guiado por uma rígida ordem espacial a partir da qual organizam-se e definem-se modulações, sistemas estruturais, disposições das caixilharias, paginações de pisos e afins. As afinidades e os contrapontos entre 
as arquiteturas americana e brasileira são mais bem esclarecidas pelas palavras das próprias autoras, ao explicarem que, no Crown Hall,

o piso principal da área nobre está elevado 1,82m do solo, o acesso é feito por escadas: do lado sul, por ampla escada, com lances e patamar em mármore, pelo lado norte por duas escadas mais estreitas e simétricas. As atividades que exigiam subdivisões mais convencionais, como os serviços, salas de aula, alguns escritórios e oficinas foram colocadas no subsolo. Deste nível só se percebe externamente uma faixa contínua de janelas que desponta no nível do solo, e que internamente corre junto ao teto do pavimento. A laje que separa salão nobre e subsolo, e cuja presença é destacada na solução da obra, é suportada por sistema convencional de pilares de concreto armado, assim, a estrutura metálica que envolve o salão superior trabalha de maneira totalmente independente. Essa estrutura tem dois tipos de pilares, todos periféricos: os oito de maior seção que formam os quatro pórticos transversais que suportam a cobertura e sessenta e quatro de menor seção que dão rigidez à estrutura. No caso do Crown Hall, o pavimento nobre é um grande salão livre de apoios, em que as divisórias baixas de madeira criam zonas distintas mas integradas num espaço contínuo.

Voltado à solução dada por Niemeyer para os palácios de Brasília, é possível perceber um diálogo com o partido pavilhonar concebido por Mies: a proporção horizontal, o programa contido numa caixa de vidro, a valorização visual das lajes do piso nobre e da cobertura, a solução de um pavimento semienterrado abrigando serviços, a ideia de uma estrutura porticada que sustém a cobertura, naturalmente, no caso de Niemeyer, apenas visualmente sugerida, não efetivada. Nesse raciocínio são desconcertantes as subversões feitas por Niemeyer, na proposital busca de assimetrias, na sugestão e simultânea negação da importância estrutural dos pilares da loggia, no tratamento plástico dos recortes da laje que permitem a integração do espaço entre os pavimentos nobres dos palácios, na posição clara em defesa de uma liberdade frente a uma norma estrita de condicionamento da forma. (BASTOS e ZEIN; 2010: 70-71)

Os resultados alcançados pelas arquiteturas de Oscar Niemeyer e de Mies van der Rohe, ainda que partam de uma mesma raiz (caixa envidraçada, desnivelada em relação ao solo, recuada, inscrita em linhas de colunatas laterais) são, cada um a seu modo, diferentes respostas a programas também distintos. A seriedade e a verdade de Mies encontra em Niemeyer um oponente à altura: é como se o arquiteto brasileiro brincasse com os princípios da ortogonalidade da arquitetura moderna e, a partir deles, guiasse sua arquitetura por outras trilhas. Trilhas essas que por vezes abusam das soluções estruturais em concreto como mote para obter mais destaque para as variáveis estéticas de seus edifícios construídos, isto é, a verdade estrutural cede espaço para a valorização plástica.

Se na nova Capital Federal Niemeyer responsabiliza-se pelos projetos arquitetônicos dos prédios cívicos/simbólicos neles incluído o próprio Palácio da Alvorada - a tarefa correspondente ao dimensionamento das estruturas de concreto armado é, uma vez mais, confiada ao engenheiro civil Joaquim Cardozo. Conta a seu favor não apenas a extrema destreza e a alta competência na execução dos cálculos estruturais, mas acima de tudo, o resultado positivo 
obtido anteriormente na parceira de ambos para o Conjunto Arquitetônico da Lagoa da Pampulha. Apreende-se a partir daí que o diálogo existente entre as disciplinas arquitetura e engenharia já parte de um alinhamento prévio entre os dois profissionais - o que corrobora para uma coesão ainda mais evidente entre forma e técnica.

O formato inusitado da colunata [Figura 4.90] desperta o interesse também pelo contraste volumétrico: delgados apoios nas partes superior e inferior e um alargamento verticalmente desalinhado - algo que remete a um losango desproporcional, de lados curvos, cuja centroide está deslocada e colocada a cerca de um quinto da altura, a partir do piso. Os delicados pontos de contato de cada uma das colunas com os elementos superiores e inferiores de apoio, isto é, com a laje de cobertura e com o solo configuram-se, eles também, como um cuidado redobrado por parte da equipe de especialistas - principalmente no que tange aos seus aspectos técnicos/tecnológicos. Rebello e Leite (2007) apontam que, assim como acontecera em obras anteriores, o engenheiro Joaquim Cardozo opta por subverter as normas técnicas estruturais então vigentes, tomando como base de trabalho as suas próprias formulações matemáticas e, consequentemente, a sua própria experiência projetual. Ao assumir tal postura ele consegue assegurar que, sob todos os aspectos, tanto a preservação das formas plásticas quanto o caráter de "leveza" e a audácia poética da arquitetura moderna de Oscar Niemeyer para o Palácio da Alvorada estejam em conformidade com as premissas ditadas pelo projeto arquitetônico.

Assume-se então que a qualidade "leveza" praticamente conduz os trabalhos dos envolvidos, sobretudo no que se refere à adoção de elementos esguios nos pontos de apoio dos pilares [Figura 4.91], nos detalhes, nas articulações, nas transições entre diferentes componentes, dentre outros. "Leveza ressaltada pelo dualismo instigante - entre grandes vãos e suportes delgados ou entre ausência de suportes e pouca espessura aparente das arquitraves" (SILVA; 2012: 302). Tudo isso visando a enaltecer as questões estéticas referenciadas por Oscar Niemeyer como fundamentais para atingir seus objetivos: volumetrias limpas, puras e calcadas em uma técnica mais apurada do uso do concreto armado.

As exigências conferidas ao próprio concreto armado para que as qualidades estéticas sejam ressaltadas indicam uma atenção de Niemeyer mais voltada à plasticidade que aos fatores técnicos/tecnológicos. Isso não significa dizer, contudo, que o arquiteto ponha em risco a sua obra em favor da beleza. O que se quer mostrar aqui é que as solicitações dos esforços absorvidas pela tríade estrutural tradicional (pilares, vigas e lajes) não são diretamente proporcionais às dimensões desses mesmos três elementos, quando construídos. Basta pensar na entrada 
monumental do Palácio da Alvorada, na qual há uma interrupção no intercolúnio anteriormente cadenciado sem que qualquer alteração na espessura da laje de cobertura, logo acima, seja providenciada [Figura 4.92]. Logo, esse espaço mais alargado e livre de apoios, passa a demandar um empenho maior tanto no vigamento superior quanto no par de colunas situado nas duas extremidades - vigas e colunas essas que também não sofrem qualquer tipo de mudança volumétrica que potencialize a absorção dos esforços mais elevados nelas incidentes. Pelo contrário: Niemeyer resolve fatiar longitudinal e verticalmente ambas as colunas, que agora possuem seção reduzida frente a um carregamento mais exigente. Sobre as cargas suportadas pelo conjunto de colunas ondulantes é possível afirmar que,

de acordo com as constatações vistas em relação aos planos de cobertura, a carga suportada pelas colunas nas fachadas é variável. Enquanto as colunas inteiras realizam o apoio compartilhado das lajes como solução geral, as semicolunas têm cargas atuantes distintas. Aquelas previstas nas extremidades do edifício possuem carregamento praticamente nulo, resultante do auxílio proporcionado pelos balanços nas vigas de bordo. Entretanto, as que definem o pórtico de acesso recebem a maior carga dentre todas, pois além de parte do carregamento comum, respondem também à considerável proporção de mais de um terço da carga resultante da laje no vão triplicado. (SILVA; 2012: 319)

Parece haver aqui certa inconsistência entre aquilo que é proclamado por Oscar Niemeyer e o que efetivamente é posto em prática. Se depois de sua primeira revisão crítica passa a existir um foco na unidade formal com o uso de soluções estéticas mais simples e equilibradas quanto às questões funcionais e construtivas, o Palácio da Alvorada, ao que tudo indica, não condiz com esse discurso. Há, nele, uma supremacia da expressão plástica em prejuízo da manifestação estrutural. E esse predomínio não se apresenta apenas na falsa impressão de que as colunas sinuosas que compõem ambos os peristilos são as únicas responsáveis pela sustentação de toda a cobertura retangular do edifício. O amplo pórtico que configura o acesso solene dá a entender que está sendo totalmente apoiado, apenas, nas semicolunas laterais. Pode-se assumir então que a plasticidade da colunata ondulante niemeyeriana camufla o verdadeiro sistema estrutural do edifício, tornando-o ininteligível ao convidar o olhar do contemplador a admirar suas formas parabólicas, as quais livram do edifício qualquer percepção das tensões pertinentes à sua sustentação, ressaltando, pois, o mesmo caráter de "leveza” anterior.

Há que se considerar que esta discussão pode, também, ser lida sob outro prisma: o do desdobramento da técnica em favor dos predicados arquitetônicos. Dito de outra maneira e tomando o Palácio da Alvorada como exemplo, tanto as colunas inteiras ou as partidas ao meio quanto a arquitrave que vence o pórtico frontal de grandes dimensões só 
puderam manter suas configurações inalteradas devido ao fato de a técnica ter readaptado seus conceitos e suas normas em um processo contínuo de criação científica para novas soluções que atendessem às peculiaridades do projeto arquitetônico e de seu fator estético. Ou seja, a partir do momento em que os tecnologistas parceiros de Niemeyer se defrontaram com situações nunca dantes vivenciadas, tomaram-nas como novos desafios, propondo então soluções inovadoras que pudessem atender às necessidades da arquitetura. Lançaram, portanto, um olhar crítico sobre aquilo que vinha sendo praticado até então e foram além: das equações algébricas tradicionais surgiram alternativas para vencer vãos maiores ou para fugir das formas curvas até então conhecidas até encontrar, em uma equação de quarto grau, a fórmula adequada para a composição estética das colunas sinuosas do Palácio.

Por fim, assim como acontece em todos os outros projetos de Oscar Niemeyer anteriormente investigados neste estudo - o Ministério da Educação e Saúde (MES), o Pavilhão Brasileiro na Feira Internacional de 1939 em Nova York e o Conjunto Arquitetônico da Lagoa da Pampulha - há um contato muito próximo e uma participação bastante ativa de vários artistas que contribuem, com suas obras, para o incremento sensorial e perceptivo do Palácio da Alvorada. Dentre outros, destacam-se o pintor, escultor e desenhista carioca Athos Bulcão (1918 - 2008) e sua pintura do teto da pequena capela, a feitura dos castiçais e de alguns objetos de culto - além dos lambris folheados em ouro que revestem as paredes internas do mesmo ambiente [Figura 4.93]. No espelho d'água localizado junto ao pórtico que delimita a entrada principal do Palácio da Alvorada, há uma escultura moldada em bronze pelo artista plástico e escultor brasileiro Alfredo Ceschiatti, chamada "As laras" [Figura 4.94]. Da escultora, desenhista, gravurista, pintora, escritora e musicista Maria Martins apresenta-se a obra "Rito dos Ritmos" [Figura 4.95], situada na elevação leste da residência presidencial e que traz implícita uma nova fase da artista, voltada, neste momento, à produção menos orgânica e mais angulosa, inspirada que está no afastamento à corporeidade em favor da a aproximação a novas possibilidades formais que remetam, metamorficamente, aos esqueletos. 


\section{LEVEZA E MONUMENTALIDADE ARQUITETÔNICAS}

Oscar Niemeyer:

Palácio da Alvorada

(Brasília, 1956-1958)

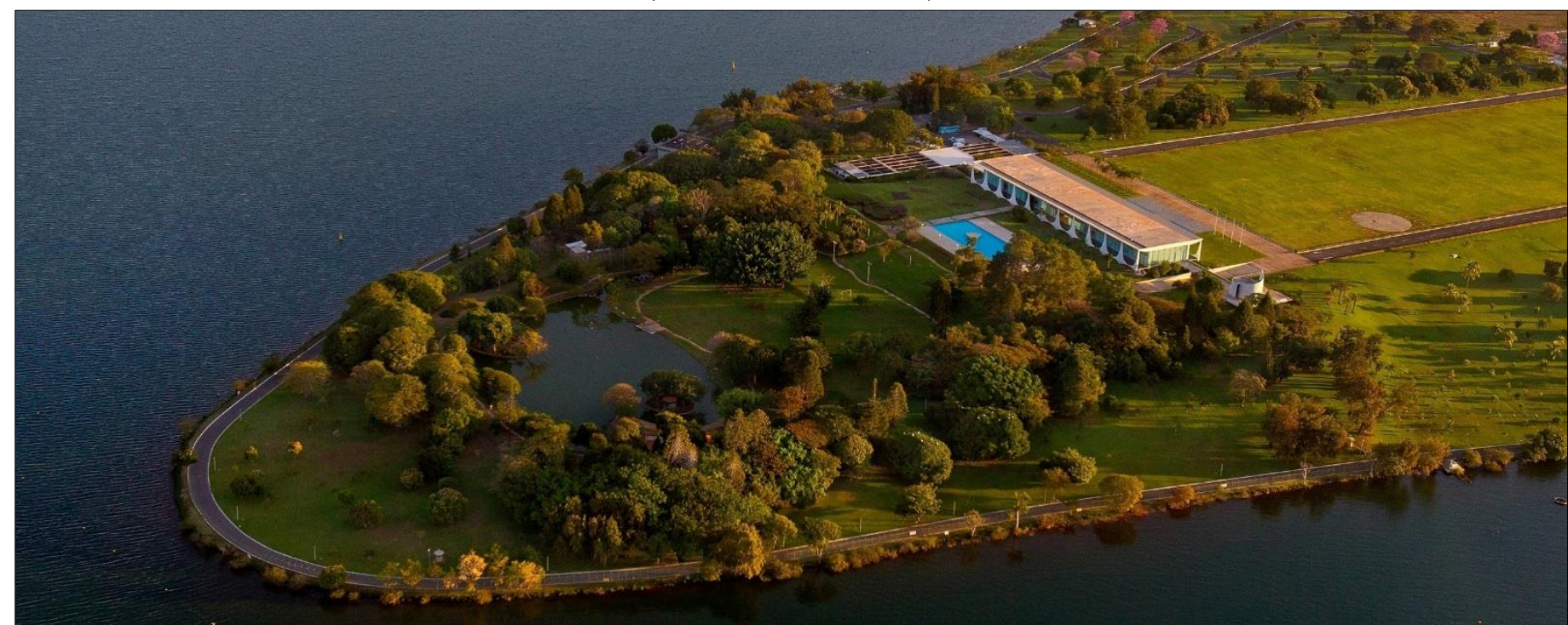

[4.82] Edifício pioneiro em Brasília, o Palácio da Alvorada localiza-se em um sítio privilegiado: uma península que avança sobre o Lago Paranoá. A implantação adotada busca tirar partido da topografia irregular do terreno para acomodar as edificações construídas, além de orientar para o norte o acesso principal ao edifício. Áreas íntimas presidenciais e de lazer faceiam o lago, portanto, são mais privativas e reservadas. Com isso, os demais ambientes internos tornam-se distribuídos e equacionados entre si.

[4.83] Oscar Niemeyer opta por um programa composto por três edificações autônomas, mas complementares entre si: a principal, acomoda a residência presidencial e é ladeada por uma pequena capela e por um bloco semienterrado, no qual estão os serviços de apoio.

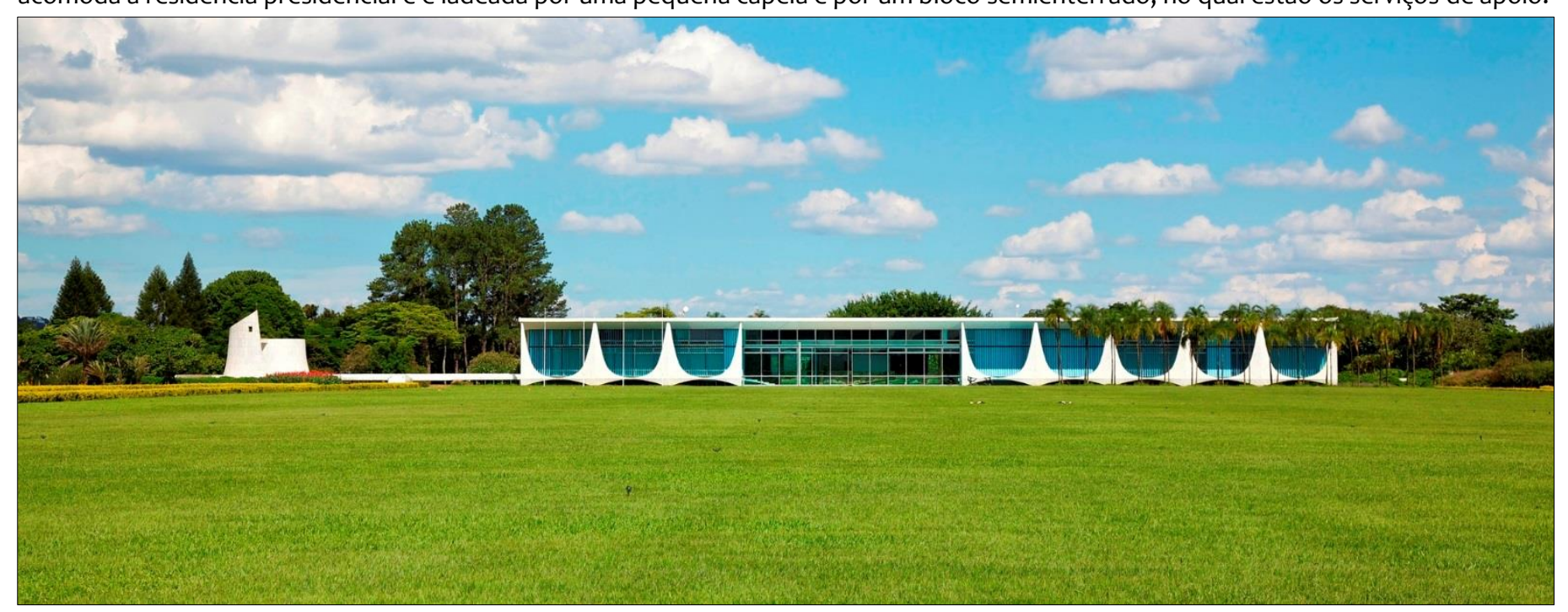




\section{LEVEZA E MONUMENTALIDADE ARQUITETÔNICAS}

Oscar Niemeyer:

Palácio da Alvorada

(Brasília, 1956 - 1958)

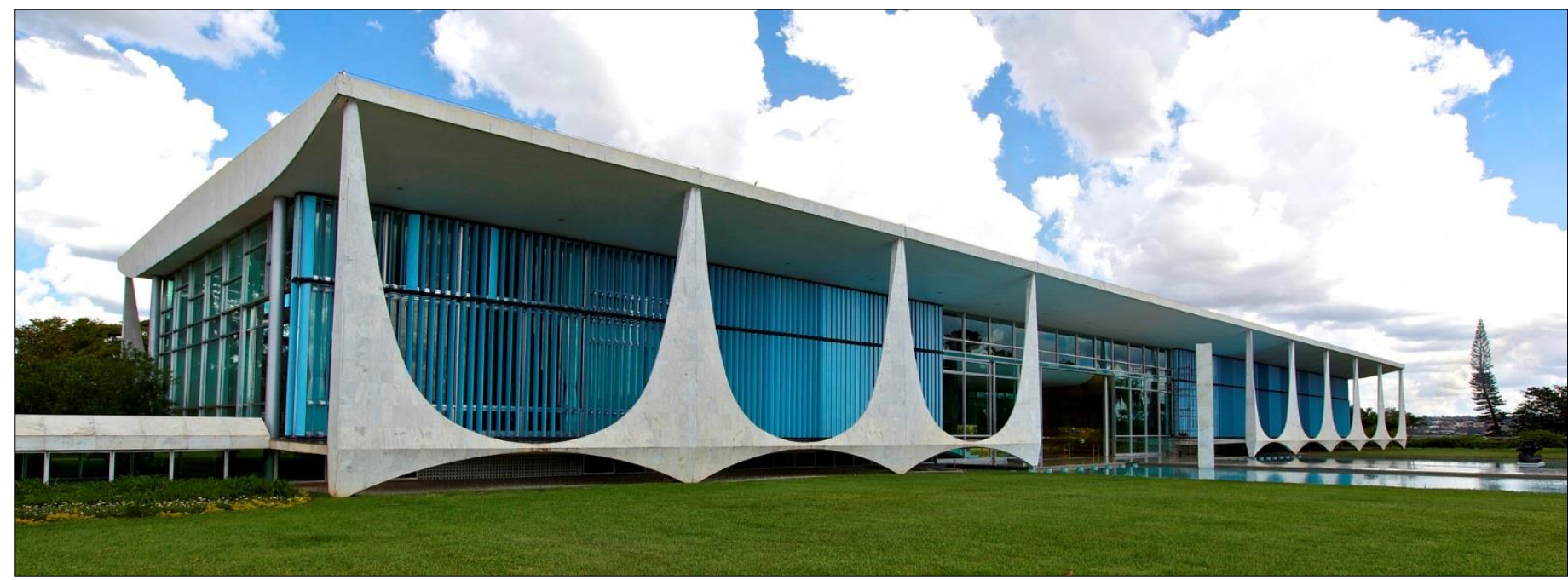

[4.84] Oscar Niemeyer exercita no Palácio da Alvorada uma solução plástico-formal que será também adotada, com variações pontuais, nos demais palácios originais de Brasília (porém, sem perder a unidade arquitetônica do conjunto construído): caixa de vidro prismática, horizontalizada, que encerra o corpo principal do prédio, recuada e protegida, em ambos os lados maiores, por peristilos compostos por colunas de formas sinuosas. Em seu projeto, o arquiteto carioca foca três importantes variáveis: espaçamento, forma e proporção.

[4.85] No sistema estrutural adotado, as colunas ondulantes exteriores amparam somente ambas as coberturas das varandas longitudinais. Os demais pilares, modulados, apoiam o restante da edificação e permanecem escamoteados internamente.

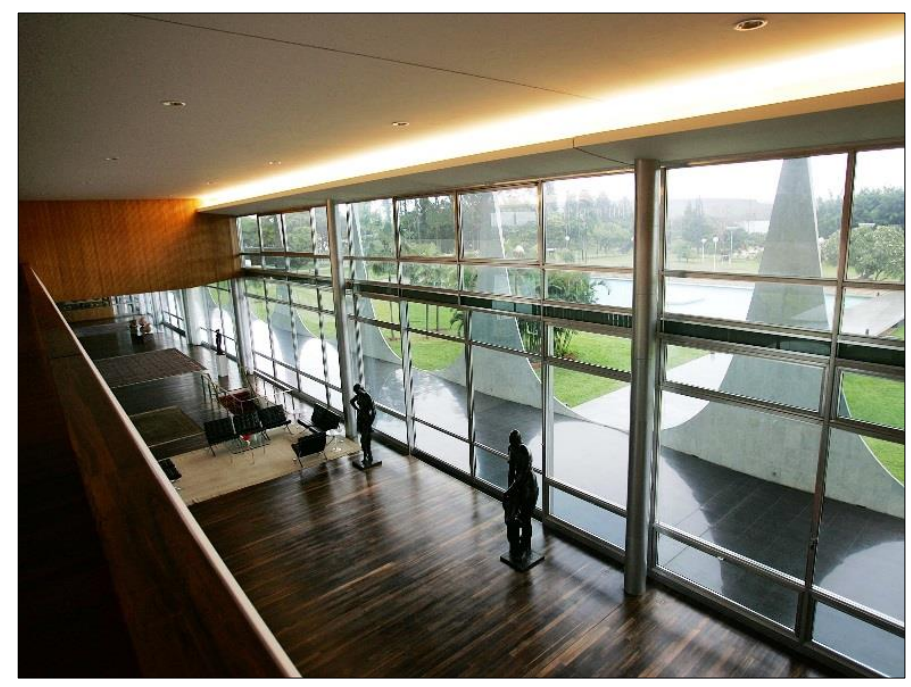

[4.86] A loggia ajuda a compor a solução arquitetônica, a debelar a forte iluminação natural do cerrado do Planalto Central e a formar um novo ambiente de acesso ao edifício. Nela, a contemplação da paisagem não é prejudicada pelas esbeltas colunas sinuosas.

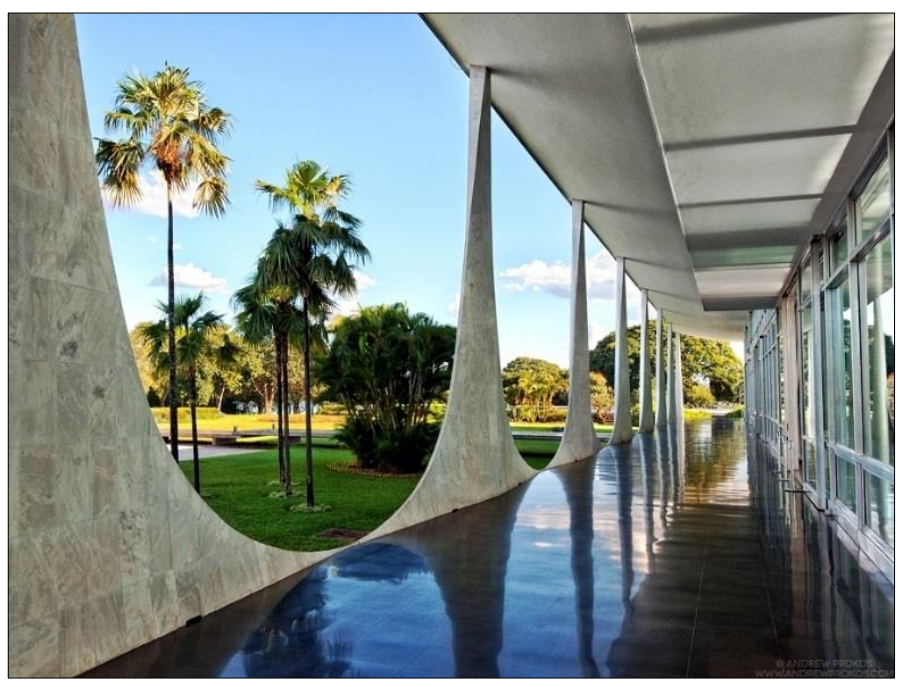




\section{ASCENDÊNCIAS PALACIANAS}

Fazenda Colubandê [4.87];

Templo Grego: Pantheon [4.88];

Crown Hall [4.89]

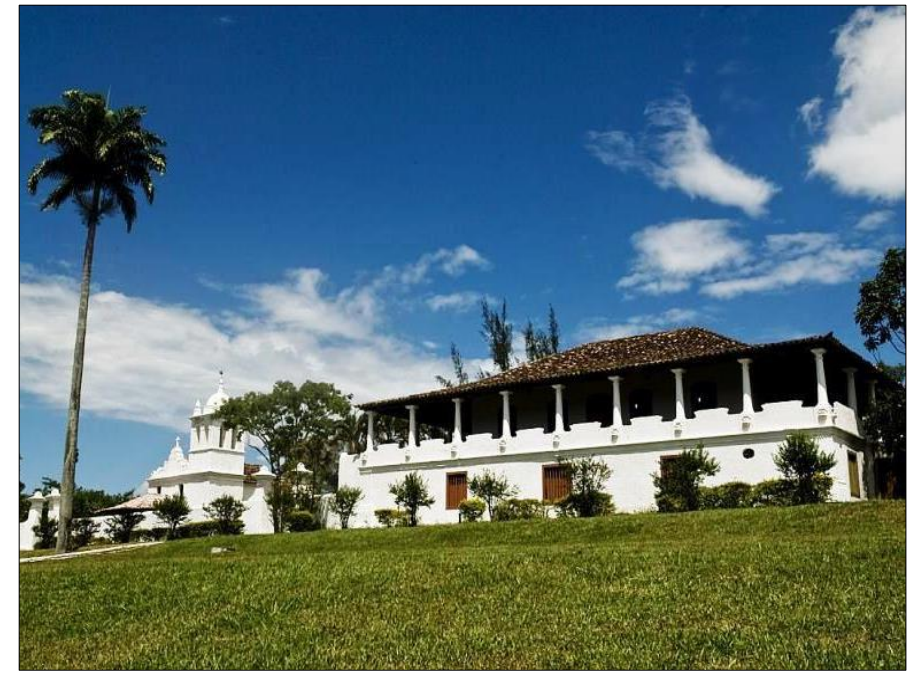

[4.87] A sede da Fazenda Colubandê guarda diversas semelhanças com o Palácio da Alvorada, dentre elas citam-se duas: na implantação, casa e capela são dispostas lado a lado e a varanda é volteada por peristilos que ajudam a sustentar parte da cobertura.

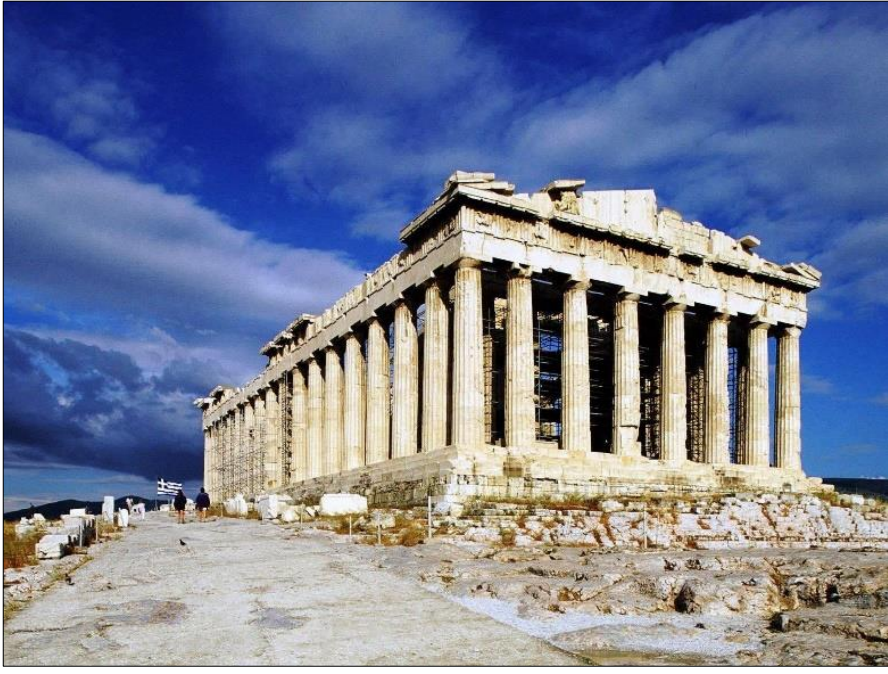

[4.88] Podem ser atribuídas inspirações nos projetos dos palácios originais de Brasília à antiga solução dos templos gregos: volume único, protegido por um contorno perimetral no qual encontram-se galerias de colunas monumentais que seguem ritmo constante.

[4.89] De Mies van der Rohe, Niemeyer pode ter subvertido os modelos-tipo universais e a independência da forma plástica. No partido pavilhonar do Crown Hall, o arquiteto alemão adota uma solução em monobloco envolta em pele de vidro, horizontalizada, limitada verticalmente pelo fechamento de cobertura e pela laje de piso destacada do solo, posicionada sobre um nível inferior, semienterrado.

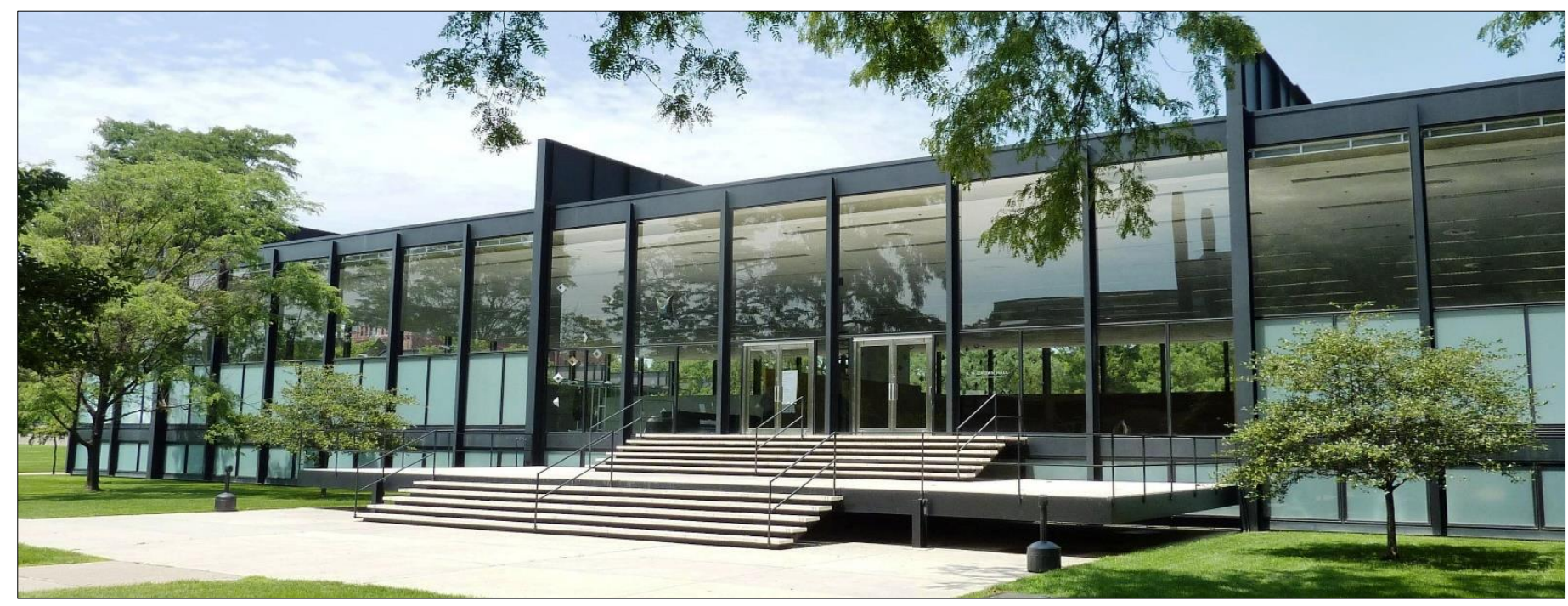




\section{LEVEZA E MONUMENTALIDADE ARQUITETÔNICAS}

Oscar Niemeyer:

Palácio da Alvorada

(Brasília, 1956-1958)

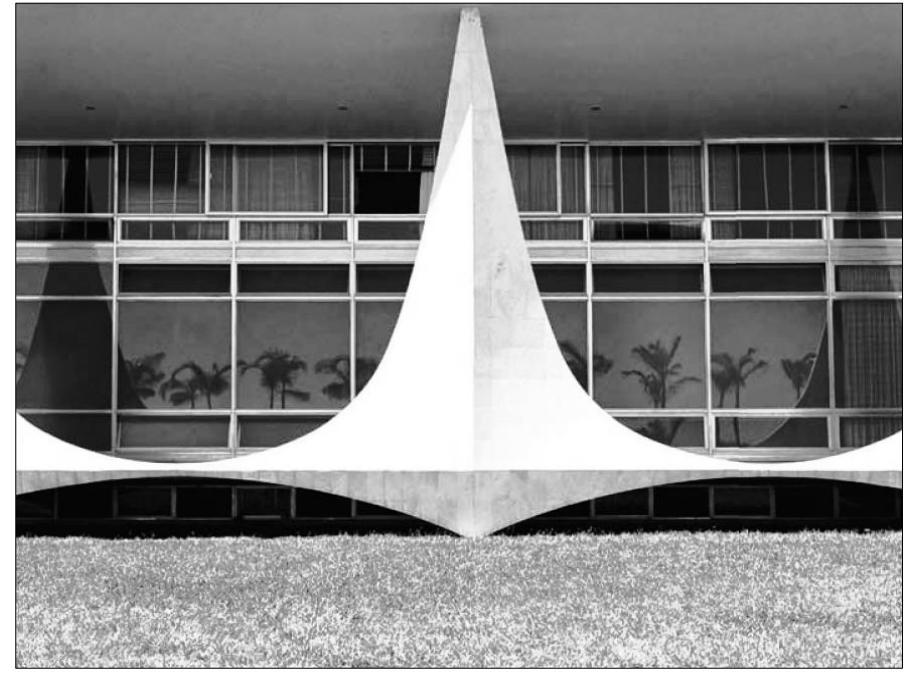

[4.90] O formato inusitado das colunas externas ao palácio são fruto da inventividade criativa de Niemeyer e da habilidade matemática de Cardozo, que define uma equação algébrica de grau quarto para a curvatura ideal desses elementos simbólicos.

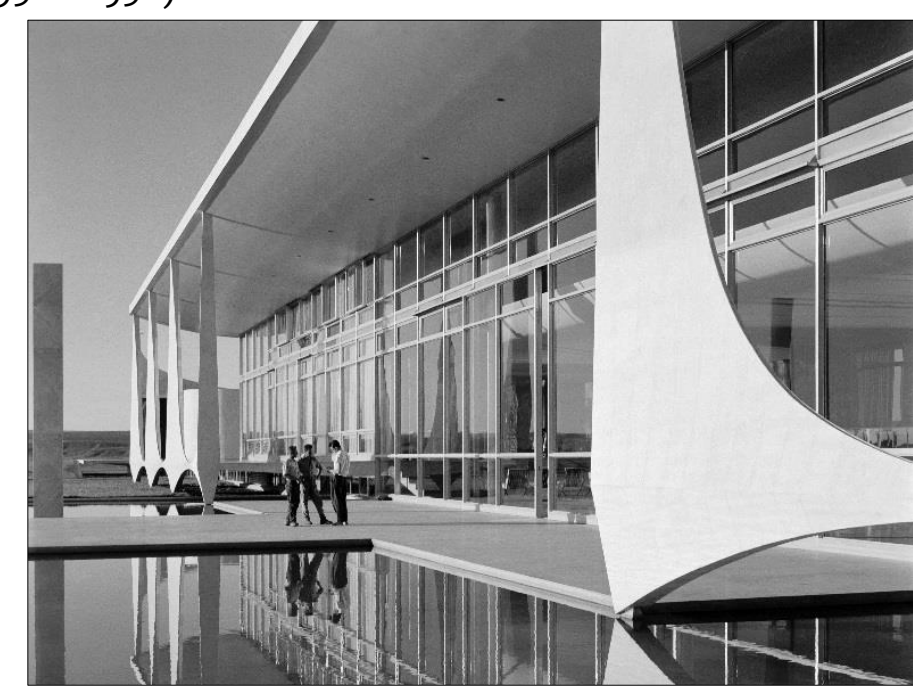

[4.91] O caráter de "leveza" atribuído às colunatas justifica-se pela esbelteza dos elementos arquitetônicos, aliada tanto aos discretos e delicados pontos de apoio quanto aos generosos vãos vencidos e à coloração branca dada aos revestimentos.

[4.92] Buscando a unidade e a leveza do edifício construído, Oscar Niemeyer adota um conjunto de dimensões pré-estabelecido para a tríade estrutural tradicional (composta por pilares, vigas e lajes). Porém, ao agir dessa forma, passam a existir aplicações pontuais no Palácio da Alvorada nas quais os esforços solicitantes que recaem sobre as peças estruturais não parecem corresponder às suas reais dimensões. Tomando a entrada solene como exemplo, nota-se uma interrupção no intercolúnio cadenciado sem que qualquer alteração na espessura da laje de cobertura, logo acima, seja adotada. Como se isso não bastasse, o arquiteto carioca fatia verticalmente ambas as colunas das extremidades que, mesmo tendo metade de seu tamanho, suportam cargas significativamente mais elevadas que as demais.

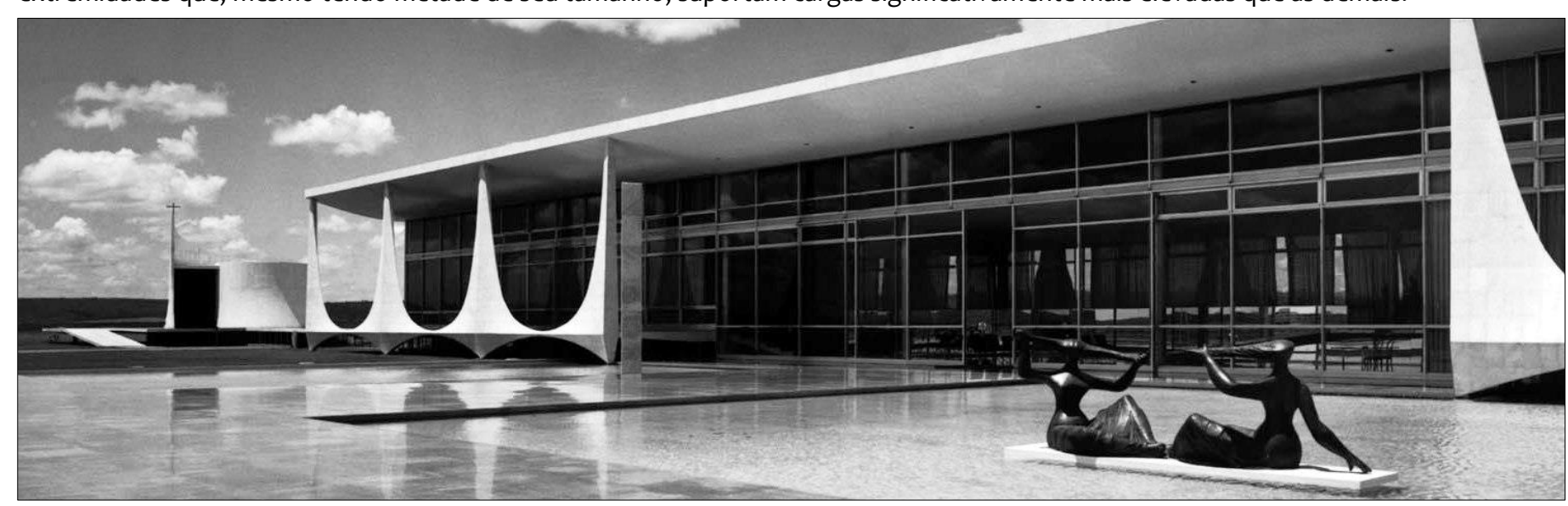




\section{LEVEZA E MONUMENTALIDADE ARQUITETÔNICAS}

Oscar Niemeyer:

Palácio da Alvorada

(Brasília, 1956 - 1958)

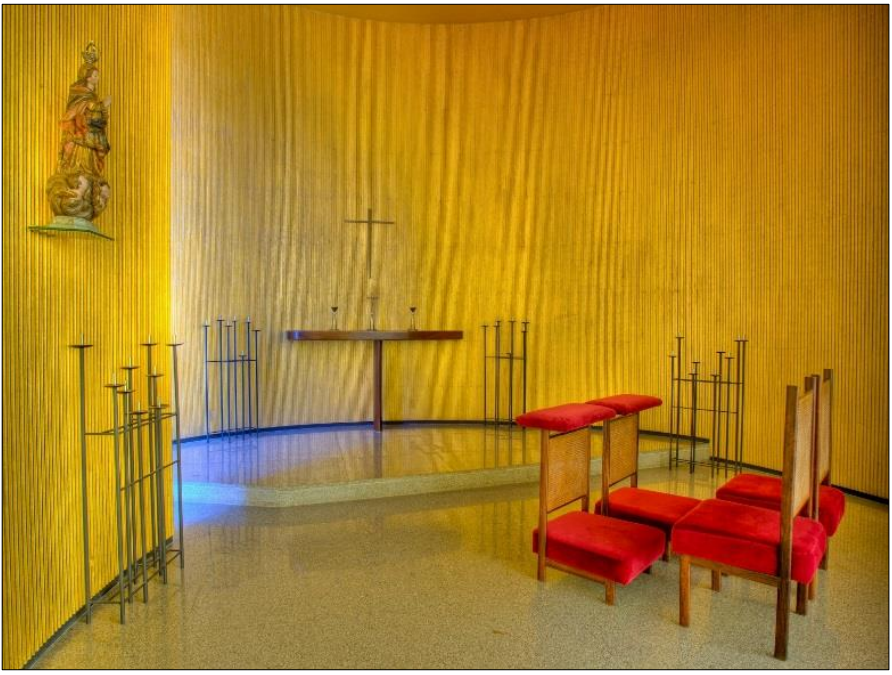

[4.93] O artista carioca Athos Bulcão responsabiliza-se pelo tratamento plástico dado internamente à pequena capela. São dele: a pintura do teto, os castiçais e alguns objetos de culto - além dos lambris folheados em ouro que revestem as paredes.

[4.94] Localizada no espelho d'água junto à entrada principal do Palácio da Alvorada, a escultura em bronze do artista plástico e escultor brasileiro Alfredo Ceschiatti, batizada de "As laras", dá as boas vindas aos visitantes da residência presidencial.
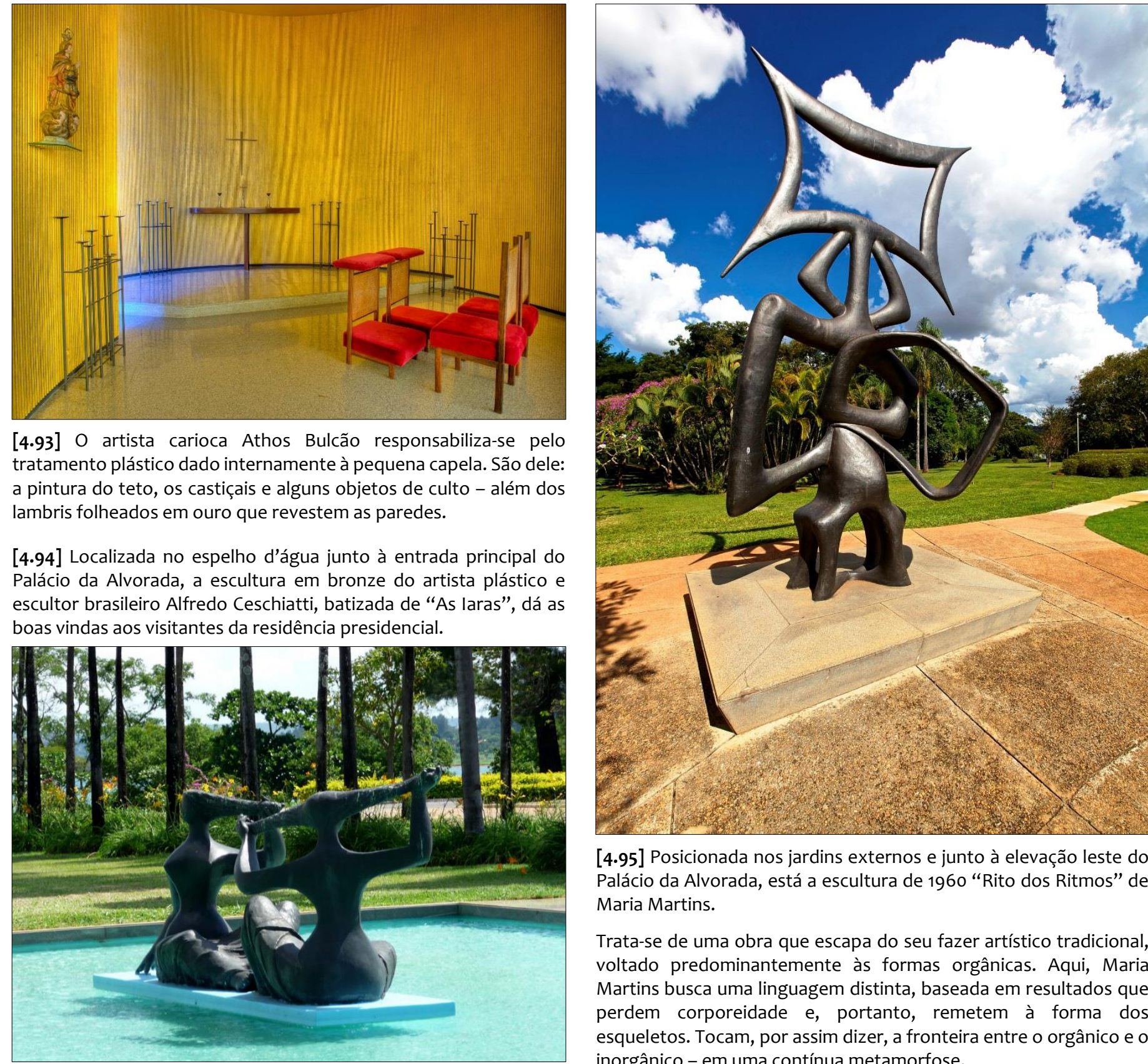

[4.95] Posicionada nos jardins externos e junto à elevação leste do Palácio da Alvorada, está a escultura de 1960 "Rito dos Ritmos" de Maria Martins.

Trata-se de uma obra que escapa do seu fazer artístico tradicional, voltado predominantemente às formas orgânicas. Aqui, Maria Martins busca uma linguagem distinta, baseada em resultados que perdem corporeidade e, portanto, remetem à forma dos esqueletos. Tocam, por assim dizer, a fronteira entre o orgânico e o inorgânico - em uma contínua metamorfose. 
Findo o entusiasmo quase generalizado pela inauguração da nova Capital Federal, o andamento da implantação arquitetônica e da complementação do plano urbanístico da cidade sofrem uma repentina desaceleração, influenciando, por consequência, a execução das obras ainda em curso. O motivo recai sobre as costas do então presidente Jânio Quadros (1917 - 1992), que prioriza outros projetos nacionais e deixa Brasília, sob muitos aspectos, à deriva. Não efetua mais na cidade ações governamentais que estimulem a manutenção das atividades de construção de edifícios e/ou de infraestrutura, o que acaba por comprometer o cumprimento dos cronogramas de continuidade e de firmação da Capital Federal. A instabilidade governamental é ampliada a partir da renúncia do próprio presidente, e não melhora nem após subir ao cargo o seu sucessor, João Goulart (1919 - 1976). A insatisfação dos militares diante de tal panorama complicado e delicado para o Brasil deflagra, em 1964, o Golpe de Estado. Todavia, ainda assim e dentro de uma conjuntura política e social de tamanha instabilidade, não há como mudar ou reverter a condição de Brasília ser oficialmente reconhecida como a nova capital do país.

É em um contexto recheado de impasses como esses que Oscar Niemeyer elabora a nova sede do Ministério das Relações Exteriores. Projeto e obra sofrem, em função das circunstâncias pré e pós-1964, atrasos, suspensões e intromissões alheias, acarretando significativas postergações nas ações ora programadas. É apenas no início dos anos 1970 que esta obra será de fato concluída. Conta, a favor de Niemeyer, a colaboração fundamental do arquiteto Milton Ramos, então vinculado à Construtora Pederneiras (responsável pela construção do Palácio), e que dedica empenho basilar para que a obra construída atinja todas as exigências técnicas e estéticas de seu projetista. Tal a importância deste edifício e de suas atividades para os cenários brasiliense e nacional que "a efetiva consolidação de Brasília estava condicionada à transferência do Itamaraty. Mais do que um ministério transplantado, o novo palácio deveria corresponder às expectativas e perspectivas políticas da diplomacia brasileira, abrigando as funções daquela instituição que fora o baluarte da formação e da constituição do Estado nacional, e que agora deveria contribuir na consolidação da Capital com seu capital simbólico, emanando-o para além dos domínios das arcadas de sua nova sede". (ROSSETTI; 2009:02) 
Concebida em 1962 - portanto quatro anos após o término da primeira fase de revisões críticas protagonizadas pelo arquiteto carioca - a nova sede do Ministério das Relações Exteriores, oficialmente denominada Palácio do Itamaraty (e também conhecida como Palácio dos Arcos) [Figura 4.96] compõe o segundo conjunto de edifícios oficiais monumentais brasilienses, do qual faz parte, dentre outros, o Ministério da Justiça. Estas duas novas edificações estão estrategicamente localizadas: uma defronte à outra em uma área fronteiriça - ou de transição - que, por um lado, toca a extremidade da longilínea Esplanada dos Ministérios e, por outro, serve como portal à Praça dos Três Poderes, na qual estão três das quatro obras notáveis originais de Brasília: os Palácios do Planalto, do Supremo Tribunal Federal e do Congresso Nacional.

Em função tanto do seu sítio de implantação quanto da representatividade inerente que carrega consigo, o Palácio do Itamaraty é idealizado com vistas à manutenção e à exaltação de uma "unidade arquitetônica" compartilhada e equiparada àquela existente nos palácios mais antigos. Talvez isso ajude a justificar a presença de uma dita similaridade plástico-formal entre todas essas edificações, a qual é destacada, estabelecida e fomentada pelas colunas das fachadas de cada uma das obras. Os formatos desses componentes são distintos entre si, e também o são seus posicionamentos e suas materialidades, porém, há que se admitir que esses mesmos elementos arquitetônicoestruturais conferem ao grupo de edifícios uma mesma linguagem coesa e, por isso, única.

Se os palácios originais "se caracterizam tanto pelo dinamismo recortado de seus apoios quanto pela combinação luminosa entre o mármore branco e os vidros esverdeados" (WISNIK; 2013: 37), esta nova obra carrega consigo uma solução geral bastante sóbria e austera composta por um prisma recuado de vidro acinzentado volteado por um peristilo de concreto aparente de tom ocre. Este mesmo peristilo é formado por 56 colunas de seção transversal trapezoidal, as quais constituem, por sua vez, arcadas simétricas de rigor quase cartesiano, cuja configuração edificada permite não só que seja estabelecida plena integração ao sítio urbano no qual se insere, como também que se forme a articulação de um interessante diálogo para com as demais edificações palacianas.

Além do edifício principal, o Palácio dos Arcos possui dois blocos anexos: o primeiro deles, com nove pavimentos, tem formato de lâmina e é reservado às funções administrativas e complementares (como garagens, ambulatórios, almoxarifados, oficinas e afins). Além disso, está implantado na parte posterior do lote e contrasta com a representatividade do edifício frontal por meio de sua neutralidade plástica [Figura 4.97]. O segundo anexo, por sua vez, possui formato de três troncos de cilindro de diferentes diâmetros sobrepostos uns aos outros, conformando 
um único volume. É conectado ao bloco administrativo por meio de uma passarela feita em concreto completamente fechada em todos os seus lados. Para este último prédio, existem restrições de acesso e de aberturas ao exterior, justamente porque ele abrigar biblioteca, arquivos e documentações sigilosas do Brasil e de outros países. Todavia, ainda que encerrem atividades complementares, as três edificações não são independentes apenas nas espacialidades, mas também o são nos quesitos estruturais e de organização interna.

Assim como ocorre com o Palácio da Alvorada, à nova sede do Itamaraty pode-se delinear uma leitura calcada tanto em uma ascendência às casas coloniais de fazenda, quanto em relação à arquitetura clássica (seja pela volumetria quadrangular ou pela colunata constante em todas as fachadas externas). Sobre esta constatação tem-se que, "os edifícios mais importantes em meio às funções ministeriais, o Ministério da Justiça e o Ministério das Relações Exteriores, retomam o tema clássico dos palácios - o que dignifica suas funções e faz com que sobressaiam na hierarquia de formas de Brasília". (UNDERWOOD; 2003: 92). Podem ser estabelecidas também analogias entre para com os ensaios volumétricos das caixas portantes das Maisons Citrohan corbusianas (estas, variações ritmadas do compasso sugerido pela estrutura independente do "Sistema Domino"). Há também uma possibilidade de cognação mais presente e mais nítida para com os pavilhões miesianos compostos por volumes únicos envidraçados, predominantemente estruturados em aço e harmonicamente contextualizados nas paisagens nas quais se inserem - como o Crown Hall, anteriormente citado com mais cuidado neste estudo.

Mas não é só isso. Percebe-se neste projeto de Niemeyer (assim como ocorrido no Palácio da Alvorada) uma alusão às soluções encontradas por Mies van der Rohe para as obras do tipo pavilhão, porém, aqui também adotadas pelo arquiteto brasileiro de um modo propositadamente corrompido, como que para diferenciar-se e/ou destacar-se. Para o caso do Palácio do Itamaraty pode-se dizer que, enquanto Mies trabalha com estruturas porticadas que suportam completamente a cobertura, o arquiteto carioca, por sua vez, faz desse mote algo apenas insinuado, mas não um sistema portante de fato, como apontam Bastos e Zein (2010).

Isso significa dizer que seja possível considerar que o Palácio do Itamaraty carregue consigo certa "falsidade" projetual e construtiva. A liberdade formal de Niemeyer para conferir mais leveza e plasticidade à área externa permite interpretações equivocadas quanto à sustentação do edifício. Tanto é que os pórticos parabólicos exteriores não se responsabilizam sozinhos pela função de suporte nem do conjunto edificado envidraçado e estruturado em concreto nem da vasta cobertura quadrada propriamente dita. Assumem, pois, uma carga ligada ao simbolismo que 
o edifício traz em si - seja ela em função das atividades diplomáticas ali realizadas, seja pela representatividade de ser mais um dentre os projetos mais notáveis da nova Capital Federal, seja por pertencer ao repertório de um dos mais importantes arquitetos cariocas no cenário arquitetônico mundial. Sobre o caráter monumental e simbólico das edificações palacianas brasilienses, é interessante considerar que

o aspecto monumental dos palácios de Brasília não se deve a uma linguagem suntuosa ou grandiloquente - incompatível com o sentido de flutuação suscitado pela leveza de suas formas -, mas a uma adequação à expressão do caráter intrínseco à sua destinação e à sua condição de marco, tanto na paisagem da cidade, quanto na história do país. Mesmo recorrendo aos ideais clássicos de beleza, Niemeyer não põe em risco sua modernidade, mas evidencia que ela não exclui a dimensão simbólica, tão valorizada na tradição arquitetônica. A monumentalidade flutuante de Brasília não é uma ruptura, mas o desenvolvimento natural de sua arquitetura. (PONTES; 2004: 85)

Ao optar por pousar no chão o volume em monobloco horizontalizado, o arquiteto carioca enfatiza um suposto despregamento da caixa envidraçada em relação à parte de baixo da cobertura quadrangular [Figura 4.98], indicando que a arcada externa assume a função estrutural de suportar toda a cobertura. $O$ ligeiro alargamento das proporções dos pilares do peristilo junto aos arcos superiores (e decorrente das solicitações estáticas de resistência e de equilíbrio de todo o conjunto) [Figura 4.99] - para além do caráter estético - contribui equivocadamente para conferir ainda mais pertinência estrutural ao exoesqueleto do que fato existe.

Na realidade, o fechamento superior descansa também por sobre uma malha de pilares modulados intencionalmente abrigada dos olhares externos e que igualmente sustenta as lajes da caixa portante recuada e protegida pelos vãos livres do contorno destacado. Todos esses fatores cooperam para que a clareza estrutural do Palácio do Itamaraty seja escondida em favor de perspectivas estéticas mais atraentes ao olhar do contemplador. Quando comenta sobre uma suposta “inverdade" arquitetônica na obra de Niemeyer para os palácios de Brasília, Valle (2000) tece uma comparação às obras cristalinas e transparentes de Mies van der Rohe, ou seja,

nos palácios de Brasília, as "verdades construtivas" expressas pelas tensões nas possiblidades construtivas do concreto armado deram lugar à expressão simbólica e à representação arquitetônica, valores de harmonia e leveza foram construídos por artifícios construtivos na estrutura do edifício, caracterizando maior complexidade e contradição em sua arquitetura quando comparada à de Mies van der Rohe. Portanto, são os valores de representação arquitetônica em Niemeyer que substituem a "verdade" ou racionalidade do tectônico sobre a expressão, tal como podemos encontrar na arquitetura de Mies van der Rohe. (VALLE; 2000: 464)

As altas colunas insinuam um contraponto tanto entre a solidez de sua estrutura e a leveza plástica geral, quanto entre as superfícies externas largamente vazadas e banhadas de luz e os panos de vidro do monobloco a elas 
internamente desalinhados, suavemente mais escuros e neutros. A cadência do intercolúnio de seis metros é quebrada apenas virtualmente pelas diferentes perspectivas do peristilo aos olhos dos visitantes, já que o deslocamento do ponto de vista do observador gera um movimento ilusório em relação aos cheios e vazios e aos volumes ora mais pesados, ora mais esbeltos [Figura 4.100]. A solução do projeto dá às arcadas monumentais externas o acabamento em concreto aparente outrora decalcado pelas texturas das fôrmas de madeira, remetendo à sensibilidade estética desejada em projeto [Figura 4.101]. Niemeyer atribui às mesmas arcadas das fachadas, 0 comando da modulação de todo o restante da edificação - externa e internamente. A respeito desse fato e sobre os recursos construtivos e óticos provocados pelo peristilo, vale a pena citar as explicações esclarecedoras de Rossetti:

O controle da estrutura se faz pela modulação dos vãos da arcada, constituída por uma sucessão de 12 arcos plenos com raios idênticos $(R=2,80 \mathrm{~m})$, arrematados por dois arcos diferenciados ligeiramente menores $(R=2,497 \mathrm{~m})$ - em cada uma das faces de suas extremidades, totalizando 14 arcos em cada uma de suas quatro faces. A arcada define uma trama geométrica com módulo $(M)$ de $6 \mathrm{~m}$ entre seus eixos, que balizará as plantas inseridas nesta trama de $6 \times 6 \mathrm{~m}$. Assim, a extensão da arcada corresponde $14 \mathrm{M}$ acrescidos da diferença dos arcos da extremidade. A trama destes é ligeiramente maior e ao invés de estarem contidos num retângulo ideal de $6 \times 14 \mathrm{~m}$, possuem $1 \mathrm{~m}$ a mais, ou seja, $7 \times 14 \mathrm{~m}$. Assim, cada lado da arcada tem o comprimento de $86 \mathrm{~m}$, delimitando uma planta rigorosamente quadrada de 86 × 86m. Os 14 arcos correspondem ao dobro dos arcos da fachada da velha sede [o também Palácio do Itamaraty, no Rio de Janeiro], cuja frontaria alinhada ao logradouro está na razão 1:2:1. No novo Palácio, esta proporção é reestabelecida pelo sistema estrutural das colunas internas que perpassam a laje e se solidarizam com a superestrutura da arcada, definindo espaçamentos na razão de 3:6:3 arcos, ou seja, a mesma razão 1:2:1 do velho palácio neoclássico. Porém, a sutileza da solução de revestimento em madeira das colunas internas relativiza esta razão compositiva para revigorar, justamente, a arcada.

Tal qual Fídias, Milton Ramos foi responsável por ajustar estas relações construtivas e ópticas entre os arcos plenos e os arcos das extremidades, através da solução da correção visual. Esta correção visual estrutura a percepção dos arcos sem romper com o ritmo dos vazios da própria arcada. Para tanto, há uma sensível redução do seu raio para $\mathrm{R}=2,497 \mathrm{~m}$, definindo um arco com sutis alterações no traçado de sua curvatura. De acordo com o desenho, a altura do arranque dos arcos é a mesma, porém, no término do arco da extremidade, a linha curva tangencia a coluna num ponto inferior àquela altura do arranque, com uma diferença de $1,06 \mathrm{~m}$. Assim, este arco diferenciado da extremidade termina seu desenho abaixo do arco pleno, mas ainda nivelado com a altura da laje do piso da varanda, sustentando o ritmo da arcada. O desenho deste arco da extremidade é formado por segmentos de curva com 3 raios distintos, traçados a partir de uma linha $15 \mathrm{~cm}$ abaixo da linha-base do arco pleno, a fim de ajustar a curvatura e sua tangência com a coluna da extremidade, que possui em planta, uma inclinação de $45^{\circ}$ em relação ao alinhamento da arcada. Tratam-se de recursos construtivos e ópticos que influem na percepção da arcada para fortalecer a própria forma do Palácio, ratificando o cuidado de Niemeyer e seus colaboradores na construção e na adoção de um procedimento de caráter clássico inconteste.

$[\ldots]$ 
A modulação estabelecida na forma e na estruturação da arcada é mantida na resolução dos espaços internos, nas divisões e no arranjo das plantas, funcionando como uma regra projetual a ser respeitada, mas também oportunamente subvertida, através de seu múltiplos e sub-múltiplos. O módulo M é $6 \mathrm{~m}$, e Murtinho [diplomata que comandou as equipes de arquitetos, técnicos e funcionários durante as obras] lembra que "...12 por 12 metros (...) é uma proporção de palácio italiano..." dentro do qual se inscrevem as dimensões do gabinete do ministro, os planos de parede dos salões sociais ou o "Ponto de Encontro" de Mary Vieira. Enquanto o valor simbólico subordina as demais decisões projetuais, as relações entre a verdade estrutural e o edifício podem ser aferidas através da rigorosa construção das plantas do Palácio. Niemeyer concebe uma planta que organiza seu programa em três pavimentos, organizando seus espaços em função da trama de $6 \times 6 \mathrm{~m}$. As áreas são derivações destas dimensões, tais como: $3 \times 6 \mathrm{~m}, 6$ × 4,5m, 6 ×9 m, 12 × 30m, $18 \times 18 \mathrm{~m}$ até $30 \times 54 \mathrm{~m}$. Esta organização da planta que subordinada à modulação se faz notar na definição do vestíbulo do térreo, tem uma dimensão equivalente a $5 \mathrm{M} \times 9 \mathrm{M}$, ou seja, $30 \mathrm{~m} \times 54 \mathrm{~m}$, totalizando $1.620 \mathrm{~m}^{2}$. A dedução lógica das áreas sociais surpreende quando se compara suas dimensões com seu porte, qualificando a escala de um palácio. Este rigor também está presente na solução da caixilharia, que é modulada em 1/5M, com 5 partes de 1,20m cada, ou ainda na caixilharia dos salóes superiores em que cada porta pivotante mede 1/4M, ou seja, 1,50m [...]. (ROSSETTI; 2009: 7-8)

Vale ressaltar que a estrutura do peristilo externo é insistentemente investigada pela dupla formada pelo arquiteto Milton Ramos e pelo engenheiro Joaquim Cardozo, não apenas por meio de um desenvolvimento teórico mais bem elaborado e detalhado das solicitações feitas por Oscar Niemeyer mas, sim, pela utilização, in loco, de elementos prototipados em escala natural para a efetuação de ensaios pertinentes à coloração do concreto, à paginação e à dimensão dos arcos, à definição do sistema adequado de fôrmas, à avaliação dos ângulos visuais, enfim, a todo e qualquer tipo de pertinência ao projeto que se mostre um tanto quanto dúbia. Isso ajuda sobremaneira a antecipar as condições da obra quando pronta e colabora para minimizar eventuais alterações projetuais, reduzindo custos e melhorando os resultados finais em termos financeiros e de tempo de execução total da construção.

É a partir de uma rigorosa modulação que Niemeyer elabora e estabelece seu projeto. É com base nela também que a equipe de tecnologistas de Joaquim Cardozo se empenha para conseguir atingir os resultados almejados pelo desenho arquitetônico De acordo com Santos Junior (2004), para alcançar amplas espacialidades totalmente desobstruídas, a equipe técnica dimensiona vigas de, no máximo, 120 centímetros de altura que vencem vãos internos de até 36 metros. Para Magalhães (2008), trata-se de uma solução só conseguida por meio de numerosos ensaios combinatórios entre cimento e agregados, até atingir um traço de concreto adequado. $O$ autor ainda comenta que esta estrutura de vigas não utiliza transpasse das armações de aço, mas emendas por solda de topo - além da adoção de contraflechas nas vigas, justamente para contrabalançar possíveis deformações quando da retirada dos escoramentos. O resultado é bastante arrojado - inclusive para os padrões atuais. "O Palácio do Itamaraty é, pois, uma 
obra plena no conjunto de congruências espaciais e construtivas que articula. Acerto que se deve não apenas ao gesto essencial de Oscar Niemeyer, mas ao pleno desenvolvimento daquelas possibilidades expressivas por meio da virtude da técnica". (MAGALHÃES; 2008: 56)

Ao que indica a planta do pavimento térreo, todas as elevações possuem generosos acessos ao edifício, sendo o principal deles, a norte, marcado por uma passarela que rasga o jardim aquático frontal projetado por Roberto Burle Marx. Ao lado esquerdo deste caminho sobre a água está disposta a escultura "Meteoro", de Bruno Giorgi, concebida em mármore e representando os cinco continentes cujas relações são objeto da diplomacia brasileira. Conduzido pela passarela, o visitante é levado diretamente a um vestíbulo retangular de grandes dimensões [Figura 4.102], no qual, segundo Wisnik (2013), há uma laje superior livremente recortada que valoriza as perspectivas visuais e que contrapõe a severa ortogonalidade externa. Há, aqui, uma discreta composição artística formada pela concatenação de revestimentos de piso e de paredes, executada sob os olhos atentos do artista plástico Athos Bulcão, a qual firma a continuidade dos ambientes internos à medida em que eles se justapõem.

A integração entre o mezanino e o nível térreo é creditada ao vazio conseguido pela subtração parcial da laje que divide ambos os pavimentos e à emblemática escada helicoidal [Figura 4.103] que, ainda segundo Santos Junior (2004), é estruturada em concreto armado e constituída por uma longarina central de sustentação para os degraus em balanço. Esta escada é apoiada na laje superior por meio de um conjunto de armaduras de aço especialmente projetado para este fim, cujo inusitado resultado final simula as raízes de uma árvore - daí a potencialização do engaste na laje em balanço e a chance de erigir uma escada de formato tão pouco convencional, o qual "transforma o percurso hierárquico num passeio, promovendo a transição dos amplos espaços de chegada para as dependências dos andares superiores" (ROSSETTI; 2009: 10).

Segundo Martins (2013), internamente o Palácio dos Arcos justifica seu objetivo: o foco nas relações protocolares e diplomáticas do Brasil para com o mundo. A configuração dos ambientes sociais é estabelecida em plantas livres e em recintos amplos que admitem diferentes arranjos espaciais a fim de atender adequadamente a eventos e a solenidades de toda ordem e de todo tamanho. A combinação de possibilidades organizacionais admite desfrutar dos diferentes salões em conjunto (ou não) com a convidativa área avarandada do último pavimento. O projeto de Oscar Niemeyer para este palácio, portanto, busca organizar as atividades diplomáticas às necessidades de arranjos 
espaciais internos, os quais demandam limitações de acesso e de permanência em função tanto do tipo de evento quanto do tipo de público ao qual se destina.

Martins (2013) ainda comenta que o destaque dado aos recintos sociais não prejudica o funcionamento propriamente dito do Ministério, pois há uma nítida separação entre aquilo que se destina a promover os ritos cerimoniais e aquilo que é voltado às atividades protocolares inerentes ao Itamaraty. Sendo assim, as funções administrativas, de serviços e as circulações verticais secundárias são concentradas nas laterais do prédio, cuja organização quase simétrica obedece à modulação das arcadas exteriores, como já citado. Ao último piso fica reservada uma extensa área de convívio, formada e organizada a partir de um terraço desobstruído, no qual está distribuída a malha de pilares revestidos em madeira e que ajuda a sustentar a cobertura quadrangular da nova sede do Ministério das Relações Exteriores.

Há, neste ambiente aberto à paisagem, além do jardim central que recebe tratamento paisagístico de Roberto Burle Marx, obras de diversos artistas, dentre os quais destaca-se Maria Martins e a escultura surrealista em bronze polido "O Canto da Noite" [Figura 4.104]. Sobre o espaço ajardinado quadrangular, abre-se no teto um rasgo zenital por entre as vigas unidirecionais de concreto que, fazendo as vezes de um ritmado pergolado, permite a entrada de luz natural sobre a vegetação [Figura 4.105]. Tal é a representatividade desta varanda suspensa para o edifício do Ministério das Relações Exteriores que ela pode ser apreendida como

o Salão Nobre do Palácio. A partir dela, vislumbra-se o espetáculo arquitetural do próprio Niemeyer, na escala monumental concebida por Lucio Costa. Deste espaço de sociabilidade aberto sobre a Esplanada dos Ministérios, avista-se o Congresso Nacional, o Palácio do Planalto, o Supremo Tribunal Federal, o Palácio da Justiça, e os demais ministérios. Tal como um mirante, dela se deduz o lugar da Praça dos Três Poderes, tanto quanto se reformula a própria presença formal do Palácio do Itamaraty em relação aos demais edifícios cívicos da cidade. $O$ aspecto estrutural do Palácio é retomando através da arcada, que de potente estrutura, revela-se como anteparo marcante das relações entre o edifício e a paisagem que se percebe de sua varanda. Da varanda a arcada emoldura o horizonte do Cerrado que se integra ao Palácio, assegurando intimidade a quem pode debruçar-se sobre a escala monumental da cidade, recostando-se em seu peitoril, abrigado sob seu arcabouço. (ROSSETTI; 2009: 11)

Concluídas ambas as fases de projeto dos palácios originais brasilienses, Oscar Niemeyer busca diversificar atividades e dar andamento à sua trajetória profissional, procurando com isso descolar sua imagem dos trabalhos anteriores e conquistar novos horizontes produtivos. Aceita então vários convites para desenvolver projetos arquitetônicos e 
urbanísticos fora do Brasil, sobretudo após a segunda metade da década de 1960. Quando na Itália em 1968 concebe, a pedido de Giorgio Mondadori, a nova sede da editora da qual sua família é proprietária, implantada na planície lombarda milanesa. Há, porém, uma ressalva: que Oscar Niemeyer baseie seu conceito arquitetônico no projeto do Ministério das Relações Exteriores brasileiro - obra que encantara o empresário italiano estivera em Brasília.

Todavia, à obra resultante - também conhecida por Palazzo Mondadori [Figura 4.106] - não se deve propor uma leitura guiada apenas por um desdobramento evolutivo do léxico utilizado pelo arquiteto, anteriormente, no Palácio do Itamaraty, pois por certo isso seria subestimá-la. Ainda que em um primeiro momento ambos os edifícios guardem entre si certas semelhanças estéticas, à medida que se investiga cada caso em particular é possível detectar significativas diferenças conceituais e arquitetônicas entre eles.

Sabe-se que ambos os projetos partem de uma mesma matriz: o peristilo de concreto aparente que circunda a edificação. Porém, se no Palácio do Itamaraty, como visto, este peristilo tem uma função predominantemente voltada à plasticidade e à representatividade (e não à estruturação do partido arquitetônico), no caso do Palazzo Mondadori a situação se reconfigura, pois as arcadas assumem um papel estrutural, de fato, essencial. Esta solução pode ser tomada como uma oportunidade de exercitar o segundo ponto de mudança de postura projetual do arquiteto carioca, ocorrido às vésperas da década de 1970, a partir de quando seus projetos assumem um viés fortemente estruturalista e tecnológico, compreendendo a estrutura como parte integrante e de mesmo nível de importância que os elementos arquitetônicos. Assim, o sistema estrutural assume, desta inflexão em diante, a responsabilidade pelo atendimento ao binômio plástica-partido, além da organização dos espaços internos das obras concebidas sob tal premissa. No entendimento do arquiteto carioca, a partir do momento em que a estrutura esteja concluída, também o está a arquitetura, dada a perfeita simbiose pretendida entre elas. Ao rememorar o uso desta nova postura arquitetônicoestrutural no prédio italiano, o próprio Oscar Niemeyer explica que

Em poucos dias elaborei meu projeto: cinco andares de escritórios suspensos nas vigas da cobertura e essas apoiadas nas arcadas que acompanham o edifício. Recordo como fiquei satisfeito ao ver a fachada desenhada, ao sentir que naquele ritmo de arcos tão diferentes - de 3 a 15 metros de vão estava a minha contribuição de arquiteto. A contribuição necessária, por mínima que seja, para que um projeto se faça diferente e inovador. Sentia que a solução era correta. Simplíssima. E que, terminada a estrutura, a arquitetura estaria presente, ao contrário da maioria dos prédios modernos, nos quais ela começa a surgir pouco a pouco, com a colocação de seus elementos construtivos: préfabricados, vidros, brise-soleil etc. (OSCAR NIEMEYER. In: Revisa Módulo; 1975/1976: 33) 
Neste projeto, "o caminho de exploração das possiblidades das grandes estruturas é adotado de maneira ponderada, sem deixar de ser igualmente ousada" (BASTOS e ZEIN; 2010: 132). Decorre daí que, como favores-chave, o Palazzo Mondadori carrega consigo tanto a qualidade de ser estruturalmente "verdadeiro" quanto a "novidade" de imputar à colunata externa uma função não conformada apenas pela estética, mas de pertinência estrutural portante - logo, diferente daquilo que é feito em Brasília, na nova sede do Ministério das Relações Exteriores.

Mas isso não é tudo. Atribui-se à estrutura o encargo pela adequação arquitetônica e de arranjo espacial, visando alcançar os limites máximos tecnológicos e construtivos disponíveis à época - o que justifica o envolvimento direto com competentes equipes de tecnologistas nacionais e estrangeiros. Sobre esse fato, Galvane Junior (2004) explica que ainda que o projeto estrutural da nova sede da Editora Mondadori tenha sido elaborado por equipes italianas, 0 engenheiro brasileiro Bruno Contarini participa ativamente das soluções técnicas ao longo da fase de concepção estrutural/arquitetônica do edifício. E o arquiteto, também brasileiro, Glauco Campello, acompanha de perto as etapas de construção da obra em Milão, atendendo um pedido do próprio Oscar Niemeyer.

De acordo com Martins (2013), o edifício monumental em monobloco é orientado segundo uma rigorosa ordem de síntese. Compõe-se essencialmente de uma caixa recuada de vidro estruturada em aço e concreto de cinco pavimentos, envolta por uma arcada também de concreto, cujo compasso é ditado pelas diferentes aberturas dos vãos (de 3,0 a 15,0 metros) [Figura 4.107]. Esse volume externo, compreendido como um exoesqueleto estrutural independente, ampara não apenas a cobertura retangular mas, também e por meio de 56 tirantes metálicos, praticamente todo conjunto arquitetônico. “As cargas de cada pavimento são conduzidas para os tirantes metálicos, em seguida, para as vigas transversais de concreto, destas, para as vigas longitudinais, depois para as colunas da fachada e, por fim, para as fundações" (GALVANE JUNIOR; 2004: 86). Dessa forma, é mantida suspensa a lâmina interna prismática e horizontal, sem obstruir o caminhamento natural descendente dos carregamentos. Tal solução faz com que, ao nível do solo, descortine-se um imenso vão, livre de quaisquer apoios e pronto para bem receber a circulação de pessoas [Figura 4.108].

Dito de outra maneira, a ousadia de direcionar ao fechamento superior o encargo por manter completamente pendurado o volume de vidro somente pôde ser alcançada mediante a distribuição de vigas unidirecionais transversais ao maior sentido do exoesqueleto autônomo, estrategicamente posicionadas por debaixo da cobertura e limitadas nas extremidades pelos encontros dos portais externos. É esta a área que absorve a maior quantidade dos esforços 
solicitantes na parte superior da arcada - daí seu formato ter relativamente mais musculatura que o corpo restante das pilastras propriamente ditas. E é justamente por causa disso que a parte inferior da laje de cobertura apresenta grandes desníveis em função do posicionamento das vigas transversais [Figura 4.109]. São dois exemplos, portanto, de elementos estruturais que nitidamente expressam as forças estáticas por eles suportadas e que preservam, ainda assim, os "verdadeiros" quesitos estéticos ditados pelo projeto arquitetônico. Como decorrência, tem-se uma obra que se vale de grandes estruturas de maneira arrojada, porém com resultado harmonioso e consciente, sem exageros e com uma expressividade plástica interessante.

De acordo com Bastos e Zein (2010), a obra italiana é composta por áreas administrativas, espaços recreativos, núcleos de serviços complementares e por um generoso parque gráfico, todos dimensionados para que a nova sede assuma a missão de atender, em um único endereço, as crescentes demandas enfrentadas à época pela empresa italiana. Assim como ocorre com o Palácio do Itamaraty, o Palazzo Mondadori estabelece também uma relação dialética para com o entorno, porém aqui ajustando-se à paisagem seja como complemento ou como contraponto, mas em função das dimensões de um e de outro, não há predominância de qualquer das partes.

A partir da implantação geral deste novo edifício [Figura 4.110], compreende-se que restaurante, bar, butiques, setores especiais de apoio e de infraestrutura, produção, áreas destinadas a serviços diversos e um pátio semienterrado são distribuídos transversalmente ao prédio retangular (que abriga as funções administrativas do complexo editorial), atravessando-o e formando a partir daí perspectivas de formas livres sinuosas que claramente contrastam com a horizontalidade monumental e rigorosa do volume principal, não apenas no que se refere às suas diferentes formas, mas, também, à evidente hierarquia volumétrica, às soluções estruturais independentes e às materialidades adotadas em ambas as arquiteturas (vidro e concreto aparente).

O conjunto externo de arcadas estruturais é concebido para ser revestido em concreto aparente. Contudo, constatase que hoje ele está coberto com pintura aplicada diretamente sobre sua superfície, ou seja, sem revestimentos intermediários. Ao contrário do que se possa imaginar, isso não descaracteriza completamente a ideia inicial, uma vez que o foco na cor natural do concreto mantém-se por meio da tonalidade da tinta escolhida. Além disso, os veios provenientes das fôrmas da fase concretagem - ainda tatuados nas arcadas externas - não foram descaracterizados pela tinta de revestimento. 
O acesso principal ao Palazzo Mondadori é efetuado por uma passarela de concreto que flutua por sobre a vasta lâmina d'água frontal [Figura 4.111]. Martins (2013) explica que, internamente, os pavimentos são compostos por áreas praticamente livres, limitadas apenas em ambas as extremidades pela localização dos núcleos destinados à circulação vertical e de serviços e que são regidos, em parte, pela modulação das arcadas estruturais exteriores. Lateralmente, os andares são balizados pelas faces envidraçadas recuadas em relação às arcadas externas de concreto armado e, pontualmente, por jardins internos longitudinais (estes, presentes apenas no quinto pavimento). Os extensos panos de vidro propiciam ampla iluminação natural, mas sem excessos, visto que a cobertura estende-se além das paredes e serve de anteparo à luz direta do sol. Na parte posterior do prédio encontra-se, em destaque, nova circulação vertical, agora helicoidal, porém, apartada do prisma de vidro e a ele conectada apenas por meio de passarelas suspensas que tocam suavemente todos os pavimentos do edifício. 


\section{ARCADAS DE CONCRETO APARENTE X SOLUÇÃO ESTRUTURAL ESCAMOTEADA}

Oscar Niemeyer:

\section{Palácio do Itamaraty}

(Brasília, 1962 - 1970)



[4.96] Fruto da primeira fase de reposicionamento crítico protagonizada por Oscar Niemeyer, a nova sede do Ministério das Relações Internacionais - ou Palácio do Itamaraty - compõe o segundo conjunto de edifícios oficiais monumentais brasilienses.

[4.97] A edificação principal, simbólica e representativa, guarda similaridades plástico-formais com os demais palácios brasilienses. Suas arcadas de concreto aparente contrastam com a neutralidade passiva de um de seus anexos, aos fundos do lote de implantação.

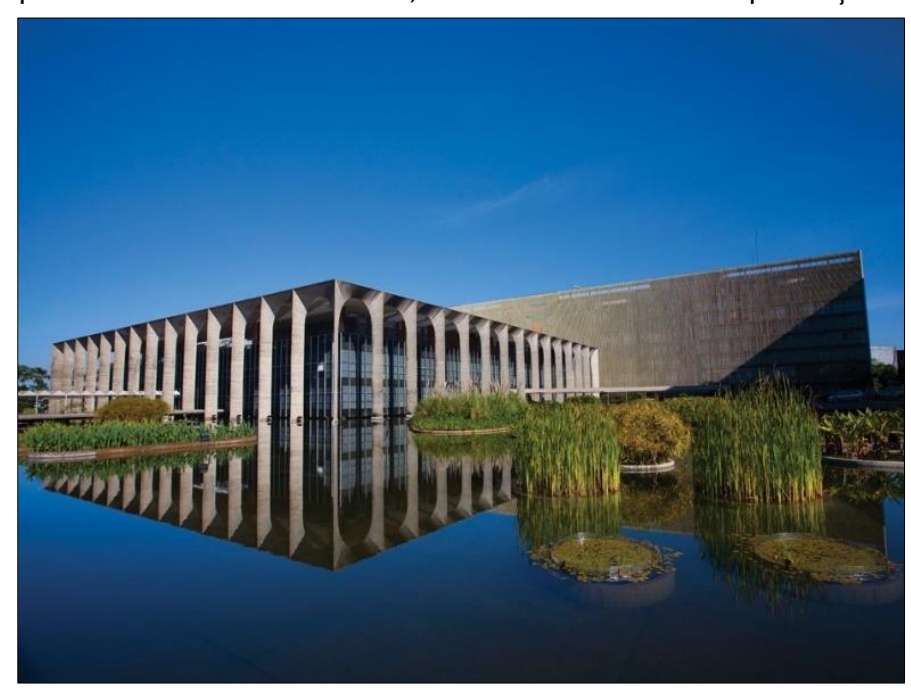

[4.98] Ao despregar o prisma envidraçado da parte de baixo da ampla cobertura quadrangular, há uma falsa indicação de que o peristilo que contorna toda a edificação assume, também, a função estrutural de amparar o fechamento horizontal superior.

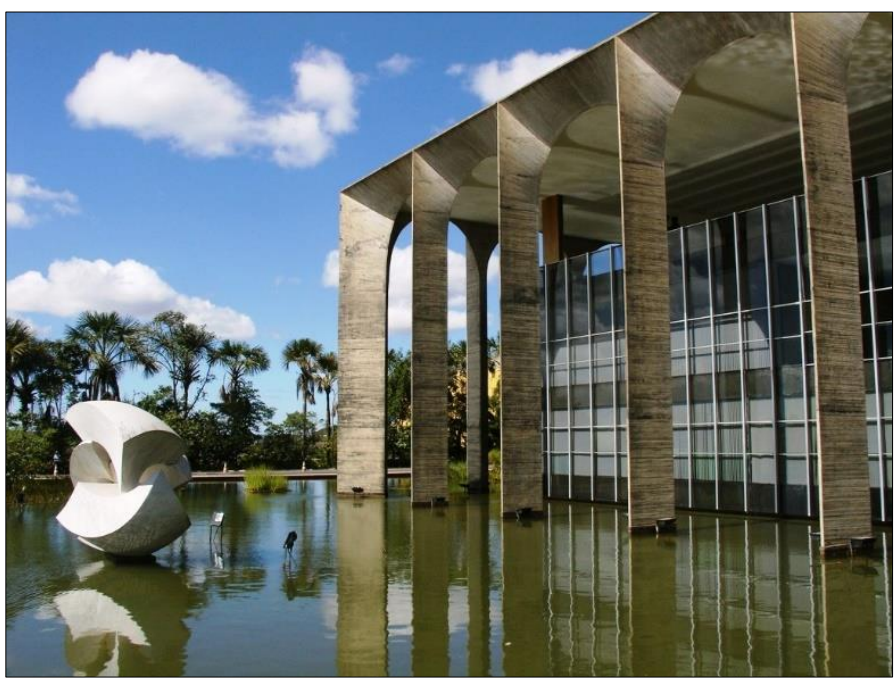




\section{ARCADAS DE CONCRETO APARENTE X SOLUÇÃO ESTRUTURAL ESCAMOTEADA}

Oscar Niemeyer:

Palácio do Itamaraty

(Brasília, 1962 - 1970)

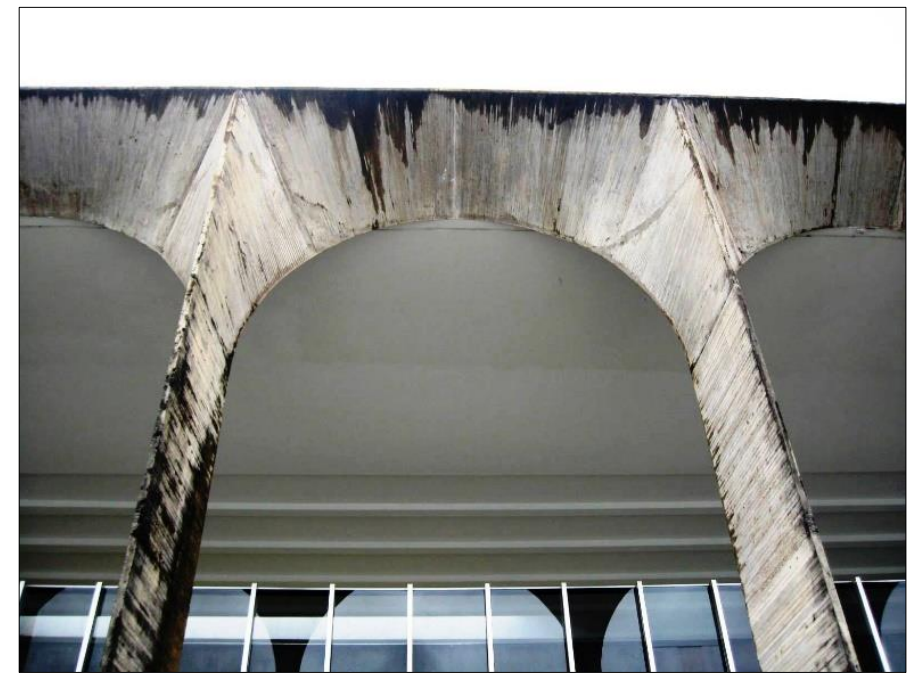

[4.99] O ligeiro alargamento das proporções dos pilares do peristilo junto aos arcos superiores - para além de qualidades estéticas contribui equivocadamente para conferir ainda mais pertinência estrutural ao exoesqueleto do que fato existe.

[4.100] A cadência do intercolúnio é virtualmente anulada pelas diferentes perspectivas do peristilo: o deslocamento do ponto de vista do observador gera um movimento ilusório em relação aos cheios e vazios e aos volumes ora mais pesados, ora mais esbeltos.

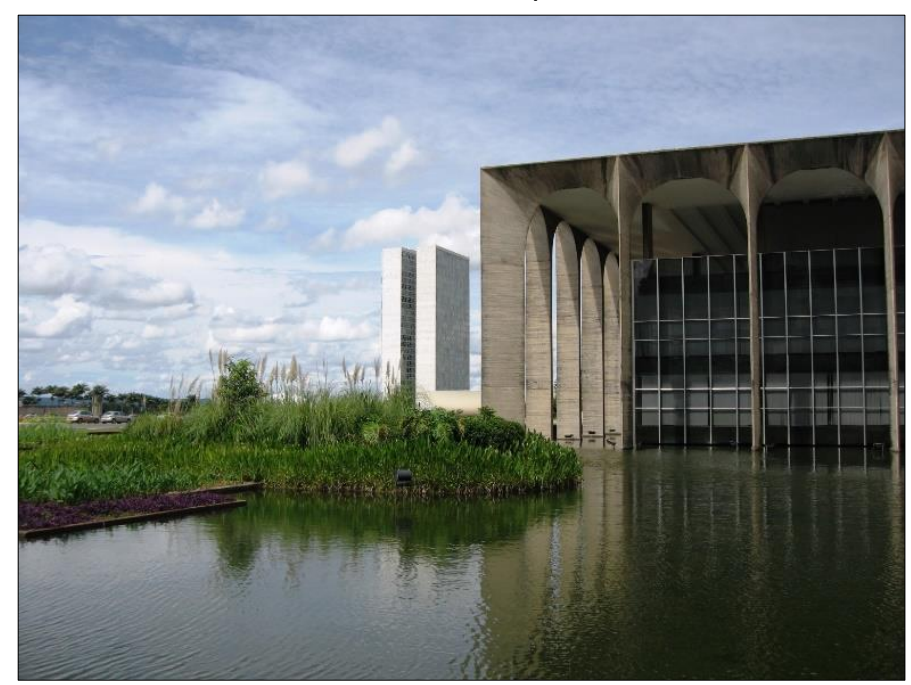

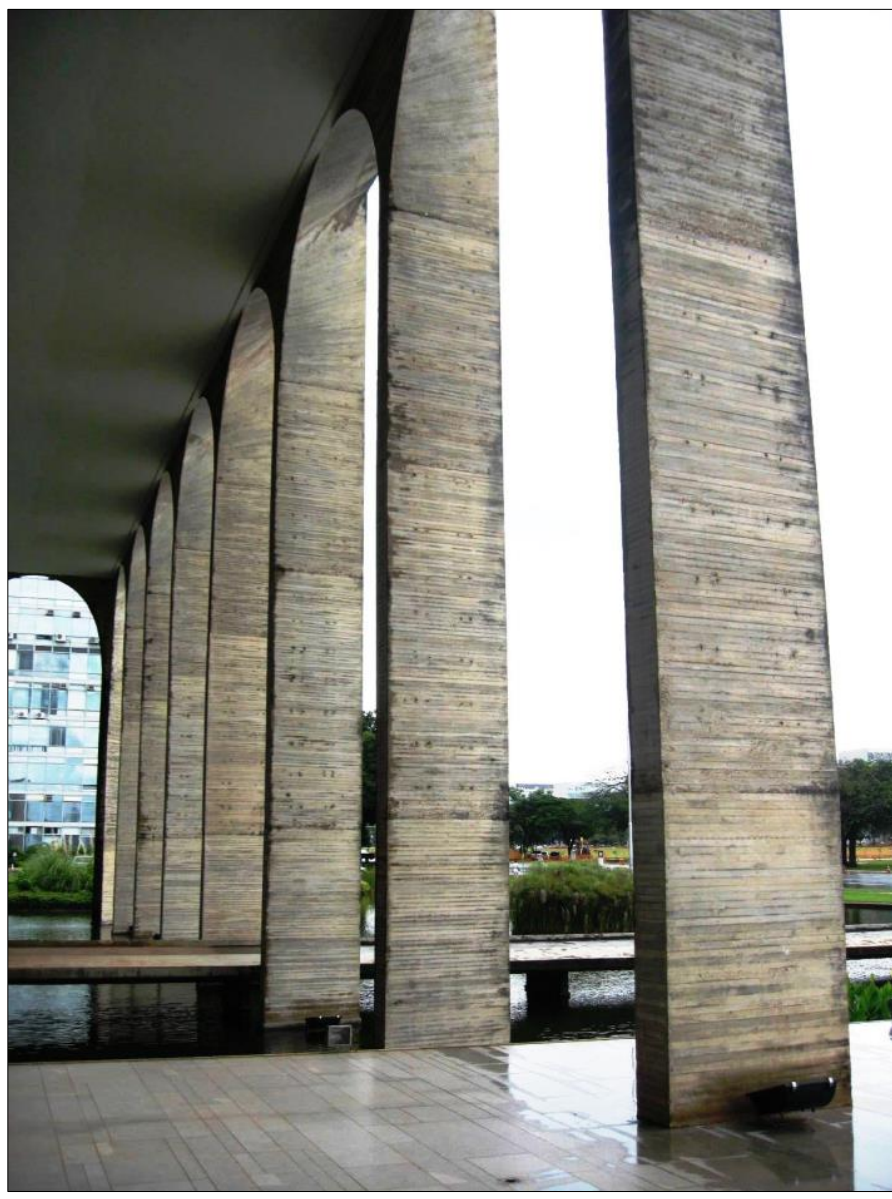

[4.101] A solução do projeto dá às arcadas monumentais externas o acabamento em concreto aparente de tom ocre outrora decalcado pelas texturas das fôrmas de madeira, remetendo à sensibilidade estética desejada em projeto.

Para a correta paginação dos veios das fôrmas de madeira, o arquiteto Milton Ramos providencia a montagem de um grupo de arcadas prototipadas em escala natural, a partir do qual suas investigações plásticas podem ser mais bem conduzidas e compreendidas (além de gerar resultados mais confiáveis).

Percebe-se, assim, que há uma nítida preocupação dos envolvidos para com o projeto, sempre visando alcançar os mais elevados anseios conceituais e arquitetônicos de Oscar Niemeyer. 


\section{ARCADAS DE CONCRETO APARENTE X SOLUÇÃO ESTRUTURAL ESCAMOTEADA}

Oscar Niemeyer:

Palácio do Itamaraty

(Brasília, 1962 - 1970)

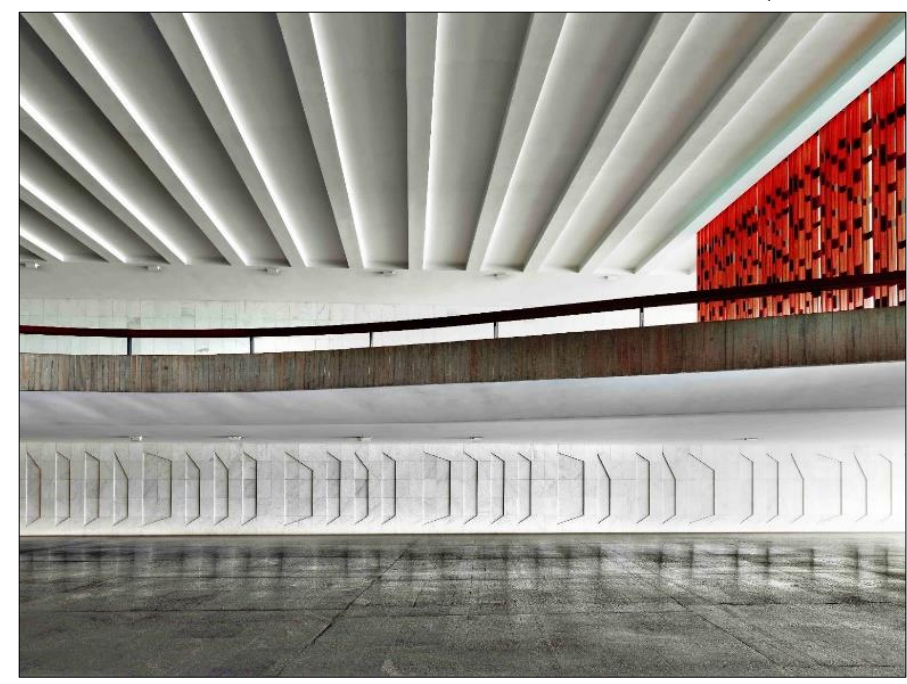

[4.102] Ao atravessar a passarela que flutua por sobre o jardim aquático frontal, o visitante chega a um amplo vestíbulo retangular destinado a abrigar vários tipos de eventos. Aqui, pisos e paredes são executados seguindo as orientações do artista Athos Bulcão.

[4.104] No pavimento avarandado da cobertura encontra-se a obra surrealista em bronze polido "O Canto da Noite" (de Maria Martins). Posicionada sobre uma plataforma elevada, divide o espaço com outras esculturas e com o jardim de Burle Marx.

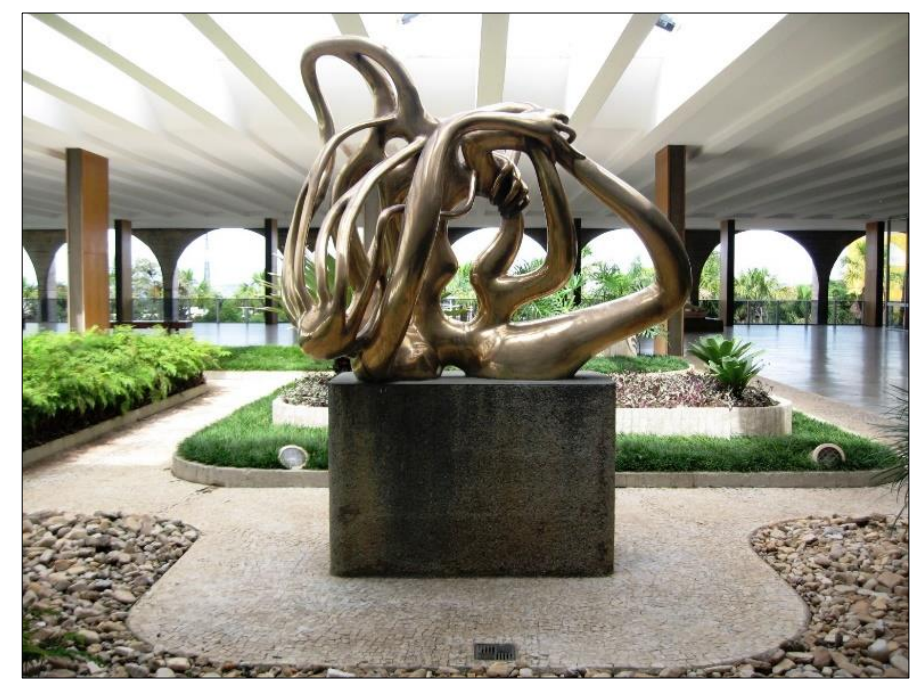

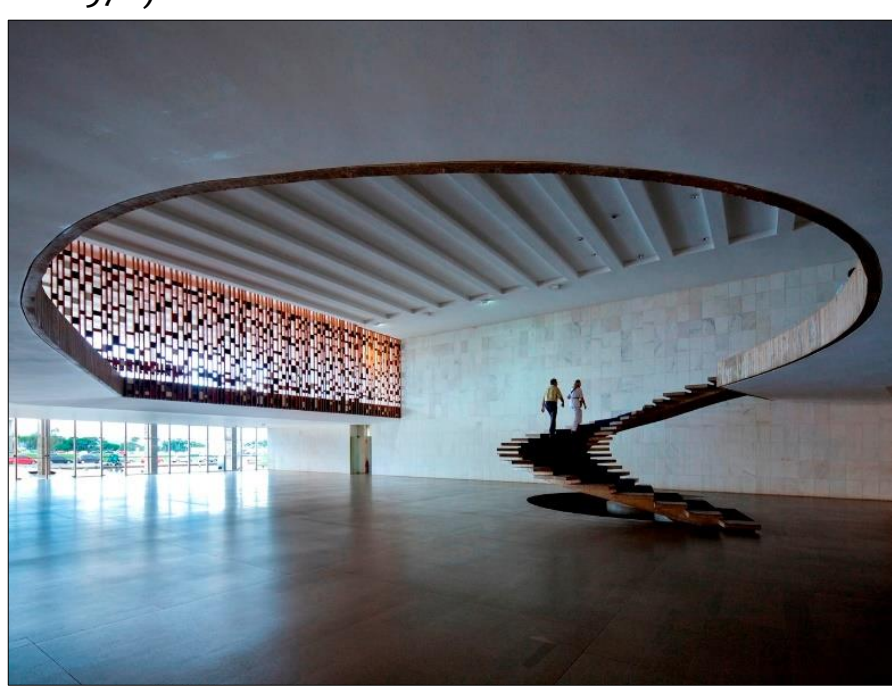

[4.103] A supressão de parte da laje do pavimento superior confere um elemento de formas livres que contrasta com a ortogonalidade austera do salão. A emblemática escada de concreto armado, helicoidal, conecta ambos os pisos e atrai o olhar dos visitantes.

[4.105] Por entre o ostensivo vigamento de concreto armado que cobre a varanda superior, há uma abertura zenital para iluminação natural. Os pilares que ajudam a sustentar a cobertura, revestidos em madeira, encontram-se plenamente integrados ao ambiente.

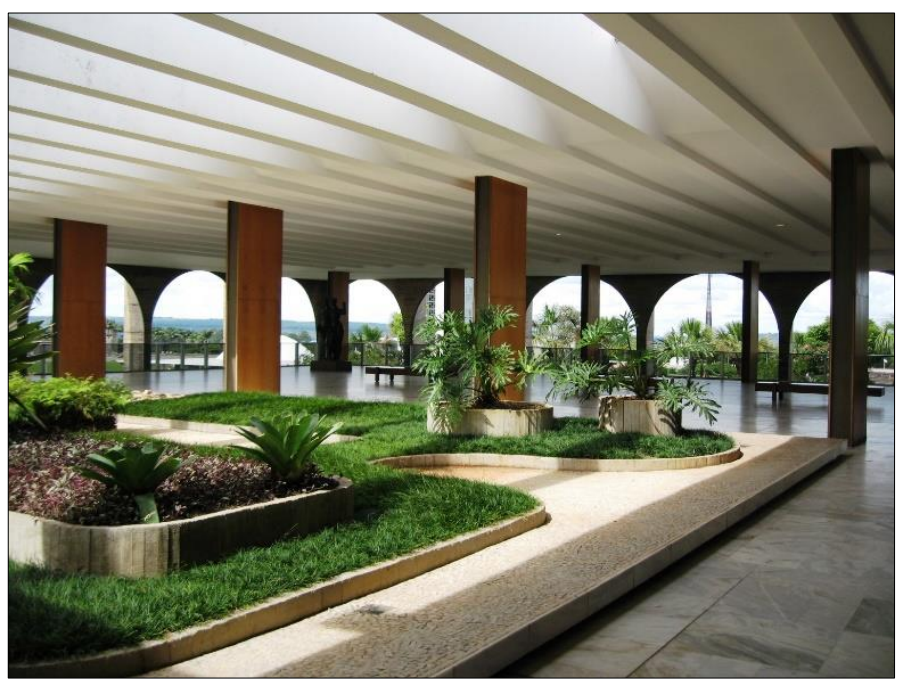




\section{ARCADAS DE CONCRETO APARENTE X SOLUÇÃO ESTRUTURAL VERDADEIRA}

Oscar Niemeyer:

\section{Palácio Mondadori}

(Brasília, 1968 - 1975)

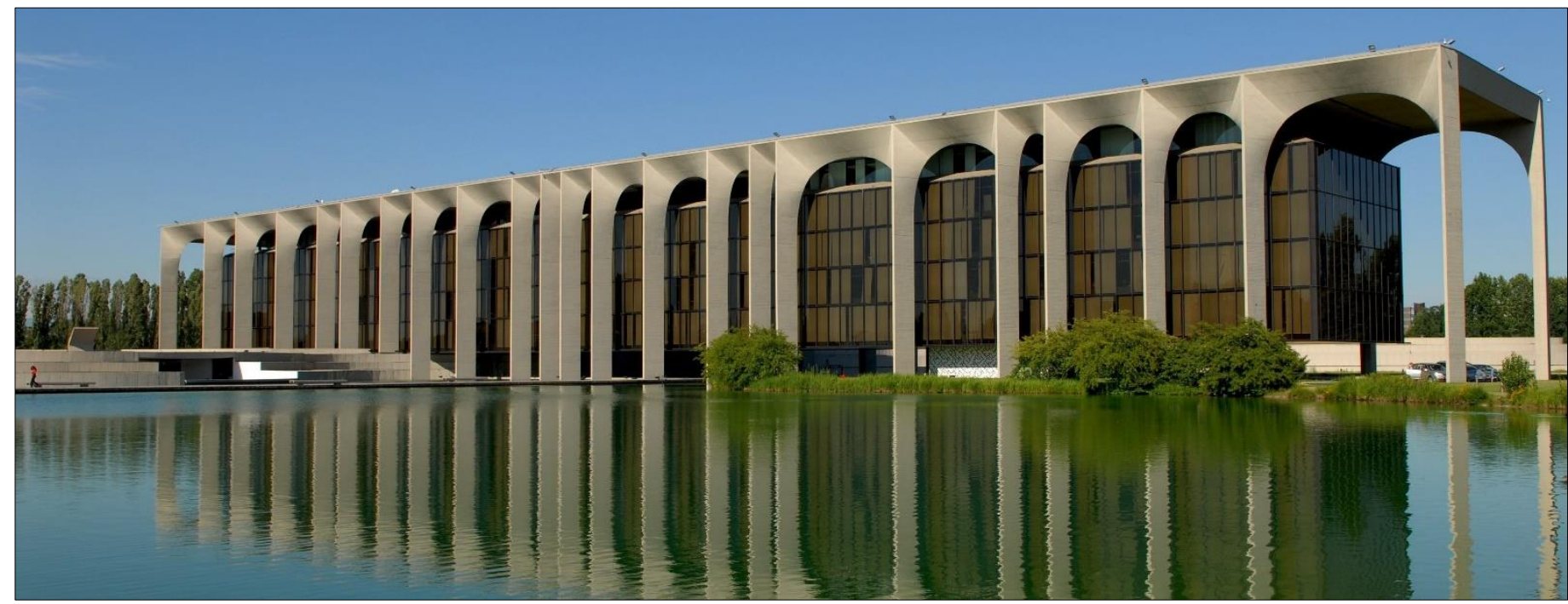

[4.106] Implantado em um terreno de grandes proporções na planície lombarda milanesa, o Palazzo Mondadori pode ser entendido como um desdobramento do léxico utilizado por Oscar Niemeyer anteriormente, no Palácio do Itamaraty. Porém, se ambas as edificações guardem entre si semelhanças estéticas, há diferenças arquitetônico-estruturais que fazem delas duas obras bastante distintas.

[4.107] O edifício italiano é formado por uma caixa recuada de vidro estruturada em aço e concreto de cinco pavimentos, envolta por uma arcada também de concreto, cujo compasso é ditado pelas diferentes aberturas dos vãos (de 3,0 a 15,0 metros).

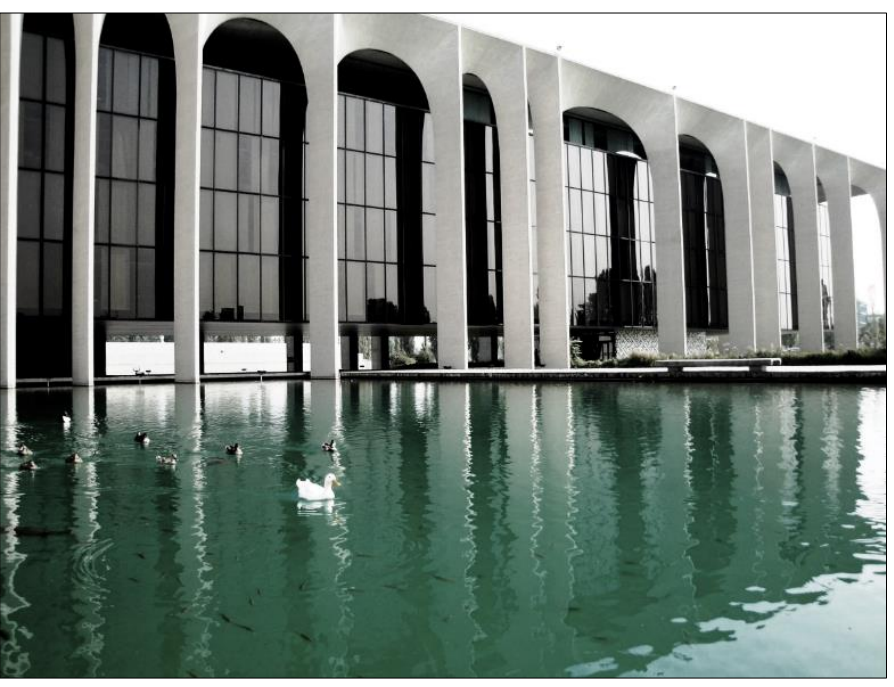

[4.108] Ao conferir à arcada externa a pertinência estrutural de fato, o exoesqueleto independente - além de atender às questões plásticas - responde pela completa sustentação do prisma de vidro recuado. Com isso, ao nível térreo, há um vão livre e desobstruído.

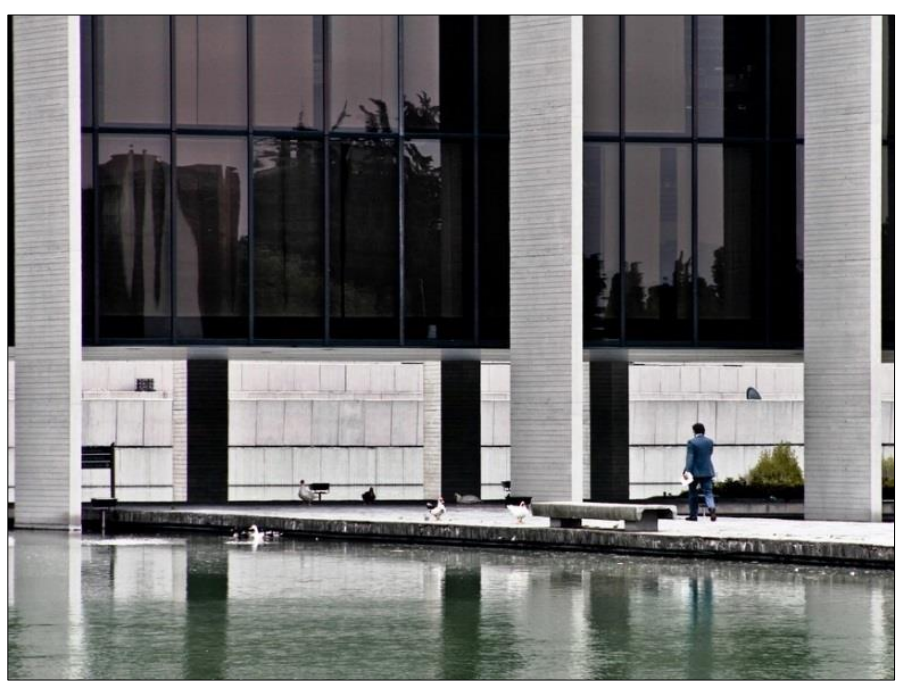




\section{ARCADAS DE CONCRETO APARENTE X SOLUÇÃO ESTRUTURAL VERDADEIRA}

Oscar Niemeyer:

\section{Palácio Mondadori}

(Brasília, 1968 - 1975)

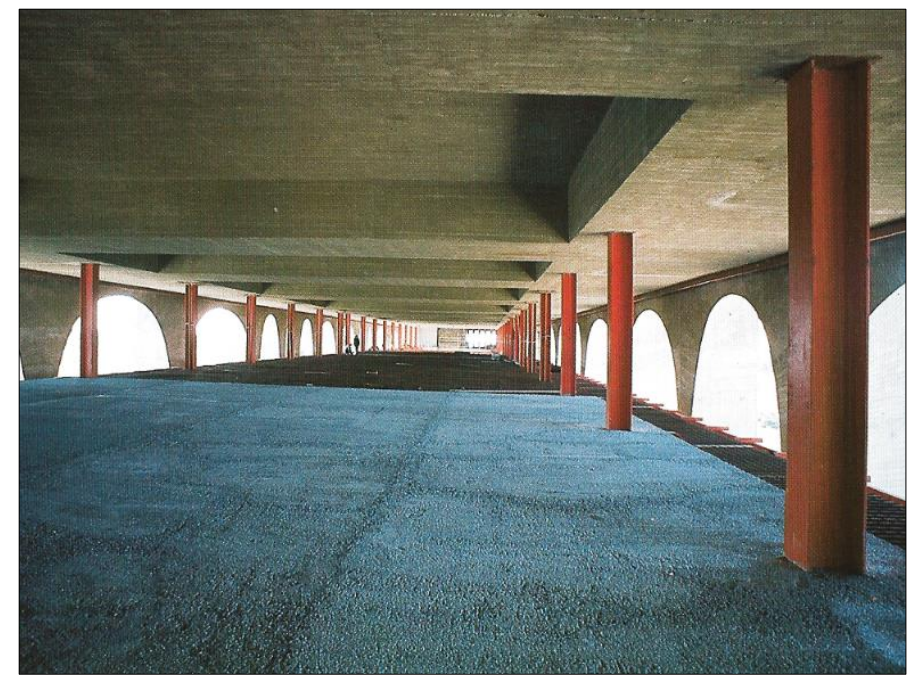

[4.109] A parte de baixo da laje de cobertura não é plana, pois nela estão embutidas vigas longitudinais e transversais de grandes dimensões. Moldado em concreto, esse conjunto estrutural garante o posicionamento elevado do caixa de vidro.

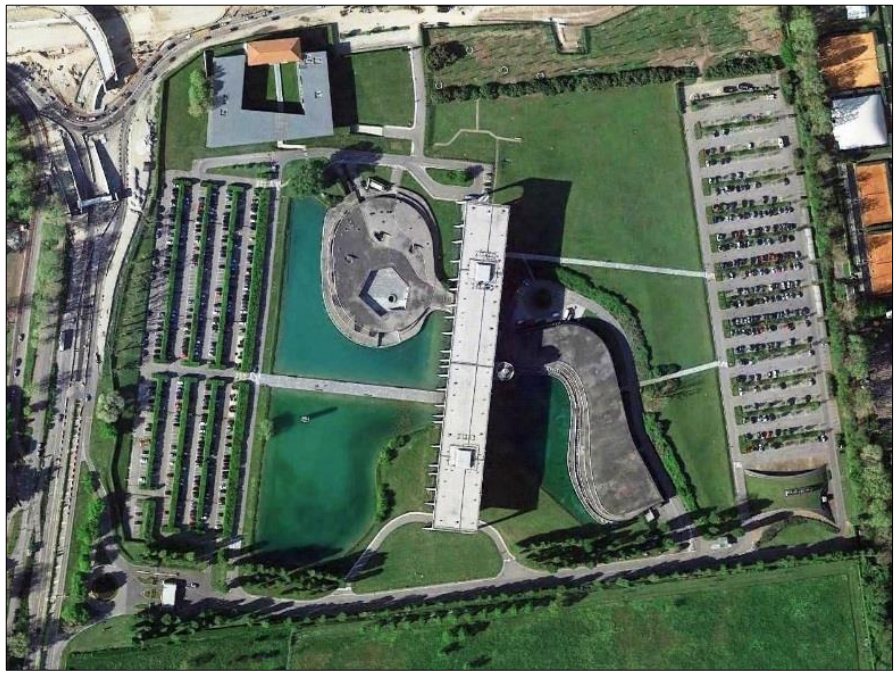

[4.110] A nova sede da Editora Mondadori é formada por contrapontos: se a lâmina principal prima pela ortogonalidade monumental e rigorosa, os demais volumes, além de serem mais baixos, possuem formas sinuosas e, por isso, mais livres.

[4.111] Por meio do acesso principal guiado por uma longilínea passarela de concreto armado - a qual rasga um amplo espelho d’água frontal - percebe-se a cadência descontínua das arcadas do Palazzo Mondadori. Esta ideia de Niemeyer ajuda a conferir ritmo e leveza à fachada, além de remeter à inspiração brasileira assumida pelo Palácio dos Arcos.

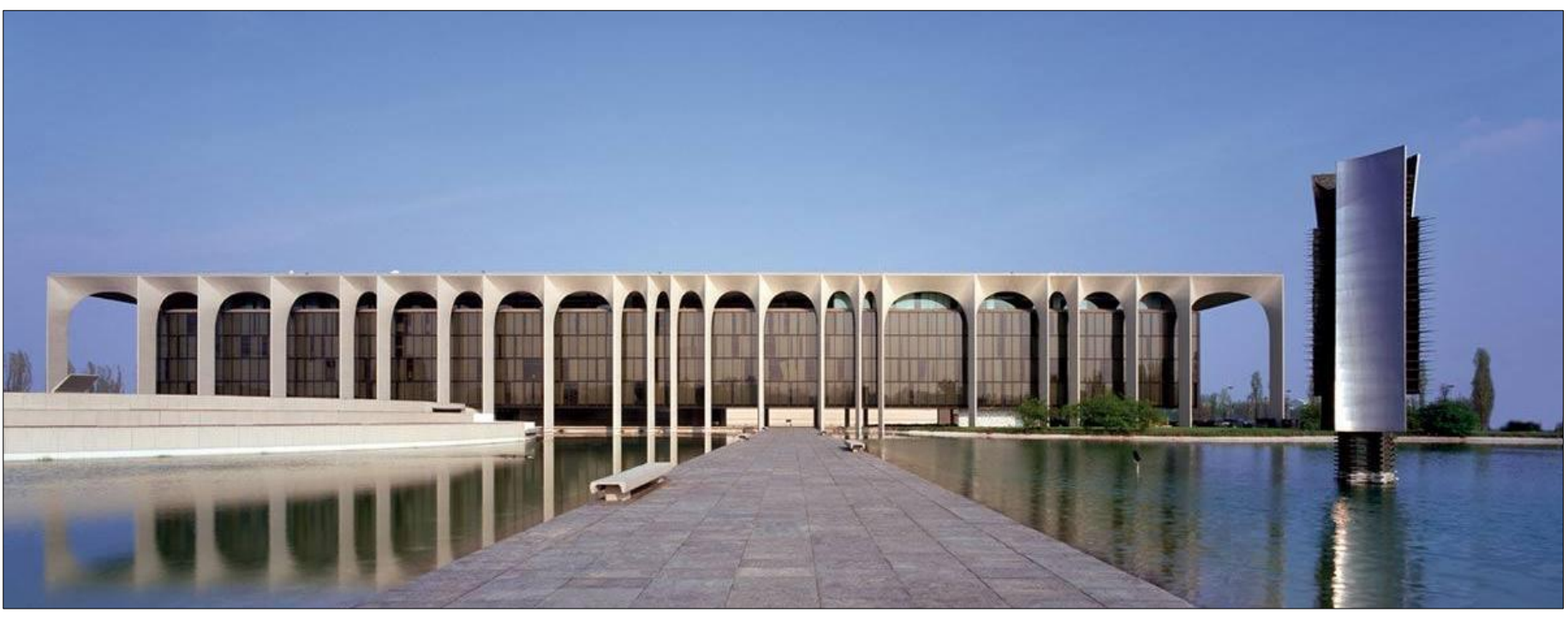


5. 
Até finais do século 19, a engenharia praticamente domina o desenvolvimento das técnicas e das tecnologias utilizadas na construção civil: da alvenaria estrutural ao ferro fundido, ao aço e, posteriormente, ao elemento quem sabe mais revolucionário: o concreto. Com o passar do tempo e à medida em que a arquitetura ganha autonomia, ela incorpora a seus projetos essas novas possibilidades construtivas, invertendo o cenário anterior. Com isso, as inovações propostas por ela por vezes passam a conduzir a engenharia a campos distantes dos de sua atuação tradicional.

Ao se afastar de suas usuais zonas de conforto, esta área do conhecimento lógico e exato precisa constantemente se reinventar, adaptando e readaptando conceitos e normas até então entendidos por ela mesma como estáveis e/ou imutáveis, investindo portanto em um exercício teórico-científico em contínua construção. Mas não só. Passa a valer também um saber criativo praticado pela engenharia a fim de enaltecer o fator plástico como principal imperativo, nem que para isso tenha que desenvolver novas proposições conceituais, novas solicitações normativas ou mesmo novas respostas práticas para atingir seus objetivos.

É o que aconteceu na participação da engenharia estrutural na sede do Ministério da Educação e Saúde (MES) no Rio de Janeiro nos anos 1930-1940. Por meio da performance ativa e empreendedora do engenheiro civil Emílio Baumgart, novos cálculos estruturais foram elaborados e incorporados ao edifício em uma tentativa, bem sucedida, de traduzir os princípios do "Sistema Domino" e do “Estilo Internacional” para o edifício carioca. Houve, por parte da equipe de tecnologistas, um empenho constante em investir na aplicação das técnicas do concreto armado para que as novas ideias modernas enfatizadas no projeto do grupo de arquitetos brasileiros chefiados por Lucio Costa fossem mantidas e plenamente ressaltadas quando da obra finalizada.

Dadas as particularidades do projeto arquitetônico, Baumgart viu-se obrigado a contornar as raras normas de construção então vigentes e desenvolver, por conta própria, soluções estruturais sempre baseadas em sua própria experiência profissional e em sua inata habilidade propositiva. Podem ser entendidos como méritos para esta obra os avanços técnicos/tecnológicos conseguidos, por exemplo, com a primeira utilização no Brasil das lajes planas de espessura reduzida denominadas pilzdecken, ou seja, as lajes-cogumelo invertidas (que ajudaram a reforçar e a sutilmente destacar a autonomia estrutural do edifício como um todo, como inicialmente desejado por Lucio Costa), além do sistema estrutural concebido para resistir às solicitações tangenciais provocadas pelo caminhamento dos ventos - cuja solução final foi ainda mais dificultada em função de o edifício verticalizado repousar sobre altos pilotis. 
A partir do momento em que estética e técnica, em comum acordo, optam por manter a essência da expressão plástica como condutora de suas ações, nasce a arquitetura propriamente dita. Como expressão artística que é, tornase então qualificada e parte ativa da vida das pessoas e da cidade, gerando em ambas uma relação de proximidade e de identidade. $\mathrm{O}$ fazer projetual da engenharia, condicionado que está aos aspectos arquitetônicos, configura-se como uma oportunidade de colocar em xeque, criticamente, os seus próprios métodos habituais e as suas próprias técnicas tradicionais. Como efeito, a engenharia direciona sua atenção para um processo de contínuo crescimento e de amadurecimento que nunca cessa, pois a produção arquitetônica é, ela também, permanente.

É o que se nota na fase de desenvolvimento do projeto da Capela de São Francisco de Assis, em Belo Horizonte (no início da década de 1940), oportunidade na qual Oscar Niemeyer e Joaquim Cardozo, em um esforço de estreita parceira, trilharam uma investigação mais particularizada e precisa sobre os novos horizontes que poderiam ser descortinados com o uso das técnicas do concreto armado desenvolvidas tanto fora quanto dentro do Brasil. Ao adaptarem uma solução já largamente aplicada em grandes estruturas para uma escala significativamente mais modesta, as teorias matemáticas e as normas de cálculo estrutural vigentes em território nacional àquela época precisaram, uma vez mais, ser contornadas. A novidade imputada à cobertura paraboloide de seção variada sugerida por Niemeyer e integralmente apoiada por Cardozo materializou a primeira obra desse formato construída no Brasil.

Em função de uma forma arquitetônica muito peculiar idealizada para este projeto, houve algumas diferenças conceituais e estruturais em relação às delgadas cascas em concreto armado construídas em outras partes do mundo, sobretudo na Europa - o que tornou a busca por referências teóricas e práticas uma tarefa complicada. O esforço justificou-se porque o arquiteto carioca encarou este desafio como uma possibilidade única de colocar em prática o seu desejo de tensionar a técnica, isto é, sua vontade de encontrar respostas arquitetônico-estruturais que buscassem novos caminhos para as soluções tradicionais, ao mesmo tempo em que propusessem fomentar o uso do concreto armado em toda sua plenitude. E sem o apoio incondicional das equipes de tecnologistas que desenvolveram saídas ideais para consolidar o ato estético niemeyeriano, o objetivo não teria sido alcançado com tamanho êxito.

Isso não significa dizer que a engenharia caminhe às sombras e discretamente sequer seja percebida pelos indivíduos que se apropriam de determinada arquitetura. Pelo contrário. Ao perseguir a valorização plástica, a engenharia dignifica outro tipo de expressão formal a ela inerente: a técnica - cujo corolário é o pleno conhecimento dos sistemas estruturais em todas as suas possibilidades e vertentes, dos elementos mais evidentes (como pilares e vigas, 
materialidades e revestimentos) aos mais discretos (detalhes e articulações, propriedades e solicitações). Destaca-se, assim, frente às questões pertinentes à arquitetura e conformadas pela plástica dos edifícios.

São arquitetura e engenharia dois universos que se entrelaçam e que se complementam com extrema sabedoria e coesão. Por isso, devem ser compreendidos como coisa única que nasce, cresce, se estabelece e frutifica simultaneamente. Por um lado, as escolhas definidas na fase projetual arquitetônica são materializadas quando na etapa de construção. Logo, um vínculo ativo e consciente com as questões técnicas e tecnológicas passa a ser fundamental, pois antecipa situações que só seriam enfrentadas na prática futura - o que pode ser demasiado tarde. Por outro lado, ao vincular seu trabalho à primazia das variáveis estéticas enquanto em concepção, a engenharia fornece respostas direcionadas a cada situação arquitetônica em particular e quando concebida, estimulando a construção do conhecimento em conjunto - e não apenas ao final, com equações algébricas arduamente calculadas para que se encaixem a algo já estabelecido e que, portanto, perde seu sentido por não mais poder ser alterado.

É o que se nota, por exemplo, no Palácio da Alvorada, em Brasília, cujos desafios na fase de desenvolvimento arquitetônico foram compartilhados pelas equipes técnicas então envolvidas. Como resultados, várias conquistas: o formato inusitado das colunas ondulantes só foi erguido após o processo de definição de uma expressão matemática de grau quarto para a sua perfeita execução em obra; a estipulação de um intercolúnio cadenciado em dez metros acabou norteando não apenas a sua própria distribuição, mas a dos pilares internos e a das caixilharias dos extensos panos de vidro que abraçam o prisma recuado em todos os seus lados; o correto dimensionamento da arquitrave superior ao solene portal de entrada permitiu um vão livre três vezes maior que o espaçamento normalmente aplicado entre as colunas da fachada sem que modificações plásticas fossem demandadas (mesmo que utilizando um par de colunas seccionadas verticalmente e localizadas nas extremidades dessa ampla abertura); a elaboração dos delicados pontos de contato de cada uma das colunas com os elementos superiores e inferiores de apoio passam a ideia de que as lajes descansam tranquilamente sobre as esbeltas colunas sinuosas; e a necessidade basilar de Joaquim Cardozo por assegurar na obra concluída, sob todos os aspectos, tanto a preservação das formas estéticas como a qualidade de “leveza” inicialmente postuladas pelo projeto arquitetônico de Niemeyer.

Ao tomar a nova sede do Ministério das Relações Exteriores em Brasília - o Palácio do Itamaraty - nota-se que a apropriação dos espaços internos como prevista pelos projetos de arquitetura só aconteceu mediante o vencimento de grandes vãos, cujo resultado reforçou a flexibilidade espacial e o correto concatenamento dos ambientes, livres 
de quaisquer obstruções. Para tanto, os estudos da engenharia estrutural comandaram um processo de descobrimento de novas técnicas de execução das vigas de sustentação de forma diferente das convencionais, ou seja, com a execução de numerosos ensaios combinatórios entre cimento e agregados até que fosse atingido um traço de concreto perfeito para uma aplicação tão particular. Além disso, a estruturação de vigas não utilizou transpasse das armações de aço, mas emendas por soldas de topo, bem como foram previamente estipuladas contraflechas nas mesmas vigas superiores, justamente para contrapesar possíveis deformações quando da retirada dos escoramentos.

Anos depois, no projeto milanês para a nova sede da Editora Mondadori - o Palazzo Mondadori - Niemeyer valeu-se da consultoria de um engenheiro calculista brasileiro (Bruno Contarini) para diagnosticar - ao longo da fase de concepção estrutural/arquitetônica do edifício - alternativas técnicas que mais bem conseguissem contribuir para a materialização de seu conceito arquitetônico: imputar à colunata externa uma função não limitada apenas pela estética, mas de efetiva finalidade estrutural portante, além de fazer dela a responsável pela adequação arquitetônica e de arranjo espacial interno - tudo isso para aproveitar os limites máximos tecnológicos e construtivos disponíveis à época. O resultado, ainda que inovador e ousado, explorou as possibilidades das grandes estruturas em concreto de forma relativamente ponderada, mas eficientemente.

Em texto de 1955 sobre as obras de Pampulha, Joaquim Cardozo apresenta um ponto de vista que notadamente pousa nos ombros da engenharia boa parte da responsabilidade pelo progresso na construção civil. Diz ele que "todos esses resultados são reveladores de que a arquitetura brasileira, longe de paralisar-se em fórmulas exaustas, vai-se desenvolvendo com uma vitalidade surpreendente e uma riqueza de tendências e soluções bem compatível com os progressos da técnica e dos métodos construtivos". (CARDOZO; 1955; In MACEDO e SOBREIRA; 2009: 114)

Porém, se realmente foi Oscar Niemeyer a mola propulsora para que novas técnicas construtivas e tecnologias inovadoras pudessem ser criadas, o resultado - suas obras construídas há anos - comprova que mesmo estando sempre um passo à frente da engenharia, contribuiu sobremaneira para os avanços desta, preocupada que estava em manter intactas as concepções arquitetônicas originais.

Dos edifícios predominantemente ortogonais às construções de formas livres, Oscar Niemeyer vivenciou uma trajetória pautada por uma evolução constante em seu fazer arquitetônico. Momentos esses condicionados por constantes reposicionamentos críticos propostos pelo próprio arquiteto e que foram gradativamente 
profissionalizando e lapidando o talento inato desse carioca de vanguarda que quebrou fronteiras e conquistou o mundo. Ao conceber arquiteturas paradigmáticas, gerou mudanças radicais no Movimento Moderno e clamou pelo uso do concreto armado em toda sua plenitude, justamente em uma época em que os projetos deveriam obedecer às limitações racionais rígidas, ortodoxas e fundamentadas em um racionalismo exacerbado.

Unanimidade ou não, o fato é que Oscar Niemeyer sobreviveu aos duros comentários que recebeu e incorporou os elogios difundidos pela crítica e pelo público dentro e fora do país. Ao assumir um fazer projetual que primou por ousadia estética, identidade própria e concepção de projetos autorais, estabeleceu novos vocabulários arquiteturais e construtivos, constantemente revisitados e reaproveitados em suas próprias obras. Sua atuação incessante até os últimos dias de vida também acompanhou e inspirou o ritmo imaginativo e renovador das novas gerações de arquitetos.

Ainda que os créditos pelos edifícios projetados devam fazer justiça ao seu talento inventivo interminável, certo é que não trabalhou sozinho. Niemeyer sempre fez questão de destacar a relação próxima e de grande sinergia que estabeleceu para com suas equipes de tecnologistas, em especial, com os engenheiros civis com os quais ora compartilhava questões projetuais, ora buscava orientações técnicas para mais bem resolver suas audaciosas concepções arquitetônicas. Especialmente com os engenheiros Emilio Baumgart, Joaquim Cardozo e Bruno Contarini (além de José Carlos Sussekind, Ana Niemeyer e Jair Valera - estes, não contemplados neste estudo), Oscar Niemeyer compreendeu as diversas variáveis estruturais imbricadas em seus projetos, testou novas soluções arquitetônicas, experimentou novos artifícios construtivos e colaborou para o desenvolvimento de novas tecnologias como mote para construir suas arquiteturas em concreto com "liberdade plástica quase ilimitada", parafraseando o próprio arquiteto.

No momento em que os projetos arquitetônicos niemeyerianos contemplaram premissas mais raras e arrojadas que por vezes colidiram com as soluções mais verdadeiras defendidas pela engenharia, percebe-se que não houve adaptação perfeita entre a estética dos arquitetos e a estática dos engenheiros. O que se nota é uma preocupação de ambos os lados para que essas áreas continuassem contribuindo entre si para um desenvolvimento cada vez mais harmonioso e promissor. Houve momentos, portanto, em que a arquitetura prevaleceu sobre a engenharia. Outros, na contramão, em que a engenharia exercitou sua autonomia sobre a arquitetura. 
6. 
BAER, Werner. Siderurgia e Desenvolvimento Brasileiro. Rio de Janeiro: Zahar Editores, 1970.

BANHAM, Peter Reyner. Teoria e Projeto na Primeira Era da Máquina. São Paulo: Editora Perspectiva, 1979.

BASTOS, Maria Alice Junqueira; ZEIN, Ruth Verde. Brasil: Arquiteturas Após 1950. São Paulo: Perspectiva, 2010.

BAUER, Luiz Alfredo Falcão. Materiais de Construção - Volume 1. Rio de Janeiro: Editora LTC, 2012.

BAXANDALL, Michael. Padrões de Intenção: A Explicação Histórica dos Quadros. São Paulo: Companhia das Letras, 2006.

BONDUKI, Nabil Georges; KOURY, Ana Paula; BOTAS, Nilce Cristina Aravecchia; NASCIMENTO, Flávia Brito do; FREITAS, Maria Luiza Macedo Xavier de. As Tecnologias Construtivas Aplicadas à Habitação Social: Um Preâmbulo pela História do Concreto Armado no Brasil na Primeira Metade do Século 20. In: I Encontro Nacional da Associação Nacional de Pesquisa e Pós-graduação em Arquitetura e Urbanismo (I ENANPARQ), 2010, Rio de Janeiro. I ENANPARQ. Arquitetura, Cidade, Paisagem e Território: Percurso e Prospectivas. Rio de Janeiro: ANPARQ, 2010. v. 1.

BRUAND, Yves. Arquitetura Contemporânea no Brasil. São Paulo: Editora Perspectiva, 1997.

CABRAL, Fernando Frank. À Procura da Beleza: Aprendendo com Oscar Niemeyer. São Paulo, 2002. 128f. Dissertação (Mestrado em Arquitetura e Urbanismo) - Faculdade de Arquitetura e Urbanismo, Universidade de São Paulo, 2002.

CAMARGO, Mônica Junqueira de. A Presença Brasileira na Historiografia da Arquitetura do Século XX. In: Desígnio Revista de História da Arquitetura e do Urbanismo, São Paulo. N. 11/12, pg. 73 - 88, mar.2011. Editora Anablume, 2011.

CARCHIA, Gianni; D’ANGELO, Paolo. Dicionário de Estética. Lisboa: Edições 70, 2009.

CARDOZO, Joaquim Maria Moreira. Arquitetura Brasileira: Características mais Recentes. Revista Módulo, Rio de Janeiro, N. 1, pg. 6 - 9, mar.1955. In: MACEDO, Danilo Matoso; SOBREIRA, Fabiano José Arcadio (Orgs.). Forma Estática - Forma Estética: Ensaios de Joaquim Cardozo sobre Arquitetura e Engenharia. Brasília: Centro de Documentação e Informação. Edições da Câmara, 2009.

- Dois Episódios da Arquitetura Moderna Brasileira. Revista Módulo, Rio de Janeiro, N. 4, pg. 32 - 35, mar.1956. In: MACEDO, Danilo Matoso; SOBREIRA, Fabiano José Arcadio (Orgs.). Forma Estática - Forma Estética: Ensaios de Joaquim Cardozo sobre Arquitetura e Engenharia. Brasília: Centro de Documentação e Informação. Edições da Câmara, 2009. 
. Forma Estática - Forma Estética. Revista Módulo, Rio de Janeiro, N. 10, pg. 3 - 6, ago.1958. In: MACEDO, Danilo Matoso; SOBREIRA, Fabiano José Arcadio (Orgs.). Forma Estática - Forma Estética: Ensaios de Joaquim Cardozo sobre Arquitetura e Engenharia. Brasília: Centro de Documentação e Informação. Edições da Câmara, 2009.

CARRIERI, Renato. Estruturas: A Resistência pela Forma, à Luz da Produção Contemporânea. São Paulo, 2007. $165 f$. Tese (Doutoramento em Arquitetura e Urbanismo) - Faculdade de Arquitetura e Urbanismo, Universidade de São Paulo, 2007.

CARVALHO, Thaís Hortense de. Análise da Segmentação Tecnológica da Indústria Siderúrgica no Brasil. Piracicaba, 2012. 56f. Dissertação (Mestrado em Ciências - Área de Concentração: Economia Aplicada) - Escola Superior de Agricultura Luiz de Queiroz - Universidade de São Paulo, 2012.

CASABELLA. Edificio per Uffici Mondadori. N. 753, 2007.

CASTELLOTTI, Flávio. Arquitetura Moderna no Rio de Janeiro - A Dimensão Brutalista. Rio de Janeiro, $2006.184 f$. Dissertação (Mestrado em Ciências da Arquitetura - História e Preservação do Patrimônio Cultural) - Faculdade de Arquitetura e Urbanismo, Universidade Federal do Rio de Janeiro, 2006.

CAVALCANTI, Lauro. Oscar Niemeyer: A Trajetória de uma Revolução. In: PORTZAMPARC, Christian de; SEGRE, Roberto (Orgs.). Tributo a Niemeyer. Rio de Janeiro: Viana \& Mosley Editora, 2009.

. Um Arquiteto Único e Raro. In: Revista Arquitetura e Urbanismo, São Paulo, Ano 22, N.165, pg. 38 - 40, dez. 2007. Editora Pini, 2007.

Moderno e Brasileiro: A História de uma Nova Linguagem na Arquitetura (1930 - 1960). Rio de Janeiro: Jorge Zahar Editor, 2006.

; LAGO, André Correa do. Ainda Moderno? Arquitetura Brasileira Contemporânea. São Paulo: Editora Nova Fronteira, 2005.

COHEN, Jean-Louis. O Futuro da Arquitetura Desde 1889. São Paulo: CosacNaify, 2013.

COLLARES, Júlio Ramos. Exoesqueletos no Modernismo Brasileiro nas Décadas de 40 e 50 do Século XX. Porto Alegre, 2003. 192f. Dissertação (Mestrado Arquitetura) - Faculdade de Arquitetura e Urbanismo, Programa de Pesquisa e Pós-graduação em Arquitetura, Universidade Federal do Rio Grande do Sul, 2003.

COLLINS, Peter. Los Ideales de la Arquitectura Moderna; Su Evolución (1750 - 1950). Barcelona: Gustavo Gili, 1970. Concrete: The Vision of a New Architecture. Quebec: McGill Queen's University Press, $2^{\mathrm{a}}$ Edição, 
COMAS, Carlos Eduardo Dias. Um Arquiteto e Quatro Fases. In: Revista Arquitetura e Urbanismo, São Paulo, Ano 28, N.226, pg. 61-67, jan. 2013. Editora Pini, 2013.

; PEIXOTO, Marta Silveira; MAQUES, Sérgio Moacir. Concreto: Plasticidade e Industrialização na Arquitetura do Cone Sul-Americano 1930 / 70. Porto Alegre: Cadernos de Arquitetura Ritter dos Reis / Propar, Volume 7, 2010.

A Legitimidade de uma Diferença. In: PORTZAMPARC, Christian de; SEGRE, Roberto (Orgs.). Tributo a Niemeyer. Rio de Janeiro: Viana \& Mosley Editora, 2009.

. A Legalidade de uma Diferença. In: Revista Arquitetura e Urbanismo, São Paulo, Ano 22, N.165, pg. 70 - 75, dez. 2007. Editora Pini, 2007.

Arquitetura Moderna, Estilo Corbu, Pavilhão Brasileiro. In: Revista Arquitetura e Urbanismo, São Paulo, N.26, pg. 92 - 101, out-nov. 1989. Editora Pini, 1989.

COSTA, Lucio. Registro de uma Vivência. São Paulo: Empresa das Artes, 1995.

DE BOTTON, Alain. A Arquitetura da Felicidade. Rio de Janeiro: Rocco, 2006.

DUARTE, Rodrigo. A Arte. São Paulo: WMF Martins Fontes, 2012.

ESPALLARGAS GIMENEZ, Luis. Arquitetura Paulistana da Década de 1960: Técnica e Forma. São Paulo, 2004. $250 f$. Tese (Doutoramento em Arquitetura e Urbanismo) - Faculdade de Arquitetura e Urbanismo, Universidade de São Paulo, 2004.

FERRY, Luc. Homo Aestheticus. A Invenção do Gosto na Era Democrática. Portugal: Almedina Brasil: 2003

FRAGA, Carlos André Soares. Museus, Pavilhões e Memoriais: A Arquitetura de Oscar Niemeyer para Exposições. Porto Alegre, 2006. 407f. Dissertação (Mestrado Arquitetura) - Faculdade de Arquitetura e Urbanismo, Programa de Pesquisa e Pós-graduação em Arquitetura, Universidade Federal do Rio Grande do Sul, 2006.

FRAMPTON, Kenneth. História Crítica da Arquitetura Moderna. São Paulo: Martins Fontes, 2008.

Studies in Tectonic Culture: The Poetics of Construction in Nineteenth and Twentieth Century Architecture. London: MIT Press, 1996.

Publications, 1983.

; FUTAGAWA, Yukio. Modern Architecture 1851-1945. New York: Rizzoli International . Modern Architecture: a Critical History. Londres: Thames \& Hudson, 1980. 
FREITAS, Maria Luiza Macedo Xavier de. Modernidade Concreta: As Grandes Construtoras e o Concreto Armado no Brasil, 1920 a 1940. São Paulo, 2011. 187f. Tese (Doutoramento em Arquitetura e Urbanismo) - Faculdade de Arquitetura e Urbanismo, Universidade de São Paulo, 2011.

FUTAGAWA, Yukio. Oscar Niemeyer: Form \& Space. Tóquio: A.D.A. Edita, 2008.

GALVANE Junior, James. A Engenharia de Estruturas na Arquitetura de Oscar Niemeyer. São Paulo, 2004. 138f. Dissertação (Mestrado em Engenharia de Estruturas) - Escola Politécnica, Universidade de São Paulo, 2004.

GIANNECCHINI, Ana Clara. Técnica e Estética no Concreto Armado: Um Estudo sobre os Edifícios do MASP e da FAUUSP. São Paulo, 2009. 164f. Dissertação (Mestrado em Arquitetura e Urbanismo) - Faculdade de Arquitetura e Urbanismo, Universidade de São Paulo, 2009.

GIEDION, Sigfried. Espaço, Tempo e Arquitetura - O Desenvolvimento de uma Nova Tradição. São Paulo: WMF Martins Fontes, 2004.

GITAHY, Maria Lúcia Caira. São Paulo e a Tecnologia, 1899-1948. Estudos de História do Trabalho como Fundamentos Sociais da Arquitetura e do Urbanismo. São Paulo, 2002. Tese (Livre-docência) - Faculdade de Arquitetura e Urbanismo, Universidade de São Paulo, 2002.

GLANCEY, Jonathan. Guia Ilustrado Zahar de Arquitetura. Rio de Janeiro: Jorge Zahar Editores Ltda, 2012.

Eu Pego a Minha Caneta. Aparece um Prédio. In: PORTZAMPARC, Christian de; SEGRE, Roberto (Orgs.). Tributo a Niemeyer. Rio de Janeiro: Viana \& Mosley Editora, 2009.

GONÇALVES, Simone Neiva Loures. Museus Projetados por Oscar Niemeyer de 1951 a 2006: O Programa como Coadjuvante. São Paulo, 2010. 323f. Tese (Doutoramento em Arquitetura e Urbanismo) - Faculdade de Arquitetura e Urbanismo, Universidade de São Paulo, 2010.

GOODWIN, Philip. Brazil Builds: Architecture New and Old 1652 - 1942. Nova York: The Museum of Modern Art, 1943.

GRANDI, Sonia Lemos. Desenvolvimento da indústria da construção no Brasil: Mobilidade e Acumulação do Capital e da Força de Trabalho. 1985, 2V. Tese (Doutoramento em Sociologia) - Faculdade de Sociologia da Universidade de São Paulo, São Paulo, 1985

INOJOSA, Leonardo da Silveira Pirillo. O Sistema Estrutural na Obra de Oscar Niemeyer. Brasília, 2010. $159 f$. Dissertação (Mestrado Arquitetura - Tecnologia) - Faculdade de Arquitetura e Urbanismo, Universidade de Brasília, 2010.

JENCKS, Charles. The Language of Post-modern Architecture. Londres: London Academy Editions, 1991.

JUNQUEIRA, Juliana Villela. Modernos Trópicos - Brasil e Brasília. São Paulo, 2014. 102f. Dissertação (Mestrado em Arquitetura e Urbanismo) - Faculdade de Arquitetura e Urbanismo, Universidade de São Paulo, 2014. 
KATINSKY, Júlio Roberto. Técnica e Arte na Obra de Oscar Niemeyer. In: Revista Arquitetura e Urbanismo, São Paulo, Ano 22, N.165, pg. 56 - 63, dez. 2007. Editora Pini, 2007.

KOOLHAAS, Rem; MAU, Bruce. Small, Medium, Large, Extra-large : Office for Metropolitan Architecture. New York: Monacelli Press, 1995.

KÜHL, Beatriz Mugayar. Arquitetura do Ferro e Arquitetura Ferroviária em São Paulo - Reflexões Sobre Sua Preservação. São Paulo, Ateliê Editorial: Fapesp, Secretaria da Cultura, 1998.

KRUFT, Hanno-Walter. A History of Architectural Theory: From Vitruvius to the Present. New York, Princeton Architectural Press, 1994.

L'ARCHITECTURE D'AUJORD'HUI. Oscar Niemeyer. N.171, 1974.

LAUANDE Jr., Francisco de Assis. Brasília: A Praça dos Três Poderes. Brasília, 2008. 178f. Dissertação (Mestrado Arquitetura - Teoria, História e Crítica de Arquitetura) - Faculdade de Arquitetura e Urbanismo, Universidade de Brasília, 2008.

LEMOS, Carlos Alberto Cerqueira. Alvenaria Burguesa. São Paulo: Editora Nobel, 1989.

MACEDO, Danilo Matoso. A Matéria da Invenção: Criação e Construção das Obras de Oscar Niemeyer em Minas Gerais (1938 - 1954). Belo Horizonte, 2002. 288f. Dissertação (Mestrado em Arquitetura e Urbanismo) - Faculdade de Arquitetura e Urbanismo, Universidade Federal de Minas Gerais, 2002.

MACEDO, Oigres Leici Cordeiro de. Construção Diplomática, Missão Arquitetônica: Os Pavilhões do Brasil nas Feiras Internacionais de Saint Louis (1904) e Nova York (1939). São Paulo, 2010. 280f. Tese (Doutoramento em Arquitetura e Urbanismo) - Universidade Federal de Minas Gerais, Escola de Arquitetura, 2002.

MAGALHÃES, Carlos Henrique. Modernidades Brasileiras: A Obra de Milton Ramos. Brasília, 2008. 100f. Dissertação (Mestrado Arquitetura) - Faculdade de Arquitetura e Urbanismo, Universidade de Brasília, 2008.

MAHFUZ, Edson da Cunha. Cinco Razões para Olhar com Atenção a Obra de Oscar Niemeyer. In: Revista Arquitetura e Urbanismo, São Paulo, Ano 22, N.165, pg. 76 - 79, dez. 2007. Editora Pini, 2007.

. Ensaio Sobre a Razão Compositiva. Viçosa, Universidade Federal de Viçosa, 1995.

MARQUARDT, Seina. A Estrutura Independente e a Arquitetura Moderna Brasileira. Porto Alegre, 2005. 101f. Dissertação (Mestrado Arquitetura) - Faculdade de Arquitetura e Urbanismo, Programa de Pesquisa e Pós-graduação em Arquitetura, Universidade Federal do Rio Grande do Sul, 2005.

MINDLIN, Henrique. Modern Architecture in Brazil. Rio de Janeiro: Colibris, 1956.

MONEO, Rafael. Inquietação Teórica e Estratégia Projetual. São Paulo: CosacNaify, 2008. 
MONTANER, Josep Maria. Arquitetura e Crítica. Barcelona: Gustavo Gili, 2007.

Barcelona: Gustavo Gili, 1993.

Después del Movimiento Moderno: Arquitectura de la Segunda Mitad del Siglo XX.

MOREIRA, André Luis Andrade. A Estrutura do Palácio da Justiça em Brasília: Aspectos Históricos, Científicos e Tecnológicos de Projeto, Execução, Intervenções e Propostas de Estratégias para Manutenção. Brasília, 2007. 180f. Dissertação (Mestrado Engenharia Civil - Estruturas e Construção Civil) - Faculdade de Tecnologia, Departamento de Engenharia Civil, Universidade de Brasília, 2007.

NIEMEYER, Oscar. Minha Arquitetura. Rio de Janeiro: Editora Revan, 2008.

A Forma na Arquitetura. Rio de Janeiro: Editora Revan, 2005.

Oscar Niemeyer: Minha Arquitetura: 1937 - 2004. Rio de Janeiro: Editora Revan, 2004.

As Curvas do Tempo. Rio de Janeiro: Editora Revan, 2000.

Sede Mondadori. In: Revista Módulo N.41. Rio de Janeiro: dezembro 1975 / janeiro 1976.

Depoimento. In: Revista Módulo N. 9. Rio de Janeiro: 1958.

Palácio Residencial de Brasília. In: Revista Módulo N. 7. Rio de Janeiro: 1957.

PALERMO, Humberto Nicolás Sica. O Sistema Dom-ino. Porto Alegre, 2006. 222f. Dissertação (Mestrado Arquitetura) - Faculdade de Arquitetura e Urbanismo, Programa de Pesquisa e Pós-graduação em Arquitetura, Universidade Federal do Rio Grande do Sul, 2006.

PAPADAKI, Stamo. The Work of Oscar Niemeyer. New York: Reinhold, 1950.

PEREIRA, Nathalia Coelho. Concepção Arquitetônica e Estrutural de Duas Obras de Oscar Niemeyer: Igreja da Pampulha e Pavilhão da Gameleira. Brasília, 2012. 48f. Dissertação (Mestrado em Engenharia Civil - Estruturas e Construção Civil) - Faculdade de Tecnologia, Departamento de Engenharia Civil, Universidade de Brasília, 2012.

PEVSNER, Nikolaus. Origens da Arquitetura Moderna e do Design. São Paulo: Martins Fontes, 2001.

PONTES, Ana Paula Gonçalves. Diálogos Silenciosos: Arquitetura Moderna Brasileira e Tradição Clássica. Rio de Janeiro, 2004. 131f. Dissertação (Mestrado em História Social da Cultura) - Departamento de História do Centro de Ciências Sociais da Pontifícia Universidade Católica do Rio de Janeiro, 2004.

PROJETO DESIGN. Oscar Niemeyer: Cidade Administrativa Presidente Tancredo Neves, Belo Horizonte. São Paulo, N.363, 2010. Arco Editorial, 2010. 
PUPPI, Lionello. A Arquitetura de Oscar Niemeyer. Rio de Janeiro: Editora Revan, 1988.

QUEIROZ, Rodrigo Cristiano. Oscar Niemeyer e Le Corbusier: Encontros. São Paulo, 2010. 229f. Tese (Doutoramento em Arquitetura e Urbanismo) - Faculdade de Arquitetura e Urbanismo, Universidade de São Paulo, 2007.

REBELLO, Yopanan Conrado Pereira; LEITE, Maria Amélia D’Azevedo. O Engenheiro das Curvas de Brasília. In: Revista Arquitetura e Urbanismo, São Paulo, Ano 22, N.165, pg. 92 - 99, dez. 2007. Editora Pini, 2007.

RECAMÁN, Luiz. Oscar Niemeyer: Forma Arquitetônica e Cidade no Brasil Moderno. São Paulo, 2003. 2V. Tese (Doutoramento em Filosofia) - Faculdade de Filosofia, Letras e Ciências Humanas da Universidade de São Paulo, 2003.

. Por uma Arquitetura, Brasileira. São Paulo, 1996. 98f. Dissertação (Mestrado em Filosofia) Faculdade de Filosofia, Letras e Ciências Humanas da Universidade de São Paulo, 1996.

REIS FILHO, Nestor Goulart. Aspectos da História da Engenharia Civil em São Paulo: 1860 - 1960. São Paulo: Editora Kosmos, 1989.

ROSENFIELD, Kathrin Holzermayr Lerrer. Estética. São Paulo: Jorge Zahar Editor, 1ª Edição, 2006.

ROSSI, Aldo. A Arquitetura da Cidade. São Paulo: WMF Martins Fontes, 2001.

ROWE, Colin. Manierismo y Arquitectura Moderna y Otros Ensayos. Barcelona, Gustavo Gili, 1978.

RUSKIN, John. A Lâmpada da Memória. São Paulo: Ateliê Editorial, 2008.

SANTOS, Paulo Ferreira. Quatro Séculos de Arquitetura. Rio de Janeiro: Instituto dos Arquitetos do Brasil (IAB), 1981.

SANTOS JUNIOR, Evaristo Clementino Rezende dos. A Estrutura do Palácio do Itamaraty: Aspectos Históricos, Científicos e Tecnológicos de Projeto, Execução, Intervenções e Proposta de Manutenção. Brasília, 2004. 105f. Dissertação (Mestrado Arquitetura - Estruturas e Construção Civil) - Faculdade de Tecnologia, Universidade de Brasília - Departamento de Engenharia Civil e Ambiental, 2004.

SCRUTON, Roger. Estética da Arquitectura. Lisboa: Edições 70, 2010.

SEGAWA, Hugo Massaki. Arquiteturas no Brasil 1900 - 1990. São Paulo: EDUSP, 2010.

SEGRE, Roberto. Ministério da Educação e Saúde: Ícone Urbano da Modernidade Carioca (1935 - 1945). São Paulo: Romano Guerra Editora, 2013.

Oscar Niemeyer: Cem Anos de Solidão. In: PORTZAMPARC, Christian de; SEGRE, Roberto (Orgs.). Tributo a Niemeyer. Rio de Janeiro: Viana \& Mosley Editora, 2009. 
Oscar Niemeyer: Tipologias e Liberdade Plástica. In: PORTZAMPARC, Christian de; SEGRE, Roberto (Orgs.). Tributo a Niemeyer. Rio de Janeiro: Viana \& Mosley Editora, 2009.

Oscar Niemeyer: 100 Anos, 100 Obras. São Paulo: Instituto Tomie Ohtake, 2007.

SILVA, Elcio Gomes da. Os Palácios Originais de Brasília. Brasília, 2012. 293f. Tese (Doutoramento em Arquitetura e Urbanismo) - Faculdade de Arquitetura e Urbanismo, Universidade de Brasília, 2012.

SILVER, Pete; McLEAN, William; EVANS, Peter. Sistemas Estruturais. São Paulo: Blucher, 2013.

STORRER, William Allin. The Architecture of Frank Lloyd Wright: A Complete Catalog. Chicago: University of Chicago Press, 1992.

TELLES, Pedro Carlos da Silva. História da Engenharia no Brasil (Século 20). Rio de Janeiro: Clavero Editoração / Clube de Engenharia, 1993.

TELLES, Sophia da Silva. Arquitetura Moderna no Brasil: O Desenho da Superfície. São Paulo, 1988. 61f. Dissertação (Mestrado em Filosofia) - Faculdade de Filosofia, Letras e Ciências Humanas da Universidade de São Paulo, 1988.

UNDERWOOD, David. Oscar Niemeyer e o Modernismo de Formas Livres no Brasil. São Paulo: Cosac \& Naify, 2003.

VALLE, Marco Antônio Alves do. Desenvolvimento da Forma e Procedimentos de Projeto na Arquitetura de Oscar Niemeyer (1935 - 1998). São Paulo, 2010. 346f. Tese (Doutoramento em Arquitetura e Urbanismo) - Faculdade de Arquitetura e Urbanismo, Universidade de São Paulo, 2000.

VARGAS, Milton (org.). Contribuições para a História da Engenharia no Brasil. São Paulo: Epusp, 1994.

. História da Técnica e da Tecnologia no Brasil. São Paulo: Editora da Universidade Estadual Paulista e Centro Estadual de Educação Tecnológica Paula Souza, 1994.

VASCONCELOS, Augusto Carlos de. O Concreto no Brasil: Recordes, Realizações, História - Volume 1. São Paulo: Copiare Duplicadora, 1985.

XAVIER, Alberto (org.). Depoimento de uma Geração: Arquitetura Moderna Brasileira. São Paulo: Cosac \& Naify, 2003.

. Niemeyer: Leveza não Tectônica. Porto: Dafne Editora, 2007.

WISNIK, Guilherme. Íntima Varanda para o Brasil. In: Revista Arquitetura e Urbanismo, São Paulo, Ano 28, N.226, pg. 36 - 41, jan. 2013. Editora Pini, 2013.

ZEIN, Ruth Verde. Um Panorama a partir dos Museus. In: Revista Arquitetura e Urbanismo, São Paulo, Ano 22, N.165, pg. 80 - 83, dez. 2007. Editora Pini, 2007. 
. A Arquitetura da Escola Paulista Brutalista: 1953 - 1973. São Paulo e Porto Alegre, 2005. 358f. Tese (Doutoramento em Arquitetura e Urbanismo) - Faculdade de Arquitetura da Universidade Federal do Rio Grande do Sul, 2005 . 
ARCH DAILY BRASIL. Disponível em <www.archdaily.com.br/br> e consultado em 20.jul.2013.

ARCOWEB. Disponível em <www.arcoweb.com.br> e acessado em 20.jul.2013.

CARVALHO, João Dirceu Nogueira de. Sobre as Origens e Desenvolvimento do Concreto. Departamento de Engenharia Civil Universidade Estadual de Maringá. Revista Tecnológica. V. 17. 2008. Disponível em <http://periodicos.uem.br/ojs/index.php/RevTecnol/article/download/8169/5163> e consultado em 18.jan.2015.

COMAS, Carlos Eduardo Dias. Feira Mundial de Nova York de 1939: O Pavilhão Brasileiro. Arqtexto 16, Porto Alegre, UFRGS, 2010. Disponível em <www.ufrgs.br/propar/publicacoes/ARQtextos/pdfs_revista_16/03_CEC.pdf> e consultado em 25.jul.2014.

. O Cassino de Niemeyer e os Delitos da Arquitetura Brasileira. Arqtexto 10/11, Porto Alegre, UFRGS, 2007. Disponível em <http://www.ufrgs.br/propar/publicacoes/ARQtextos/PDFs_revista_1011/3_COMAS.pdf > e consultado em 21.set.2014.

CPDOC | FGV. Centro de Pesquisa e Documentação Histórica Contemporânea do Brasil - Fundação Getúlio Vargas. Disponível em <http://cpdoc.fgv.br/producao/dossies/AEraVargas1/apresentacao> e acessado em 06.set.2014.

CRAMER, Johannes; BREITLING, Stefan. Die Galerie des Machines in Paris. Disponível em <http://baugeschichte.a.tuberlin.de/owl/19.Jahrhundert/Paris_Galeriedesmachines/Paris_Galeriedesmachines.html> e consultado em 07.jan.2015.

DE PAULA, Germano Mendes. Estudo da Competitividade de Cadeias Integradas no Brasil: Impacto nas Zonas de Livre Comércio - Cadeia: Siderurgia, dezembro de 2012. Disponível em <http://www.redmercosur.org/iepcim/ RED_MERCOSUR/biblioteca/ESTUDOS_BRASIL/BRA_15.pdf> e consultado em 14.jan.2015.

ESPALLARGAS GIMENEZ, Luis. Novos Argumentos de uma Mesma História. Resenhas Online, São Paulo, ano 04, n. 044.02, Vitruvius, agosto de 2005. Disponível em: <http://www.vitruvius.com.br/revistas/read/resenhasonline/ 04.044/3152> e acessado em 29.agosto.2014.

FLORENÇANO, José Carlos Simões; ABUD, Maria José Milharezi. Histórico das Profissões de Engenheiro, Arquiteto e Agrônomo no Brasil. Universidade de Taubaté, Revista de Ciências Exatas, V.5-8, 1999-2002. Disponível em: <http://site.unitau.br/scripts/prppg/exatas/downloads/historicoprofissoes-99-02.pdf> e consultado em 22.jul.2014.

FURTADO, José Luiz. Fenomenologia e Crise da Arquitetura. KRITERION: Revista de Filosofia, $n^{\circ} 112$, dezembro de 2005. Disponível em <www.scielo.br/scielo.php?pid=S0100-512X2005000200022\&script=sci_arttext> e consultado em 29.mai.2012. 
GIANNECCHINI, Ana Clara. Técnicas e Estética: O Uso do Concreto Armado nos Edifícios do MASP e da FAUUSP, 2009. Disponível em: <www.docomomo.org.br> e acessado em 20.jul.2013.

GOVERNO DO RIO DE JANEIRO. Disponível em <www.ri.gov.br> e consultado em 20.jul. 2013.

GRALA DA CUNHA, Eduardo. A Abordagem Estética no Projeto de Estruturas de Edificações: Do Ensino à Concepção de Sistemas Estruturais. Arquitextos, São Paulo, 11.132, Vitruvius, maio de 2011. Disponível em <http:// www.vitruvius.com.br/revistas/read/arquitextos/11.132/3870> e consultado em 15.jul.2013.

INSTITUTO AÇO BRASIL. O Aço - História. Disponível em <http://www.acobrasil.org.br/site/portugues/aco/ siderurgia-no-brasil--desenvolvimento.asp> e consultado em 14.jan. 2015.

JERMANN, Arthur Eugênio. A Técnica do Concreto Armado e Emílio Baumgart - Symposium de Estruturas - $1^{\circ}$ Volume - Instituto Nacional de Tecnologia. Junho de 1944. Disponível em <http://aquarius.ime.eb.br/ webde2/ prof/ethomaz/baumgart/baumgarto1.pdf> e consultado em 17.jan. 2015.

MACEDO, Danilo Matoso. As Obras de Oscar Niemeyer em Belo Horizonte. MDC Revista de Arquitetura e Urbanismo, 2006. Disponível em: <http://mdc.arq.br/2006/02/28/as-obras-de-oscar-niemeyer-em-belo-horizonte/\#more-321> e consultado em 22.set.2014.

MACIEL, Carlos Alberto. Villa Savoye: Arquitetura e Manifesto. Arquitextos, São Paulo, ano 02, n. 024.07, Vitruvius, maio 2002. Disponível em: <http://www.vitruvius.com.br/revistas/read/arquitextos/02.024/785> e consultado em 20.jan.2015.

MAHFUZ, Edson da Cunha. Ordem, Estrutura e Perfeição no Trópico. Mies van der Rohe e a Arquitetura Paulistana na Segunda Metade do Século XX. Arquitextos, São Paulo, 05.057, Vitruvius, fevereiro 2005. Disponível em: $<$ http://www.vitruvius.com.br/revistas/read/arquitextos/05.057/811> e consultado em 19.jul.2012.

O Sentido da Arquitetura Moderna Brasileira. Arquitextos, São Paulo, 02.020, Vitruvius, janeiro de 2002. Disponível em: <http://www.vitruvius.com.br/revistas/read/arquitextos/02.020/811> e consultado em 19.jul.2012.

MARTINS, Alexandre Augusto. Variações Brutalistas na Obra de Oscar Niemeyer. X Seminário Docomomo Brasil. Arquitetura Moderna e Internacional: Conexões Brutalistas 1955-75. 2013. Disponível em: < http://www.docomomo. org.br/seminario\%2010\%20pdfs/CON_29.pdf >. Consultado em 21.jan.2015.

PIRES, Hindenburgo Francisco. Planejamento e Intervenções Urbanísticas no Rio de Janeiro: A Utopia do Plano Estratégico e sua Inspiração Catalã. Revista Bibliográfica de Geografía Y Ciencias Sociales - Universidad de Barcelona, setembro.2010. Disponível em <http://www.ub.edu/geocrit/b3w-895/b3w-895-13.htm> e consultado em 15.jan.2015.

REBELLO, Yopanan Conrado Pereira. Engenheiros, Arquitetos e um Único Objeto: a Edificação. Revista Integração Universidade São Judas Tadeu, $\mathrm{n}^{\circ}$. 53, ano XIV, abril/maio/junho 2008. Disponível em: <ftp://ftp.usjt.br/pub/revint/119_53.pdf> e acessado em 15.jul.2013. 
ROSSETTI, Eduardo Pierrotti. Palácio do Itamaraty: Questões de História, Projeto e Documentação (1959-70). Arquitextos, São Paulo, ano 09, n. 106.02, Vitruvius, março 2009. Disponível em: <http://www.vitruvius.com.br/ revistas/read/arquitextos/09.106/65>.e acessado em 27.dez.2014.

SANTA ROSA, Tatiane Schilaro. Henri Labrouste: Arquitetura entre Passado e Presente. Arquiteturismo, São Paulo, ano 07, n. 074.06, Vitruvius, abril de 2013. Disponível em: <http://www.vitruvius.com.br/revistas/read/arquiteturismo/ 07.074/4727> e consultado em 06.jan.2015.

SANTOS, Ana Carolina Melaré dos. Viollet-le-Duc e o Conceito Moderno de Restauração. Resenhas Online, São Paulo, Ano 04, n. 044.01, Vitruvius, agosto de 2005. Disponível em: <http://www.vitruvius.com.br/revistas/read/ resenhasonline/04.044/3153> e acessado em 06.jan.2005.

SANTOS, Fausto dos. A Caminho da Estética. Revista VERITAS, v. $52 \mathrm{n}^{\circ}$ 2, junho de 2007. Disponível em <http://revistaseletronicas.pucrs.br/ojs/index.php/veritas/article/viewFile/2075/1569> e consultado em $02 . j u n .2012$.

SNIC - SINDICATO NACIONAL DA INDÚSTRIA DO CIMENTO. 0 Cimento no Brasil. Disponível em <http://www.snic.org.br/pdf/Historia_do_Cimento_no_Brasil.pdf> e consultado em 15.dez.2014.

ZEIN, Ruth Verde. Breve Introdução à Arquitetura da Escola Paulista Brutalista. Arquitextos, São Paulo, 06.069, Vitruvius, fevereiro de 2006. Disponível em: <http://www.vitruvius.com.br/revistas/read/arquitextos/06.069/375> e acessado em 30.junho.2012. 


\section{Capa}

\section{Logo FAUUSP}

http://www.acropole.fau.usp.br/imagens/fau.png

21.fev. 2015

\section{Contracapa}

Palácio da Alvorada, em construção - Fotografia de Peter Scheier - Acervo do Instituto Moreira Salles

\section{Aço e Cimento: Agentes de um novo Significado para Arquitetura e Engenharia}

\section{Bibliothèque Sainte-Genèvieve}

[3.1] http://upload.wikimedia.org/wikipedia/commons/8/8b/P1130230_Paris_V_place_du_Panth\%C3\%A9on_n\%C2\%Bo

10_biblioth\%C3\%A8que_Ste-Genevi\%C3\%A8ve_rwk.JPG

[3.2] http://img.lumas.de/showimg_RNE275_1600_1600.jpg

\section{Bibliothèque Nationale de France}

[3.3] http://graphics8.nytimes.com/images/2013/03/14/arts/14LABROUSTE/14LABROUSTE-superJumbo.jpg

[3.4] http://www.ikaros.cz/images/201301/farkas7.jpg

\section{Catedral de Notre Dame de Paris}

[3.5] http://1.bp.blogspot.com/-iA6vdXmpcSI/U5DDHQHsRul/AAAAAAAAACE/7KIm-bagmM4/s160o/notre.JPG

17.fev.2015

\section{Basílica de Sainte-Marie-Madeleine de Vézelay}

[3.6] http://static.panoramio.com/photos/original/84816026.jpg

17.fev.2015

\section{Castelo de Roquetaillade}

[3.7] http://fondationmh.fr/wp-content/uploads/2014/10/Image1.jpg

17.fev.2015

${ }^{11}$ Para a montagem da relação de créditos e fontes das figuras incorporadas a esta dissertação, a coluna da direita refere-se à última data de consulta ao sítio da Internet que contém a imagem à qual ela se refere (quando for o caso). 


\section{Castelo de Vincennes}

[3.8] https://tolisworld.files.wordpress.com/2014/og/chateau-de-vincennes.jpg

\section{Aqueduto de Pontcysyllte}

[3.9] http://upload.wikimedia.org/wikipedia/commons/o/od/WalesCo047.jpg

17.fev.2015

\section{Palácio de Cristal}

[3.10] http://upload.wikimedia.org/wikipedia/commons/d/d8/Crystal_Palace_General_view_from_Water_Temple.jpg

\section{Galérie des Machines}

[3.11] https://classconnection.s3.amazonaws.com/263/flashcards/2418263/png/untitled121362869584630.png

\section{Torre Eiffel}

[3.12] http://7-themes.com/data_images/out/58/6968286-paris-eiffel-tower.jpg

17.fev.2015

\section{Barco em Ferrocimento (de Joseph-Louis Lambot)}

[3.13] http://www.la-provence-verte.net/decouvrir/patrimoine/brignoles-musee_p9_max.jpg

17.fev.2015

\section{Reservatório de Água em Ferrocimento (de Joseph Monier)}

[3.14] https://lh4.googleusercontent.com/-Io8cieb118Y/VHCJpnIOdol/AAAAAAAAGXw/prZqXlyyhXs/Monier reservoir Clamart.jpg

\section{Fábrica de Chocolates "Chocolat Menier"}

[3.15] http://upload.wikimedia.org/wikipedia/commons/2/25/Chocolaterie_Menier_moulin_Saulnier_1.jpg

\section{Home Insurance Company Building}

[3.16] http://www.constructionweekonline.com/pictures/gallery/PMV/fskyscraper_web.jpg

17.fev.2015

\section{Sistema Estrutural em Concreto Armado (de François Benjamin Joseph Hennebique)}

[3.17] https://s-media-cache-ako.pinimg.com/736x/a9/03/3d/a9033d636578a601dgb63a924699a2cb.jpg

17.fev.2015

\section{Igreja de Saint-Jean-de-Montmartre}

[3.18] http://3.bp.blogspot.com/-vYYyX7XAhWg/Uev6J4IqXhI/AAAAAAAAG5o/UccvxcHiTlk/s160o/IMG_6029.JPG

17.fev.2015

\section{Jahrhunderthalle}

[3.19] http://static.panoramio.com/photos/large/93397203.jpg

17.fev.2015

\section{Unity Temple}

[3.20] http://www.doi.gov/news/photos/images/Unity-Temple.jpg

17.fev.2015

\section{Edifício à Rue Franklin}

[3.21] https://c1.staticflickr.com/3/2839/12679681793_44047432bb_b.jpg 


\section{Igreja de Notre-Dame du Raincy}

[3.23] https://classconnection.s3.amazonaws.com/743/flashcards/2738743/jpg/eglise-notre-dame-du-raincy 1363208027326.jpg

[3.24] http://upload.wikimedia.org/wikipedia/commons/8/8a/\%C3\%89glise_Notre-Dame_du_Raincy__Le_Raincy__Seine-Saint-Denis__France_-_M\%C3\%Agrim\%C3\%A9e_PA00079948_\%281\%29.jpg

\section{Ponte sobre o Rio Zuoz}

[3.25] http://upload.wikimedia.org/wikipedia/commons/o/08/Innbruecke_Zuoz_01_11.jpg

17.fev.2015

\section{Ponte sobre o Rio Reno}

[3.26] http://www.heimatschutz-gr.ch/neu/cms/images/content/danis_tavanasa/ capaclanclanooooogns18cfa21moaf10603.jpg

17.fev.2015

\section{Armazém na Rua Giesshübel}

[3.27] http://upload.wikimedia.org/wikipedia/commons/o/06/Eidg._Getreidelager_Altdorf_08_11.jpg

\section{Pavilhão da Companhia de Cimento Portland na Exposição Nacional de Zurique de 1939}

[3.28] https://pschwagl.files.wordpress.com/2012/10/robert-maillard-1938-cement-hall.png

\section{Pont de la Libération}

[3.29] http://img.publicoton.fr/1018182_107758_1368127665.jpg

\section{Pont de Plougastel - ou Pont Albert-Louppe}

[3.30] http://mieux-se-connaitre.com/wp-content/uploads/2012/04/louppe05.JPC

17.fev.2015

\section{Hangares no Aeroporto de Orly}

[3.31] http://discoverfrance.net/France/Images/Transportation/Air/orly_airship_hangars-01-lg.jpg

17.fev.2015

[3.32] http://www.explorations-architecturales.com/data/upload/images/hst63.jpg

17.fev.2015

\section{"Sistema Domino"}

[3.33] http://2.bp.blogspot.com/-4_RdqfG7rA/UiWst-NAaLI/AAAAAAAAAIE/m75jkJZHrAA/s16oo/domino.jpg

\section{Villa Savoye}

[3.34] http://cdn.archinect.net/images/650x/t7/t74ws9gwmr7q4e8r.jpg

\section{Palácio dos Soviets}

[3.35] http://mydesignstories.com/admin/wp-content/uploads/2013/06/628.jpg

17.fev.2015

\section{Unité d'Habitation}

[3.36]

http://culturebox.francetvinfo.fr/sites/default/files/styles/asset_in_body/public/assets/images/2013/01/citeradieuse.jpg?itok=dJXpv56c 


\section{Ponte Maurício de Nassau}

[3.37] http://4.bp.blogspot.com/-ogN9joZmXEs/UvKJ2SfvnlI/AAAAAAAARCo/JKjWW_XW54I/s160o/IMG_7401.JPG

\section{Ponte dos Arcos em Indaial}

[3.38] http://static.panoramio.com/photos/original/75156255.jpg

17.fev.2015

\section{Edifício Banco do Brasil}

http://www.bing.com/images/search?q=\%22viaduto+santa+ifig\%C3\%AAnia\%22+\%2B+banco+do+brasil\&go=Envia

[3.39] $r \& q s=n \& f o r m=Q B I R \& s c o p e=i m a g e s \& p q=\% 22$ viaduto+santa+ifig\%C $3 \% A A n i a \% 22+\% 2 B+b a n c o+d o+b r a s i l \& s c=0-$ 27\&sp=-1\&sk=\#view=detail\&id=7A340391867F47C9EEB205859C022AF5AD5186Eo\&selectedIndex=7

\section{Copacabana Palace}

[3.40]

http://4.bp.blogspot.com/-IVC2D85OoFI/U1XL4OKV4zI/AAAAAAAAEFo/x8I3gz6VWLQ/s160o/copacabana_ palace.jpg

17.fev.2015

\section{Oscar Niemeyer: Razão e Liberdade na Arquitetura Moderna Brasileira}

\section{Ministério da Educação e Saúde - MES}

[4.1] https://c2.staticflickr.com/8/7128/7618714472_9fdd475740_b.jpg

18.fev.2015

http://arquiteturaurbanismotodos.org.br/wp-content/uploads/2014/03/Pilotis-Edif\%C3\%ADcio-GustavoCapanema-wikipedia.org_.jpg

18.fev.2015

http://img2.adsttc.com/media/images/520e/7a7a/e8e4/4e20/3000/0119/large_jpg/MESP_Marina_de_Holanda_2 .jpg?1376680542

[4.4] http://2.bp.blogspot.com/_NxPF_Z-acXk/Sw2e8TA5cql/AAAAAAAAB3Y/PdGkS8ymY28/s1600/PA010062.JPG

18.fev.2015

[4.5] https://b.geolocation.ws/img/021/711/933-F.jpg

18.fev.2015

[4.6] https://c2.staticflickr.com/4/3485/3972944284_66co6df8bb_b.jpg

18.fev. 2015

[4.7] http://upload.wikimedia.org/wikipedia/commons/a/ag/MESP1.JPG

18.fev.2015

18.fev.2015

[4.8] https://www.flickr.com/photos/comunicadiversidade/8074978860/sizes/k/

18.fev.2015

[4.9] http://3.bp.blogspot.com/-iNqD910ZhYg/T3ljmVIITrl/AAAAAAAAOgA/N2a2b72GsIM/s160o/MEC6.jpg

18.fev.2015

[4.10] http://img2.adsttc.com/media/images/520e/7b63/e8e4/4e20/3000/011a/large_jpg/MESP_FLICKR_Jonas_de_Car

[4.11] https://www.flickr.com/photos/fadb/7921064536/sizes/l

18.fev.2015

18.fev.2015

[4.12] http://4.bp.blogspot.com/-bPOEHomEY48/UiZutIXj7rl/AAAAAAAAEKc/ygF69cWquE4/s1600/IMG_0937.JPG

18.fev.2015

[4.13] https://rionaveia.files.wordpress.com/2009/10/mec5.jpg

18.fev. 2015

[4.14] https://rionaveia.files.wordpress.com/2009/10/mec2.jpg 


\section{Estado Novo e Política de Boa Vizinhança}

[4.15] http://pills52.com/upload/d/36/d3659044c9f5a782.jpg

18.fev.2015

[4.16] http://blog.sympla.com.br/wp-content/uploads/2014/01/Carmem-Miranda-1024x512.jpg 18.fev.2015

[4.17] hhttps://rescharf.files.wordpress.com/2010/02/welles11.jpeg

18.fev.2015

[4.18] http://www.1papacaio.com.br/modules/Wallpapers/gallery/wall1024/disney/variados/ze_carioca3_1024.jpg

18.fev.2015

\section{Feira Internacional de Nova York de 1939}

[4.19] https://dietsch.files.wordpress.com/2013/11/w08_90227011.jpg?w=1272

18.fev.2015

[4.20] http://photo.sf.co.ua/g/286/41.jpg

18.fev.2015

[4.21] http://cp12.nevsepic.com.ua/55-6/1354928745-0602927-www.nevsepic.com.ua.jpg

[4.22] http://www.fresher.ru/manager_content/images2/retrospektiva-vsemirnoj-vystavki-1939-goda/big/2.jpg

18.fev.2015

18.fev.2015

[4.23] http://cdn.theatlantic.com/assets/media/img/photo/2013/11/the-1939-new-york-worlds-

[4.24] http://www.fresher.ru/manager_content/images2/retrospektiva-vsemirnoj-vystavki-1939-goda/big/15.jpg

18.fev.2015

18.fev.2015

[4.25] https://s-media-cache-ako.pinimg.com/736x/30/57/3c/30573c3b98eec502a97d89230c169863.jpg

18.fev.2015

18.fev. 2015

[4.27] http://adbroo1cdn.archdaily.net/wp-content/uploads/2012/08/1345906874_pavilhaony_9.jpg

18.fev.2015

[4.28] http://img3.adsttc.com/media/images/52ff/8oee/e8e4/4e15/8900/01b8/large_jpg/1345906812_pavilhaony_1_2.j

[4.29] http://adbroo1cdn.archdaily.net/wp-content/uploads/2012/08/1345906858_pavilhaony_7.jpg

18.fev.2015

18.fev.2015

[4.30] https://teturaarqui.files.wordpress.com/2012/09/1346445219-1345906821-pavilhaony-2-1-1000x810.jpg

18.fev. 2015

[4.31] https://s-media-cache-ako.pinimg.com/236x/bd/af/50/bdaf5054f6980223bebb610083384906.jpg

18.fev.2015

[4.32] http://adbroo1cdn.archdaily.net/wp-content/uploads/2012/08/1345906886_pavilhaony_11.jpg

[4.33] http://img5.adsttc.com/media/images/52ff/814f/e8e4/4e54/8200/01a3/large_jpg/1345906893_pavilhaony_12.jp g?1392476489

18.fev.2015

18.fev.2015

\section{Grande Hotel de Ouro Preto}

[4.34] http://2.bp.blogspot.com/-uQc9Z5A_c1k/UJ5V2HZvvsI/AAAAAAAAASo/a7cJMekNYus/s16oo/grande+hotel++niemeyer+-+geolocations.jpg

[4.35] https://ppcdn.50opx.org/71981131/62907a9acdd7e94accd21c2b453a216381911079/3.jpg?v=0 


\section{Conjunto Arquitetônico da Pampulha: “Cassino"}

[4.37] http://cnod.demolaymg.org/wp-content/uploads/2011/04/bh6.jpg

18.fev.2015

[4.38] http://upload.wikimedia.org/wikipedia/commons/2/26/Museu_de_Arte_da_Pampulha_1.jpg

18.fev.2015

[4.39] http://3.bp.blogspot.com/-5SJivkfuCZc/T7geoiw3c-I/AAAAAAAACOE/65edAvvuBdw/s1600/IMG_7789.jpg

18.fev.2015

[4.40] http://4.bp.blogspot.com/_hXokZRjBvrw/THMPbn_MuDI/AAAAAAAAAKQ/oK7LCwyy8Nw/s1600/DSC04581.JP

[4.41] http://2.bp.blogspot.com/_KfRdMZXxoVY/TLcUvrnqPrl/AAAAAAAAAMY/ohO24m2Y561/s160o/museu+de+arte

[4.42] http://4.bp.blogspot.com/-

[4.43] http://d3u970w7fhbwyj.cloudfront.net/wp/wp-content/uploads/2009/10/IMG_4311-2-800x533.jpg

\section{Conjunto Arquitetônico da Pampulha: "Casa do Baile"}

[4.44] https://www.ufmg.br/online/arquivos/casa\%20do\%2obaile\%20-\%20aerea.JPG

[4.45] http://2.bp.blogspot.com/_roseBJnT46k/TND7Zq7f8ql/AAAAAAAAAC8/sRzLkTAq-eU/s160o/(46).JPG

18.fev.2015

[4.46] http://media-cache-eco.pinimg.com/736x/f9/3a/ob/f93aob7721d964cc5315955be5687foc.jpg

18.fev.2015

[4.47] http://vejabh.abril.com.br/blog/sem-moldura/wp-content/uploads/sites/9/2014/01/Casa-do-Baile-foto-Glenio-

[4.47] Campregher-2.jpg

[4.48] https://c1.staticflickr.com/9/8539/8971478235_24edb463ab_b.jpg

18.fev.2015

[4.49] https://soubh-imagens.s3.amazonaws.com/media/uploaded_images/eventos/2805-Casa_do_Baile-

[4.49] 20140918182136.jpg

\section{Conjunto Arquitetônico da Pampulha: "late Clube"}

[4.50] http://static.panoramio.com/photos/large/79587341.jpg

[4.51] http://3.bp.blogspot.com/-4E2jGoBIYHA/UpHYYVe7ocl/AAAAAAAAFsE/TDKuPCWfIdI/s160o/ARQ+341_late.jpg

[4.52] http://2.bp.blogspot.com/-05mmHuLnoaQ/TjzDGO6beal/AAAAAAAAAGk/hcLiXzpsFUY/s1600/L1110655.JPG

[4.53] http://1.bp.blogspot.com/-VSvz71DwRhc/TjzDF1-zJGI/AAAAAAAAAGc/ixevR_nrfCo/s160o/L1110652.JPG

18.fev.2015

[4.54] http://i914.photobucket.com/albums/ac350/AdrianaAugusta/137.jpg 


\section{Conjunto Arquitetônico da Pampulha: "Capela de São Francisco de Assis"}

[4.56] http://blog.lopes.com.br/wp-content/uploads/2014/11/Pampulha-Alberto-Andrich.jpg

18.fev.2015

[4.57] http://upload.wikimedia.org/wikipedia/commons/4/4b/lgrejaPampulha.jpg

18.fev.2015

[4.58] http://biapo.com.br/site/wp-content/uploads/2004/08/Pampulha-4.jpg

[4.59] http://commondatastorage.googleapis.com/static.panoramio.com/photos/original/77019326.jpg

18.fev.2015

18.fev.2015

[4.60] http://cdn.homesthetics.net/wp-content/uploads/2014/03/Reinterpretating-Religious-Architecture-Church-of-

[4.60] Saint-Francis-of-Assisi-by-Oscar-Niemeyer-Homesthetics-5.jpg

[4.61] http://www.foto-grafo.de/Oscar_Niemeyer/Belo_Horizonte/_DSC1499_web.jpg

18.fev.2015

18.fev.2015

\section{Entreatos: Reflexão Crítica e Apuro Projetual}

[4.62] Acervo Próprio (Elaborado pelo Autor)

\section{Entreatos: Reposicionamento Crítico 1}

[4.63] https://www.mercadoarte.com.br/blog/wp-content/uploads/2012/08/Edmundo-Cavanellas.jpg

18.fev.2015

[4.64] http://www.haifa-univ.ca/tempimages/aerial.jpg

18.fev. 2015

[4.65] http://leopart.fr/wp-content/uploads/2013/05/Niemeyer-L1.jpg

18.fev.2015

[4.66] http://www.oscarniemeyer.com.br/sites/default/files/repositorio/PRO059/PRO059-FOT-0001-001-G.JPG

18.fev.2015

\section{Entreatos: Reposicionamento Crítico 2}

[4.67] http://niemeyer.org.br/sites/default/files/repositorio/PRO156/ft\%20Univ\%20Constantine\%206\%20-\%20Moch.jpg

[4.68] http://static.panoramio.com/photos/large/74471523.jpg

18.fev.2015

[4.69] http://www.niemeyer.org.br/sites/default/files/repositorio/PRO145/PRO145-CRO-0000-001-G.JPG

18.fev.2015

[4.70] http://www.niemeyer.org.br/obra/pro207 


\section{Entreatos: Reposicionamento Crítico 3}

[4.71] http://www.xptoonline.com.br/blog/wp-content/uploads/2014/og/mac-niteroi-2.jpg

[4.72] http://nosnobrasil.com.br/blog/wp-content/uploads/2014/07/Museu-Oscar-Niemeyer.jpg

18.fev.2015

[4.73] http://img.gqitalia.it/wp-content/uploads/2014/06/1403015414_Oscar-Niemeyer_1-1200x800.jpg

18.fev.2015

[4.74] https://arcowebarquivos.s3.amazonaws.com/imagens/54/05/arq_25405.jpg

18.fev.2015

\section{A Nova Capital Federal Descobre o Brasil}

[4.75] http://vejabrasil.abril.com.br/assets/uploads/images/2/27/f6a/227f6afd3b7f8gb96c4bb91f95d50f6d.jpg

18.fev.2015

[4.76] http://fotospublicas.s3.amazonaws.com/files/2014/02/construcao_de_brasilia01-1024x698.jpg

18.fev.2015

[4.77] JUNQUEIRA; 2014: 182

[4.78] JUNQUEIRA; 2014: 174

[4.79] oscar-niemeyer-photos/jcr:content/gallery/84505a72-ca06-4ac6-b558c2bob4dae87c/image.img.2560.1440.jpg/1354873501329.cached.jpg

[4.80] http://arquiteturaurbanismotodos.org.br/wpcontent/uploads/2014/04/Vista_a\%C3\%A9rea_do_final_da_Asa_Sul.jpg
http://www.copa2014.gov.br/sites/default/files/styles/galeria_de_imagem_600_400/public/galeria/1209_brasili
a mobilidade_aerea_6416.jpg?itok=S1C5FuBS

\section{Palácio da Alvorada}

[4.82] http://www2.planalto.gov.br/presidencia/palacios-e-residencias-oficiais/palacio-da-alvorada/galeria-de-

imagens/palacio-da-alvorada/@@images/image.jpeg

[4.83] https://www.flickr.com/photos/aragao/8212939735/sizes/k/

18.fev.2015

[4.84] https://www.flickr.com/photos/aragao/8579255418/sizes/k/

18.fev.2015

18.fev.2015

[4.85] http://upload.wikimedia.org/wikipedia/commons/c/c5/Palacio_da_Alvorada_Mezzanine.JPG

18.fev.2015

[4.86] http://brazil.qc.cuny.edu/files/2013/11/PALACIO-ALVORADA-9351-100oPX.jpg

18.fev.2015

[4.87] http://radios.ebc.com.br/sites/_radios/files/sao_goncalo_fazenda_01.jpg

18.fev. 2015

[4.88] http://wfiles.brothersoft.com/a/athens_52341-1920x1200.jpg

18.fev.2015

[4.89] http://virtuearchitects.com/wp-content/uploads/2012/10/crown-hall.jpg

18.fev.2015

[4.90] SILVA; 2012: 452

[4.91] http://www.lai.fu-berlin.de/brasil/bildergalerie/bild_Palacio_da_Alvorada_1962_/Pal_cio_da_Alvorada__ 1962 550.jpg?ts $=1367077543 \&$ width $=$ 
[4.92] http://www.ims.com.br/images/71/15/prog_imginterna_1417717115.jpg

[4.93] http://www2.planalto.gov.br/presidencia/palacios-e-residencias-oficiais/palacio-da-alvorada/galeria-de-

[4.94] https://www.flickr.com/photos/ginasant/4121485072/sizes/l

[4.95] https://www.flickr.com/photos/aragao/8612248752/sizes/k/

\section{Palácio do Itamaraty}

[4.96] https://proximosdestinos.files.wordpress.com/2012/04/dsc04534.jpg

[4.97] http://www.oppelarquitectura.com.ar/oppel_news/galerias/may0014/no03/08.jpg

18.fev.2015

[4.98] http://mimoa.eu/images/10461_l.jpg

18.fev.2015

[4.99] Acervo Próprio (Imagem feita pelo Autor)

[4.100] Acervo Próprio (Imagem feita pelo Autor)

[4.101] Acervo Próprio (Imagem feita pelo Autor)

http://4.bp.blogspot.com/-zLZhqvXKaP4/Ubd44JaTSLI/AAAAAAAAC3k/wBEFGIDCEjM/s160o/

[4.102] Instituto+Tomie+Ohtake_Arquitetura+Brasileira+III_MASSIMO+LISTRI_Pal\%C3\%A1Cio+do+Itamaraty_Orcar+Ni emeyer_1965_Bras\%C3\%ADlia+DF.jpg

18.fev.2015

18.fev.2015

[4.103] https://sobrearquitecturas.files.wordpress.com/2014/05/mbiernatniemeyer-11.jpg

18.fev.2015

[4.104] Acervo Próprio (Imagem feita pelo Autor)

[4.105] Acervo Próprio (Imagem feita pelo Autor)

\section{Palazzo Mondadori}

[4.106] https://s-media-cache-ako.pinimg.com/originals/69/50/92/695092d7cb4c06a5e4368255f5d2bfa7.jpg

[4.107] http://pietroporcinai.net/uploads/work_images/13/DSCo0231_2.JPG

18.fev.2015

[4.108] https://www.flickr.com/photos/eziobeschi/5812758299/sizes/l/

18.fev.2015

[4.109] FUTAGAWA; 2008

[4.110] Google Earth

[4.111] http://www.mondadori.it/var/ezflow_site/storage/images/media/images/immagini-hp/palazzo01/3310-1-ita- 